







\title{
CONCHOLOGIA ICONICA:
}

OR.

\author{
I L L U S T A TIO N S
}

(IF THE

\section{SHELLS OF MOLLUSCOUS ANIMALS。}

VOL. XI.

GONTAINING MONOGRAPHS OF THE GENFRA

PINYA.

PERNA.

MALLEUS.

VITSELLA.

CRENATULA.
UMBRELLA.

PEDUM.

IANTHINA.

COLLTBELLA.

META.

CALIPTREA.
CREPIIULA. CRUCIBULUM. TROCHITA.

ANOMIA.

PLACL NANOMIA.

BY

LOVELL AUGUSTUS REEVE, F.L.S., F.G.S., CDBREYUNDING MEMBEK OF THE NATT RAI. HISTORY SOCJETY OE WÜETEMBERG, IND OF THE LYCETM OF NATURAI HISTORI OP SEW YORE.

"Why stand we gazing on the sparkling brise,

With wonder smit by its transparency,

And all-enraptured with its pority :

Because the unstained, the clear, the crystallive,

Have ever in them something of benign."- "Wordsworth

LONDON :

LOVELL REEVE, HENRIETTA STREET, COVENT GARDEN 



\section{MONOGRAPH}

OF THE GENUS

\section{P I N N A.}

Give me your gloves, I 'il wear them for your sake."

Shakspeare. 
Pinna. Pl. I. 


\section{P I N N A.}

\section{Plate I.}

Genus PINX.1, Lw woples.

Testa aquivalvis, obriyua, longitudinaliter cuney jomis, fibrolaninaris, plerinupue squamata, unbonibus ternizalibus, lateribus sapè kimutibus. Curdo luteralis, edentulus, ligamento subinterno per totum longitudinem continuo. Intpressio muscularis composita.

shell equivalvc, oblique, longitudinaily wedge-slaped, filbrolaminar, generally sealed, nmboes terminal, sideз often gaping. Hinge lateral, toothless, with the ligament rather internal, continued throughont its whole length. Muscular impression compound.

The large typical species of this genus, $P$. rotundata, being an inhabitant of the Mediterrancan, it was one of the few shells described by the old Greek father of natural history, Aristotle. Ilis designation of Пuvva was therefore adopted by the founder of our nomenclature in his 'Systema Nature;' and it is one of the few Linnæan generil that has escaped the knife of modern genusmongers. The Pinne are so nearly allied in form and tissue that they are semreely susceptiblc of even subgeneric division. Their chief variation is in sculpture, the scales with which they are mostly armed being in some, as in $P$. serrata, very minute and sharp; in others, as in $P$. alta and Cumingii, raised and tubulous; and in others, as in $P$. nobilis and rugasn, promiscuously distorted; while many species, as $P$. fumata, bicolor, and Plitippinensis are smooth. They are all of fibrous brittle texture, and often brilliant in colour, though a dull-olive rather predominates.

The Pinne are chiefly inhabitants of the Old World. Out of fifty species of which the habitats are known, fully balf are from the region of the Philippine Islands, Malacca, and the Molnceas. Only onc species, abundant chiefly on the south-west coast, inhabits our own shores, and three the Mediterratican and Adriatic. Australia contributes six fine species, and New Zealand two, Japan one, and the Cape of Good Hope one. Of the western species. comprising only the proportion of a fifth, the three finest are from Panama. Three are from the West Indies, one from Honduras, one from Puerto Portrero, and thirec from South Carolina.

In cxamining the species of this genus, great care is necessary to observe them in different stages of growth. Individnals which in a young state are characterized by a profusion of scales, often become roughly laminated and denuded of sculpture in an advanecl stage of growth: and the same species is found, even at the same apparent age, so variable as to be scaly in one habitat and smootl. in another. All these differences may bowever be observed, and their gradations detected, by sufficiently copious observations.

Species 1. (Fig. $a, b$, Mus. Cuming.)

Pinna Cinemnitzm. Pinn. testä subarcuato-trigonâa, $\ell$ mi, ventricosâ, sordidè olivaceâ, longitudinaliter radiatime costatâ, costis interdum subobisoletis, muticis, interstitiis transversè striatis; concentricè sublicalï, plicis distuntibus, citis enanidis; maryine dorsali incurcato, plerumque muricato-squamato.

Cinennitz's Pinna. Shell somewhat arenately triangular, thin, ventricose, dull-olive, longitudinally radiately ribbed, ribs sometimes obsolete, smooth, with the interstices transversely striated; concentrically slightly plicated, the folds being distant and soou disappearing; dorsal margin incurved, generally prickly scaled.

Hanley, Pro. Zool. Soc. 1858, p. 136.

Hah. Philippine Islands; Cuming.

A thin ventricose shell of a sombre-olive colour, prickly sealed only along the dorsal edge. 




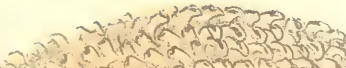

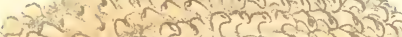

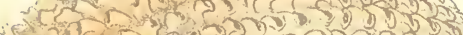

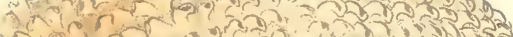

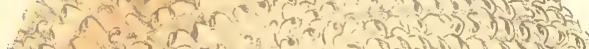

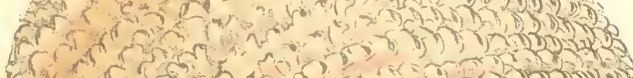

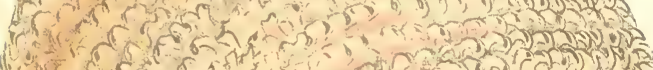

du 35 की को

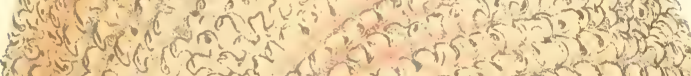

is of

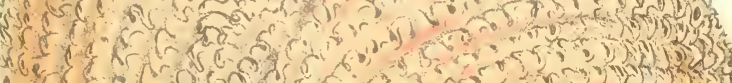

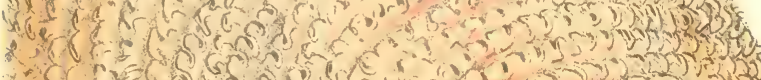

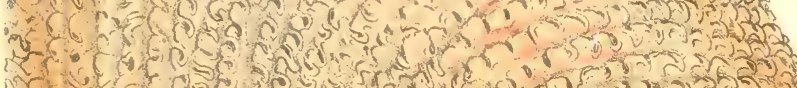

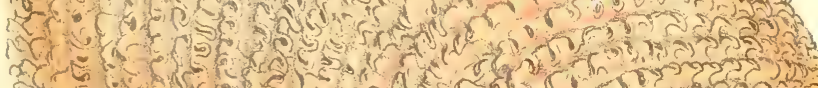

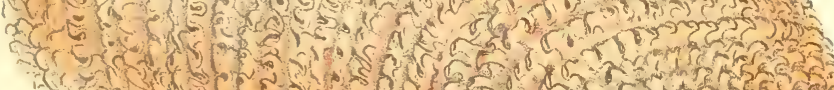

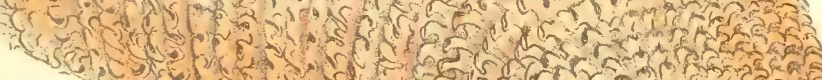

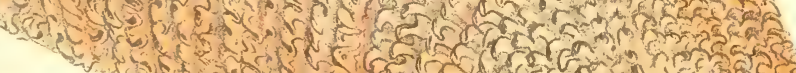

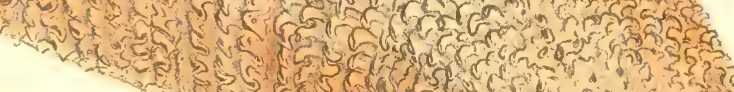

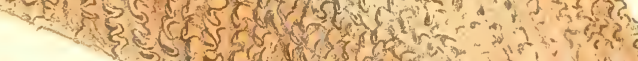

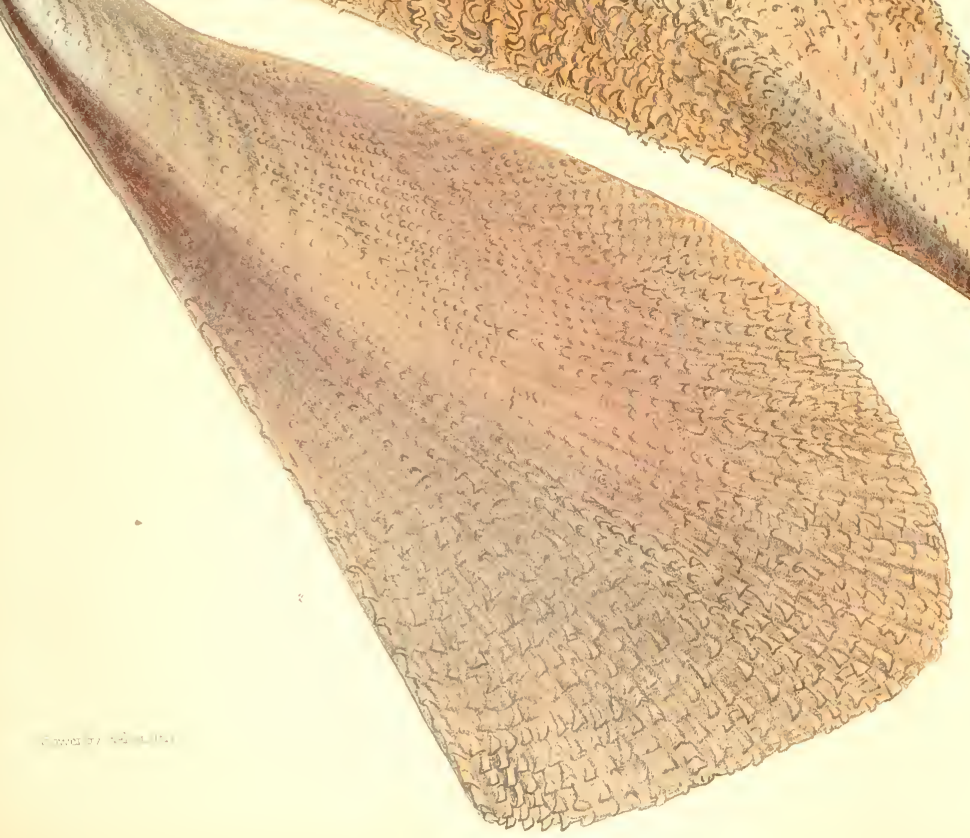

Pinna PI.II.

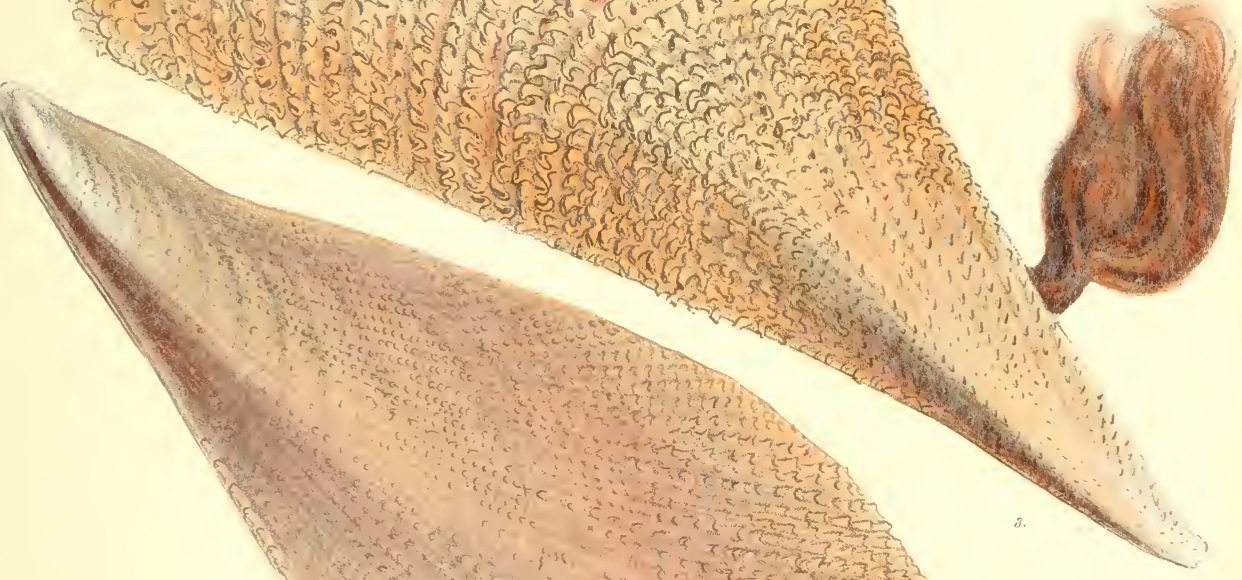




\section{P I N N A.}

\section{Prate II.}

Sipecses 2. (Mus. Cuming.)

Pinna seminuda. Pirn. testâ trigonâ, truncatä, latere postico longitudinaliter costato, multisquamoso, squamis tenuibus, erectis, latere antico squamis copiosis minutis, cersus umbones subobsoletis, rugis perpancis amplis concentricis: sordidè olivaceâ.

Tire half-Naked Pinna. Shell triangular, truneated, posterior side longitudiually ribbed, many-sealed, scales delicate, erect, arterior side with the scales plentiful, minute, rather obsolete towards the umboes, with a few large concentric wrinkles; dull olive.

lamarck, Anim, sans vert. vol. rii. p. 61.

Pinna squamosissima, Plilippi.

Hah. Sonth Carolina.

This species, of a dull olive horny substance and peculiarly truncated form, is densely scnlptured on the posterior angle with delicate, ereet scales, while on the anterior angle the scales are even more numerous, but smaller, and, being almost obsolete towards the umboes, impart a comparative smoothuess to that portion of the shell.
Species 3. (Mus. Cuming.)

Pinna rotundata. Pinn. testâ elongato-trigonâ, extremitute rotundatâ, radiatin subflexuoso-liratâ, undique densissimè squamosä, squamis peculiariter irregularibus, quasi papillaribus; griseo-rufescente.

Trie rounded PrNa. shell elongately triangular, rounded at the extremity, radiately subflexuously ridged, everywhere very densely scaled, scales peculiarly irregular, as though papillary; greyish-red.

LinNevs, Syst. Nat. p. 1160.

Pinna squamosa, Gmelin.

Pinna marina, Chemnitz.

Hab. Mediterranean.

This well-known species, an inhabitant chiefly of the Mediterranean, is the larigest of the genus, growing frequently to two feet in length. The seales with which it is everywhere densely beset have a peculiar papillary look, and are distorted promiscuously in all directions. It is of this species that the fine silken byssus has been sometimes used for the manufacture of a pair of gloves. 



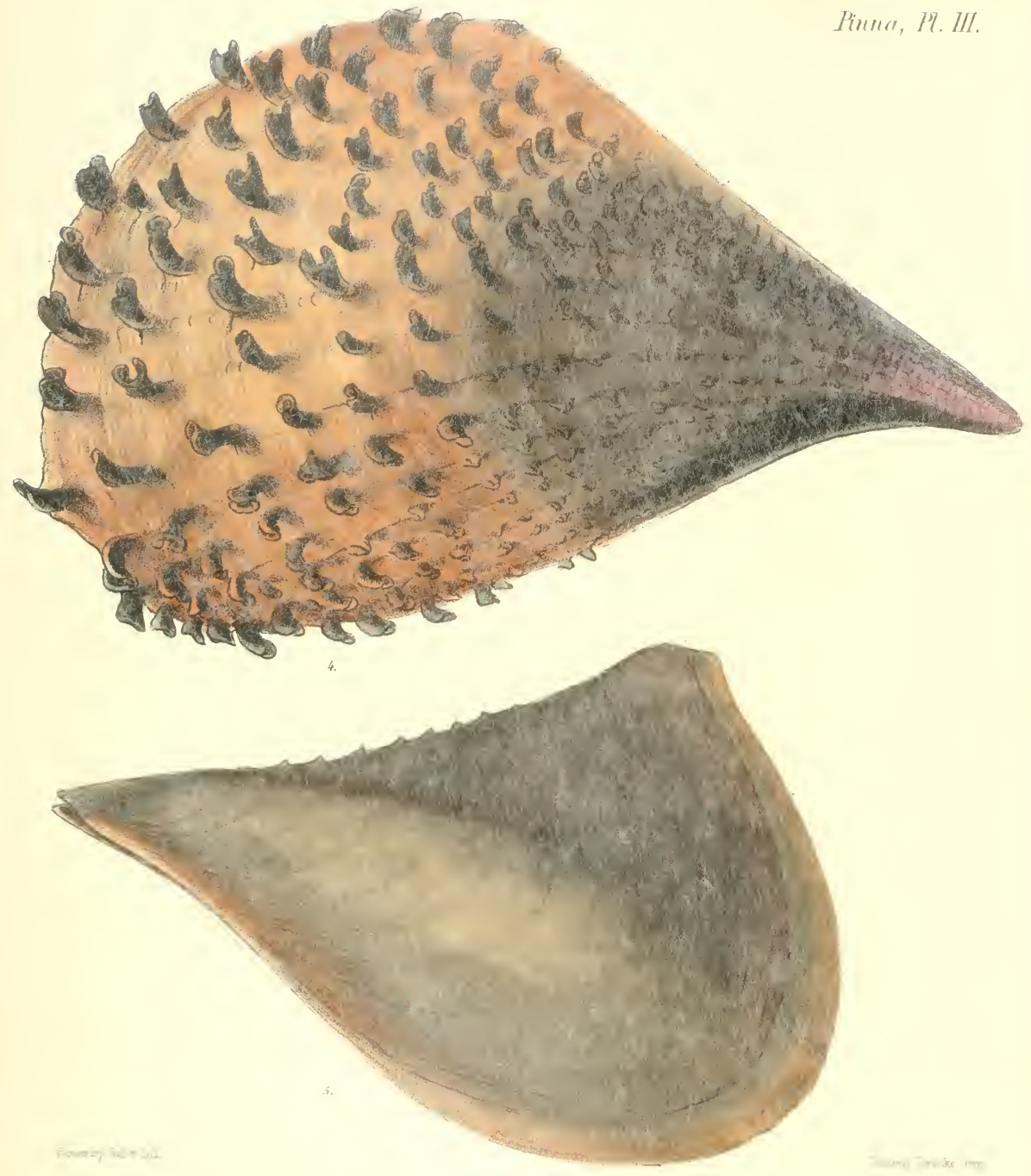




\section{P I N N A.}

Plate III.

species 4. (Mus. Cuming.)

Pinsa xigua. Pinu. testä trigono-flabellatâ, versus umbones attenuatá, liris flesuosis obscurè radiatâ, vel hevigatâ vel squanat $\hat{n}$, squamis amplis distantibus, recurvo-erect $s x$; nigrâ.

The BLAck Pisna. Shell triangularly fan-shaped, attenuated towards the umboes, obscurely rayed with flexuous ridges. smooth or scaled, scales large, distant, recurvedly erect; black.

Chemsitz, Conch. Cab. vol. viii. p. 221. pl. 89. f. 774. Pinna nigrina, Lawarck.

Hab. South Seas and Philippine Islauds; Curuing.

This well-defined specics varics materially in sculpture, being sometimes umusually strongty scaled and somctimes smooth and of large size. It is not often that specimens occur with such holdly developed scales as in the shell here figured. Of the large, smooth variety there are some remarkible specimens in the British Museum.
Species 5. (Mus. Cuming.)

Pivsa inflata. Pinn. testâ obliquè trigonâ, subtortâ, tenui, valdè inflatâ, lavigatâ, liris minutis obscurè serratis radiatâ, anticè profusè minutissimè serrato-squamatis, margine cardinali uuricato-squanato, squamis paucis granditus; alivaceo-corneâ.

The inflated Pinna. Shell obliquely triangular, somewhat distorted, thin, very inflated, smooth, rayed with minute, obscurely serrated ridges, anteriorly very mimutely serrately scaled, hinge-margin prickly-scaled, scales few, large; olive-borny.

Chenvitz, Conch. Cab. vol. viii. p. 215. pl. 8. f. 771

Hab. Philippine Islands; Cuming.

This is a very distinct species from the Linnean $P$ pectinata of our European sliores, with which it is confounded by Lamarck. It is singularly inflated, and, though apparently smooth will be found on examination to be crowded on the anterior side with very minute appressed scales, and to be rayed with minute serrated ridges. 




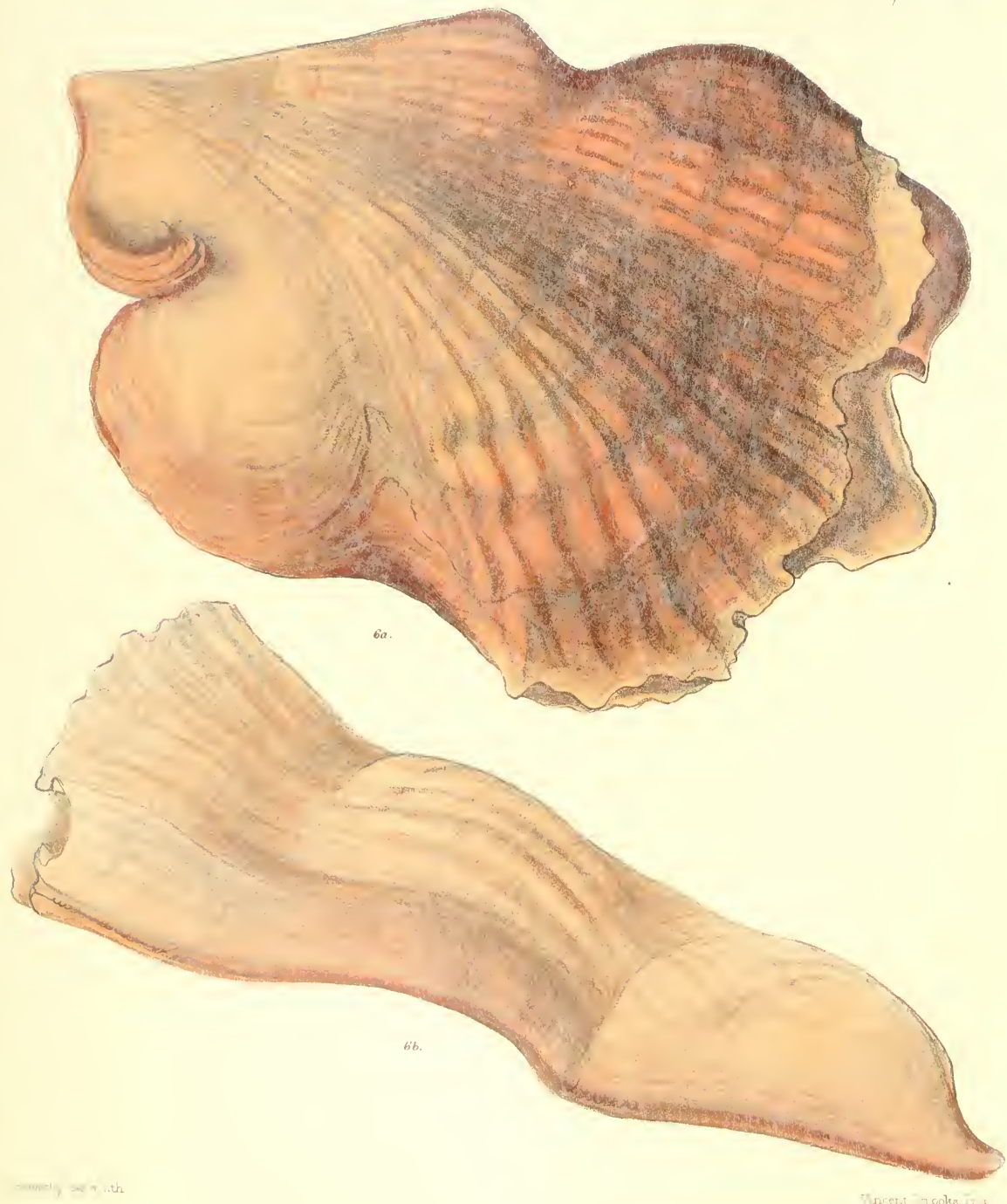




\section{P I N N A.}

Plate IV.

\section{species B. (Tig a A Mus. Cuming.) \\ I. Na sacCata. Pinu. testâ irregulariter trigonâ, nunc oblongâa nune lat ks 'ulat, semper plus minus distortâ, radiatim costutit, costis amplis, obtusis, undatis, inter- dum nodatis, luter. anticu sape sinu coarctato; suc- ineo-rufescente, cornế.}

'THe satchel-suaped PINXi shell irregularly trianyular, sometimes oblong, sometimes rather broad, always more or less distorted, radiately ribbed, ribs large, obtuse, waved, somctimes noduled, an- terior side often eontracus: by a siuus: amber-red, horny.

Linneus, Syst. Nat. p. 1160.

Var. elongata, P. Nuttallii; Conrad.

Hab. Sandwich Islands and Philippine Islands; Cuming.

There is $\mathrm{no}$ defining the varicties of this very charaeteristie speeies. It has a wide range of habitation, and is found distorted into all sorts of forms between those selected for illustration. Its amber-red horny substanee is quite peculiar. 



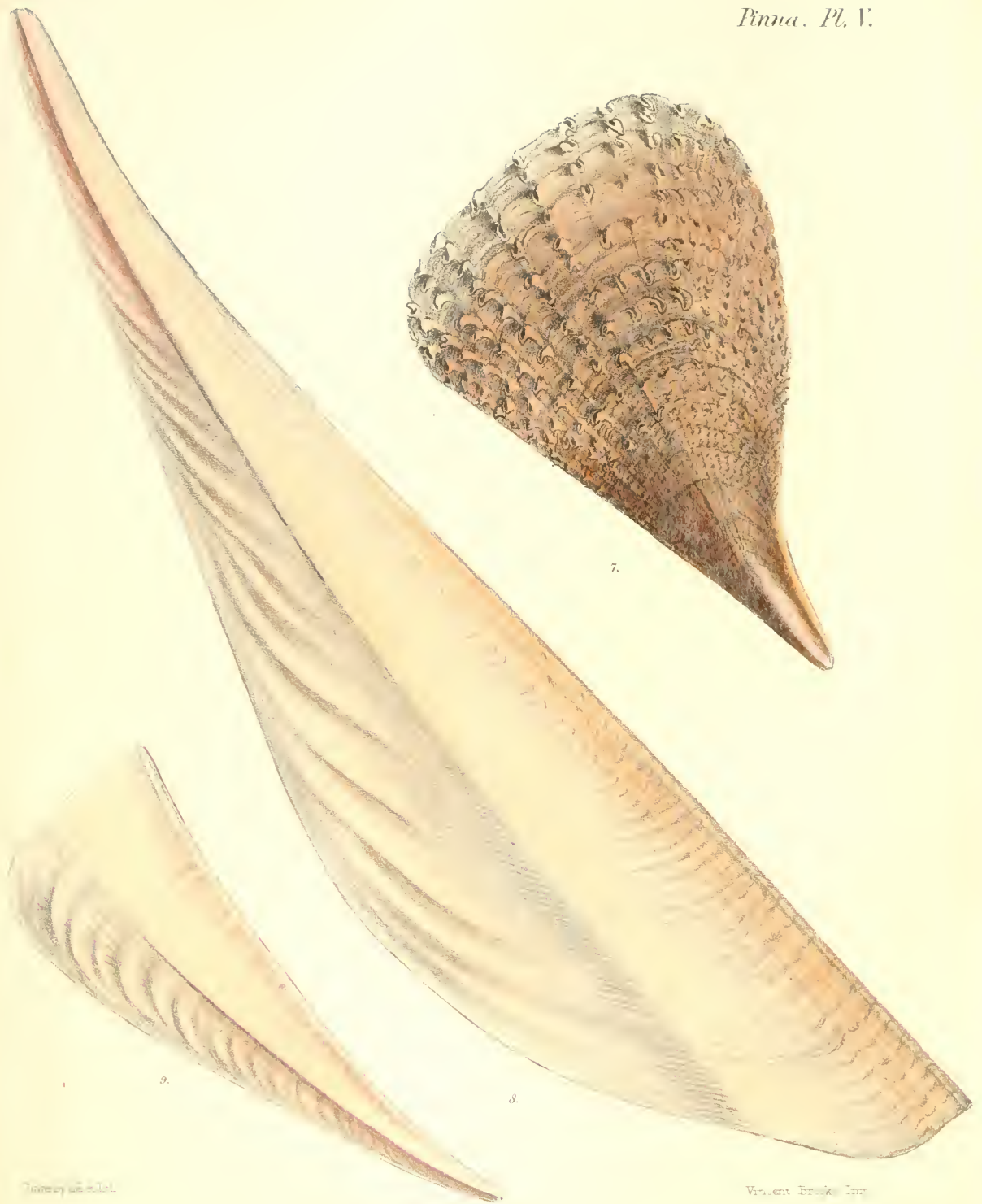




\section{P I N N A.}

\section{Plate V.}

sircies 7. Mus. Cuming:

PINia riglda. P'inu. testä subpyriformitr wiscurè costel-

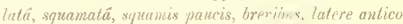
ruedè decussat iut rnyoso; fusco-olivoréá.

THE RIiTD l'Lisa Shell somemhat pear-shaped, obscurely ribbed, scaled, seales few, short, anterior side rudely decussately wrinkled; fuscous-olive

Dilum $x \times$. Deseriptive Catalogue of Shells, p. 327. Hah. - ?

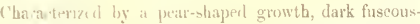
wive colont, and irregular senlpture of promiseuous, short. r.poken seales

\section{species s. Mus. Cuming.}

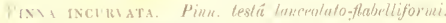

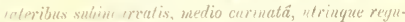

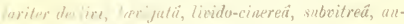

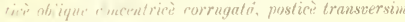
trater angumis.

Fon. IXCeRved PINA. Slull lancelately fan-shaped, keeled in the mithlke retrularly sloping on pach side. smooth, livid-ash, glassy, anteriorlyobliquely wrinkled, posteriorly transversely finely rugose.

CHemnitz, Coneh. Cab, vol. viii. p. 229. pl. 90. f. 778. Hab. Moluceas.

Readily distinguished from all other species by its lanceolate form aud thin, livid-ash, brittle substance.

\section{Species 9. (Mus. Cuming.)}

Pinna Kumpun. Pinu. testât uracili-trigomä, rarcah.

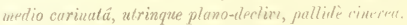
subpellucidie, obscurissimè longitudinaliter liratä ul peruliariter malleatü, unticì calidè obliquè corrugutu.

Romphus's Pinna. shell slenderly triangular, enrvet. kceled in the middle, flatly sloping on each side. pale-ash, rather transparent, very ubscurely longitudinally ridged and peenliarly walleated, anteriorly strongly obliquely wrinkled.

HaNi1 Y, Pro. Zool, Soc. $1<:<$.

Hab. Moluccas

Very closely allied to the preceding species, but un formly smaller and more curved, whilst the surtace is in riously finely malleated. 

Pinna, Pl. VI.
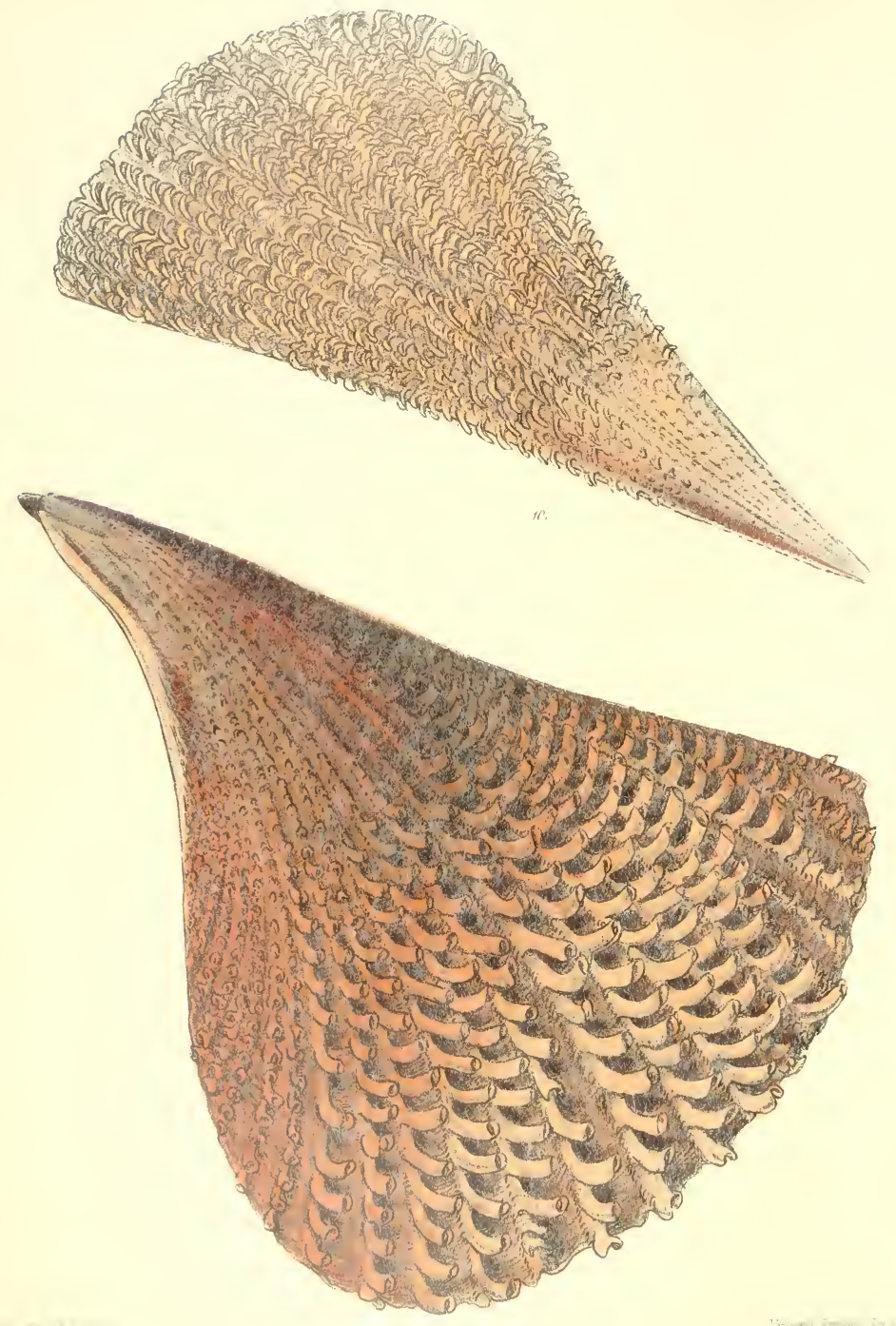


\section{P I N I A.}

Pi.ATE VI.

Fig. 10 (Mit A tuminz

Clue shet! here figured is a young spetemen of $I^{3}$. squaansa. in which the seales are more produced though preserving the same characteristic promiscuous growth. Chemnitz described and figured it as a distinet species, with the name $P$. aculeato-squamosa, while Poli confounded it with the Linnean $P$. wobilis. It is an extremely interesting state of the species, and should be carefully preserved in colleetions with the adult form.

Species 11. (Mus. (uming.)

Pinna alta, Pimn, tostâ pyriformi-flabellatâ, radiatim longiludinaliter costulatâ, costetis ampliter squamatis, squamis regularibus, conspienè productis, recurvis, tubulatis ; fusco-olicaceâ.

THE HIGH PINNA. Shell pyriformly fan-shaped, radiately longitudinally ribbed, ribs largely scaled, scales regnlar, conspicuously produced, recurved, tubular; fuscous-olive.

Lowerby, Pro. Zool. Soc. 1835 , p. 84.

Hab. Bay of Honduras (on sandhanks).

This fine species is remarkable for the conspicuous remularity of its large, recurred, tubular scales. 

Pinna, Pl. I7I.

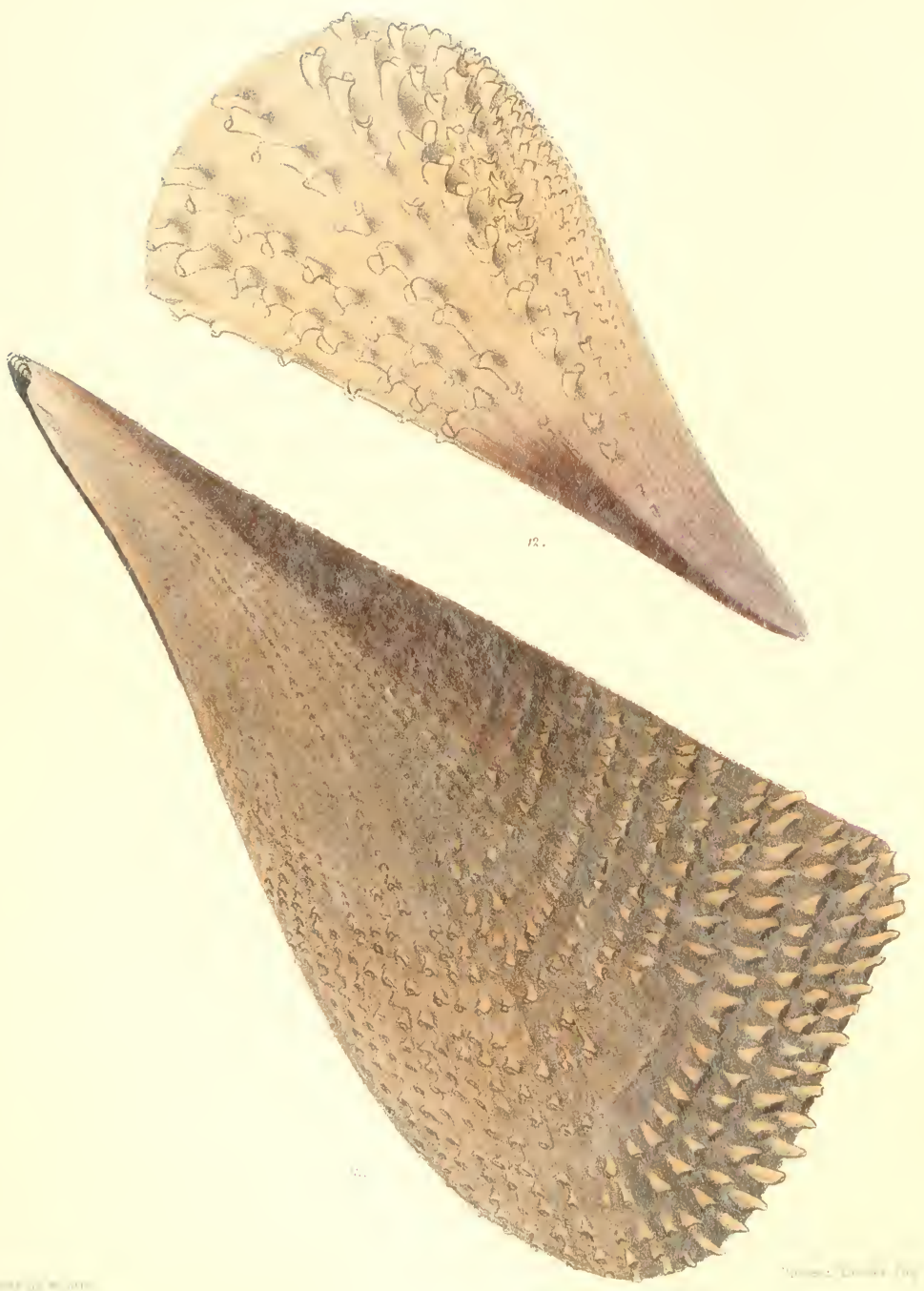




\section{P I N N A .}

PLATE VII.

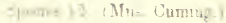

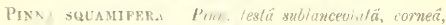 \\ instellis perucia wamereris longiludinatiter radiatâ, \\ squamis subdistautwa, majoribus, latiusculis, subre- \\ Alexis, rotunda tis. hyalims. maryine dorsali recto, pos- \\ tices ventralique rotudatis, continuis, areâ bentrali \\ rugosî̀.
}

Гhi. seramferots PINKa. Shell somewhat lanceolate, horns longituditally rayed with a few small squamiforous ribs, scales rather distant, larger than usnat, rather broad, somewhat reflected, rounded, hyaline, dorsal margin straight, posterior and ventral margins rounded, continuous, ventral area rugose.

Sowerbi, Pro. Zool. Soc. 1835, p. 85.

Hab. Cape of Good Hope.

The distinguishing features of this speeies consist in its broad-spreading, recurved scales, and comparatively distant ribs.

$$
\text { species 13. (Mus. (uroing.) }
$$

Pinna Zelanica. Pinn. Lestâa subablongo-triyonâ, lavi, vìr costellatâ, promiscuè squamatâ, squamis brevibus, patulis, erectis, valdi arregularibus; nigrescente-olivaceá.

The New Zealand YinNa. shell somewhat oblongtriangular, smootl, scarcely ribbed, promiscuously scaled, scales short, open, erect, very irregular; very dark olive.

GRaY, Appendix to Dieffenbach's New Zealand.

Hab. New Zealand.

The scales of this spceies are distinguished for their very promiscuous, incomplete growth, being curiously short, open, and erect. 



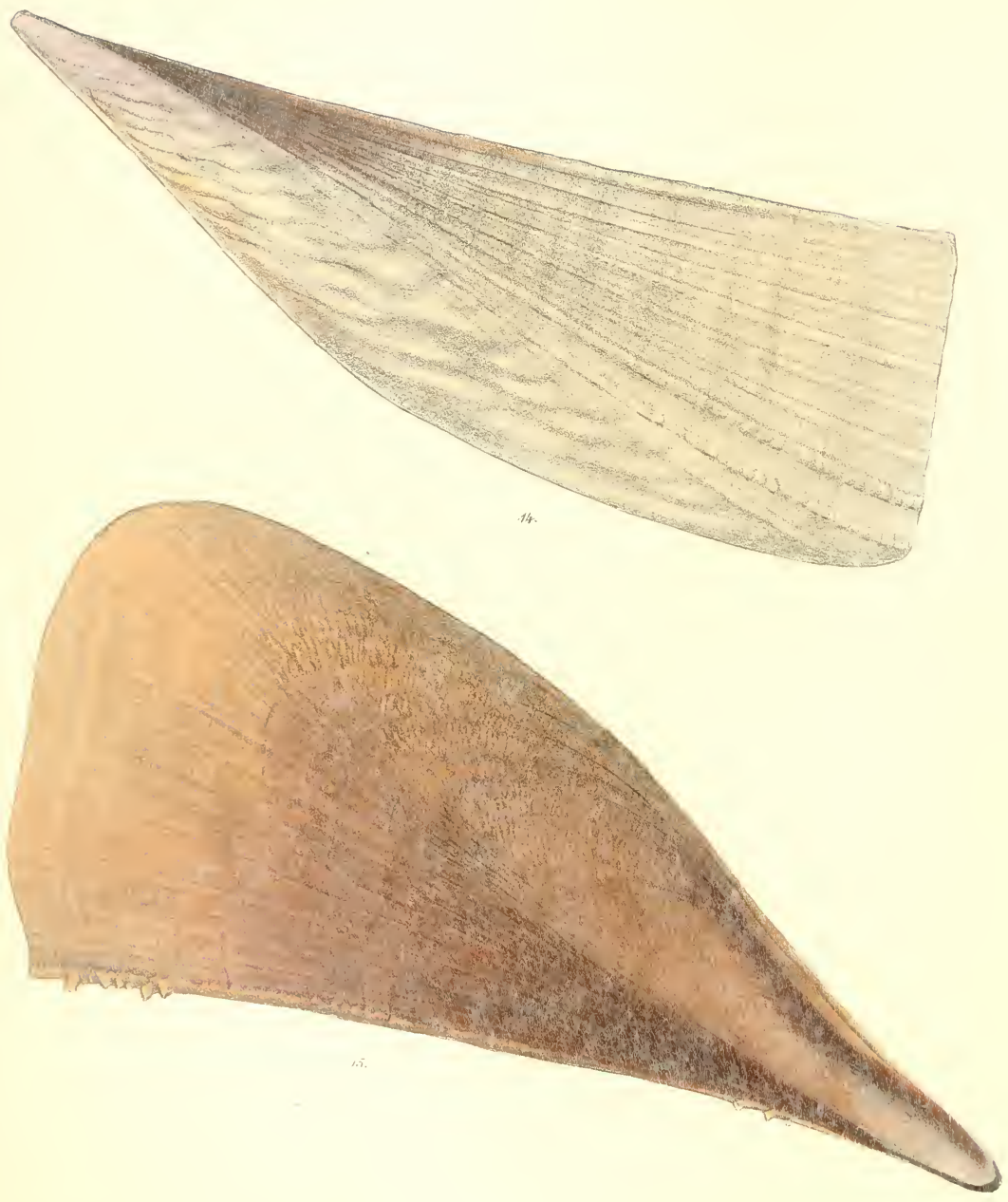




\section{P I N A.}

Plate V1II.

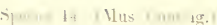

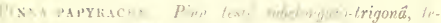

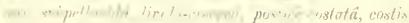

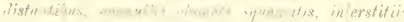

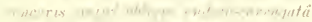

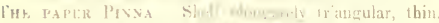

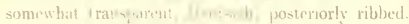

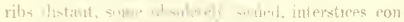

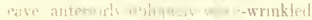

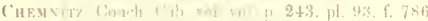
Itol

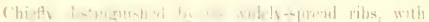

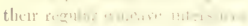

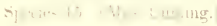

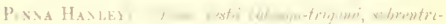

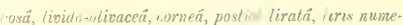
rosis, irregularibus, interstitiis serratis, anfice oblique. rudè corrugatâ, superficie zodiquè peculiariter decusstim malleatá, margine postico incurvato, muricatosquantat $\vec{u}$.

HANLEY's l'INAA. shell obloug-triangular, somewhat ventricose, livid-olive, horny, posteriorly ridged, ridges numerous, irregular, intersticcs scrrated, anteriorly obliquely ruddy wrinkled, with the surface curously dectissately mallented throughout, posterior unrgin incurved, prickly-scaled

Hab. Ambovia.

A curiously-sculptured species, which gives me an opportunity of acknowleiging the valuable assistance kindly afforded me by Mr Hanley in the examination of this qu'nus.

April, 1555 




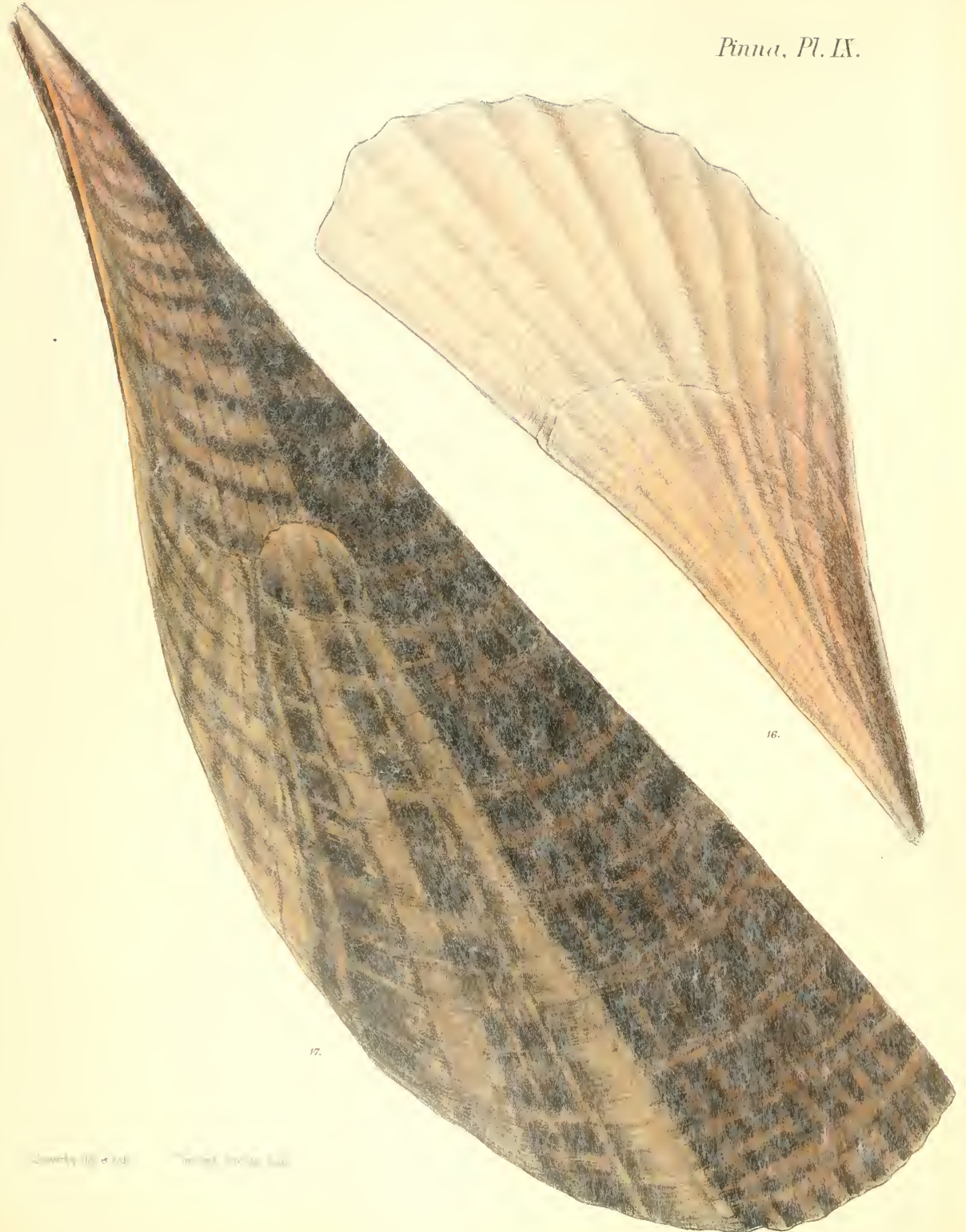




\section{P I N N A.}

PLATE IX.

\section{Species 16. (Mus. Cuming,)}

Pinva nullata. Pinn. testä abliquè trigona', margire decliri-rotundatâ, tenui, sulpellucidâa, radiatim costatât. costis gradatin latioribus; rordinlis albâ, versess zmbones aurantio-rufü.

THE BLBBLE-LIKE PINAA. Sliell obliquely triangular, slopingly rounded at the margin, thin, semitransparent radiately ribłed, nbs gradually broaier: deadwhite, orange-red towards the umboes.

swanson, Hanley, Ms. Mus. Cuming.

Hab. Moluecas

Of light, borny substance, tinged with orange-red towards the umboes. The ribs radiate to the margin, but hecome gradualiy broader and almost superticial. species 17. (Mus. Cuming.)

Pinna bicolor. Pinn. testä elongatâ, nargine dectivirotundatâ, radiatim costutat, cost is angust is, subobsoletis, perulo flexuosis, intersfitiis parum concucis; lividocinere $\hat{a}$, subpellucidâ, olivaceo-nigricante radiatri.

The two-coloured Pinna. Shell elongatcd, slopingly rounded at the margin, radiately ribbed, ribs narrow; rather obsolete, a little flexuous, interstices but littlc. concave; livid-ash, somewhat transparent, rayed with olive-black.

Chemnitz, Conch. Cab. vol. viii. p. 2:34. pl. $4(1,178 \%$. Pima dolabrata, Lamarck.

IIab. Malacca.

This fine species is chictly tharacterized by it: blackrayed painting. 


Pinne, Pl. X.

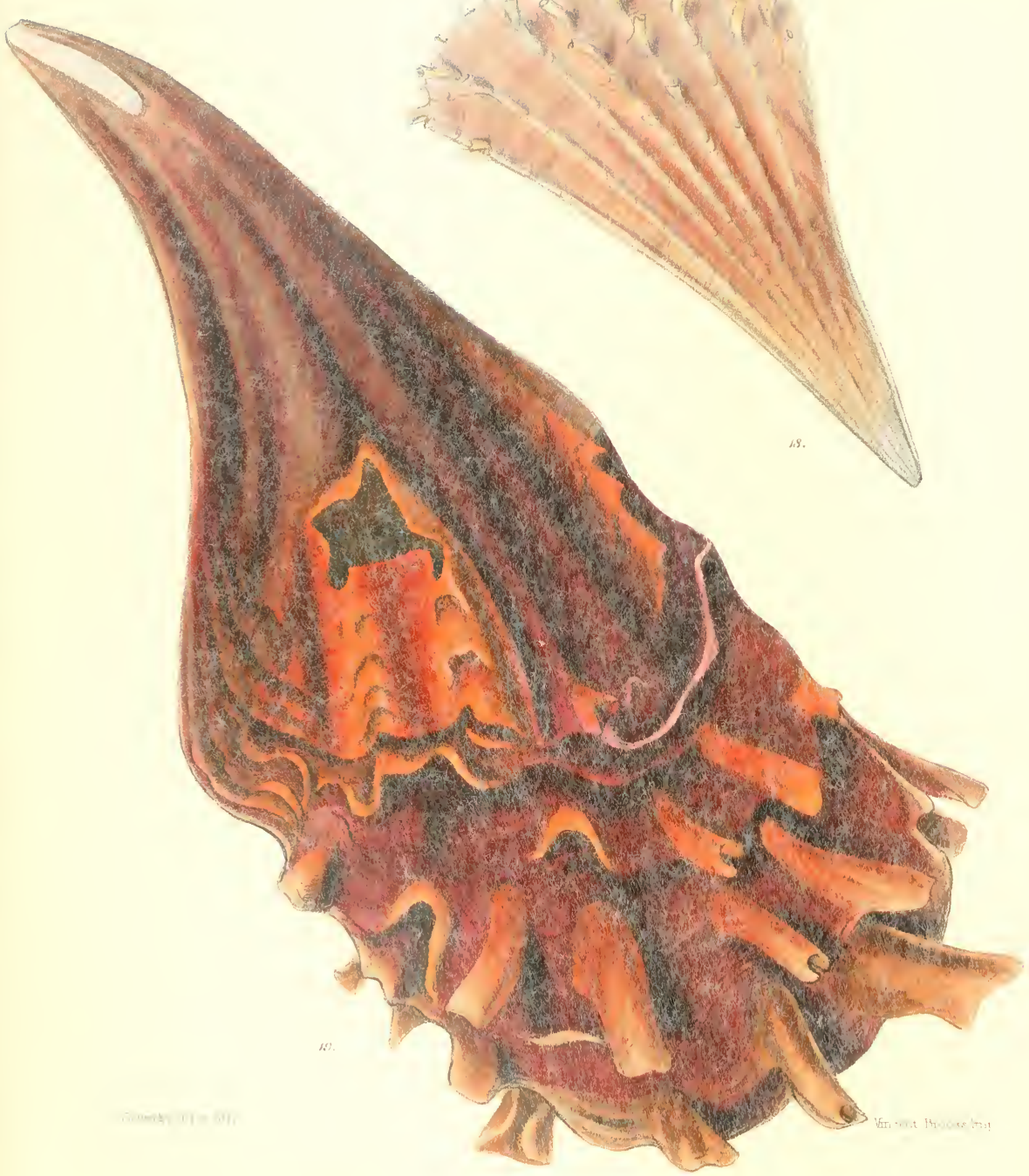




\section{P I I N A.}

\section{Plate X.}

\section{Specters /9. (MHs. C'uming.}

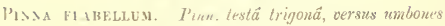
subcontracta, rutiatim roslatâ, cost is tubulato-squanalis, squanis distantitur, erectis: olivaceo-comeá, anrantiu-rufo tinctid.

THE JITTLE PAS PINSA. Shell triangular, rather eontracterl towards the umboes, radiately ribbed, ribs rulularly scaled, seale- distant, ereet; olive-homy. linged with orange-fect.

LAmarch, . Inim. saus vert. vol. vii. p. 61

Pimna hand ignobilis, Clemnitz.

Hab.

A light olive-horny shell, of a compaet triangular form, muntracted into a fan-shape towards the umboes, rather distantly ribhed, the ribs being surmounted with nearly reet unbular sciles.
Species 19. (Mus. ('uming.)

Pinsa rudis. Pinn. testấ rudè fabelliformi, tenuticulâ, subventricusä, obscurè costatâ, costis squamiferis, squawis magnis, irregularibus, semitululosis: aurantio-r'tbente.

The rude Pinna. Shell rudely fan-shaped, rather thin, sonuewhat ventricose, obscurely ribbed, ribs scaled. scales large, irregular, semitubular: orange-red.

Livi.eus, srst. Nat. p. 1159.

Has. Nest Indies.

This fine speeies is distinguished by its very irregular, blistered growth, and deep orange-red colour. The seales, which are large and semitubular, are also of a rude, irregular growtls. 




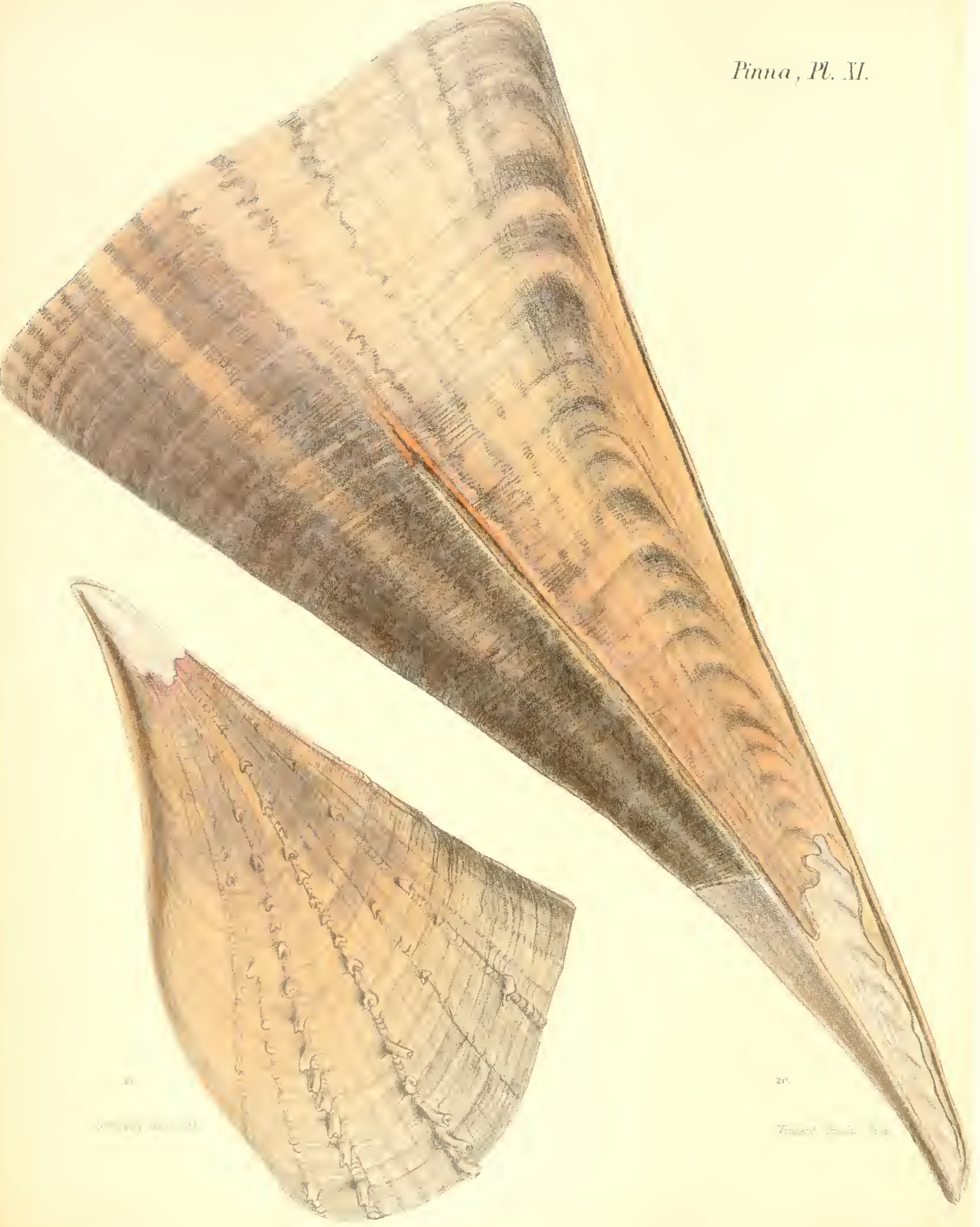




\section{P I N N A.}

\section{Plate 11.}

Speet-20. (Mus, Cuuning.

Pinna Phimpinexsis Pinn. testâ rongato-trigonâ, lateribus rectis vel subincurvis, medio subaculè anguLuto, utrinque dectivi, nudique lovigat $\vec{a}$, submargaritacể; livido-cinerêt. funev-nigricante radiatâ et undutü.

line Pilluppine Pinna. shell elongately triangular, sides straight or slightly incurved, middle rather sharply angled, sloping down each side, everywhere smooth and somewhat pearly; livid-asl, rayed and waved with smoky-black.

Hanley, Pro. Znol. Soc. 1858.

Hab. Philippine Islands; Cuming.

A fine, elongately triaugular shell, conspicuously angularly raised in the middle, and everywhere peculiarly smooth and pearly. In colour it is a dull livid-ash. promiscuously raved and waved with smoky-black.

\section{Species 21. (Mus. Cuming.)}

Pinxa Gouldn. Pinn. testẩ rudè flabelliform, anticè rotundatä, subventricos $\hat{a}$, olivaceo-corne $\hat{a}$, sex-cosfatâ, costis valdè irregularibus, subflexuosis, nune rudè serratis, nunc tubuloso-squamatis.

Gould's PInNa. Shell rudely fan-shaped, anteriorly rounded, slightly ventricose, olive-horny, six-ribbed, ribs very irregular, rather flexuous, now rudely serrated, now tubularly scaled.

Hanley, Pro. Zool. Soc. 1858.

IIab. - ?

Of very irregular growth, and ambiguous specific character.

May, 1858 

Pinna, Pl. III.

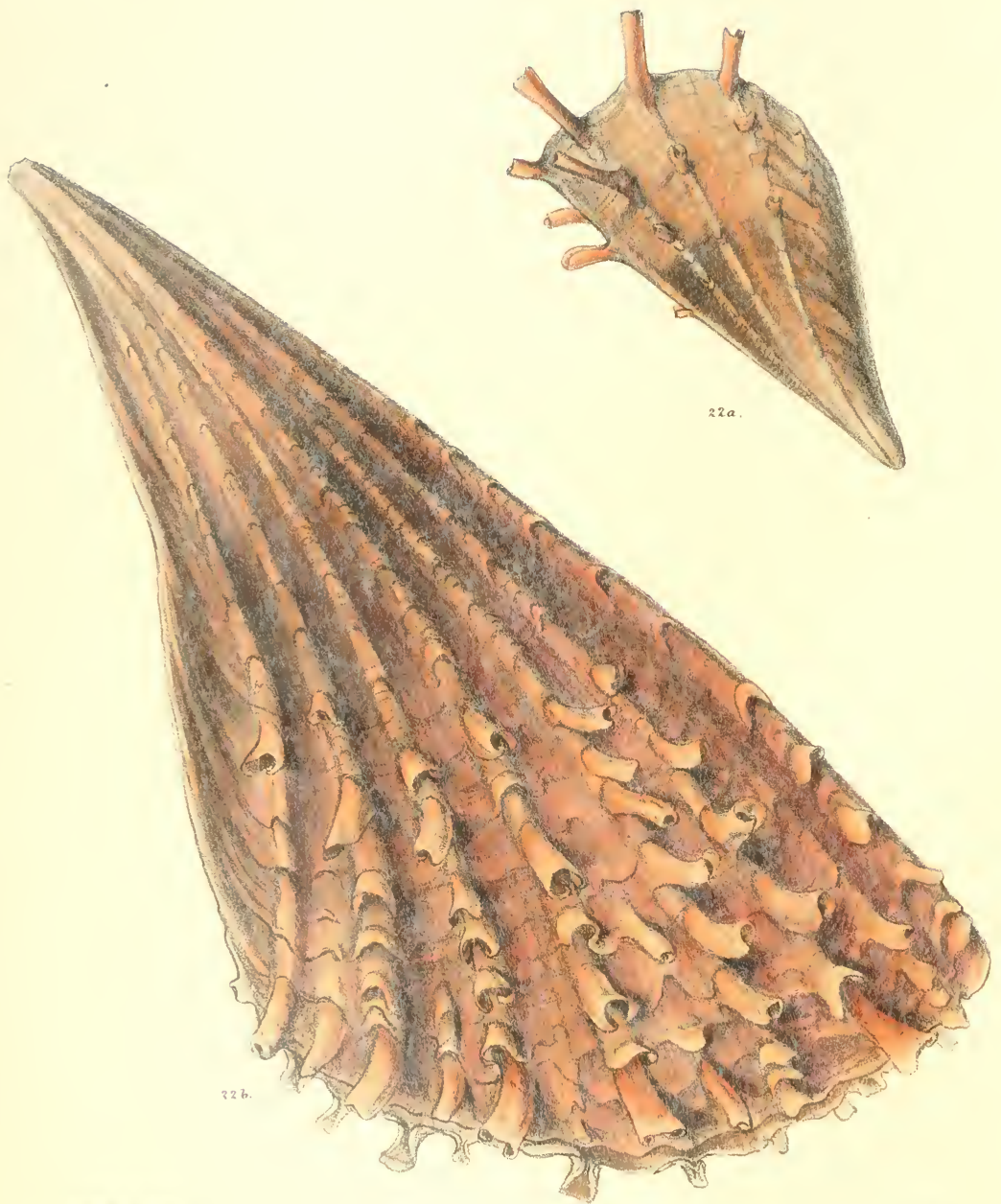




\section{P I N N A.}

Plate XII.

Species 22. (Fig. a, b. Mus. Cuming.)

PiNia penvel. Pinn. testá subelongato-flabrlliformi, tenniculä, ventricosâ, sex- ad septem-costatâ, costis magnis, squamatis, squamis amplis, tubulosis, suthirregutaribus, suberectis, costarum in rrstitiis latè concrovis; vires ente-rubente, squamis olivaceo-flavo tinctis.

THE LitTle ham PinNa. Shell somewhat elongately fan-shaped, rather thin, ventricose, six- to sevenribbed. rihs largc, scaled, scales large, tubular, somewhat urregular, rather erect, interstices between the ribs broadly concave; greenish-red, scales tinged with olive-yellow
Chemattz, Conch. Cab. vol, viii. p. 242. pl. 92. f. 785 . $\mathrm{Hab}$.

It will be seen that in the young state of this species, represented at Fig. $22 a$, the spines are longer and more tubular, and they appear to become broken off or decomposed with agc. This is probably the case with all Piunce, and as the shell advances in growth the seales are developed with less precision, ruder in form and more irregular in position. The Pinna pernula is a deep amber-red colour, somewhat resembling that of $P$. rudis, and the scales have a semitransparent yellowish tinge.

May, 1858. 
. 
Pimma, PI. IIII.

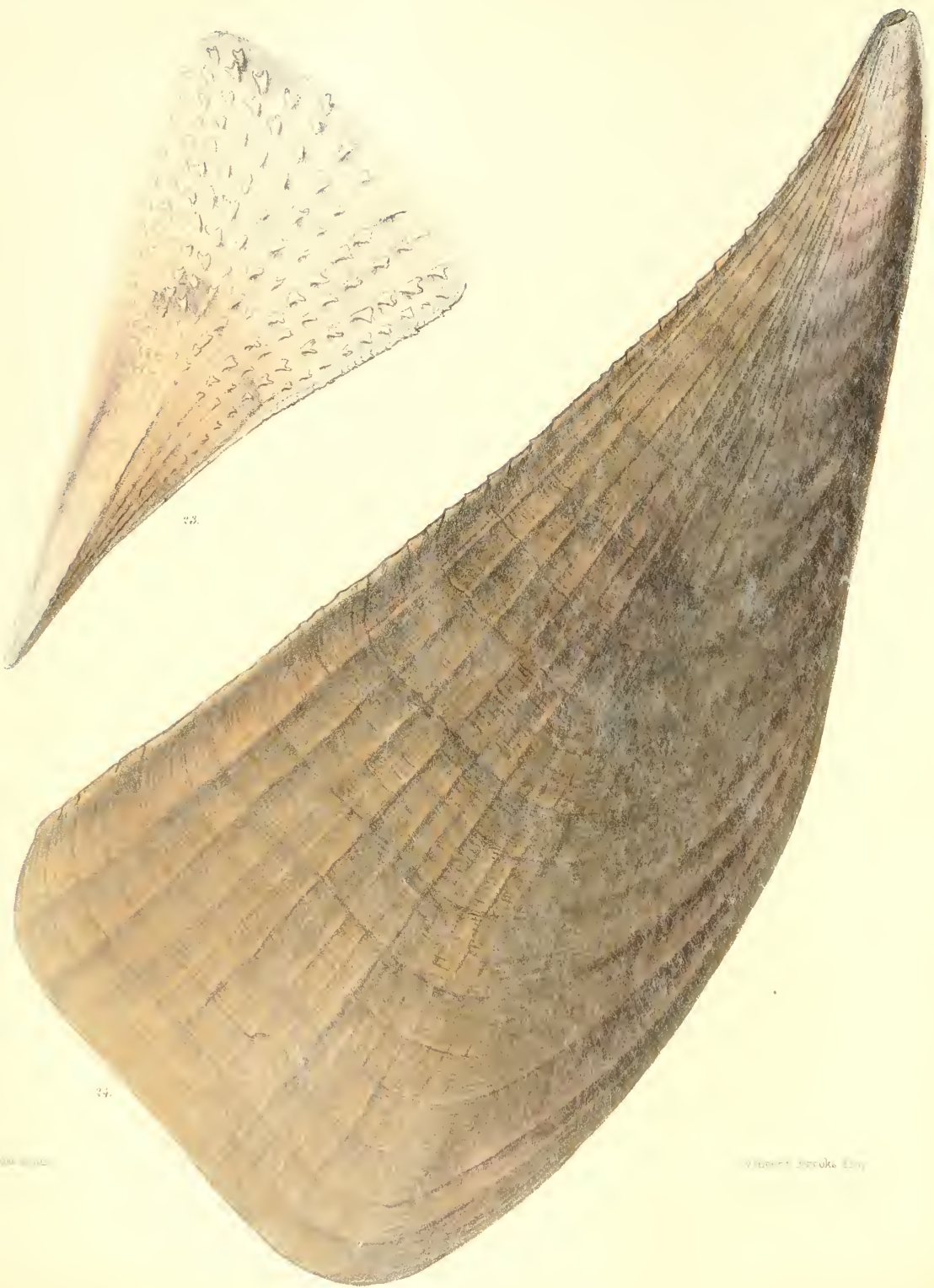




\section{PIN N A.}

\section{Phate XiII.}

\section{Species 23. (Mus. Cumıng.)}

Pinva muricata. Pinn. testâ trigonâ, ad liera szbincurvâ, pellucido-allâa, subventricosâ, abscurè costatâ, costis squamis triunguluribus nitidè armutâ.

Tye prickly PIXNa. Shell triangular, rather incurved at the sides, transparcot whitc, somewhat rentricose, obscurely ribbed, ribs neatly armed with triangular scales.

Linx.fes, Syst. Nat. p. 1160.

Hab. West Indies.

This, according to Chemnitz and Lamarck, appears to be the Liunæan $P$. muricata. It is of semitransparent horny-white substance, neatly scaled, the scales having a peculiarly open triangular growth.
Species 24. (Nus. Cuming.)

Pinna lURida. Pinn. testâ subelongato-fabeltiformi, turido-corneá, temi, subrentricosî, posticè radiatim liratâ, margine subincurvâ, obscure muricatâ. anticè concentricè rugosâ, margine rotundatä.

THE LURID PIxNa. Shell somewhat elongately fanshaped, lurid-horny, thin, rather ventricose, posteriorly radiately ridged, margin rather incurred and obscurely prickly, anterioriy concentrically wrinkled. rounded at the margin.

IIah. Philippinc Islands; Cuming.

This approaches very nearly to $P$. Chemnitzii, but the decussated sculpturc which is characteristic of that species is wanting in the specimen before us. 


Pisma, I', I/I'.

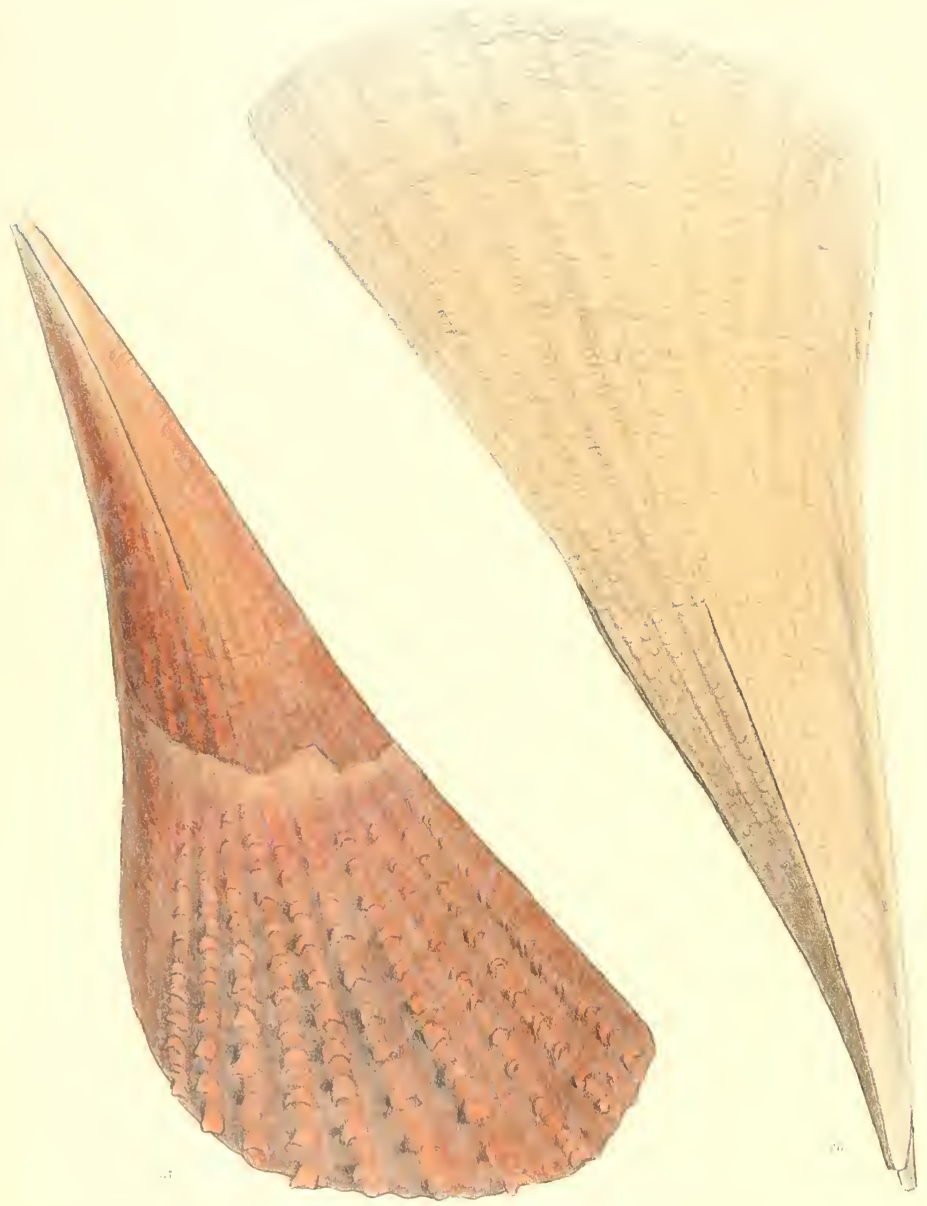




\section{P I N N A.}

\section{Plate Xiv.}

\section{Sipenes as Mus. Cineung.}

Pixina enectrina. F'rin. testit ef mestè flabelliformi, ad latera incurva $r$ raves un hones witio angulato-ventricosiat, radiotim fexthoso-lirotâ, liris furi obsoletis, rersus marginem spumatis, squanis brevibus, patulis; we trino-rutente, variè nulbeulatâ.

PuE amber Prina. Shcll narrowly fan-sbaped, incorved at the sides, atgularly ventricose in the middle torards the umboes, radiately flexuously ridgrd, ridges almest obsolete, sealed towards the margin, scale short, open; amber-red, variously clouded.

Hab. Moluceas.

This very characteristic species, narrowly incurved at the sides, is of an elegant contour, and of a peeuliar elouded amber-red eolour. The seales also are curnonsly short and widely open.

$$
\text { Species 26. (Mus. Cuming.) }
$$

Prnna Zebrensis. Pinn. testä elongato-trigonä, subflabelliformi, tenui, pellucido-corneâ, versus umbones medio acutè angulatâ, deinule liratâ, liris plus minus obsoletis, muticis, andique obscurè nodulatis.

The ZeBU PrNna. Shell elongately triangular, rather fan-shaped, thin, transparent-horny, sharply angular in the middle towards the umboes, then ridged, ridges more or less obsolete, smooth, everywhere obscurely noduled.

Hab. Island of Zebu, Philippines; Cuning.

An elcgant speeies of light transparent substance, sculptured throughont with faint nodules in the place of seales.

May, 1858. 


Pinna, Pl. TI:
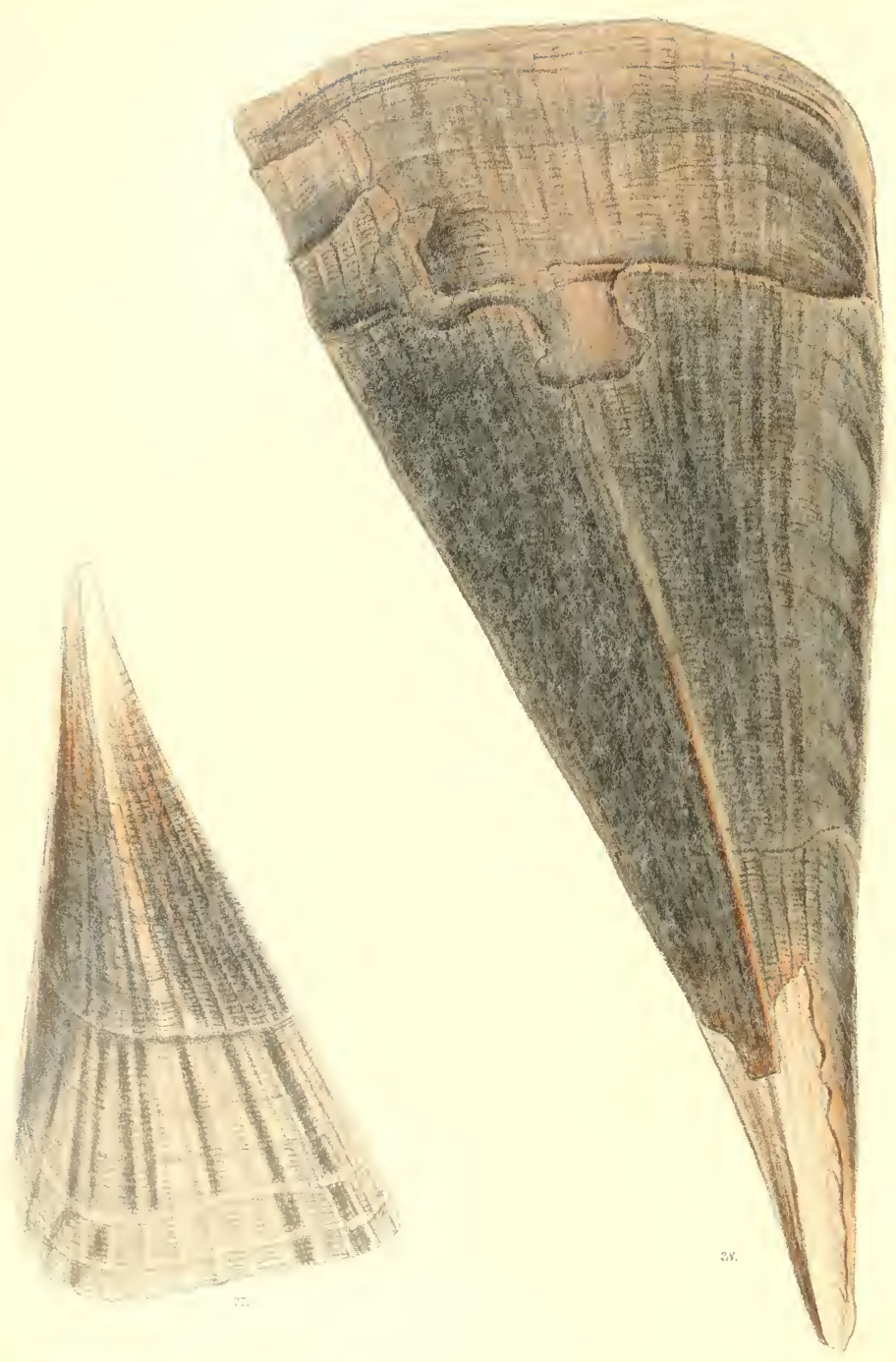


\title{
P I N N A.
}

\author{
Plate XV.
}

Species 27. (lig. 27. 25, Mus. Cumung.

PiNa fimata. Pinn. testâ elongato-trigoná, radialim lirat $\vec{a}$, liris tenuibus, lovibus, subffexuosis, interstitiis. concavis, lineis concentricis densè decussalis, latere antico subrugoso; livido-cinereâ, olinaceo-nigricante fumatâ.

THe SMOKx PINna. Shell elongately triangular, radiately ridged, ridges thin, smooth, rather flexuous, interstices concave. densely crossed with coneentrie lines, anterior side rather rugose. livid-is in smoked will olive-black.

Hanley, Pro. Zool. Soc. 1858.

IIab. San Nieolas, Island of Zcbu, Philippines.

The specific pecubarities of this species are very distinct. the radiating ridges being slight and rather flexuous, with the interstices closely beset with concentrie stria. In colour it has a characteristic smoky hue.

May, 1858. 

Pinnu, Pl. XIT.

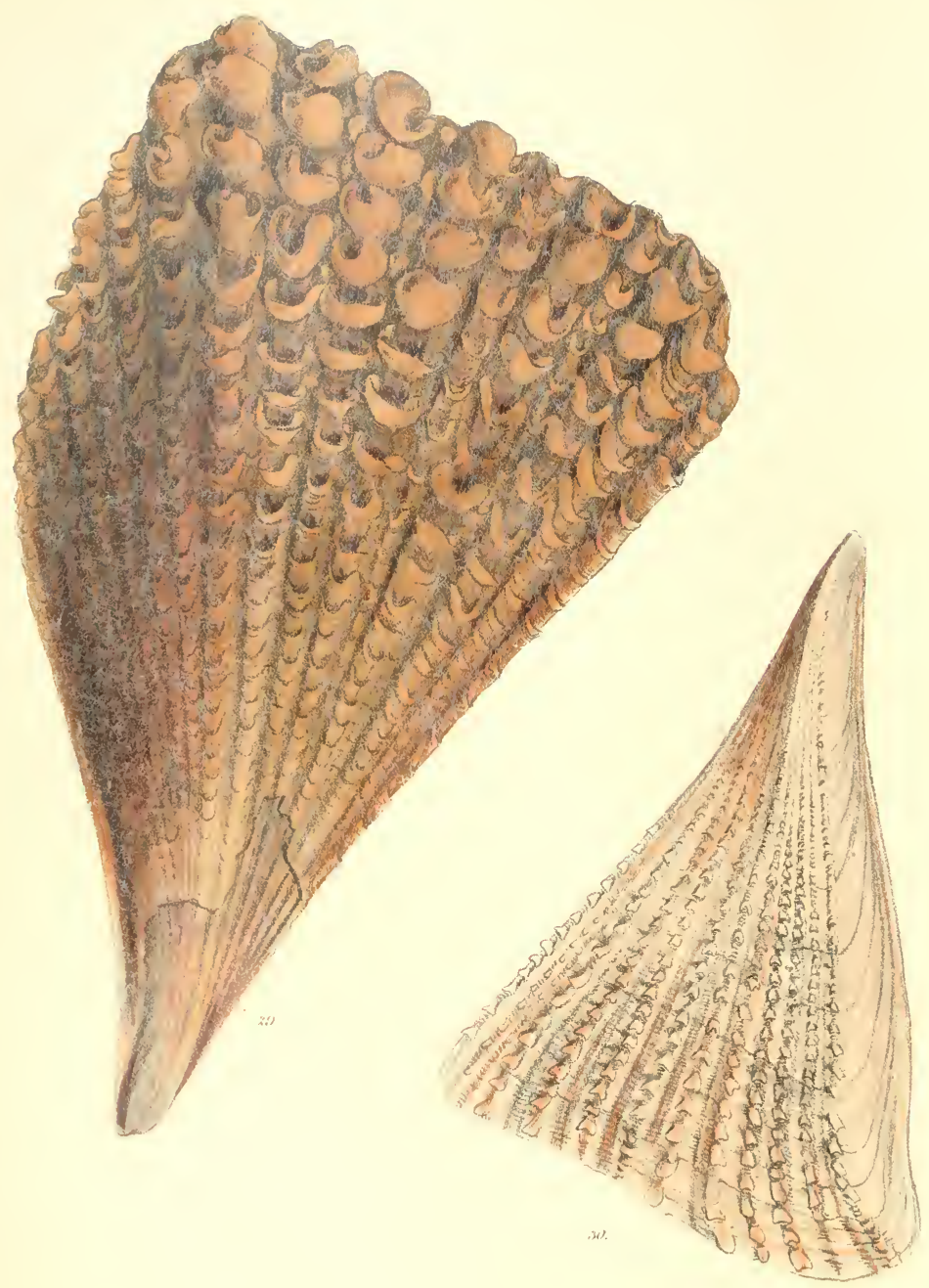




\section{P I N N A.}

\section{Plate ivi}

Freer- 29. (Mus Commg.

Hinxa Comingir. Pinu, testá subquadrato-flabellatâ, rorneâa, vbersâ. zentrirosâ, radiation costatô, costis amplis, rotundutis, densè squen untis, squamis latè inflatis. interdum globosis, interstitiis serratis; tivido-alivacent.

Cuming's PinNa. Shell somewhat squarely fan-shaped, horny, stout, ventricose, radiately ribbed, ribs large, rounded, densely scaled, scales broadly inflated, sometimes globose, interstices serrated; livid-olive.

Hanley, Pro. Zool. Soc. 1859 .

$H a b$. Austratia.

This tine shell is remarkable for its densely-set scales, which are peeuliarly broally inflated, ant near the margin almost globowe
Species 30. (Mus. Cuning.)

Pinna semicostata. Pinn. testá trigonâ, prope umbones acutè ventricosá, albicante-comeâ, fascïs mufescentefuscis interitum radiatâ, temuicostatâ, liris squanis: parvis patulis obsitis, latere antico mutico.

The half-ribBed PiNina. Shell triangnlar, sharply ventricose ncar the umboes, whitish-horny, sometimes raved with reddish-brown binds, finely ribbed, ribs beset with small open scales, anterior side smooth.

llab. Philippine Islands; Cuming

A light silvery horny species of an unusually abrupt triangular form, sometimes rayed with light brown bands, beset with seales, which are short and open. 

• 
Pinna, Pl. XVII.

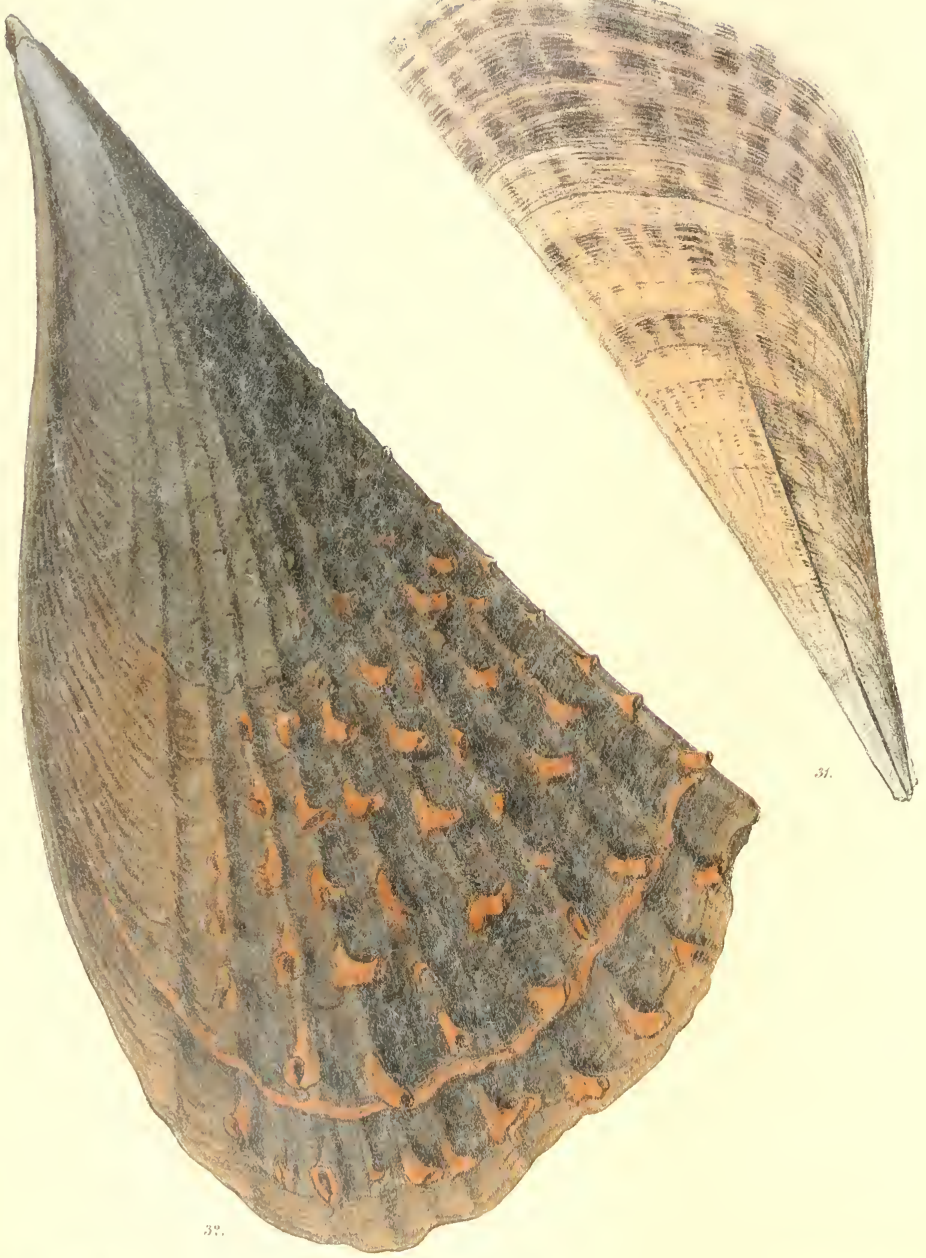




\section{P I N N A .}

\section{Plate XVII.}

Groces in (Mus. Giming.)

i'INNA Madida. Pinn. testâ obliquè trigonâ, subangustâ, ad latern incurcha, versus umbones ncutè elevatâ, tenuiculä, densè concentric' lamellatâ, lamullis appressis. subolsolvtis, radiatim olscurè unduto-lirata $\vec{a}$;ividocinere $\vec{a}$. radiis fumeo-nigrescentibus interruptis.

TUE SODDEN P'INAs. Shell ollliquely triangular, rather narrom. incurved at the sides, sharply raised towards the urivoes, rather thiu, densely concentrically lamel. lated lamella appressed, rather obsolete, radiately obscurely wave-ridgral; livid-ash, with interrupted smoky-llack rays

Hab. Port Essington, New Ilolland.

The concentric lamelle of this species do not appear to be analogons to the scales which predominate in this genus, but are an unusual devclopmert of the layers of growth.
Species 32. (Mos. Cuming.)

Pinna subviridis. Pinn. testâ trigono-flabellatat, margine postico incuroo, antico rotundato, radiatim cos. tatâ, costis squanutis, squamis grandibus, recurtis, sublubutosis. costarum interstitiis latè concavis, latere antico conspicuè concentricè corrugato; olivaceo-viridi. subpellucidâ.

The greenish Pinna. Shell triangularly fam-shaperl. posterior margin incurved, anterior rounded, radiately ribbed, rilss sealed, scales large, recurved, some what tubular, interstices between the ribs broadly concave, anterior side conspicuously concentrically wrinkled; olive-green, rather transparent.

IIab. Sonth Carolina.

A fine semitransparent olive-green species, boldly ribbed and scaled, with the anterior side closely concentrically wrinkled. 

Pinna, Pl. ITIII.

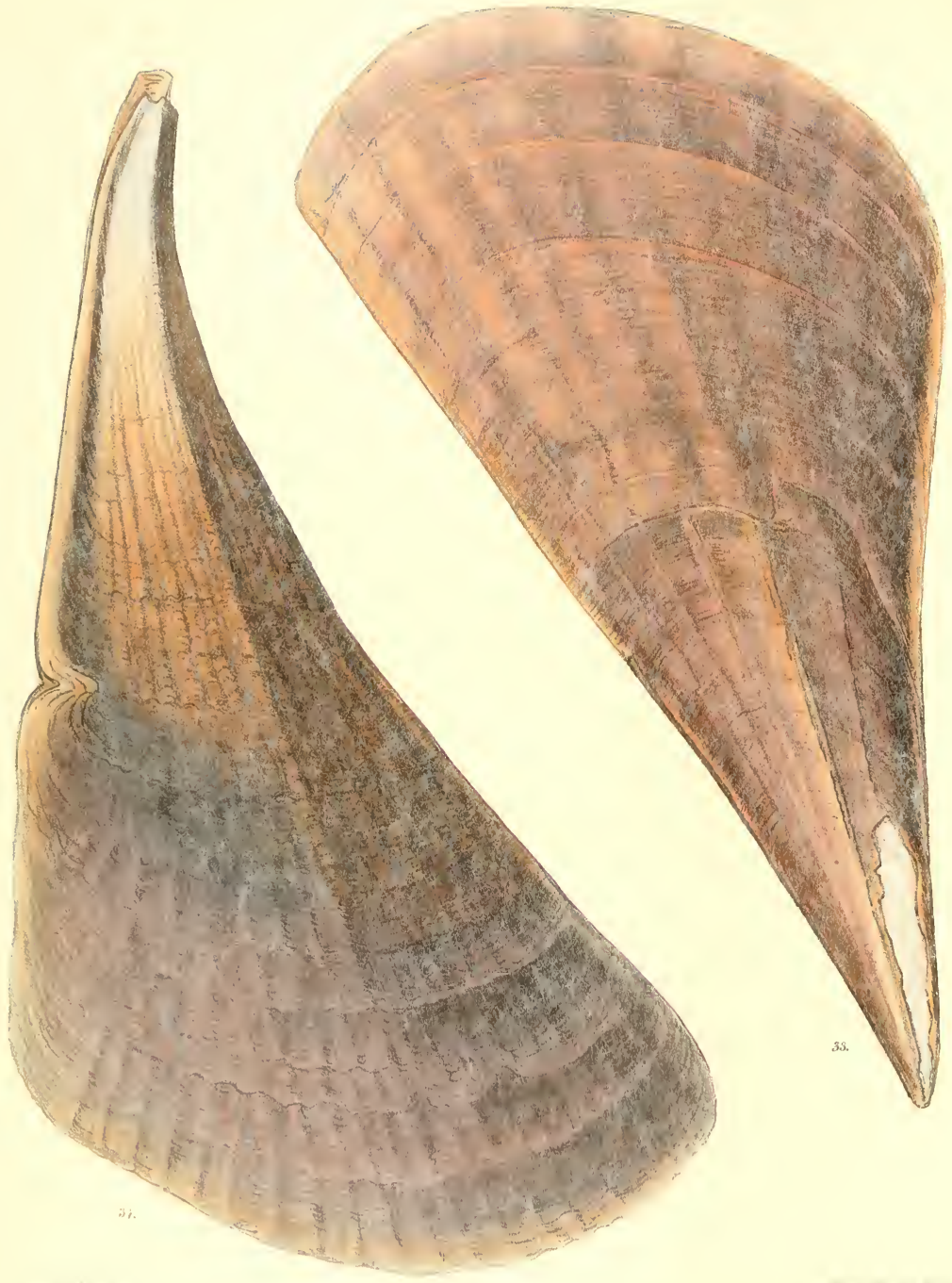




\section{P I N N A.}

\section{Plate XVIII.}

\section{Species.4 (Mtus. Cuming.)}

Pix:a nutica. Pinn. testü elongato-trigonâ, subobliquâ, lavigatä, radiation undato-liratá, liris paucis, anticè plus minus obsoletis: rufescente, fumeo-fusco tinctá.

Tне sмооті Pinna. Shell elongately triangular, rather oblique, smooth, radiately wave-ridged, ridges few, anteriorly more or less obsolete, reddish, tinged with smoky-brown.

Hab. Island of Negros, Philippines; Cuming.

A smooth, dingy-red species, rayed with ridges, which are rather distant, and towards the nmboes are regular, hut about the mildle of the shell they become waved, and anteriorly altogether disappear.
Species 34. (Mus. Cuming.)

Pinna Menkej Pinn.testâ subtrigonâ, curvato-fabellata. margine postico valde incurvo, radiatim liratä, liris confertis, subrudibus, undatis, anticè irregulariter rugosâ; rufescente-cinereû, fumeo-nigrescente tinctâ.

Menke's Pinna. Shell somewhat triangular, curvedfanshaped, posterior margin much incurved, radiately ridged, ridges close-set, somewhat rude, waved, anteriorly irregularly rugose; reddish-ash, tinged with smoky-black.

Hanley, Pro. Zool. Soc. 1858.

$\mathrm{Hab}, \mathrm{L}$ ?

Chiefly distinguisleed by its curved form and close-set wave-ridged sculpture. 
Pinna, 1". U1.

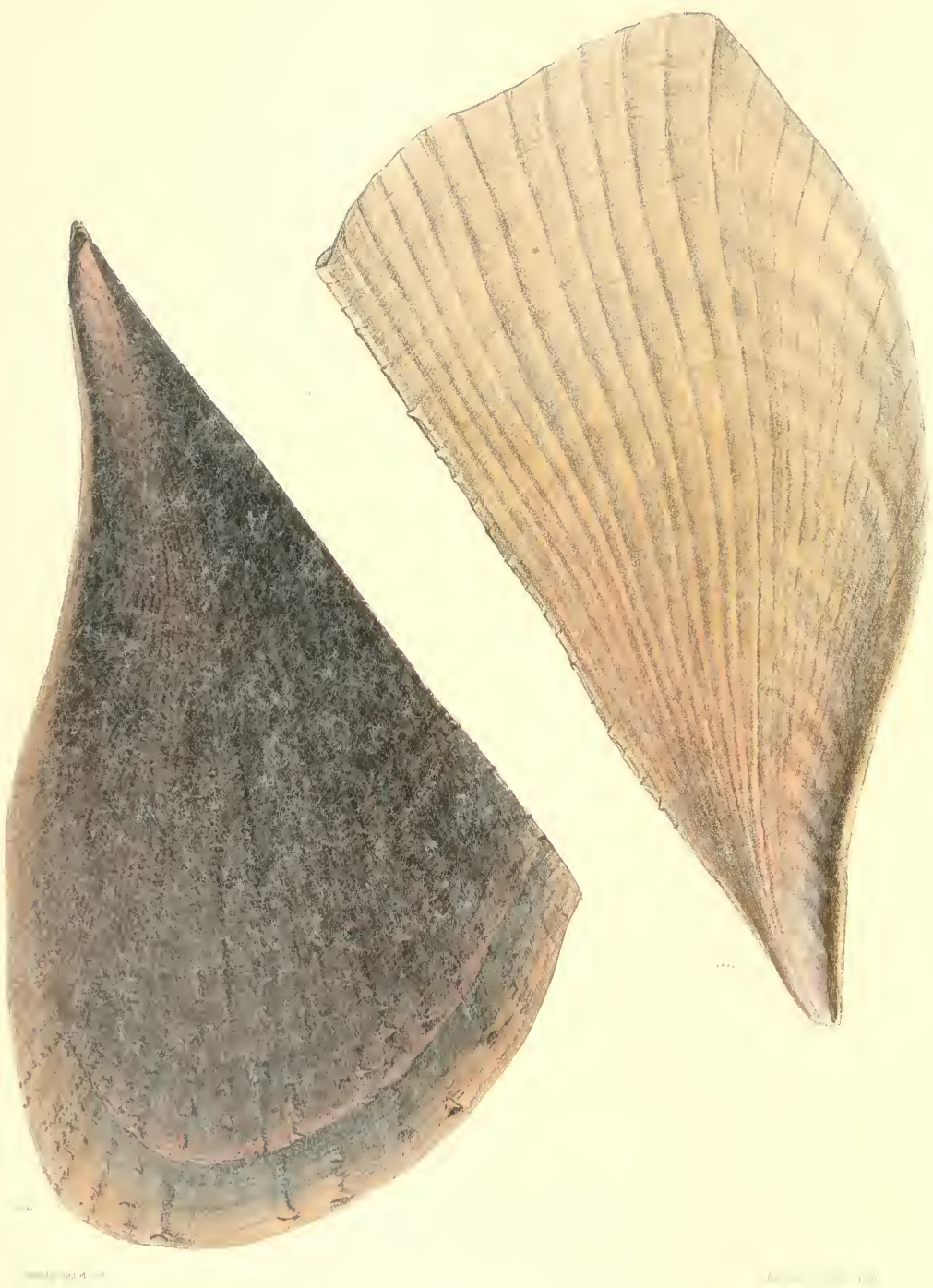




\section{P I N N A.}

\section{Plate XIX.}

\section{Stantes 35. (Mus. Cuming.)}

PINNa TRINoita Pinn. testấ rudi fabellatä, subventricasâ, tenur livido-olinace $\hat{a}$, semipellucidâ, radiatim 'iratâ lerk subangustis, regularilus, interstitiis concants, tirus onteis tenuioribus, margine postico squamato.

The truncaten Pinna. Sluell rudely fan-shaped, rather rentricos: thu, livid-olive, semitranspareut, radiately ridged. ridges rather narrow, regular, interstices coneave, anterior ridges thinuer, posterior edgc scaled.

Pinilippi, Enum. Moll. vol. ii. p. 54. pl. 16. f. 1.

Hab. Mediterranean.

A thin, semitransparent, olive shell, sculptured regularly throughout with narrow ridges, which are thinner on the anterior side.

\section{species A6. (Mus. Cumug.)}

Pinna vexilutim. Pinn. testât trigono-flabellates, metion subventricosâ, radiation liratâ, liris parcis, raldè irregularibus, irregulariter muricato-squamatis, latere untico promiscuè rugoso-striato; nigrâ, versuss mar gines ferrugineá.

The flag Pinna. Shell triangularly fan-shaped, sume what ventricose in the middle, radiately ridsed ridges small, very irregular, irregularly prickly-scaled, anterior side promiscuously rugoscly striated; black rusty towards the edges.

Born, Mus. Vindobonensis, pl. 7. f. «.

Hab. Amboyna.

A black, rusty-edged sticll. ridged and prickly-scalcd with singular irregularity.

June, 1858. 


Pimu, , P. .T.

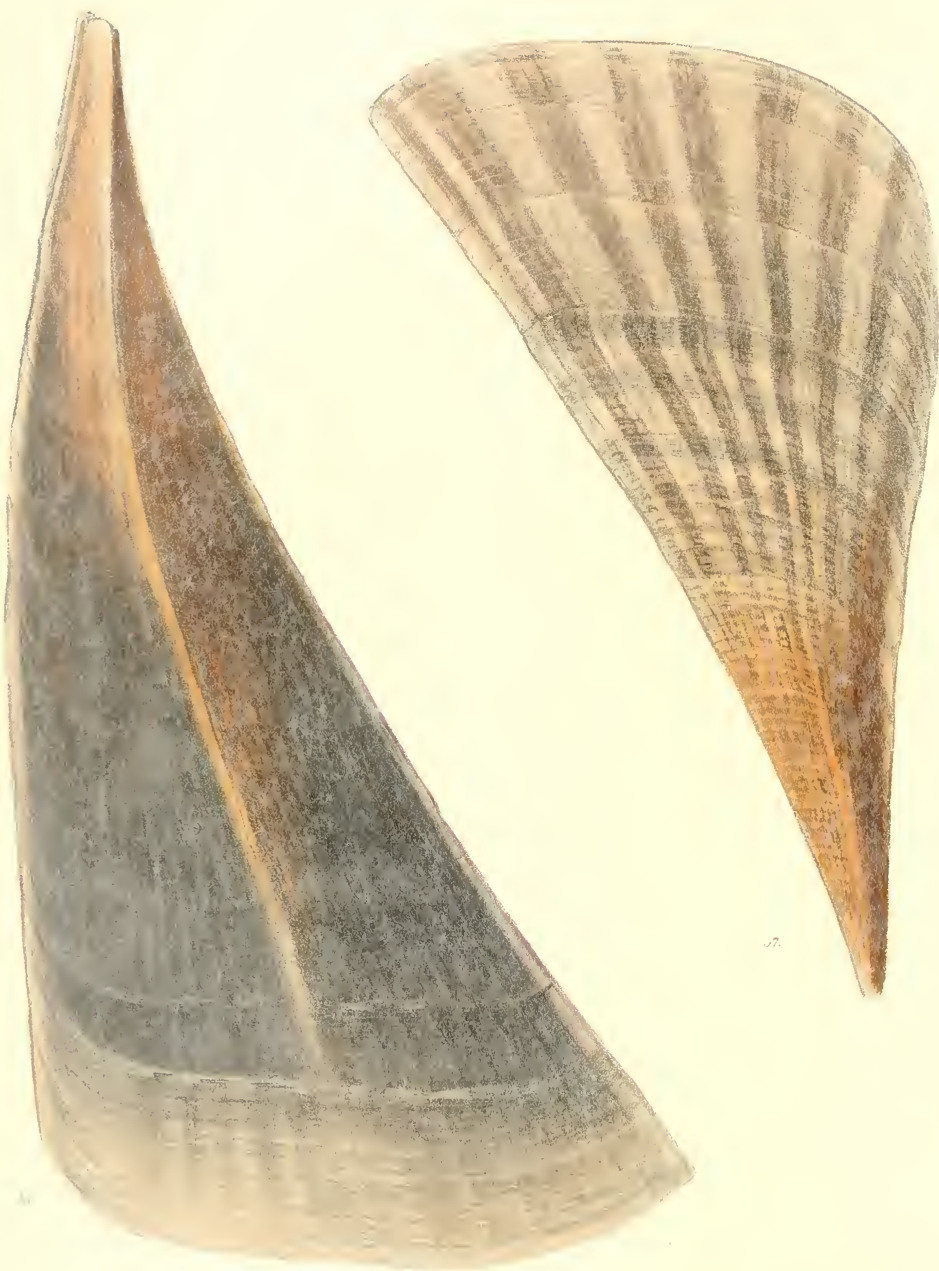




\section{P I N N A.}

\section{Plate XY.}

ᄀyeun- 37 (Fig. i7, 38, Mus. Cuming.)

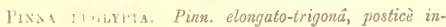
curva $\hat{i}$, rersus umbones medio angulato-elevatâ, et ulringus lirut $\vec{a}$, lecvigatâ, plus minus pellucidâ, minutisstal cuncentricè striat $\hat{a}$, livido-cinereâ, versus umhomex $j / u$. minus vividè olivaceo-flavescente fumeofusere unt linetât aut undato-radiatä.

THE CARVED PINNA. Shell elongately triangular, incurved postcriorly, angularly raised in the middle and ridged on each side towards the umboes, smooth, more or less transparent, very minutely concentri- cally striated; livid-ash, more or less bright oliveyellow towards the umboes, stained or wave-rayed with smoky-brown.

HANLeY, Pro. Zool. Soc. 1858.

Hab. Amboyna.

A very characteristic species, allied to $P$. fumata. In the young specimen, it is a delicate translucid texture, coloured towards the umboes with a bright olivaceous amber, and the peculiar smoky-brown which is not uncommon to this genus is disposed in gracefully waved rays. 


Penna I'I . . .

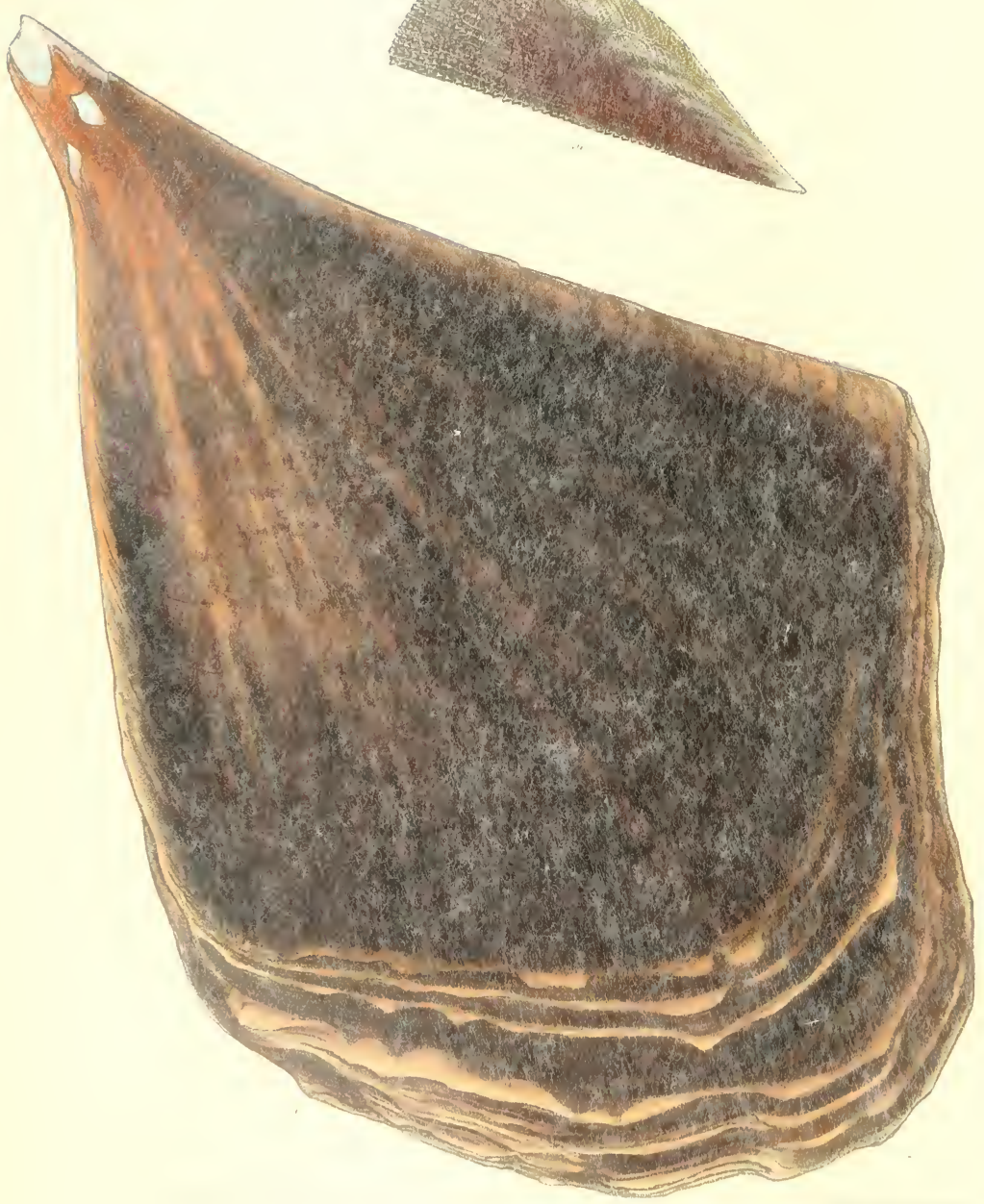




\section{P I N N A.}

\section{Plate X.il.}

Species 39. (Mus. Cuming.

P'IN: A PENxis. Pinu. testû́ olilongo-trigonâ, tenu, densè liratö, liris squamis minutis densissimè obsitis. latere antico subruyosu-corrigato; olinaceá. rersus umbones purpurnseente-rufiti.

THe litrle wing PrNna. Shell oblong-triangular, thin, densely rulged, ridges very thickly set with minute scales, anterior side somewhat roughly wrinkled; olive, purple-red towards the unboes.

Hab. Philippine Islands; Cuming.

The shell here figured is probably in a young state, but the sculpture is too characteristic to allow of its being excluded from the monograph.
Specics 40. (Mus. ('uming.)

Pinna deltodes. Pinn. testä latè trigono-flabellutu, rule planatû, radiatim costatâ, costis irretfularibus, fierì obsoletis; rubido-fuscâ, ferrugineâ.

The Deltord Pinna. Shell broadly triangularly fanshaped, rudely flattened, radiately ribbed, ribs irrugular, almost obsolete; redc'ish-brown, rusty.

Meske, Moll. Nov. Holl. p. 37.

Hab. Near Victoria River, west coast of New Holland.

A shell of very rough peculiarly flattened structure, broadly triangular, characterized by an olsolete radiation of irregular tumid ribs. 




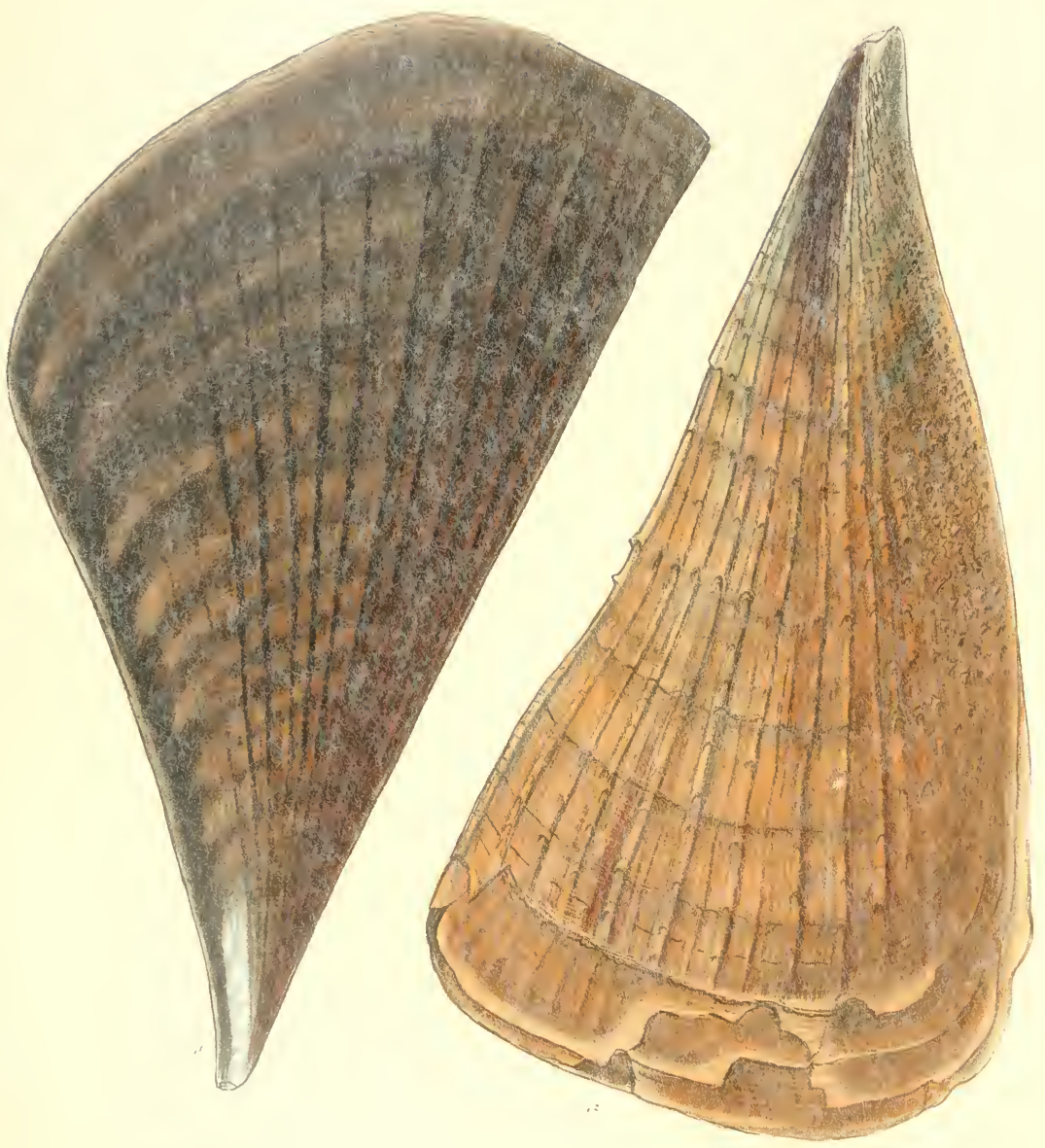




\section{P I N A.}

Plate XXII.

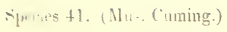

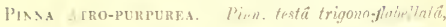

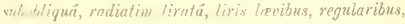
lut.are antico mutico; atro-purpureat.

JIII DARK-PI KPLt. PINNA. Shell triangularly fanshaped, rather oblique, radiately ridged, ridges smooth, regular, anterior side not ridged; dark purple.

-owensy, Tankerville Catalogue, Appendix, p. 5. no. $531 a$.

Han Iinboyute.

This species is well characterized by the peculiar regularity of its ridged sculpture, and by its dark purple coinuring.
Species 42. (Mus. Cuming.)

PINNA PECTINaTa. Pim, testä trigoná, subventricosâ, radiatim liratî, liris subcontortis, sparsin squamatis, latere antico rugoso et nuricato-squamoso; semipellucido-olivaceấ.

The pectinated Pinna. Shell triangular, rather ventricose, radiately ridged, ridges somewhat twisted, sparingly squamate, anterior side rough and prickly sealed; semitransparent-olive.

LiNn æus, Syst. Nat. p. 1160.

P'ima inflato, Chemnitz.

Hah. Britaiu.

In many cxamples of this species the anterior side is curiously blistered. The shell is rather light and ventricose, and of somewhat irregular growth. 
- 



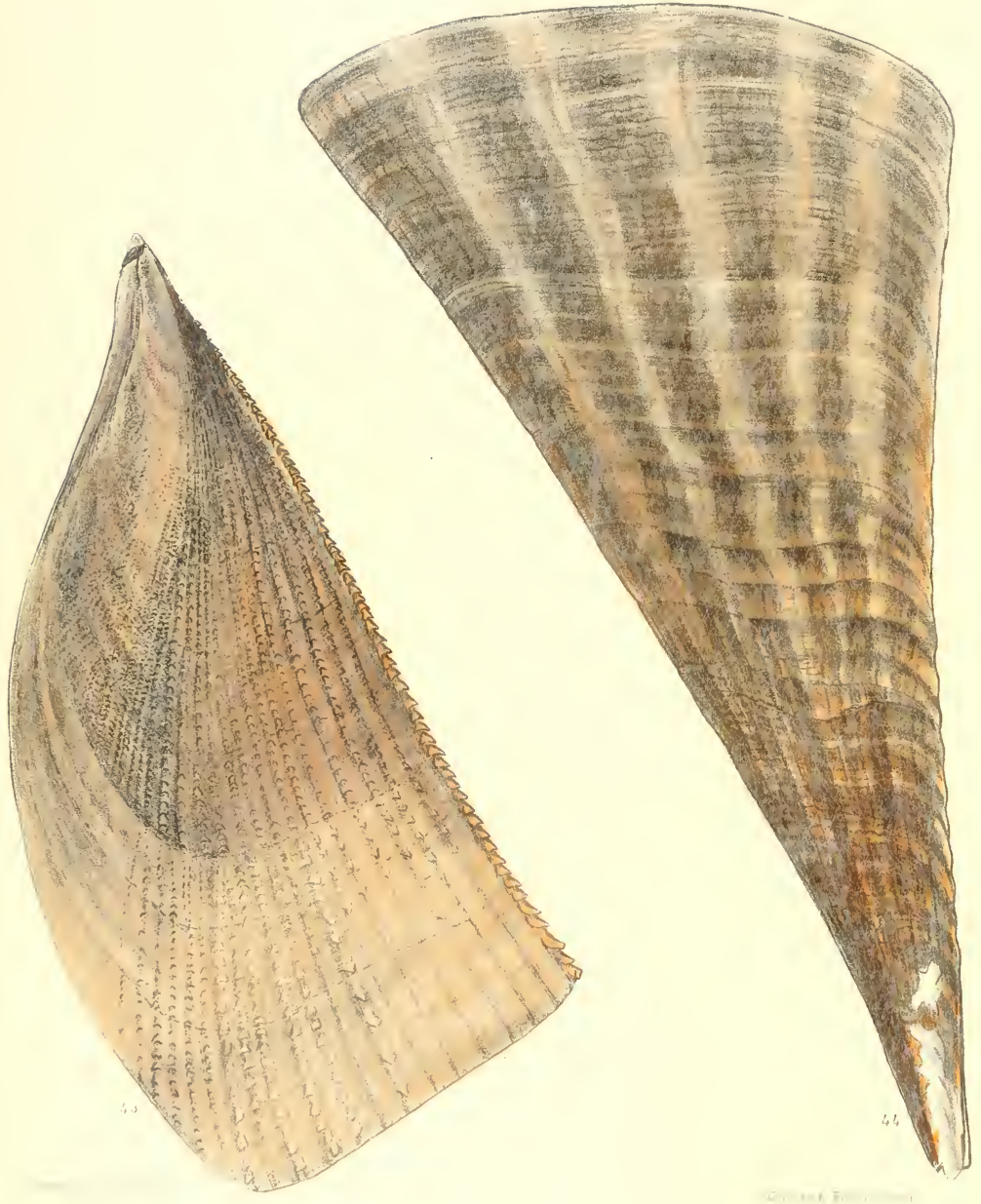




\section{P I N N A.}

\section{Plate NAlli}

\section{Species fit (Mus. ('inging.)}

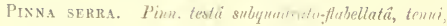

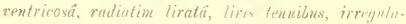
ribus, densè squamatis, squamis purtis, breribus, margine postico syuamis grandioribes dense servolo, lutere antico tumidinsculo, peculiariter minutè squanalo-reticulato; pellucito-olirareá.

Tize saw PInNa. Shell somewhe squarely fan-slaped, thin, ventricose, rudiately ridged, ridges thin, irregular, densely scriled, seales small, short, postenor edge denscly serrated with hurger seales, anterior side rather swolleu, peen larty muntely senle-reticulated; transpareut-olive.

IIab. Moreton Bay.

A light transparcut-olive shell somewhat irregularly sculptured with small prick!y seals, having the posterior edge regnlarly closely set throughout with seales of a larger size.

Species 44. (Mus. Cuning.)

Pinna vespertina. Pinn. testât elongato-trigond. wi: lalera subincurvâ, prope unijones liratâ, deinde lavyotâ; olivaceo-cinere $\hat{a}$, rodiis fumeo-fuscis ef floxessmtibus ornatâ.

Tile sunbeam Pinva, Shell elongately triangular, ratther incurved at the sides, ridged towards the nnboes, then smooth; olive-ash, oruamented with rilys of smoky-lrown and yellow.

II $\mathrm{l}$ b.

$\Lambda$ beautifully-eolonred speries, partaking of the characters of $P$. fumata and $P$. euglypta. 




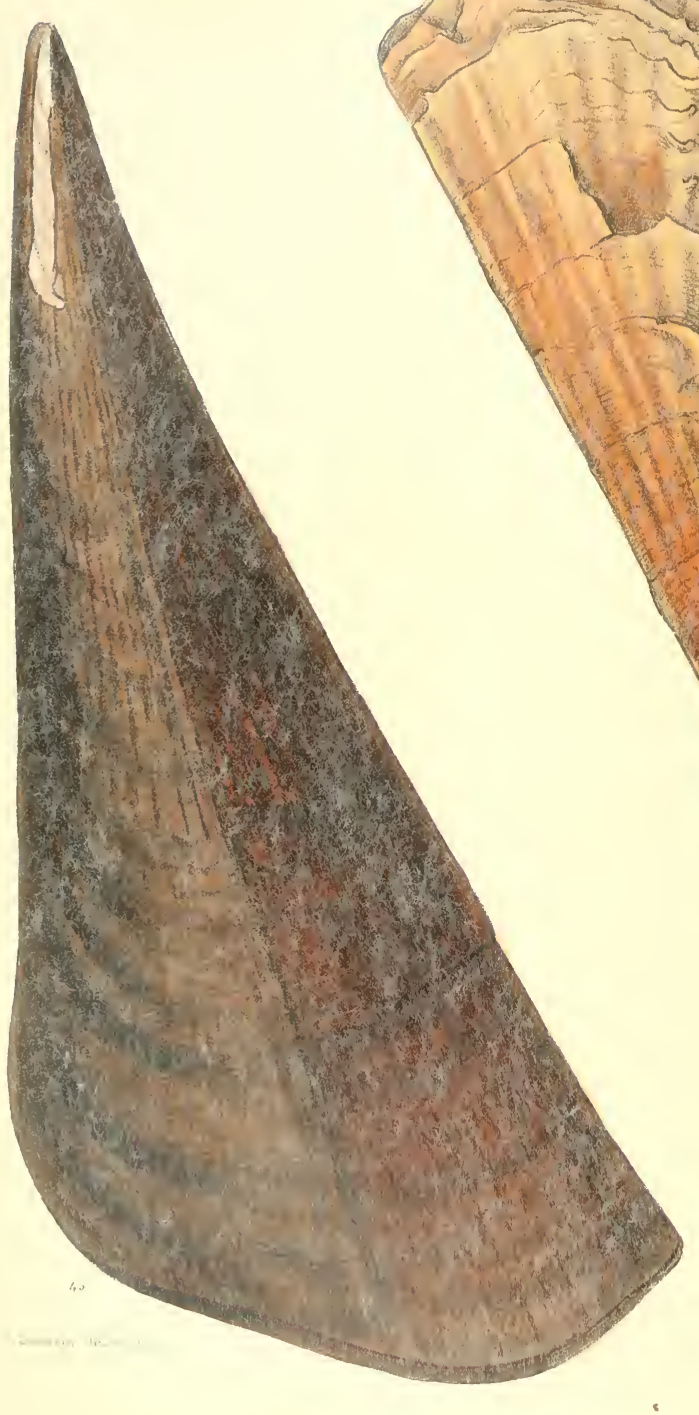

Pinua Pl XXT 


\section{P I N N A.}

Plate XIIV.

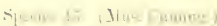

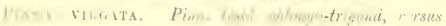

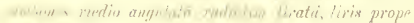

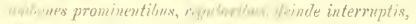

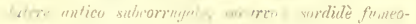
wa.

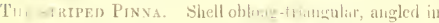

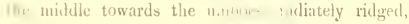
rimes near the umboes promin: at inul regular, then onrtrupted, anterior sicle somewhit wriuhled, inweited dull smoky-brow:1

Ilr. Kr, Moll. Nov. Holl. p. 36i.

1lai). 1-laud of Vegros: ( uming

A dark, diugy sne res, ehiefly distingui-hed by the inarupted charaeter of the radiationg ridge-
Species 46. (Mus. Cuming.)

Pinna atrenuata. Pinn. lestâ elonguto-fabellatá, latere postico radiatim costato, antico concent ricè plicatocorrugato, versus extremitatem interdum pauci-squamato; favicante-oliraceá.

Tile attenuated Pinna. Shell elongately fan-shaped, posterior side radiately ribbed, anterior concentrically plicately wrinkled, sometimes sparsely sealed towards the extremity; yellowish-olive.

Hab. Moluceas.

There is no indication of scales in this species, except towards the anterior extremity : and that is not always the case. 



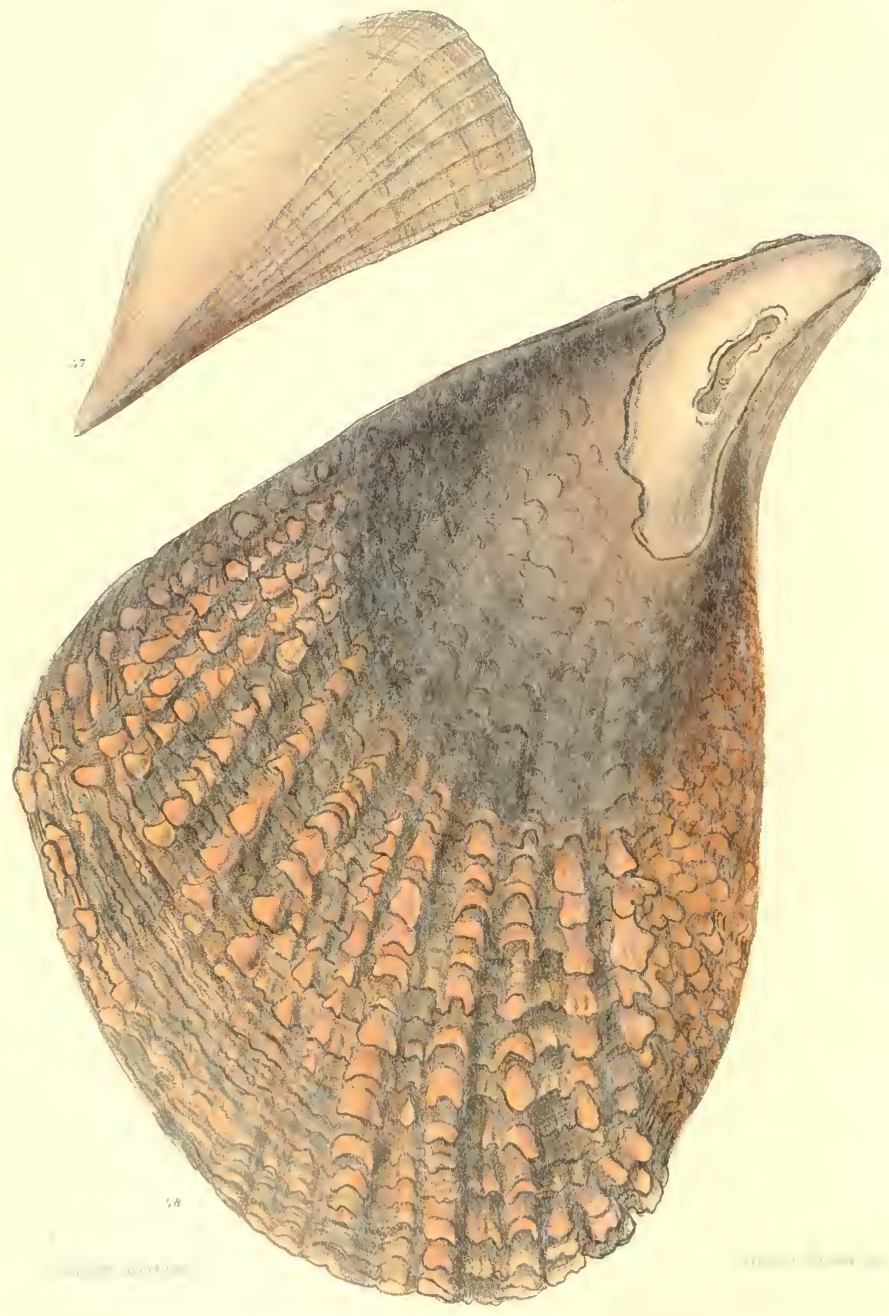




\section{P I N N A.}

\section{Plate XXV.}

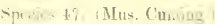

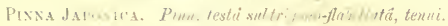

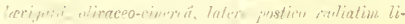

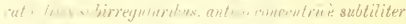

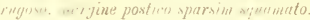

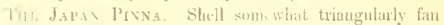
shitwod, thin, smootb, olivi-ash, posterior side radiately ridued, ridges rither irrecrular, anterior side roneutrically finely rugose, posterior margin sparsely saled.

Haxicy, Pro. Zool. Soc. $185 \mathrm{~s}$

Hab. Japan.

This has very much the appearanee of a young shell. It is of a semitransparent horny substanee, distinctly rayed with flattened ridges ou the posterior side, and faintly eonceutrically rugose ou the anterior. sjecies 48. (Mus. Cumuus.)

Pinna tuberculosa. Pinn. testï subrotundato-trigoná, fusco-nigricante, sipumulis pallidioribus obsoletè subradiatâ, squanulis foluceis, brecibus, posticè incurvis, fornicatis, tubercula simulantibus.

The tUBercled PINNA. Shell somewhat rotundately triangular, fuscous-blaek, obsoletely rayed with scales of a paler colour, seales foliaceous, short, posteriorly curved inwards, vaulted, resembling tubercles.

Sowerby, Pro. Zool. soc. 1535, p. 84

Hab. Pauama (obtained from muddy banks); ( uning.

Chiefly distinguished by the peculiarity of its scales, which are short and vaulted, extremely irregular, and of a ycllowish-white hue upon a rusty-black ground. 
. 



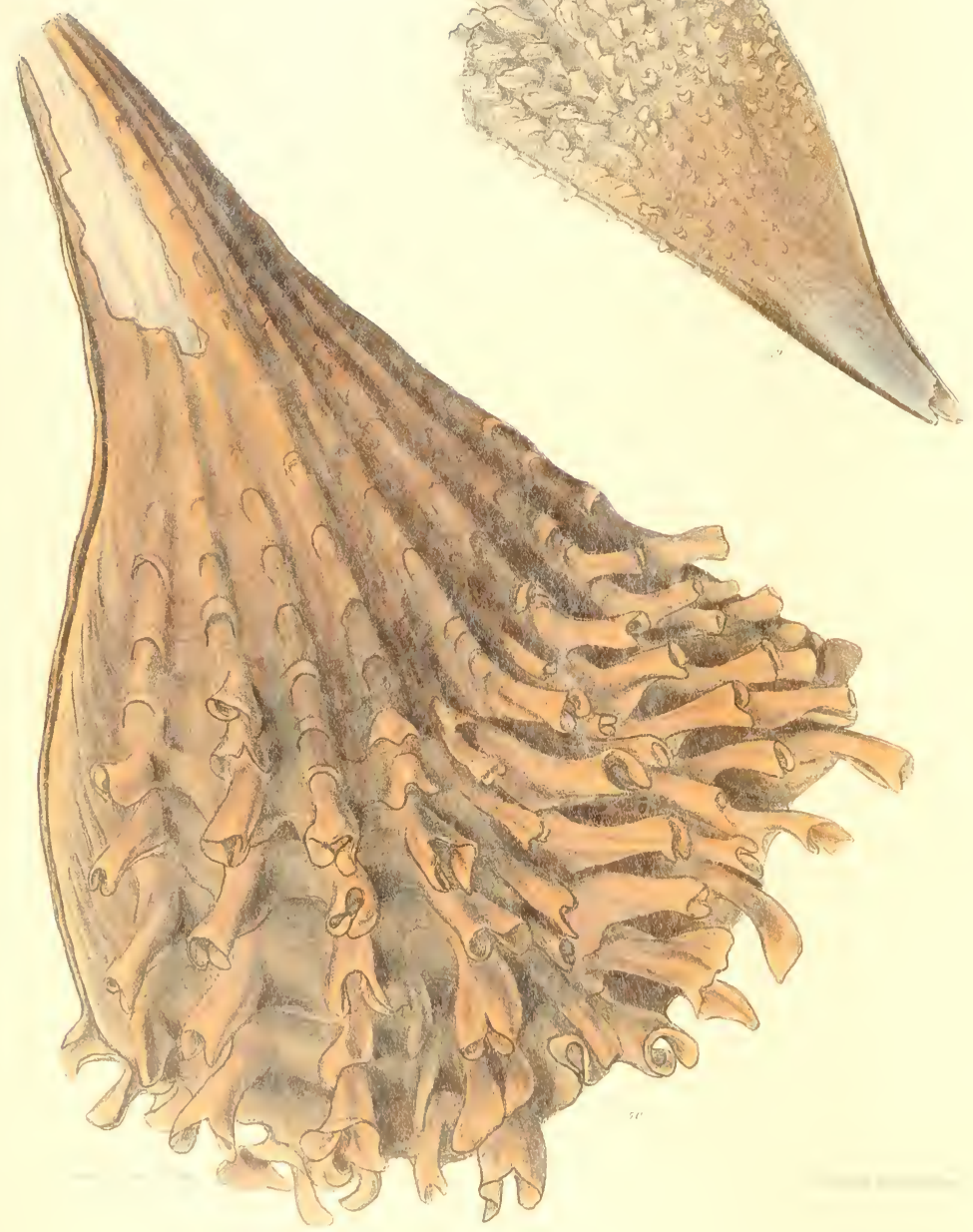




\section{P I N N A.}

Plate Xivi.

sirecu 49. (Mu foming.,

PINTA 1)'Orbignyi. Pimn. testä, Jungust trigomâ, ven-

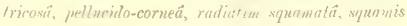
rerses marginem spathulatis, prominentibus, rarie lortuosis.

IYOKBIGNY's P'INNA. Shell somewhat narrowly triangular, ventricose, transparent-horny, radiatcly scaled. scales towards the inargin spathulate prominent, variously twistcel.

HaNle1. Pro. Zool. Soc. 1858.

IIab. West Indies.

The scales of this species are characteristic They become gradually cnlargeil towards the margin, spathulate and variously twisted, first on one side, then on the otber.
Species 50. (Mus. Cunng.)

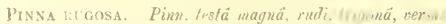
unbenes contractä. longitudiuntiter ânusè rudiut m. rostatâ, restis versus marginem squaniferis, squmat. magnis, rlongatis, irregularibus, subrecnrtis, foliow... tubulosis.

'l'uE rovgh PINna. Shell large, rude, triangular, worr tracted towards the umboes, lougitudinally, obture?! radiately ribbed, rils full of sciles towards the mar crin, seates large, clongated, irregular somewhat re curved, foliaceous, tubular

Sowerby, Pro. Zool. Soc. 1835, p. 84.

Ulab. Isle of Rey, Bay of Panana (trom sand-banks). Cuming.

This interesting species, remarkable for the bold, folitceous, tubular growth of its scales, is sometimes a foot and a ball in length. 




\section{Pinmu Pl IITIII}

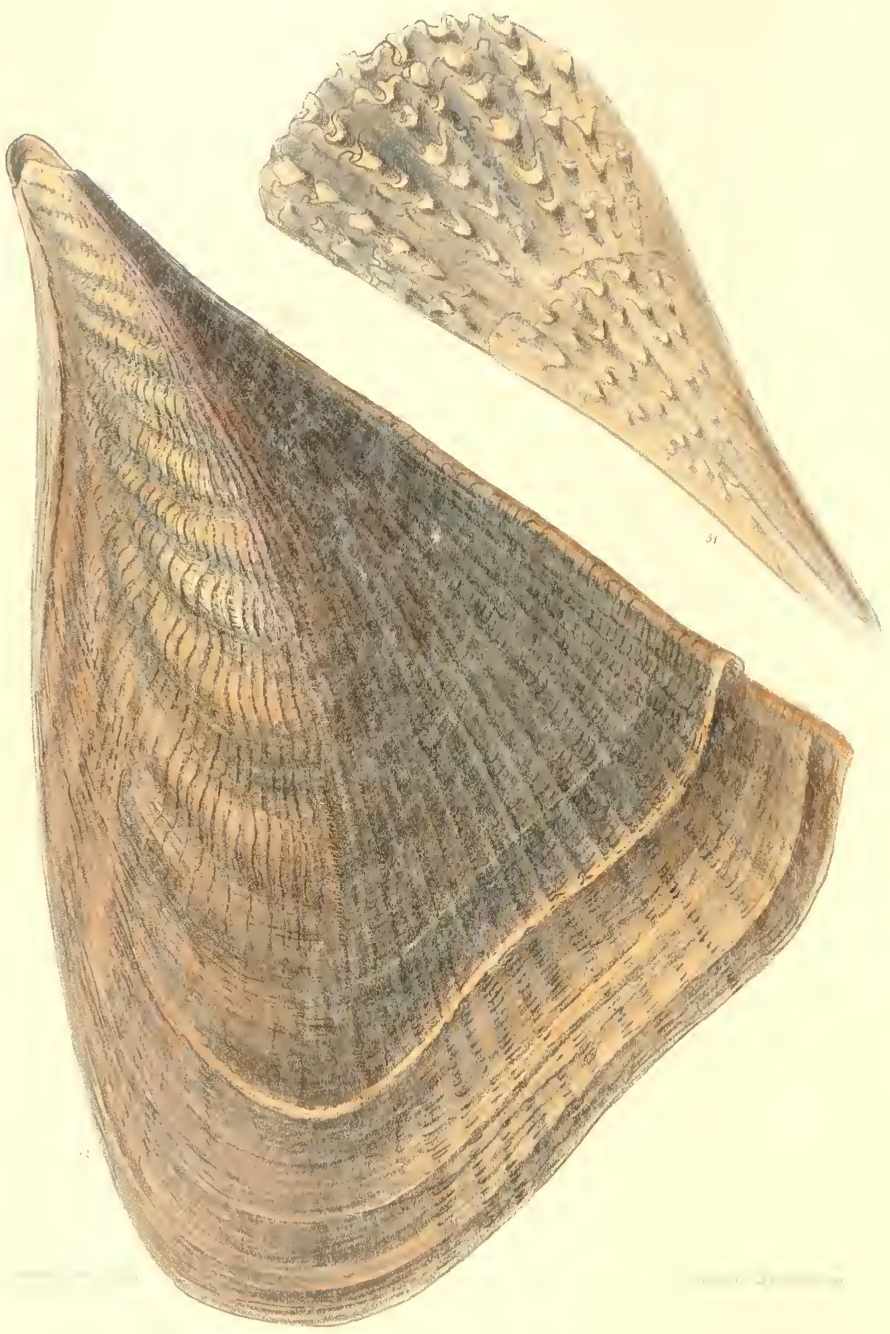




\section{P I N N A.}

\section{Plate XXVII.}

Spuna 7. (Hu timing.

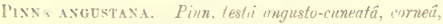
purpurea-nigrironte radial $\vec{a}$, versus umbones medio anyulatâ, squamifori, squamis brevibus, undatis.

lHE NARROWED Piva. Shell nartowly wedge-shaped, horny, rayed with purple-black, angled in the middle towards the umboes, sealed, seales short, waved.

LAMABCK, Anim. sans vert. vol. vii. p. 62.

Hat. Molucets.

The seales of this species are short, characterized by a transversely waved form of growth.

Sipecies 52. (Mus. ('uming.)

Prsxa straxger. Pinn, testât trigonâ, latè flabellatâ, subirregulari, livido-nigrâ, purpureo tinctâ, radiatic liratä, liris numerosis, subacutis, versus marginen plus minus obsoletis, latere antico ventricoso, rugoso. latè validè plicato-corrugato.

Strange's Pinna. Shell triangular, broadly fan-shaped, somewhat irregular, livid-black, tinged with purple, radiately ridged, ridges numerous, rather sharp, more or less obsolete towards the margin, anterior side ventricose, rough, broadly, strongly, plicately wrinkled.

Ilanley, Pro. Zool. Soc. 1858.

Hab. Moreton Bay.

A bold characteristic species, of a broad, unconth, triangular, fan-like growth, raycd with narrow and rather sharp ridges. The anterior side of the shell is wrinkled with strong broad folds.

August, 1858 . 




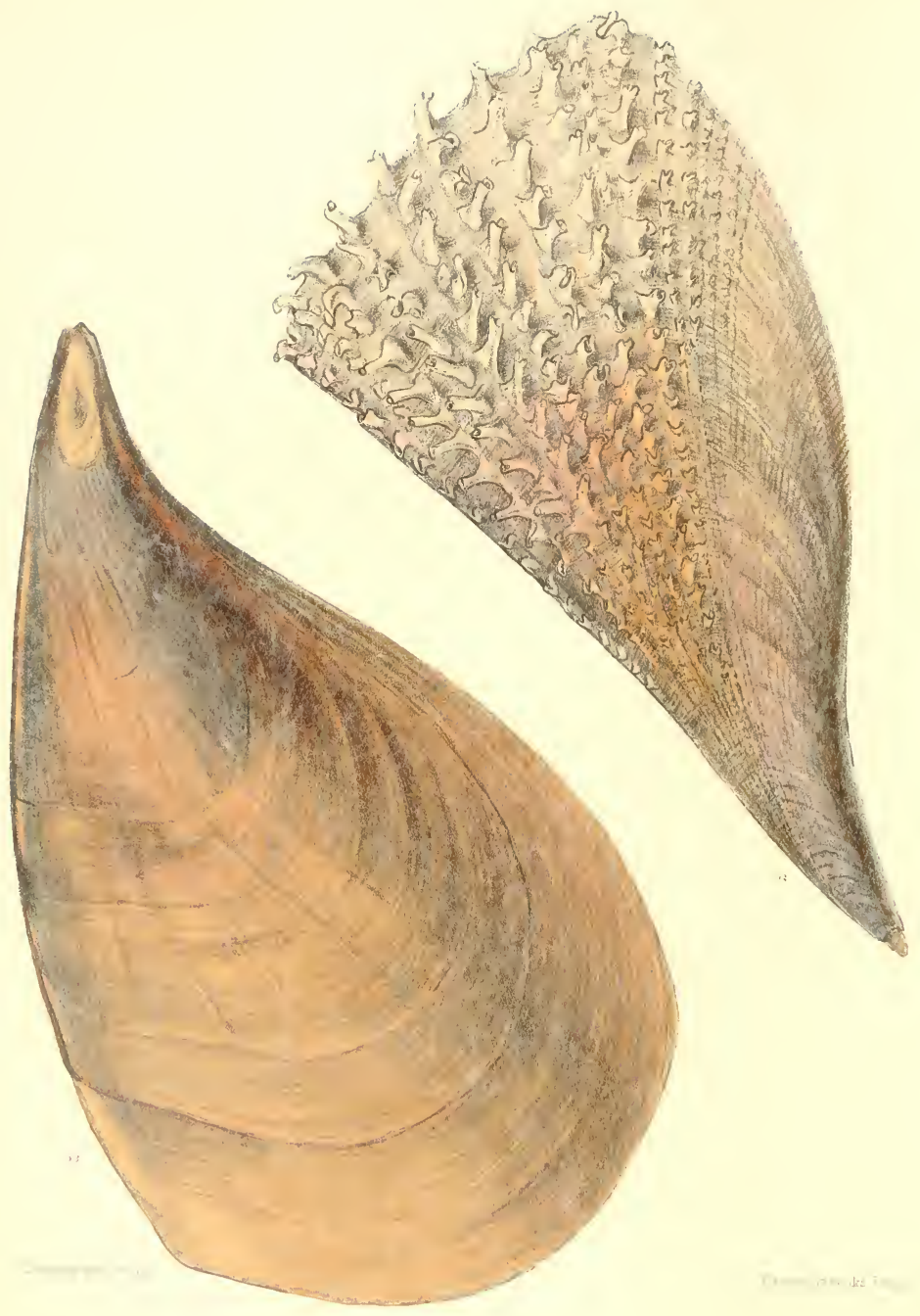




\section{P I N N A.}

\section{Plate XXVIII}

Species 52. (Mus. Cuming.)

Pinna iamolosa. Pinn. testâ trigonâ, margine postico recto, untico flexnoso-rotundato, temui, semipellucidocurneâ, radiatim liratâ, liris conspicuè squamatis, syjeamis tubulosis, acutè erectis, irregularibus, latere antico mutico.

The bRanched Pinna. Shell triangular, straight at the posterior edge, flexuonsiy rounded at the anterior, thin, semitransparent-horny, radiately ridged, ridges conspicuously scaled, scales tubular, sharply ereet, irregular, anterior side smooth.

$H a b$. West Indies.

A light, transparent-horuy shell, profuscly beset with erect, spouted scales, variously directed.
Fig. 53. (Mus. Cuming.।

The shell here figured, Pinna ingens of Pennant, Brit. Zool. vol. iv. p. 115, and Lamarck, Anim. sans vert. vol. vii. p. 66 , proves to be a smooth state of the British $P$. pectinata, and presents a remarkable instance of variation in growth. It is of a dull, nebulous, horny colour, without a vestige of the scales which characterize the type of the species; it has, however, the radiating posterior ridges. It appears to be uniformly of large size, and is more rounded. 




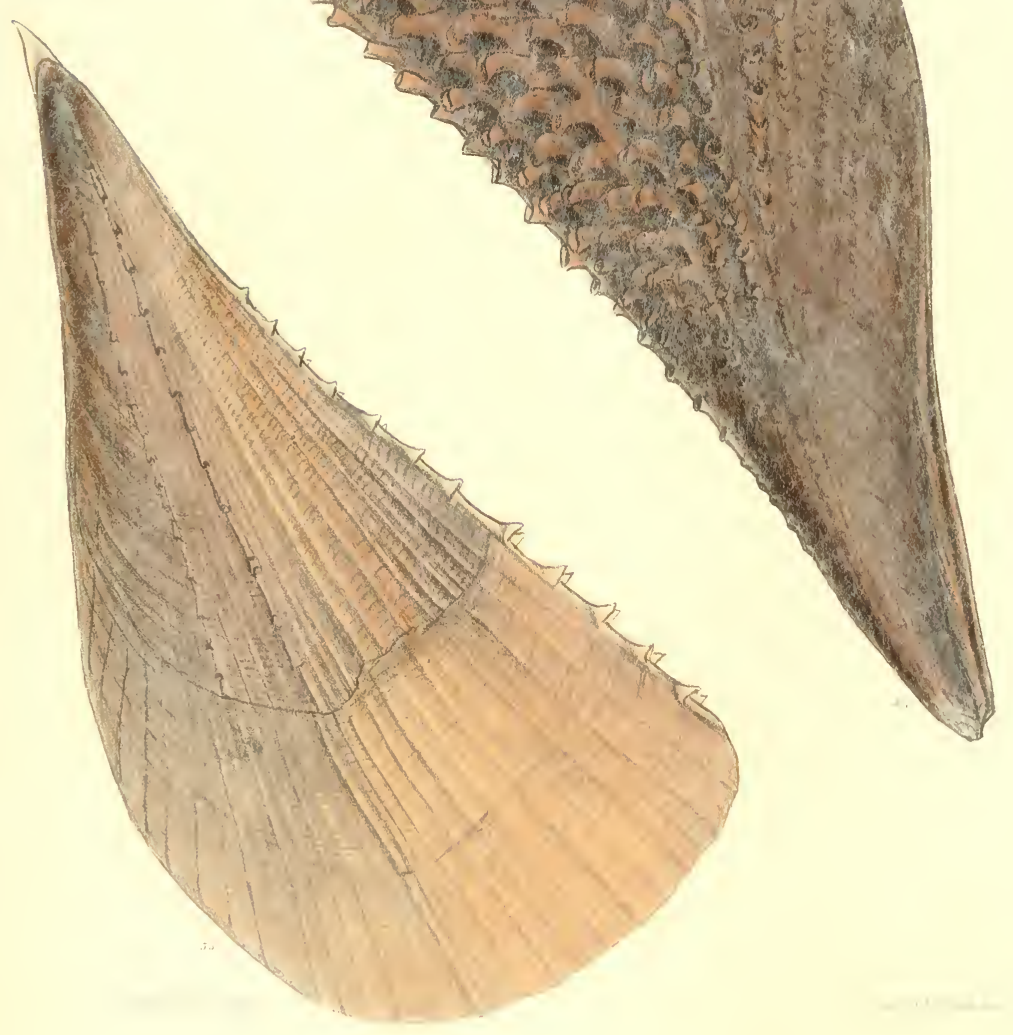




\section{P I N N A.}

\section{Prate XXIX.}

Speres - .4. (Mt:- Cunng.

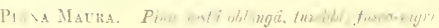

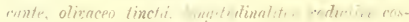

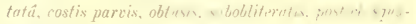
mitiris, squames forwicatis. tubutosis. wherearvis, ... lisì submuticä

The Muor PrNna shell obloug, swollen, brown-black, tinged with olive. Jongitudinelly mantely riblesl, ribs small, obtuse. somemhat oblitcrated, posteriorly full of seales, scales arched, tubular somen hat recurved. anteriorly nearly smooth.
Sumprai, Pro. Zool. Soc. 1835, p. 84.

Halb. Panama (from muddy banks); Cuming.

This shell is of a peculiar bistre-brown colour, rinsin: into dark greenish-olive, and the spines are rather close-set and of umisually regular, recurved, tubular growth.

Fig. 55. (Mus. Cuming.)

The shell here figured is an accidental repetition of the spined variety of $P$. Chemnitzii represented at Plate 1 . Fig. $1 a$. 




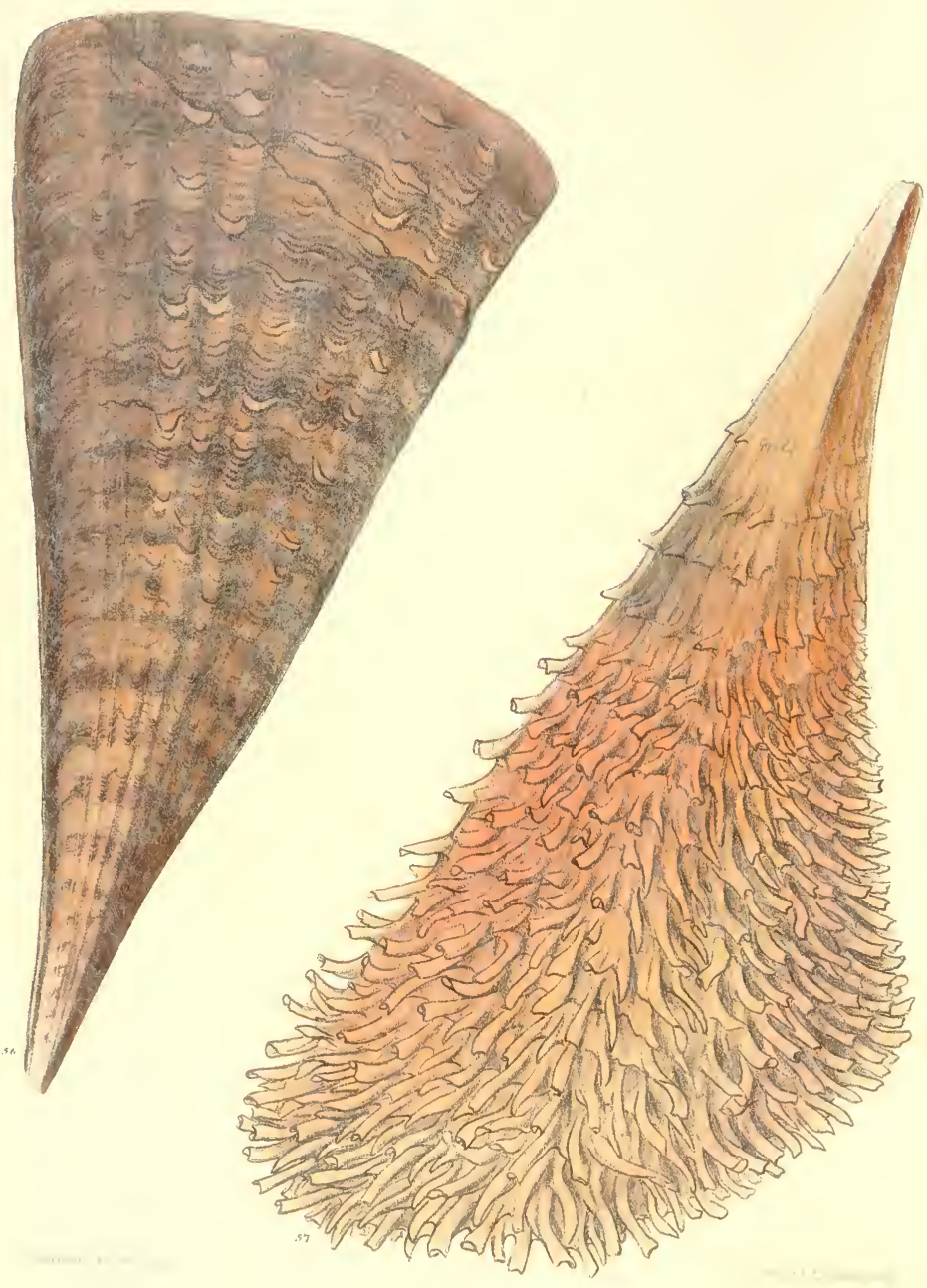




\section{P I N N A.}

\section{Plate XXX.}

Spures 56. (Mus. Cuming.)

P1NNa Regia. Piun, testâ oblongo-trigonâ, lateribus subincurvis, concê, fumeo-purpurto profusè nebulosâ, obsoletè latè costatá, costis superficiariis, squamis brevissimis perpaucis asperatis.

T'He roval Pinna. Shell oblong-triangular, sides slightly incurved, horuy, profusely clouded with smoky-purple, obsoletely broadly ribbed, ribs superficial, roughened with a few very short scales.

I1 A. LEY, T'ro. Zool. Sue. 1858 .

II 4. Amboyna.

(If a glossy, horuy substance, richly mottled with -noky-purple, and roughened with extremely short scales.
Species 57. (11\%. Cuming.)

Pinna nobilis. Pinn. testä trigono-fabelliformi, semipellucido-rufescente, versus unbones olivaceo-cinereâ, radiation costralâ et densè echirato-squamosá, subtubulosis, erecto-recurois, squamis variè divergentibus, lutescentibus.

THE NOBLE ?'1NNA. Shell triangularly fan-shaped, semitransparent reddish, olive-ash towards the umboes, radiately ribbed and densely prickly-scaled, somewhat tubular, erectly recurved, scales variously diverging yellowish.

Linnæus, Syst. Nat. p. 1160.

IIab. Adriatic.

Distinguished by its very dense armature of diverging tubular scales, of a yellowish colour upon a tramsparent reddish ground.

August, 1858. 



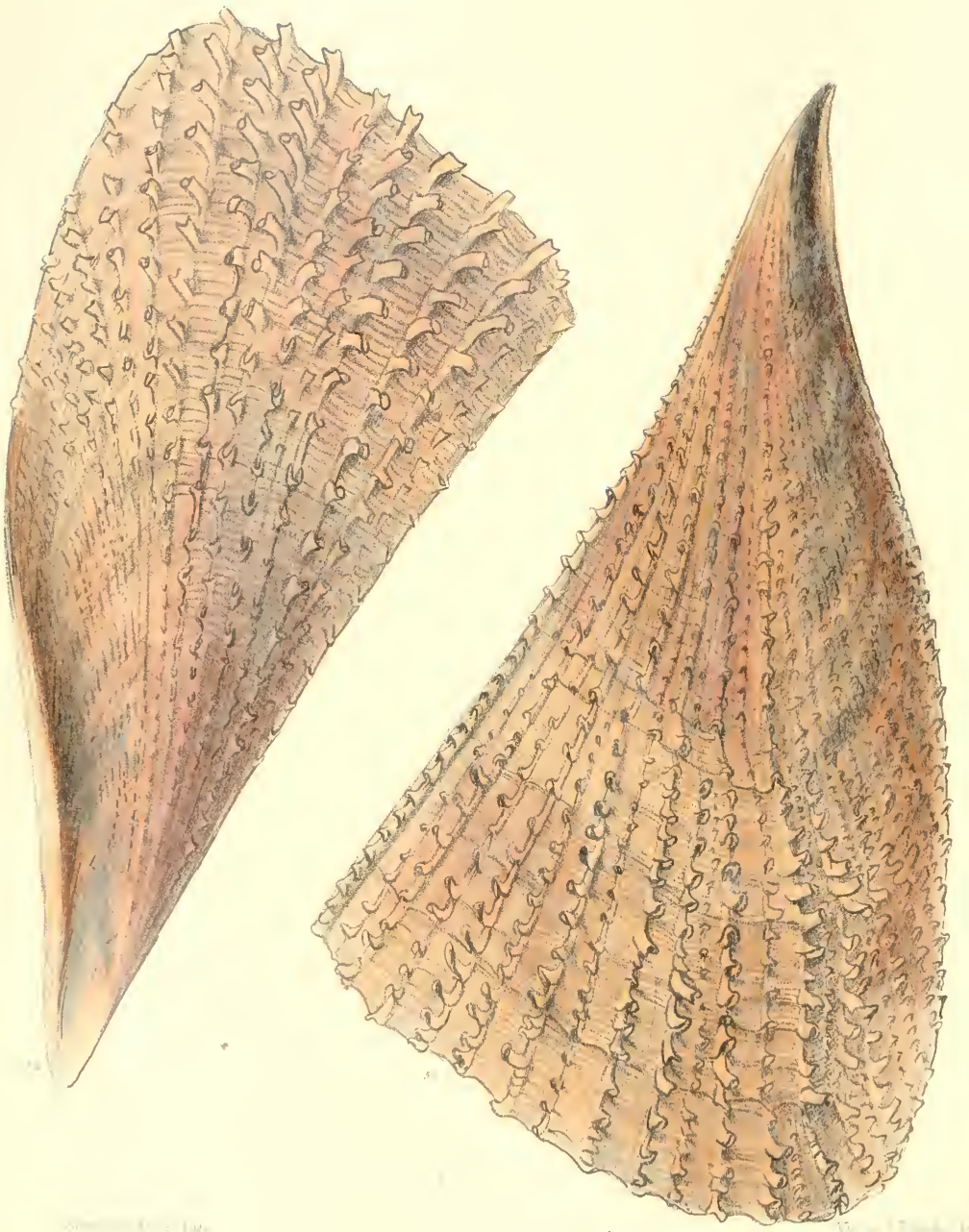




\section{P I N N A.}

Plate XXX1.

\section{Sperues is. (Mlus. Cuming.)}

PI. va lanceolata. Pinn, testä sirhlmuceolato-flabelliformi, rufescente-olicaceâ, medio "I posticè rudiutim costellatät, anticè ferè muticâ, rostellis squanatis. squamis regularibus, sublubulosis, recurvis.

I he Lanceolate Pinna. Shell lanceolately fan-shaped, reddish-olive, radiately ribbed in the midelle and in the posterior side, almost smooth on the auterin: ribs scaled, scales regular, somewhat tubular, re curred.

Sowerby, Pro. Zool. Soc. 1835 b. 84.

Hab. Near Puerto Potrero (dredged from sandy mud, at a deptl of thirteen fathoms); Cuming.

The seales of this species, of a recurved tubular form. are set with somewhat more than usual regularity, but on the anterior sidc of the sbell they almost disappear. species 59. (Mus. Cumng.)

Pinna assimilis, Pinn. testâ trigono-flabellatâ, antici tumidâ, subrotundat $\hat{a}$, cinereo-come $\hat{a}$, undique radiatin liratî, liris profusè squamatis, squanis peculiariter irregularibus.

The allied PinNa. Shell triaugularly fan-shaped, anteriorly swollen and somewhat rounded, ash-horuy, every where rayed with ridges, ridges profusely scaled. scales peeuliarly irregular.

Hanley, Pro. Zool. Soc. 1858.

Hab. Raincs's lsland, Torres Strats; Lient Inee.

A dull ash-horny speeies, elaracterized by a singular irregularity in the development of the scales, with whieh it is rayed throughout.

August, 1858. 




\section{P I N N A.}

\section{Plate XXXII}

Species 60. (Fig. 60 and 61, Mus. Cuming.)

PrNiA urstrix. Pim. testá latè ceneiformi, temuiculâ, inflatî, posticì subquadratâ, cornể, livido-purpurascente et nigro-fusco variegatâ, multicostat $\vec{a}$, costis parris, squamatis, squamis subangustè tubulosix, erectis, irregniaribus, costarum interstitiis latis, plano-concuris, lamellis incrementi subconspicuis.

ThF polcupine PINxa. Shell broally wedge-shaped, rather thin, inflated, posteriorly somewhat square, horny, variegated with livid-purple and black-brown, many-ribbed, ribs small, squamate, scales rather stenderly tubular, erect, irregular, interstices between the rilus flatly concave, with the lamella of growth rather conspicuous.

HanLex, Pro. Zool. Soc. 1858 , p. 226.

Hab. Amboyna.

This very beautiful species, which I had regarded as a spined rariety of $P$. Strangei, has been deseribed by Mr. IIanley as a distinct species; and I think rightly so. 


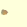


Pinna Pl. EXTIII.

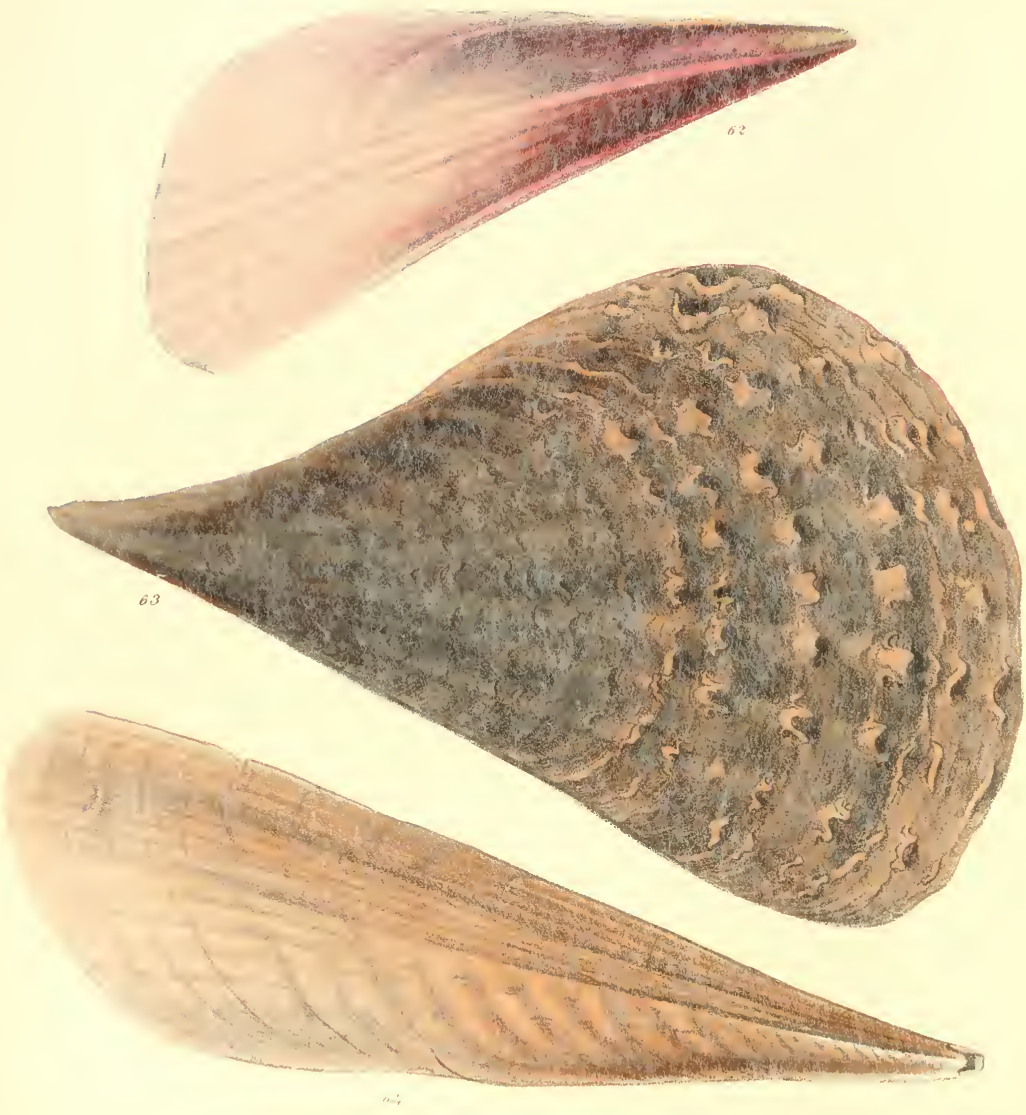




\section{P I N N A.}

\section{Plate XXXIII.}

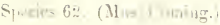

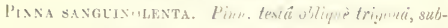

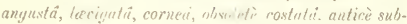
corruga $a_{;}$pullutü, versus umbenes cupreo-sunguined finctá.

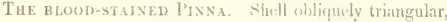
rather narrow, smooth, horny, olwoletely ribbed, anteriorly fitintly wrinkled: pale, stinined towards the t mboes with coppery blood-red.

Nlab.

Chiefly distinguished by its blood-stained colouring, which has a peculiur metallic hue.

species 63. (Mus. ('uming.)

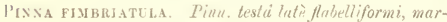
gine rotumdatâ, radiatim costat $\hat{\imath}$, castis amplis autem obscuris, subdistuntibus, paulo mulatis, squamatis, squamis ntrinque peruliuriter fimbriatulis; lutescenterornet, lizido-oliraredi, interdum uigrescente tinctît.

TIIF FURBelowed PINNA. Shitl broally fan-shaped, rounded at the margiu, radiately riblsed, ribs large but obseure, rather distant, a little wavel, scaled, males peculiarly furbelowed on each side; yellowishIturny, stained with livid-olive, sometimes blackish.
Hab. Japan.

The scales of this species present the peculiarity of being furbelowed with a recurved curl on cither side.

\section{Species 64. (Mus. Cuming.)}

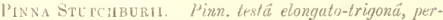
antyustâ, medio anyulato-carinatâ, obscurè radiatim rostutî, lavoigatâ, anticè subampliter obliquè plicatocorrugat $\vec{a}$ : lutescente-spadice $\vec{a}$, versus umbones obscurè ulivaceo maculatâ.

STUTChBORY's PINAa. Shell clongately triangular, very narrow, augularly keeled down the middle, obscurely radiately ribbed, smooth, anteriorly rather largely obliquely plicatcly wrinkled; yellowish-fawn, sometimes obscurely sjotted with olive.

Hab. Moreton Bay, Australia; Stutehbury.

A characteristic Anstralian species, of narrow angularly keeled growth, broadly plicately wrinkled down the anterior slope. I name it in menury of the collector, $\mathrm{Mr}$. Menry Stutchbury, a resident of the town of Bristol, who has just departed this life, after spending many years in the successfinl pursuit and study of natural history. 


\section{.}





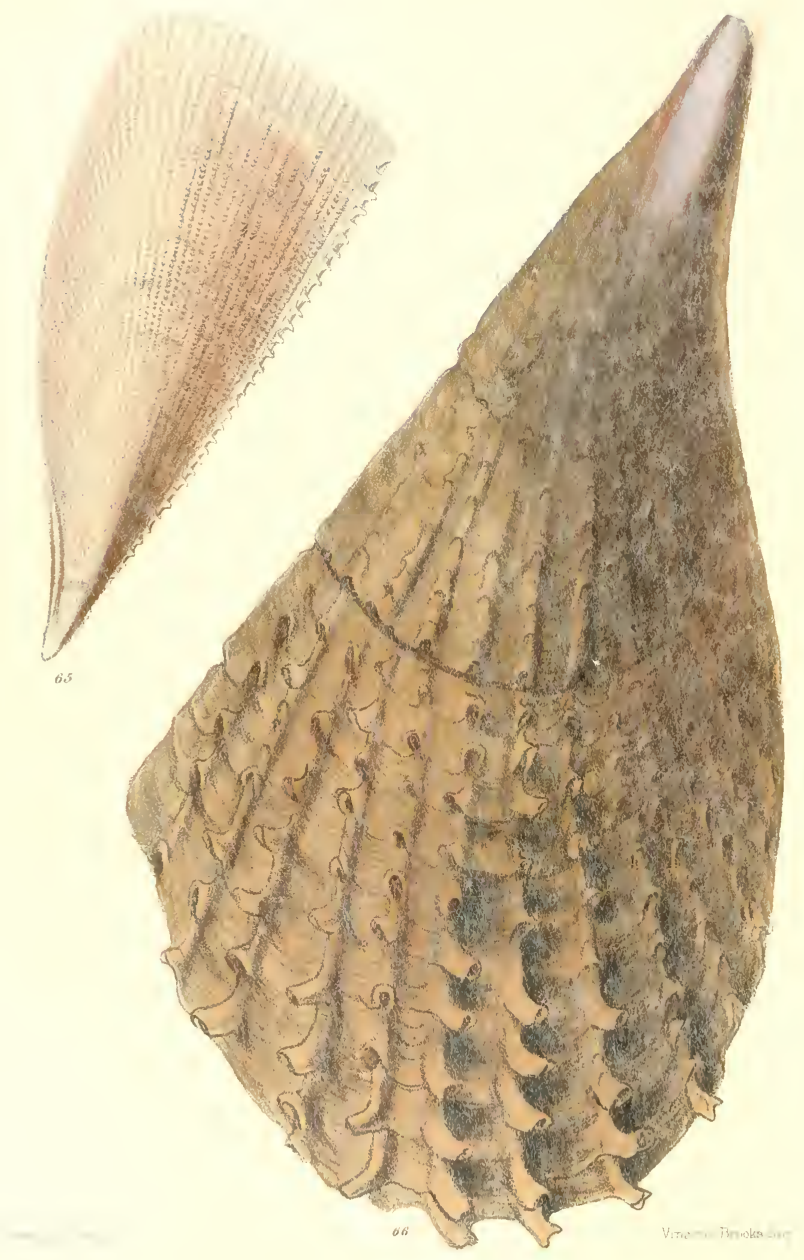




\section{P I N N A.}

\section{Plate XXXiv.}

Species is- (Mus, Brit.)

Pinna serrata. Pinn. teslä ublongo-flabelliformi, margine subquadratâ, pellucido-corneâ aul vitreni, radiatim liratä, liris numerosissimis, densè minutè squanutiv, anticè decussatim corruyato-strintá, maryine dorsali acutè serrato-squamato.

The serrated Pinna. Shell oblong-fanshaped, rather square at the margin, transparent-borny or glassy, radiatcly ridged, ridges very numerous, densely minutely scaled, anteriorly decussately wriukle-striated dorsal margin sharply serrately scaled.

SULANDER, Sowerby's Genera of Shells.

Ilab. West Indies.

This little species is especially distinguished by the profusion of its serrated sculpture of minute scales.
Species 66. (Mus. Brit.)

Pinina Carolinensis. Pim. testä oblongo-flabelliformi, margine rotundat $\hat{a}$, solidiusculâ, subinflatâ, olivaceâ, radiatim costat $\hat{\imath}$, costis nalidis, subdistantibus, fortiter squamatis, squamis versus marginem tubulosis of $\mathrm{rr}_{\mathrm{r}}$ curvis, costarum interstitiis concavis.

The Carolina P'isixa. Shell oblong-fanshaped, rounded at the margin, rather solid, a little inflated, olive, radiately ribbed, ribs strong, rather distant, strongly sealed, seales towards the margin tubular and recurved, interstices between the ribs coucave.

H AN LEY, T'ro. Zool. Soc. 1858, p. 225

Hab. South Catolina.

A shell of large size and rither rough growth, in which the ribs are rather distant, and armed with spines, which towards the margin are recurved and tubular. 



\section{P I N A.}

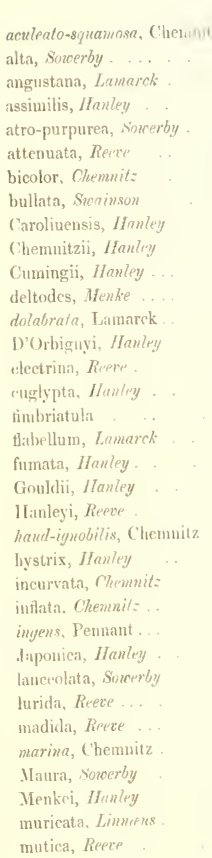

\begin{tabular}{|c|c|}
\hline P'lete & specters \\
\hline VI. & 10 \\
\hline VI. & 11 \\
\hline X.Yill. & 5 I \\
\hline XXXI. & 59 \\
\hline XXII. & 41 \\
\hline XXIV. & 46 \\
\hline IX. & 17 \\
\hline IX. & I6 \\
\hline XXXIV. & 66 \\
\hline I. & 1 \\
\hline XV1. & 29 \\
\hline XXI. & 40 \\
\hline IX. & 17 \\
\hline XXVı. & 49 \\
\hline XIV. & 25 \\
\hline XX. & 37 \\
\hline XXXII. & 63 \\
\hline $\mathrm{X}$ & 18 \\
\hline $\mathrm{XV}$. & 27 \\
\hline II. & 21 \\
\hline VIII. & 15 \\
\hline $\mathrm{X}$ & 18 \\
\hline XXXII. & 60 \\
\hline V. & s \\
\hline III. & 5 \\
\hline XXVIII. & 53 \\
\hline XXY. & 47 \\
\hline XXXI. & 59 \\
\hline Sill. & 24 \\
\hline IVII & 31 \\
\hline 11. & 3 \\
\hline IXIX. & 54 \\
\hline XVIII. & $3+$ \\
\hline XIII. & 23 \\
\hline IVIII. & 33 \\
\hline
\end{tabular}

\begin{tabular}{|c|c|c|}
\hline nobilis, Linnerus & & XXX. \\
\hline nigra, Clemnitz & & III. \\
\hline niyrina, Lamarek & & 111. \\
\hline Nuttallii, Conrad. & & IV. \\
\hline papyracea, Chemnitz . & & VIII. \\
\hline pectinata, Linnous & & XXII. \\
\hline peruula, Chennitz . & & XII. \\
\hline Philippiuensis, Hanley & & XI. \\
\hline penna, Reeve....... & & XX1. \\
\hline ramulosa, Reeve .... & & XXV111. \\
\hline regia, Hanley ....... & & XXX \\
\hline rigida, Dillwyn. . . . . . & & V. \\
\hline minundata, Linnous & & 11. \\
\hline rudis, Limncus..... & & $\mathrm{X}$. \\
\hline ruyosa, Sozerby .... & & XXVI. \\
\hline Rumphii, Hanley & & V. \\
\hline saceata, Linnceus & & IV. \\
\hline sanguinolenta, Reeve. & & XXXIII. \\
\hline seminuda, Lamarck. & & I1. \\
\hline semicostata, Conrad & & XVI. \\
\hline serra, Reeve. . . . . . & & XXIII \\
\hline serrata, Solander. & & XXXIY \\
\hline squamosa, Gmelin. & & 11. \\
\hline squamifera, Sowerby & & VII. \\
\hline squamosissima, Philippi & . 1 & II. \\
\hline Strangei, Hanley... . . & & XXV1I. \\
\hline Stutchburii, Reve. & & XXXIII. \\
\hline subriridis, Reere. & & XTII. \\
\hline truncata, Philippi & & IIX. \\
\hline tuberculosa, Sunerly. . & & XXY \\
\hline vespertina, Reere.... & & X.III \\
\hline vexillum, Born ... & & XIX \\
\hline virgata, Menke. & & XXII: \\
\hline Zebuensis, Reere & & XIV. \\
\hline Zelanica, Gray & & V'II \\
\hline
\end{tabular}

ERRATUM.

Plate XX11. Sp. 42, P. pectinata, dele svnonym $P$. inflatu, Chemnitz. 



\title{
MONOGRAPH
}

\author{
OF THE GENUS
}

\section{P E R N A.}




Perna. PII.

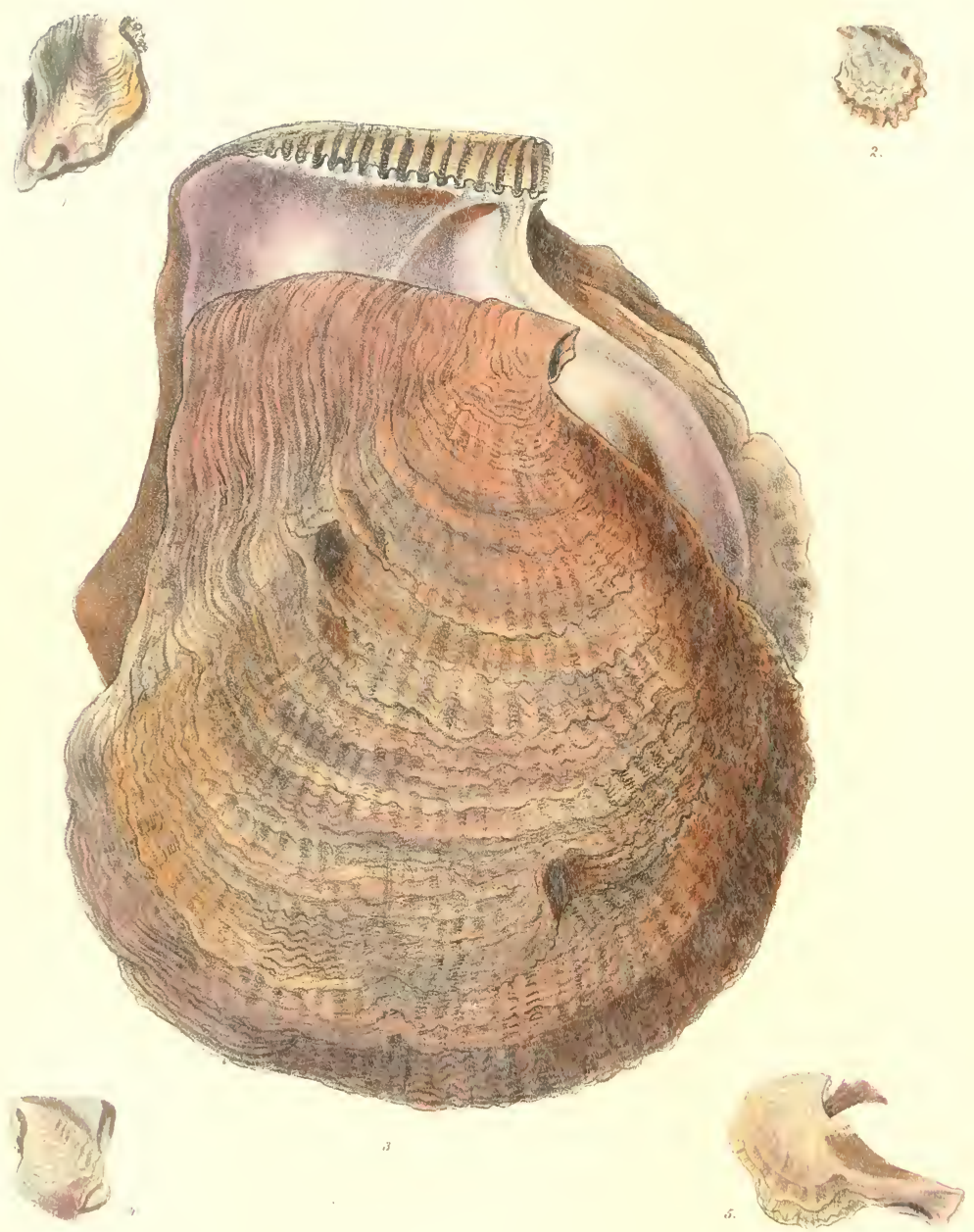




\section{P E R N A .}

Plate 1.

Ganns PERNA, Lamarck.

Testi planwivie, fibro-lominaris, subaquivalvis, umbonibus partix, nept' terminalibus et aduncis. Cardo latus, marginalis, sutris parallelis liyamentum excipientibus. Lxcuna pro bysso infro carlinis extremitotem post $i$ cum. Impressio muscularis obliqua, distincta.

Shell flat, fibro-laminar, nearly equivalve, umboes small, often terminal and bookeil. Ilinge broad, marginal, with parallel gronves recciving the ligament. Opening for the byssus beneath the posterior extremity of the hinge. Muscular impression oblique, distinct.

The shells assembled under the head of Perna are characterized by a special construction of the hinge, and like the Ariculir, they attach themsctres by a tough, bristly hyssus. The bince is in the form of a broad, marginal plate cut across with regular parallel grooves, and the intermediate ridues do not interlock with ench other like tecth, but press in contact, leaving the cavities between them for the reception of the ligament.

The shells of Perua have a strong affiuity with those of Mulleus, in respect of their winged and laminar growth, but they altogether differ in the arrangement of the hinge and byssus. They are chiefly from the Eastern seas. A few are from the West Indics and the Pacific islands.

\section{Species 1. (MLus, Cuming.)}

PLRXa LOBATA. Pern. testêt subyuadratâ, utrinque concaro-comjressâ, medio longitulinaliter lobutâ, concentricè rudì laminatä; purpurascente-albâ.

THE LOBED Perxa. Shell someshat square, concavely compressed on each side, longitudinnlly lobed in the middle, concentrically rudely lamiuated; purplishwhite.

Ilal. L ?

Of a contracted trapezoid form, with the laminx pressed into a central lobe projecting longitudinally.

\section{Specics 2. ( Mus. Cuming.)}

perNa pectiNata. Perm. testât suborbiculari, pectinatî, tenuiculi, comechtricè nitide luminata, laminis fimbriato-squenatis, umbonibus arcuatix, aducis; sordide olivaccü.

The pectinate Persa. Shell somewhat orbicular, pectinate, ratlicr thin, concentrically neatly laminated, laminæ fimbriately scaled, nmboes arched, looked; dull-olive.

IIab. - ?

Distinguished by a neat sculpture of flattcued, overlapping, conecntric frills of scales.

Species 3. (Mus, Cuming.)

PEINA Cuminin. Pern. testẩ suborbiculari, latere antico busali prodıcto, crassiussculâ, concentricè rudè laminatâ, ratiation sulcutâ, laminis subfimbriatis; violaceo-purpureâ, fusco tinctî.

Cuming's Penna. Shell somewhat orbicular, basal anterior side produced, ratber thick, conecutrically rudely laminated, radiately grooved, laminte slightly frilled; violet-purple, tinged with brown.

Hab. Australia.

This fine species has probably been confounded with $P$. eploippium, but it is well distinguished by its radiating grooves, which impart a frilled character to the concentric laminæ.

\section{Species 4. (Mus, Cuning.)}

Perxa nucleus. Pern, testâ subquadrato-ovali, concentricè leminat $\hat{\imath}$, laminis ad marginem strialo-fimbriatis, umbonitus urcuatis, adurcis; sordidè olivaceû.

The hard-crusted Perna. Shell somewhat squarely ovite, concentrically lamiuated, lamine towards the margin striately frilled, umboes arched, houked; dullolive.

Lamarck, Anim. sans vert. vol. vii. p. 78.

Hab. $\longrightarrow$ ?

Less fimbriated than the preceding species, with the base broader, and the amboes still more sharply hooked.

\section{Speeics 5. (Mus. Cuming.)}

Penna caudata. Pern. testâ obliquè ovatâ, crassiusculâ, posticè longitudinuliter lobatâ, rucliatiul striatä; lutescente-albîi, purpurascente-striatâ.

THE TAILED PERNa. Shell obliquely ovate, rather thick, posteriorly longitndiually lobed, radiately striated; ycllowish-white, tinged with purple.

Hab. ㄴ. ?

Of a solid radiate growth, produced obliquely into a rude, longitudinal lobe.

November, 1858. 



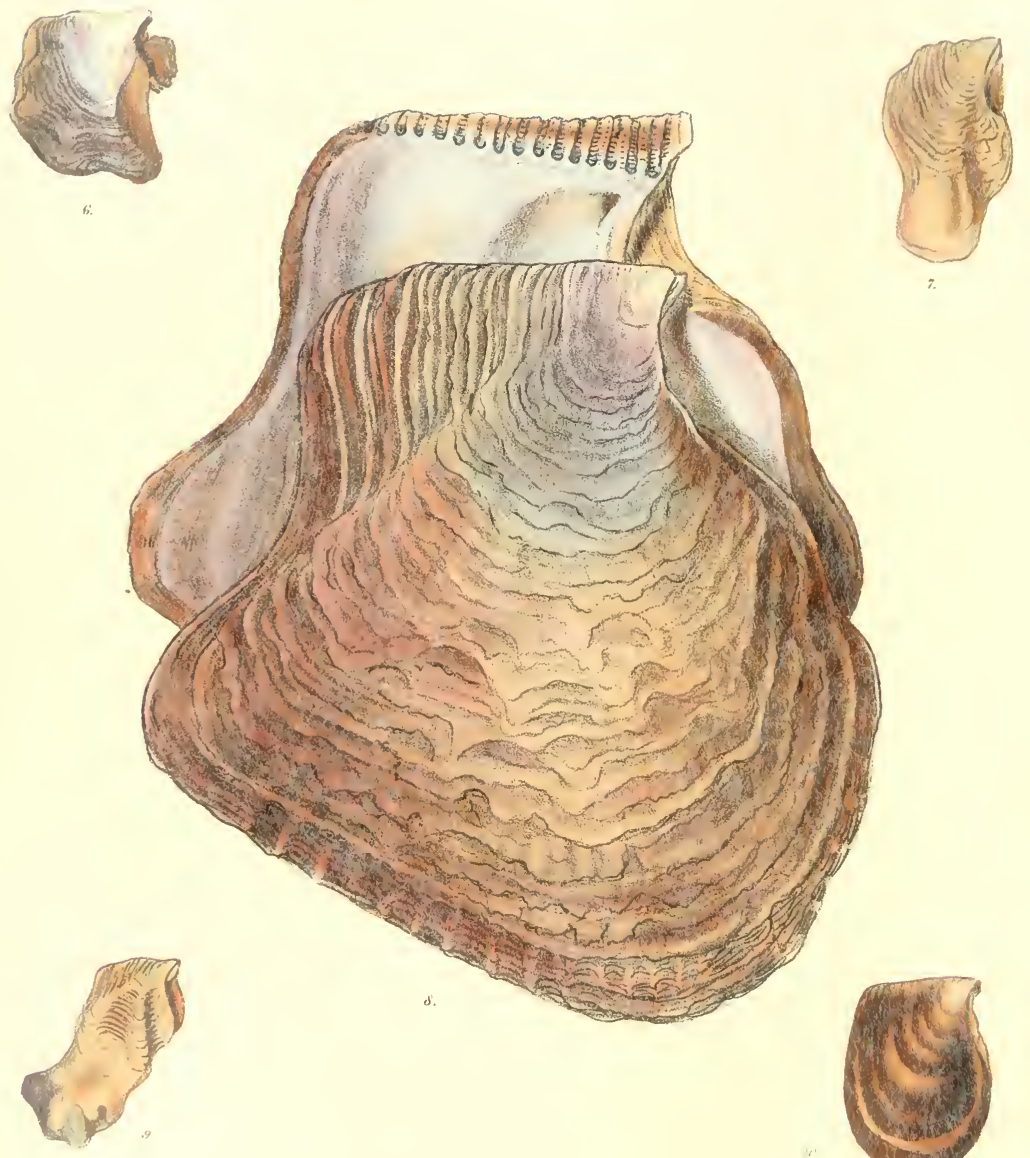


\section{P E R N A.}

Plate II.

\section{Sjugien 0., (Mhis Cuning.)}

Perna quadiangt laki. Pern. testê subquadratâ, mule angulatâ, poxtirc rueravo-impress $\vec{a}$, versus cardinem lavigatî, deinde oliseurè temù concentricè laminatü; purpureo-nigrescente.

The setare Perna. Shell somewhat square, rudely angled, posteriorly coucavely impressed, smooth towards the binge, theu obscurely, thinly, concentrically lamisated; purple-black.

Hub.

A dark-purple specics, of naarked quadrangular growtl, ronspicuously concavcly impressed beneath the area of the byssus.

\section{Species 7. (Mus. ('uning.)}

Penna lingleformis. Pern. testa longitudinali, versus rardinem irregulariter concentrirè laminatü, deinde tave: sorilid: allut.

The tongee-smaped Perna. Shell longitudinal, irregularly concentrically laminated towards the hinge, then smooth; dead white.

IIal. Suciety Islands.

Of a longitudinal flexuous tongue-shape and dead white hue.

\section{species 8. (Mus. ('uming.)}

Pfirna ephippium. Peru. testa subtrigono-orlicutori, planâ, compressè laminatî, Laminis ferè obsoletis, latere antico auriformi, concarinsento; ceneo-rufescente.

Tue sadde Perna. Shell somewhat triangularly orbicular, flat, compressly laminated, laminæ almost obsolete, anterior side ear-shaped, rather concave; coppers-red.
Ostrea ephippium, Linuru-, Syst. Nat. 1. 1149.

Perna eplippizm, Lanarck.

Hab. Honduras.

This species, which appcars to be the old type of the genus, is characterized by its flat, coppery-red aspect, the lamiur being compressed or caked together so as to be almost obsolete. The autcrior sidc of the shell is, moreover, of a peculiar concave ear-shape.

Species 9. (Mus. Cuming.)

Penna laticostata. Pern. testâ longitudinali, flexuoxa. tri-quadricostatâ et conspienè concentricè lavinata. deinde levei; sordidè atb $\vec{a}$, purpureo-nigrescente versus extremitatem tinctâ.

The broad-ribbed Perna. Shell longitndinal, flexuous, three- or four-ribhed and conspicuously concentrically laminated, then smooth; dead white, tinged towards the extremity with purple-black.

$\Pi a b$.

Of a somewhat squarer longitudinally flexnous form than the preceding species, rudely rayed with three or four broad ribs.

\section{Sprecies 10. (Mlus. Cuming.)}

Perna vitrea. Pern. testẩ subquadrato-orbiculari, temui. leovigat $\hat{a}$, vix laminat $\hat{a} ;$ nitente-castaneâ.

The gLASsy PEIRA. Shell somew hat squarely orbicular thiu, smooth, scarcely laminated; shining-chestnut.

Hab. Red Sea.

Unlike most species of the gemus, this is of comparatively thin substance, and of a slining, dark chestnut-red colour. 
Pana, Pl.III.

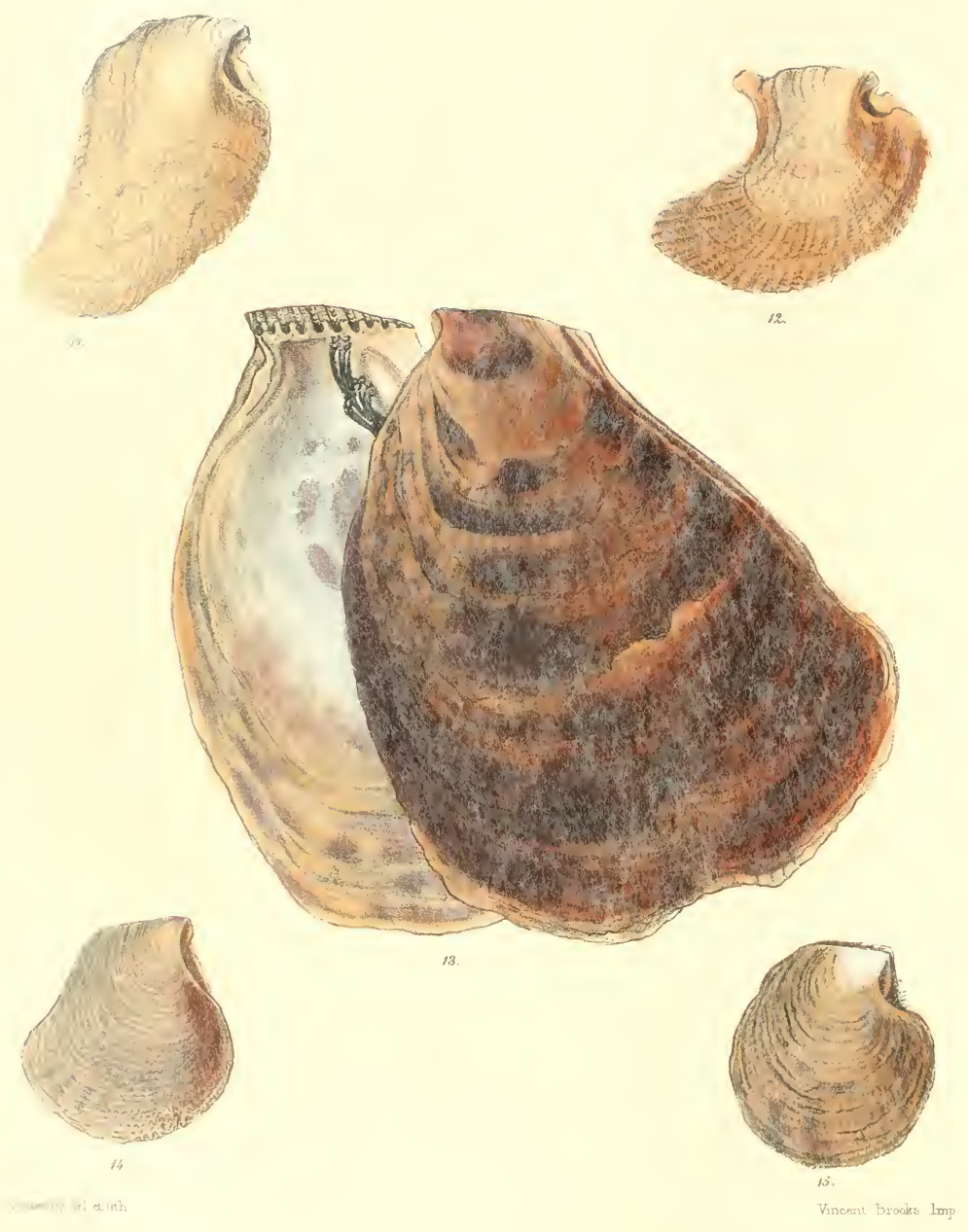




\section{P E R N A.}

\section{Plate III}

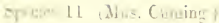

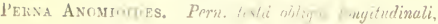
tenui, sub, ilucidh, concentive ,rituriter fimbriatolaminatấ; lutescer te-albut.

The ANomis-iıke Perna. Slint nbliquely longitudiual, thin, rather transparent, conceutrieally peculiarly finbriately lamiuated; ycllowish-white.

Hai, California.

A delicate yellowish-wlite semitranspareut shell, in which the concentric laminæ are curiously fimbriatcd in a blistered-like manner.

Species 12. (Mus, Cuming.)

Girixa Austrabica. Prm, testâ obliquè fabellatä, tenui, subpellucida, liris superficiariis serratis irregulariter densè radiatî̈; rufescente-albä.

line acstralian Perna. Shcll obliquely fan-shaped, thin, rather transparent, densely irregularly rayed with serrated superficial ridges; reddish-white.

IIab. Anstralia.

Broadly obliquely fan-shaped, of thin, transparent substancc, peculiarly seulptured with irregularly flexuous delicately serrated superficial ridges.

\section{Spceics 13. (Mus. Cuming.)}

l'ersa Californica. Peru. testẩ obliquè trigonâ vel flabellatâ, tenuiculâ, loevi; lutcscente-albâa, livido-purpureo nebulatâ.

Teg Califorkian Perna. Shell obliquely triangular or fan-shaped, rather thin, smooth; yellowish-white, clouded with livid purple.
Conrad, Journ. Acad. Nat. Sc1. Pbil. vol, vi.. p. 25. pl 19. f. 13.

Mlab. California; Conrad. Honduras; Dyson.

Chiefly distinguished by its Pedum-like form, and clouded livid-purple colouriug.

\section{Species 14. (Mus. Cuming.)}

Perna serratela. Pern. testá trigono-orbiculari, tenui, planâ, laminis tenuibus serratulis densè concentricè radiatế; sordidè albâ.

The finely-serrated Perna. Shell triangularly orbieular, thin, flat, denscly concentrieally rayed, with finely serrated lamine; dead white.

Hab. Island of St. Vincent; Guilding. Philippine Islands; Cuming.

Well characterized by the delicately serrated laminæ with which the whole surface is closely sculptured.

\section{Species 15. (Mus. Cuming.)}

Perna marsupium. Pern. testâa orbiculari, solidiusculä, rudè concentricè laminat $\hat{a}$; sordidè albâ, purpurascente tinctâ.

Tite purse Perna. Shell orbicular, ratber solid, rudely concentrically laminated; dead white, tinged with purple.

LAMARck, Anim. sans vert. vol. vii. p. 77.

Hab. Philippine Islands.

Of a simply rounded form, of rude, rather solid substance, indistinctly roughly lamiuated. 




$$
\frac{\pi}{8}
$$




\section{P E R N A.}

Puate IV

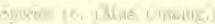

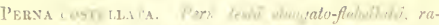

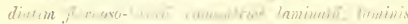

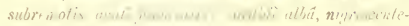
purpureroliniti

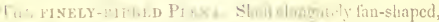

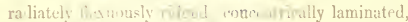

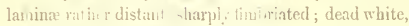

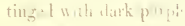

Con ris1, Jom dead. I at. Sci. Phil, vol, vii, p. 246.

Hab. Soci ty Iolumls.

The famma of this sprorits are fritlcd with small serwate points

\section{Species 17. (Mts, Cuming.)}

PERia LrMe ides. P ru. les/âa so detongoto-flabellatâ, conconlricè fi, briato-la in uhti, lamin's planatis, sububsoletis; purpureuscente.

The Lima-Line Perna. Shell somewhat elongately fansbaped, couceatrically limbriately laminated, lamine flattened, rather obsolute; muplish.

Hab. Moluceas.

Allied to the preceding species in having the lamina festuoned with small points, to at dliflerime in substance and greneral charncter.
Specios 18. (Mns. ( uning.)

Penna fimbriata, Pern. lestâ elongaloooblongâ, tenui. culâ, compressâ, concentricè fimbriato-squamatâ, squamis versus marginem subproductis; anticè alatâ, alu medio concavâ et obscurè lirată ; nigricante-purpuretat

The frillem Perna. Shell clongately oblong, rather thin, compressed, concentrically fimbriately sealed, scales towards the margin rather produced; anteriorly winged, wing concave in the middle and obscurely ridged; blackish-parple.

Hab. Moluceas.

A thin, dark-purple shell, in which concentric frills of produced scales form rather a conspicuous character.

Species 19. (Mus. Cuming.)

Penna patibulcm. Pern. testâ elongatâ, anticè elongatoalatä, plano-laninatâ, laminis obscuris, alá medio serruto-sulcatâ; semipellucido-purpureâ.

The giBBet Perna. Shell elongated, anteriorly elongately winged, flatly laminated, laminæ obsenre, wing serrately grooved in the middle; semitransparent purple.

Hab. $\longrightarrow$ ?

(hiefly distinguished by its elongately produced wing. of which the uiddle webbed portion is serratcly grooved. 


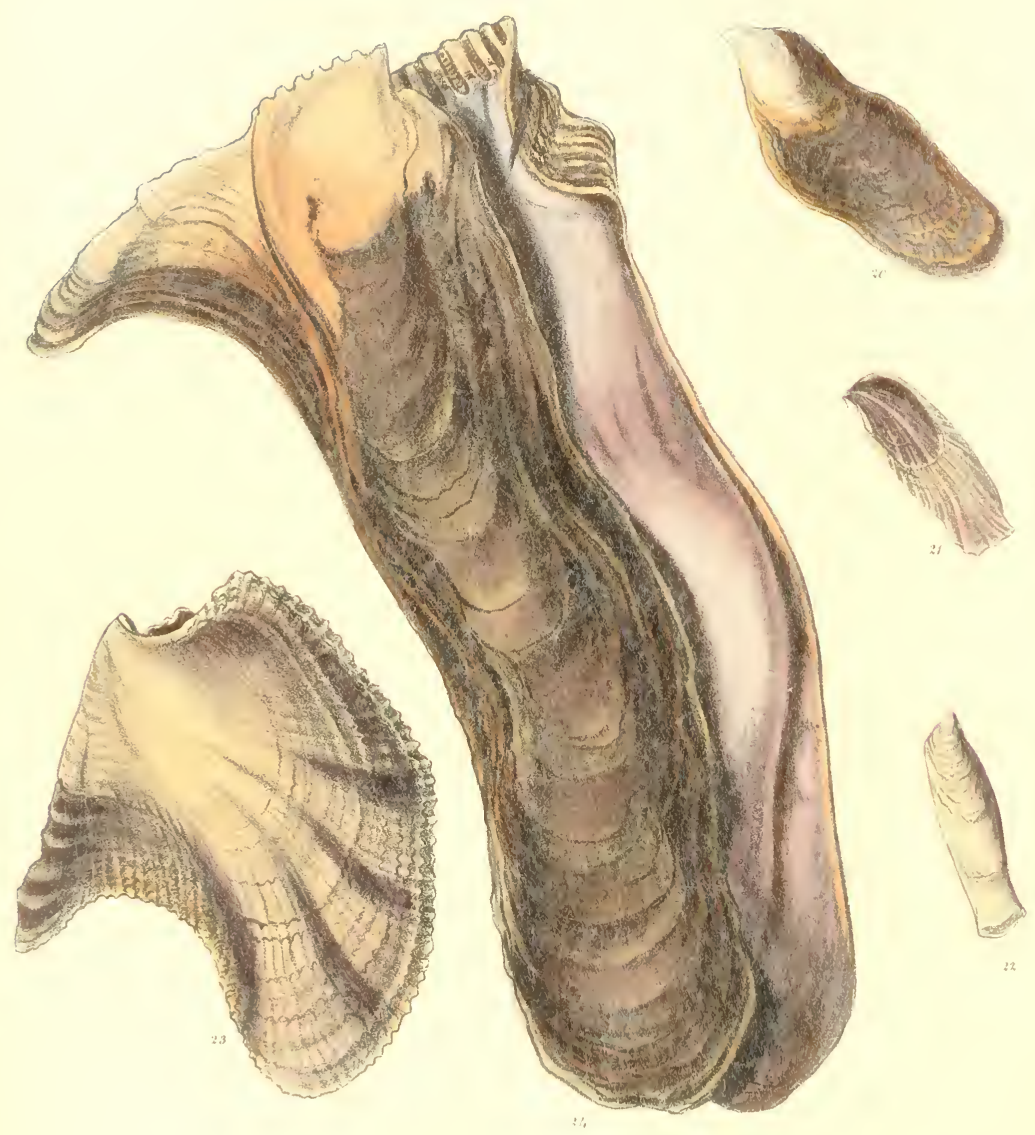




\section{P E R N A}

Plate V.

Species 20. (Mun. ('uming.)

PEnsa ridis. Pern. testá subftrxnoso-elongatâ, rudè laminatâ, umboniluss rostrutis, purpureo-fitscât.

Tue rude Perna. Shell somewhat flexuonsly elongated, ruclely lauinated, umboes beaked, purple-brown.

$\mathrm{Hab}$ - - ?

Of a flexuously elongated form, composed externally of rude concentric lauivie, rather barren of charncter.

\section{Species 21. (Mus, Cuming.)}

Penxa I ulsenla. Pern. testä elongato-quadratä, linguceformi, leci, nitente, livido-fuscescente, albo radiatim lineatâ et fusciat $\vec{t}$, umbonibus parvis, aduncis.

The Vulsella Perna. Slicll elongately square, tongueshat]ed, smooth, shining, livid-brown, radiately lineated and banded with white, umboes small, hooked.

Lamarck, Anim. saus vert. vol. vii. p. 79. Ilab. - ?

Distinguished by its smootl surface and whitc-banded painting, and by the small hooked character of the uraboes.

\section{Sipecies 22. (Mus. Cuming.)}

PERNa letiomen. Pern. testâ elongato-linuuceformi, versus winlones rudè concentricì taminat $\hat{a}$, deinde lovigat $\hat{a}$, irregutari; sordidè albat.

THz POD PERNA. Shell elongately tongue-shaped, molely eoncentrically laminated towards the umbocs, then smootl, irregular ; dull-white.

Ostrea legumen, Gmeliu, Syst. Nat. p. 3399.

$H n h$. Lord Hood's Island; Cumiug.

Of a curiously elougated pinched growth, of a deadwhite colour, the laminæ being first arranged concentrically and afterwards irregularly blistered.
Species 23. (Mus. Cuming.)

Penna fimbriata. Perm. testâ obliquè ovatâ, anticè latè alatâ, locvigatâ, versus marginem undique fimbriatâ tot subsquamatê; Intescente-albâ, versus marginem liridopurpureo tinctât et radiatâ.

The fimbriated Perna. Shell obliquely ovate, anteriorly broadly winged, smooth, everywhere finbriatcd and finely scaled towards the maryin; ycllowish-white, stained and rayed towards the margin with liviclpurple.

Hab. Moluecens.

The obliquely ovate, broad-winged form of this species is peculiar, and its fimbriated sculpture is characteristic.

\section{Species 24. (Mus. Cuming.)}

Perna isognomum. Pern. testâ elongatî, plerunque subflexuosî, depressâ, rudè laninatâ, basi anticè angustè alatâ, alâ plus minns curvatâ, posticè abruptè latè sinuatü; purpurev-nigrâ.

The carpenter's square Perna, shell elongated, generally rather flexuous, depressed, rudely laminated, base narrowly winged anteriorly, wing more or less curved, posteriorly abruptly broadly simuated ; purpleblack.

Ostrea isognomum, Linnæus, Syst. Nat. p. 1149.

Varietates $P$. femoralis and canina, Lamarck.

Hah. Philippine Islands; Cuming.

This well-known species varies in haviug the wing sometimes longer, with the body of the shell less elongated than in the specimen figured. Sometimes the shell is even more elongated than this, in which case the wing is almost obsolete.

November, 1958, 


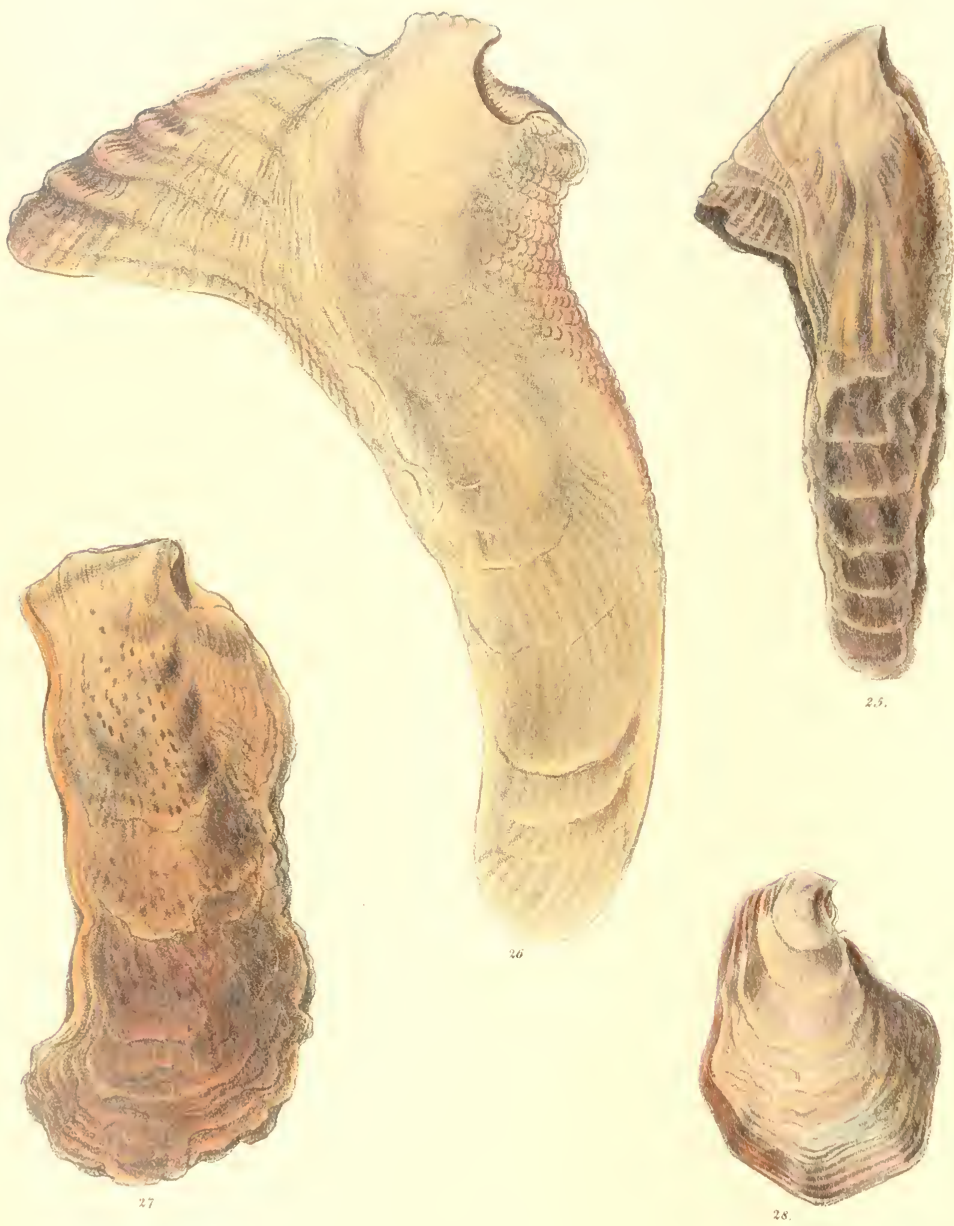


\section{P E R N A.}

Plate Vi.

Species 25. (Mus. Cuning.)

Perna atrenuita. Pern. textâ elomiatä, rudi laminatä, anticè fimbriato-alutâ, versus umbones attcnuat $\hat{a}$; purpureo-nigrá.

The atrentated Perna. Shell elongated, rudely laminated, anteriorly fimbriately winged, attenuated towards the umboes; purple-black.

Hab. Red Sea.

Of a narrow form, with a broad, fimbriated wing, peeuliarly attenuately pressed inwards.

$$
\text { species 26. (Mus. Cuning.) }
$$

Peraxa vespertilio. Pern. testâ plongatâ, arcuntâ, conspicuè latè alatâ, utrinque fimbriato-sulcatấ: sordidè lutescente-alba, ad basin subpurpurascente.

The bat Perna. Shell elongated, curved, eouspicuonsly broadly winged, fimbriatcly grooved on each side; dullyellowish-white, tinged with jurple at the base.

Hab. Bay of Manilla; Cuming.

The bat's-wing lobe of this species is strikingly developed. All the speeimens taken by Mr. Cuming were of the same unitorm dull yellowish-white colour.

\section{Species 2\%. (Mus. Cuming.)}

Prana lentiginosa. Pern. testâa elongatâ, irregulari, tenui, subpellucido-corneci, larigatâ, versus extremitatem taminatâ, basi angustâ; lutescente-albâ, nitente, maculis purpureis undique lentiginos $\hat{a}$, ad marginem purpureo tinctâ.

The freckled Penna. Shell elongated, irregular, thin, semitransparent-horny, smooth, laminated towards the extremity, base narrow ; yellowish-white, shining, freckled throughout with purple spots, tinged with purple at the margin.

IIab. Philippine Islands; Cuming.

The freckled painting of this species is a character not observed in any other, and the narrow base is peculiar.

\section{Species 28. (Mns. Cuming.)}

Perna spathulata. Pern. testâ subpyriformi-ovatâ, depressiuscnlä, irregutari, versus marginem rudè taminatî́; lutescente-albâ, purpureo marginatâ.

The spathulate Perna. Shell somewhat pyriformly ovatc, rather depressed, irregular, rudely lamiuated towards the margin; yellowish-white, edged with purple.

IIab. Island of Negros, Philippiues; Cuming.

Very rudely laminated in respect of sculpture, but peculiar in form.

November, 1858. 



\section{PE K N A.}

\begin{tabular}{|c|c|c|c|c|c|}
\hline Anomioides, Reen ... ... & $\begin{array}{l}\text { Phate. } \\
\text { III. }\end{array}$ & $\begin{array}{l}\text { secies. } \\
\text { II }\end{array}$ & Limoides, Reeve $\ldots \ldots$ & $\begin{array}{l}\text { Plate } \\
\text { IV. }\end{array}$ & $\begin{array}{r}\text { specim } \\
17\end{array}$ \\
\hline attenuata, Reeve & VI. & 25 & linguaformis, Reeve....... & II. & 7 \\
\hline Australica, Reeve. - & III. & 12 & lobata, Reeve..... ... & I. & 1 \\
\hline Californica, Conrat & III. & 13 & marsupium, Lanzarck ...... & III. & 15 \\
\hline canina, Lamarek... ... . & $\mathrm{V}$ & 24 & mucleus, Lamarck..... ,... & I. & + \\
\hline caudata, Reere ... .... ... & I. & 5 & patibulum, Reeve...... . & IV. & 19 \\
\hline costellata, Conrad ........... & IV. & 16 & pectinata, Rever .. ... ... & I. & 2 \\
\hline Cuminrii, Reere ... & I. & 3 & quadrangularis, Recve & II. & 6 \\
\hline ephippium (Ostrea), Linuxus.. & II. & 8 & rudis, Reeve........ . ... & V. & 20 \\
\hline femoralis, Lamarck . ....... & V. & 24 & semiunda, Lamarck........ & II. & 6 \\
\hline fimbriata, Reeve .... . ..... & IV. & 18 & serratula, Reeve..... . . . & III. & 14 \\
\hline imbricata, Reere .... ...... & v. & 23 & spathulata, Reve. ....... & VI. & 28 \\
\hline isognomum (Ostrea), Linnæus. & V. & $2 t$ & vespertilio, Reeve. . . . . . . & VI. & 26 \\
\hline laticostata, Reete.......... & II. & 9 & vitren, Reeve ......... . . & II. & 10 \\
\hline legumen (Ostrea), Gmelin .... & T. & 22 & Tulsella, Lamarck........ & V. & 21 \\
\hline lentiginosa, Reeve ....... . . & VI. & 27 & & & \\
\hline
\end{tabular}

ERRATUML

Plate V., species 23, for P. fimbrinta read $P$. imbluricala, Reeve. 



\title{
MONOGRAPH
}

\author{
OF THE GENUS
}

M A L L E U S。

Fool. Canst tell hov an (hammer) oyster makes his shell?

Lear. No.

Foul. Nor I neither. 




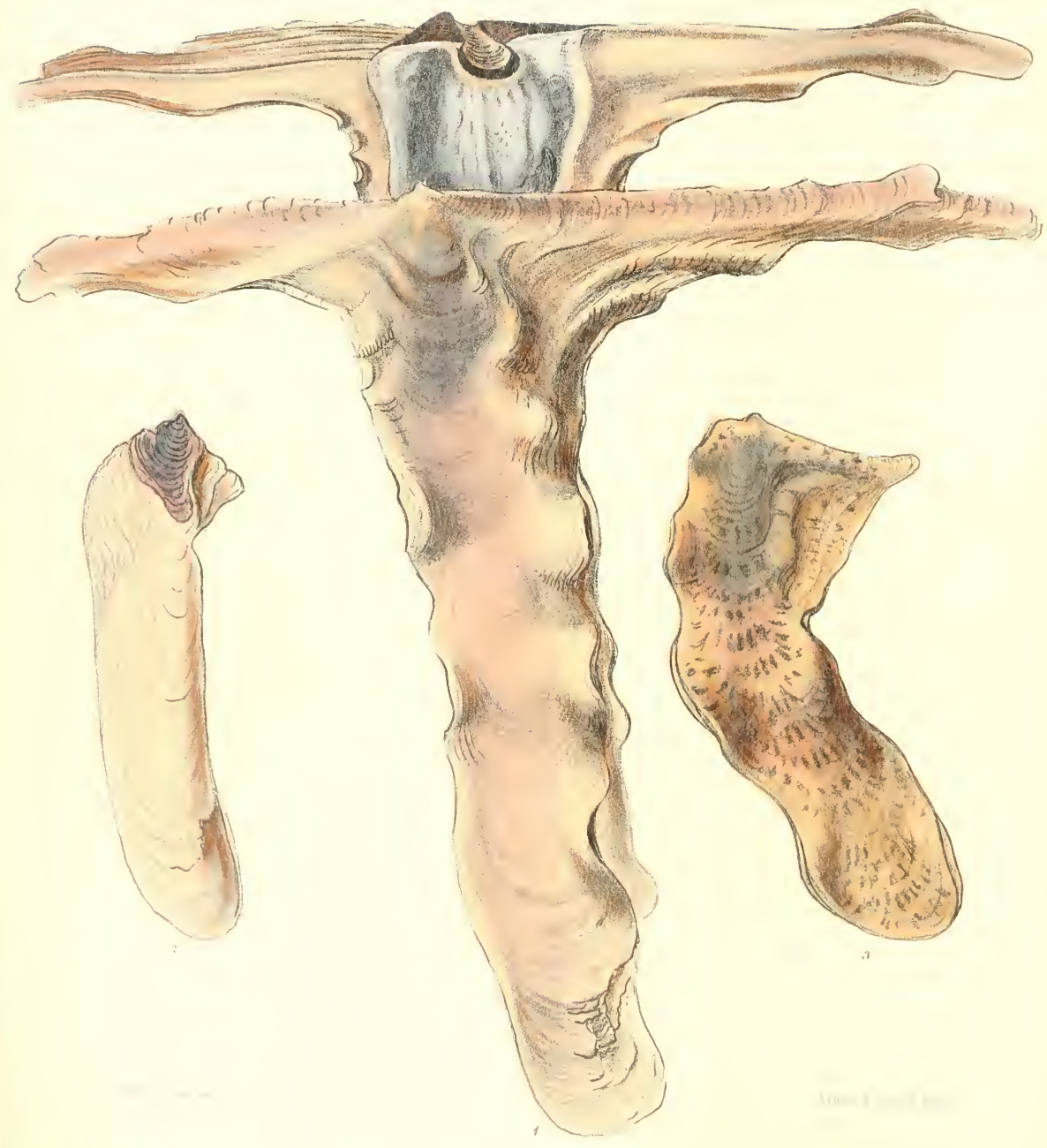




\section{A L L E U S.}

\section{Plate I.}

\section{Genus MALLEU's, Lamarck.}

Testa irregularis, subcequivalvis, elungata, ad basin interdum. utrinque lobata, umbonibus licuri at is. Carduedentulus, ligane'nto partim externo in area declivi, portim interno in fossulâa venicâ centrali, lacuná parvula pro bysso. Impressio musculeris composita.

Shell irregular, nearly equivalve, elongated, sometimes lobed on each side, umboes diraricate. Hinge toothless, with the ligament partly external on a sloping area, partly internal with:n a singlc central pit, with a small passage for the byssus. Musenlar impression compound.

The present genus was founded for the reception of two oyster-like shells of very remarkible longitulinal growth, of which the hinge portion or base is prolonged at a right angle on each sidc into a narrow lote. The term Malleus, signifying a mallet or hammer, aptly desinnates this form. Corious enough, however, in nonc of the species since discoveren, bearing the same natural afluities in other respects, is the linge-base lobed. The $M$. anatimus may be said to be slightly lobed on one side, but the lobe is webbed, and there is therefore no outlinc of the hammer structure. The central hinge-cavity is constant throughout the genus, and all the species commence from the umboes with a concentric laminated plan of growth. In the small species this latuinated growth soon terminates, forming a kind of nucleus. and the remaining portion of the shell is an independent, transparent deposit of simple calcareous matter, often characterized, however, apart from the body of the shell, by a different speciality of eolouring.

The Mnilei are found in both hemispheres.

$$
\text { Species 1. (Mus. ('uming.) }
$$

MalLecs ALiscs. Mall. testâ longissimâ, ad latera coñpressè umlatic, basi utrinque inguestè lobatâ, lobis prelongis, lavigat $\vec{t}$; sordidì alluá.

TIIE White Mablevs, Thell very long, compressly waved at thie sides, base natrowly lobed on each side, lobes very long, sunoth; dull white.

Lamarck, Anim. saus vert, vol, rii. p. 91.

Ostrea Mallens-albus, Chemitz.

Varietas Malleus momalis, Lamarck.

Jab. Philippine I-lands; ('uning.
The shell figured by Mr. Sowerby in bis 'Genera of Shells,' and by myself in 'Conchologia Systematica,' as 1I. normalis, Lamarek, is a distinct speeies, described in 1785 by Chemnitz, for which see 1 . analinus.

\section{Species 2. (Mus. Cuming.)}

Malleus legumen. Mall. Lestâ longissimấ, tenui, sublaminatâ, ad latera rect $\vec{a}$, prope umbones distortâ, concentricè rudè plicato-laminala ; albâ, nucleo laminato purpureo.

The pod MaLlecs. Shell very long, thin, slightly laminated, straight at the sides, distorted near the umboes, concentrically rudely plicately laminated; white, laminated nucleus purple.

Ffab. Philippine Islands; Cnming.

This singular speeies has a ronghly laminated nucleus at the commencensent of its formation, alter the manner of some of the small Perne. The valves are then produced of a thin, semitransparent, brittle substance, into a long pod.

\section{species 3. (Mus. Cuming.)}

Maldeus axatixus. Mall. testâ elongatâ, obliquè rudè contortâ, ad latera subundatä, basi ad latus pasticum alato-lobatî́; livido-albî, subpellucidé, maculis purpureo-migris aspersä.

The Duck MalLees. Shell clongated, obliquely rudely twisted, somewhat waved at the sides, base wing-lobed on the posterior side; livid-white, subtransparent, sprinkled with purple-black spots.

Lamarck, Anim. sans vert. vol. vii. p. 93. Ostrea anatiua, Gmelin. - tuas domestica, spengler. Ostrea figurata, Chemnitz. Mlalleus normalis, sowerby (not of Lanarck).

IIab. Moluceas,

This species may always be recognized by its purpleblotched colouring. The hinge-base is lobed on the posterior side, but the lobe is webbed, so to speak, so as to becoine winged. 

Malleus Pl II.

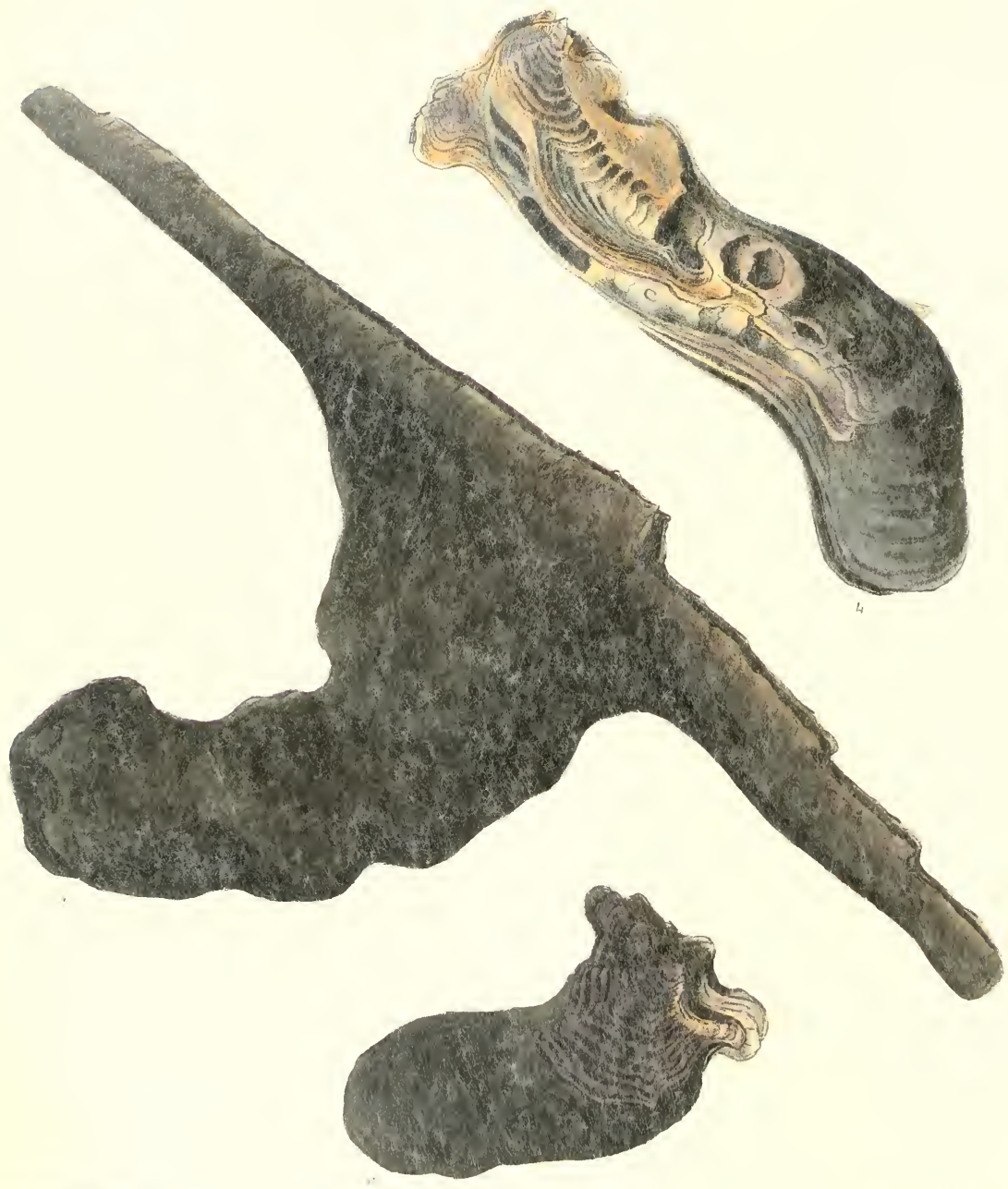




\section{A L L E U S.}

\section{Plate II.}

\section{Specics 4. (Mus. Cuming.)}

Malleus regula. Mall. testâ elongatâa, depressâa, interdum undato-distorici, prope umbones concentricè liratolaminatâ, laminis deinde irregularibus, plus minus decorticatis, basi posticè subalatâ; purpureo-nigrá.

The rule Malleus. Shell clongated, depressed, sometimes wave-distorted, concentrically ridge-laminated near the umboes, lamina then irregular, more or less decorticated, base slightly winged on the posterior side; purple-black.

Ostrea regula, Forskacl, Descr. Anim. p. 124.

Ostrea ocrea, Martini

Fexillum Moluccanum, Chemnitz.

Ostrea $\Gamma_{\text {ulsella, Gmelin. }}$

Mulleus vulsellatus, Lamarck.

Hab. Philippine Islands.

A purple-black, strongly laminated species, mostly decorticated, so as to expose the laminæ in broken concentric ridges.

Species 5. (Mus. Cuming.)

Malleus vulgaris. Mnll. testâa subelongatâ, valdè rugoso-contortâ, basi angustissimè lobatâ, lobis subalatis, prolongis; inlus extusque purpureo-nigrâ.
The commos Mallevs. Shell somewhat elongated, very roughly contorted, very narrowly lobed at the base, lobes slightly webbed, very long; purple-black within and without.

Ostrea malleus, Linnæus, Syst. Nat. p. 1147.

Malleus vulgaris, Lamarck.

Hab. China Seas.

Distinguished from $M$. albus not only by its intense purple-black colouring, bnt by its very rude, roughly blistcrcd, tumid, contorted growth.

Species 6. (Mus. Cuming.)

MaLLeUS Demoniaces. Mall. lestâ rudè linguaformi, ob̋iiquâ, concentricè lirato-laminat $\vec{a}$, ad basin utrinque aurită; intensè purpureo-nigrâ.

The demoniacal Malleus. Shell rudely tongue-shaped, oblique, concentrically ridge-laminated, eared at the base; deep purple-black.

Hab. Philippine Islands.

This shell might, perchance, be regarded as the young of $M$. regula; but it is of an oblique growth, conspicnonsly eared on each side, the umboes and ligamentary cavity being exactly central. 


Malleus Pl. III
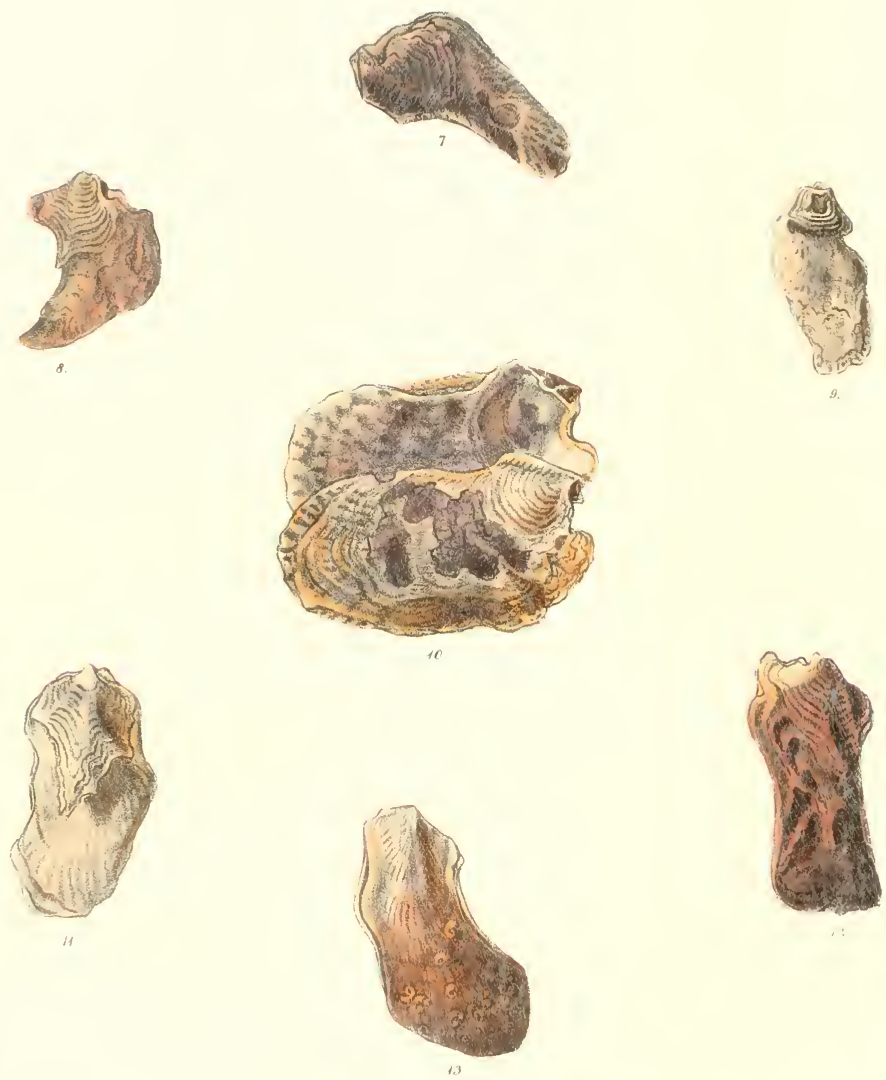


\section{A L L E U S.}

Plate III.

Spuctes 7. (Mus. Cuming.)

Malleus 'TIGRixts. Mall. testâ oratâ, subpectinatâ, validè coneentricè plicato-laminatâ, deinde teuni, obliquè prolongatâ; albidei, parte tenni naculis purpureis aspersâ.

The tiger-spotted Matleus. Shell ovate, somewhat pectinate, strongly concentrically plicately laminated, then thin, obliquely prolonged; whitish, the thin portion sprinkled with purple spots.

Hab. Moluceas.

It is a curious typical peculiarity of the smaller species of Matleus asscmbled in this Plate that the sculpurred shell is formed as a nucicus about the umboes, from which proceeds a more or less elongated, semitransparent, irregular lamina.

Speeies 8. Mus. Cumint.)

Malleus refipunctatts, Wall, testä sublrigono-orathi, concentricè pliento-lawinati, drinde irregnimiter temui prolongat ât; allithi. parte temni litido-corneâ, maculis purpurascente-rufis obscurè fictat.

THE RED-DotTed MaLeus, Shell snmewhat triangularly ovate, concentrically plicatcly laminated, then irregular, thinly prolonged; whitish, thin portion lividhorny, obscurely painted with light purple-red spots.

Hab. West Columbia; Cuming.

As in the preceding species, the most charncteristic fetture lies in the colnuring of the thin, irregular, protruding lasuina.

\section{Species 9. (Mus. Cuming.)}

MALLEIS Macelosts. Hall, testâ trigono-quadratä, parvâ, subulscurè lasmimntii, drinde tenui, anipliter prolongati, tumidiusculi, petluritu-corneä, purpureo maculoxí.

IHE rRecklid Miftets. Shell tiangularly square, small, somewlat obsemely laninated, then thin, largely prolonged, ratler swollen, trausparent-lioruy, spotted with purple.

Hab. Lord Ilaod's Island, Pacific Ocean; Cuming.

The thin, prolonged lanina of this shell is almost bladder-like, the sentptured nucleus having the appearance of it parasite upon it.

\section{Species 10. (Mus. Ciming.)}

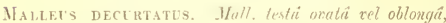
prope unbmes nitide lammatri, drinde valdè ruyusä; albidit, purpureo lincti et ancululá.
The shortened Malleus. Shell ovate or oblong, neatly laminated near the umboes, then very rough; whitish, stained and spotted with purple.

Lamarck, Anim. sans vert. vol. vii. p. 93.

Ilab. New Ilolland.

Of a less delicate texture than either of the preceding species, purple-spotted, with a rougher exterior.

\section{Species 11. (Mus, Cuming.)}

Malleus aquatilis. Mall. trostâ lrapezoideá, concentricè undato-plicatâ, deinde tenuè prolongatâ, parte tenui pellurido-rorneẩ, obseurè faxciatî.

The kippled Mallees. Shell trapezoid, concentrieally wave-plaited, then thinly prolonged, the thiu portion transparent-horny, obscurely banded.

Hub. Is]e of [lata, West Columbia; Cuning.

The nuclcated portion of this shell is arranged in conspicuous trapezoid plaits, whilst the thin portion is obscnrely banded.

\section{Species 12. (Mus. Cuming.)}

Mallevs vesictlates. Mfoll. trstât subtrupezuideñ, concentricè densè plicato-laminatâ, deinde tennè protongatä, parte tenui oblongo-quadratî, longitudinaliter lirato-striutâ, tmidat, irregulariter vesirmlutâ; intensè rufo-purpureâ.

ThE BListered MALlecs. Shell somewhat trapezoid, concentrically densely plieately laminated, then thinly prolongel, the thin portion oblong-square, longitudinally ridge-strinted, swollen, irregularly blistered; deep reddish-purple.

Hab. Isle of Plata, West Columbia; Cuning.

The prolonged laminar growth of this species is singularly: swollen and unch blistered.

\section{Species 13. (Mus. Cuming.)}

Malieus solitarius. Mall. testri obliquè elongatä, tenuissinâ, pellncidtu, pallidè ceneo-rufescente, radiatim undato-liratâ.

Tue solitary MLalets, Shell obliquely elongated, very thin, transparent; light coppery-red, radiatcly wateridged.

Hab. Grimwood's Island, Pacific Ocean; Cuming.

A delicate, transparent, coppery-tinged shell, not belonging to the nucleated type, which is characteristic of the other species in this Plate. 


\title{
MONOGRAPH
}

\author{
OF THE GENUS
}

V U L S E L L A.

"Free from extremes of ebb and flow, Not swelled too high, nor sunk too low. Such shall thy life's smooth current be, Till from time's narrow shore set free, It mingle with the eternal sea." - Hughes. 

Cielsella Pl. I
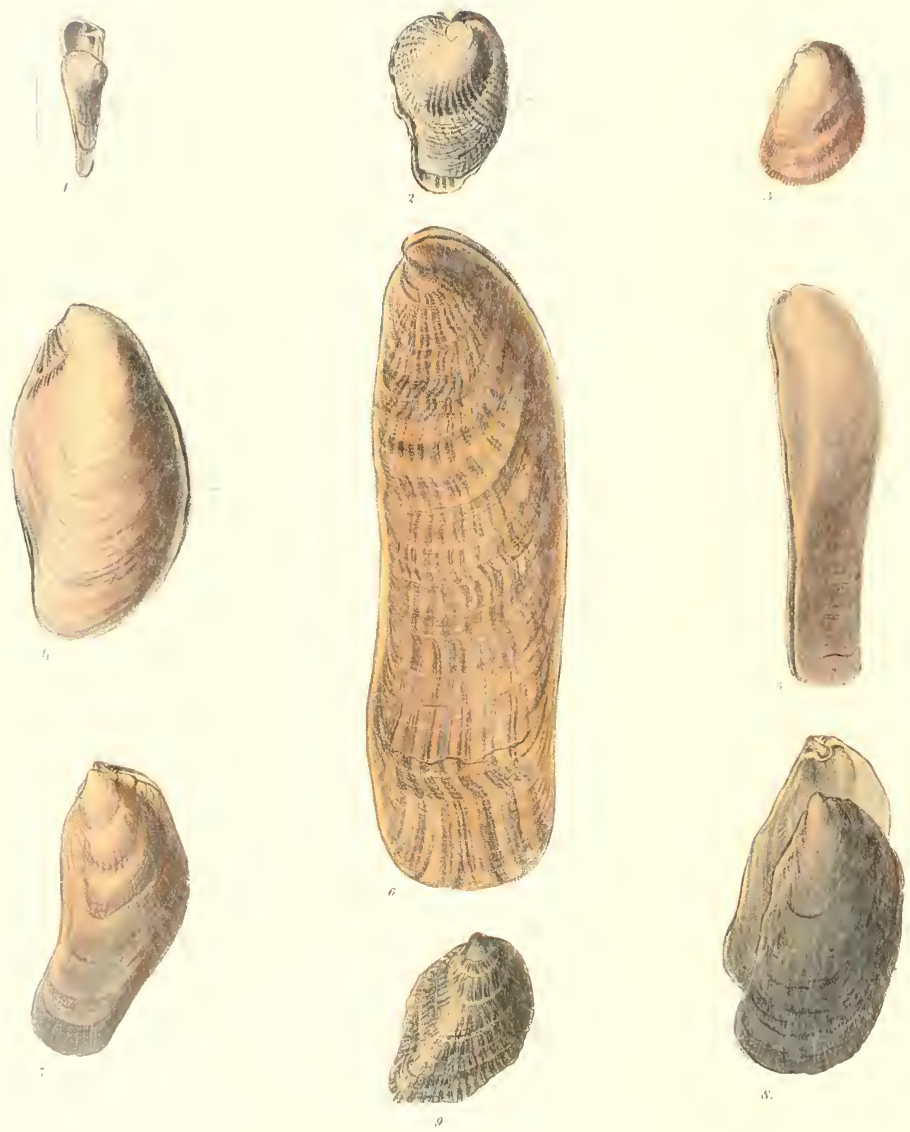


\section{U L S E L L A .}

\section{Plate I.}

\section{Gicuus VLLSELLA, tomutrof}

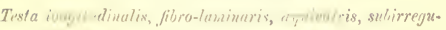

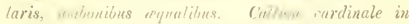
utrâtue caleâ prominulum, supernè drinessum, cum foveâ conicâ obliquè arcuatû desuper impressum, ligamento inserto. Impressio muscularis subcentralis, versus basin distinctè imbuta.

Shell longitudinal, fibro-laminar, equivalve, somewhat irregular, umboes equal. IIinge-callosity in each valve prominent, depressed at the upper part, impressed above with an obliquely-arched conical pit enclosing the ligament. Muscular impression nearly central, distinctly marked towards the base.

The shells which constitute the genus Fulsella are all of a dull-brown fibrous texture, of very irregular growth, living chiefly imbedded in sponge. They present great sinilarity of sculpture, being mostly beset with laminæ of minute crcnulated scales, and the umboes are invariably attenuated and more or less looked. The most conspicuous structure of the binge is a central spoonshaped pit, as in Mallens; but besides this, the valves incline to recede from one another at the base, so as to form a sloping area.

The list now numbers seventeen species, chiefly from the Red Sca.

\section{Species 1. (Mtus. Cuning.)}

Vulsella Pholadiformis. 「ul. testa elongato-trigonâ, graciti, decussatim fimbriato-striatâ.

The Pholas-3haped Vulsella. Shell elongatcly triangular, slender, decussately fimbriately striated.

Hab. Ceylon; E. L. Layard.

Distinguished by its slenderly triangular Pholas-shape.

sprecies 2. (Mus. Cuming.)

Velselia Isncanda. Tul. testâ ovatâ, depressâa, umbonibus intortis, concentricè squamato-laninatis, squnmis crenatis : sordùlè albît obscurè radiatâ.

The Isocardia Vuiseila. Shill ovate, depressed, umboes turned inwards, concentrically squamatcly lamiwated, scales crenated; dirty-white, obscurely rayed.

Hab. Red Sea

The surface of this species is almost wholly overlaid with a plating of finely-pointed scalcs, the umboes being convoluted inwards, as in Isocardia.

\section{Species 3. (Mus. Cuming.)}

Vulseila TAsmanica. Vul. testât subtrigono-ovatâ, rudi, distorti, umbionibus parvis, densè squamato-striatis, fermeineo-albâ.

The Tasmanian Vulsella. Shell somewhat triangularly ovate, rude, distorted, unboes small, densely squamately striated; rusty-white.

Hub. Tasmania.

Of very uncouth growth, closely scale-striated, and rusty-white.

Species 4. (Mus. Cuming.)

Vulsella Mrtilina. $V u l$. testâ oblongo-ovatât, anticè subcomprrssâ, sulidiusculâ, obscurè decussatim squamalo-slriatấ; ferrugineo-albâ.

The Mrtilus-shapid Vulsella. Shell oblong-ovate, antcriorly somewhat compressed, rather solid, obscurely decussately squanately striated; rusty-white. Lamarck, Anim. sans vert. vol. vii. p. 268.

IIab. Red Sea; Dr. Ruippell.

More solid, and less definitely scaled than its congeners.

\section{Species 5. (Mus. Cuming.)}

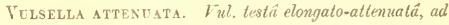
extremitatem depresso-subquadratâ, radiatim obscurè squamato-striati ; comeo-albidâ, deinde livido-purpurascente-brunneat.

The atrenuated Vulsella. Shell elongately attenuated, depressly subquadratc at the extremity, radiately obscurely scale-striated; horny-white, then lividpurple-brown.

\section{Hab. Red Sea.}

The example of this species here figured may be more than ordinarily attenuated, owing to some external conditions in its situation of growth.

\section{Species 6. (Mns. Cuming.)}

Vulselia lingulata. Ful. testâ elongatâ, rectâ, concen- 
VULSELLA.-PLATE I.

trict striatâ, fuscâ, lineis fasciisque pallidioribus undatim pictâ.

IHI TONGUE-SHAPED VULSELla. Shell elongated, straight, concentrically striated, brown, painted in a waved manner with lighter bands and lines.

Vya Iulsella, Linnæus, Syst. Nat. p. 1113.

$V$ ulsella lingulala, Lamarck.

1lah. Red Sea.

This original and well-known species far transcends the rcuainder in size and general definition of character.

Species 7. (Fig. 7 and 8, Mus. Cuming.)

$\mid$ Ul.SELLA RUGOSA. Vul. testâ obliquè oblongâ, subarcuatâ, planulatä, longitudinaliter rugosâ, striis transversis crenalis rugas decussantibus; purpureo-fuscâ.

THE WRINKLFD VUSELLA. Shell obliquely oblong, some- what arched, flat, longitudually wrim wey, wite $\mathrm{cre}-$ nated transverse stria crossing the wrink, purplebrown.

LAMARCK, Anim. sans vert. vol. vii. p. 269

Hab. Red Sea.

A rugose purple-brown species, having is somewhat obliquely arched growth.

\section{Species 9. (Mus. Cuming.)}

Vulsella crenulata. Ful. testî orutu-trapezoideci, squamato-laminatä, squanis crenulutis: sordu" ${ }^{2}$ alhi

The cRenulated Volsella. Shell ovately trapezod squamately laminated, scales crenulated - dirt $y-8 h_{1, t}$ Hab. Red Sea.

Very similar to $V$. Isocardia in ser Intur. 


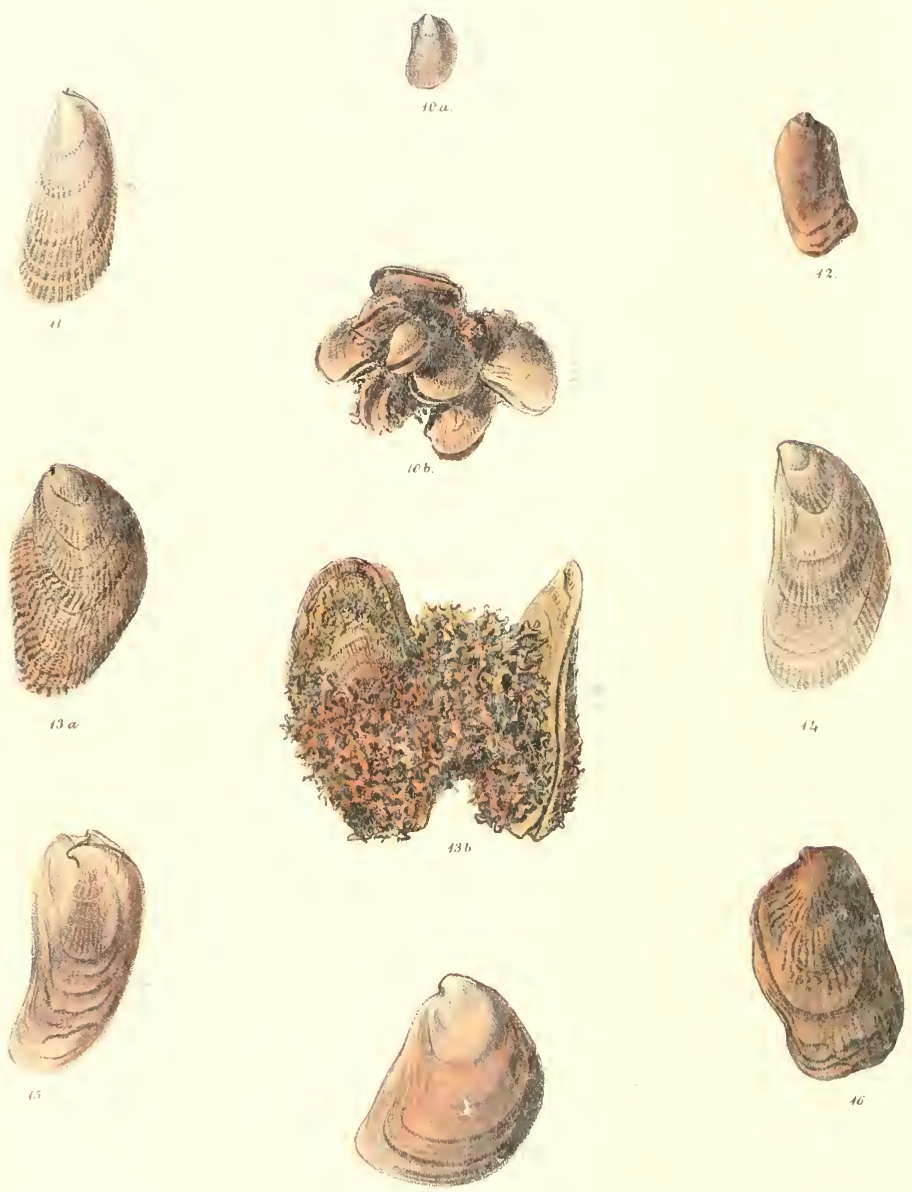

14

16 
speries 10. (Fig. Ho" and 106, Mus. ('umung.)

Vulselda TIM.FFORMrs. Viul. Testa subpectinatii, ventri$\cos \hat{\imath}$, tenuissimi cremuluto-squematí; sordidè albî.

THE LIMA-sHAPED I LSELLA. Shell subpcetinate, ventricose. very fiuely cremulately scyumate; dirty-white. Hak. Port Adelaide, south Australia.

This little species, of which Fig. 10 b represents a group invested with spouge, is characterized by a subpectinate auriculated growth on each side of the umboes, which gives it a Limn-like appenranee.

\section{Sirecies 11. (Mus, Cuming.)}

Vilselia phasianojtaka. tul. testá elongalo-cuneiformi, versus umbones attennatá, densè scabroso-striatá; fuscâ, radiis pallidis angustis subundatis nilidè pictû.

ThE PHEAsANT'S-WING VulselLA. Shell elongately wedge-shaped, attenuated towards the umbocs, densely scabrously striated; brown, neatly painted with waved narrow pale bands.

Hab. Australia.

An attenuated Mytilus-like form, exquisitely painted in a mamner somewhat resembling that of $\zeta$. lingulata.

$$
\text { Species 12. (Mus. Cuming.) }
$$

Vulsella rudis, Tul. testâa oblongo-quadrat $\hat{\imath}$ obliquâ, rudi, subirregulariter laminatâ, minutissimè crenulatosquamat $\vec{a}$; soritide fruscescente.

The kUDE Vuiseili. Shell oblong-square, oblique, rude, somewhat irregularly laminated, very minutely crenulatcly sealed; dull-brown.

IIal. Swan river, Australia.

of rucle, irregular growth, yet minutely erenulately scaled, so as to give the surlace a somewhat granular appearance.

Firecics 1:3. (Fig. 13 and 13 h, Mins. ('uming.)

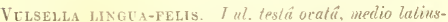
culâ, undique densì cromulato-squamuta, squamis subererlis. sputiceo-fusci.

THE CAT'S-TONGUE VULSELLA. Shell ovate, rather broad ncross the middle, densely crenulately sealed throughout, scales somewhat erect; tray-brown.

\section{$\mathrm{Hal}$}

This species is distiugushed by its thick-set coating of comparatively erect crenulated scales. Fig. 136 represents a group invested with sponge.

species 14. (Mus. Cuming.)

Vulseria coroldata. Inl. testí attenuato-cuneiformi, concentricè densi two inatis, laminis crenulato-squamatis; sordide /msrit

THE FESTOOSED TILsELLA. Shell attenuately wedgeshaped, eoncentrically densely laminated, lamine erenulately sealed; dirty-brown.

IIab. Zanzibar.

Of a characteristic Wytitus form, densely sculptured throughout with festoons of crenulately scaled lamine.

Speeies 15. (Mus. Cuming.)

VUlsella spongiarum. $\quad \vec{u} l$. testä oblonga, areuati, ad basin latiusculi, umbonious divergentibus, radiatim minntissimè crenulato-synomalâ; f fuscescente.

THE SPONGE VUlsella. Shcll oblong, arched, rather broad at the base, muboes diverging, radiately very minutely crenulatcly scaled; light-brown.

LАзавск, Anim. sans vert. vol. vii. p. 268.

IIab. Sutz.

Although it is a generic character of the Fulsella to bave the umboes diverge from each other with advancing growth, they appear to be more than usually divergent in this species.

Species 16. (Mus. Cuming.)

Velsella IIANs. Ful. testâ oblongo-quadratä, subobliquâ, anticè liante, rudè laminatâ, radiatim crenulatosquamatâ, radiis undulatis; fuscá.

ThE GaPixg Vulsej.LA. Shell oblong-square, rather oblique, gaping in front, rudely lamiuatcd, radiately crepulately striated, rays a little waved; brown.

LAMARCK, Anim. saus vert. vol. vii. p. 267.

Hab. Pbilippine Islands; Cuming.

Of somewhat rude irregularly laminated growth, gaping in front, and sometimes a little gaping behind, with the crenulated seales, which is the predominating sculpture of this genus, ranged in waving rays.

\section{Species 17. (Mus. Cuming.)}

Tulsella TKITA. tul. testấ subtrigono-oratî, latiusculâ, solidâ, concentric̀ striatá, medio lavigalâ; spadiceofuscî.

THE WORN VULSELLA. Shell somewhat triangularty ovate, rather broad, solid, concentrically striated, smooth in the middle; bay-brown.

Ilab. Red Sea.

A more solid species than usual, with no perceptible indication of crenulated scales. 


\title{
MONOGRAPH
}

\author{
OF THE GENUS
}

\section{$\begin{array}{llllllllllll}C & R & E & N & A & T & U & L & A\end{array}$}

"Natare never did betray

The heart that loved her; 'tis ber privilege, Through all the years of this our life, to lead From joy to joy ; for she ean so inforin The mind that is within us, so impress With quietness and beanty, and so feed With lofty thoughts, that neither evil tougues, Rash judgments, uor the sneers of selfish men, Nor greetings where uo kindness is, nor all The dreary iutercourse of iaily life Stall e'er prevail narinst us or disturh Our eheerful faith, that all which we beholi Is full of blessings."-Wordswerth. 



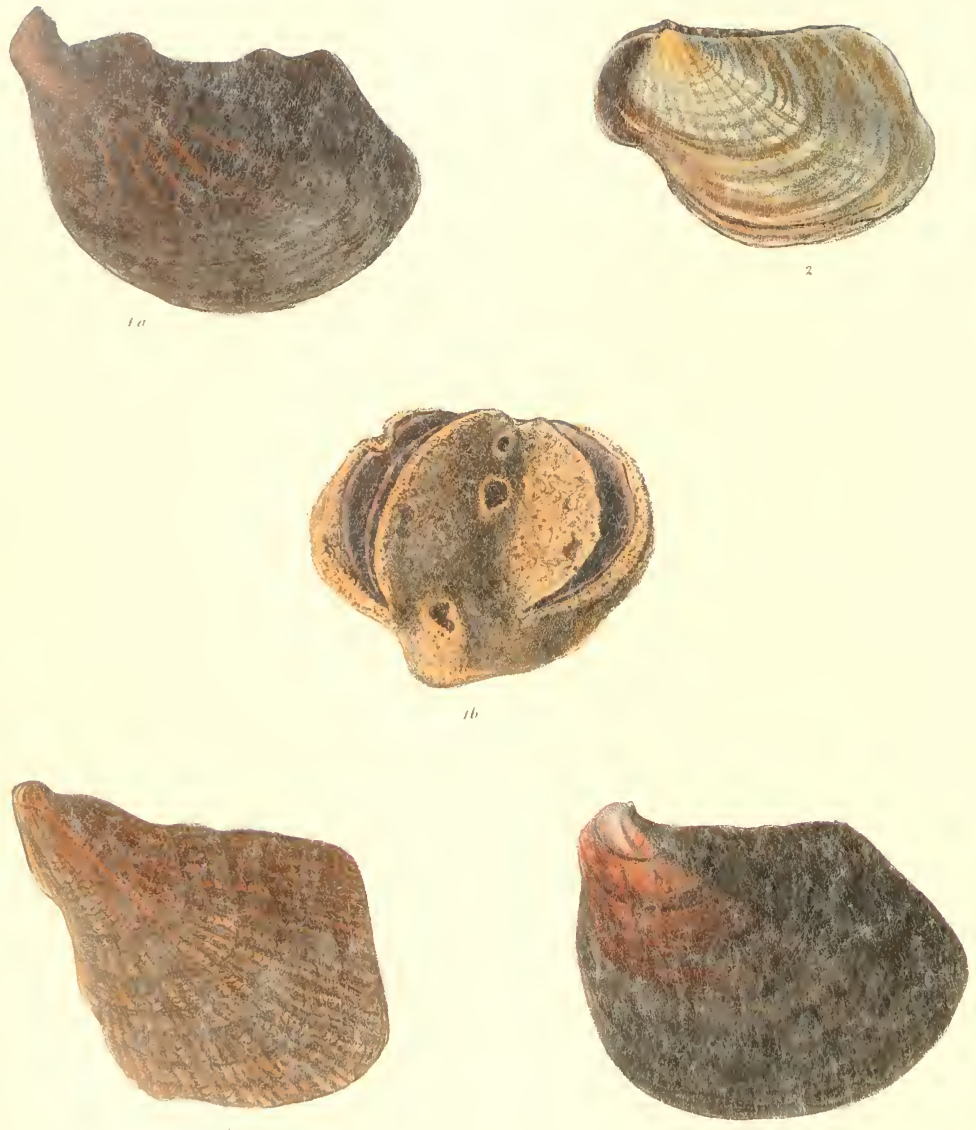

, 


\section{PLATE I.}

Genus CRENATULA, La rark.

Testa tenuis, subcequivalris, cmplanatu, plerumque concentricè striata, fibro-laminaris, obtinua. Cardo lateralis, linearis, marginalis, crenulatus; crenis in seriem ordinatis, callosis, subercavatis, ligamentum excipientibus. Impressio musenluris oblonga, indistincta.

Shell thin, nearly equivalve, smooth, mostly concentrically striated, fibro-laminar, oblique. Hiugc lateral, linear, marginal, cronulated; crenules set in a row, callous, rather hollow, recciving tbe ligament. Muscular inpression oblon, indistiuct.

This very characteristic genus was established about balf a century ago, by Lamarck, in the 'Annales du Museum' of Paris. It is a member of the family of Aviculacea, and is distiuguished by a narrow linear linge, presenting a row of bollow crenules or jutting cavities for the reception of the ligament. But concomitant with this are other peculiarities of not inferior importance. The shells are all of a delicate horny substance, and of a constant obliquely quadrate or obliquely orate growth; and it is their habit to live imbedded in sponge.

All the species arc from the Red Sca except a new one, which I have the pleasure of introclucing, of a very distiuct typical forn, from New Caledonia.

Species 1. (Fig. $1 a$ and $1 b$, Mus. Cumiug.)

Crexatula nigriva. Cren. testâ obliquè ovatâ, subunduto-distort $\vec{a}$, anticè rotunduta, posticè dectini-angulatu, nigrinâ, corneâ, concentricè interruptè plicatostriatâ ; rudiis juscescentibus distantibus undulatis subobisurè̀ pictâ.

The вlack Crenatula. Sliell obliquely ovate, somewhat wave-distorted, anteriorly rounded, posteriorly slopingly angled, black, horty, coucentrically interruptcrly plicately striated, rather obscurely painted with waved, distant, brownish rays.

LaMarck, Anim. sans vert. vol, vii. p. 72.

Hab. lied Sea.

Chiefly distinguished by its painting of distant faint brown rays upon a black horny ground.

Species 2. (Mus. Cuming.)

Crenatula riridis. Cren. testâ transversè ovalâ, sitbobliquâ, convexâ, anticè rotundalâ, posticè subangulato- productâ, tenw, concentricè striatî; viridi, pallide radiatâ et fasciatê.

The green Crenatula. Shell transversely ovate, rather oblique, couvex, auteriorly rounded, posteriorly angularly produced, thiu, concentrically striated; green, faintly rayed and banded.

Lamarck, Anim. sans vert. vol. vii. p. 72.

IInb. Red Sea.

A species of delicate borny substancc, easily recognized by its Anodon-like form, and bright-green colour.

Species 3. (Miss. Cuming.)

Crenatela avicclaris. Cren. testâ trigono-flabellatâ, declivè utrinque angulari, versus umbones attenuat $\hat{a}$. depressâ, concentricè interruptè plicato-striatât ; rufescente-nigrâ, radiis linearibus rufo-fuscis profusè pictá.

The avicular Crenatula. Shell triangularly fanslaped, slopingly augular on each side, attenuated towards the umboes, depressed, concentrically interruptedly plicately striated; reddish-black, profusely painted with linear red-brown rays.

LaMarck, Anv. du Mus. vol. iii. pl. 2. f. 1, 2.

IIal. Red Sea.

Distinguished by its sloping, angular form, and profuse browu-rayed painting.

Species 4. (Mus. Cuming.)

Crenatula bicostalis. Cren. testâ subquadroto-ovatâ, anticè convex $\hat{a}$, rotundutâ, posticè coneavâ, abbreviatoangulutâ, medio obscurè radiatin bi-tricostata $\overrightarrow{\text {. costis }}$ subnodosis, concentricè striatâ ; nigrâ.

The two-RIBBed Crevatoia. Shell somewhat squarely ovate, anteriorly convex, rounded, posteriorly concave, shortly angled, obscurely rayed in the middle with two or three ribs, which are slightly noduled; black.

LAM $\Delta R c k$, Anim. sans vert. vol. vii. p. 72.

$H a b$. Red Sea.

In this species there is a more characteristic difference between the conrex anterior portion of the shell, and the concave posterior part, which describes a more contracted angle. About the middle, radiating from the umboes, there is a faint iudication of noduled ribs. 



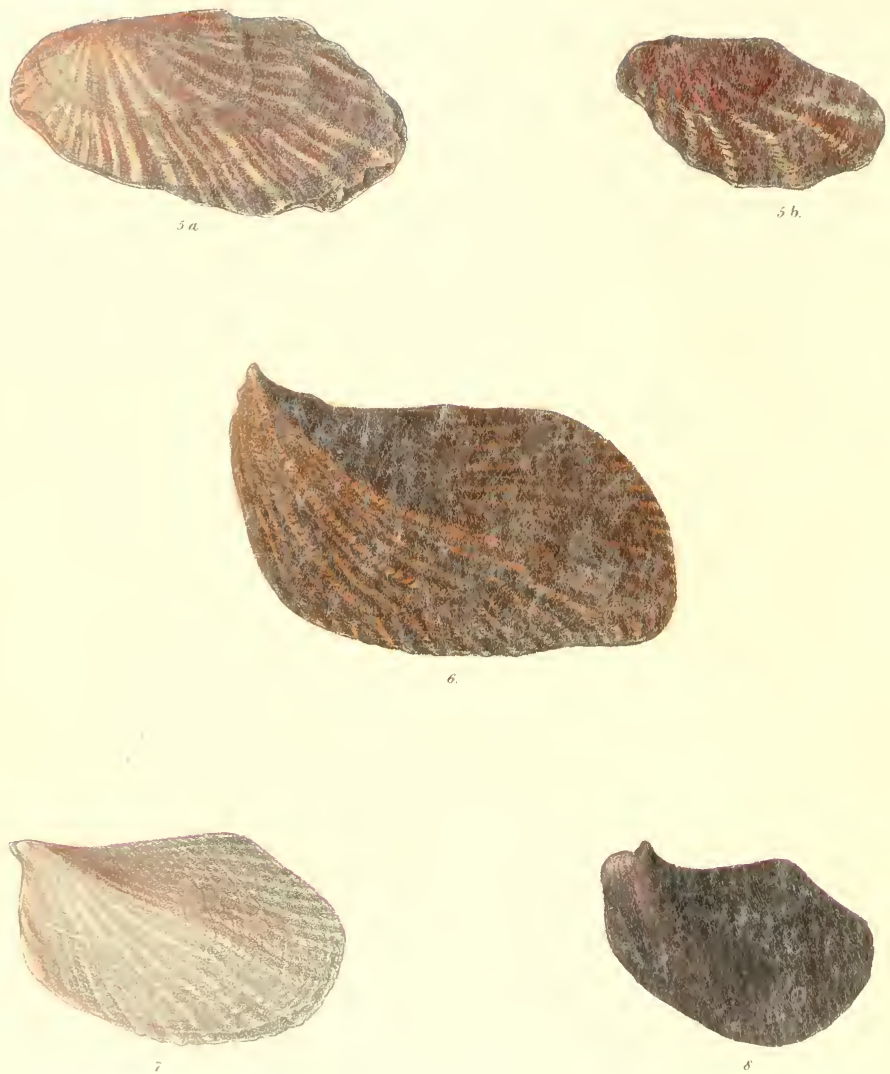


\section{R E N T U L A.}

\section{Plate Il.}

Species 5. (Fig. 5. and $5 b$, Mus. Cuming.)

Crenatula flammea. Cren. testâ transetersè ovatâ, subangust $\hat{a}$, obliquâ, rudè ronvera $\hat{a}$, lenui, concentricè striat $\vec{a}$; rubiel $\vec{a}$, fasciis acutè undatis pallidis variè dislantibus peculiariter obliquè lentiginosâ flanmatâ.

The FLAMED Crenatula. Shell transversely ovate, rather narrow, oblique, rudely convex, thin, concentrically striated; red, flamed with variously distant zigzag pale bands, which are peculiarly obliquely freckled.

Hab. New Caledonia.

This interesting species differs materially from the Red Sea type. It is of a rather narrow transverse oval form, ronvex and thin, and of a dull coppery-red colour, more or less raved with sharply zigzag bands and lines, which are curiously obliquely freckled across.

\section{Species 6. (Mus. (uming.)}

('inenatula picta. Cren. lestâ transversè oblongo-quadratü, obliquè subundut $\hat{a}$, depressit, umbonibns rostrntis, concentricè interruptè plicato-striatä; rufescente-nigrâ, radiis linenribus rufo-fuscis profusè pictâ.

The painted Crenatula. Shell transversely oblongsquare, obliquely slightly waved, depressed, umboes beaked, encentrically interruptedly plicately striated; reddish-black, profusely painted with red-brown linear rays.

Ostrea picta, Gmelin, Syst. Nat. n. 127.

Crenatula picta, Deshayes.

Crenatula phasianoptera, Lamarck.
HIab. Red Sea.

Except in form, there is no difference betwcen this species and $C$. avicularis. The colouring is identical.

\section{Species 7. (Mus. Cuming.)}

Crenatula folium. Cren. testâ transzersè rhomboideá, obliquè eonvexâ, utrinque obtusè angulat $a_{\text {; }}$ livido-albidâ, costis nodosis opaco-albis radiatâ.

The leap Crenatula. Shell transverscly rbomboid, obliquely convex, obtusely angled on each side; lividwhite, rayed with opaque-white noduled ribs.

GraY, Brande's Journal, pl. 2. f. 81.

$H a b$. Red Sca.

Characterized by a pale-livid bue, rayed with noduled ribs of opaquc-white.

\section{Species 8. (Mus. Cuming.)}

Crenatela Mrtiloines. Cren, testâ obliquè subquadratâ vel oblongâ, prope unbones convexâ, deinde depressâ, densè concenlricè striatâ, lacvi; purpureo-nigrâ.

Tie Mrtilus-like Crenatula. Shell obliquely subquadrate or oblong, convex near the umboes, then depressed, densely concentrically striated, smooth; purple-black.

Lamarck, Ann. du Mus. vol. iï. p. 30. pl. 2. f. 3, 4 . Hab. Red sea.

Mostly somewhat distorted in form, jet-black, without any indication of rays. 



\section{MONOGRAPH}

OF THE GENUS

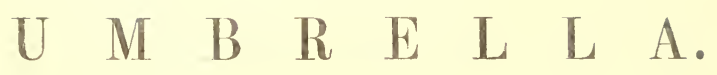

A lovely dwelling by the wave

of the blue deep which bathes Italia's shore,

Far from all sonnds but rippling seas, that lave

Grey rocks with foliage richly shadow'd o'er,

And sighing winds, that murnur through the wood

Fringing the bach of that Hesperian flood."

$$
\text { Mrs. Hemans. }
$$





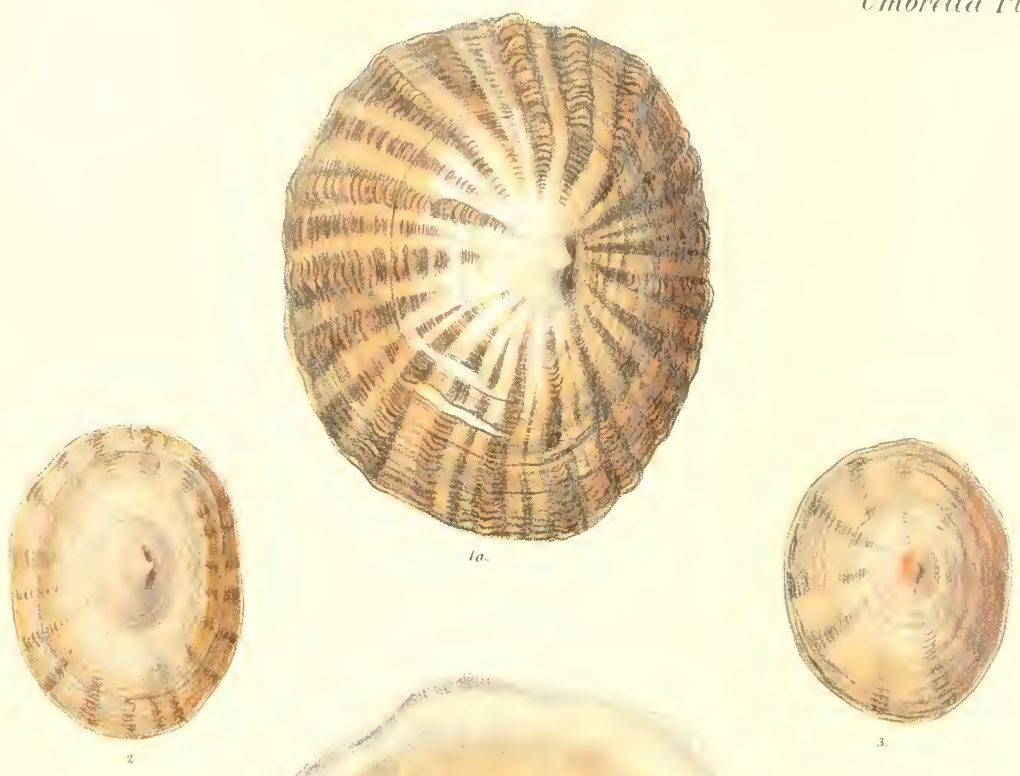


\section{U M B R E L L A.}

\section{Plate I.}

Gismis LMBRELLA, Lmirark.

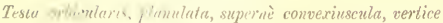
minur , sulicentrali, infernè concavinsculâ, disco centrali, impressione musculari irregulari continuâ ad centmum circulariter imbutâ.

Shell orbicular, flat, rather convex at the upper part, with a very small nearly contral vertex, rather concave beneath, impressed with a central disc, having an irregular continuous muscular impression around it.

The "Chinese Parasol" of the older French naturalists being found to differ in general character from the rest of the Limpet tribes, a genus was created for its reception by Lamarck, nuder the title of Tmbrella. On the discovery of the animal it was found to be a large tumid warty mass, with the shell imbedded flat upon the back.

The principal species has a wide range throughout the Eastern seas; a second species inlıabits the Mediterranean; and third was collected by Nlr. Cuming at the mouth of the Chiriqui river, in the Bay of Panama.

Species 1. (Fig. $1 a$ and $1 b$, Mus. Cuming.)

UMBRELLA INDica. t'mb. teslấ swbtus concavinsculä, radiatim stiviat $\hat{t}$, alba, medio intensè nurantio-sulphureê, extus concentricè strintâ, uargine undulatä; carneoalbidâ, rudintim fusciut $\hat{a}$, fasciis fuscescent ibus, epidermide plicatii imlulat.

The Ixdiay I mbrelia. Shell rather concave beneath, radiately striated, white, decp orange-sulphur in the middlc, concentrically striated without, waved at the margin; flesh-wlite, radiately banded, bands browuish, covered with a plicated epidermis.

Lamarck, Auim. sans vert. vol vii. p. 573.

Patella nimbellata and Sinica, Gmelin.

Hab. Eastern seas.

Fig. $1 a$ in the accompanying Plate represents a specimen ratlucr more than usually convex, in a very fresh state of preservation, being covered with an epidermis, which, on the radiating bands, is set in thich-set folds. Fig. 16 shows the richly orange-sulphur interior of a specimen of larger and flatter growth.
Species 2. (Mus. Cuming.)

Umbrella Mifmiterranea. Umb. testâ ovatâ, tenviculâ, depressâ, concentricè interdum rugoso-plicatâ ; carneoalbulâ, subobscurè fuscescente radiatâ, subtus medio pallidè sulphureá.

Tire Mediterranean Umbrella. Shell ovate, rather thin, depressed, concentrically, sometimes rugosely plicated; flesh-white, rather obscurely rayed with light-brown beneath, pale-sulphur in the middle.

Lama13ck, Anim. saus vert. vol, vii. p. 574. Umbrella Lanarckina, Recluz.

IIab. Mediterranean Sea.

A much less solid species than the preceding, with little appearance of radiating striæ on the inner surface. M. Recluz described, in 1843, Revue Soc. Cuviérienne, p. 109, a second species of I mbrella from the Mediterranean, but his vicws in this respect have not been confirmed.

\section{Species 3. (Mus, Cuming.)}

UMbrella ovalis. Unh. testâ ovali, lenui, subpellucidâ, planulatât subtus aurantio-albât, lavigatâ, extus concentricè strialâ, murgine integrâ, vertice parvo; carnooalbielä, fuscescente pallidè remotè radiatâ, epidermide tenui indutâ.

The oval Umbrella. Shell oval, thin, rather transparent, orange-white beneath, smooth, concentrically striated witbout, entire at the margin, vertex small; flesh-white, faintly distantly rayed with brown, covered with a thin epidermis.

Carpenter, Pro. Zool. Soc. 1856, p. 161.

Hab. Nouth of the Chiriqui river, Bay of Panama; Cuming.

The specific differences in this genus are slight and variable, but the discovery in the above-named locality of a genus of so characteristic a type as Umbrella, hitherto known only in the eastern hemisphere, adds materially to the importance of the species. 



\title{
MONOGRAPH
}

\author{
OF THE GENUS
}

\section{P E D U M.}



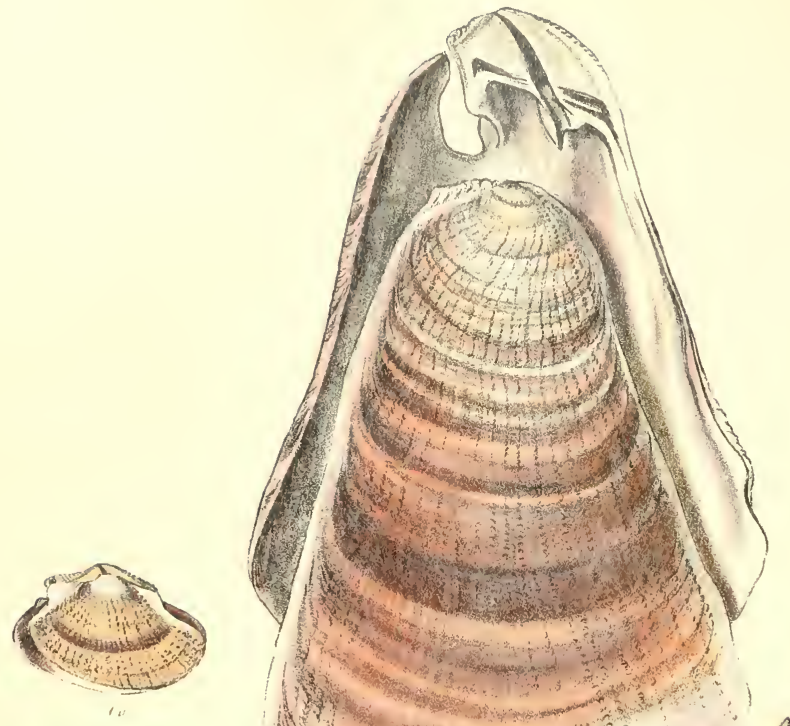

Pedrem Plo I.
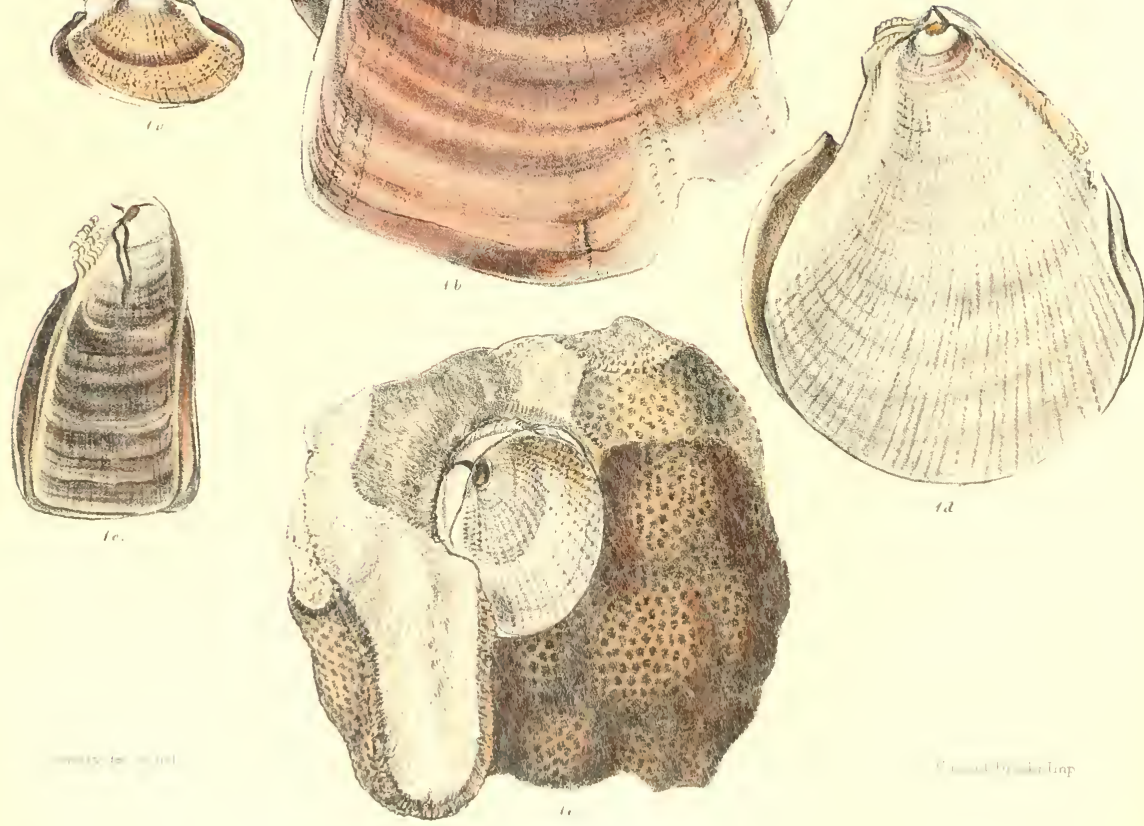


\section{P E D U M.}

Plate I.

\section{Genus PEDT'S, 3rugurer.}

Testa longitudinalis vel chusifur. ... rompressa. imaprivalvis, subauriculata; valvâ infir we cansexiusculi, ad latera reftexâ, prope cardinem protimulì simuat $\hat{a}$, valcâ superiore planâ. Curdo exteutrius, liyamento parlin externo in fossula canaliformi sulu aream productan valece inferioris.

Shell longitudinal or wcdge-shaped, compressed, inequivalve, slightly cared; lower valve rather convex, reflected at the sides, deeply simnated near the hinge, lower valve flat. Hinge toothless, with the ligament partially external contained within a channelled pit running across a prodnced area of the lower valve.

The earliest publication of the shell which forms the subject of this genns was the mention of "a rare Oyster from the Indies," nearly a linndred years ago, in the "Catalogue Raisonné of Davila. Gmelin and Chemnitz obsercing, almost simultaneously, its resemblance to spondylus, named it "the Spondylus-like Oyster, Ostrea Spondyloideum;" but Broguière, while establishing some important improvements in the classification of shells in the 'Encyclopédie Méthodique,' perceived the remarkable peculiarities of this so-called Oyster, and founded the genus Pedum for its special reception. Until lately this shell continued to be one of great rarity. It has now, however, been found in comparative abundance in the Red Sea, imbedded chiefly in masses of madrepore. No second species has been discovered.

The animal of Pedum, according to the observations of
MM. Quoy and Gaimard, made during the voyage of the 'Astrolabe,' partakes of the character of those of Spondylus and Pecten, but its shell is quite nnique in structure, being slight in substance, reflected at the sides, and having, with its ligamentary area, an unusually deep sinus for the passage of the byssus.

Species 1. (Fig. $a, b, c, d$, e, Mus. Cuming.)

Pedum Sponuylomeum. Ped. Lestâ longitudinaliter ret ovato-cuneiformi, planulatâ, superiore iongitudinaliter striatâ, striis granulato-scabris; albâ, purpurec-rufo plus minus tinet $\hat{b}$ et transversin fasciatâ.

Tire Spondyuds-like Pedem. Shell longitudinal or ovately wedge-shaped, flat, upper valve longitudinally striated, striæ granulately scabrons; white, more or less stained and transversely banded with purple-red.

Ostrea Spondyloidea, Gmelin, Syst. Nat. 13th edit. p. 3335 Hab. Ried sea (in madrepore).

Of the specimens of this well-known and interesting shell represented in the accompanying Plate, Fig. $1 a$ illnstrates its early stage of growth, while Fig. $1 b$ is a fine adnlt, and Fig. $1 c$ similarly adult, bnt a dwarf variety. Fig. $1 d$ is a charactcristic white variety, almost uniformly more ronaded than the typical form; and Fig. $1 e$ shows a mass of madrepore with a young Pedun in its uatural habitat. 



\title{
MONOGRAPH
}

\author{
OF THE GENUS
}

$\begin{array}{llllllll}\text { I } & \text { A } & \mathrm{N} & \mathrm{T} & \mathrm{H} & \mathrm{I} & \mathrm{N} & \mathrm{A} .\end{array}$

Yet kuow not what we iear. But doat upon a wild and violent sea.

Each way, aod move."-Shakspeare. 



-


Innthinn PI.I.
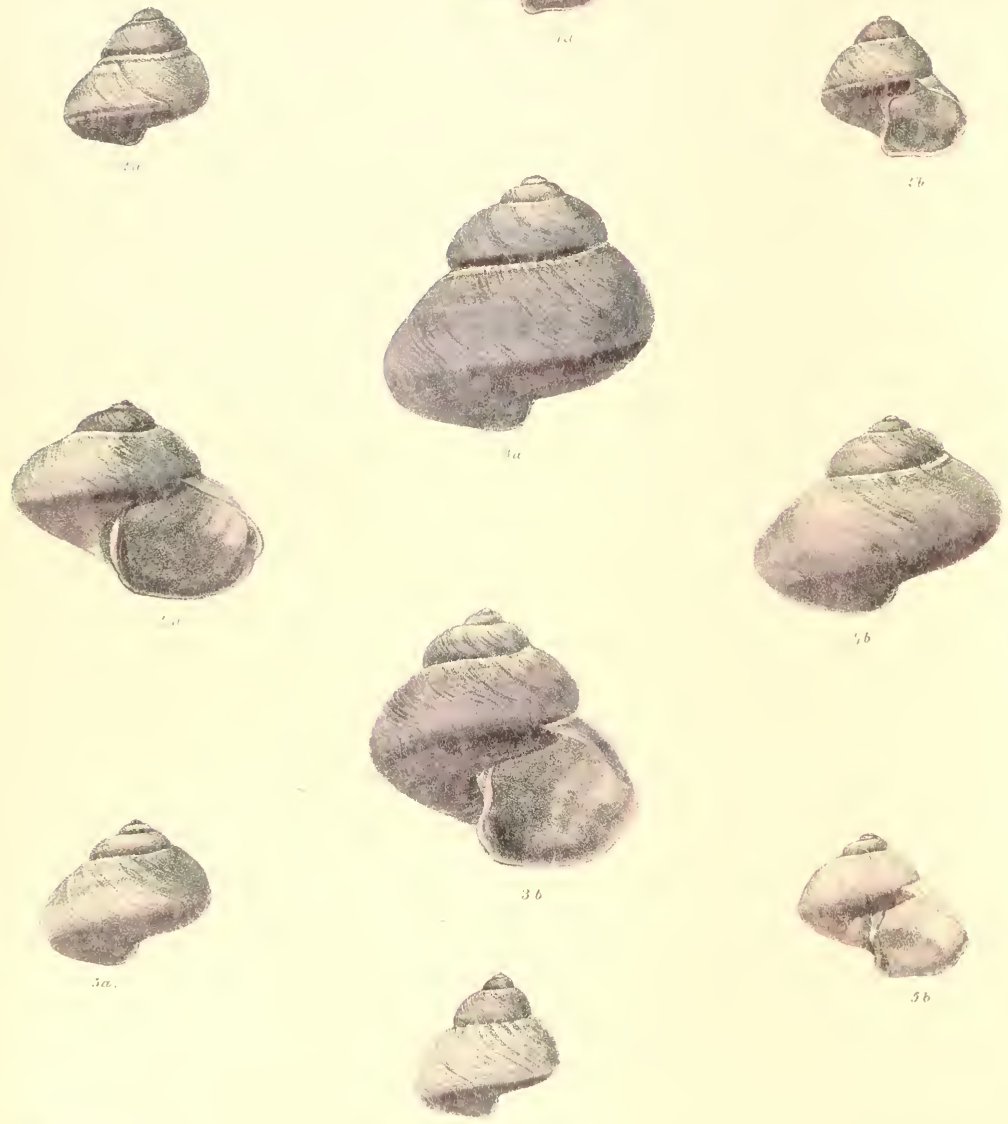

36 


\section{A N T H I N A.}

\section{Plate I}

\section{Genus I.INIIIIX.1, Landern}

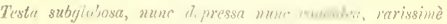

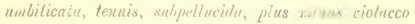

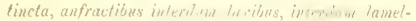

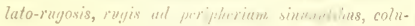

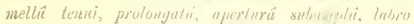
simplici, medio plemmeque sinuato vel purners wetw.

Shell subglobose, sometines depressed, sometinn's cunoil. very rurely umbilicated, thin, subtransparent, more or less stained with violet, whorls sometimes smooth, sometimes lamellately wrinkled, the wrinkles sinuatisg at the periph ry, columellat this, prolonged, aperturc rather large, lip simple, generally siutuated or notched in the middle.

The beatiful oceanic shclls comprised in this monograph are not nucoumon, but they have never been specially investigated, and their varieties of form have never been fairly submitted to the test ol comparison. To arguc that the shells of Ionthina are all modifications of one and the same species, varying according to sex or geograplical position, simply beeause they are characterized by an unusual uniformity of convolution and colour, is erroneous. The specitic diffurences of shells are often best defined where there is a marked resemblance of general character, and so it is with Lunthing. This molluse, as is well known, is an inhabitant of the open sea, feeding on the gelatinous Velulla and other surface fry, and buoving itself ou the waves by means of an agglomeration of air-bladders, beneath which are secreted the eggs. It results that the Iantline have a wide range of habitation, and few shore stations are recorded as habitats except where a tempestuous sea may have wafted the amimal in troops upon the sands at comparatircly distant intervals. Instauces are known where a period of twenty years and more las elapsed hetore the locality has been again visited by the same mollusc. In some tropical waters, on the other hand, the Ionthince have been observed in such shoals as to be deposited on the shore in a series of violet ripples.

To rclate the history of Iarthina we must go back two centuries and a half, to the time of Fabius Colonna, a nember of the illustrious house of Colomia, who wrote a special work on the purple-yielding creatures of the ocean, De Purpuri, etc., 1616, and to whom the Innthina, both shell and animal, was known. Linneus iucluded a species in his genus Helix. Lamarek observed and de- scribed two specics, founding the present genus for their reception, and ten more have been descrilsed sinee his time in different works by De Blainville, Leach, D'Orbigny, Menke, and others.

Owing to the gregarious habits of the Ianthina, their habitats are very iuperfectly knowu. The Atlantic and Pacilic Oceans lay elaim to all that have been actually captured. Three species are recorded by Forbes and Hanley as baring been washed upon the British shores, and I have authority for adding a fourth.

Specius 1. (Fig. $1 a$ and $1 b$, Mus. Cuming.)

Ianthina roseola. Ianth. testâ ovato-conicâ,, spirit subelatî, anfractibus convexis, obliquè plicato-striatis, spiraliter subobsoletè lineari-sulcatis; calcareo-albidâ,, subopacâ, violascente tinclâ, subtus vioidè violaceâ, columellâ et aperturce fauce carneo-rosaceis; columellâ prolongutâ, tenuè contort $\vec{a}$.

The roseate Ianthina. Shell ovately conic, spire somewhat elevated, whorls convex, obliquely plicately striated, spirally rather obsoletcly lincarly grooved; chalk-white, rather opaque, faintly tinged with violet, deep-violet bencath, columella and interior of the aperture tinged with flesh-rose; columella prolonged, thinly twisted.

Hab. Island of Nicobar.

The chief characteristies of this species consist in the semi-opaque chalky texture of the last whori, which is more convex than in the nearest allied form, I. affinis; and in the surface being more or less obsoletely spirally livearly grooved or scratched. The roseate colouring of the aperture and columella are also peculiar. The specimens in Mr. Cuming's pussession were collected at the Island of Nicobar in the voynge of the 'Galatea.'

Species 2. (Fig. $2 a$ and $2 b$, Mus. Cuming.)

Ianthina AFrivis. Ianth, testât ovato-conicut, spira sub-

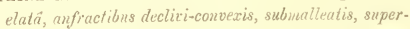
ficiliater decussafim striatis; violnscrnte-albä, niticliusculă, subtus intensè violaceá; columellâ tenuè recurvấ.

The allied Iasthina. Shell ovately conic, spire somewhat elevated, whorls slopingly convex, some"hat indented, superficially decussatcly striated; vio-

December, 1855. 


\section{LANTHINA.-PLATE I.}

let-white, rather shining, deep-violet beneath ; columella thinly recurved.

Hut. - ?

Though so very similar in form to the preceding speeies, there is a depression and indented eharaeter about the surfaee of the last whorl whieh appears to be eonstant. There is 110 indieation of the roseate hue whieb tinges the aperture aud columella alike in all the specimens we bave seen of I. roseota.

Speeics 3. (Fig. $3 a$ and $3 b$, Mus. Cuming.)

IANTIINA GRANDIS. Ianth. testâa subgloboso-turbinatâ, apice depressiusculâ, anfractibus tumitis, rotundatis, de suturis declivis, ultimo gradatim descendente, obliquè striatis, lineis paucis flexuoso-sulcatis spiraliter decussatis; intensè violaceâ, prope apicem albicante; columellấ temuissimè recurvâ, deinde sinnoso-contortâ.

The large Iantuina. Sliell somewhat globosely turbinated, rather depressed at the apex, whorls swollen, rounded, sIoping from the sutures, the last whorl gradually descending, obliquely striated, decussated spirally with a few flexuously grooved lines; deep-violet, - whitish near the apex; columella very thinly reHab. eurved, then sinuously twisted.

This fine species may probably be the exotic representative of our British $I$. conmunis, resembling it both in form and in intensity of colour. The whorls slope more from the sutures, and the last one deseends more than usually below the previous whorl. The surfaee is moreover eharaeterized by a distinct pattern of flexuous linear grooving.

Species 4. (Fig. $4 a$ and $4 b$, Mus. Cuming.)

I. ANthina casta. Ianth. testâ depresso-turbinatâ, anfractibus latè declivibus, deinde subangustè rotundatis, striis tenuibus impressis undique cingulatis; purpu- rascente-rintaceá, versus apicem coruteo-albicante; mellẩ arcuatâ, reflexâ, aperturâ transversâ, medio subsinuatâ.

The chaste Ianthina. Shell depressly turbinated, whorls widely sloping, then narrowly rounded, eneircled throughout with fine impressed striæ; purplish-riolet, bluish-white towards the apex; columella arebed, refleeted, aperture transverse, slightly sinuated in the middle.

Hab. — ?

Distinguished by a more than usually depressed form, in which the strix of growth are less conspicuously plieated, whilst the spiral impressed striæ, though minute, are numerous and well defined.

\section{Species 5. (Fig. $5 a$ and $5 b$, Mus. Cuming.)}

Ianturna communis. Ianth. lestâ depresso-semiglobosâ, subtus planulatâ, anfractibus declivi-convexis, subrudè decussatim striatis; supra albicante, infra purpurascente-violaceá, circa columellam albicante; columellâ subcontorto-reflexâ, aperturấ transcersä, medio paulo sinuatá.

The common Ianthina. Sbell depressly semiglobose, flattish beneath, whorls slopingly eonvex, rather rudely deeussately striated; white above, purplishviolet below, white round the columella; columellis rather twistedly refleeted, aperture transverse, a little sinuated iu the middle.

LAMARrk, Anim. sans vert. vol. ix. p. 4.

Helix ianthina, Linnæus.

Ianthina bicolor, Menke.

Ianthina penicephala, Péron.

Hab. Mediterran au and Atlantic.

This species is distinet from $I$. fragilis of the West Indies and Mazatlan though nearly related to it. The speeimen here figured was eaptured by Mr. Cuming in the Atlantic. 

Ianthina Pl.II.

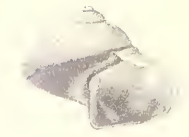

sia
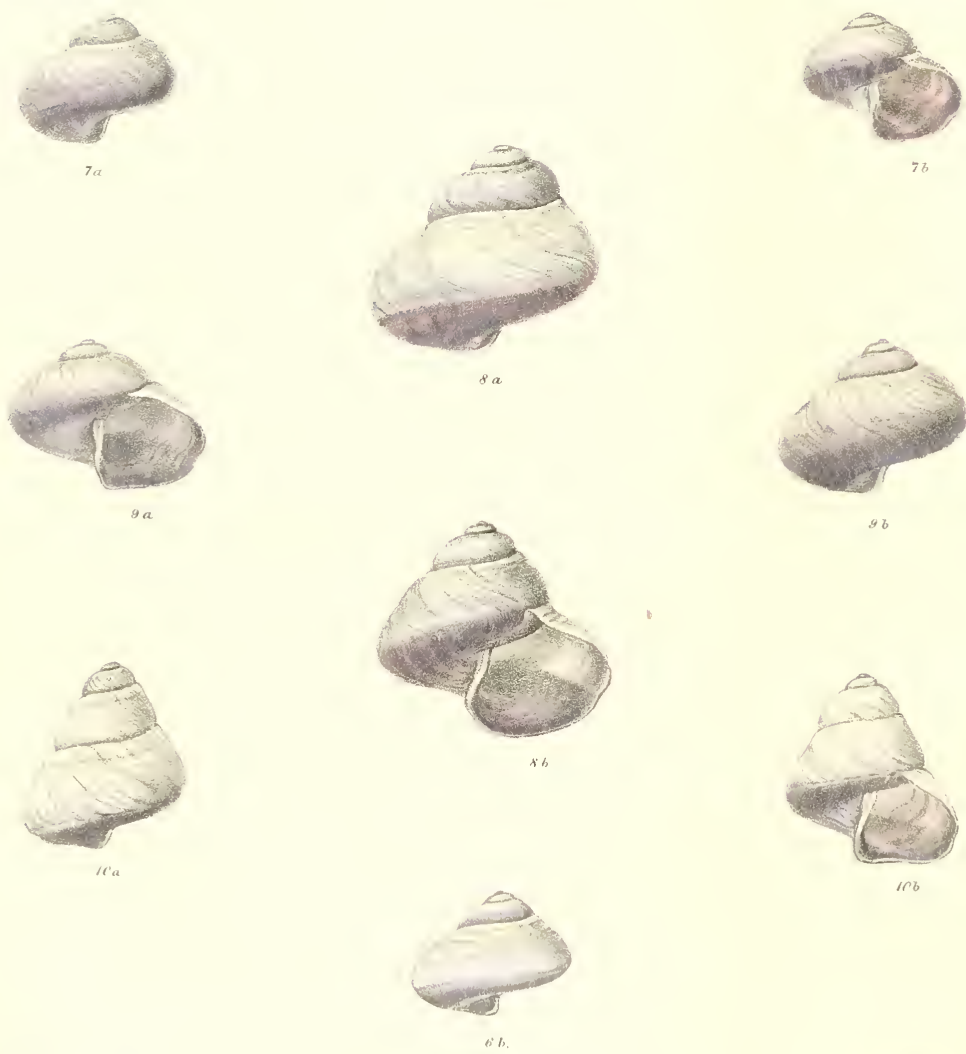


\section{A N T II I N A.}

Plate II.

Species 6. (Fir $6 a$ and $6 b$, Mus. Cuming.)

IANTIINA Frafitis. Ianth. lestâa depresso-conoide $\vec{a}$, anfractibus suiplano-declivibus, striis obliquis minutis et spirulibus inpressis, undique decusatis, supra violaceo-albicante, infra intensè riolaceá; columellâ sabrectí.

THE FRAGILE IANTHINA. Shell depressly conoid, whorls rather flatly sloping, cverywhere decussated with minute oblique and spiral impressed strix; violet-whitc above, decp-violet beneath; columella nearly straight.

LAMARck, Syst. des Anin. sans vert. 1801, p. 89

Ianthina striuluta, Carpenter.

Hab. West Indies; Mazatlau; California.

Lamarck appears to have confounded two other spccies with this, naming it first $I$. fragilis and afterwards $I$. communis. For the second of thuse from the Atlantic and Mediterrancan, the name $I$. communis should be retained. For the third, inhabiting our own shores, I propose to take the aane 1 . Britannica, given to it, according to $\mathrm{Mr}$. Jeftrcy, by Dr. Leach.

Species 7. (Fig. $7 a$ and $7 b$, Mus. Cuming.)

IANTHINA c.riruleata. Ianth. testa depresso-turbinat spirâ parvä, anfractibus declini-convexis, obliquè subrudè plicato-striatis, spiraliter densì minutè malleatostriatis; intensè cceruleo-violaceâ, versus apicem albicante. fasciâ latí pallida cirra columellam; rolamellá subrectâ, appresso-reflexa ; aperturâ transversit, medio sinuatia.

The blu-staned Ianthina. Shell depressly turbinated, spire small, whorls slopingly convex, obliquely rather rudely plicately striated, spirally densely minutely indentedly striated; deep blut-riolet. whitish towards the apex, with a broad palc band round the columilla; columella nearly straight, appressly reflected; aperturc transverse, sinuated in the middle. Lab.

The special sculpture of this specics appears in the form of minute indented strix, and the colour is of a peculiar blue-stuined violet.

Species 8. (Fig. $8 a$ and $8 b$, Mus. Cuming.)

[a NTHisa Africana. Ianth. testâ subgloboso-turbinatâ, ventricosi apice subobtusä, anfractibus declivi-convexis, deinde subangulatis, spiraliter superficialiter sulcatostriatis: supra carulescente-albidâ, infra purpurascente-violace $\vec{a}_{;}$colunellä reflex $\vec{a}$, arcuato-product $\vec{a}$, labro subanipliter sinuato.

THE AFBICAN IANTHiNa. Shell somewhat globoscly turbinated, ventricose, rather obtuse at the apex, whorls slopingly convex, then slightly angled, spi- rally superficially groove-striated; bluish-white above' purplish-violet beneath ; columella reflected, arcuately produced, lip rather largely sinuated.

\section{IIab. Zauzibar.}

Belonging to the same typical form of the genus as 1. grandis, it is nevertheless more slopingly couvex than that species, and is distinguished by a strong peculiarity of colouring. The delicate purplish-riolet of the base terminates suddenly at the angle of the whorl, so as to show an unusually defined boundary.

Species 9. (Fig. $9 a$ and $9 b$, Mus. Cuming.)

IanfHina planospirata. Ianth. testa depressá, anfractibus declici-concexis, deinde subacutè rotundatis, obliquè subrude plicato-striatis; carulescente-alb $\vec{a}$, al piripheriam purpurascente-violaceat; columella arcuatâ, subdilatato-reflexâ; aperturâ transwersâ, medio sinuatâ.

ThE Fiat-spized IANThiNa. Shell depressed, whorls slopingly convex, then rather sharply roundal, obliquely rather rudely plicately striated; bluish-white, purple-violet at the periphery; columella arched, somewhat dilately reflected; apcrture transverse, sinuated in the middle.

Adams and Reeve, Moll. Voy. Samarang, p. 54. pl. 11. f. 10 .

Hab. Atlantic Ocenn.

Taken in the Atlantic by Sir Edward Belcher. It is less sharply angularly formed than $I$. fragilis, and is whitebanded round the columella.

Species 10. (Fig. $10 a$ and 10b, Mus. Cuming.)

IANTHINA TrocholdeA. Ianth. testâ pyramidali-conicá, solidiusculata, anfractibus declivi-convexis, ultimo angulato, ad basin plano-concavo, decussatim striatis, suturis subrudibus; coruleo-albidht, basi purpurascente-violacea $\vec{a}$ columeliâ tenuè reflexâ, subconlortä, aperturä ad angulum sinwatâ.

The trochoid Ianthina. Shell pyramidally conic, rather solid, whorls slopiugly convex, last whorl angled, flatly convex at the base, decussately striater, sutures rather rude; bluish-white, purple-violet at the base; columella thinly reflected, slightly twisted: uperture sinuated at the angle.

$\mathrm{Hab}$.

Of rather solid growth, distinguished from all the other species of the genus by its regular trochoid form. The boundary of the purplc colouring is as sharply defined round the basal angle as in the preceding species. 


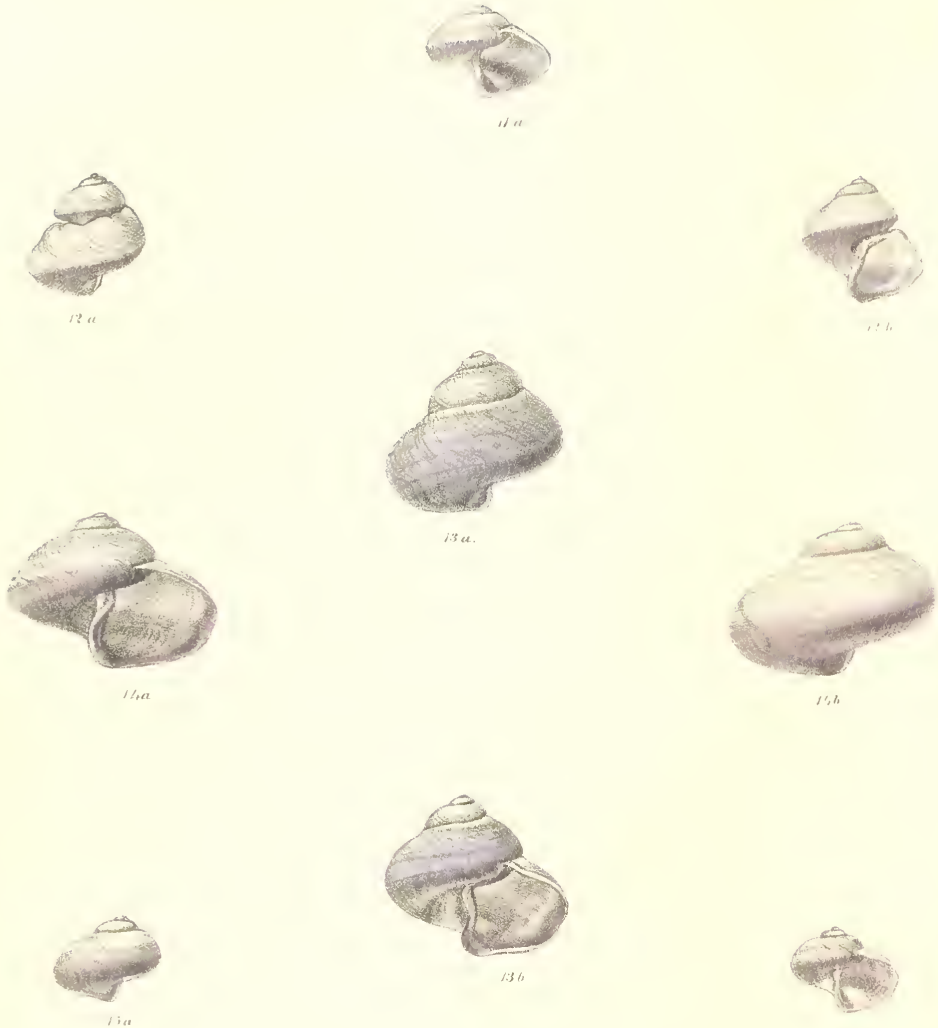

136

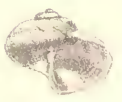

ish

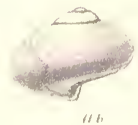




\section{A N T H N A 。}

Plate III,

Specics 11 (Wh Ho and 11 \%. Mus. C'uming.)

IANTHINA BALTtiat: tanti testä depresso-furbinatí,

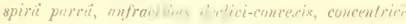
pliculo-eorrugutis, spiratur striatis; supra riolus-

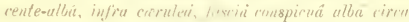
columellam, colnwellä watatè ciolucea: apertura transerersí, metio sinmulie.

THE BELted IANTHixa. Sindl ilepressly turbinated, spire small, whorls slmtingly couver, conceutrically plicatcly wriukled, spirally striated; violet-white above, blue beneath, with a conspicuous white band round the columclla, which is very dark violet; aperture transversc, sinuated in the middle.

Hab. Cape of rood Ilope.

This is certamly distinct from $I$, froyilis, though resembling it iu general form. The surfice is coneentrically plicately writkled, and the under surface is characterized by a white band round the coluuella, which is prominently dark-coloured. Its nearest ally is $I$. Simithire. represented at Fir. 15 .

Species 12. (Fig. 12 a and 12 $b$, 11us. (uming )

IAXTHIXA IXvoLITA. Ianth. testä nralo-conicri, arifact tibus oblique subrude strintis, converis, whimre wrsm aperturan incoluto: snpra violescente-albâ, opmea infra cormlescente; sjimbliter sutruto-striatit, strics binis, colmmalli breci, aperturä suburbculari, morgine continuo.

THE INROLLED IANTIINA. Sheli ovately conical, whorls obliquely somewhat rudely striated, convex, last whorl unrolled towarls the aperture; above violet-white, below bluish: spirally groove-striated, strie in patrs, colnmella short, aperture nearly orthicular, margin continuous.

Hab. — ?

The detached convolution of the last whorl of this species is not a mere lusus. Mr. Cuming possesses severa] specimens, all preciscly agreeing in this and other specific peculiarities.

Species 13. (Fig. $13 a$ and 136 , Mus. Cuming.)

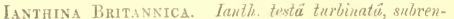

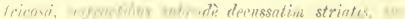

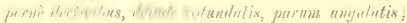

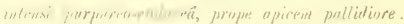

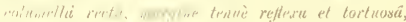

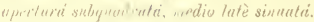

Tü: Britrsn lasimina. Shell turbiuated, somewhat ventricose, whorts rather roughly decussately striated, sloning at the upper part, then rounded, but little angled; decp purple-violet, paler near the ajex; columella straight, thiuly reflected and twisted at the citge, aperture somewhat square, broadly sinuated in the middle.

LEACH, MS. firl Jeffrey in Forbes and Hanley's Brit. Moll. vol. iv. Appendix, p. 260.

Imulhina communis, Forbes and Hanley.

Ilul. Perranzabuloe, Cormwall; Cuming

The deep-coloured rentricosely turbinated species indiented, according to $\mathrm{Mr}$. Jettrey, by Dr. Leach uncler the above title, and of which the spccimen here figured was captured alive by Mr. Cuming off the coast of l'crranzabutoc, Cornwall, must not be confounded with $I$. "ommnwis of the Mediterraneari and Atlantic, or I. frayilis of the Hest Indies and Mazatlan. Both thesc specics are more angulated and less decply colourcd.

Species 14. (Fig. $14 a$ and $14 b$, Mus. Cuming.)

TAXTHINA DEPRESSs. Innth. troti depresso-turlinati, spiri lrari, plannleti, an/inclibus declivi-concexis, oblique plicato-corrumtis, spirmliter conspicuè sulcutostriatis, stries imeqularibus, subfexuosis; supra vio-

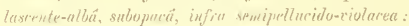
columelli contorto-appressa $\vec{a}$, apertura transtersä, cut sinuatii.

THE DEPRESBED TANTHINA. Shell depressly turbinated, spire short, flattened, whorls slopingty convex, ob. liquely plicately wrinkled, spirally couspicuously groove-striated, stria irregular, rather flexuous; violet-white, rither opaque, aborc semi-transparent, violet beneath; columella twistediy appressed, aperture transverse, scarcely sinuated.

Ilab.

In elegant species, of couvexly depressed form and peculiar opaque- or chalk-wbite violet-tinged substance.

December, 1850 
IANTHINA.-PLATE III.

species 15. (Fig. 15a and 15b, Mus. Cuming.)

LANтHina Smithiz. Ianth. testä depresso-ovatâa, spirâ brrvi, anfraclibus subangustis, decussatim striatis, vix ungulatis ; anfractis ultimi peripheriä niolaceit, spirât et circa columellam albidâ; columellâ tenuè reflexá.

Siмrтu's IANTHINA. Shell depressly ovate, spire short, whorls rather narrow, decussately striated, scarecly angied; periphery of the last whorl violet, spire and around the columella whitish: columella thinly reflected.

Hab. Glamorganshire, South Wales (left alive on the sands near Penrice Castle): Mrs. Hill.

Since our figure was drawn, from a shell in Mr. Cuming's possession, unaccompanied with any information is to its locality, I had the good fortune to bave my atintion called to a small box in the cabinet of Mrs. New- man Smith, containing three undoubted specimens, with the following well-authenticated memorandnm of their capture :-

"A bont twenty-seven years since, Lady Mary Cole (then Lady M Talbot) picked up on the shore by Penrice Castle, two or three of the Helix janthina, but ue more appeared there until three years ago, when many were left on the sands alive,-M. HuL.

$$
\text { "Llandaff House, April 11th, 1829." }
$$

The three specimens accompanying this memorandum. especially characterized by the presence of a white band round the columellat, being identical with the one figured from Mr. Cuming's collection, arc unquestionably distinct from any hitherto described species, and leave no doubt in my mind as to their being a new and valuable addition to the British Fanna. It is with much pleasure I dedicat it to the assiduons conchologist Mrs. Newman smith. to whom I am indebted for its discovery. 


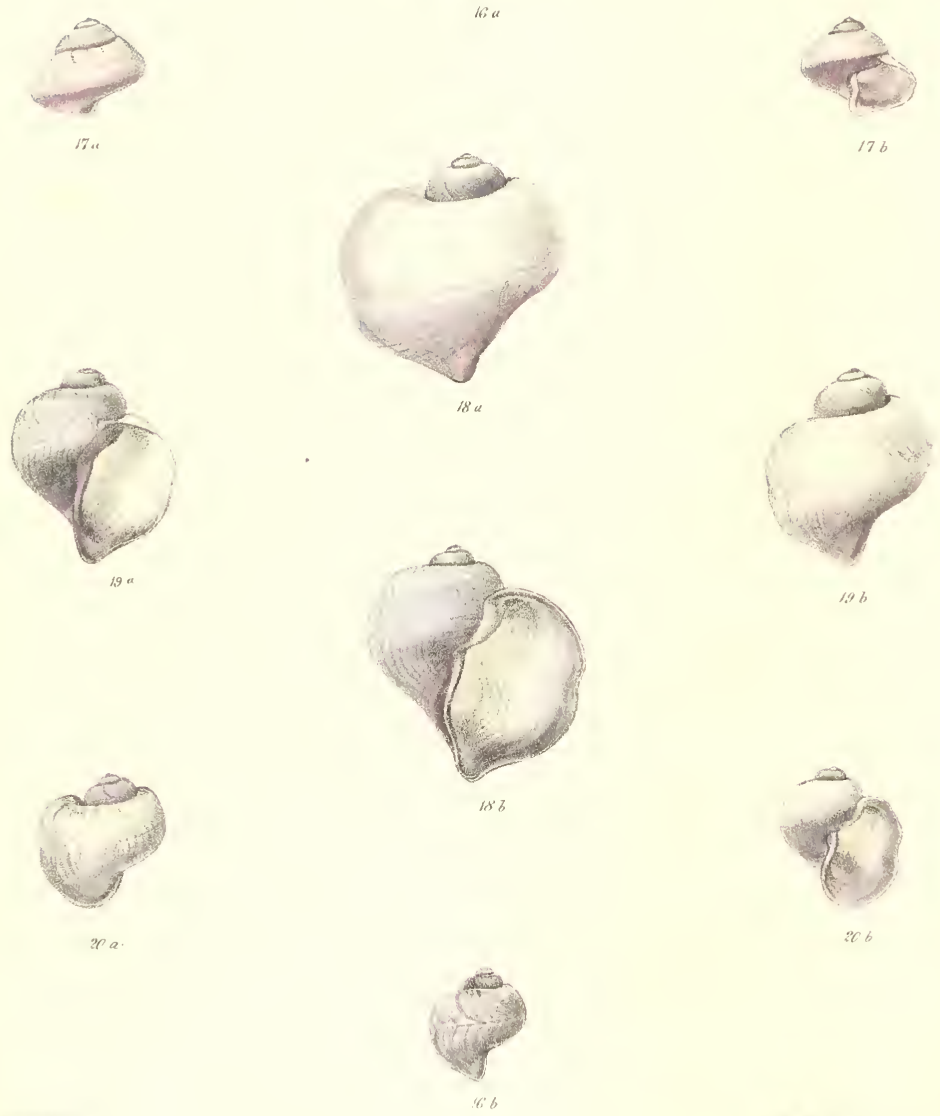


\section{I $\Lambda \mathrm{N}$ TH I N A.}

\section{Plate IV.}

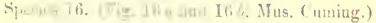

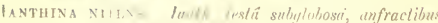

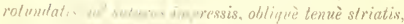

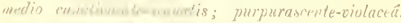

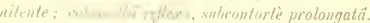

THe shising lasiuise. Shell somewhat globose, whorls roundit. supresse it the sutures, obliquely tinely -triated, comblieulately sinmated in the middle murple-tir:atd viulet: columella reflected, somewhat twistedly prolon

Mexke, Syn, p. 14I. Thilipp, Lnum. Moll. p. 164. pl. 9. f. 15.

Iantima prolon juta, Payzuuleau.

Hab. Mediterranean

The shining surfice of $\mathrm{t} / \mathrm{is}$ sprecies, after which character it is name l, appears to he crinstant.

Species 17. (Fig. $17 a$ and 17b, Nus. Cuming.)

lantuina finila. Ianthi, Lestî́ glohoso-conicä, anfractibus declivibus, spiraliter lintari-sutculis; supra niolascente-alba infra intensè riolace $\vec{a}$, roseo pallidè linctî: colume? î lenuè reflexín, parme contortâ.

Tue Butтos lastmixa. Sliell grlobordy conieal, whorls sloping, spirally linearly groured; above violet-white. beneath deep violet, faintly tinged with rose; coluinella thinly reflected, but hittle twisted.

Hoi. —?

Closely allied to 1 , frugitis, lont its more glohosely couic lorm and rosy colouring render it casily recognized.

Sinecies 1s. (Fig. 12 a and 186. Mus. Cuming.)

fasthixa rilobosa. Ianthe lextä globusä, lenui, inflatá, spirâ breri, subimmersat, a fractitins aul suturas impressix, deinde rotuntutic, undïgur subliliter derussatim strialis; albuti, ad spiram basinque purpuras. rente-violacen; columethat temuis reflexâ, prolongati. aperturât amplit, patulit, mialio subsinuala, ad basin canaliculalâ.

The globose lanthina. Shell globose, thin, inflated. spire short, somewhat immersel, whorls impressed at tlie sutures, then rounded, everywhere finely decussately striated; whitish, purple-violet at the spire and at the base; eolumella thinly reflected, prolonged; a)erture large, open, slightly sinuated in the middle, ehauneiled at the base.

Sirassox, Zoological Illustratious, First Series, vol. ii. pl. 85 .
Inuthena protumialn, Blainvile

Uab. — ?

This fine species is ehicfly characterized by the fuld inflation of the last whorl, which almost rises into a collar at the point of conjunction of its lip with the penullimate whorl.

Speeies 19. Fig. $19 a$ and $19 b$, Mus. Cuming.

LANTHiva decollata. Ianth. leslá globosâ, spirá brevi, subimmersâ, anfractilus ad suturas impressis, deinde rolundatis, undique subtiliter decussatim striatis; albidä, ad spiram basinque jurpuraceo-violuscente, columeltẩ tenuè reflexâ, supernè apprissâ, deinde prolonualâ;: aperturẩ subamplâ, medio subsinualá, ad basin canaliculalá.

The decollated Iaxthina. Shell globose, spire short, somewhat immersed, whorls impressed at the sutures, then rounded, everywhere finely decussately striated; whitish, purple-violet at the spire and base; columella thinly reflected, appressed at the upper part, then prolonged; aperture rather large, slightly sinuated in the middle, channelled at the base. Carpenter, Cat. Reigen Coll. in Brit. Nus, p. 157.

IIab. Mizatlan.

Until better information is obtained on the habits ot the lunthince, I forbear to disregard this species; but my eunviction is that it will prove to be nothing more than a variety of the preceding. There is no specific peculiarity in the apparent decollation of the apex.

Species 20. (Fig. $20 a$ and $20 b$, Mus. Cuming.)

lanthisa pallida Ianih. lestâ globosil, spirá parvá, aufructibus ad suturas plano-immersis, deinde rotundatis, undique decussatim striatis; cerulescente, ad basin purpureo-violacrấ; columellâ lemuè reflexâ; aperturî amiplä, patulá.

The pale fantiina. Shell globose, spire small, whorls flatly immersed at the sutures, then rounded, everywhere decussately striated; bluish, purple-violet at the base; columella thinly reflected; aperture large. open.

Harvey, Thouplyson, Brit. Narine Conch. p. 152. Forbes and Hauley, Brit. Moll. vol. ii. p. 553. pl. 69. f. 10, 11 . Ianthina patuta, Philippi.

Hab. Miltown Malbay, County Clare, Ireland; Harvey. Mediterranean; I'hilippi. Madeira; $\mathrm{M}$ 'Andrew.

Of uniformly smaller size than $I$. globosa and less inflated lorm. 

किe
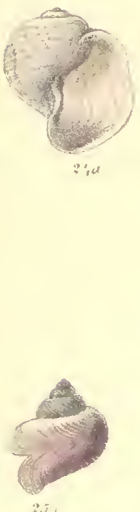
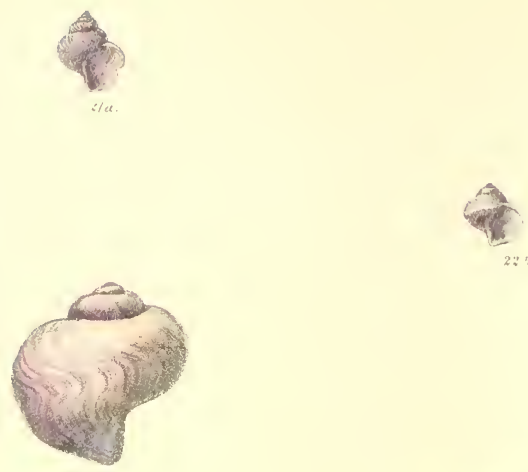

$2.3 a$
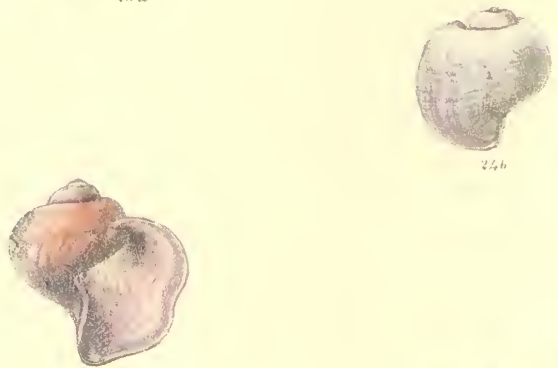

$2: 36$
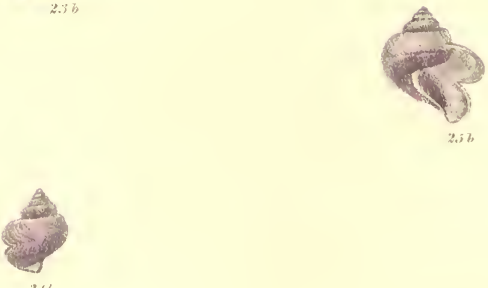


\section{A N TH I N A.}

\section{Plate V.}

species 21 (1.0 $91 \times$ and:1h. Mu. Tumiur.)

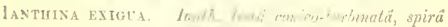

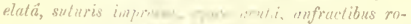

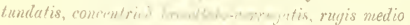

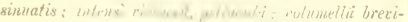

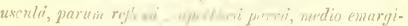
misâ.

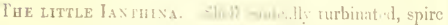
raised, with the suture. in pom if, tharp at the apex, whorls romdel, concomingalls, fincellately wrinkled, wrinkles sinuated in the southis. dentriolet, traus-

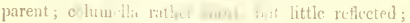

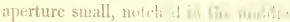

Lamarck, Amu. sats rert. swl, w. po 0

Hab. Cornwall; Turton. Comizedo suntlewortl.

This little species may be rewat icd o itar Briti-h forn of $\mathrm{Mr}$. Nuttall's /. Girize. The sortace is similarly wrinkled with fine landlar ritg ', which incline into a sinus in the mildli, arisiug thrumbent the growth of the shell by the notch in the aurerture: and the suirc is more couically turbinated thim in any nolir species of the genus. I cannot agree wi h Torbes and IImley in quoting I. riviucen, De Blainville. aud I. nana, Quoy and Gaimard, as synouyms of $I$. exiyua. It is, however, ensicr to say what those species ase no, than to detcrminc what they are.

Sprcies 22. (Fitg. 22 $z$ and $22 b$, Mus. Brit.)

laxthix: tMBILICATA. Iauth testâa subgloboso-ovatä, tenvi. pellucida, spirá tun inntî, anfractibus coneeris, minutissime cone mtrice strittis, stries medio in arinain sinuatis; violoceit : columullâ rectâ, tenuè reflexá, subunbilicalá.

THE I MBILICATED IAXiHisa. Shell somewhat globosely ovate, thiu, transparent, spire turbinated, whorls couves, very minutely concentrically striated, striac sinuated in the middle into a keel; violet; columella straight, thinly reflected, slightly umbilicated.

D'Orbigry, MS. in Mus. Brit.

Hab. -

This species, of which D'Orbigny's original type is in the Britush Museum, is much smaller than 1 . exigua. The shell is slightly umbilicated, and the fue conccutric strix incline rather to subate rom the periphery of the last whorl into a kerl.

Species 23. (Fig. 230 and $23 b$, Mus. Cuming.)

laNTHINA IRICOLOR. Ianth. testâ subglobosä, temissimá, spirî́ oblusè conica, plus mimus iminersä, anfractibus subanumstis, rotundatis, concentrice irrogulariter plirato-striutis, striis wedio sinuat is ; purpurascente-violaceât, pellucido-inidescente; columellâ vix reflexâ, subrontorlâa; apreturât putulâ, basi subcanaliculatâ.

TIIE RAINBOW-COLOURED IANTIINA. Shell somewhat globose, very thin, spire obtusely conical, more or less immersed, whorls ratber narrow, rounded, concentrically irregularly plicately striated, strie sinuated in the middle; purplc-violet, transparcntly iridescent; columella scarccly reflected, rather twisted; aperture open, sligbtly channelled at the base.

This species is unquestiouably distinct from 1. g7obosa. It is of a lighter aud more transparcut texture, and is violet-tinged throughout, the colour being characterized by a more iridescent huc. The whorls are narrower, less glolosely juflated, and the stria of growth are more roughly gathered into folds, iuclining to a peripheral sinus.

Species 2t. (Fig. 2ta and 24b, Mus. Cuming.)

IANTHiNa s'rurolata. Ianth. testä globosâ, solidiusculä, spirât obtusè conicâ, plus minus immersä, anfractibus convexis, tumidinsculis, spiraliter peculiariter linearisulcatis, sulcis undulalis, valdè irreyularibus : violascente-albâ, medio subopacá, nitente; columella sublatè reftria, appressâ; aperturẩ mediocri, haud sinuatâ.

ThE CHAMFETED IANThiñ. Shell globose, rather solid, spire obtusely conic, more or less immersed, whorls convex, rather swollen, spirally peculiarly linearly grooved, grooves waved, very irregular; violet-white, somewhat opaque in the niddle, shiniug; columella rather broally reflected, appressed; aperture middling, not sinuated.

AdaMs and ReEve, Moll. Voy. Samarang, p. 54. pl. 11. f. 9.

Hab. Pacific Ocean.

Chiefly distinguished by an irregular waved pattern of linear grooving. The shell is of rather a solid texture 


\section{IANTHIA.-PLATE V.}

for this genus, shining opaque-white, tinged with violet of a peculiarly delicate hue. There is no sinus in the aperture, and consequently no spiral sinuation of the striæ of growth on the periphery.

Species 25. (Kig. $25 a$ and $25 b$, Mus. Cuming.)

IANTHINA BIFIDA. Ianth. testấ turbinatâ, spirâ acuminato-conicâ, anfractibus rotundatis, subangustis, concentricè densè tamellato-striatis, striis medio perobliquè sinuatis; intensè violaceá; columellâ tenuè reflerâ, arcuatâ; aperturâ parvâ, enormiter emarginatâ.
The bifio Ianthina. Shell turbinated, spire acuminately conic, whorls rounded, rather narrow, concentrically densely lamellately striated, striæ very obliquely sinuated in the middle; deep-violct; columella thinly reflected, arched; aperture small, enormously notched.

NutTall, Jay's Catalogue of Shells, p. 68 .

Hab. Pacific Ocean (Sandwich Islands); Nuttall.

The densely set lamellar striæ are less conspicuously wrinkled in this species than in its congener 1 . exigua. Its principal characteristic is the enormous notch in the aperture, which gives the lip a bifid structurc. 


\section{A N T H N A.}

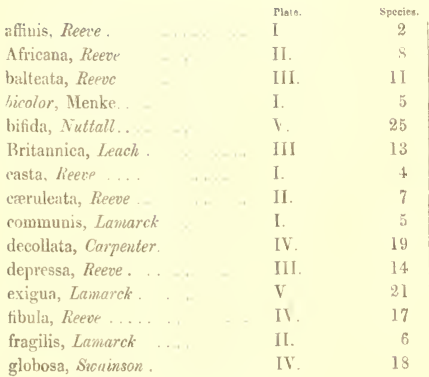

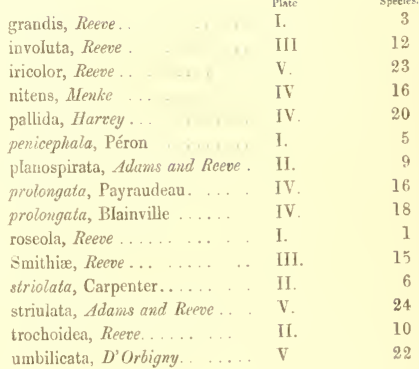





$$
\begin{gathered}
\text { MONOGRAPH } \\
\text { C O L U M B E L L L. }
\end{gathered}
$$






$$
\begin{array}{lll}
1 & 1 \\
1 & 1 \\
1 & 1
\end{array}
$$




\section{O L U M B E L L A.}

\section{Plate I.}

Genus COLUMBELLA, Lamarck.

Testa parvinscula, ovato-oblonga vel trigona, interdum acicularis vel fusiformis, plerumeque solida, aut lavigata ant costata. Columella srope arcuata, interdum denticutata, labro pterumque incrassato, plus minus varicoso, intus denticulato.

Shell rather small, ovately oblong or triangular, sometimes acicular or fusiform, generally solid, either smooth or ribbed. Columella often arched, sometimes denticulated, lip generally thickened, more or less varicose, denticulated within.

The genus Columbella, as defined by the members of the Lamarckian school of conchology, is not a satisfactory one. Originally it served for the grouping of about a dozen to eighteen specics, characterized in a special manner, like C. rustica, mercatoria, and strombiformis, by the development of a row of teeth on an inner swelling of the lip; but since Lamarck's time uprards of two hundred species of shells bave come to light, of not one of which have we any knowledge of the animals, all having a more or less obvious indication of this character, extremely diverse in form and texture, and not wanting in the characteristics which usually go to determine distinct genera. Even Dr. Gray, the Messrs. Adams, and other more subtle followers of the school of De Montford, have failed to bring their analytical powers to bear on the varied forms which come under the head of Columbella; and the genus must still remain as a receptacle for that incongruous residuum of shells which are characterized by the preseuce of denticles on the inner surface of the lip.

The geographical range of the Columbelle lies chiefly on the western shores of South and Central America. A few small species inhabit the West Indics, and some very characteristic forms have becn collected at Australia and New Zealand: some are also from the Philippine Islands. The genus is unknown to Britain, and only one species, C. rustica, may be said truly to belong to the Mediterranean.

Species 1. (Fig. $1 a, b$, Mrus. Cuming.)

Colembella angelaris. Col. testá oblongo-pyramidali, pallidâ, fusco variâ, spirẩ subulatâ, anfractibus decem, tongitudinaliter costatis, ultimi medio gibloso-angulıto, basi reflexo; aperturâ subquadratâ, canali tongiusculo, tato, labro incrassato.
The angular Colcmbella. Shell oblong-pyramidal, pale, variegated with brown, spire subulate, whorls ten, longitudinally ribbed, middle of the last whorl gibbously angled, reflected at the base; aperture somewhat square, canal rather long, broad, lip thickened.

Sotterby, Pro. Zool. Soc. 1832, p. 118.

Hab. Panama.

A single specimen only of this remarkable species was collected by Mr. Cuming, thirty years since, at the abovenamed locality.

\section{Species 2. (Fig. $1 a, b, c$, Mus, Cuming.)}

Columbella turrita. Col. testâ elongato-pyramidutâ, spirẩ subulatâ, anfractibus decem, albidis, fusco reticulatis, prope suturam articulatis; aperturá oblongâ, supernè acuminotâ, subcanaliferâ, labro incrassato, peritremate albo, subreflexo, intus levi, columellî arcnatâ.

The turreted Columbella. Shell elongately pyramidal, spire subulate, whorls ten, whitish, reticulated with brown, articulated near the suture; aperture oblong, acuminated at the upper part, somewhat cbannelled, lip thickened, peritreme white, a little reflected, stnooth within, columella arched.

Sowerв Y, Pro. Zool. Soc. 2832, p. 115.

Hab. Bay of Montija and St. Elena, Central America (found in coarse gravel and sand, at a depth of ten fathoms); Cuming.

Of the samc subulate form as the preceding species, but smooth, and rather stout, densely reticulated with brown.

\section{Species 3. (Fig. $a, b, c$, Mus. Cuming.)}

Coltmbell.1 lanceolata. Col. testâ fusiformi-oblongâ, turritâ, albidâ, futvo variâ, spirâ acuminato-pyraridali, anfractihus decem ad duodecin, serie unicâ tuberculorum instructis, ultimi dorso subgibbo, parte inferiore transersim striatâ; aperturâ +lonigat $\hat{a}$, ad basin subcanaliculata $\vec{a}$ et recurvâ, labro incrassato, varicoso, intus medio trmido et denticulato.

The laxceolate Columbella. Shell fusiformly oblong, turreted, whitish, variegated with brown, spirc acuminately pyramidal, whorls ten to twelve, furnished with a siugle row of tubercles, back of the last whorl 


\section{COLUMBELLA.-Plate I.}

sather gibbous, lower portion transverscly striated; aperturc elongate, slightly channelled and recurved at the base, lip thickened, varicose, swollen and denticulated within in the middle.

Sowerbi, Pro. Zool. Soc. 1832, p. 116.

Hah. Galapagos Islands (found in coral sand, at a deptlı of from sis to eight fathoms); Cuming.

A fine fusiform species, of solid structure, armed throughout with a row of tubcreles.

Species 4. (Fig. $a, b$, Mus. Cuming.)

Coltmbella elegans. Col. testâ elongato-subulatâa, alb,a, fusco variegatâ , t reticulatâ, epidermide tenui fulvâ indutâ, anfractibus undecim ad duodecim, primis paucis hevibus, coteris longitudinaliter costatis, ultimo infru spiraliter sulcato; aperturâ parviusculâa, oblongâ, columellâ subarcuatä, labro incrassato, varucoso, intus. validè dentato.

Tue elegant Columbelia. Shell elongately subulate, white, variegated and reticulated with brown, covered with a thin fulvous epidermis, the first few whorls smooth, the rest longitudinally ribbed, the last spiraliy grooved below; aperture rather small, oblong. columella slightly arched, lip thickened, varicose strongly toothed within.

Somerbx, Pro. Zool. Soc. 1832, p. 114.

Hab. Guacamayo, Central America (found in sandy mud) Cuming.

This species, as its name truly denotes, is the most clegant of the genus. Of solid growth, tapering sharply to the apex, the whorls are ribbed with peculiar lightness and regularity, and the main generic ebaracter of the genus-the inner tecth of the lip-is unusually strongly developed. 
, 
Ginmbelle, Pl.II.

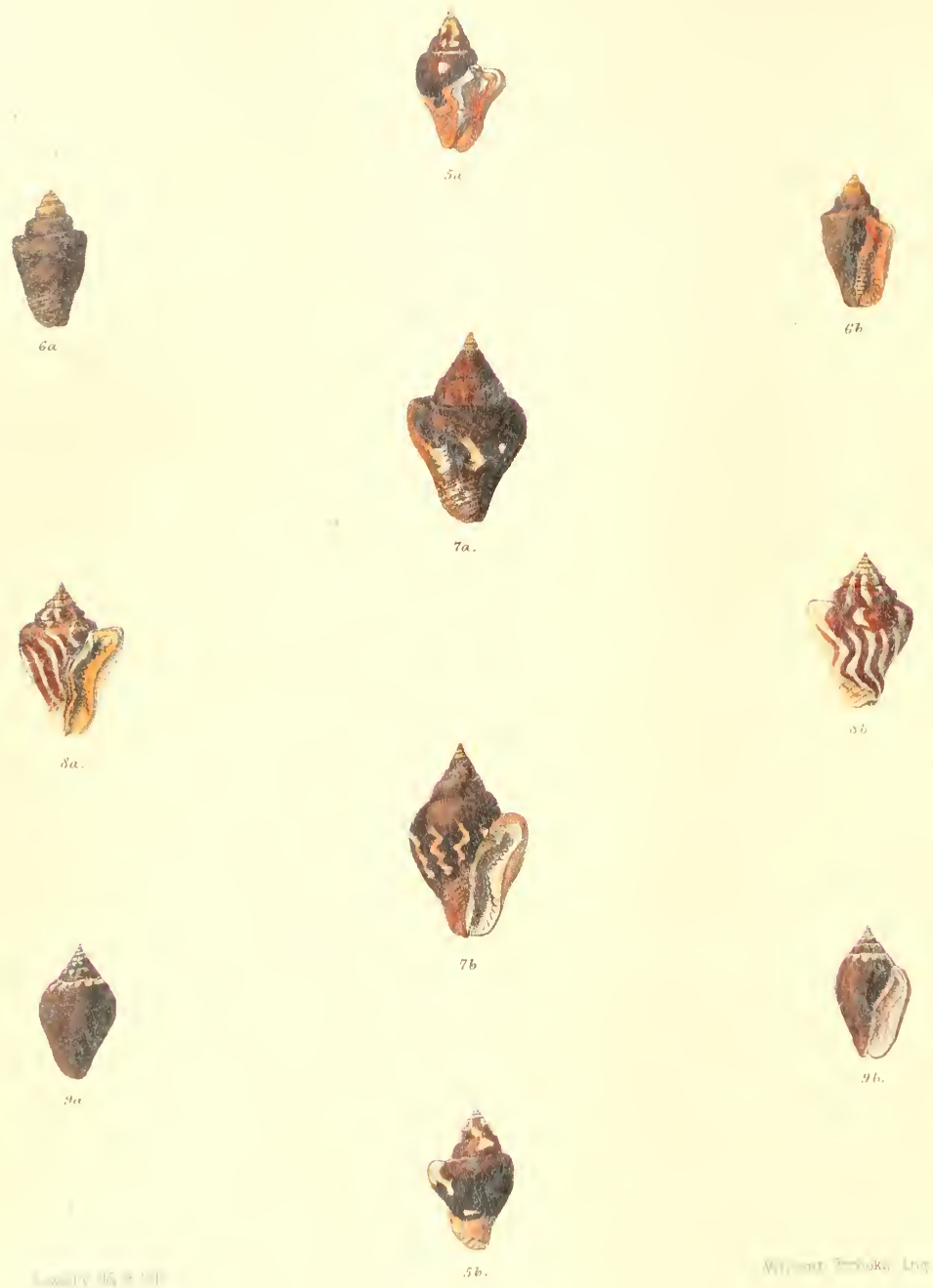




\section{O L U II B E L L A.}

\section{Plate II.}

Siveris i, (Fis. e, B. Mus. Cuming.)

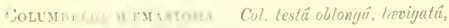

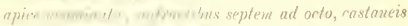

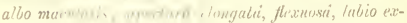

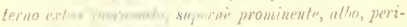

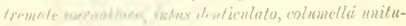
(iimern? 1 ;

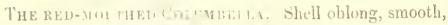
apes acumitales whirls seren to cirlat, chestnut spotted witi whif... Husture dougated, flexnous, outer lij thickem in whingt, prominent at the upper part, white, peritres.

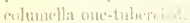

Someliby l'ru. Zoul. Soc. 18:22, p. 116

Hah Galapagos Istands and Panama (ander stones); ('uminer

l'rettily charisterizal by an orange-red mouth, confruted and tuluereled in the muldle.

species 6. (Fig. e. $b_{2}$ Mas. (uuning.

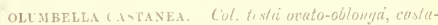

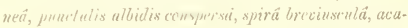
minali, anfruelibus quintur, supermè anyulifers, ullimo mayno od basin spiraliters sulcuto: uperturat elongutë,

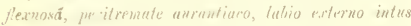

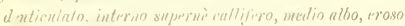

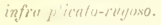

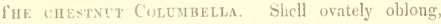
chestunt, sprinkled with whitish dots, spire rather short, acuminated, whorls five, angular at the upper part, the last large, spirally grooved at the base; aperture elongated, flexuous, peritreme orange, outer lip denticulated withiti, inner lip callous at the upper part, white and eroded in the middle, below plicately wrinkled.

Śnwerby, J'ro. Zool. Soc. 1832, p. 118.

IIab. Real Llejos, ('entral America.

A minutely dotted chestuut sbell, peculiarly depressly .ugled at the suture.

sprecies 7. (Fig. a, b, Mus. Cuming.)

Colcmbela mator. Col. testi orata, medio gibbosá, rastuneit albo punctatie et strigatie, spinit pyramiduli, arminatii, anfractilues sex ad septem, lecigutis, ultino muximo, supernè rofumlato-turgide, infru spiruliter sulcato; "perturi Plongalä, flrxuosat, albit, suyernè augulati, luvio externo supernè obtusè angruluto, albo, intus denticulato, labio columellari supernè callifero, infra plicuto-rmyoso.

The lakger Columbella. Shell ovate, gibbous in the middle. clicstnut dibsol and striped with white spire pyramilal, acumuated, whorls six to seven, smooth, thic last very large, rotundately swollen at the upper part, spirally grooved below; aperture elongated, fex 10us, white, angled at the upper part. outer lip obtusely angled at the upper part, white. denticulated within, columellar lip callous at th upper part, plicately wriukled below.

Sowerby, Pro. Zool. Suc. 1532, p. 119.

Hul. Island of Muerte, West Columbia (under stones). Cuming

Closely allicl to C. Strombiformis, from which species it chiefly differs in having the spirc more acuminated.

Species 8. (Fig. $a, b$, Mus. Cuming.)

Columbelia strombifokmis. Cul. testá trigono-orati, turgitlit, castaneat atbo strigat te, spirit breviusculi, acutê, anfructibus sex supremè obtnsè angulatis, suturts subimpressis; labio externo supernè prominente, medio contracto, inlus incrassato of temidentimlato.

The Strombus-silafed (olumbela. Shell triangularly ovate, swollen, chestnut streaked with white. spire ratler short, sharp, whorls six, obtusely angled at the upper part, with the sutures rather impressed; outcr lip proninent at the upper part, contracted in the middle, thickened and finely denticulated within.

Lamarck, Anim. sans vert. vol. x. p. 266.

Hab. Island of Yuerte, Wiest Columbia; Cuming.

This species has very much the appearance of the last, liffering in having a sharper and less pyramidal spire sunk at the sutures.

\section{Speries 9. (Fig. $a, i$. Mus. Cuming.)}

Columbella pescata. Col. testâa ovato-acuminatâ, medio ventricosa $\vec{a}$, castaneä albo guttulatâ, epidermile , fuscâ indutâ, spirấ acutî, anfractibus septem, levigatis; aperturä elongatâ, flexnosá, peritremate albo aut violaceo, intus denticulato, columellá infernè denticulatâ.

THe Fiscots Colembeli. Shell ovately acuminated, ventricose in the middle, chestnut dotted with white, covered with a fuscous epiderwis, spirc sharp, whorls sevcu, smooth; aperture clongated, flexuous, peritreme white or violct, denticulated within, columella denticulated below.

Sowerbi, Pro. Zool. Soc. 1s32, p. 117.

IInb. Panama and IV cst Columbia (under stones): Cuming

Of a smooth oxil form, profusely whitc-dotted upon a dark lirid-chestuut ground. 



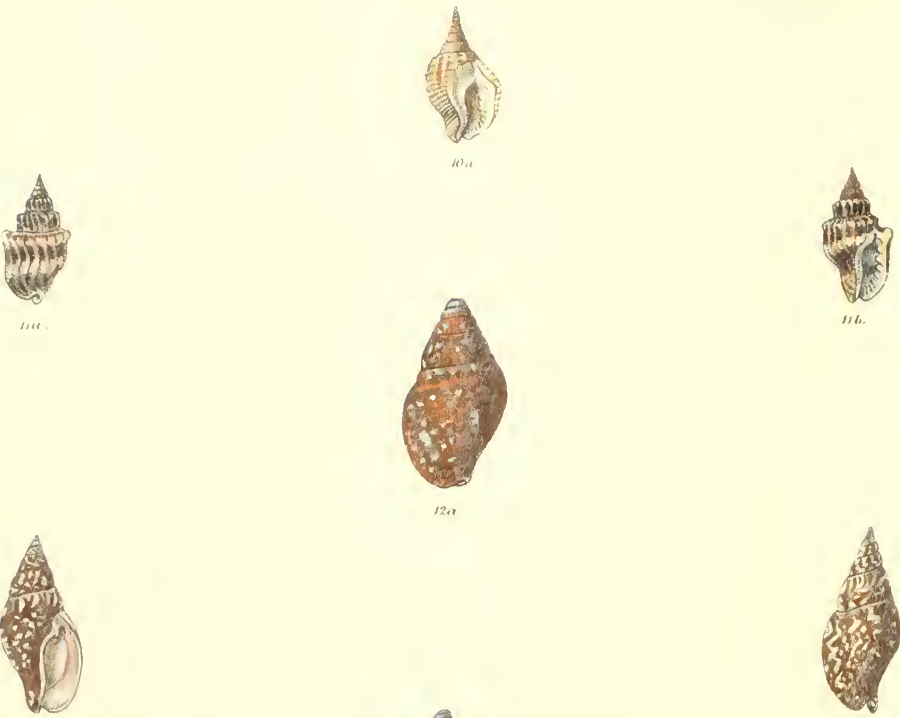

12,1
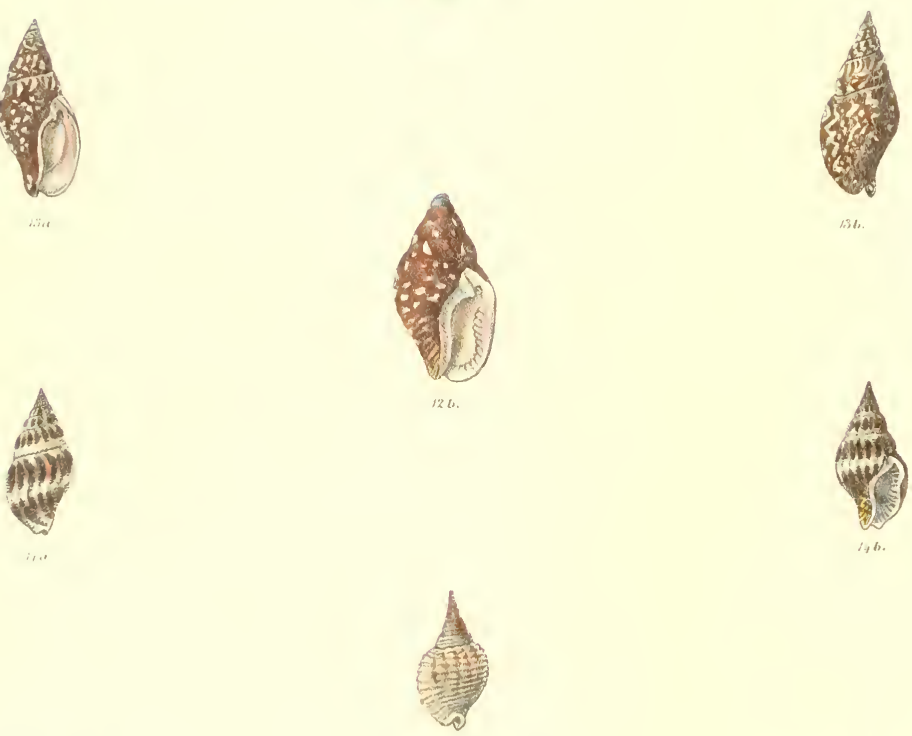


\section{COLU MBELLA.}

PLATE Ill

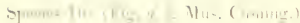

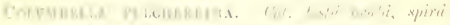

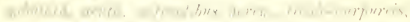

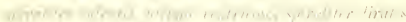

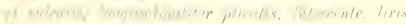

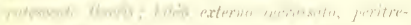

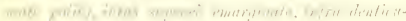

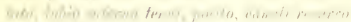

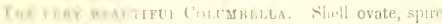

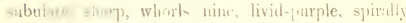
Qunoveh, tha last whitutoe, spirally rilged and gruved, hongitudinally plicated; yelhwish, ridges tinged with red : outur lip thi hem.d, peritreme poustul, emarcmated within at the upper part, dent culis ted besinth inner lip thin, polshed, canal reair.ted

now an. Pro, Zool. she 193\%, 1. 11:

It ${ }^{\prime}$ the of Dulce ('entral tmerieat.
\end{abstract}

()nt: a cingle specimen of this murkithle specis has fon dis antred. It was dredged b. Mr. C'unimg in the finose-n+med lowality from a sandy mudh bottom, at the I fith if in fathoms.

\section{Dirotes 11. (Fis, a, b, Mus (uming.)}

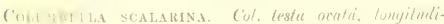

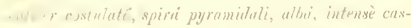

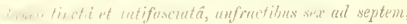

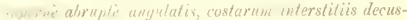

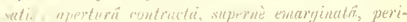

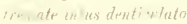

fIE LADDFR Cold MBella. shell orate, lonqitudinally finely riblsed, spire pyranndal, white, stained and luroadly bauded with dark-ehestnut, whorls six to -even, abruptly angled at the upper part, interstices between the ribs decussated, aperture contracted, emarginated at the upper part, peritrome denticulated witlin.

Werex, Fro. Zool. Soc, 1<32, p. 116.

Haú. Pauama (under stones); Cuming.

1)ensely finely flexuously ribbul throughout, the whorls luing turgid and abruptly angled at the upper part.

Species 12. (Fig. a, b, Mus. Cuming.)

Columbella fasciata. Col. testâa oblmgâa, irevi, apice

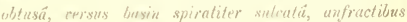

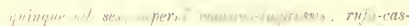

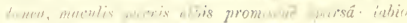

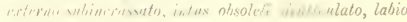

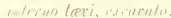

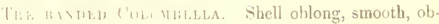
tul... at the apex, spirally grooved towarts the base, whork five to six, concavely impressed at the mper part; redliwh-chestmut, promiscuously sprinkled with small white spots outer lip slightly thickened, obinletely denticulated within, ioner lip smooth, exenrated.

Sowkizy, Tankerville Catalogue, App. p. 25

$11 u t$.

In stur ohloug-ovate smooth shell, the pattern of wh th is sy ued ratber than banded.

Fines. 13. (Fig. a, b. Mns. Cuming.)

('olemBLLLA (ft TrATs. Col. testâ oblongo-pyramidali,

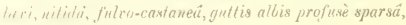

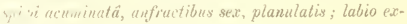
wrino, trmut, interno cecavato

THE SPTTED C'OLUMBeLLA. Shell oblong-pyramidal, smooth, shining, fulvous-chestnut, profusely sprinkled with white spots, spire acuminated, whorls six, rather tlattened, outer lip thin, inner excavated.

Sowerby, Thesaurus Conchyliorum, p. 131. pl.39. f. 124 IInb.

Closedy allied to the preceding species, but smoothes and more pramidally elomgated.

Species 14. (Fig. $a, b$, Mus. (uming.)

Columbella varia. Col. testâa oblonga decussato-costati apice acuminato, anfractibus octo ad nowem, custaneis albo raretgatix. custis fleccuosis ; aperturi parvinsculá, Lutio estermo parmin incrassato, vix dentirulato.

The variable ('olu urella. Shell oblong, decussately ribbed, acuminaterl at the apex, whorls eight to nine, chestmut variegated with white, rilss flexuous; aperture ratler small, outer lip but little thickened, scarcely denticulited.

Sowerry, Pro. Zool. Soc. 1892, p. 116.

Hab. Panama (under stones); Cuming.

The sculpture of flexuous ribs which encircle this species is similar in character to that of $C$. scularina. The shell is of a more acuminately oval form.

January, 1858. 


Gitumbellu, PI. Ir:
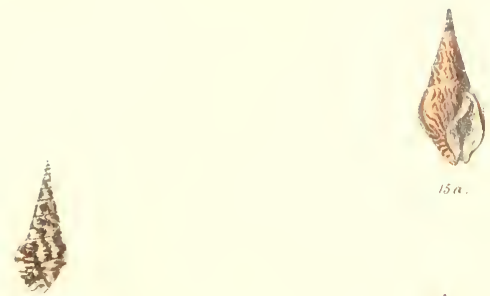

150
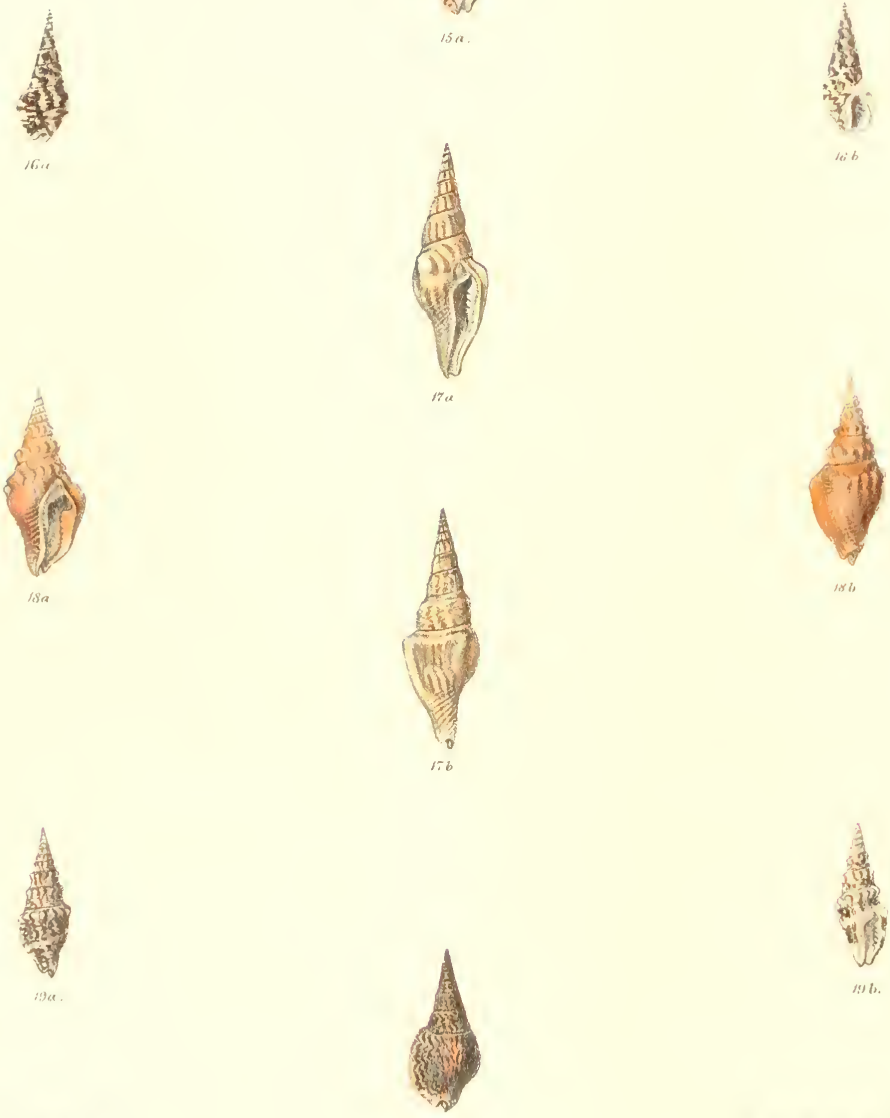

156 


\section{O L U M B EL A.}

Plate [V,

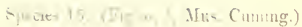

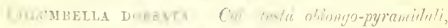

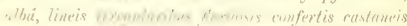

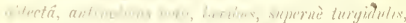

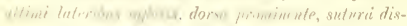

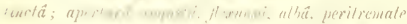

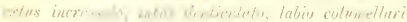
cownoto.

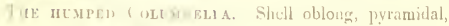
white, wrort with close-set irregular flexuous lines, wherls cirlit. smooth, swollen at the upper part, sides of the last whorl inflated, back prominent, suture Histinct; aperture uarmow, flexuous, white, peritreme thickened withont, denticulated within, columellar lip excarated.

Strvit RBY, P'ro. Zu-l. sine. 1832, p. 120

Ih... the of Murve and Bay of (stayaquil, West Columblat: ('mu ins.

Allind to $C:$, Mberence, lut of larger size, having the asturella excavated in the middle.

specie 16. (Fig. a, b, Mus, Cuming.)

This shelt, which partakes of the charaeters of Colum. bures and Plourotomen, has already been described and fignerl muler th latter genus, Pl. XJ1. sp. 106, Plenrover a ciaruens.

specius 17. (Fig. "1, b, Mhus. Cuming.)

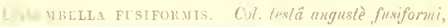

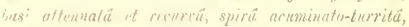
mefractibus dece is ad underim, septems prin is longitnWiut ter costatic, deimde levilurs, supernè concavo-de-

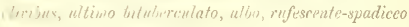
lentigine : lwbio externo reftexo.

InE fusiform CoLunBelda. Shell narrowly fusiform, attenuated and recurved at the basc, spire acuminately turretcd, whorls ten to eleven, the first seven longitudinally ribed, then smootl, coucavely stanting at the npper part, last whorl bi-tubercled, white, freckled with reddish-fawn; outer lip reflected.

Itisos, Moll. Toy. Sulphur, pl. 10. f. 17, 18.

IIab.

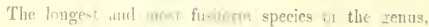
the spire being shorply arominately turreted, and the basal canal produced and recurved.

Species 19. (Fig. a, 1, Mus. Cuming.)

Columbella reccria. Col. lestâ oblongû, lurritá, fulce. spirẫ ucuminalu-pyramidali, anfructibus decem ad undecim, sex primis lomiludimuliter costatis, ceteris serie tuberculonum unicâ instnclis, ultimi dorso subgibbo, purte inferiori transversim sulcatri; aperturá anyuslu, cunali recurvo, labio externo reflexo, valdè incrussuto, intus tuberculato.

The recurved Colimbella. Shell oblong, turreted, fulvons, spire acuminately pyramidal, whorls ten to elever, first six longitulinally ribbed, the rest furnisleed with a single row of tubereles, back of the last whorl rnther gibbous, lower part trinsversely grooved; aperture narrow, canal recursed, onter lip reflected, very much thickened, tubercled within.

Sowerby, Pro. Zool. Soc. 1532, p. 115.

Hab. Isle of Plata, Nouth America (in coral sand, at depth of scventeen fathoms); Cuming.

Of more solid structure than the preceding species, lese attenuated at the basc.

Species 19. (Fig. $a, b$, Mus. Cuming.)

Conmabella macclosa. Col. testî̀ subulat $\vec{a}$, allida $\hat{a}_{y}$ fulvescente-rufo irregulariler maculosâ, spirâ acuminato-py,rmidali, anfractions nocem ad decem, septem ad oclo primis lecigatix, coteris tuberculorm serit unicâ coronatis; aperturấ brevi, canali subrecureo.

The spotted Columbeili. Shell subulate, whitish, irregularly spotted with fulvous-red, spire aenminately pyramidal, whorls nine to ten, the first seven or eight smooth, the rest coronated with a single row of tubercles; aperture short, canal slightly reeirsed.

Sowerby, T'to. Zool, Soe, 1832, p. 116.

Hab. Guacamayo, Central America (in sandy mud); Curning.

Chicfly distinguished by its sharply acuminated spire, which is almost of Tirutra-like proportions. 


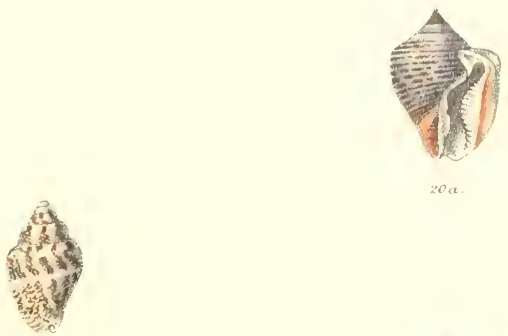

$20 a$
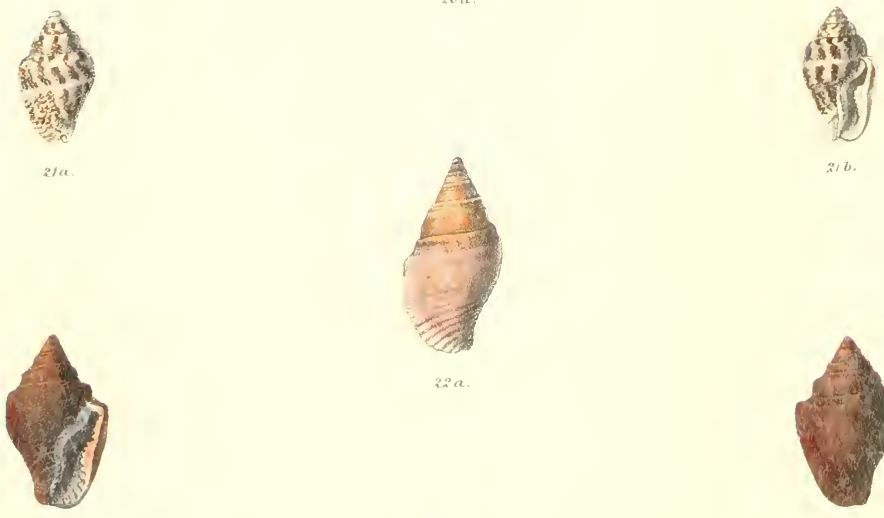

2la

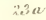

(n)
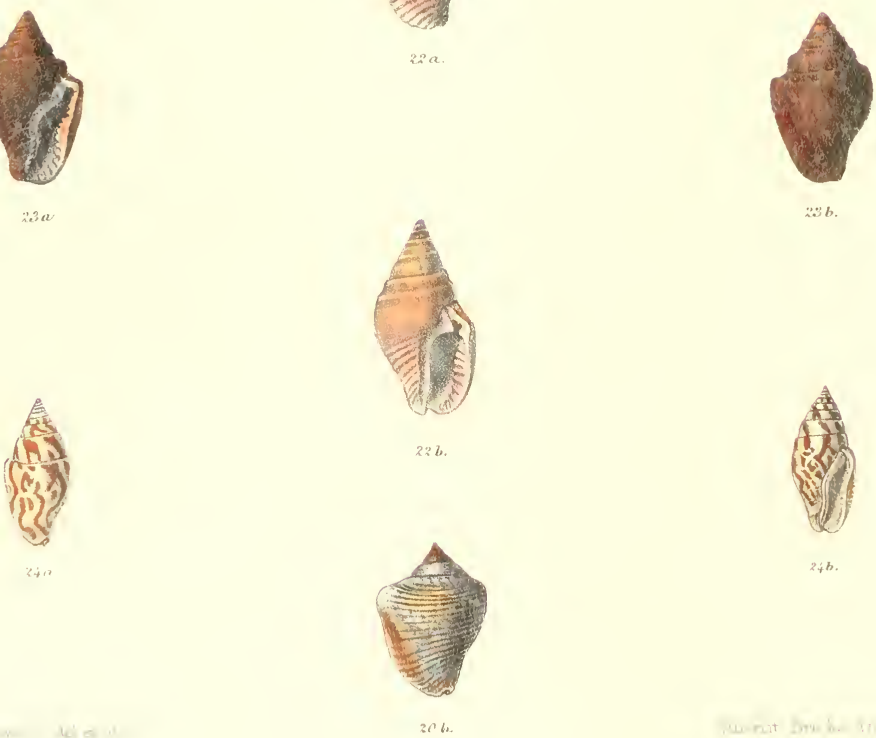

$\because \because b$.

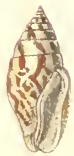

$24 b$. 


\section{OLU II BEL L A.}

Plate V

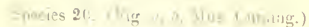

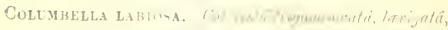

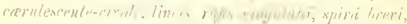

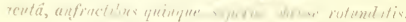

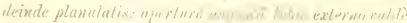

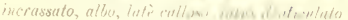

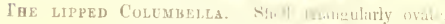
smooth, bluish-green, encirchit whs: red lines, spire short, sharp, whorls five, obtra!; roumled it the upper part, then ratlier hat ape ture nar ow, outer lip very mueh thiekened. white. lumally eallous, dentienlated within

Sowerby, Genera of slu-lls, No. 4

Hab. St. Elena, West Columbia; Cunung.

Chiefly distinguisheal by its eallonsly thi kened onter lip aud peeuliar painting of red liues upon a shiuing blue-green grouml.

\section{Species 21 (Fig. 20, 6, Mis, Cuming.)}

Columbella aspersa rol. tersts ablongo-ucutit, theri.

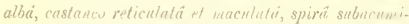

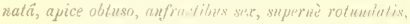
ad basin obsoletè strictis: apr rturat fle enosai, lutio exterino medio tinkerculato, dentiodis fere obsoletis.

The SPRINELED CoLumbela. Shell obloug-ovate, smooth, white, retieulated and spottect with chestuut, spire somewhat acummated, ipex ohtuse, whorls six, rounded at the upper part, obsoletely striated at tlut base; aperture flextuons, onter lips tubercled in the middle. teeth nearly obsolite

sowerbx, Thesaurus Conch. vol. i. p. 123. ph. 37. f. 79. S0.

\section{$\mathrm{Hab},-$}

The whorls of this speeies are peculiarly roumled at the upper part, giving an impressed charaeter to the suture.

Species 22. (Fig. a, b, Mus. Coming.)

2. GUMBELla JAFACENsis Col. subfuxiformi-oblongu, hecigatî, pr.rpurascente-spadiceú, lantiginosấ, spira acn, inafi, suturẩ dis/inctü, arifractitus sex ad seplem, supernè concaro-impressis, ad busin lulì sulcalis - aperturâ ovat $\vec{a}$, lutio externo intus dentimututo, purpuras. cente tincto, lubio colmellari excavato

The Jafa Colunbella. Shell somewhat fusiformly oblong, smooth, purple-fawn, freckled, spire acumi-

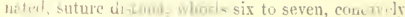
impressed rount the mpere fort, brondly groowin at base; aperture vvale, outer lip, denticulate whlim, purple-staned, colnuellar lip exeavated.

Gaskoln, Pro. Zoul. Soe, 1 \$ 48 .

Hah. Javit.

$\therefore \quad$ Iit isifurmly ovate fawn-coloured shell, tinged with lighlit-purple.

Species 23. (Fig. $a, b$, Mus. Cuming.)

Columbrila Paytensis. Col. testâ trigono-oralât, sub.

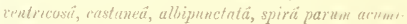
uatii, aufructibus septem, supernè depresso-angulutis siperturi oblongü, labio externo flextoso, subinerussuti. intus dentienlato, lubio columellari subexcavato.

Tú Parta Columbella. Shell triangularly ovate, somewhat ventrieose, chestnut, white-dotted, spire but little atununated, whorls seven, compressly angled at the upper part; aperture oblong, outer lip flexuous, slightly thickened, denticulated within, columeilar lip somewhat excavated.

Lesson, Voyage de la cirunille.

Coftembrilla Paytalida, Duelus.

Calumbetla spurca, Sowerby.

Hab Inner Lobos Island, Peru (under stones); Cuming.

A minutely-dotted adust shell, rather ventricose, with the whorls narrowly depressly angled round the upper part.

Specits 24. (Figg, $a, b$, Mus. Cuming.)

Columbella tringa. Col. testáa oblongo-cylindraceu, leprighata, albit, maculis rufis incequalibus $f l$ xuosis pictu, spirat subelongutu, obtusi, sulnerä distinclï, anfra libus woto ad nocem, convero-planis, ad basin sulcalis; aperturầ sublangustât.

THE RED A v W WHTE ('olid Bella. Shell oblong, eylindrieal, smooth, white, painted with unequal flexuous red spots, spire rather elongated, suture distnet, whorls eight to nine, eonvexly flattened, grooved at the base; aperture ratlier narrow.

sownk132, Thesaurus Conch. vol i. p. 119. pl. 37. f. 62. Mitra tringu, Lamarek.

Hab. - ?

Very like the cylindrieal forms of Mitra, and first described in that genus by Lamarek. The Colmulelle iv however devoist of plaits. 


Crlumbells, PT. IT.
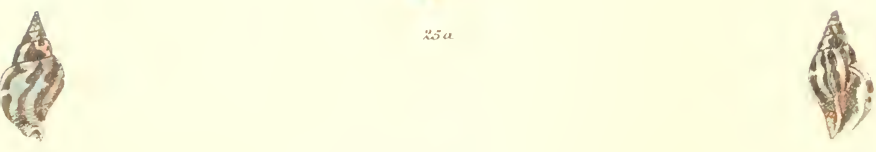

966
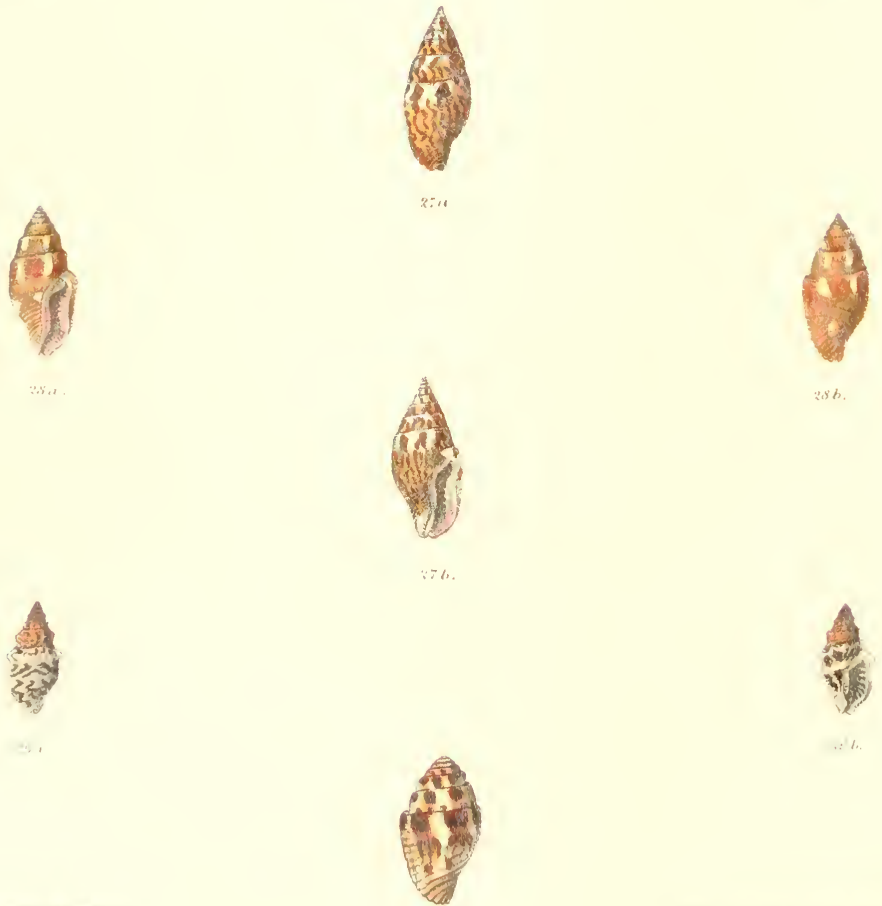


\section{O L U II B E L L A.}

\section{Plate Vi}

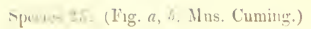

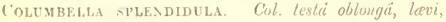
aurantiaci, mantis aljis costaneisque variegatä, spirâ breminscutie suturi impressâ. anfractibus septem ad orto. brimibus, versus basin latè sulcatis; uperturi fexuosi, tabio externo incrassato, intus denticulalo.

THE SPI.FNDID COLUMBEILA. Shell oblong, smooth, orangr variegated with whitc and chestuut spots, spire rather short, with the suture impressed, whorls seven to eight, sliort, broadly grooved towards the base; aperture flexnous, outer lip thickened, denticulated witlin.

Sonerby, Thesaurus Conch, vol. i. p. 120. pl. 37 . f. 65 , 66.

Ifab. Island of Corregidor, Bay of Manila (in coarse sand, at the depth of seven fathoms); Cuming.

('haracterized by a peculiar obtusely eylindrical spire, wh a rulely tesscliated style of paiuting.

Species 26. (Fig. $a, b$, Mus. Cuming.)

Columbella pavosina. Col. tristâ subfuriformi, basi conlractâ et recurvâ, cinerascente-albî, fiulvo-castaneo obliquè latistrignt $\hat{a}$, spirâ acuminat $\vec{a}$, anfractibus sex ad septem, brevibus, conresis, ad basin lineari-salcalis; aperfurấ parviusculá, tubio externo incrassato, intus denticulato.

THe peacock Coltubelta. Shell somewiat fusiform, contracted and recurved at the basc, ash-white, obliquely broadly striped with fulvous-chestnut, spire acuminated, whorls six to seven, short, convex, linearly grooved at the base; aperture rather small. outer lip thickened, denticulated withio.

Hivds, Moll. Voy. Sulphur, pl. 10. f. 19, 20.

thab.
Typically distimuished from any other speries of the genus by its thickened fusiform shape and contracted base.

Species 27. (Fig, 27 and 28, $u, 4$, Mus. ('uming.)

Coldmbella f1.Aya. Col. testâ cylindraceo-oblongâ, tavi, flavescente-rufä, albo maculatâ et punctatá, spirâ subacuminatâ, anfractibus plano-convexis, al basu linearisulcatis ; aperturấ parviusculä, labio externo parum incrassato, intus denticulato.

The rellowisli Columbella. Shell cylindrically oblong, smooth, yellowish-red, spotted and dotted with white, spirc somewhat acuminated, whorls flatly conrex, hincarly grooved at the base; aperture rather small, outer lip but little thickened, denticulated withiu.

Buecinum flavum, Bruguière, Dict. No. 53 Columbella flavida, Laruarck.

Hab.

A cylindrically oblong shell, neatly filotched and dotted with white upou a yellowish-red ground.

\section{Species 29. (Fig. $a, b$, Mus. ('uning.)}

Columbella coronata. Col. testâa oblongo-acuminatâ, albâ, brunneo variejatâ, anfractibus septem ad veto, lavibus, tribus ultimis serie unicá tuberculornin mueronatorum roronatis; labio externo intus denticutato.

The coronated Columbella, sbell oblong acuminated, white, variegated with brown, whorls seven to eight, smooth, the last three coronated with a row of pointed tubcreles; outer lip denticulated within.

Sowerby, Pro. Zool. Soc. 1832, p. 114.

IIab. Bay of Panama.

The variegated brown painting of this species has mostly a freckled reticulated appearance. 


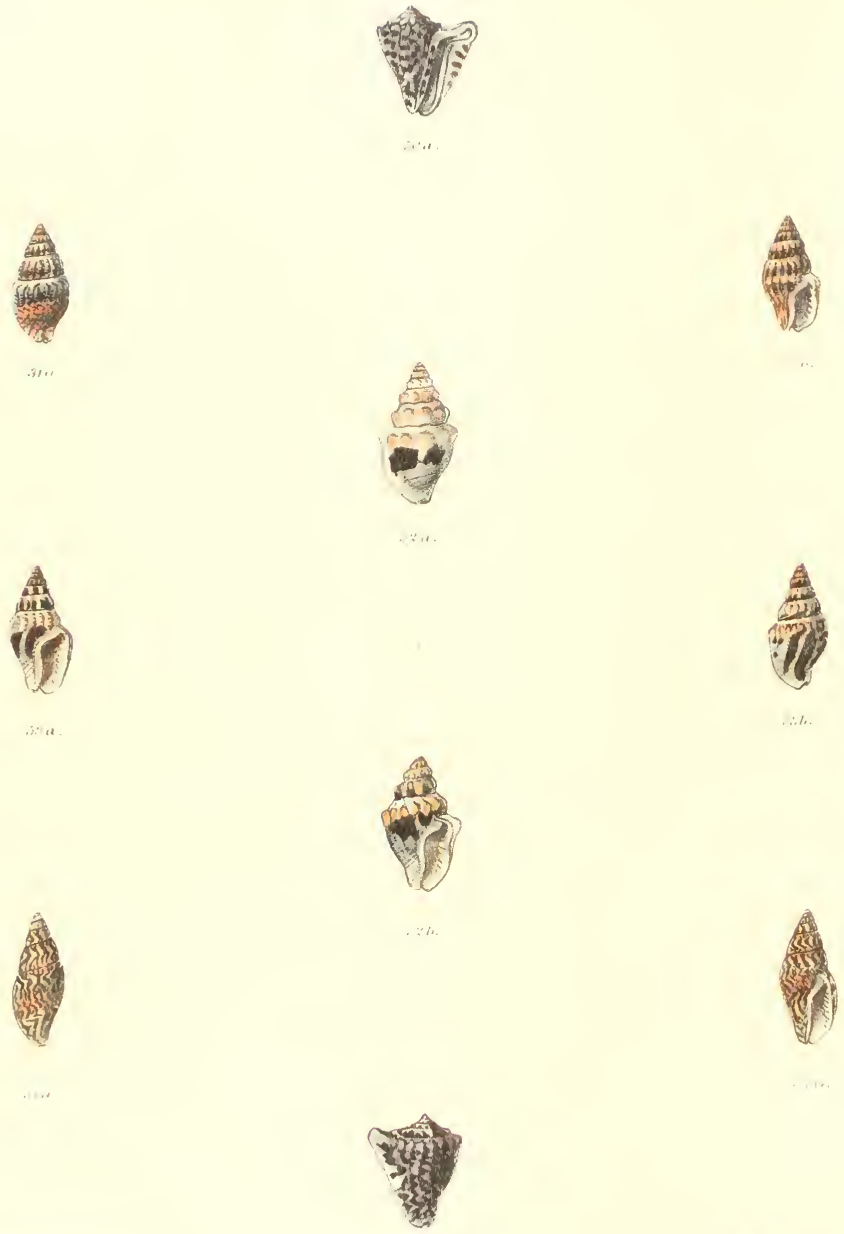


\section{O L U II B E L L A.}

Plate VII.

Siperne 30. (1hg. a, a Mus. Cuming.)

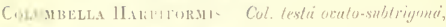

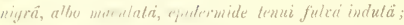

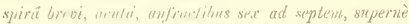

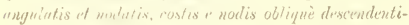

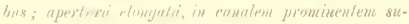

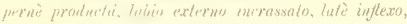

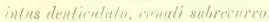

The Harp-shaped Columbella. Shell ovately subtriangular, black, spottcel with white, covered with a then fulvons epidermis, spire short, sharp', whorls six to seven, angled and notuled at the upper part, with ribs obliquely desceuding liom the nodules; aperture elongater, produced at the upper part into a prowimeut canal, outer lip thickened, broadly reflected, denticulited within, canal slightly recurved.

Suwkisy, Pro. Zool. soc. Is32, p. II 3.

IIab. Bay of Panama (found on dead shells in ten fatboms); C'uming.

('urionsly distingni-hed from all other species of the genus by its chamel-winged aperture, which gives the shell a characteristic harp shape.

Species 31. ( Tig, a, b, Mtus, ('uming.)

Whembella vabicosa. Col. Teslá oblongo-ackmimatii,

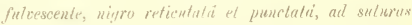

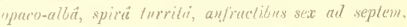
varicoso-e.ostalis; ajurturat puriciuscula, lubio extemo supernè sinuate, intens demterelelo.

THe varfoose coltingella. Shell acuminately oblong, fulvous, reticulated and dotted with black, opacyue white at the sutures, spire turreted, whorls six to seven, varicosely ribbed; aperture rather small, outer lip thickencl, notehed towards the upper part, denticulated within.

Gaskoin, Pro. Zool. Soe. Isth

Hub. Payta, Peru.
Oblinnely seulptuat thenghout with tarrow nos ditscending with the angular declivity of the whorls.

Sprecies 32. (Fig. a, b, Mus. Cuming.)

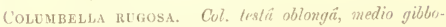
sulat, albidâ, maculis peramplis nigris tinctâ, spirr turritît, ad upicem plerumque erosî, aufractibus septem, longitudinaliter rugoso-costatis, costis supernè tuberculatis; aperturit subapertit.

TIIE RUgOSE CoLtMBELla. Shell oblong, rather gibbous in the middle, whitish, stained witls large black blotches, spire turreted, generally eroded at the apex, whorls seven, longitudinally rugosely ribbed, ribs tubereled at the upper part; aperture rat her open. Sowerry, Pro. Zool. Soc. 1S32, p. 115.

IIab. Panama and Xipixapi (under stones); Cuming.

A strongly tubercled chalk-white shell, picd with one or two large black blotches.

Fig. 33. (Fig. $u, t$, Mus. Cuming.)

This shelf, thongh so unlike the preccding in appearance, is nevertheless a variety, in which the tubcreles are modificd into concentric sutural ridges.

Species 34. (Fig. a, b, Mus. Cuming.)

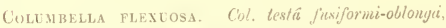
albă, fuseu densè Jlexroso-ieticulotit, spirâ acuminatit, anfractibus sex, pluno-conexis; nperturä parvä, Labio externo incrassato.

THE fLEXUOes CoLlimbela. Shell fusiformly oblong, white, densely flexuously reticulated with brown, spirc acuminated, whorls six, flatly convex; apcrture small, outer lip thickened.

Buccinum ftexuosam, Lamarck, Anin, saus vert. vol. $\mathrm{x}$. p. 175 .

Hab. — ?

Chiefly remarkable lior its very densely uctted chestuut pattern. 


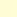



Cisumbella, Pl. IIII.

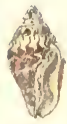

$35 a$
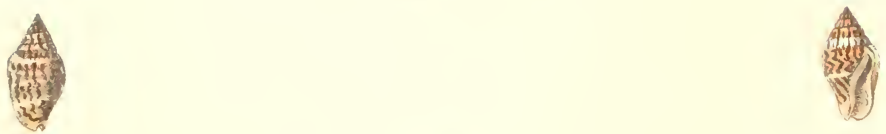

360

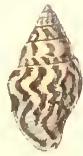

;a
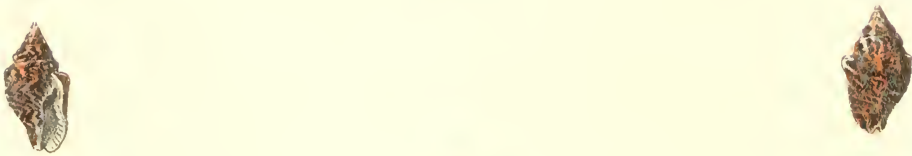

is a

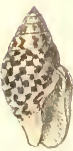

586

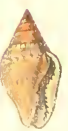

(avey

$37 r$
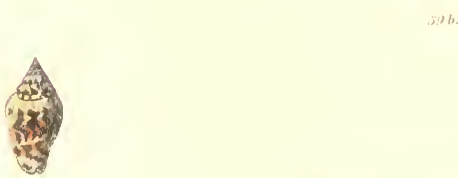


\section{O L U M B E L L A.}

\section{Plate VIII.}

Sperm= 35, (Fis $85 a, 4$ and $36 a, b$.)

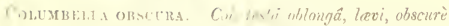
futr: strigis tommitudiumblure pigrescente-fuscts, spirô

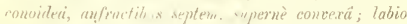

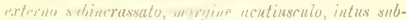
denticuluto. curali breci, sutireftero.

Г'he: obsct ine Colembella. Shefl oblong, smonth, obscurcly fulvous, with longitudinal blackish-brown streaks, sjire conolid, whorls scren, convex at the upper part; outer lip rather thickened, rather sharp at the erlge, slightly denticulated within, canal short, a little reflected.

sowerry, Thesaurus Conch. vol. i. p. 121. pl. 37. f. 70, 71 .

11ab. North-west coast of New Holland.

The colouring of this species is peculiar, the ilexuous Inngitudinal black-brown streaks appeariug over a faint network or stained band of seorehed-fulvons.

\section{Speecies 37. (Fig. a, b, II 1 s. Cuming.)}

Coltmbelli TYLERT. Col. testii orato-oblongä, lirvi, albui, fusco-nigyo cticulatá et strigatâ, spirá subobtusè uruminotio, aufractibus septen, nemiricosinsenlix; aper-

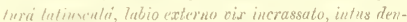
ficmlite, columellit arenati.

Triti.'s Coftubelia. Shell ovately oblong, smooth. white, reticulated and streaked with rusty black, spire somewhat obtusely acuminatcil, whorls seven, rather ventricose; aperture rather broad, outer lip slightly thickened, denticulated within, columella arched.

(insY, Griffith's Cuvier's Animal Kunglom.

C'olumbella Prelmerina, Duclos.

11ah. Australia.

This species is variously mottled. In the present sperimen the pattorn is striped on one side and ncatly tessellated on the other.
Specics 38. (Fig. $a, b$, Mra - Cuming.)

Columbella rluctuata. Col. testâ subtrigono-ovatâ, crassâ, ustulato-nigrä, lineis fulvo-albidis acutè angulatis transversim fluctuat $\hat{a}$, spira conico-turritâ, anfractibus septem, supernè validè tuberculatis; aperiurâ subangustû, labio externo superiè calloso-sinuato, medio intus denticulato.

THE Waved Colcarbella. Shell somewhat triangularly ovate, thick, scorched-black, transversely waved with sharply zigzag fulvous-white lines, spire conically turreted, whorls seven, strongly tubercled at the upper part; apcrture rather narrow, outer lip callously simuated, denticulated within in the middle.

Sowerby, Pro. Zool. Soc. 1832 , p. 115

Hab. …?

A solid strongly-tubercled shell, of a dark burnt-brown colour, picked out with fine transversely zigzag yellowishwhite lines.

\section{Species 39. (Fig. $a, b$, Mus. Cuming.)}

Columbella spongiarum. Col, testâ ovalâ, medio obesâ, ad basin contractâ, lovigatâ, albillâ, flavescente-tinctá d. reticulatâ, spirât acuminutu, roseâ, anfractibus septrma ad octo, supernè subrotundatis: aperturâ angustâ, labio exteruo subincrassato, medio intus tumido et nitidle denticulato.

The sponge Colcmbelia. Shell ovate, stout in the micklle, contracted at the basc, snooth, whitish, stained and reticulated with yellow, spire acuminated, rose-coloured, whorls seren to eight, rather rounded at the apper part; aperture narrow, outer lip slightly thickened, swollen and neatly denticulated in the niddle within.

Declos, Monog. du geure, pl. 3. f. 13-16.

Hlab.

A very elegantly-formed shell, swollen in the middle and contracted at the base, with a very sharp spire. 



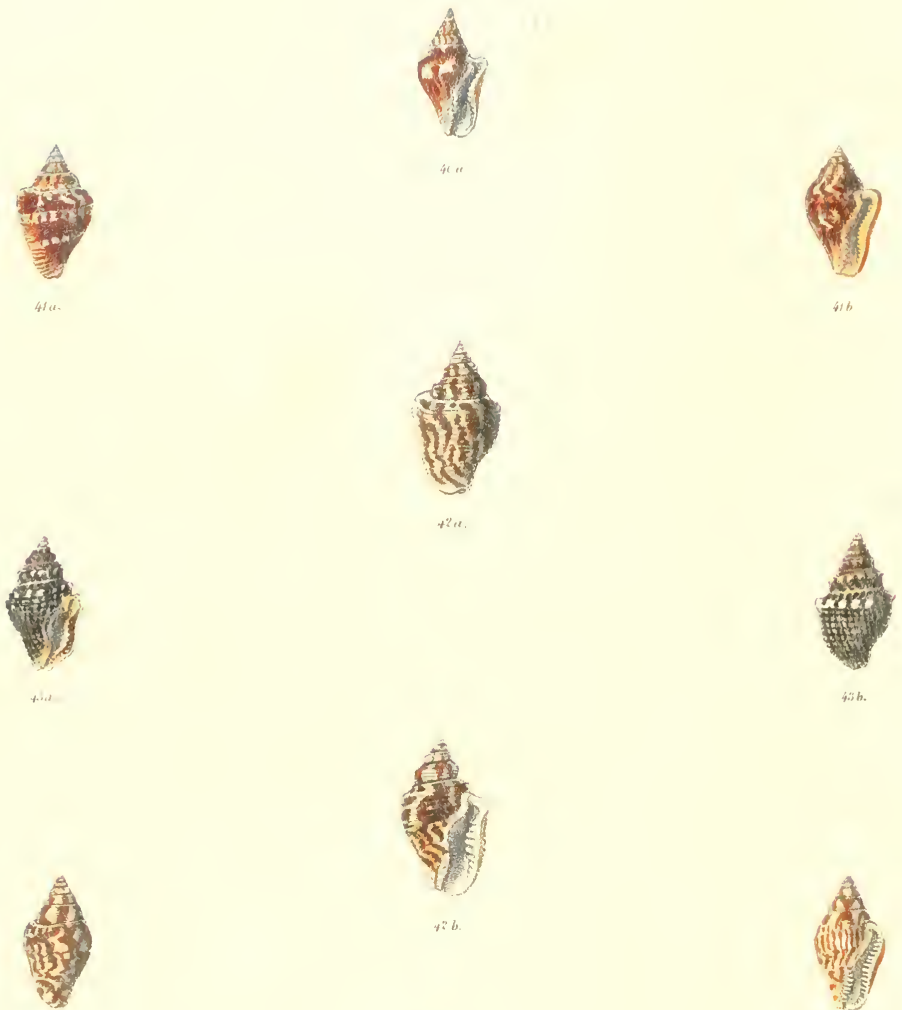

$4: 6$
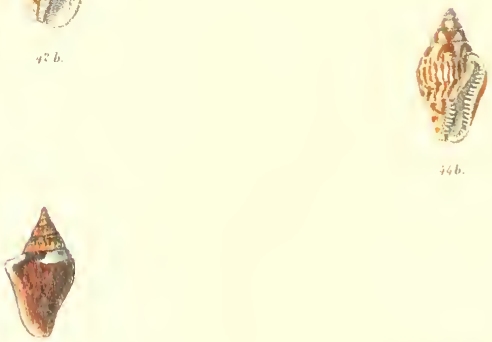


\section{O L U M B E L L A.}

Prate IX.

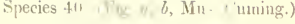

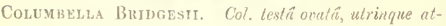
tenuat $\hat{a}$, fuscersente-ruf $\hat{a}$, albipunctati, nucul $\hat{a}$ alb $\hat{a}$ ampla obliquâ in medio, xpirâ breviusculie, acuminatä, aufractibus septem lrevitus; uperturá supernè anugulato-auriculatâ, intus calluso-denticulutî.

Brivirs' Colombrlat. Shell ovate, attemuated at each end, brownish-red, white-dotted, with a large, white, oblique bloteh in the middle, spire rather short, acuminated, whorls seven, smooth; aperture narrow, augularly anrienlited at the upper part, callously denticulated withiu.

Hab. Panama- Bridges.

A very characteristic and pretty species, roumled in the riddle, and more or less attenuated at utch extresuity, with the aperture angularly produced into an auricle.

Species 41 . (Figr. $a, b$, Mus. Cuming.)

Columbella reticl lata. Col. lestä ovatä, medio obesâ, subanyulari, spiraliter limenri-xulculat, fusco-rufä, punctis albis proutiscuè reliculatî. spirâ breoi, acutâ, anfrestibus ser ad septem; aperturi suthanyustâ, supernè angulato-productî, intus calloso-rlentimelatá.

The reticulated Columbella. Shell ovate, obese in the middle, somewhat angular, spirally linearly grooved, fuscous-red, promiscuously reticulated with white dots, spire sluort, slarp, whorls six to seven; aperture rather narrow, angularly produced at the upper purt, cullonsly denticulated within.

Lamarck, Anim. sams vert. vol. x. p. 270.

Hab. Brazil.

Of a solid, augularly ovate form, mostly luscous-red, inlerrupted promisenously uith aggregations of white dots.

Species 42. (Fig, a, b, Mus. Cuming.)

Columbella Pleer. Col. testî subauyulatu-ovotâ, tumidit, spiruliter sulcutie, athü, flesco-rufo variegat $\hat{a}$,

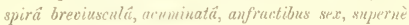
depresso-concavis: uperlurî̀ oblonght, supernè sinuatâ, intus calloso-denticulatu.

Plee's Columbela. Whell somewhat angularly ovate, swollen, spirally grooved, white, varicgated with fus- cous-red, spire rither short, acuminated, whorls six, depressly concave round the upper part; aperture oblong, sinnated at the upper part, callously denticulated within.

KiEner, Icon. Coquilles Vivantes, p. 24. pl. 5. f. 2 .

Columbellu rudis, Sowerby.

Hab) Plulippine Islands; Cuming.

1)istinguished by a rather tumid growth, the whorls being depressly concave round the upper part.

species 4.3. (Fig. $a, b$, Mus. Cuming.)

('olumbella Borvini. Col. testẩ oratât, crassâ, cceruleu-

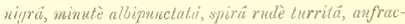
tibus sex ad septem, supernè tuberculatis, infernè spiratiter sulcatis; aperturâ ovatâ, breciusculâ, supernè sinualâ, labio incrassuto, intus denticulalo, denticulis purpureo-violaceis.

Bolvin's Columelta. Shell ovate, thick, blue-black. minutely white-dotted, spire rudely turreted, whorls six to seven, tubercled round the upper part, spirally grooved round the lower; aperture ovatc, ratlier short, sinuated at the upper part, lip thickencd, denticulated within, denticles purple-violet.

Hab. Gulf of Nicoyo, Central America; Hinds.

Of rude tuberculated growtl, minutely dotted with white on a peculiarly bluc-black ground, laving the Jenticles within the aperture curiously stained with purpleviolet.

Species +4. (Fig. a, b, Mus. Cuming.)

Columbella xiphitelda. Col. testấ cylindraceo-verutâ, lavigat $\hat{a}$, nitente, albâ, ancrantio-rufo strigatâ et variegatî; aperturâ oblongî, utrinque denticulatá, denticulorum interstitiis intensè purpureis.

The yellow-streakeb) Columbella. Shell cylindrically ovate, smooth, shining, white, strcaked and variegated with orangc-red; aperture oblong, denticulated on both sidcs, interstices between the denticles darkpurple.

Declos, Monog. du genre, pl. 9. I. 13, 14.

A delicately paiutcd, shining, cylindrically ovate shell. curiously stained with dark-jurple in the interstices between tbe denticles of the aperture. 




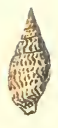

离)
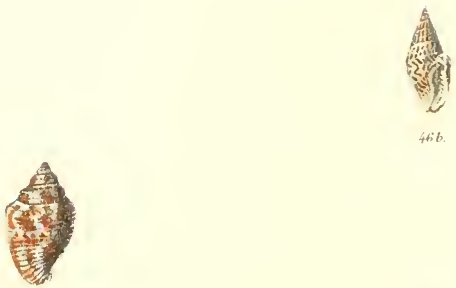

tia.
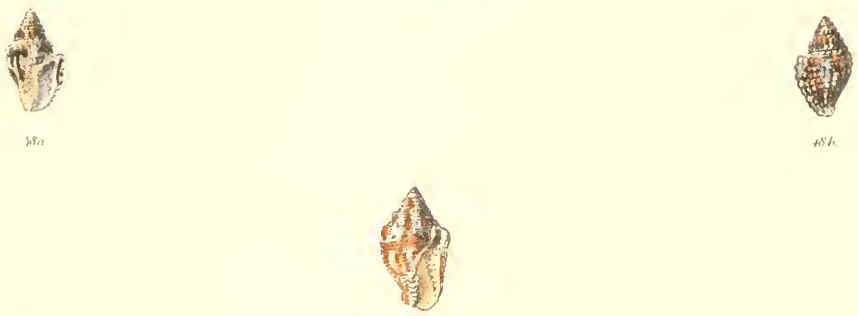

ith.

ํㅐㄱ

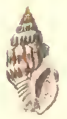

센 


\section{OLU M B E L L $\Lambda$.}

Plate X.

\section{Speri.. 45. (Fis nat, Mus. Cuming.)}

Colimbetla Japonica. Col. test $\vec{\imath}$ orut $\vec{r}$, utrinque attematu. cormlescente-ullui, nigro strigatä et reticulatä, spira aruti, suturis inpressis, anfractibus sex, planoconvexis, versus busin spiraliter lirutis; aperlurá oblonghâ.

THE Japax (Oolvabella. Shell ovate, attenuated at each cul, bluish-white, streaked and reticulated with black, spire sharp, sutures impressed, whorls six, flatly consex, spirally grooved towards the base; aperture obloug.

Hab. Japau.

of a peculiar bluc-white hue, delicately streaked and reticulated over with blark.

Specics t6. (Fig, a, b, Mus. Cuming.)

Coltmbelea actcela. Col. tratâ subulatä, gracili, solidit, opuco-albo flemmelisque juscis undique variegut $\vec{t}$, syiri acutit, anfructious septen, pluno-convexis; aperturi parvit, labio incrassuto, intus denticulato.

The NeEDle Coltubelda. Shell subulate, slender, solid, variegated throughout with minute browu flames and opaque-white, spire sharp, whorls seven, flatly convex; aperture small, lip thickened, denticulated within.

Hab. California.

I solid, subulate shell, beautifully painted with bands of fine longitulinal brown flames, relieved with opaque-white.

Species 47. (Fig. a, b, Mus. Cuming.)

Columblla mercatoma. Col. testâ oucutâ, tumidiuscula, undique spiraliter sulcutâ, variè pictä, interdum articulutit, spirá brevi, anfractibus sex, supernè concaco-lepressis, ad basin iecurvis; apertura obiongi, subanyusti, lubio externo valdè calloso-dinticulato.

Tue common Colun beila. Shell ovate, rather swollen, spirally grooved throughout, variously painted, somctimes articulated, spire short, whorls six, concavely depressed round the upper part, recurved at the base; aperture oblong, rather narrow, outer lip thickened, very callously dentieulated.
Voluta mercatoria, Liunius, Syst. Nat. (Gimeliu's edit.) p. $3+46$.

Columbella mercatoria, Lamarck.

Hab. West Indies.

This well-kuown species is chiefly characterized by its somewhat tumid growth and grooved seulpture, and by its paintiug, which is generally sparingly articulated.

Species 48. (Fig. a, b, Mus, Cuming.)

Columbella declssata. Col. testâa oblongâ, crassâ, albü, fusco-murmoratâ, spirâ turritâ, anfructibus quinque', turgidiusculis, decussatim costatis; aperturâ parvá, subsinuosä, labio externo incrassato, depresso-angulato, intus lenticuluto.

The decussated Columbella. Shell oblong, thick, white, marbled with brown, spire turreted, whorls five, rather swollen, decussately ribbed; aperture small, rather sinuous, outer lip thickened, depressly angled, denticulated within.

Sowerby, Thesaurus Conch. vol. i. p. 134. pl. 39. f. 133. Uab. Anstralia.

The decussately ribbed sculpture of this species gives it the appearance of being granulated.

Species 49. (Fig. $u, b$, Mus. Cuming.)

Colvmbella macrostoma. Col. testä subacuminatoturritâ, carulescente-albâ, lixirio-fasciatâ, spirâ acutá, anfractitus octo ad novem, longitudinaliter lyrato-costatis, costis fuscis; uperturâ parviuscula, intus denticulatît.

The loxg-mouthed Coldibella, shell somewhat acuminately turreted, blue-white, livid-banded, spire sharp, whorls eight to nine, longitudinally lyrately ribbed, ribs brown; aperture rather small, denticnlated within.

Anton, Ms. Mus. Cuming.

IIab. California.

A sharply acuminated species, lyrately ribbed throughout, distingruished by a peculiar arrangement of colouring. 
• 

Columbella, PI.XI.
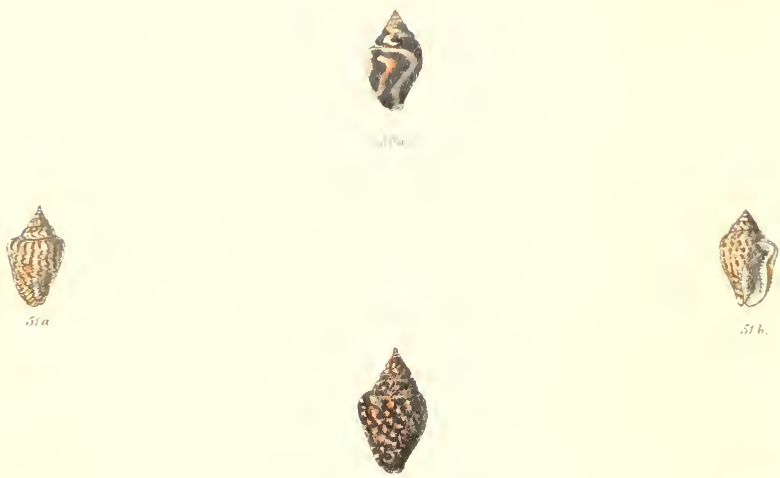

503
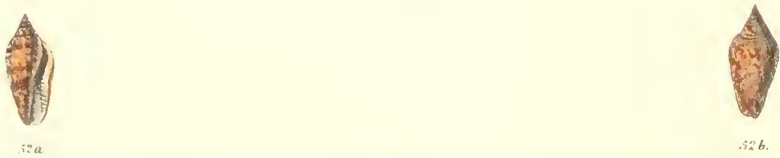

$i \approx b$.

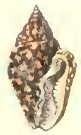

(i)

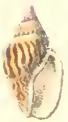

$53 b$.

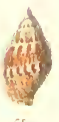




\section{O L U II B E L L A.}

\section{Plate XI.}

Spertes 50. (Fig. $a, h, c$, Mus ('uming.)

Columaella fulgtrans. Col. testâ ometî, crassiusculat, purpureo-atrî, nlbo vel puectritî vel fulguratî, spirấ brevi, acuta, aifractibus ser all septem, levibus, supernè tumidis; apertur $\hat{i}$ oblongî, lubio externo incrassalo, intus calloso-denticulato.

The highting-Marked Columbelia. Shell ovate, rather thick, purple-black, either dotted or lightningmarked with white, spire short, sharp, whorls six to seven, smooth, swollen at the top; aperture oblong, outer lip thickened, eallonsly denticulated within.

LAMARCK, Anim. sans vert, vol. x. p. 272.

Foluta flommen, var., Gmelin.

Buccinum fulgurans, Wood.

Eadem var. Columbella punctata, Lamarck.

Hab. Philippine Islands.

Curiously variable in marking, being sometimes boldly lightning-marked with white, and sometimes profusely dotted upon a dark purple-black ground.

Species 51. (Fig. $a, b$, Mus. Cuming.)

Columbella versicolor. Col. testât ovatât, medlio venlricosâ, pallinlâ, rolorilus rariis pictâ, spirấ brevi, acuminatô, anfractibus sex, transversim sulcatis, supervè tumilis ; aperturẩ oblong $\vec{a}$, flexuosî, labio externo intus calloso-denticulato.

The varicoloured Columbella. Shell ovate, ventricose in the middle, pale, painted with various colours, spire short, acuminated, whorls six, transversely grooved, swollen at the upper part; aperture oblong, flexuous, outer lip callously denticulated within.

Sowerby, Pro. Zool. Soc. 1832, p. 119.

$H a b$. Island of Annaa, Philippine Islands; Cuming.

Chiefly remarkable in form by the swollen angularity of the upper part of the whorls.

\author{
Species 52. (Fig. $a, b$, Mus. Cuming.)
}

Columbella nitida. Col. testâ oblongá, levi, nitente, albicante, fulvo-rufescente narmoratá, spirá brevi, acut $\overrightarrow{\hat{u}}$, aufractibus septem, plano-convexis; apertur $\overrightarrow{\hat{t}}$ oblongâ, angustấ, labio externo intus denticulato.

The smining Colcmbelia. Shell oblong, smooth, shining, whitish, marbled with fulvous-red, spire short, sharp, whorls seven, flatly convex; aperture oblong, narrow, onter lip denticulated within.

LAMARCK, Anim. sans vert. vol, x. p. 271.

Columbella nitidula, Sowerby.

Hab. West Indies.

$\mathrm{Mr}$. Sowerby thinks that this is the Buccinum nitidulum of Linnæus, but M. Deshayes docs not agree with him in this opinion.

Species 53. (Fig. $a, b, c$, Mus. Cuming.)

Columbella levigata: Col. testâ ovatâ, tenuiculä, subventricosî, lavigat $\hat{a}$, aurantio-luteâ, fusco et roseo strigatâ et variegatâ, spirn̂ brevi, acutá, anfractibus sex, convexis; colunellâa subcontort $\hat{n}$, labio externo simplici, uperturât ovatê, albế.

The smoorn Columbella. Shell ovate, rather thin, somewhat ventricose, smooth, orange-yellow, striped and variegated with brown and rose, spire short, sharp, whorls six, convex; colmmella somewhat twisted, outcr lip simple, aperture ovate, white.

Buccinum levigatun, Linnæus, Syst. Nat. (Gmel. cdit.) p. 3497 .

Columbella concinna, Sowerby.

$\mathrm{Hab}$. - ?

An extremely pretty, light, ventricose species, striped and variegated with fulvous-brown or delicate rose. 


Columbella, PI, III.
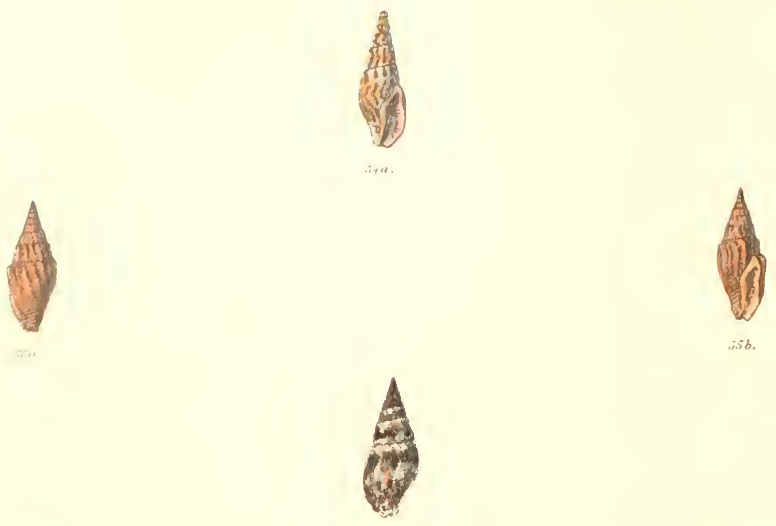

s.s.
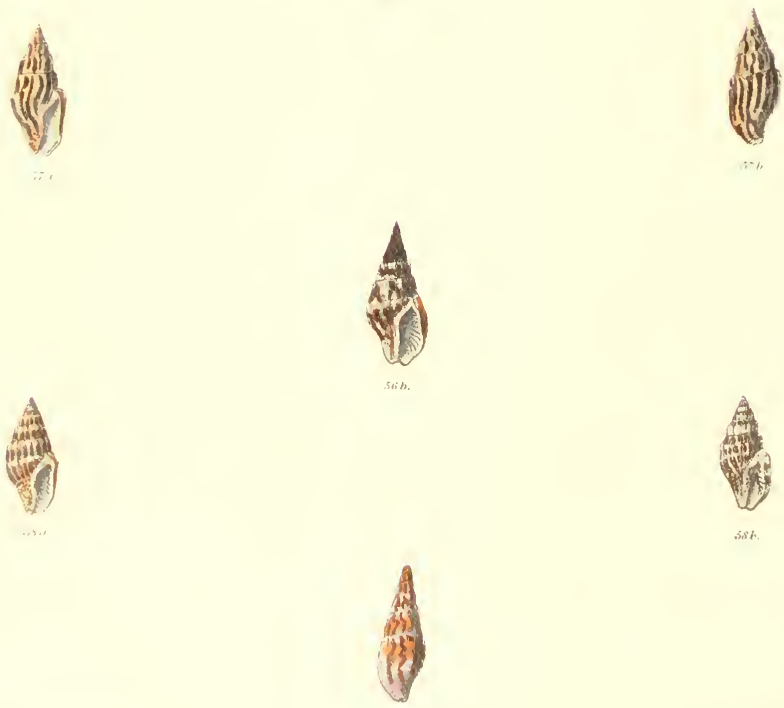


\section{O L U M B E L L A.}

Plate XII.

Fuase 7.t. ( Fiz wi 6. Mus. Cuming.)

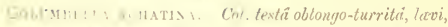

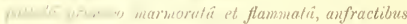

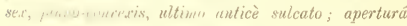

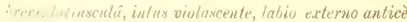
with

Th1 AGi1. ( ULLMBELL3. Shell oblong, turreted, stmoth, pale, marbled and thaned with brown, whorls six, flatly couvex, the last grooved in front; aperture short, ratler broad, interior violet, outer lip effused in front.

Sowerix, Thesaurus Couch, vol. i. p. 132, pl. 39. f. 125 Hab. Swan River.

An elezantly painted slender species, approaching some int the longated Buccine in form.

Siecies 55 . (Fig. n, l, Mus. Cuming.)

1 Osumbli, FULA. Col. testá voato-subulatâ, fulvâ,

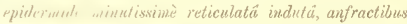

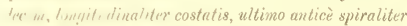

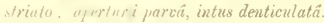

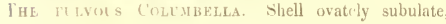
fulvous, covered with a miuutely reticulated epidermis, whorls ten, longitulinally ribbel, the last spirally striated in front; aperture small, toothed within. Soweris, Pro. Zool. Soc. 1532, p. 115.

Hah. Panama (under stoncs); Cuming.

A solid, corspicuonsly ribbed shell, of a dull-fulvous clour, with an unusually slarply acuminated spire.

\section{Specits 56. (Fig. $a, b$, Mus. Cuming.)}

(OLLUMBella ENCAUSTICA. Col. testât oblongo-subulatâ, solidiuscutii, fulvo-brunneâ, albo tessellato-muculatâ, spiri ucutâ, suturis impressis, anfractibus novem, longitulinatiler cosfatix, sulcis spiralibus decussatis; apertura purriusculai, inlus denticulato-liratî.

1 Hе ENCAC:TIC COLUMBELLA. Sticll oblong, subulatc, rather solid, fulvous-brown, tessellately blotehed with white, syire sharp, sutures impressed, whorls nine, longitudimally ribbed, decussated with sjiral grooves; aplerture rather small, dentienlately ridged withiu.

Hah. linlf of California; Lient. shipley.

A finc, solid, sbarply subulate shell, decussately ribbed ad grooved throughout, couspicuousiy matbled witb dark :ulrous-brown aud wbite.

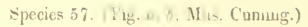

Columbella vexillum. Cot. tostấ acuminato-iblaiga. subturritâ, flacescente, nigriunte-fusco longitudinuliter conspicuè strigatê, anfractibus octo, supernè tunidiksculis, longitulinaliter costatis, ultimo concrvo-coarctato; aperturä parvá, intus crerulescente.

THE FLAG Colvmbella. Shell acuminately oblong, somewhat turreted, yellowish, longitudinally conspicuously striped with dark-brown, whorls eight, somewhat swollen at the upper part, longitudinally ribbed, the last concavely contracted; aperture small, interior bluish.

Hab. Gulf of California.

Another striking new species, longitudinally ribbed, and painted in the same dircction with conspicuous, flexnous, brown stripes.

\section{Species 58. (Fig. 58 a, Mus. Cuming.)}

Columbella lyRATA. Col. testâ oblongâ, actminatâ, fulvescente, anfractibus veto, subrotundatis, nitidè longitudinaliter costatis, cust is nigro albonue articulatis; aperturî̀ prrể, angustâ, minutè denticulatâ.

The haRp-string Collubella. Shell oblong, acumiminated, yellowish, whorls ejght, somewhit rounded, neatly longitudinally ribbed, ribs articulated with black aud white; aperiure small, narrow, minutcly denticulated.

Sowerby, Pro. Zool. Soc. 1832, p. 114.

Hab. Fanama (under stones); Cuming.

Remarkable for the beautiful regularity and neat articulated painting of the longitudinal ribs.

species 59. (Fig. 55 , Mus. Cuming.)

Columbella Tehpsichore. Col. testâ oblongâa, crassitustulit, albidht, punctis strigilisque fuscis ornatâ, anfractibus septem, lompitudinaliter temuè costatis, costis supernè nuricutis; aperturä parzâ, intus denticulatâ.

The Terpsichone Coht urella. Shell oblong, rather thich, whitr, adoned with brown dots and fine streaks, whorls s. prickly at the щp)er part ; aperture small, denticulated within.

Sowerby, Genem of Sliclls, t. 6 .

IIab. Nevis, West Intie's.

A solid, rather prickly ribbed shell, laeed with fine brown lines upon a white ground. 



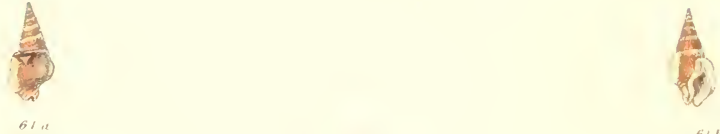

tion

62"
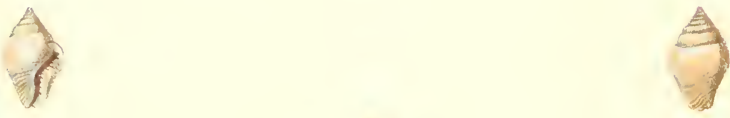

(1)

637

1

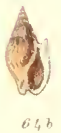

2 


\section{O L U II B E L L A.}

\section{Plate XIII.}

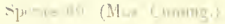

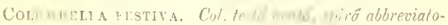

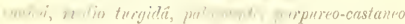

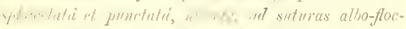

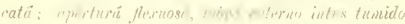
at nelide de viculato.

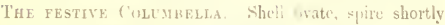
eonical, swollen in the mirldle Wotclued and dotted with pale purple-chistnut, shinins, flaked with whitc at the sutures; ipertur: flex wus, onter lip swollen within and neatly denticu at it

h IEXEk, Coquilles vivantes, p. 15. p1. 11. f. 4.

Hab. Aenpuleo.

An clegnat little shiming speries, richly painted with white-Alaked j mple-brown.

\section{Splecies 6il. (Mus. Ciming.)}

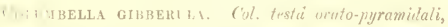
spinai subiluta, anfruetitus plano-converis, brmmeo

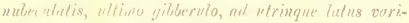

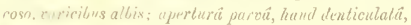
wam li lireti. riflero.

[HE GH:BOL ( oLCMBELL. Shel] ovately pyramidal, spire subulats, whorls flatly convex, clouded with brown. the last somewhat gibbous, varieose at each side, variees white; aperture small, not denticulated, eanal short, refleetel.

Sowerbi, Pro. Zoul. Sie. 1832, 1. 11 J.

Hab. Bas of Caraccas and Pucrto Purtrcro, Central America (in sandy mul, at the depth of eleven fathoons); Cuming.

A solicl acrumated species, rather gibhously angled round the lower 1 art, with a white callous varix on either int:

Spu ies 62. (Eig. $a, l$, Mut. Ctiming.)

Columbella t'RIIRARIA. Col. lestâ oblongo-pyramiduli

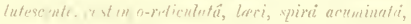

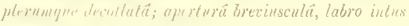
dentiruluto, so primè sinuato.

THE sierL-L1AE (ULemBELLA. Shell oblong-pyramidal, yeilowi-h, reticulated with chestunt, smooth, spire acuminated, Fencrally decollated; aperture ratber short, lip denticnlated witlin, notehed at the upper part.

Quor and Garman, Zool. Voy. te l'Astrolabe, vol. ii. p. $2+1$. pl. 30 . f. $21,22$.

Coluzbella gullut $n$, Sowerby.

Hal. Panama (common under stones); Cuming.

This speeies, confounded originally with Buccinnu, may be reeognized by its characteristic reticulated painting

Species 63. (Fig. $a, b$, Mus. ('uming.)

Colembella tumida. Col, tes/ä nrata, medio tmilila, coprulescente-albi, epidermide fluridä indutit, spirat breviusulat, acuti, anfraclibus convexis, ultimo transversim subobsolelie sulcalo, suturis subundibus: lubro medin et supermè inerassato, intus denticulato.

The swollex Columbella. Shell ovate, swollen in the middlc, bluish-white, covered with a yellow epidermis, spire rather short, sharp, whorls convex, the last trausversely rather obsoletcly grooved, sntures somewlat rude; lip thickened in the middle and upper part, dentieulated within.

Dectos, Momog, du Genre, pl. 13. f. 13, 14.

Hab.

A stout white speeies, faintly grooved across, coverul with a light yellow epidermis.

speeies 64. (Fig. $a, b$, Hus. Cuming.)

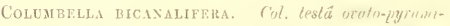
dali, apice aculo, basi spiraller velcato, spirat armainutâ, aufractibus superioribus lomitudinatiter costutis; pallescente-livida, lineis futcr-infescentibus longiludimalites undati; aperturt $\vec{t}$ oblongâ, sujernè in crtur-

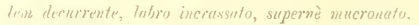
brasi sulwiofterw.

THE Two-chaxXkLfo Colcminela. Shell ovately pymuidal, sharp at the apex, spirally grooved at the base, spitre acuminated, uppermost w liorls longitudinally ribled; pal-livid eolour, lomertulimally waved with fulvous-red liues; aperture oblong, ruming at the upper part into a eanal, lip thickencel. pointed it the top, slightly reflecteal at the base.

Sowr kny, l'ro Kunt. soc. 1<32, p. 113.

Ili. Galapagos 1-lanuls; Cuming;

October, 185:. 


\section{COLUMBELla.-Plate XIII.}

A strikingly characteristic species, distinguished by its channelled aperture and pointed extension of the lip.

\section{Species 65. (Mus. Cuming.)}

Col, mbella puellid. Col. testâ subfusiformi, spirâ lurritâ, anfractibus plano-convexis, longitudinaliter costatis, ultimo ad basin larigatî; nufescente-aurantiá. "n medio el ad suturas albifasciatâ; aperturâ parrius"ulâ, "virinque denticulutit, comali at tenuato et recurro
The young Columbella. Shell somewhat fusiform, spire turreted, whorls flatly convex, longitudinally ribbed, the last smooth at the base, reddish-orange, white-banded in the middle and at the sutures; aperture rather small, denticulated on both sides, canal attenuated and recurved.

Sowerby, MS. in Mus. Cuming.

Hab. Philipuine Islands.

A delicate fusiform species, contrasting curiously in form of the base with the preceding. 
Colnmbella Pl. ITV

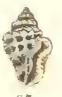

$67 a$

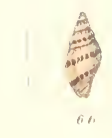

$\theta n$
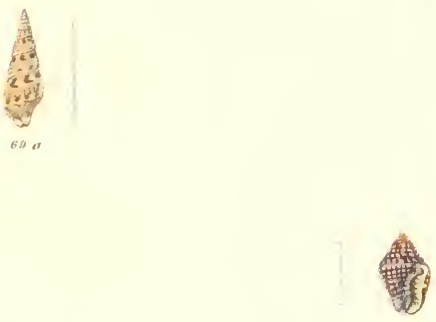

b7

$\because$

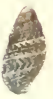

$7 t$
8 


\section{O L U M B EL L A.}

\section{Plate XIT.}

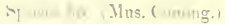

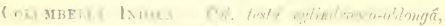

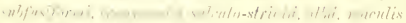

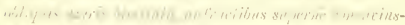

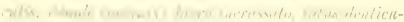
Whe.

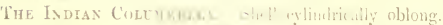

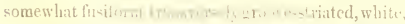

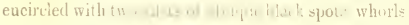
rather concave in the vericr fatt, the eonrex, lip thichened, denti rduine af. hin.

Jub. India.

Distinguished by a cyimanally furitorm growth, neatly painted with distant tinich of cbliqu. black spots upon a white ground.

\section{Species 67. (iliz. a, h, Mur. (uming.)}

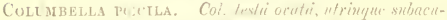

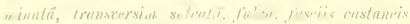

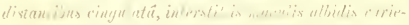

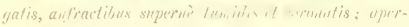

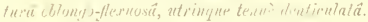

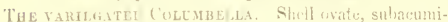
nated at each xtremity, trmstersty urooved, fulrous, encirelest with distam. chatrut bands, the interstices varimgated with white spot, whorls swollen and coromated it the upper part: anwiture oblong, flexuous, fintly der tieutated on each side.

sometur, The-aurus Conch vol. i. p. 118. pl 37. f. 57, 52.

Mat. Island of Matnog, Philippines; Cunoing.

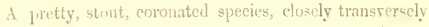
grooved thr ughout, painted with characteristic browu transverse and oblique bands.

Speeres 6\$. (Mus. ('uming.)

Colcurbella miser. Col. textât vrato-oblongâa, albicante

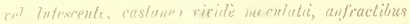

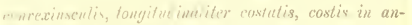

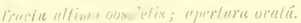

Tux visme Cou uset.L.1. Shell ovately oblong, whitish 1- yllowish, virilly spofterl with ehestnut, whorls

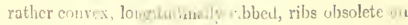
the last whorl; aperiture urate.

Son lary, Thesaurus Conch. vol. i. p. 129. pl 38. f. 111. II:Ih.

strikingly variegated with rarious-sized chestnut blotches.

S,eecios 69. (Fig. "1, l, Mus. Cuming.)

Columbelda Menkeana. Col. testî angustè acuminatä,

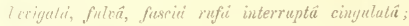
aprituri breci, canali trmucato, labro supernè subsiand to, intus ric dentirulato.

MeXKe's COLTMBLLA. Shell narrowly acuminated, smooth, fulvons, encireled with an interrupted red band; aperture short, eanal truucated, lip slightly notched at the upper part, faiutly denticulated within. Colnube/la acrminata, Nenke (not of Nuttall).

Ilub. Australia.

This interesting Anstralian species has very much the appearauce of a Tirebra. It is of a bright fulrous colour, encircled beneath the suture in each whorl with an interrupted red band, the spots being sometimes arrow-headed, filleted with white.

\section{Speeies 70. (Mus. Cuming.)}

Colembella phasisola. Col. testâa glubuso-ovatâ, rubitlic, grunis ulbis vingulutâ, spirit abbreviato-conicá, suturis . Limprexsis; uperturâ coarctatâ, utrinque dentimlatie.

The mitasant Columberita. Shell globosely ovate. red, encircled with white graius, spire shortly conical, sutures rather impressed; ajerture contracted, denticulated on each side.

Deiclus, Monog. du Genre, pl. 8. f. 13 to 16. Hal. ㄴ.?

An obtuse subglobose shell, beaded throughout with large white graius set iu a deep-red ground.

$$
\text { Species 71. (Mus. Cumiug.) }
$$

Columbelia rugulosa. Col. testâ oblongo-ovatä, crassat, longitudinaliter plicato-rugusâ, vivlaceo-nigricunte, maculis albis aspersâ, olscurè fuscintâ, spirẩ obtus $\hat{b}$, an- 


\section{COLLMBELLA.-Plate YIV.}

fructum nexis, transzersint sulcato-striatis; aperturẩ pariv uscutâ, labro incrassato.

The fixely-Trixiked Columbella. Shell oblongovate, thick, longitudinally plicately wrinkled, violetblack, sprinkled with white dots, obscurely banded, spire obtuse, whorls convex, transversely groove-striated; aperture rather small, lip thickened.

Sowerbr, Thesaurus Conch. vol. i. p. 133. pl. 39. f. 131. Hab. Galapagos Islands.

A stout, obtuse, violet-black shell, more or less freckled with white dots, opening sometimes into a band.

\section{species 72. (Mus. Cuming.)}

Columbella electroides. Col. testá ovatä, tenuiculâa, lavigatâ, rufescente-fulvâ, prope suturas alb $\hat{a}$, spirât breviusculâ, suturis impressis; aperturâ ovatá, labra tenui.

THE amber Columbella. Shell ovate, rather thiu, smooth, reddish-fulvous, white next the suturcs, spirc rather short, sutures impressed; aperture ovate, lip thin.
Hab. Bay of Guayaquil.

A delicate reddish-fulvons shell, of light substain, urticulated round the upper edge of the whorls with white.

Species 73. (Mus. ('uming.)

Columbella avara. Col. testâ subanyustè acuminatá. albâ, fusco vet fulco-aurantio macrlatä, suturis impressis, anfractibus tongitudinaliter flexuoso-rostatis. interstitiis striis reticutatis; apertuiti parvit, labru varicosa.

ThE covetot's Columbella. shell rather narrowly acuminated, white, blotched with brown or fulvousorange, sutures impressed, whorls longitudinally flexuously ribbed, interstices reticulated with stria : aperture small, lip varicose.

sis, Journ. Acad. Nat. Sci. Philadelphia, vol. ii. p. 230 Hab. Bay of Massachusctts, United States; Gould.

Always characterized by a strongly reticulated sculpture, whilst the shell is olten less acuminated than the specimen herc figured. 

Columbelle !' II 


\section{Plate XV.}

Sinour 74. (Mus. Cuming.)

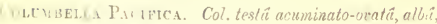

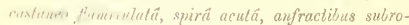
indalis: apurturit partä, labio tenuiculo.

Tur: P'scrfic Columbella. Sliell acuminately ovate, white, flamed with chestunt, spire sharp, whorls somewhat rounderl; aperture small, lip rather thin.

Gaskos, P'm: Zuol, Soc.

Ilab. Galapagos Islands.

An elegantly acmminated species, conspicuous, painted throughout with chestnut flames upon a smooth white ground.

Species 75. (Fig. $a, b, c$, Nus. Cuming.)

('olembella pardalina. Col. trstấ ovatâ, loovi, alhat, moculis retiformilus nigris ornat $\vec{a}$, spirêt brevinsculli, anfiactibus brebilus, wllimo magno, ad basin striato; aperturầ subungmstit, fiexuosit, labio medio tumido et denticuluto, cumali brexi, loto.

THi. Pavthei Columisela. Shell ovate, smooth, white, ormamented with black net-like spots, spire rather short, whorls short, the last large, striated at the base : aperture rather narrow, flexous, lip swollen and denticulated in the middle, canal short, broad.

LakARCk, Anim. sins vert. vol. x. p. 270.

Hub. Islands of Gutmaras and Ticao, Philippines; Cuming.

The painting of this species is extremely variable in pattern, but it is always a brownish-black upon a clear white ground.

Species 76. (Fig. a, b, Mus. Cuming.)

lolcmbelia Duclosiana. Col. testât ovatâ, utringue ucuminutie, longitudinceliter costellatâ, saturatì fuscût. zonis binis pallidioribns cinctâ, interstitiis costamen. tranoersim striatis, partim lovigulis; aperlurä latiusculti, Hhruosâ, nigricante, utrinume denticulatit, labio externo incrussato, canali brexiter acuminato, subreft. $n$; epirtermide crussinsculá.

Duclos Cotlmbeld. Shell ovate, acuminated at either estremity, longitudinally finely rihbed, dark browu, encircled with two paler zones, iuterstices of the ribs fincly striated, partially smooth; aperture rather broad, flexuous, blackish, deuticulated on each side, outer lip thickened, canal shortly acuminated, somewhat reflected; epidermis rather thıck.

Sowerby, Thes. Conch. vol. i. p. 113. pl. 36. f. 15, 16. Hab. Malacca, Java (found under stones); Cuming.

This species is of a distinct typical character, readily listinguished from other of the genus at present known.

\section{Species 77. (Mus, Cuming.)}

Columbella fablla. Col. Leslât ovatâ, lavi, pallidâ, variè reticulutv-pietấ, spirấ brevi, acutâ, anfractibus medio concexn-tumidis; aperturấ oblongî, labio tenuiculo, superne subemarginuto, intus vix denticulato.

The hittle bean Columbell. Shell ovate, smooth, pale, variously reticulately painted, spire short, sharp, whorls convexly swollen in the middle; aperture oblong, lip rather thin, slightly notched at the upper part, faintly denticulated within.

Suw EnBy, Thes. Conch. vol. i. p. 124. pl. 38. f. 86, 87.

Colmutella Padonostu, Duclos.

Hab. Philippine Islauds; Cuming.

A rather lightly convoluted shell, globosely solid in the middle, more or less finely reticulated with brown.

\section{Species 78. (Mus. Cuming.)}

Columbella Australis. Col. testâa fusiformi-oblongâ, fulvescrente, rufo reticulatä, prope suturas albifasciatâ, mufo maculatâ, anfinctiluss supernè impressis, deinde concexis, ultimo sulcato-striato ; aperturấ oblongâ, dentimlatâ.

The Australiax Colembella. Shell fusiformly oblong, fulvous, reticulated with red, white-banded next the sutures, blotched with red, whorls impressed round the upper part, then convex, the last groove-striated; aperture oblong; denticulated.

Gaskon, Pro. Zool. Soc.

IIab. Sydney (under stones, at low-water).

This pretty and well-defined species partakes somewhat of the characters of the Buccinoid form of Triton.

\section{Species 79. (Mus, Cuming.)}

Columbella zebra. Col. testâ oblongû, subpyramidali, lerri, fulvescmele, castaneo conspicuè strigat $\vec{a}$; aperturá lutiuscula, hubio intus subincrassuto, vix denticulato.

THE zEBra CoLUMBELLA. Shall oblong, somewhat pyramidal, smooth, fulvous, conspicuously striped with chestnut; apcrture rather broad, lip slightly thickened within, faintly denticulated.

Gray, Sowerly, Thes. Conch. vol. i. p. 127. pl. 38. f. 105. HLab. New Zealand.

A shell of simple form, void of sculpture, painted longitudinally with characteristic chestnut stripes upon a fulvouswhite ground. 



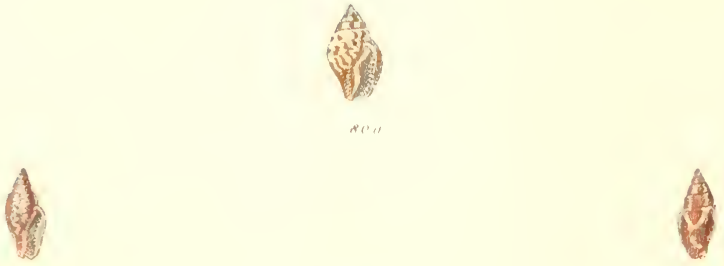

dia

त)
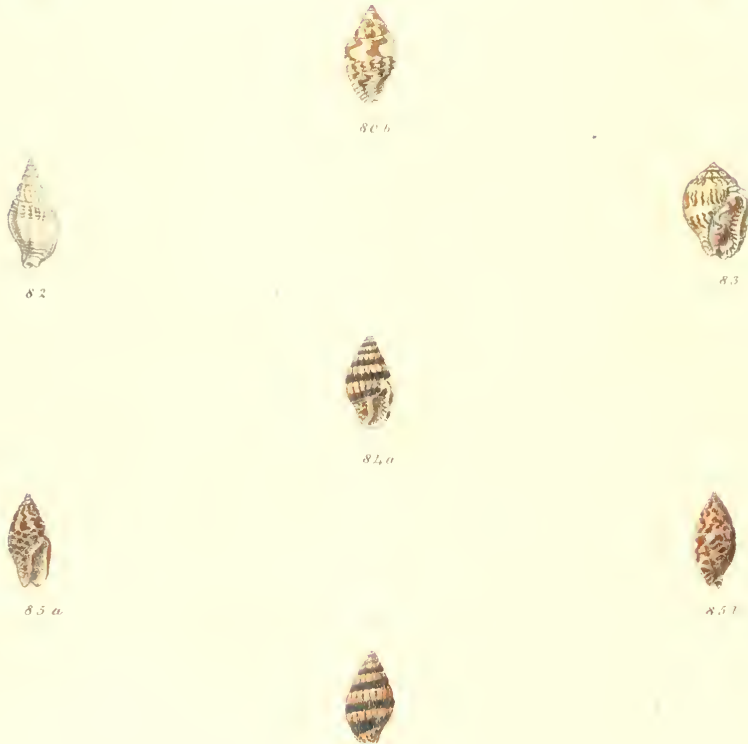


\section{O L U M B E L L $\Lambda$.}

\section{Plate XVI.}

Sperits St. (Fig, it b, Mtus, Cuming.)

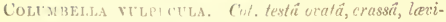

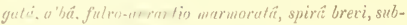
obtusâ, anfructibus supurul planutis, deinde concexis, ultimo sulcutostrivto: "perturâ subangustâ, labro incrassalo, deuticulato.

The fox Columbellat. Shell ovate, thick, smootl, white, marbled with fulvous-orange, spire short, rather obtuse, whorls flat at the upper part, then convex, last whorl groove-striated; aperture rather narrow, lip thickencel, denticulated.

Sow Enis:, Thes. Conch. pl. 38. f. 90.

Hab. Australia.

$\Lambda$ solid shell, mathled with fulvous-orange upon a white ground.

\section{Specius SI. (Nus. Cuming.)}

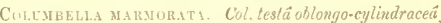
lerigat $\hat{i}$, nitente, fulru-arerentiâ, allo strigatấ et punctatâ, "urfractibus plano-rontcits, ultimo ad basin sulcato-striato; aperturî́ subangustâ, supemé subemarginalu, labro intus denticulato.

The marbleb Colcmberla. Shell oblong-cylindrical, smooth, shiuing, fulvous-orange, striped and dotted with white, whorls flatly convex, the last groovestriated at the l,ase; aperture rather uarrow, slightly notched at the upper part, lip denticulated within.

GraY, Zoolung of Beechey's Voyage, p. 129. pl. 36 . f. 11. Hab. Isle of Capul, Philippines (on the reefs); Cuming.

Of a somewhat Mitra-like shape, shining, fulvousorange, promiscuously streaked and dotted with white.

\section{Species 82. (Mus, Cuming.)}

Columbella nivea. Col. testâ avalü, spirâa acuminato-

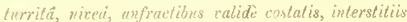
obseurè reticulato-striatis; aperturit oblongä, superni subenarginatâ, canali subincrassatim recurvo.

The snowy Columbelua. Shell ovatc, with the spire acumiuately turretet, white, whorls strongly ribbed. with the interstices obscurely, reticulately striated; aperture oblong, slightly emarginated at the upper part, canal rather thickly recurved.

Sowerisy, Thes. Conch. vol. i. p. 139. pl. 39. f. 151 ,

This colourless shell is not a very satisfactory species, yet it is not exactly referable to any other at present described.
Speries 83. AHus. Cuning.)

Columbella turterina. (a). testii bremi crussit, suit utubosit, albielü, aurantio-finse rarig is. aufractibus transversim sulcato-strintis; aperturâu ublongo-flexuosá utrinque roseâ, columetid bidenticulatii, labro crassis. simo, denticuluto.

The turtle dove Columbella. Shell short, thick, subglobose, whitish, variegated with orange-brown, whorls transversely groove-striated; aperture oblong-flextrous, pink on each side, columella bidenticulated, lip very thick, denticulated.

lamareK, Anim. sans Vert. vol, x. p. 273.

Hab. Philippine Islands; Cuming.

Well distinguished by its short bulbous growth and wramulated columbella with jiuk colouring.

Species S.t. (Fig. $a, b$, Mus. Cuming.)

Columbella mirata. Col. testâ ovatâ, utrinque altenuatii, ubique densè costat $\vec{a}$, interstitiis versus basin fenestralis, allbâ, fusciis dunbus latis nigris cingulatâ ; aperlurẩ parciusculâa, inlus denticulatâ.

Tue mitre Columbelia. Shell ovate, attenuated at each end, closely ribbed throughout, interstices towards the base latticed, white, encircled with two broad bands of fuscous-black; aperture rather small, deuticulated within.

Menke, Moll. Nov. Hollandiæ.

Hab. New IIolland.

A stout ribbed shell, conspicuous binded with fuscousblack.

Species 85. (Fig. $a, b$, Mus. Cuming.)

ColtmBella obTcsa. Col. testâ oblongo-cylindraceâ, spirâ oblusü, apice aculeat $\hat{a}$, pallidâ, castaneo-rufo reliculato-maculutî, maculis obliquè trapeziformibus, anfractibus supernè subimpressis, deinde convexis, aperturit partit, subangustit, supernè emarginatä.

The obtuse Columbella. Shell oblong-cylindrical, spire obtuse, prickly at the apex, pale, reticulately spotted with cliestnut-rci, spots obliquely trapezilorm, whorls slightiy impressed round the upper part, then couvex; aperture small, rather uarrow, notched at the upper part

Sowerby, Pro, Zool. Soc. 1832, p. 117 .

Hab. Huaheine, Socicty Islands: Cuming.

Of a regular cylindrical form, curiously obliquely ruticulated. 


Columbella PI. ITII
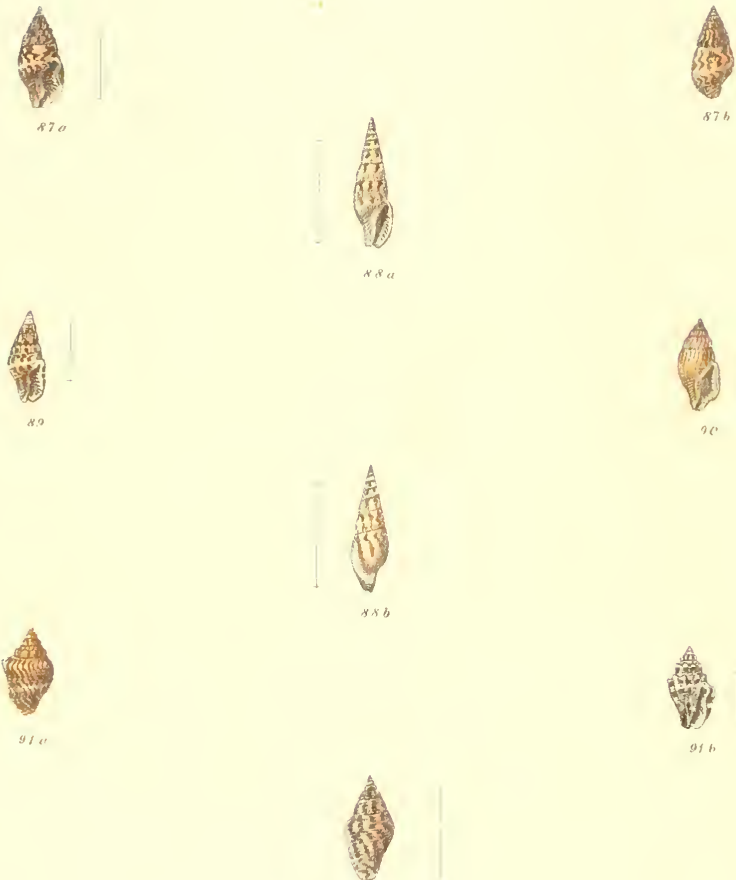
Plate XVII.

Species 86 . (Tig. 86 and 87, $a, b$, Mus. Cuming.)

Columbelia polchella. Col. testît acuminato-cylindraceit, pallidit, witente, maculis fummisque fulvo-aurantiis variegutü, anfractibus superioribus longitudinuliter costalis, interstitiis iuterdun fenestratis; aperturî parvit, supumè emarginatâ, intus denticulatâ.

The beautiful Coluabella. Shell acuminately cylindrical, pale, shming, variegated with fulvous-orange spots and flamcs, upper whorls longitudinally ribbed, interstices so netimes latticed; aperture small, notebed at the upper part, denticulated within.

Sow enry, Thes. Cmel. vol. i. p. 131. pl. 39. f. 121,122. Buccinum puichellum, Kiener.

Hah. Caffraria.

An elegantly painted species, partaking in a measure of the characters of Triton and Pleurotoma.

Species ss. (Fig. a, b, Mus. Cuming.)

Columbella intertexta. Col, testí aciculari, semipellucidâ, opaco-tullo undique punctatâ, flammis aurantio-fuscis ad suturas pictâ, anfractibus plnno-concexis transcersìn minutè strialis; aperturá parviusculä, labro tenui, intus denticuluto.

The interworen Colunbella. Shell acienlar, semitransparent, everywhere dotted with opaque-white, painted with orange-brown flames at the sutures, whorls flatly convex, transversoly minutely striated; aperture rather small, lip thin, denticulated within.

Gaskotn, Pro. Zool. Soc.

Hab. Australia.

An extremely delicate semitransparent shell, flaked with white dots, and paiuted at the sutures with orange-brown spots, descending in short flames.

Species 89. (Fig. $a, b$, Mus. Cuming.)

('olembelda suffusa. Col. testá oblongê, spirât lurritâ, albat, punctis rufo-fuscis piclê,, anfractibus convexis, longitudinatiter costatis, interstitiis feneslralis ; aperturê parvä, supernè emarginat $\vec{a}$.

The suffuseu Coluabella. Shell oblong, spirc turreted, white, painted with red-brown dots, whorls conser, longitudinally ribbed, interstices latticed; aperture small, notehed at the upper part.

sowerby, Thesaurus Conch. vol.i. p. 142. pl. 40. f. 166, 167.

Hab. Pacific; Cuming.

The red-brown painting in this specics, described as dots, has sometimes the form of hieroglyphic characters.
Species 90. (Mus. Cuming.)

Columbella jaspridea. Col. testît cylindiaceo-oblongä, apice mucronato, pallidè rosêt, anfractibus convexis, confertim tongitudiuatiter costatis; aperturnt parviusculâ, supernè emarginatâ, intus denticulatâ.

THE JASPER COLUMBELLA. Shell cylindrically oblong, apex pointerl, palc rose-colour, whorls consex, closely longitudinally ribbed; aperture rather small, notched at the upper part, denticulated within.

Sowerby, Thcsaurus Conch. vol. i. p. 132. pl. 39. f. 125.

Hab. Island of 'Ticao, Philippiues (found under stones, at low-water); Cuming.

A cylindrically oblong sbell, closely ribbed throughout, of a uniform pale pink.

Species 91. (Fig. $a, b$, Mus. Cuming.)

Colombella varjans. Col. testä ovat $\vec{a}$, medio ventricosî, albielâ, coloriłus variis pictît, spirâ breciter pyramidnli, anfractibus transversin sulcatis, supernè interdun nodulatis; aperturấ angustâ, flexnosî, supernè angulatî, intus denticulatit.

The variable Colcmbella. Shell ovate, ientricose in the middle, whitish, painted with various colours, spire slortly pyramidal, whorls transversely grooved. sometimes noduled at the upper part ; aperture narrow, flexuous, angled at the upper part, denticulated within.

Sowerry, Pro. Zool. Soc. 1832, p. 118.

IIab. Galapagos Islauds.

The painting of this little species is so variable that it cannot be specially cbaracterized.

\section{Species 92. (Mus. Cuming.)}

Columbella Dysoni. Col. testâ fusiformi-conicä, lutescente-albâ, maculis rufo-fuscis undatin strigatû, spirấ brevi, acutü, anfractibus undique validè spiraliter sulcatâ; ; aperturî elongatâ, labro plano-incrissato, intus denticulato.

Dyson's Columbella. Shell fusiformly conical, yellowisl-white, painted with wave stripes of red-brown spots, spire short, sharp, whorls strongly spirally grooved throughout; aperture elongated, lip flatly thickeued, denticulated within.

Hab. Honduras; Jyson.

A very chancteristic type of the genus, partaking of the peculiar form of Conohelix. 



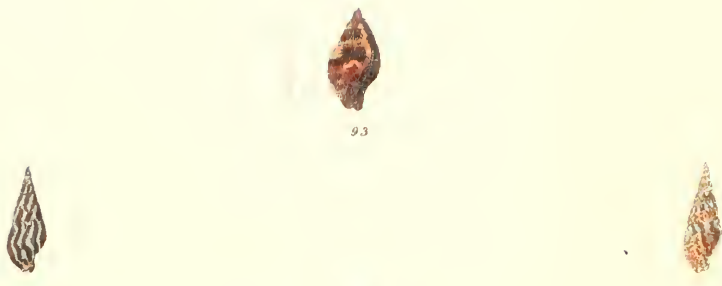

(3)
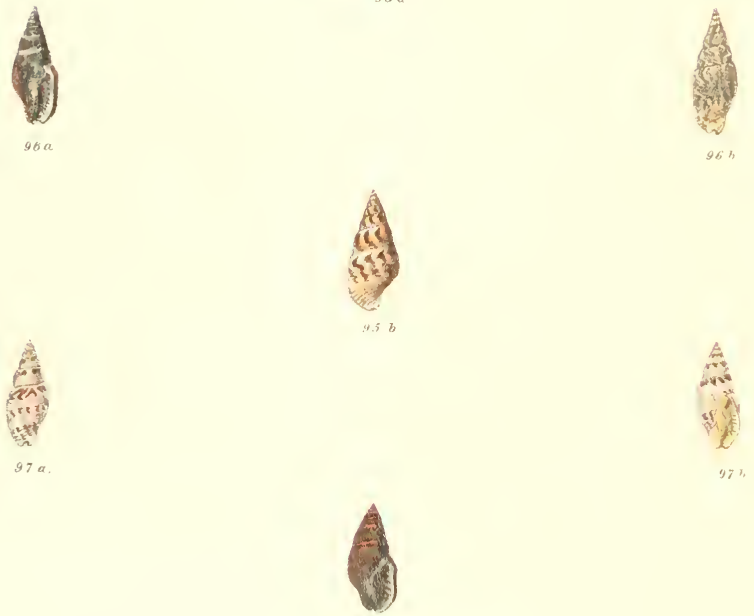


\section{Plate IVili.}

Species 93. (Mus. Cuning.)

Columbella Ticaonis. Col. testä cylindraceo-ovatâ, ad Lasin restrictá, ajice aculâ, pallescente, castaneo ampliter splacelatâ, unfrutibus plano-conzexis, spiraliter striatis, suturis impressix, anfractu ultimo basi sulcato; aperturâa oblongi, supernì emarginalâ, intus denticulatĩ.

The Ticao Colcybelia. Shell cylindrically ovate, restricted at the base, sharp at the apex, pale, largely blotched with chestnut whorls, flatly convex, spirally striated, sutures impressed, last whorl grooved at the bise; aperture oblong, notched at the upper part, denticulated within.

Sowerby, Thesaurus Conch. vol. i. p. 134.

11al. Island of Ticao, Philippines (in sandy mud, at a depth of seren fathous); Cuming.

A bright, r:ohly painted shell, rather more attenuately restricted at the basc than is usual in this genus.

\section{Species 94. (Mus. Cuming.)}

Colcmbella comictlata. Col. testâ acioulari, lavigatâ, nitent, rujo-fuscescente, variè strigatâ aut marmorat $\vec{a}$, anfractlus pluno-convexis; aperturâ parvâ, intus denticulatii.

Tine horned ('oltinblla. Shell acicular, smooth, shining, variously striped or mottled with red-brown, whorls flatly courcx; aperture small, denticulated within.

Buccinum corniculntmin. Lamarck, Anim. sans vert, vol. x. p. 175 .

Columbella corniculata, Deshares.

Buccinesin Linnei, Payraudeau.

Hurex comulus, Olivi.

Columbella conulus, Blainrille.

Hub. Mediterranean.

A very sharp acicnlar shell, richly variegated in a variety of patterns with red-brown.

Species 95. (Fig. $a, b$, Mtis. (utning.)

('olumbella semiconvexa. Col. testâ ovato-subulatá, crussiusculâ, lavi, jallidâ, rufo-fusco longitudinaliter flammatâ, anfractibus planiusculis, ad suturas convexis, ubscurè striatis; aperturâ parviusculá, conspicuè denticulatâ.

THE SEMI-CONVEx ColumbelaA. Shell ovately subalate, rather thick, smooth, pale, lougitudinally flamed with red-brown, whorls rather hat, convex at the suture, obscurely striated; aperture rather small, conspicuously denticulated.

Wh ccinum semiconvexum, Lamarck, Anim. sans vert. vol. x, p. 171.

Columbella semironvexa, Sowerby.

Inb. Port Lincoln, Australia.
This shell is not of the same acicular type as the preceding sjecics, with which it has been compared, but stout and rounded. The longitudiual red-brown flames with which it is painted are very constant.

Species 96. (Fig. $a, b$, Mus. Cuming.)

Coltmblela ligula. Col. tratî́ oblongâ, acm mintatâ lari, albidî, varïix coloribus piclâ, suppè albijunctnlâ, spirâ produclï, anfractibus plunat is ; aperturit oblongâ. superuè absolitì enaryinatê, denticulatá.

THe Litrle roxgee Coldnbelia. Shell oblong, acuminutcel, smooth, whitish, painted with various colours, often white-dotted, spire produced, whorls flattened; aperture oblong, obsoletely notehed at the upper part, denticulated.

Peclos, Monog. iu genre, pl. 11. f. 11-16.

Hah. Islaud of Ticao, P'hilippines; Cuming.

Although extremely variable in colour, the painting is mostly characterized by a peculiar dotting and lacing of opaque-white.

Species 97. (Fig. a, b, Mus. Cuming.)

Colunbella albina. Col. testä oblongo-acuminalâa, lrexi, ad sultrus restricth, allistâ, punctis rufo-fuscis varie viltatî, anfractibus plino-convexis, ultimo ad basin sulcato ; aperturể parvinsculâ, frruosâ, labro varicoso. intus denticulato.

THE Whitrsh Columbell. Shell oblong, acuminated, smooth, restricted at the sutures, whitisb, variously filleted with red-brown dots, whorls flatiy convex, last whorl grooved at the base; aperture rather small, flexuous, lip varicose, denticulated within.

Kiener, Coquilles vivantes, p. 34. pl. 13. f. 4.

Hat. Island of Alindoro, Plilippines; Cuming.

Very nearly allied to the preceding species, but more restricted and curved in outline.

\section{Species 98. (Mus. Cuuniug.)}

Columbella Buccinordes. Col. testât oblongâa, lrer $r$, piceo-nigrâ, prope suturas interthm pallidè maculatn. anfjactibus pleno-conrexis; aperturấ ovatâ, supermu sinuatit, tabro intus denticulato.

The Buccinum-like Colcmaella. Shell oblong, smooth, pitch-black, sometiunes faintly srotted next the sutures, whorls slightly convex; aperture oratc. sinuated at the upper part, lip denticulated within.

Sowerbi, Pro. Zool. Soc. 1532, p. 114.

Hab. Ancon, Peru (ivund under stones, at low-water): Cuming.

This species has a peculiar slaty look, with not often any indication of light spots at the suture. 


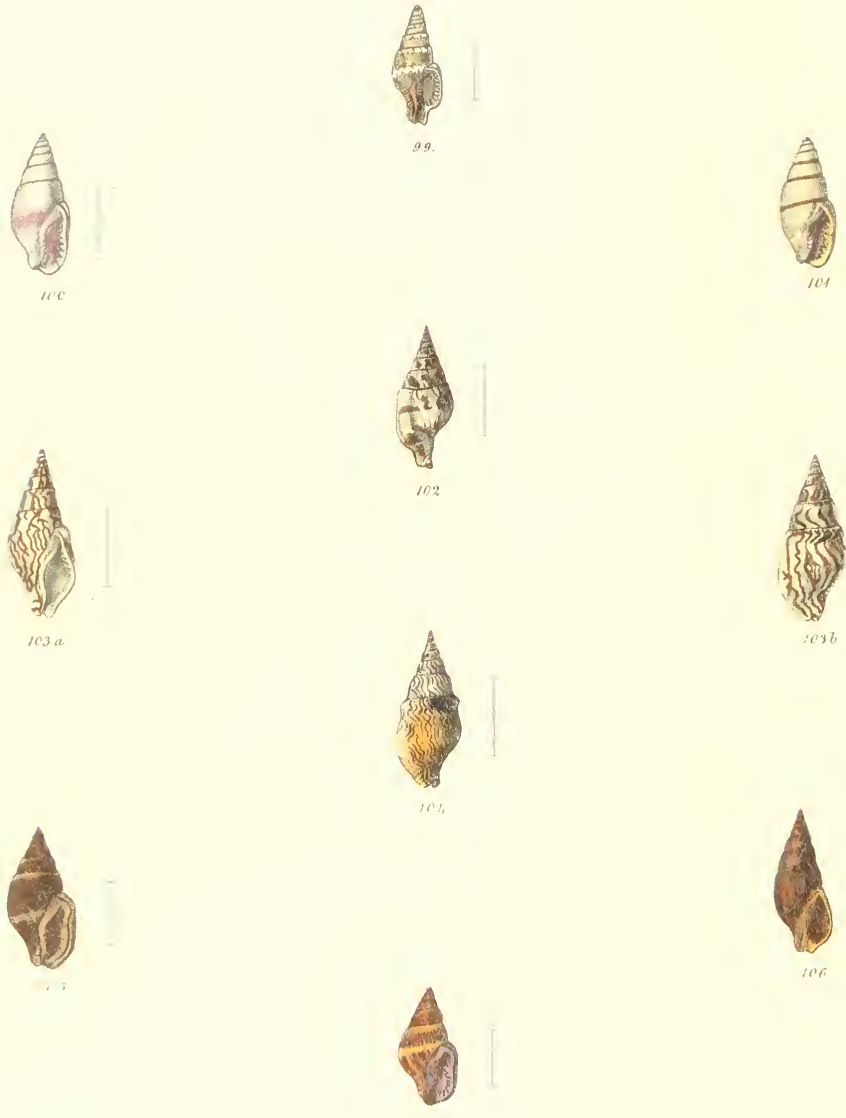

inf 


\title{
C O L U II B E L L A.
}

\author{
Plate IIX.
}

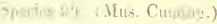

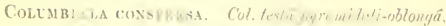

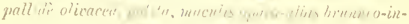

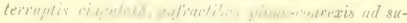

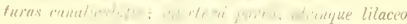

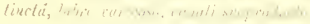

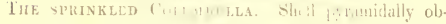

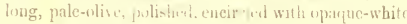
blotche interrofed with fint brown lines, whorls flatly comes, whanclicel at the sutures; aperture sizall, tian of on rath sild wh lilic, lip varicose, caul rather greslated.

Gaskon, Pro. Zuol. soc. Isil, p. 11.

Hab.

A solicl polisted shril, enrirchel with opaque-white brown-interrupteal blotches tирen a elull-olive ground, while the aperture is tinged on either side wi'h lilae.

\section{Sirecies 100. (Mfus. Ciming.)}

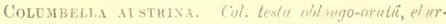

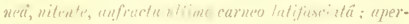

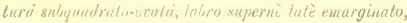
intus conspicum uenticulute.

The southers Concmenil. Shell oblong-ovate, ivorywhite, shining, last whorl encircled with a broad flesh band; aperture rather squarely ovate, lip broadly notehed at the upper part, eonspienously clenticulated within.

Gaskoln, Pro. Zool. Soc. 1851, p. 9.

Hab. Australia.

A shining ivory-white shell, broadly banded on the last whorl witl soft fle-li-culour, and having the lip broadly but rather superfieially notelicd at the upper part.

Species 101. (Mus. C'uning.)

Coly ybela asNulata. Cul, testâ oblongo-oratât, loveigatö, eturuêt, lineri custamế conspicuá medio cingulata, spirit suboistusu; aperlurä subquadruto-nvatâ, labro supernè sulemaryinato, intus denticulato.

Tue ringed Columbeli. Shell oblong-ovate, smooth, ivory-white, encircled round the widdle with a con- spicuous chestnut lime, syis father whtuse, aperium somewhat squarely ovati fir. Faintly notehel at the upper part, dentieulated is iswit.

Hab. Australia.

Of the same typical form as the preceling species, but not of the same enturel-like substance. The conspicnous central chestnut line which eneireles it appears throughout the spire in the sutures.

$$
\text { Tpecies 102. (Mus. ('umiug.) }
$$

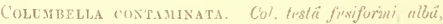
aurantio-fusco sphacelat $\vec{a}$ vel Grunnure, imelio albifasriati, spirci wevfu, suture crumaliculuti, niffactibus plunimsculis, longitudinaliter plicato-liratis, liris in anfrectn ullimo infernè manidis: aperturía parziusculat laliro incrassato, varicaso, intus demficulato, canuli crmeduto.

Tue staived (olumbela. Shell fusiform, white, stained with orange-brown or brown, white-banded round the middle, spire sharp, snture ehannelled, whorls rather flat, longitudinally plicately ridged, ridges on the last whorl disappearing towards the lower part; aperture rather swall, lip thickened, varicose, denticulated within, canal caudate.

Giskoin, Pro. Zool. Soc. 1551, p. 7.

$H_{i} b$, —?

This speeies unay be only a variety of $C$. puellu.

Species 103. (Eig. $103 a, 103 b$, and 104, Mus. Cuming.) Columbel. Blanda. Col. Lestẫ otato-pyramidali, pallidâ, aurantio-fusco longitudinaliter undatu-lineatâ et flammatâ, lineis prope sufuran dorsalem atranentariis; aperturî́ lut ti, lubro supernè calloso et subemarginato, infirmè turgito, intus vix denticututo, canali latiuseuto.

The fair Coltaiblia. Slicll ovately pyramidal, pale, longitudinally wave-lineated and flametl with orangebrown, lines ncar the dorsal suture inky-black; aperture broad, lip callous and faintly notched at the upper part, swollen at the lower, scarecly toothed within, canal rather broad.

Sow Enby, Thesaurus Conch. vol. i. p. 137.

November, 1858. 


\section{COLUMBELLA.-Plate IIX.}

Hab.

An elegantly formed species, singularly characterized by the presence of an inky stain of short black lines on the back next the suture.

Species 105. (Mus, Cuming.)

Columbella cricolor. Col. testâ ovatâ, medio ventri-

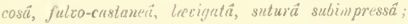
aperturâ latiusruli, suyra et infra subefficsâ, labro incrassato, intns denticulato.

The oNe-colovend Coltubelia. Shell ovate, ventricose in the middle, fulvous-chestnut, smooth, suture rather impressed; aperture rather broad, somewhat effused above and below, lip thickened, denticulated within.

Siowerby, Pro. Zool. Soc. 1832 , p. 119.

Ifal. Galapagos Islands; Cuming.

The effused contour of the aperture and outer lip of this species arises from its inclination to become notched.

Species 106. (Mus. Cuming.)

(OLLMBELLA PLLLA. Col. testí acuminato-oblongà, mitus extusique saturatè brunnể, columellâa allâ, aufractibus convexiusrulis, leribus; uperturâ latiusculâ, labro tenui.
THE RUSSET-BROWN COLCMBELLA. Shell acuminately oblong, dark-brown within and without, columella white, whorls slightly convex, smooth; aperture rather broad, lip thin.

Gaskorn, Pro. Zool. Soe. 1851. p. 6.

Hlab.

It is extremely doubtfnl whether this shell is ("reme) placed in the genus Colmubellu.

Species 10i. (Mus. ('uming.)

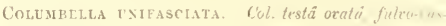
taneâ, zonula fulvescente-albấ medio cingulat $\hat{\imath}$, aufrum tibus contexis, lavibus: aperturä breviusculin, summen it infra effiusâ, intus minutì denticulatâ.

The one-Baxded Colmmella. Sliell orate, fuivouschestnut, encircled round the middle with a narrow fulvons-white zone, whorls conves, smooth : aperture. rather short, eftiused above and below, nimutely deuticulated within.

SuWERBy, Pro. Zool. Soc. 1s32, p. 114

Columbella mizoncalis, Gray.

IIab. Talparaiso (under stones, at low-1kater); Cuming.

So closely allied to $C$. unicolor as to render it doubtful whether it is a distinct species. 


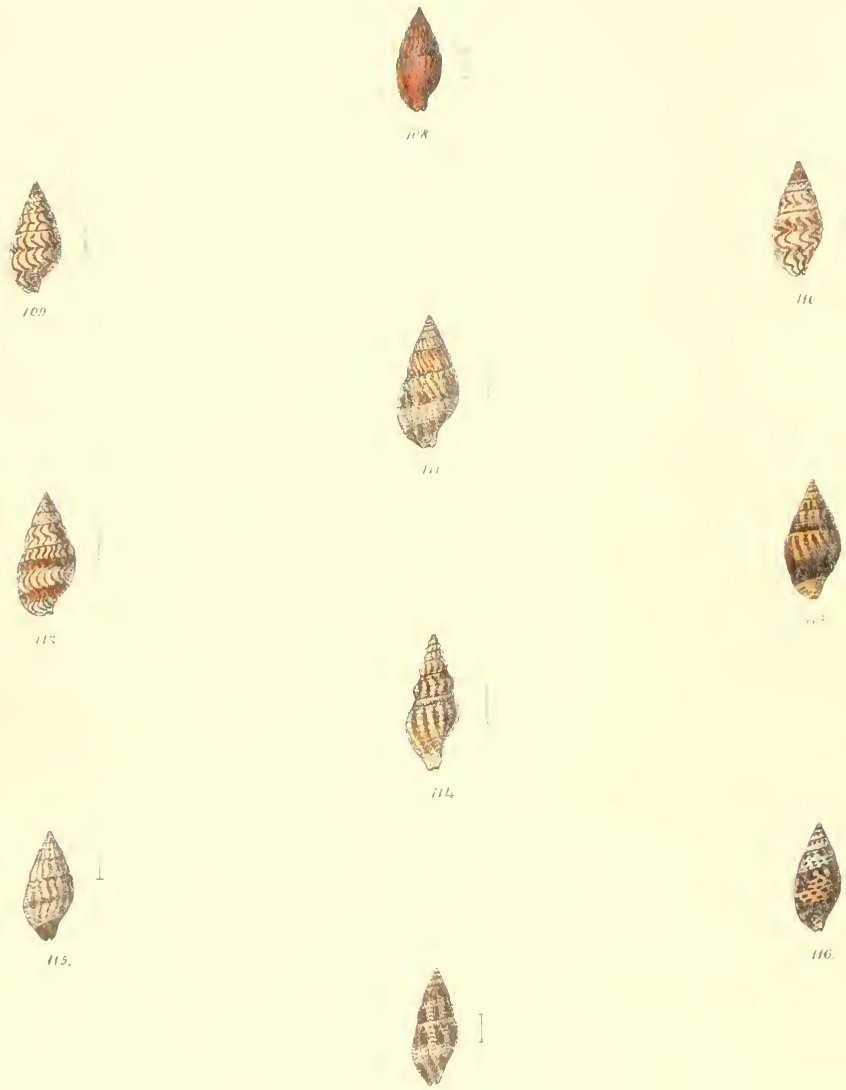


\section{O L U II B ELL $A$.}

\section{Plate S.}

speen lion (Mus. Cumug.)

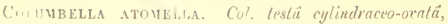

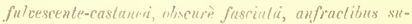
pernè obliquè cost tis: aperturấ oralâ, labro raricusa.

THF LITTLE-ATOM (oLtBBella. Shell rylimirically ovate, fulsons-chestnut, obseurcly banded, whorls obliquely ribbed round the upper part; aperture ovate, lip varicose.

Duclos, Monog. du Genre, pl. 11. f. 5, 6.

Ilal. West Indies.

Of a livid-chestnut colour, faintly banded, with the whorls partially obliquely ribberl.

Sprecies 109. (Fig. 109, 110, and 112.)

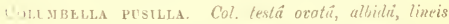
unrantio-brunneis longitulinalibus, fexuoso-rundat is variè pirtit, aufractibus convexis, levoibus; apertura â parnii, labros temiculo, brumeo, vix denticulato.

Tue small Contrabela. Shell ovate, whitish, varicusly painterl with orange-brown longitudinal flexuously waved lnes, whorls convex, smooth; aperture small, lip rather thim, brown, scarcely denticulated.

Sowerby, Pro. Zool. soc. 1st4, p. 53.

Nitidellu Gimtdlii, ('arpenter.

Hal. Island of - t. Viucent, West Indies.

Chiefly distinguished by its conspicnous painting of arange-brown lincs, ranged in more or less close-set longiIndinal festoons.

\section{Specics 111. (Mus. Cuming.)}

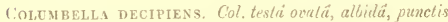
auruntio-fuscis sperrsin promiscuè pictî, spirâ breviusculä, acreli, anfractibus densè temuiliratis, interalitiis cancellatis, liris anfracluss ultiwi eranidis; operturn partit, labro caricoso, supemi subemarginuto, intus deuticuluto.

Tue deceptry. Coltabellat. Sheil ovate, whitish, spanngly promiscuously painted with orangc-brown dots, spire rather short, sharp, whorts closcly finely ridged, interstices caucellated, ridges of the last whorl disappeariog; aperture small, lip saricose, slightly emarginated at the upper part, denticulated within.

(C. 13. AD.1Ms, Contributions to Conchology, p. 58 .

1Iab. Jamaica C. B. Adams.
The coloured dots of this spcties have a flame-iike chatracter next the sutures, and eluster into an imperfect batul at the basc.

\section{Species 113. (Mus. Cuming.)}

Columbella parva. Cul. testia oblonua $\hat{a}$, subobesí, albidi, fasciấ latâ centrali nigricante-castuneá cingnlatâ, spirâ conicâ, anfractibus convexis, longitudinatiter costatis, inberstitiis densè rancellatis, costis anfructis ultimi prope labrum exanidis; aperturâ ovalâ, labro supernè subemarginato, intus dentienlato.

The littele Columbella. Shell oblong, rather stout, whitish, encircled with a broad central blackish-chestnut band, spire conical, whorls convex, longitudinally ribbed, interstices densely cancellated, ribs of the last whorl disappearing near the lip; aperture ovate, lip lightly emarginated at the upper part, denticulated within.

Sowerki, Pro, Zool, Soc. 1844, p. 52.

Hab. Woutc Christi, West Columbia; Cuming.

A solid rather obese shell, densely cancellated, encircled round the middle with a broad blackish-chestnut band.

Fig. 11t. (Mus, Cuming.)

The shell here figuresl proves to lie a specimen of . Mantgelia (C'yllirirn, nonuull.)

Specics 115. (Mus. Cuming.)

Columbella Dimisuta. Col. testâ ovatä, utrinque atteunat $\vec{u}$, allidi, sparsim fusco-punctatâ, fasciä nigricante ad basin, superficie ormino densè valdè cancellatâ : aperturî parvâ, labro latè varicoso, superuè emarginuto.

The Mintte Columbella. Shell ovate, attenuated at each end, whitish. sparingly brown-dotted, with a blackish band at the base, surface closely strongly cancellated threrghout; aperture small, lip broadly varicose, notched at the upper part.

C. B. ADAss, Cat. Shells of Panama, p. 95.

IIab. Panama; C. B. Adams.

A small, strongly marked species, rudely cancellated throughout, with a characteristic dark band at the extreuc base of the shell. 


\section{COLUMBELLA.-Plate XX.}

Species 116. (Mus. Cumin:-)

('olvmbella pulchrior. Col. testú ovatú, tenuiculâ, Irvigatâ, subpellucido-albá, maculis punctisque aquidistantibus purpureo-fnscis ornatâ, anfructibus declivironvexis; aperturấ ovatá, lnbro teniculo, supernè submarginato.

The beautiful Columberls. Shell ovate, rather thin, smooth, subpellucid-white, ornamented with purplebrown blotches and equidistant dots, whorls slopingly convex; aperture ovate, lip rather thin, slightly notched at the upper part.

C. B. Adaus, Cat. Shells of Panama, p. 9.

Hab. Panama (under stones, at low-water mark);

C. B. Adams.

Rather an abnormal form of Columbella, finely dotted and blotehed with chocolate-brown, the colour being rather gathercd and filleted at the sutures. The dots are mon ninute than is represented in the accompanying figure.

Species 117. (Mlus. Cuming.)

C'olumbella monilifera. Col. testá oblongo-acuminata solidhâ, undique valdè decussutim costnt $\hat{a}$, albâ, mn 'xlis subquadratis brunneis bifasciatim cineta ; aperturî́ sub angust $\vec{a}$, intus denticulatit.

The Necklace Columbelda. Shell oblong-acumuated, solid, strongly decussately ribbed throughout, white. encircled with two bands of somewhat square brows spots; aperture rather narrow, denticulated withum. sowerby, Pro. Zool. Soc. 1sit, p. 53.

Hab. West Indies.

The granules formed at the points of dccussation of the ribs have a delicate pearly appearance. 


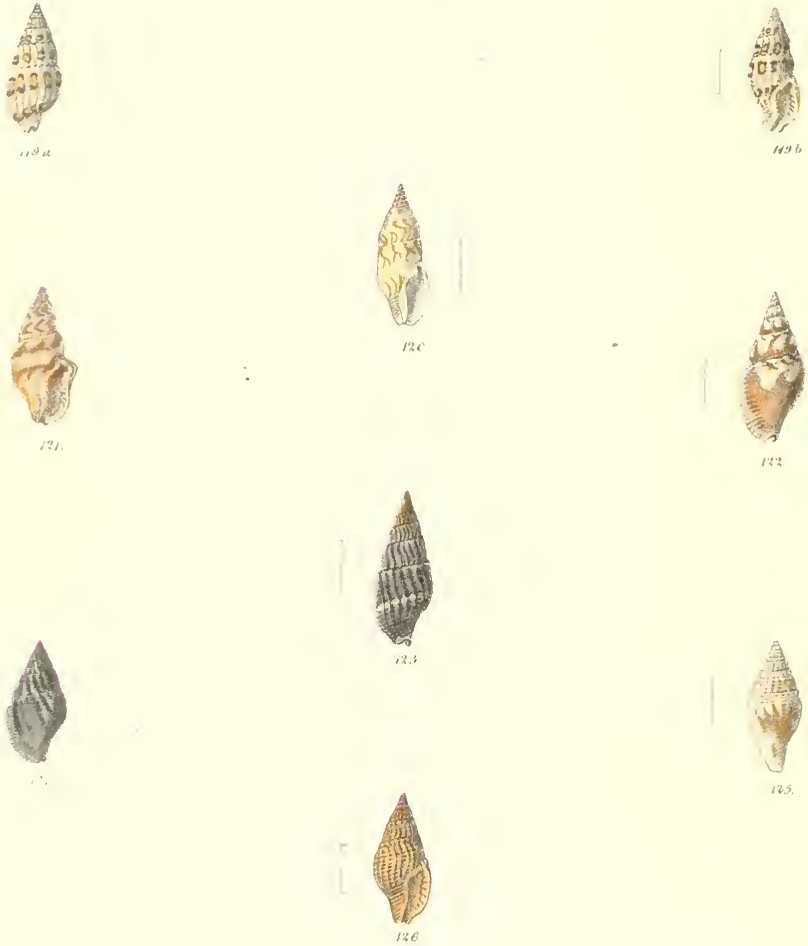


\section{O L U II B E L L A.}

\section{PIATE XXI.}

Species 119. (Mus. Cuming.)

Columbella cfirealis. Col. testâ pyramidali-oblongá, albidlü, nitente, line'is tenuibus aurantiis longitudinaliter undatis eleganter pictâ, anfractibus subrotundatis, superni tuberculato-costatis; aperturâa parvâ, columella tortuosä.

The corn Columbelia. Shell prramidally oblong, whitish, shining, elegantly painted with delieate longitudiually waved orange lines, whorls somewhat rounded, tubercularly ribbed at the upper part ; aperture small, columella twisted.

Menee, MS. Mus. Cuming.

$\mathrm{Hab}$ -

Chicfly charaeterized by the tubcrcularly ribbed sculpture of the whorls beneath the sutures, and by the painting of light longitudinally waved orange liues.

Spccies 119. (Fig. $a, b$, Mus, Coming.)

Columbelia catenata. Col. testâ oblongâa, crassâ, pallidâ, maculis lineisque aurantio-castaneis tessellatis bifasciutim marmoratâ, spirâ subrcuninutâ, anfractibus longitudinaliter fortiter deysì costatis, ud basin strictis; aperturâ parvinsculâa, utrinque denticulatâ, labro superne emarginato.

The chamed Colvmbella. Shell oblong, thick, pale, marbled with two bands of tessellated orange-brown bands and lines, spire rather acuminated, whorls longitudinally strongly elosely ribbed, contracted at the base; aperture rather small, denticulated on each side, lip notched at the upper part.

Sotverby, Pro. Zool. Soc. 1844, p. 52.

Columbella costulata, C. B. Adams.

Hab. Jamaica.

A strongly ribbed shell, encircled with two eharacteristic orange-brown bands, blotched on the alternate ribs.

Species 120. (Mus. Cuming.)

Colombella lactea. Col. testâ ovatâ vel oblongo-cylindraceâ, tenui, pellucidâ, nitente, aurantio pallidissimè tinctá et flammulatâ, apice roseo; aperturâ brevi, labro subincrassato, supernè emarginato, vix denticulato.

The MiLky Columbelia. Shell ovate or obloug-eylindrical, thiu, transparent, shining, very faintly tinged and flamed with orange, apex pink; uperture short, lip rather thiekcned, notched at the upper part, searcely denticulated.

Hab. Gulf of California; Mr. Babb, R.N.

So transparent that the eolumella may be seen throughout, from its eommencement within the apex to the base.

Species 121. (Mus. Cuming.)

Columbella carisata. Col. testâ pyramidali-ovatá, fulvâ, fasciis duabus castaneis albifloccatis cirgulatá, anfractibus convexis, ultino versus aperturam conspicuè carinato; aperturâ subquadratâ, livido-violace $\vec{a}$, denticnuat $\hat{a}$, effusû, supernè sinuatâ.

THE GEELEn Columbela. Shell pramidally orate, fulvous, encircled with two white-flocked elestnut bands, whorls convex, the last eonspienonsly keeled towards the aperture; aperture somewhat square, lividviolet, denticulated, effused, sinuated at the npper part.

Hrnds, Moll. Toy. Sulphur, p. 39. pl. 10. f. 15, 16.

Mab. Bodegas and Sun Diego, California (at seren fathoms depth); Ilinds.

The keel which distinguishes this species being at the back of the last whorl, is not seen in the accompanying figure, liut is indicated by the sinus of the aperture.

\section{Species 122. (Mus. Cuming.)}

Coldmbella Santa-Barbarensis, Col. testá subfusifurmi-oblongâ, ventricosinsculâ, pallidè fulvo-olizaceá, infra suluras albimacutatâ, spirá acutâ, anfractibus convexis, spiraliter lineari-sulcatis ; aperturấ subquadratâ, fauce violaceâ, labro supernè emarginato.

The Santa Barbara Columbella. Shell somewhat fusiformly oblong, rather ventricose, pale fulvous-olive, white-spotted below the sutures, spire sharp, whorls eonvex, spirally striately grooved; aperture somewhat square, intcrior violet, lip notched at the upper part. Carpenter, Pro. Zool. Soc. 1856, p. $20 \mathrm{~S}$.

Hab. Santa Barbara, Upper Cahifornia.

The surface of this well-marked species is not merely faintly striated, as described by irr. Carpenter, but distinctly linearly grooved, unusnally so for a Columbella.

November, 1858 , 
Species 123. (Mus. Cuming.)

Columbella SPADices. Col. testâ cylindraceo-oblongâ, apice acuminatâ, castaneo-nigrâ, zonulâa albidâ medio cingulalâ, basi albidâ, anfractilus longitudinaliter densè costatis, costis subgranosis ; aperturâ parvâ, subdenticulatâ.

The bay Columbelda. Shell cylindrically oblong, acuminated at the anex, chestnut-black, encircled round the middle with a small whitish zone, base whitish, whorls longitudinally closely ribbed, ribs slightly grained; aperture small, faintly denticulated.

Philippi, MS. Mus. Cuming.

Hab. Mazatlan.

A shining chestnut-black shell, discoloured specimens of which are probably of a light red or bay colour, closely ribbed throughout, encircled round the middle with a narrow white zone.

\section{Species 124. (Mus. Cuming.)}

Columbelia atramentaria. Col. testâ acuminato-ovatâ, crassâ, medio ventricosâ, coruleo-nigrấ, sparsim albipunctatâ, spiraliter densè sulcato-striatâ, longitudinaliter plicato-costatâ, costis infernè exanidis; aperturâ ovatâ, denticulatâ, fauce intensè violaceâ, labro supernè subemarginato.

The IN Ky Columbella. Shell acuminately ovate, thick, ventricose iu the middle, blue-black, sparsely whitedotted, spirally densely groove-striated, longitudinally plicately ribbed, ribs fading towards the lower part; aperture ovate, denticulated, interior deep-violet, lip slightly notclied at the upper part.

Sowerby, Pro. Zool. Soc. 184t, p. $5 \mathrm{I}$.

Hab. Chatham Island, Galapagos.

A solid, partially ribbed, blue-black shell, obscurely white-dotted towards the base, with the aperture deepviolet.

\section{Spccies 125. (Mus. Cuming.)}

Coldmbella lachryma. Col. testâ abbreviato-fusiformi, utrinque atienuatâ, niveâ, aurantio-fusco pallidè tinctâ, superficie omnino cancellutâ, spira $\vec{a}$ conicâ, densè gra-

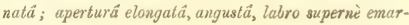
ginato.

The tear Colombelia. Shell shortly fusiform, attenuated at each extremity, snow-white, faintly stained with orange-brown, surface entirely cancellatcd, spire conical, densely grained; aperture elongated, narrow, lip notched at the upper part.

Gaskoin, MS. Mus. Cuming.

Hab. - ?

Of a distinct typical form, unusually attenuated towards the base, while the spire is largely conical.

Species 126. (Mus. Cuming.)

Columbella cancellata. Col. testâa ovatâ, medio ventricosiusculâ, aurantio-carneâ, apice basique rosaceis, superficie omnino cancellatâ, infra suturas granulatâ; aperturâ brexi, intus denticulatâ, labro supernè subemarginato.

The cancellated Colombella. Shell ovate, rather ventricose iu the middle, orange-flesh, apex and base pink, surface entirely cancellated, grauulated below the sutures; aperture short, denticulated within, lip slightly notched at the upper part.

Gaskorn, Pro. Zool. Soc. 1851, p. 6.

Hab. West Indies.

Readily distinguished by its solid cancellated sculpturc and soft orauge-pink tone of colouring. 




\section{O L U B E L L A.}

\section{PLATE XXII.}

Species 127. (Mus. Cuming.)

The shell here figured proves to be a variety of C. Hindsii, Gaskoiu.

Species 128. (Fig. 128 and 129, Mus. Cuming.)

Columbella pygmea. Col. testâ acuminato-ovatâ, albida, nitente, maculis intensè castaneis infra suturas interruptè pictü, anfractitus supernè obliquè costatis; aperturâ parviuscula $\vec{a}$, labro incrassato, supernè subemarginato.

The pigmy Columbella. Shell acuminately ovate, whitisb, shining, iuterruptedly painted beneath the sutures with dark-ehestuut spots, whorls obliquely ribbed round the upper part; aperture rather small, lip thickened, slightly notehed at the upper part.

Sowerby, Pro. Zool. Soc, 1832, p. 119. Columbella tceniata, Philippi.

Hab. St. Elena, West Columbia (in sandy mud, at the depth of ten fathoms); ('uming.

A pearly-ribbed shell, distinguished by a very characteristic band, next the sutures, of dark-chestnut spots.

\section{Species 130. (Mus. Cuming.)}

Columberla venusta. Col. testâ ovatâ, albâa, lineis castaneis rquidistantibus undique cingulatâ, anfractibus subrolunlatis, infira suturas tuberculato-costatis; aperturâ parvä, labro supernè emarginato, intus denticulato.

The handsome Columbella. Shell ovate, white, encireled throughout with equidistant chestnut lines, whorls somewhat rounded, tulercularly ribbed beneath the sutures; aperture sinall, lip notched at the upper part, denticulated within.

Columbella teniata, Philippi.

Hab.

A rather solid shell, well marked by its tubercularly ribbed sculpture and paiuting of parallel circular chestnut lines.

Species 131. (Mus. Cuming.)

Columbella MEsta, Col. testẩ elongatâ, fulvo-nigri- cante, anfractiluts declivi-convexis, obliquè costatis, interstitiis cancellatis, costis aufractís ultimi evanidis; aperturâ parvâ, labro varicoso, supernè emarginato.

The sad Columbella. Shell elongated, fulrous-black, whorls slantingly convex, obliquely ribbed, interstices cancellated, ribs of the last whorl disappearing; aperture small, lip varicosc, notehed at the upper part.

C. B. Adans, Cat. Shells of Panama, p. 94.

Hab. Panama (about sticks and stones, in a grove of trces, a little above balf-tide level); C. B. Arlams.

A dark but rather delicately toned fulvous-black shell, strongly cancellated on the upper whorls, whilst towards the lower part of the last whorls only the transverse stria are prescut.

Species 132. (Mus. Cuming.)

Columbella sulcosa. Col. testâ acuminalo-cylindraceâ, plumbeo-nigrâ, longitudinaliter obliquè costat $\vec{a}$, costis pallidis, infra suturas granulatis, interstitiis densè cancellatis; aperturâ parvâ, labro supernè emarginato, intus denticulato.

The grooved Columbella. Shell acuminately cylindrical, leaden-black, longitudinally obliquely ribbed, ribs pale, granulated beneath the sutures, interstices densely cancellated; aperture small, lip notched at the upper part, denticulated within.

Sowerby, Pro. Zool. Soc. 1s32, p. 118.

Hab. Annaa aud Lord Hood's islands; Cuming.

Of a peculiar dult leaden-black colour, with the ribs of a lighter hue, ranging across the sbell in an oblique flexuous direction.

Species 133. (MLus. Cuming.)

Columbelia вассата. Col. testâovatâ, lavigatâ, nitente, albidâ, auruntio-brunneo fasciatâ et lessellatim marmoratia ; aperturâ subquadratâ, labro supernè emarginato, iutus denticulato.

The pearl-set Colunbella. Shell ovate, smootb, shining, whitish, banded and tessellately mottled with orange-brown; aperture rather square, lip notched at the upper part, denticulated within.

Gaskorn, Pro. Zool. Soc. 1851, p. 9.

November, 1858. 


\section{COLUMBELLA.PLATE XXII.}

Hab.

The network painting of this species has a characteristic pearl-like appearance.

\section{Species 134. (Mus. Cuming.)}

Columbella tesseliata. Col. testâ ovatâ, utrinque attenuatâ, nigricante-olivaceâ, maculis parvis subquadratis albis promiscuè tessellatâ, spirâ acutâ, anfractibus spiraliter lineari-sulcatis, longitudinaliter costatis, costis prope labrum evanidis; aperturâ parviuscula, labro supernè emarginato.

The tessellated Colombella. Shell ovate, attennated at each end, blackish-olive, promiscuously tessellated with small, somewhat square white spots, spire sharp, whorls spirally linearly grooved, longitudinally ribbed, ribs disappearing near the lip; aperture rather small, lip notched at the upper part.

C. B. ADAMS.

Hab. - ?

Very closely allied to C. atramentaria.

\section{Species 135. MIus. Cuming.)}

Colombella GouldiI. Col. testâ gracili, subfusiformi, livido-fuscâ, nitente, spirấ acuminatâ, anfractibus declivi-convexis, densè lirato-costatis, anfractu ultimo medio levigato, ad basin spiraliter sulcato; aperturâ parvâ, angustâ, labro varicoso, intus denticulato.
Gould's Coldmbella. Shell slender, somewhat fusiform, livid-brown, shining, spire acuminated, whorls slopingly convex, closcly ridge-ribbed, last whorl smooth in the middle, spirally grooved at the base; aperture small, narrow, lip varicose, denticulated within.

Agassiz, MS. Mus. Cuming.

Hab. New York Harbour.

Of a peculiar vellowish-livid-brown colour, shining, and sharply slenderly ribbed, the ribs gradually disappearing on the last whorl.

\section{Species 136. (Mus. Cuming.)}

Columbella dichroa. Col. testâ subpyramidali, lavigat $\hat{u}$, politâ, albâ, castaneo-aurantio latè longitudinaliter reticulato-strigatấ; aperturấ parvâ, latiusculâ, labro vix denticulato.

The two-coloured Columbella. Shell subpyramidal, smooth, polished, white, longitudinally broadly netstriped with chestnut-orange; aperture small, rather broad, lip scarcely denticulated.

Sowerby, Pro. Zool. Soc. 1844, p. 50.

$H a b$. Island of St. Vincent, West Indies; Guilding.

Distinguished by a marked style of colouring, consisting of broad stripes of ehestnut-orange network descending conspicuously from the apex. 



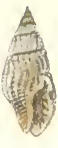

$1,37$.
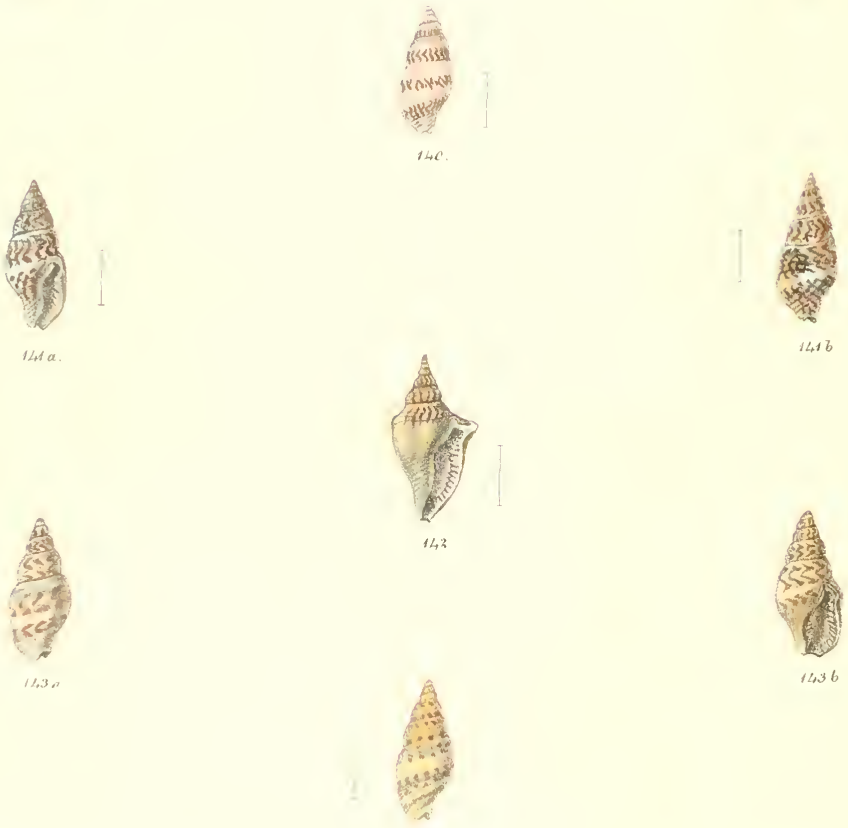


\section{COL U M B E L L A.}

\section{Plate XXIII.}

Sprctes 137. (Mus, ('urring.)

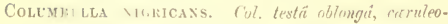
migricaute, n, iere acuminat $\hat{t}$, superficie omnino cancel-

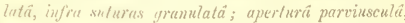

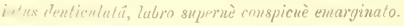

THe bhackism Coljmbela. Shell oblong, blue-black, acumiluated at the apex, surface cutirely cancellated, yraunated beneath the sutures; aprerturc ratber suall, denticulated within, lip conspicuously notehed.

Sumerpy. Pro. Zoul. soe. 1844 , p. 52.

Ifat. Gideipargos Islands.

I cry sinilar in form and sculpture to Mr. Guskoin's C: rencellistu, from the West Indies.

Species 138. (Mus. Cuming.)

Colombelia albisondulosa. Col. testá oblomgo-oralata, palliele cinerhî, punrtis lirmeneis olliquè quadratis biseriulim trifusciulâ, spirit acuminatâ, "unfractibus supiemi plicato-madulosis, nudulis opaco-albis; aperturâ oblonyâ, labro incrassato, intus deryticulato.

THE WHTE-NODUled Columbell.. Shell oblong-ovate, pale-ash, encircled with three bands of obliquely squarc brown spots in double rows, spire acuminated, whorls plicately noduled round the upper part, nodules oprayup-white; aperture oblong, lip thickened, denticulated withiu.

Gaskorn, Pro. Zool. Soc. 1851, p. 3.

Hak, -

Prettily banded with thrce pairs of rows of obliquely square chestnut dots, the plicatch nodules of the whorls below the suture being flaked with opaque-wbite.

\section{Species 139. (Mus. Cuming.)}

Columbella Broneripir. Col. testâ ovatâ, hrevi, nitente, albida, aurantio-castaneo variè reticulatâ; aperturấ oblongâ, latinsculâ, labro subincrassato, supernè latè emarginato, intus denticulato.

Broverip's CoLvMrell. Shell ovate, smooth, shining, whitish, variously reticulated with orange-chestunt; aperture oblong, rather broad, lip somewlat thickencd, broadly notehed at the upper part, denticulated within.

Somerbi, Pro. Zool. Soc. 18tt, p. 53.

Hab. Alboran Island.
A smooth shimng spccies of simple character, tessel tated and interlaced with delicatc orauge-chestnut lincs.

Species 140. (Mus. Cuming.)

Columbella t.eNitita. Col, testâ fusiformi-ovatâ, rufes-

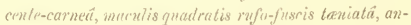
frarlibus pluno-concexis, lorvibus, nitentibus; aperturấ parvi, lube iacrassato, superne sinuato.

The billeten Colombelid. Shell fusiform, ovate, reddish flesh-colour, filleted with square red-l)rown spots, whoris flatly convex, sluonth, shining; ilperture smalt, lip thickened, siuuated at the upper part. Aduss and lieeve, Moll. Voy. Samarang, p. 34. pl. 11. f. 19 .

Ha's. Borneo.

In the typical specimen of this species, figured in the Nollusea of the Voyage of the Simarang, there are two tillets of red-brown spots on each whorl, the tower of which is concealed in all but the last whorl.

Species 141. (Mus. Cuming.)

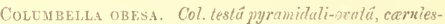
cente-albî, aurantiv-fusco tessellatu-marmoratâ, faseiâ albi centrale, anfractibus plano-ronvexis, plicato-costellatis, costellis in anfractu vltimo evanidis; aperturât oblongit, labro superici emaryinato, intus denticutato.

Tie stout Columbella. Sholl pyramidally ovate, bluish-wlite, tessellately marbled with orange-brown, lcaving a central white band, whorls flatly convex, plicately finely ribbed, ribs disappearing in the last whorl; aperture oblong, lip notched at the upper part, denticulated within.

Buccinum obessm, C. B. Adams, Pro. Nat. Hist. Soc. Boston, $18+5$.

Hab. — ?

Mottled with an irregular network of orange-bruwn, leaving a broken spiral white band in the middle.

Species 142. (Mus. Cuming.)

Coltmbella uncinata. Col. lestá trigono-oratê, Strombiformi, fulvescente-olivacetü, punctis pallidis lentiginosî, supernè maculis allis lineis rufo-brumeis interruplis cingulatä, spirâ brexiusculä, acutî, anfractibus primis supernè nodulosis, coler'is supernè angulotis et

November, 1858. 


\section{COLUMbella.-Plate XXiH.}

1 neari-sulcutis; aperturâ longitudinali, amplâ, fauce violuceâ, columellấ excavalâ, basin versus granulutâ; luhro supernè in canalem uncinatum porrecto, intus undique denticulato.

TIze hoокеd Colvmbella. Shell triangularly ovatc, Strombus-shaped, fulvous-olive, freckled with pale dots, encircled round the upper part with white spots, interrupted with red-brown lines, spire rather short, sharp, the first whorls noduled at the upper part, the rest angled and linearly grooved at the upper part; aperture longitudinal, large, interior violet; columella excavated, granulated towards the base, lip extended at the upper part into a hooked eanal, denticulated within throughout.

Sow f.rbY, Pro. Zool. Soc. 1832, p. 114.

Hal. Island of Muerte, and Bay of Guayaquil ; Cummg.

A very characteristic species, of the same peculiar type a C. harpiformis.

$$
\text { Speeies 143. (Fig. } a \text {, "), Mus, Cuming.) }
$$

Colimbella IIindsi. Col. testá oblongo-ovatä, spiratiter striat $\hat{a}$, rufescente-cinere $\hat{a}$, maculis saturatis obscurè teniuta, anfractibus supernè tumidiusculis; aperturâ subqualratî, intus denticulatâ, supra et infra tfingsit.

Haxis coldmbelLA. Shell oblong-ovate, spirally striated, reddish-ash, obscurely filleted with dark spots, whorls rather swollen at the upper part; aperture somewhat square, denticulated within, effused above and below.

Gaskoin, Pro. Zool. Soc. 1851.

IIab.

A dull reddisb-ash shell of rather light growth, obscurcly filleted with spots of a darker tone.

$$
\text { species 144. (Mus. Cuming.) }
$$

Columbella dermestordes. Col. testâ abonga-pyjamidali, lavi, nitente, fulvescente-rufä, fasciis marulisque albicantibus cingulatâ, anfructibus subplanulutis; aperturâ parviusculâ, labro simplici, vix emarginalo. intus denticulato.

The leather-worm Columella. Shell oblong, pyramidal, smooth, shining, fulvous-red, eneireled with whitish bands and spots, whorls rather fat; aperture rather small, lip simple, scarecly emarginated, dentieulated within.

Sowerix, Thesaurus Conch. vol. i. p. 131. pl. 39. f. 123. Buccinum dermesloides, Kiener.

II $a$. West Indies.

Mottled and banded with pale fulvous-red and white, beneath a shining enamelled surface. 


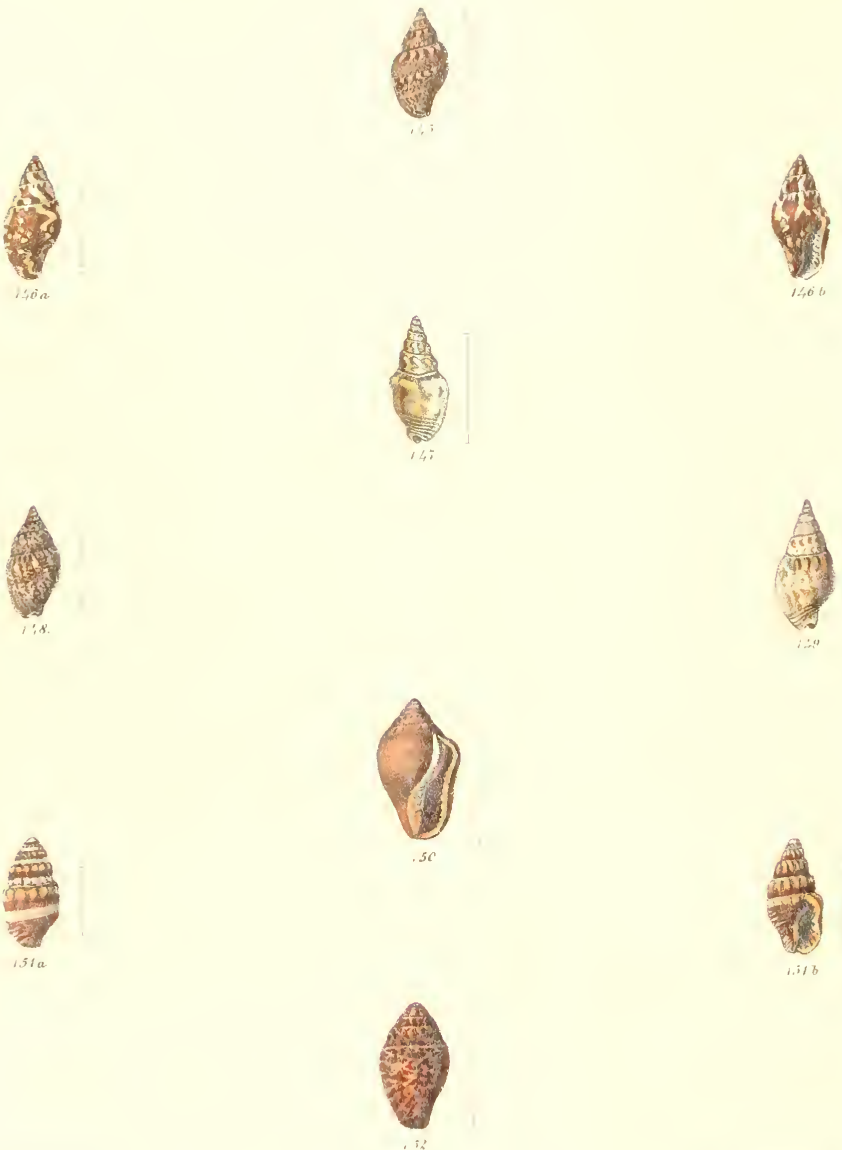


\section{O L U M B L L $A$.}

\section{Plate XIIV.}

Speces 145. (Mus. Cuming.)

Coltmbella ala-pendicis. Col, testî subfusiformi-turbinatâ, trnuiculâ, spirâ acuminatâ, anfiractibus convexis, lacribus, ultimo infuto; albilâ, maculis rufofuscis bifascint $\hat{n}$, fasciarmm interstitizs densè lentiginosâ;; columellât subescaratâ, albâ, ad basin uniplicatâ, aperturi ovatâ, luliro simplici.

The partridge-Wing Cottubelia. Shell fusiformly turbinated, rather thin, spire acuminated, whorls couvex, smooth, last whorl inflated; whitish, encircled with two bands of red-brown spots, interstices between the bands densely freckled; columella rather excavated, white, one-plaited at the base, aperture ovate, lip simple.

Hab. - ?

In aberrant form of the genus, of light inflated growth, with no indication of any internal denticles.

\section{Species 146 . (Nus, Cuming.)}

('olembella picta. Col, trata ovati, crassiuscula, spirâ elatâ, sububtusâ, anfractibus levibus, plano-declivibus, deinde subyibhusis; castaneo-oliracrat, maculis albis reticulatè flammatń; aperturâ paroinscutâ, labro incrussato, intus deuticulato.

Ihe painted Columbeld. Shell ovate, rather thick, spire rather obtuse, whorls smooth, flatly slanting, thin, rather gibbous; chestnut-olive, retieulately flaucd with white spots: aperture ratber small, lip thickened, denticulated withiu.

Hab.

A stunt, hrightly painted shell, marked with a few irrezular flames of white network.

\section{species 147. ( II sus. ('uming.)}

Columbella pumilio. Cul. testâ abbreriato-fusiformi, crassâ, subgibbosâ, spirât turritâ, anfractibus supernè rude angulalis et nodatis, nodis in anfractu ultimo tumidis, irregularibus; albidâ, aurantio-fusco pallide tinctâ; aperturấ angnstâ, Iabro demsè varicoso, intus obtusè denticulato.

Tire DWARF Colcmbella. Shell shortly fusiform, thick, rather gibbous, spire turreted, whorls rudely angled and noduled, nodules on the last whorl swollen, irre. gular; whitish, faintly tinged with orange-brown: aperture narrow, lip thickly varicose, obtusely denticulated within.

Hab. Cumana, Tenezuela; Dyson.

Very closely allied to C. recurva, but of shorter growth. more bumped, and more irregularly noduled; and from its habitat there is also reason to believe it to be distinct.

Species 148. (Mus. Cuming.)

Colcmbelia Livescens. Col. testâ ovato-turbinatâ, solidiusculâ, spirầ acutâ, rersus apicum tenuicostatâ, anfractibus subobesis, concexis, hevibus; anrantiofuscâ nitente. licerscente, punctis albis narmarata ; coInmellâ luhintâ, "perturâ parriusculâ purpurascente. fabro incrassuto, medio subcoarctuto, intus denticulato.

The bluisfi Coldmbella. Shell ovately turbinated, rather solid, spire sharp, finely ribbed towards the apex, whorls rather stout, convex, smooth; orangebrown, shining, bluish, marbled with white dots: columella lipped, aperture rather small, purplish, lip thickened, slightly contracted in the middle, denticulated within.

Hab. Island of Luzon, Philippines; Cuming.

A stout, shining species, with a sharp spire finely ribbel near the apex. The colour is a mottled pattern of orangebrown, livid bere and there with bluish-purple.

\section{Species 149. (Mus. C'uming.)}

Colcmbella solidula. Col. testä subfinsiformi, crussä, vitente, spiri acutâ, anfractibus plono-declicibus, uttimo dorso juxta suturam plicato-tuberculato; albui, inaculis perpancis aurantiis et reticula variegat $\vec{a}$. aperturấ subangustâ, labro incrassato, intus denticulato.

The solid Columbella. Shell somewhat fusiform, thick, shining, spire sharp, whorls flatly slanting, the last plicately tubcreled at the back next the suthire: white, variegated with a few orange-brown spots anil with is nctwork; apcrture rather narrow, lip thickened, denticulated within.

Hab.

The specinen here figured is ratber faintly colourcel, and in a manner indicative of it being sometimes darker stained. 


\section{COLl MBELLA.-Plate XYIY.}

Spccies 150. (Mus. Cuming.)

ColUMBella luteola. Col. testât subtriyono-oratâ, tumidâ, spirấ brevi; luteolâ, epidermide levigatá indatâ, rufo ad suturas panctatâ; aperturâa oblongâ, labro tenuiculo.

The yellowisu Columbella. Shell somewhat triangularly ovate, swollen, spire short; yellowish, covered with a smooth epidermis, dotted with red at the sutures; aperture oblong, lip rather thin.

KiENer, Icon. coquilles vivantes, p. 12. pl. 4. f. 2.

llab. —?

Not baving a specimen of $C$. luteola without its epidermis, it is impossible to say what may be the pattern of colouring of the species.

Species 151. (Mus, Cuming.)

Columbella valida. Col. testâ subgloboso-ovatát, solidâ, undique validè costatâ, spirâ subobtusâ ; fuscescenterufä, medio albi-fasciatâ, ad basin albi-punctatâ, aperturâ parvể, labro intus denticulato.

The strong Columbella. Shell somewhat globosely ovate, solid, everywhere strongly ribbed, spire rather obtuse; brownish-red, white-banded round the nut dle, white-dotted at the base; aperture small, lip denticulated within

Hab. Guatemala.

This species very much rcsembles the sliort globose Mitres in appearance.

\section{Species 152. (Mus, Cuming.)}

Columbella zelina Col. testâ cylindraceo-obtongä, medio gibbosiusculâ, solidâ, spir $\hat{\imath} \vec{b}$ revi, oblusâ, tavigat $\hat{a} ;$ rufo-castune $\hat{a}$, lineis brevibus angulato-undatis obliquè variè scalptâ; aperturâa perangustâ, labro intus denticulato.

The rival Columbelta. Shell cylindrically oblong, rather gibbous in the middle, solid, spire short, obtuse, smooth; rcddish-chestnut, obliquely variously scratched with short angularly waved liucs; aperture very narrow, lip denticulated within.

Duclos, Monog. pl. 4. f. 5, 6 .

Hab.

A very characteristic and rarc species, at once recognizable by its singular peculiarity of marking. 



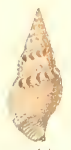

(iㅣ)
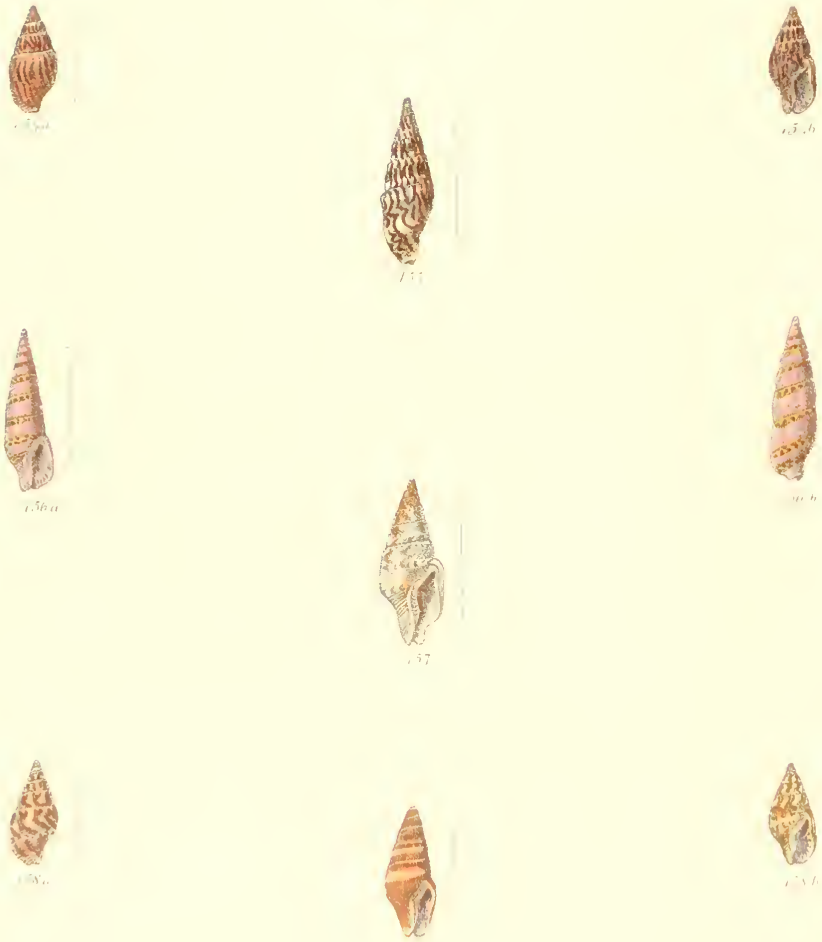


\section{O L U II B E L L A.}

\section{Plate XVT.}

\section{Sivoue 15: (Mus. Cuming.}

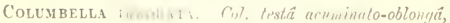

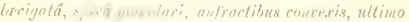

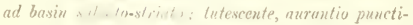
culutä, mn whis nime maroutio-mmbratis infra sufuras cinyululi: uprefturi uretai, labro intus denticulato.

THE BEDEWED CULI MBELIA. Shell acuminately oblong, smooth spire acicular, whorls convex, the last groovestriated at the base: yellowish, fiuely dotted with orange, and encircled beneath the sutures with orangeshaded snow-white spots; aperture ovate, lip denticulated within.

$H a b$ Australia.

Distinguished by its acieular form and very peculiar tnarkııg.

species 15t. (Fig, a, b, Mus. Cuming.)

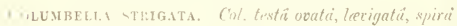
mediorri, anfuactibus conceris; purpurascentr-einerea, strigis anyustis sanguineo-castaneis longitudinaliter premicuè pictä; apritura parviusculä, Inbro simplici.

lie streaked Colcmbelia. Shell ovate, smooth, spire middling. whorls convex; purple-ash, lougitudinally promiscuously painted with blood-stained chestuut streaks; aperture rather small, lip simple.

Hab.

A smooth shell, painter with longitudinal streaks of a juruliar irregularly smeilred character.

\section{Species 155. (Mus. Cuming.)}

Coltabella flata. Col. testâ elongatá, mbfusiformi, solidie, spirâ produrtâ, anfractibus subangustis, longitudina iter plicato-costatis; albâ, castaneo variè undato-lineatî; aperturi parvä, columellâ temue labiatu.

The stitely Columbelda. Shell elongated, somewhat fusiform, solid, spire produced, whorls rather narrow, longitudiually plicately ribhed; white, variously wave-lineated with chestnnt; aperture small, columolla thiuly lipped.

$\mathrm{Hab}$. —?

A narrow solid Mitre-like shell, conspicuously painted with longitudinally waved chestnut lues upon a white grouud.

Sppecies 156. (Fig. $a, b$, Mus. Cuming.)

Columbella ('emingin. Col. lestâ elongatá, subcylindraceit, ad basin recurvê, syiri valdè productî, prope apicem minutè custatâ, anfructibus angustis, planoconvexis, spirniter sulcato-striatis; purpurascenteviolaceâ, bifasciatim rufipunctutî́; uperturâ parrâ, brect, supernè emarginatâ, labro subincrassato, intus denticuluto.

Cthixg's Conjmelda. Shell elongated, subcylindrical, recurved at the base, spire very produced, minutel. ribbed near the apes, whorls narrow, flatly convex, spirally groove-striated; purple-violet, encircled witl two bands of red dots; aperture smnll, short, notehed at the upper part, lip rather thickened, deuticulated. Hab. Islaud of Capul, Philippines; Cuming.

A very intercsting violet-coloured species, with the spure. euriously produced.

\section{Species 157. (Mus. Cuming.)}

Columbela bictlus. Col. testâ fusiformi, solidä, ad basin contractâ et recurtui, spira acuminatâ, suturis subcanaliculatis, anfractibus plano-declivibus; albidâ, aurantio vittatî et maculatí ; aperturá parvấ, columbell â labiatâ.

The clo в Columbella. Shell fusiform, solid, contracted and recurved at the base, spire acumiuated, with the sutures slightly channelled, whorls flatly slanting: whitish, filleted and spotted with orange; aperture small, columella lipped.

Hab. China Seas.

A solid shell of good typical character, coutracted aut recurved at the base.

Species 15 S. (Fig. $a, b$, Mus. Cuming.)

Columbella avena. Col.testä ovatâ, spirâ breviusculu, acuminati, anfractilus contexis, lovigatis; albidi, aurantio nitidè reticulato-maculatá et striyatä; aper-

Februar. 1859 . 


\section{COLUMBELL1.-Plate XXV.}

turâ parviusculä, supernè subemarginatâ, columellâ excavatâ, labro intus denticulato.

TuE oat Columbelda. Shell ovate, spire rather short, acuminated, whorls convex, smooth; whitish, neatly reticulately blotched and streaked with orange; aperture rather small, slightly notched at the upper part, columella excavated, lip denticulated within.

Hab. Buffalo, Cape Colony.

A pretty brightly-painted shell, the pattern being developed in orange network. This and the remaining species of the Plate are enlarged, it may be observed, about a third of their natural dimensions.
Species 159. (Mus. Cuming.)

Colembella impolita. Col. testâ elongato-turritâ, spirá versus apicem plicato-costatâ, anfractibus plano-convexis; fulvescente-castaneâ, fasciâ albâ cingulatâ : aperturâ parvâ, labro intus denticulato.

The unpolished Columbelia. Shell elongately turreted, spire plicately ribbed towards the apex, whorls flatly convex; fulvous-chestnut, encircled with a white band; aperture small, lip denticulated within.

Sowerby, Thesaurus Conch. vol. i. p. 132. pl. 39. I. 127.

Hab. - ?

Only a worn specimen of this is known, but it is suticiently indicative of a distinct species. 


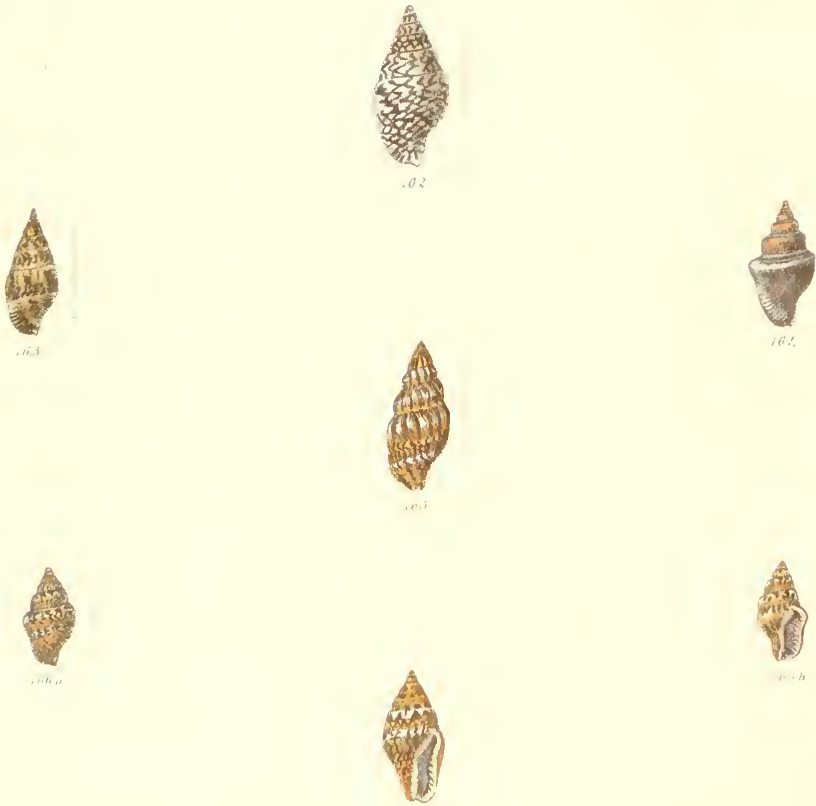


\section{O L U II B E L L A.}

\section{Plate XXIi.}

Sprow 160. (N11, Euming.)

Columbelia Flä at 1. Col. testi cylindraceo-ovat $\vec{a}$, in

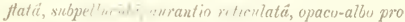
miscuè flocenti, syurá subobtusâ, anfractibus converis.

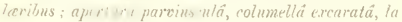
bro simplici.

The rlaked Columbela. Shell eylindrically ovate inflated, sulstransparent, reticulated with orange, promiscuously flaked with opaqne-white, spire rather ob. tuse, whorls convex, smooth; aperture rather small. columella exeavated, lip simple.

Hab. Buffalo, Cape Colouy.

An inflated, cylindrically ovate shell, of semitransparen substance, delicately reticulated with bright-orange, intes spersed promiseuously with flakes of opaque-white.

Species 161. (Fig. $a, b$, Mus. Cuming.)

'uLemBeli.a PERT'sa. Col. testâ subfuxifurmi-oratat solidinsculâ, undique spiraliter lineari-sulcatâ, suloi purtusis, latescente-al'sâ, castrneo peculiariter tessellatä, aufractibus supernè obtusè tumidis; aperturci subangustä, labro intus denliculato.

THE PRICKED COLUMBELLa. Shell somewhat fusiformly ovate, rather solid, spirally lincarly grooved througltout, groores pricked, yellowish-white, peculiarly tessellated with chestnut, whorls obtusely tumid round the upper part; uperture rather narrow, lip denticulated within.

Hab. Guatemala.

A rather solid shell, tessellately painted with chestnut in a manner quite characteristic.

\section{Speeies 162. (Mus. Cuming.)}

Columbella sagexa. Col. testâ fusiformi-ovatâ, levigatä, versus basin sulcriâ, albâ, fusco-nigro conspicuie reticulatâ, spirâ subobtusâ, anfractibus plano-convexis: aperturâ subungustâ, labro intus denticulato.

The fishinci-net Coltubella. Shell fusiformly ovate, smooth, grooved towards the base, white, conspicuously reticulated with browu-black, spire rather olytuse, whorls slightly convex; apcrture rather narrow, lip denticulated within.

Hab. Japan.
Allied to $C$. parlalina, but at a different form, strongly grooved towards the base. From C. Tyleri, peeuliar to Iustralia, it differs essentially in habitat.

Species 163. (Mus. Cuming.)

(jolumbella moltivoluta. Col. testâ acuminato-or $u$ tâ, longitudinaliter obscurè allicostatâ, lineis nigris Gifascinlim rariegatâ, spira attenuatĥ, anfractibus numerosis; aperturâ parviısculâ, columellâa contractú. sulcatâ, labro simplici.

The many-Whorled Columbella. Shell acuminately ovate, longitudinally obscurely white-ribbed, variegated with two bands of black lines, spire attenuated, whorls numerous; aperture rather small, columella contracted, grooved, hip simple.

$H a b, \ldots$

A sharply acuminated species, sculptured with opaquewhite ribs, which are almost obsolete.

\section{Species 164. (Mus. Cumiug.)}

Colombella collaris. Col. testâ ovatâ, levigatâa, livido-fusctit, anfractibus supernè tumido-productis, ad basin sulcatis; aperturä quadrato-avatâ, labro vix denticulato.

The collar Columbella. Shell ovate, smooth, lividbrown, whorls tumidly produced round the upper part, grooved at the base; aperture squarely ovate, lip scarcely toothed.

$H a b . \longrightarrow$ ?

Allied to $C$. varians, though characterized by a peenliarly produced swelling round the upper part of the whorls, whilst the shell is of a decided purple-livid colour throughout.

Species 165. (Mus. Cuming.)

Columbella Ca Lifornica. Col. testâ fusiformi-oblongâ, longitudinaliter lirato-rostatâ, albâ, lineis rufo-fuscis subtilissimè reticulatî, costis saturatioribus; aperturâ subangusta $\vec{a}$, labro vix dentimlato.

The Californian Columbella. Shell fusiformly oblong, longitudinally lirately ribbed, white, finely reticulated with red-brown lines, ribs dark; aperture rather narrow, lip scarcely denticulated.

April, 1859. 


\section{COLUMBELLA.-PLATE XXVI.}

IIab. California.

Somewhat allied to $C$. Terpsichore, but of a quite distinct style of painting.

\section{Specics 166. (Fig. $a, b$, Mus. Taylor.)}

Columbella sivosa. Col. testâ ozatâ, medio tumidâ, fulvescente, puntis castaneis bifasriat $\vec{a}$, interstitiis punctis opaco-albis lentiginosâ, spirâ breviusculâ, anfractibus convexis, supernè obtusè tumidis; aperturâ quadrato-oblongâ, labro intus denticulato.

The sNowy Columbella. Shell orate, tumid in the middle, yellowish, encircled with two bands of ches: nut dots, the interstices freckled with opaque-white dots, spire rather short, whorls couvex, obtusely swollen round the upper part; aperture squarely obloug, lip denticulated within.

Hab. Guatemala.

A beautifully paiuted species, allied to $C$. carans. freckled with chestnut network and snow-white dots.

Fig. 167. (Mus. Cuming.)

A very cbaracteristic orange-red variety of $C$. fabula described at Plate XV. Sp. 77. 


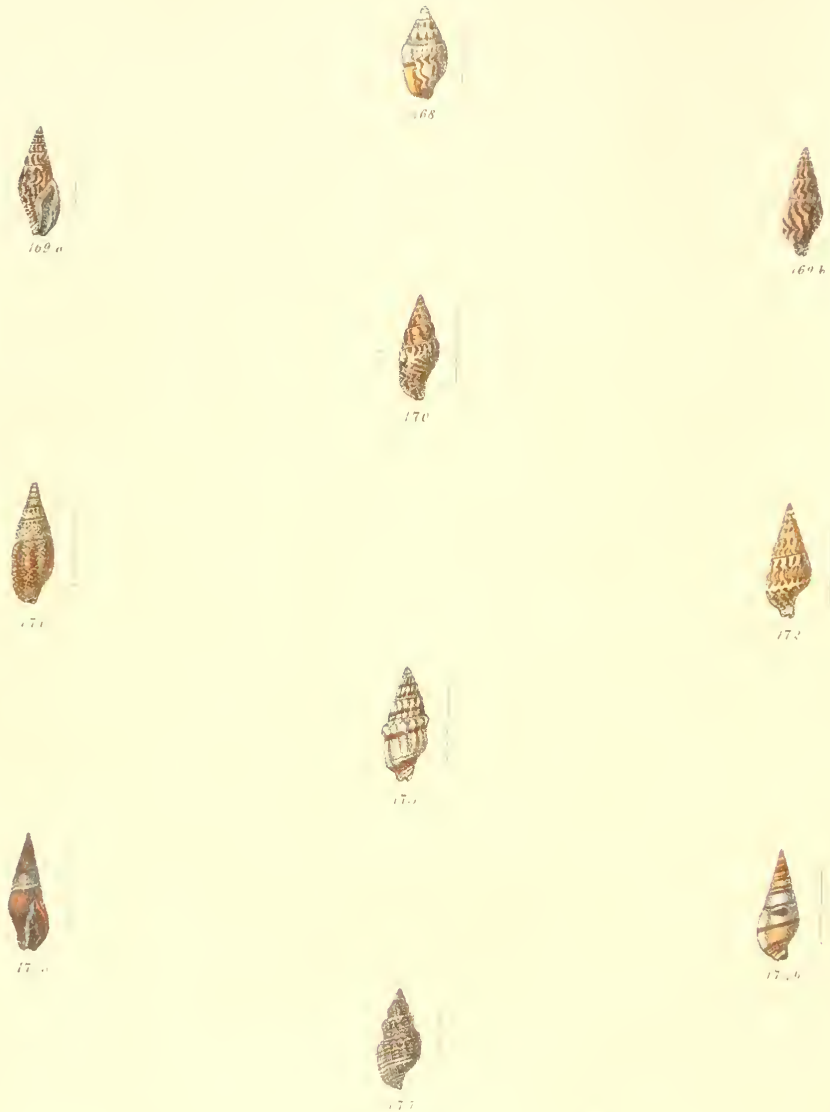


\section{O L L M B E L L A.}

\section{Pl.ite XXVII.}

Spreses 168. (Mus. ('umming.)

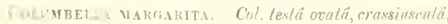
homignta, witente, sub lente punct is minutis aurantiofuscis tentignesa $\vec{x}$, interlum flucturlat, maculis opuco"bis jurta suturam cingulutü, spira obtusá; aperturá inyuxtî, tubro incrossuto, raricoso.

Tut Pfant Colvmbella shell ovate, rather thick, smooth, shiming, frcekled beneath the lens with very minute red-brown dots, sometimes waved, eucircled with opaque-white spots next the suture, spire obtusc; aperture narrow, lip thickened, varicose.

Hub. Sandwich Islauds

Extrenty delicately painted, solid and obtuse in form, with a broad varicose lip.

\section{Species 169. (Fig. $a, b$, Mus. Taylor.)}

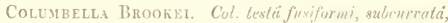
subangustit, lerigati, al busin linuri-sulcuti, lulescrute, strigis castuneis dense nulutis, at tarin nigricante; apurturai angustu, labre intus denticuluto.

BRooke's Colcurella. Shell fusiforn, varrow, somewhat curved, smooth, linearly grooved at the base, yellowish, densely waved with chestuut streaks, blackish at the base: apcrture narrow, lip denticulated within.

Hat. Sarawak, Borueo.

An attenuately fusiform shell, somewhat curved or bent, of a very distinet typical character, which I bave much pleasurc in dedicating to the woll-known Euglish Rajab.

\section{Fig. 170. (Mus. Cuming.)}

This shell proves to be a variety of $C$. suffusa, described at Plate XIII. Sp. $\$ 9$.

\section{Species 171. Miss. Cuming.)}

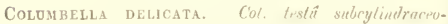
oblongä, lerigatä, nitente, aufiactu ultime angusto,

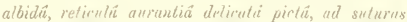
maculat $\hat{\imath} ;$ aperturit purvâ, supernè subsinuatû. iabro intus dentiulato.

The delicate ColduBElla. shell somewhat cylin- drically oblong, smooth, whing, last whorl narrew whitish, paiuted with a delicate orange notwork, spotted at the sutures; aperture small, slightly siuuated at the upper part, lip denticulated within.

\section{Hab. Guatemala.}

Painted throughout with a particularly delicate network somewhat after the manner of $C$. crillraria.

species 172. (Mus. Cuming.)

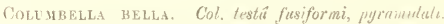
Intrarenter-albut, limeis anerautio-fuscis undutis fuscriatu. spirâ lonyiusculti, suturis impressis, anfructibus plunoroner xis, ultimo ael basin contracto; aperturit parri.

The PRETTY Columbella. Shell fusiformly pyrauidal, yellowish-white, painted with bands of waved orangebrown lines, spirc rather long, sutures impressed, whorls flatly couvex, the last contracted at the base aperture small.

ITab. China.

This pyramidal species is distinguished by a very characteristic and uniform style of painting. Round the upper edge of the whorls, next the suture, are dark flames at rather distant intervals. The flames are then lighter and more numcrous, and leave a conspicuous white zone.

\section{Species 173. (Mus. Cuming.)}

Columbella tuberculati. Col. testa $\vec{a}$ oeut $\hat{\imath}$, longitudinaliter obliquè rostalâ, costix juxta suturas tubercu-

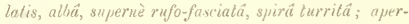
turût parra $\vec{a}$, supernè sinuat $\vec{t}$, labro incrassato, intus denticuluto.

The tebercled Columbella. Shell ovate, longitudinally obliquely ribbed, ribs tubercled next the sutures, white, cncircled round the upper part with a red band, spire turreted; aperture small, sinuated at the upper part, lip thickened, denticulated within. Hal.

Chiefly distinguished by its tubercularly ribbed sculpture, and very closely resembling in gemeral aspect a welkuown division of the Mitres. 
Species 174. (1 1 1 . a, b, Mus. Cuming.)

tim. mbella Essingtonensts. Col. testä acicuiari, luvatâa, leri, politâ, livido-purpurêa rel albâ, rufofasciatâ, spirẩ acutâ, anfractibus subangustis, uttimo sul,gibboso; aperturâ parvâ, supernè sinuatâ, labro inrassato, varicuso.

fare lissington Columbella. Shell acicular, clubshaped, smooth, polished, livid-purple or white. banded with red, spire sharp, whorls rather narrow, the last somewhat gibbous; aperture small, simuated at the upper part, lip thick, varieosc.

Hab Port Essington, Australia.

A rather solid, acicular, club-shaped shell, smooth and shinung, with a thickened, varicose lip.
Species 175. (Mus. Cuming.)

Columbella renestrata. Col. testa $\vec{a}$ ooct, st. transorrsis et longitudinalibus undique fencutrat at albidâ, pallidè rufo-fasciatâ, spirá subturritâ, anfras. tibus rotundatis, costis subtuberculatis: apri uri parviusculä, labro incrassato, intus denticulato

The latticed Columbelas. Shell ovate latticed throughout with longitudinal and transverse ribs whitish, faintly red-banded, spire somewhat turreteil whorls rounded, with the ribs slightly tuherrit of aperture rather small, lip thiekened, denticulateil within.

$H a b . \longrightarrow$ ?

A faintly red-banded sbell, roughly latticed thronghent 

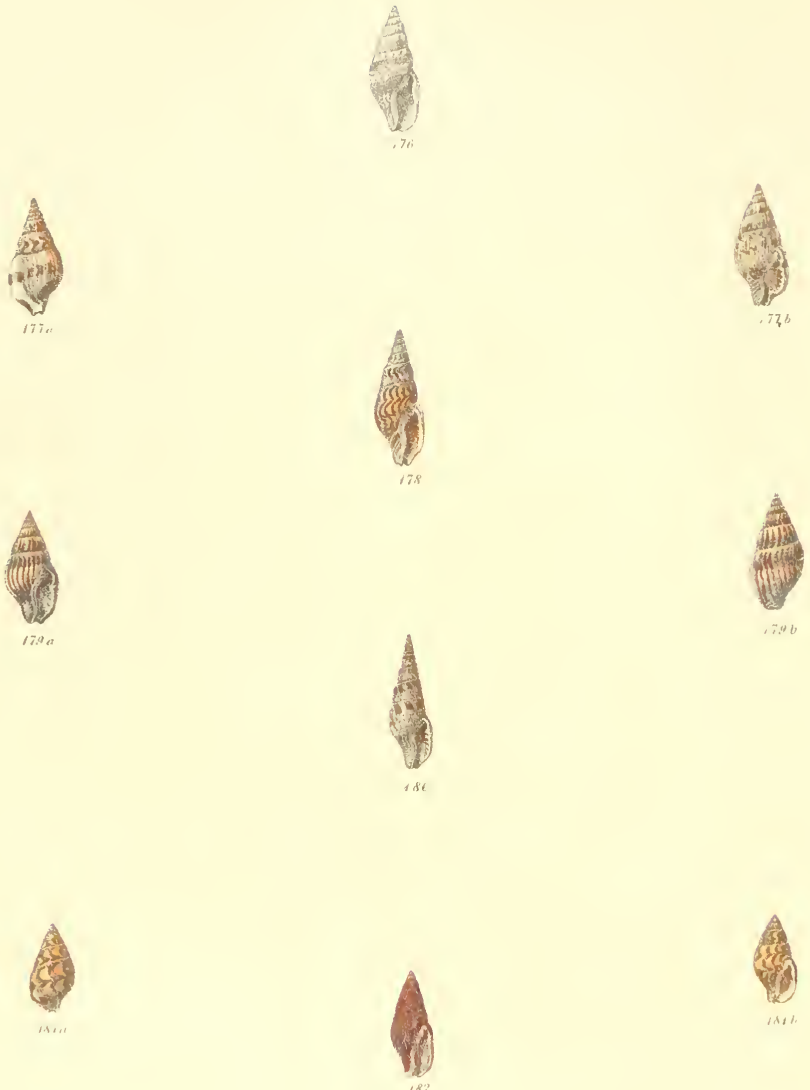


\section{O L U M B E LA.}

\section{Plate XXVIII.}

\section{Species 176 (Mus. Cuting.)}

Colembella rerida. Col. lestû́, himugonatâ, pellurillo-allu, ritreâ, punctis oparo-allis medio fasciatâ, anfinctims concexis, supernè leviter roncavo-impressis; "Ijurturi subanyustu, labio simplici, supernè sinuato.

The bewy Colt MBelis. Shell oblong, ovatc, transparent-white, glassv, encircled round the middle with a band of opaque-white dots, whorls conrex, slightly concavely impressed at the upjer part; aperture rather narrow lip simple, sinuited above.

Hab. Lord Hool's lstand (found on Avecula margarilifera, in coral sand, at it deptli of six fathoms); Cuming.

A transparent, glussy shell, encurcled round the middle with a tiecklace of opaque-white dots, like little pearls or hiewdrops.

\section{Species 17\%. (Fig. a, b, Mus. Taylor.)}

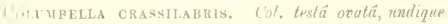
inmì cancrllatii, utexcente, nuculis rufo-fuscis saqitti-

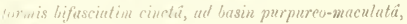
wivi breriusculi, acutu; aperturât parva $\vec{a}$ lubro crussisvinue, earitioso.

EIF THJE-Lip ColvMBELA. Shell ovate, finely eanfellnted through ut, yellowish, encireled with two batuls of recl-brown arrow-headed marks, purple- motted at the hase, spire rather short, sharp; aperture small, lip very thick, varicose.

Ilul

A small, stont shell, with an unusually thickened varirose lip, cncircled with bands of brown arrowhend-shaped uarks, with generally a conspicnous purple bloteh about the base.

\section{Sprecies 175. (Mus. Cuming.)}

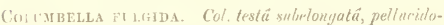

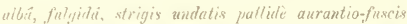
longuludinaliter pirlat. nperturá subanyustâ, labro intus denticulato.

THe glittering ColdmbeliLa. Shell rather elongated, transparent-white, glittering, painted longitudinally with faint, waved, orauge-brown streaks; aperture ralther narrow, lip denticulated within.

Hutb. Port Lincoln, Australia.

I narror, glassy shell, very delicatcly waved with inge-brown longitudinal streaks.

\section{Fig. 179. (Mus. Cuming.)}

The shell here figurel is a variety of $C$. diminuta, $C$. B. Adlams, described at Pl. XX. Sp. 115.

\section{Speces tall (Mus. Taylor.)}

Columbella sagitrta. Col. tustâ acicular, pelluidoalbâ, prope suturus upacio, macul is sagittiferis lontyitudinalibus, deindir punctis opaco-allyis cinyulat $\hat{a}$, anfractibus plunulatis, ultino contracto; aperturâ parrá, supernè sinuntä, labro intus denticulato.

THe arkow CoL MBeLLA. Shell acicular, transparentwhite, opaque next the sutures, with longitudinal arrow-headed snots, then encircled with opique-white dots, whor's rather flat, the last contracted; aperture small, sinuated at the upper part, lip denticulated withis.

Gaskoin, Pro. Zool. Soc. 1851 , p. 10.

Hab. Africa. West Indies.

It is impossible to represent the glassy texture, and pearly, opayue-white dots of this beautiful speeies in a ligure

specics 181. (Mus. Cuming.)

Colcmbelita lenata. Col. testấ oratâ, medio sudulubosit, albiti, lineis castureis undatio subulislantibus longitudinutiter pictï, ul basin purpureo-marginatấ; aperturá purva, lal ie intus vir denticulalo.

Tite lunar-marked Columbelia. Shell ovate, somewhat globose in the middle, white, painted longitudinally witb rather distant, waved, chestnut lines, purple-erged at the base; aperture small, lip scarcely dentieulited within.

Nasan lznata, Siay, Journ. Acad. Nat. Sci. vol, v. p. 213. Buccinum lunatum, Adams.

IIIIb. Cape Cod, Bay of Massachusetts, United States (a few feet below low-water mark, elinging to stones, scaweed, and other shells); Gould.

The lunar spots on this shell are formed by a longitudinal striping of rother distant waved chestnut lines uрол a white ground.

Species 182. (Mus. Taylor.)

Colcubella velata. Col. tentît avalâ, lrovi, mitente, custunto densissinè reticulatâ, anfractibus subplenublatis; aperturâ parrâ. labro intus denticulato, supernè sulbsizualo.

Тни: veiled Columbela. Shell ovate, smooth, shining, very densely reticulated with chestmut, whorls rather flattened; aperture small, lip denticulated witbin, slightly sinnated at the upper part.

Hab. — ?

I smooth shell, of simple growth, veiled, as it were with a very elose network painting of dark ehestuut. 



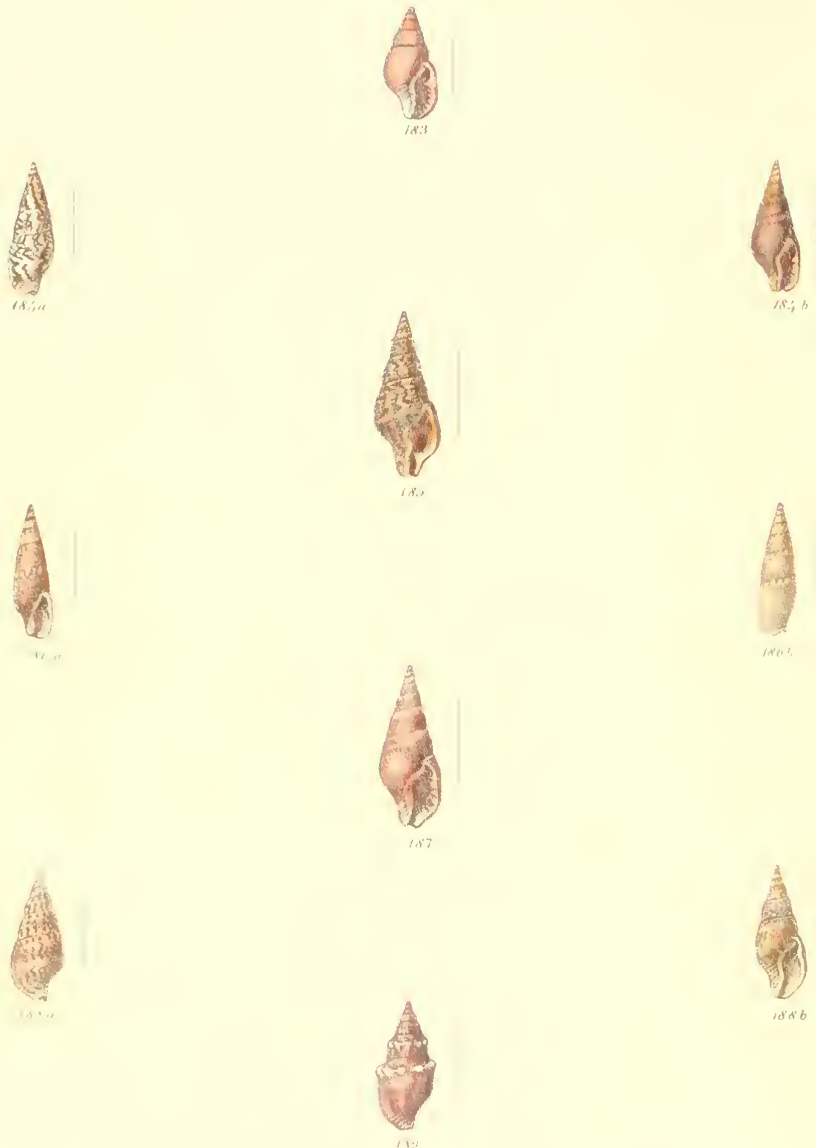


\section{Plate XIIX.}

\section{Syentere 183. (Mus. Cuming.)}

Columbella marca. Col. Leslâ oratâ, crassâ, lavi, cameo-rowa i, mefractibus plenulatis ullino gibbosiuscrul, al wiz intrueto : upuerturâ parcâ, labro sub-

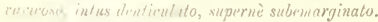

THE IXXk Coltumita. Shell ovate, thick, smooth, the-h-p ink, whorls tlattened, the last rather gibbous, contractes at the Irise, aperture small, lip subvaricose, denticulated within, sliglitly notehed at the upper part Hii:

Of emmith solid growth, coloured throughout with Preli-rose. which is leeper towards the apex.

Spccies 184. (Fig. a, b, Nus. Taylor.)

('u1, ybela Lixcolinensis. Col. lestä acuminatâ,

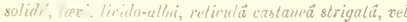
purpunu-1 sturee reriti, linctâ, anfructibus planulatis,

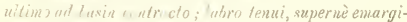
wate. wles dentir d ilo.

InE Liveolx CoLember.s. Shell acuminately solid, sun oth, livil-white, streaked with chestnut network, or varion-ly stuined with purple-chestnut, whorls rather flattened, the last contracted at the basc, lip thu, notches at the upper part, denticulated within.

Ilis Port Lincoln, Australia.

This Australian species is curiously analogons with the Hediteratean $C$. comimulata.

\section{Species 145. (Mus. Cuming.)}

C(1.TMBELla ARATA. (u) leslấ fusiformi-acuminalä, undique $s p$ iraliter sulewlit, lutescente, maculis rufo-

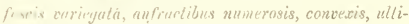
Wnis al bavin contracto it recusvo ; aperturâ parvâ, comentla reare $\hat{t}$, lauro simplici, subexpanso.

The plodghed Coltabelis. Shell fusiformly acuminated, spiriily grooved throughout, yellowish, variegated with red-brown spots, whorls numerous, convex, the last contracted and recurved at the base; aperturc small, columella cxeavated, lip simple, slightly expanded.

II wi - ?

This shell might very fairly be regarded as the type of a new gemns, Its generic characters have little in common with thinse of Cols whiella.

Speccirs 186. (Fir, 12, 1, Mus, Cuming.)

Colcunetha ll MBk.cts. Col. testâ cylindraceo-aciculari, leevigula, nilente, rasucco-fuecescenle pallule reliminti, anfraclibus plenentulis, prope apicem longiludi-

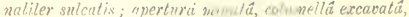
lubro simplic.

THe gruls Columbeth. Shell cylindrically acicular, smooth, shining, laintly reticulated with pink-brown, whorts rather flat, longitudinally grooved near the apex; aperture very small, columella excarated, lip simple.

Hab. Isle of Capul, Philippines; Cuming.

Of a narrow, Tirelure-like form, marked with a faint network of pink-brown.

\section{Species 187. (Mus, Cuming.)}

Colvmbelia sarcharata. Col. teslä acuminalit, pelincido-rosaceri, ad basin opaco-albit, anfraclibus convexis. leevibns, nltimo infernè contracto it sulcato: aperturâa ovatü, columellấ labroque ilenticulatis.

The CaNdied Coltmbelda. Shell acuminated, transparent-pink, opaque-white at the base, whorls convex, smooth, the list contracted at the lower part, and groorcd; aperturc ovate, lip and columella denticulated.

Hab. Van Diemen's Land.

Although a shell of comparatively stout growth, all the specimens I bave scen are of the same uniform transparcut-pink substance, white in the colnmella.

Fig. 188. (Mus. Taylor.)

Since describing at Plate XV. the C. australis of the late Mr. Gaskoin, I have had an opportunity of examining the original types of that spccies, now in the collection of Mr. Taylor. It will be seen, by comparing the accompanying figure with Fig. is, that the species raries considerably:

\section{Species 189. (Mus. Cuming.)}

Coltabella stgillata. Col. lesla aratâa, lividofuscia vel morpurascenle, spirâ lurrilä, anfraclibus supernè tulurculato-costalis, luberculis niveis; aperturâ subquadrato-ovatâ, labro subvaricoso, supernè subangulalo, inlus denliculato.

The breised Colembelia. Shell, ovate, livid-brown or purple, spire turreted, whorls tubercularly ribbed round the upper part, tubercles white; aperture somewhat squarely ovate, lip slightly varicose, angled at the upper part, denticulated within.

Hab. China Seas.

Of a livid-brown or purplish bue, the tubercles with which it is strongly coronated throughout being tipped with white. 


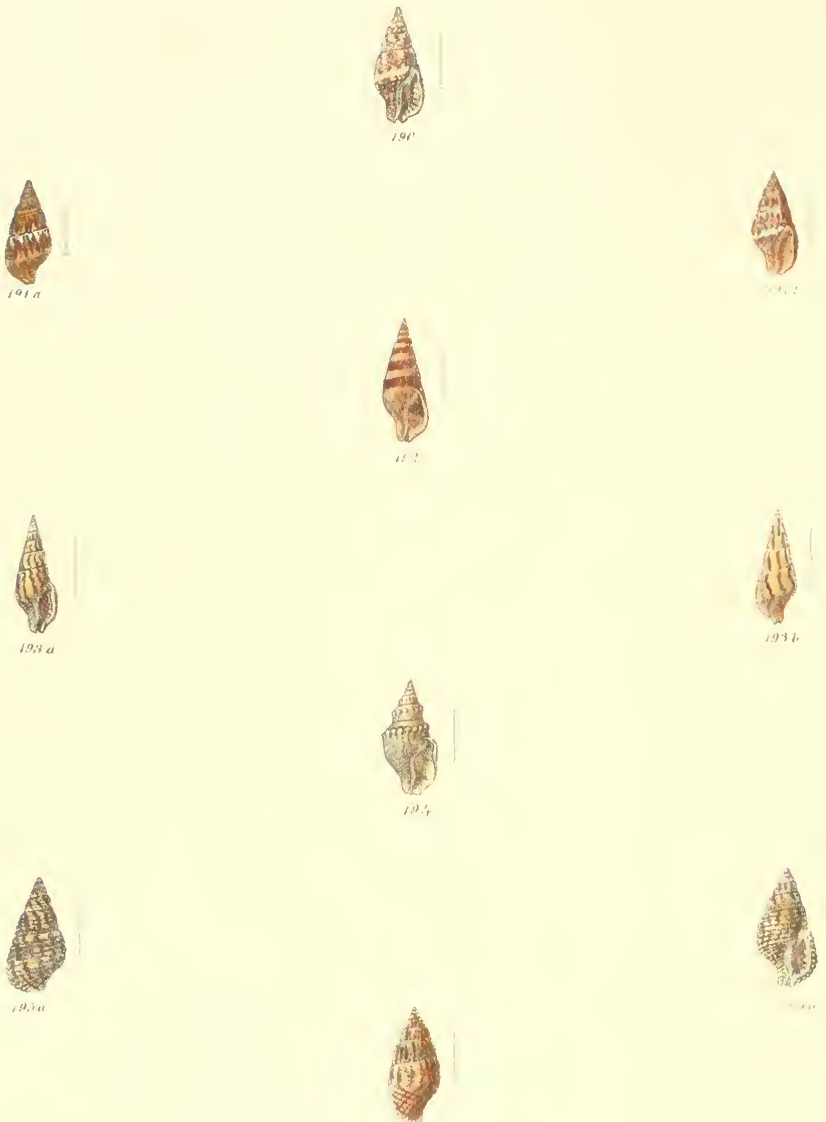


\section{O L U M B E L L 1 .}

\section{PLATE XXX.}

\section{Speete 190. Mus. Cuming.)}

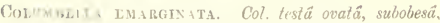

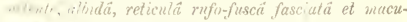
Lanos nemas apicent spiraliter bilineatâ, spirâ breviuswhith montit, unfrartibus prope apicen costellatis, de-

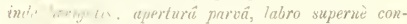
spicue margimion to intus vulid' denticulato.

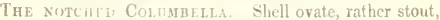
shiuing. whitish, banted and blotehed with redbrown netnork, spirally bilineated towards the apex, spire rather short, sharp, whorls ribbed near the apex, then smooth; aperture small, lip conspieuously notebed at the upper part, strongly dentirulated within.

Hab.

This shell partakes very much of the eharacters of $C$. meletelue, but is of more solid character and more decided entouriug, with a more than usual emargination of the lip.

\section{Speeies 1yl. (Mus. Cuming.)}

Coilabella scitulata. Col. teslä oratê, fulco-rustaneâ, albo promiscuè tessellatâ, anfractibus longitudinaliter costatis, ultino levigato, ad basin suicato; aperiurâ parvâ, labro supernè emarginato, intus denticulato.

The wrought Colembella. Shell ovate, fulvous-chestnut, promiscnously tessellated with white, whorls longitudinally ribbed, the last smooth, grooved at the base : aperture small, lip notebed at the upper part, denticulated within.

Ilals.

A very characteristic, prettily tessellated shell, allied to c caterota.

specic 192. (Mus. Cuming.)

('olumbella vittata. (ól. testât aciculari, fulrescente, fascriâ unici castane $\hat{\imath}$ cingulatêt, anfractibus plano-convexis, levibus; aperturí parvâ, lethro simplici.

THE RIBBON-BOUND COLTYBELLA. Shell acicular, fulvous, cucircled with a siugle broad chestnut band, whorls flatly convex, smooth; aperture small, lip simple.

Hab. Iba, Province of Zambales, Island of Luzon, Philippines; Cuming.
A very distinct specses, of sin le chinacter, of which only a single speciment was collected by Mr. Cuning at the above locality.

Species 193. (Fig. $a, b$, Mus. Taylor.)

Coldunella Mindoressis. Col. testâ aciculari, ad basin multo contractâ, fulvescente, flammis castaneis longitudinulibus distantibus pictê, anfractibus numerosis, plamul tis, nlimo ad basin ungulato et spiraliter sulcato, canuli subrecurvo; aperturâ parvâ, labro varicoso.

The Mindoro Columbella. Shell acieular, much contracted at the base, yellowish, painted with distant longitudinal chestnut flames, whorls numerous, rather flat, the last angled and spirally grooved at the base, canal stightly recurved; aperture small, lip varicose. GaskoIs, MS, in Mus. Taylor,

IIab. Puerto Galero, Island of Mindoro, Phitippines (in coarse sand, at a depth of about twelve fathoms); Cuming.

An elcgant and well-marked species, both as regards form and painting.

\section{Species 194. (Mus. Cuming.)}

Columbella spectrums. Coul. testâa ovatâ, tenuicula $\hat{a}$, stramineẩ, spirât brevi, acute turritâ, anfractibus superuè concarouleclivibus, ad nu!julum nodulatis, ultimo spirnliter sulcato, nodulis albidis; aperturâ orntâ, labro simplici.

The firost Colcmbella. Shell ovate, rather thin, straw-coloured, spire short, sharply turreted, whorls coneavely slanting round the upper part, uoluled at the angle, the last spirally grooved, nodules whitish; aperture ovate, lip simple.

Mab. Lsland of Mindoro, l'bilippines: Cuming.

Chiefly distinguished by the white noduled slanting edge round the upper part of the whorls.

Species 195. (Fig. $a, b$, Mus. Cuming.)

Coldmbella porcata. Col. Lestâ oratâ, undinue spirnliter porcatî, interslitiis conspickè excacatis, albâ, purpureo-rufo wullo tincti et muculutí, anfractibus con-

April, 1859 
vexin, suturis excavatis; aperturâ parvâ, intus denticulatâ.

THE RIDGED COLUMBELLA. Shell ovate, spirally ridgcd throughout, the interstices being conspicuously exeavated, white, much stained and spotted with purplcred, whorls conrex, sutures excavated; aperture small, denticulated within.

$11 a b$

A well-defined species, strongly spirally excavately ridged throughout, and mucb stained with deep purplered colouring.
Species 196. (Mus. Cuming.)

Colembelua Antillarom. Col. testä ovatâ, lutescente, castaneo-fusco subtilissimè reticulatâ, anfractihus subventricosis, supernè longitudinaliter costellatấ; aperturâ parvâ, lubro simplici.

The West Indian Columbella. Shell ovate, vellowisb, finely retienlated with chestnut-brown, whorls slightly ventricose, longitudinally ribbed at the upper part; aperture small, lip simple.

Hab. Island of St. Thomas, West Indies.

The network of this species is very delicate, stretehed, as it were, morc transversely than usual. 


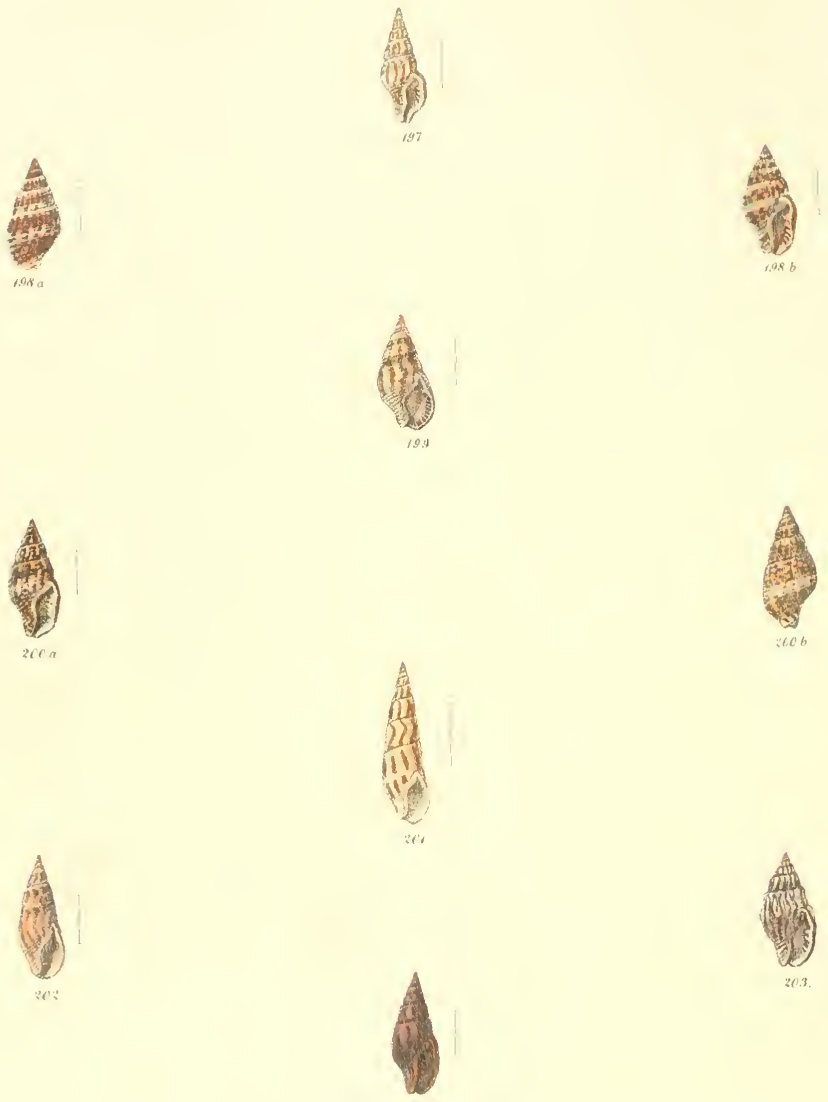


\section{O L U II B E L L A.}

\section{Plate XXXl.}

sproes 197. (Mius. C'ummg.)

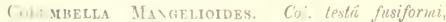

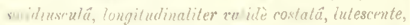
memis auruntio-fuscis aspersit, unfruct ins memerosis.

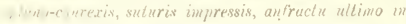
inatem producto; aperturä parvi, labro varicoso, whe denticulato.

Tue Mavgela-like Colombrich. Slell fusiform, rather solicl, lougitudinally strongly ribled, yellowish, sprinkled with orange-brown spots, whorls uumerous, flatly convex, sutures impressed, the last whorl produced into a canal ; aperture small, lip varicose, denticulated withiu.

Hab. Test Indies.

A solid shining shell, vcry couspicuously ribbed throughout, with a strongly varicose lip.

Speeies 198. (Fig. a, b, Mus. Cuming.)

Colvmbella Guatemalexsis, Col. testī ovati $i$, subobesï, Imuitudimaliter tenuicostali. sulcus linearibus transversis decussatü, purpureâ et rufä, maculis opaconlbis quallotis medio cingulatä, unfractibus convexis, supemè albis; aperturấ oblongá, labro inlus denticulate.

The Glatemala Coldmbella. Shell ovate, rather stout, longitudinally finely rilsbed, decussated with trausverse finear grooves, purple aud red, encircled round the midlle with square opaque-white spots, whorls convex, white round the upper part; aperture oljlong, lip denticulated withio.

Hab. Guatemala.

Necklaced round the body-whorl with square, opaquewhite spots upon a rich purple-red ground, while the upper edges of the whorls remain white.

Species 199. (Mus. Cuming.)

Coldmbella pellucida. Col. Leslâa opatâ, versus basin obliquè expansisi, peilucidä, lavi, aurantio-castaneo maculatâa et flummatâ, spirá breviusculâ, acuminulâ. aperturâa ovatât, columella excavatâ, lubro varicoso. intus purpureo-tincto, supermè unidentato.

The pellucid Coltmbella. Shell ovate, obliquely expauded towards the basc, transparent, smooth, spotted and flamed with oraugc-chestuut, spire rather short, acuminatiel/ aperture uvate, colsinellis excavated, lip varico-. purple-stained within, onetoothed at the upper part.

Hab. -

Rather inclined to the typical form of Nassa, of solid texture, yet so transparent as to allow the columella being scen throughout the shell.

Species 200. (Mus. Cuming.)

Colvmbella sparsa. Col. testâ fusiformi-ovatô, lomgle tudinaliter costellatâ, interstitiis cancellatis, iutescente, pronctis rt reticula castaneis sparsă; aperturá parvâ, tabro varicoso, supernè emarginato, intus denticulato.

The SPRINKLed Columbella. Shell fusiformly ovate, longitudiually finely ribbed, interstices caucellated, yellowish, sprinkled with chestunt dots aud network, aperture small, lip varicose, notched at the upper part, deuticulatcd within.

Hab. - ?

Similarly sculptured and painted to C. suffusa, but of a shorter form.

Species 201. (Mus. Cuming.)

Coldmbella acus. Col. testâ angustè elongatâ, versus apicem longitudinaliter minutè costellat $\vec{t}$, lutescente, aurantio-fusco irregulariter strigatâ, anfractiobus planulatis; aperturâ minutâ, colluneltâ subexcavatâ, truncatit, lubro simplici, intus vix denticulato.

The NeEdle Columbelia. Shell narromly elongated, longitudinally miuutcly ribbed towards the apex. yellowisb, irregularly streaked with orange-brown, whorls rather flattened; aperture very small, columella slightly excavatcd, truncated, lip simple, scarcely denticulated witbin.

$H a b$. Isle of Capul, Philippincs; Cuming.

This species, together with the $C$. limbrims and Oumingii, all from the Isle of Capul, present a local type of treat iuterest, and a good basis for a distinct subgenus.

\section{Species 202. (Mus. Cuming.)}

Colvmberla obltis. Col. Lest $\hat{a}$ acuminato-oblonga. undique minutè spiraliter elevato-striatâ, pellucido.

April, 1859. 


\section{COLUMBELLA.-PLATE XXXI.}

When strigis ingitudinatibus aurantio-fuscis oblitâ, infractibus supernè concavo-impressis; aperturâ parvâ, inlumellâ excavatâ, labro simplici.

THE SMEARED COLUMBELLA. Shell acuminately oblong, minutely spirally elcvately striated throughout, transparent-white, smeared with longitudinal orangebrown streaks, whorls concavely impressed round the upper part; apcrture small, columella excavated, lip simple.

Hab. Peru.

Spirally sculptured throughout with close-set raised striæ, and colourcd promiscuously with longitudinal smears if orange-browu.

\section{Species 203. (Mus, Cuming.)}

tolumbelia cavea. Cal. testâa ovatâ, media abesâ, validè obliquè tuberculato-castatâ, castaneâ, castis purpurpis; aperturẩ oblong $\vec{a}$, labro supernè emarginato, intus denticulato.

Tiit bIRD-cage Coltmbella, Shell ovate, stout in the middle, strongly obliquely tubercularly ribbed, chestnut ribs purple ; apcrture oblong, lip notched at the upper part, denticulated within.

$\Pi a b$.

The longitudinal ribs of this species are unusually promincnt and dark-coloured, giving the shell a somewhat cage-like appcarance.

Species 204. (Mus. Cuming.)

Columbella tenebrica. Col. testâa acuminata-ovatä. laeri, intensè fulvo-castaneâ, obscurè longitudinatiter strigatä. anfractibus subplanulatis; aperturâ parvâ, funce nigricante-castaneâ, labra simplici.

The Dark Colcmbella. Shell acuminately ovate, smooth, dark fulvous-chestnut, obscurely longitudinally streaked, whorls rather flattened ; aperture small interior blackish-chestnut, lip simple.

Haib. — ?

Allied to $C$. pulla in form and general appearnuce, but it will be found on cxamination to be obscurely striped, while it has not the white columella distinctive of that spccies 
. 

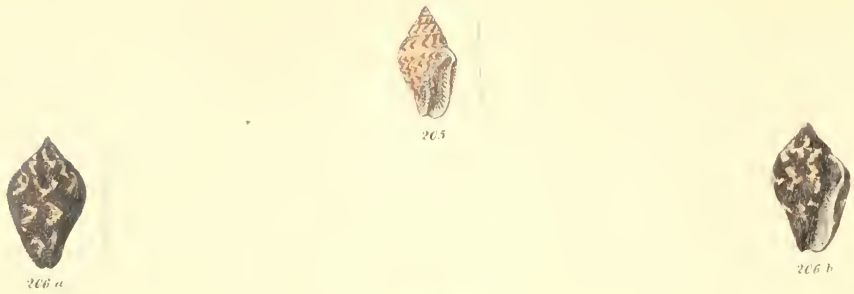

2661

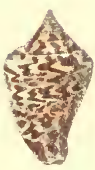

267
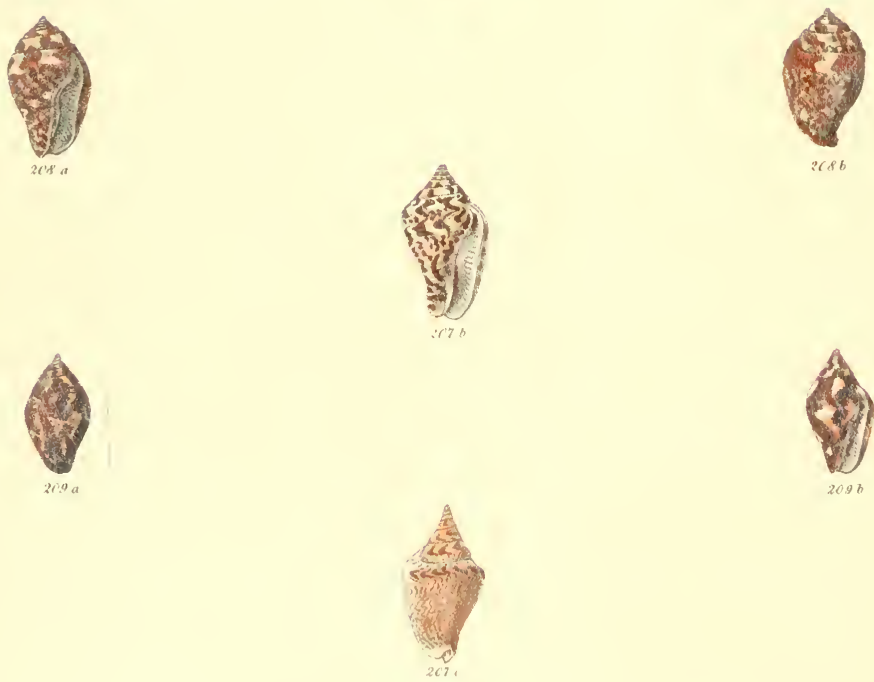


\section{O L U M B E L L .}

\section{Plate XXXII}

\section{Fures 205. (Mus. Taylor.)}

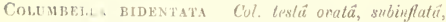
pulluentr-flaticunte, punctis rufis el opaco-albis angu-

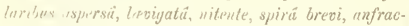
tibus soperair suldectivibus, drinde robnulatis, apice nigricunte: aperturie oblonght, utrinque denticulatä, rolume-llie intus bidenticutatâ, lutro supernè subemarfinato.

Tue nouble-tootued Columbela. Shell ovate, somewhat inflated, transparent-yellow, sprinkled with angular red and opaqne-white dots, smooth, shining, spire short, whorls a little slanting round the upper part, theu rouuded, apex blackish; aperture oblong, denticulated on both sides, columella doublc-toothed within, lip slightly notehed at the upper part.

MENkE, somerby, Thes. Conch. vol. i. p. 118. pl. 37. f. 53,54 .

Hab. Swa River

This degrant species is curiously distinguished by the presence of two suall tceth on the inuer surface of the columella.

sipecies 206. (Fig. 206 and 20i, Mus. Cuming.)

Colvmbella picata. Col. testä conoideä, unalique spiraliter tentiliratâ, purpureo-nigri tis opaco-albis in manculis triangularibus et in strigis prowi $i s c$ is untat $\vec{a}$, spir $\vec{a}$ parva $\vec{a}$, mecronat $\vec{a}$, aufractibus supernì obesè rotundutis, versus basin attenuat is; aperturi etongatä, ungusti, fauce carulescente, labro intus supremè sulitscendente, obsoletè denticulato.

THE pied ('olumbella. Shell conoid, spirally finely ridged throughout, purple-black or chestnut, marked with triauglar blotches of opaque-white dots and promiscuous streaks, spire small, pointed, whorls obesely rounded at the upper part, attennated towards the base; iperture elongated, narrow, interior bluish, lip slinhtly ascending at the upper part, obsoletely denticulated withiu.

Conella picata, Swaiuson, Treatise on Malacology, 14. 151.

f. $17 a$.

Colinubltin orutata, Sowerby.

Colnmbeltu varia, sowerby.

Ilah. Australit.

The two shells represented at Fig. 206 and 209, intended to illustrate Mr. Sowerby's C ovulata and varia, prove to be one and the same species, and the type of MIr. Swainson's genus' Conetla. The conical Strombus-likc species, which have been confounded by some writers with this subgeneric division of the Cotumbetla, 1 propuse to arrange under a new genus, with the name of Wrta.

species 207. (Fig. a, b, c, Mus. Cuming.)

Columbella Philippinarum. Col. testâ conoideâ, crax$s \hat{a}$, alb $\vec{a}$, purpureo-fusco strigat $\vec{a}$ ot fusciata $\vec{a}$, smint brevi, acutâ, anfractibus supernè giłbosu-angulalis, deinde subconcavis, anfractu ultimo ad basin recurro et spiraliter sulcato; aperturâa elongatâ, angustâ, latiru subincrassato, supernè subasrendente, intus obsuletè denticulato.

Tue Puilippine Columeella, Shell conoid, thick, white, streaked and banded with purple-brown, spire short, sharp, whoris gibbously angled round the upper part, then slightly concave, last whorl recurver and spirally grooved at the base; aperture elongated, narrow, lip rather thickenel, slightly ascending at the upper part, obsoletely denticulated within.

Reclez, Pro. Zool. Soc. 1842, p. 199.

Conella Philippinarum, Adams.

Hab. Philippine Islands; Cuming

This species would also belong to Mr. Swainson's genus Conell $n$, by reason of the ascending tendeney of the outer lip, as distinguished from the decided conical species which constitute my genus Meta.

Species 205. (Fig. c, b, Mus. Cuming.)

Colembella piscors. Cot. testấ cylindraceo-conoideä, ierrigatâ, viridè castaneâ, iufernì albo-punctatâ, supernè albimaculatâ, maculis yranditus, distantibus, spirâa obtusè globosá, apice elevato, mucronato; aperturî̀ elongatî, fauce violacể, labro subinerassato, supermì ascendente, intus olsotetì denticulato.

The differing Columbelia. Shell cylindrically conoid, smootb, bright-chestnut, white-dotted below. white-blotched alove, blotehes large and distant, spire obtusely globose, apex raised, pointed; aperture elongated, violet in the interior, lip somewhat thickened. ascending at the upper part, obsoletely denticulated within.

Tolutn discors, Gmelin (tide Deshayes), syst. Nat. p. 3455 .

Buccinum punctatum, Bruguière.

Columbella semijunctula, Lanarch.

IIab. Philippine Islands; Cumiug

This fine and long-known species belongs also to the Conella division of Columbella, as well as its very near ally C. sptenditula, and a few other species. 

बहिक

a.

है

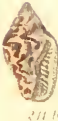

a)
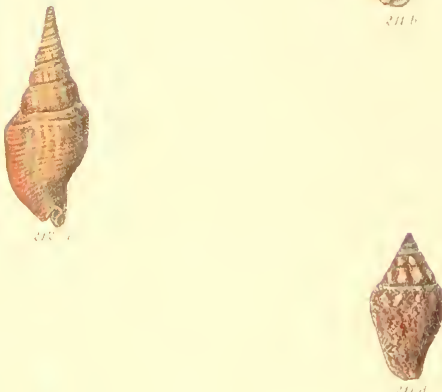

(i)
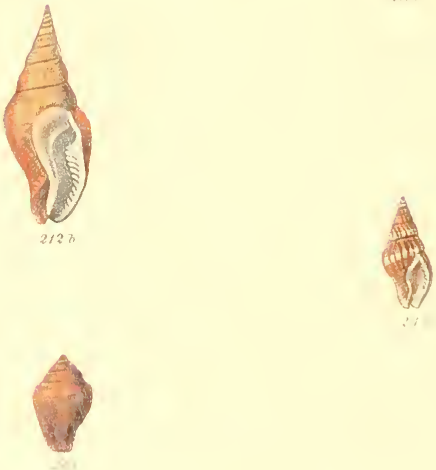


\section{OLU II BELLA.}

\section{Plate X.jili.}

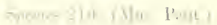

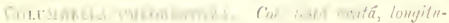

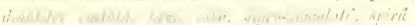

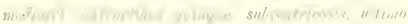

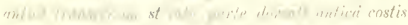

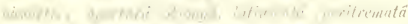

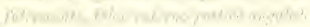

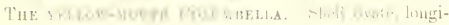

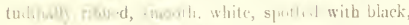

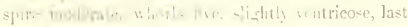

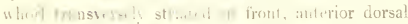

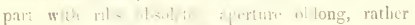

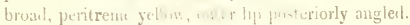

Petit, Sowerby, The (math wol. i f. 113 , pl 36 f. 17,18 .

Ilab. ㄴ?

Of this species, which is 1 th himm 11 me, I copy the description and figure frou Mr. Sowerby'. 'Thesaurus Couchyliorum, as comnunicited to him hy M. Petit de La Saussaye, of Paris.

Species 211. (Fig. $a$ to $d$. Mus. Taylor.)

Columbella nustica. Cot. testâ onala , nunc lavigali, nunc spiraliter strialú, albidâ, rufo-fusco rel purpureo plus miues densè linclî vel punctulit, spira breriusculâ, conicâ, aufractibus superuè obesè rotumlatis : aperturá obtungâ, labro intus wediu incrassito, denticulato, interstitiis purjureis.

THE RISTY CULCMBElia. Sirll orate, sometimes smooth, sometiues spirally striated, whiti-h, more or less densely stained or spotied with reddish-brown or purple, spire rither short, conienl, whorls stoutly rounded at the upjer part; aperture oblong, lip thickened in the middle within, denticulated, interstices purple.

Foluta rustica, Linniens, Srst. Nat. p. 1190.

IIab. - ?

A very good distingnishing claracter of this ancient specics is presented in the purple colouring in the interstices between the denticulations within the lip.

Species 212. (Mus. Norris.)

Colcmbela sebtlata. Col. testî́ pyramidali-turritâ,

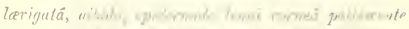

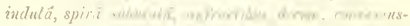

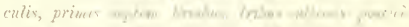

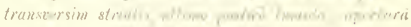

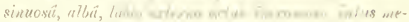

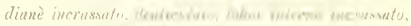

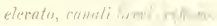

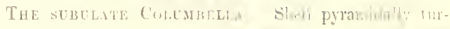

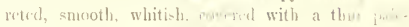
horny epidermis, spire sundum, whorls ten, rather consex, the first seven smouti, the last three posteriorly transwersely striated, the last swollen posteriorly; aperture sinuous, white, outer lip thickened outwardy, thickenced and denticulated within in the middle, imer lip thickened and elerated, canal short, reflected.

Sowergy, Thesaurus (onch. vol. i. p. 140) pl. 40, f. $15 \mathrm{~s}$ 159.

IIab. — ?

Uukuown to we. Description and figure copied from 'Thesaurus Conchyliorum.'

Species 213. (Mus. Brit.)

Colvmbella Kraussi. Col. lestâ ovalo-oblongri, lacri, allicunte, lineis castaneis undatis longitulinaliter pictâ, anfraclibus subtentricosis, obsoletè longiluetinaliter costmlalis, costellis tistantibus; aperturit latâ. lalio simpliri.

Kratss' Colcmbelia, Shell ovately oblong, smooth, whitish. longitudinaliy painted with wased chestnut lines, whorls slightly ventricuse, obsoletely longitudinally ribbed, ribs distant; aperture hroad, lip simple.

Sowerby, Thesaurus Conch. vol. i. p. 144. pl. 40. f. $1 \leqslant 0$, 181.

IIab. Natal, South Africa; Dr. Krauss.

The waved lincar painting is conmon to scveral species, but this is the only one of that type kuown to me that is at all ribbed.

\section{Species 214. (Nus. Brit.)}

Colembella Guildisghi. Cul. testâ pyramidali-oblonyá, pallescente, brunnco rariegutâ, spiri acuninatî, sub-

A pril. 1559. 


\section{COLUMBELLA.-Plate XXXIII.}

turritâ, anfractibus longitudinaliter costatis, striis transversis decussatis; aperturâ ovatâ, sinuosâ, labro intus tenuè denticulato

Fil'ILDING's COLUMBELLA. Shell pyramidally oblong, pale, variegated with brown, spire acuminated, slightly turreted, whorls longitudinally ribbed, decussated with transversc striæ, apcrture ovate, sinuous, lip finely denticulated within.

Sow frby, Thesaurus Conch. vol. i. p. 143. pl. 40.f. 175. 176 .

Hab. Island of St. Vineent, West Ludies; Guilding.

of a somewhat sivuous form of eonvolution, closely lecussated throughout.
Species 215. (Mus. Taylor.)

Columbella nucleus. Col. testâ subtrigono-ovatâ, spiraliter tenuisulcatü, lovigatä, futvo-castaneä vel rosaceâ, spirâ brevi, anfractibus supernè obesis; apertur $\hat{a}$ angustâ, labro intus denticulato, interstitiis purpureis.

The kernel Columbella. Shell somewhat triangularly ovate, spirally finely grooved, smooth, fulvousbrown or pinkish, spirc short, whorls stout round the upjer part; ajerture narrow, lip denticulated within, interstices purple.

Kiener, lcon. exquilles vivantes, p. 14. pl. 3. f. 4.

$\mathrm{Hab}$.

This is a specics of somewhat doubtful character, and may prove to be a variety of $C$. mustica. 


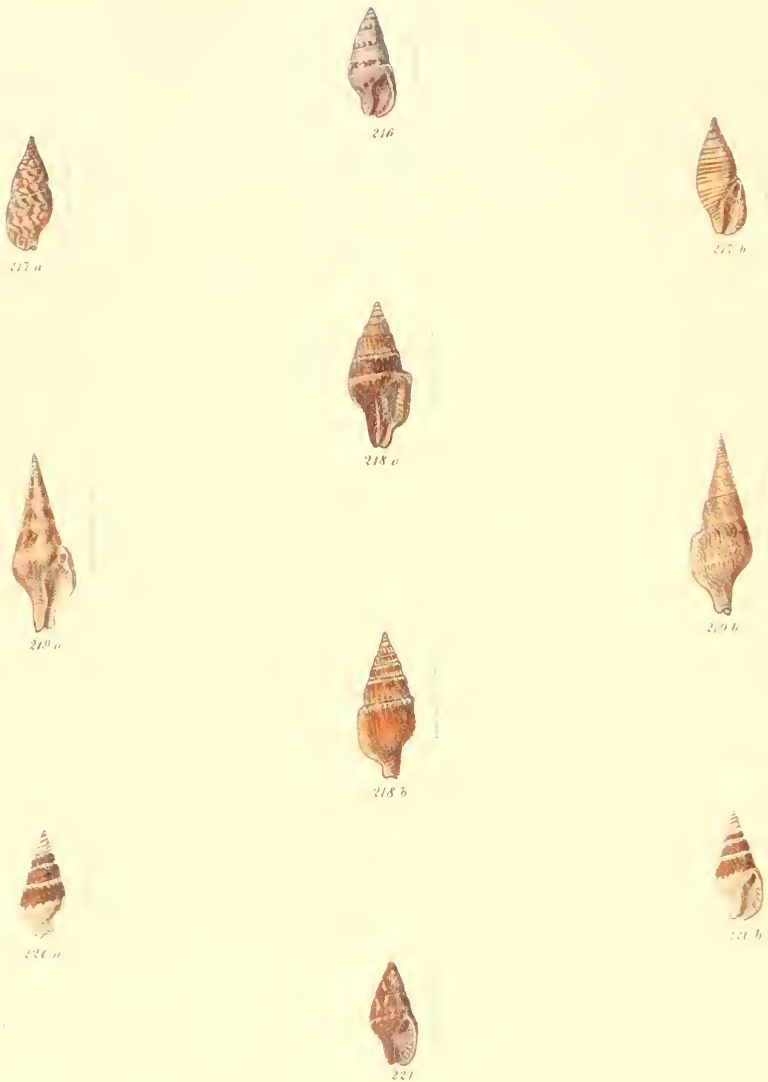


\section{O L U M B E L L A.}

\section{Plate XXXiv.}

\author{
Specit-23: (111:- liaylor.)

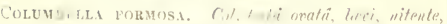

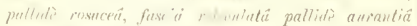

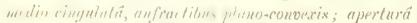

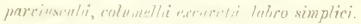 \\ Tre heilififte Columblit. Shell ovate, smooth, \\ shining, pale pirk, exircled round the middle with \\ a faint bant of orange network, whorls tlatly con- \\ vex: aperture rather small, columella excavated, hp \\ simple. \\ Giskoin, Pro. Zool. Sic. 1s5i.
}

llab.

Of a beautiful transparent flesh-piuk colour, extremely delicately reticulated round the middle, aud at the base and sutural edges.

\section{Supcies 217. (Tig. $a_{2} b$, Mus. Taylor.)}

Colemblela Varovesa. Col. Lestâ ovatâ, levi, temuiculit, pellucidonalhat, medio anrantio reticulato-flanmatât xet linentâ, unice ross â, anfractibus convexis, primis puncis longitudinutiter costatis; aperturú parvâ, lebro supremè conspicuè enarginato.

Tue Marquesas Colcmbella. Shell ovate, smooth, rather thin, transparent-white, reticulately flaned or lincated round the middle with orange, pink at the apex, whorls convex, the first few longitudinally ribbed; aperture small, lip conspicuously notched at the upper part.

Gaskols, Pro. Zool. Soc. 1851. p. 11.

Hab. Marquesas Islands.

This species comes very near to $C$. pulckella, and presents the same rariety of prainting. Sormetimes the orange-brown is disposed in reticulated bands, sometimes in lines.

Species 218. (Fig. $a, b$, Mus. Taylor.)

Columbella iodostoma. Col. testấ fusiformi, orossâ, medio obesâ, lomgitudinaliter plicato-costatâ, albidâ, utrinque violaceá, anranlio-fusco variè fasciată, anfractibus conrexis, suturis impressis, ultimo basi in canalem brexpit recurvo; aperlurấ brevi, utrinque denticulutâ, labro varicoso.
The violet-motth Columbella Sl, il fusiorm, thick, stout in the middle, longitudinally plientely ribbed. whitish, violet at each end, variously bauded witl orange-brown, whorls convex, with the suturcs impressed, last whorl recurved at the base into a short canal; aperture small, denticulated on cacb side, lip varicose.

Gaskors, Pro. Zool. Soc. 1851. p. 13.

IIab. Port Essingtion.

Closely allicd to $C$. puella, which is smonther and more variably marked.

Species 219. (Fig. $a, b$, Mus. Taylor.)

Columbella hrundo. Col. lestî́ fusiformi-clavatá. solictâ, lavi, nitente, albutha, limeis aurantio-fuscis undulatis lentiginosî, spirî̉ uttemato-acuminalâ, anfractiburs subplanulatis, ultimo gibboso, all basin canalienlatât el rostrat $\vec{a} ;$ aperlura angzestâ, supernè emarginat et utrinque unistentalâ, columellê excanatâ, labro subvuricoso.

The swallow Columbela. Shell fusiformly clubshaped, solid, smooth, shining, whitish, freckled with waved orange-brown lines, spire attenuately acuminated, whorls rather flattened, the last gibbous, channeled and beaked at the base; aperture narrow, notehed and one-toothed on each side at the upper part, columella excavated, lip slightly varicose.

G.ss kor,, Pro. Zool, soc. 1851. p. 12.

Ilub. — ?

A remarkably characteristic clavate species, curiously beaked at the extremity.

Species 220. (Mus. Taylor.)

Columbella LEucostous. Col, testî umiminato-ovatâ, lacvi, supernè densè aurantio-reticulutü, infernè albâ, apice pellucido-albâ, anfractibus convexis, ultimo ad basin coarctuto et sulcato; aperturấ purvâ, columelláa excavatä, lnbro vix incrassato, intus denticulato.

THE WHTE-MoLTI COLUMBLLA. Shell acuminately ovate, sinooth, densely orange-reticulated above, white below, transparent white at the apex, whorls convex, the last contracted and grooved at the base;

April, 1859 


\section{COLUMBELLA.-Plate NXX11.}

. perture small, eohmella exeavated, lip scareely thickened, denticulated within.

Gaskols, Pro. Zool. Soe. 1851. p. 4l.

\section{$\mathrm{Hab}$.}

In this species the upper half of the whorls is darkly stained with elose orange-brown network, whilst the lower half is almost pure white, but it is only of the last whorl that the lower half is seen.

Speeies 221. (Mus. Taylor.)

Colembella polita. Col. testâ ovatä, solidiusculâ, kert, nitente, aurantio-castaneá, albo hic illir sparsin ma- culatî et reticututu, anfractibus subobtuse sonv is , aperturâ parcấ, columellâ excavatâ, lubro intus denticulato.

The polished Columbrila. Shell ovate, rather solid, smooth, shining, orange-chestnut, here and there spariugly blotched and reticulated with white, whorls rather obtusely convex; aperture small, columella excavated, lip denticulated within.

Hab. - :

This speeres, fount in the collection of the lat. Mr. Gaskoin without name or particulars of habitat, is mottlec in a peeuliar manner with promiscuous white blotehes and little patches of uetwork. 


.



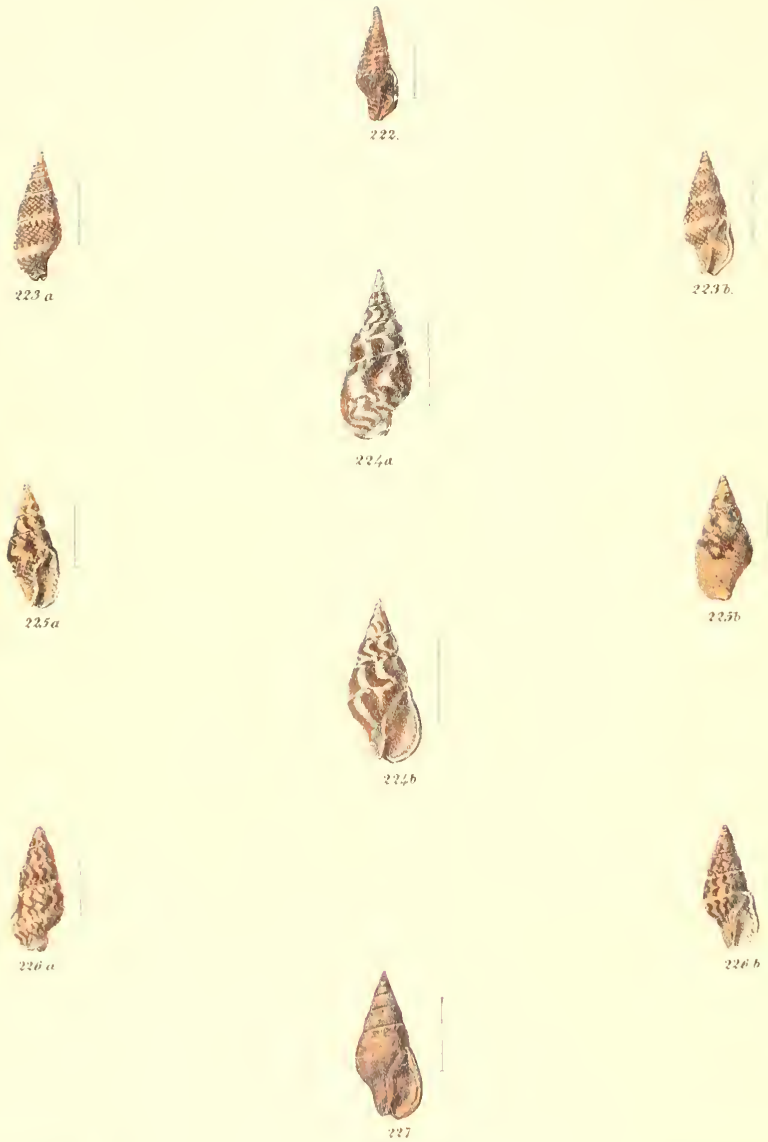


\section{O L U II B E L L 1 .}

\section{Plate SXXV.}

Species 22:. Mus. Taylor.

Colembella eximia. Col. textât ucuminatâ, sulicleratâ,

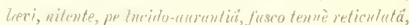
macnlis opary-nimes bifasriutim cingulatri, anfraclibes: plamelalis, witino ad busin coarctuto et sulento, subrecurvo; aperturit breci, Ialiro rariroso, supermè subemaryiuto.

THe chorce Columbelis. Shell acuminated, somewhat club-shaped, smooth, shining, transparent-orange. finely reticulated with brown, encircled with two bands of opaque snow-white flakes, whorls rather flat, the last contracted and grooved at the base, slightly recurect; aperture small, lip raricose, faintly notched at the inper part

$H a b . \longrightarrow$ ?

Of a particularly rich golilen transparent colour, encircled with two characteristic necklaces of opaque-white spots

Species 223. (Fig. $a, b$, Mus, Taylor.)

Columbella albuginosa. Col. tistâ ountâ, levi, nitente, pellucido-albâ, aurantio-fusco undiyeu nitidè reliculutu, reticulâ bifasciatim suturatiore, anfroctibus plano-convexis, ultimo suteontorto et sulcato; aperlurâ parrâ, labro sinullici, supermè subemarginato.

Tue white-eyed Coltabella. Shcll ovite, smooth, shining, transparent-ivlite, neatly reticulated throughout with orange-brown, the network darker, in two bands, whorls flatly convex, the last somewhat twisted and grooved; apcrture small, lip simple, sliglitly notelied at the mper part. $H a b$.

Painted throughout with a particularly neat network of orange-brown, which in the last whorl is darker above and below.

Species 224. (Mus, Taytor.)

1 GLCMBELLA TEXtis. Col. testä aruminato-oratâ, leri, atbidä, aurantio-fusco irreyuluriler fammat $a$, aufractibus conxexix, viltime centricoso, teuuè inflato, ulisoletè angulutu, ad busin sulcroto; aperturâ subexpunsâ, tabro simplici, suneruè sinuato.

The thin Columbelia. Shell acuminately ovate, smooth, whitish, irregularly flamed with orange-brown, whorls convex, the last whorl ventricose and thinly inflated, obsoletely angled, groored at the hase; aperture a little expanded, lip simple, sinuited at the upper part.

Gasko1n, Pro. Zool. Soc. 1551, p. 2.

Hab. ——?

Of a more inflated growth than usual, boldly striped with longitudinal orange-brown flames.

\section{Species 225. (Fig, $a, b$, Mus. Taylor.)}

Columbella Tayloriana. Col. testâa oxatâ, dorso subgibbosâ, solidâ, lerigat $\hat{a}$, nitente, yellucido-albâ, anrantio-rustaneo maculatâ et tenuè reticulatâ, spira subobtusi, anfractibus pluno-convexis, ultimo ad basin sutcato; aperturá quadrato-ovatâ, columellä subexcavatâ, labro parum incrassato, supervè emarginato, intus lenticulato.

TAYlor's Columbella. Shell ovate, rather gibbous at the back, solid, smooth, shining, transparent-white, finely reticulated and blotched with orange-chestnut, spire rather obtuse, whorls flatly convex, the last grooved at the base; aperture squarely ovate, columella shightly excavated, lip but little thickened, notched at the upper part, denticulated within.

Hab. North-west Australia.

An interesting species, of which the late Mr. Gaskoin had received several specimens from North-west Australia. I have much pleasure in naming it after Thomas Lombe Taylor, Esqq., of Starston, to whom wc are indebted for the prescrvation intact of several of the genera of shells which Mr. Gaskoin had collected with so much intelligent research, and which in Mr. Taylor's cabinet are now still wore materially enriched.

\section{Species 226. (Fig. a, b, Mus. Taylor.)}

Coj,umbela biflamiata. Col, testâa cylindraceo-ovat $\vec{a}$, lacrigatâ, nitcute, albidâ, aurantio-fusco undique densè flammatât, spirâ suboblusâ, anfractibus convexis ; apertur $\vec{a}$ paretât, cotuimella subexcurat $\vec{a}$, Vabro varicoso, supernè suberuaryinato, intus denticulato.

THE DOUBLE-FLAMED COLUMBela. Shell cylindrically ovate, swooth, shiniog, whitish, densely flamed

April, 1859 


\section{COLUMBELLA.-PLATE XXXV.}

throughout with orange-brown, spire rather obtuse, whorls convex; aperture small, columella slightly excasated, lip varicose, faintly notched at the upper part, dentieulated within.

Hab.

Encircled with two bands of longitudinal orange-brown flames, quite peculiar and uniform in eharacter.

Species 227. (Mus. Cuming.)

Columbella nux. Col. testâ cylindraceo-ovatâ, lavigatá, nitente, pellucido-olivace $\hat{a}$, luteo tinctâ, maculis parvis ulbidis fascintin cingulatá, spirâ breviusculâ, apice acuminatá, anfructibus convexis, ultimo obliquè expanso; aperturâ ovatâ, labro simplici supernè subemargiunto.

The nut Columbella. Shell cylindrically ovate, smooth, shining, transparent-olive, yellow-stained, encircled with two rows of small whitish spots, spire rather short, acuminated at the apex, whorls conves, the last obliqucly expanded; apcrture ovate, lip simple, faintly notehed at the upper part.

llab. Port Adelaidc, New IIolland.

Of a semitransparent, livid, yellowish-olive colour, showing a faint band of interrupted spots next the suture and round the midulle of the last whorl. 


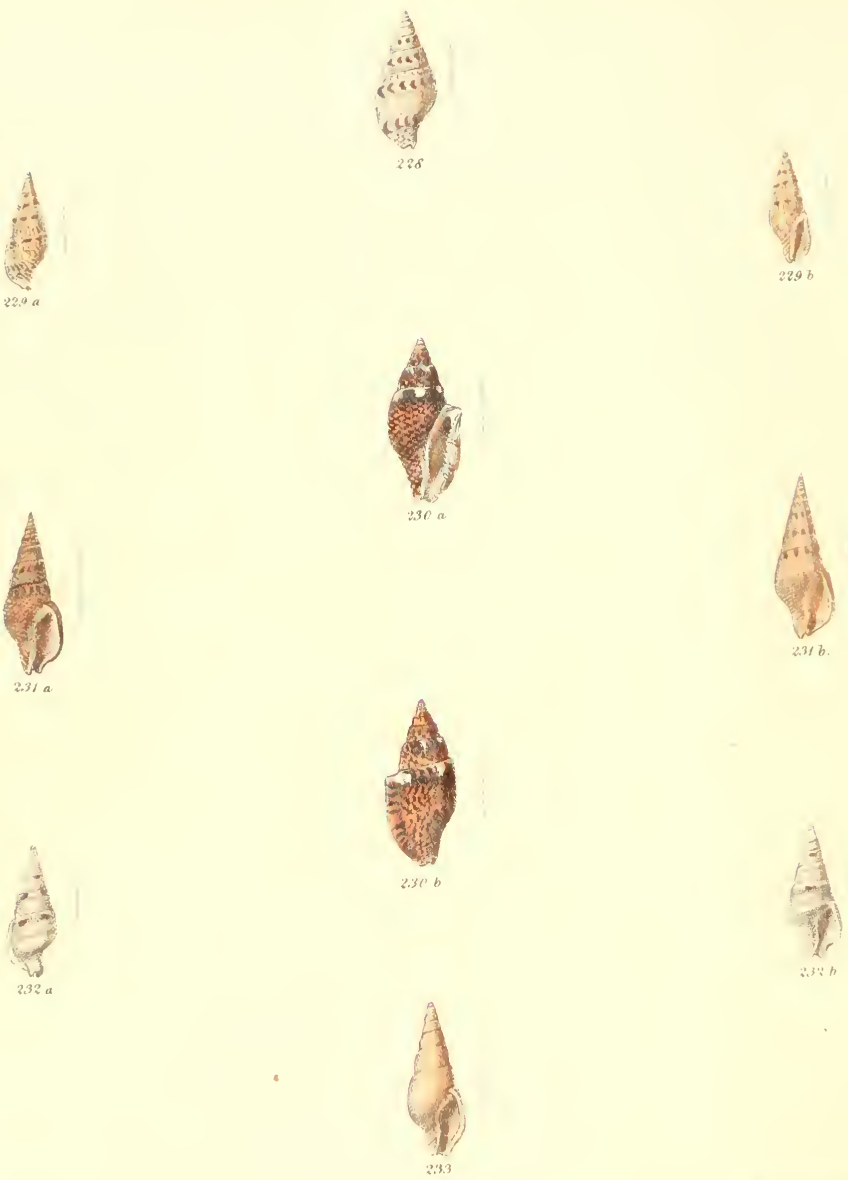


\section{O L U II B E L L A.}

\section{Plate XYITI.}

Ai.en-224, Mus. Taylor.1

Colvuber.1, Nonepta. Col. textâ ovalü, utrinque

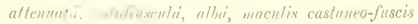

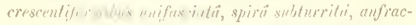

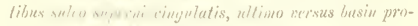

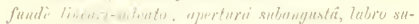

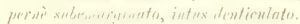

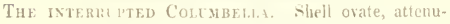
aterl at both ends, rather whil, whitc, encircled with a band of erescent-shaped chestunt-bromn spots, spire somewhat turreted, whorl, eneircled with a aroove rourd the upper part. the lant deeply linearly grooved towards the bave; aperture rather warrow, lip slightly motehed at the appur part, denticulated within.

Gaskorx; Pro. Zool. Soe. I 4,51, p. 3.

IIab. —?

Conspicuously encircled round the upper portion of each whorl with a band of crescent-hluped brown spots, while the sbell is more than usually lincarly grooved.

Species 229. (Fig. $a, b$, Mus. Taylor.)

ColtuBeLla Gulaxias. Col, textü fusiformi-oratû, solidinsculi, laxigatâ, nitentu", spirit subobtusüu, aufracti-

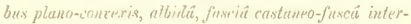
ruptî supuruè cingululat, drinde reticnlatä; ajerturâ parvât, utrimune dent ieulatá, lubro subeuricowo.

The MLKY-WAY COLTMBelia. Shell fusiformly ovate, rather solid, smooth, shining, spire rather obtusc, whorls flatly convex, whitish, cncircled round the upper part with an interrupted band of cbestnutbrown, and then retienlated; aperture small, deuticulated on each side, lip somcwhat varicose.

Hab. -

A subtransparcnt shell, filleted with a broken, linear, red band, and sprimbled with opaçue-white pearly spots.

\section{Spccies 230. (Mus. Taylor.)}

Coleubella cithara. Col. lestâ subquallintu-oratâ, solidula, allistri, castanco-reliculat $\hat{t}$, prope suluras nigricante et ulbimaculatia, spirit breciusculî, anfractibus supernè plicato-liratis, iufra spirmiter sulcatat; aperturẩ anyustâ, lubro supernè anyuluto-producto el emarginato, intus tenuè dentirulato.

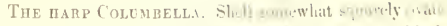
ratlier solid, whitish, vetientaied with chestnut, blickish, and white-bloteled next $\mathrm{A}_{\mathrm{r}}$ sutures, spire rather short, whorls plientely ridged rotw the upper part. spirally grooved below; apertume nirrow, lip anzalarly producerl and notched at the upper part. fiucly denticulated within.

\section{1ul. - ?}

An clegantly-formed harp-shaped shell, approaching to C. fluctratu, but differing obviously enougb in all particuliurs.

Species 231. (Fig. 231", Mus. Taylor.)

Coltubela creptsculty. (u). testä subulatá, solidh-

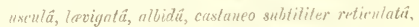
prope suturas migricante et albimm rulalâ, spirấ ucumimatâ, anfrnctibus plano-convexis, nitentibus, ultimo parwo, red basin sulcato el rermero: apurlurât purreii. labro varicoso, intus subtiliter denticulato.

Tie twilight Colembella. Shell subulate, rather solid, smooth, whitish, finely reticulated with chestnut, blackish, and white-spotted next the sutures, spire acuminated, whorls flatly couvex, shiuing, the last small, grooved aud recurved at the base; aperture small, lip varicose, fincly denticulated within. IIab.

The patteru of this species is a delicate white-puncturet network upon a dull orange-brown gronud.

\section{Specics 16. (Fig. 231 b, Mus. Taylor.)}

Colunbella fusmidus. Col. testấ subulatâ, solidinsculâ, lutescente-albit, uturantio-fusco temnè undulutâ, prope suturas maculat $\vec{a}$; aperturt pareü, labro varicoso, inferiè fusco warrelato.

The t.ItTle spinden Columbela. Shell stibulate, rather solid, yellowish-white, fuintly waved with orange-brown, spotted next the sutures; aperture simall, lip varicose, brown-spotted at the lower part.

Hab. -

The last whorl of this species is unusually small and contracted, and the lip is marked with a characteristic blotch of colour at the base. 


\section{COLUMbella.-Plate XXXY'}

Specles :32. (Fig. $a, b$, Mus. Taylor.)

f.u. mbella alabastres. Col. tes/i fusiformi, subpyrmuidali, marmoreo-albâa, prope suturas opacâ, maculis nstaneis distantibus sparsim notatâ, anfractibus plawatis, ultimo ad basin contracto, contorto et sulcato; yerturâ parvá, labro variroso.

Tilf. alabaster Colcmbelia. Shell fusiform, somewhat pyramidal, marble-white, opaque next the sutures, sparingly marked with distant chestuut blotches, whorls Hattened, last whorl contracted at the base, twisted and grooved; aperture small, lip varicose.

$11+1$

The substance of this very interesting species has the appearance of alabaster or white marble, a portion of which is polished, while the rest is rough and opaque.

$$
\text { Species 233. (Mus. Taylor.) }
$$

Colvmbella plerisulcata. Col. testâ subulatâ, undique spiraliter sulcutâ, anfractibus convexis; aperturá parnî, labro supermè subenarginato.

T'he masx-grooven Coltmbella. Shell subulate, spirally grooved throughont, whorls convex; aperture small, lip faintly notched at the upper part.

$\mathrm{Hab}$

Characteristically grooved throughout, but not included in this genus without considerable doubt as to the correctness of assigning it a place amongst the Columbellee. 

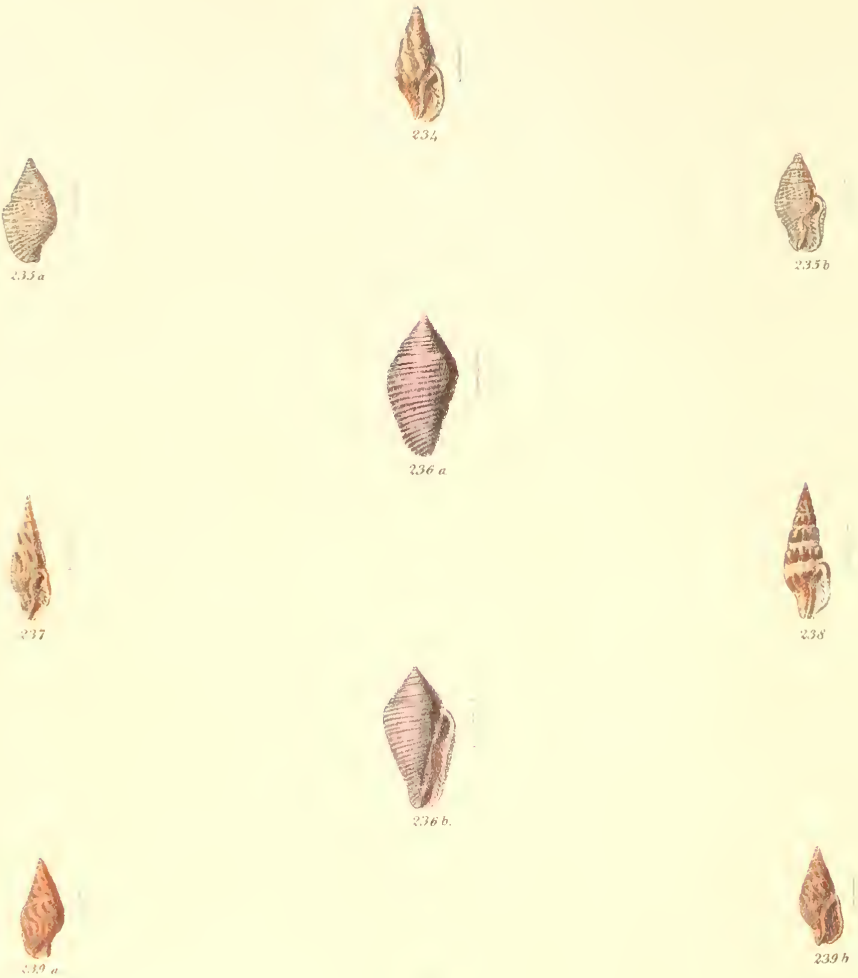

ifi 


\section{O L U II B E L L A.}

\section{Pute XXXVII}

Siven-234. Ins. Taylor.

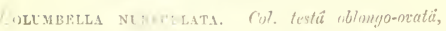

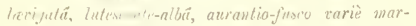

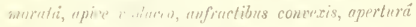
jurri, labro superute owerginato, intus praminente W. ntato.

Tire chocden Colombella. Shell oblong-ovate, smooth, yellowish-white, variously mottled with orange-brown, apex violet-tinged, whorls convex ; aperture small, lip notched at the upper part, prominently toothed within.

IIab. - - ?

Rather obscurrly clouded in respect of colouring, which inclines towards the base to form a fine network.

Species 235. (Fig. $a, b$, Mus. Taylor.)

Colcmbella scalpta. Col. testâa ovalî, pellucillo-aureâ, limeis pullinlis anguluribus transoersim notatâ, spirâ brevi, anfractibns longitulinatiter plicuto-costutis; "p.rturita parcâ, oblongo-sintusin, labro incrassato, superiè +warginato, intus dentirulati.

The scratcaied Columberca. Shell ovate, transparent golden-yellow, marked transversely with angular pale lines, spire short, whorls longitudinally plicately ribbed; aperture small, oblong, sinnous, lip thickened, notched at the upper part, denticulated withiu.

IIal.

A very striking species, of pellucid golden-yellow texture, marked transversely with light sharply-angled lines, like scratehes.

\section{Species 236. (Fig. $a, b$, Mus. Cuming.)}

Columbella ponmitor. Col. testri cyltudracro-ronoideá, undinue spirnliter liratii w. sulterlâ, violareâ, spirâ

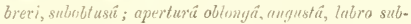
incrassato, superuè sulpmarginato, intus denticulato.

The sleeper Critumella. Shell cylindrically conoid, spirally ridged and grooved througlıout, violet, spire short, rather obtusc; aperture oblong, narrow, lip rather thirkened, faintly notched at the upper part, denticulated within.
Sotrensy, Thesaurus Conch. rol, i. p. 1+3. pl. 40. f. 173. Ilab. Island of St. Vincent, West Indies; Guilding.

This little species, of a distinctly typical ovuloid form, may be regarded as a characteristic example of Mr. Swainson's genus Conella.

Species 237. (Fig. $a, b$, Mtus. Taylor.)

Coltmbella oceldata. Col. testâ subulatâ, undique Ir mitudinaliler plicato-costellutâ, albidâ, aurantivfusco tinctâ et ocellatâ, spirit turritâ, anfrectibus plano-convexis, angustis, ultino ad basin sulcato ef recmo; aperturá parva, labro validè varicoso, intus. deaticututo.

THE EYed Columbelia. Shell subulate, longitudinally plicatcly ribbed throughout, whitish, stained and ocellated with orange-brown, spire turreted, whorls flatly convex, narrow, last whorl grooved, and recurved at the base ; aperture small, lip strongly varicose, denticulated within.

\section{Hal. - ?}

Finely longitudinally ridged throughont and marked with cye-like points dipping at rather distant intervals from the sutures.

\section{Species 238. (Mus. Cuming.)}

Columbella pelacia. Col. testâa siebulatâ, tnazgitutinuliter subtuberculato-costatâ, albâ, anrantio-fusco marmuratâ, spirât turritî, anfractibus angust is ; aperŁnrâ parrû, labro validè varicoso, supernè emarginato, intus devtirulato.

The deep sea Colchbella. Shell subulate, longitudinally somew bat tubercularly ribbed, white, marbled with orange-hrown, spire turreted, whorls narrow; aperture small, lip strongly varicose, notched at the upper part, reticulated within.

Ital. $\longrightarrow$ ?

Conspicuously marbled with orange-brown so as to lcave a central whitc band and a series of white sutural spots.

Species 239. (Fig. a, b, Mus. Cuming.)

Coltmbella chuavi. Col. testâ ocatâ, levigatâ, lutcs-

April, 1859. 


\section{COLUabella.-Plate Xixti.}

cente, castaneo-fusco lentiginosâ, spirâ obtusâ, anfractibus convexis; aperturâ parvâ, labro simplici, supernè subemarginato

The coffee-berry Coldmaella. Shell ovate, smooth, yellowish, freckled with chestnut-brown, spire obtusc, whorls convex; aperture small, lip simple, faintly notehed at the upper part.

Hab. Auckland, New Zealand.

A small olive-brown shell, mottled with somewhat obscure waved marks of chestnut-brown.

Species 240. (Mus. Taylor.)

Columbella lentiginosa. Col. testâ ovatâ, undique longitudinaliter costatâ, olivaceo-nigrâ, punctis albis bifasciatim lentiginosâ, anfractibus convexis, ultimo ad basin sulcato; aperturâ oblongâ, labro supernè emarginato, intus denticulato.

Tae freckled Columbella. Shell ovate, longitunatly ribbed throughout, olive-black, freckled with two bands of white dots, whorls convex, the last grooved at the base; aperture oblong, lip notched at the upper part, denticulated within.

Hinds, Moll. Voy. Sulphur.

IIab. Morton Bay, Australia (dredged in six fathoms water); Strange.

A dark olive-chestnut specics, freckled in a characteristic manner with white dots, mostly disposed into two bands. 


\section{O L U M B E L L A.}

\begin{tabular}{|c|c|c|c|c|c|}
\hline achatin., Sowerly & XII. & $\begin{array}{c}\text { Species. } \\
54\end{array}$ & cithara, Reeve ... ... i n - & XXIVI. & 230 \\
\hline acicula, Rrpere ... & $\mathrm{X}$. & 4.6 & clavulus (Pleurotomet, Sowerby & IV. & 16 \\
\hline acuminatr, Menke & XIV. & 69 & collaris, Reeve.... . ...... & XXVI. & 161 \\
\hline neus, Reere.... & XXXI. & 201 & concinua, Sowerby $\quad \ldots$. & XI. & 53 \\
\hline alabastrum, Reeve. & XXIVI. & 232 & conspersa, Graskoin .... & IIX. & 99 \\
\hline ala-perdieis, Recve & XIIV. & 145 & contaminata, Gaskoin ....... & XIX. & 102 \\
\hline albisa, Kiener.... . & XVIII. & 97 & conulus, Blainville. ... . . . . . & XVIII. & 94 \\
\hline albinodulosa, Gaskoin & XXIII. & 138 & corniculata (Buccinum), Lamarek & XV11I. & 91 \\
\hline albuginosa, Reeve. ...... & XXXV. & 223 & coronata, Sowerby .......... & VI. & 29 \\
\hline augularis, Sowerby. . ..... & I. & 1 & erassilabris, Reeve .......... & XXVJII. & 177 \\
\hline annulata, Reeve.... & XIX. & 101 & crepusculum, Reeve........... & XXXVI. & 231 \\
\hline Antillarum, Reeve.... . . & XIX. & 196 & cribraria (Buccinum), Lamarck. . & XIII. & 62 \\
\hline irata, Reere.......... - & XXIX. & 185 & Cumingii, Reeve ........... & XXY. & 156 \\
\hline aspersa, Sowerby ... & V. & 21 & decipiens, C. B. Adans....... & XX. & 111 \\
\hline atramentaria, Sowerty. & XXI. & 124 & deenssata, Sowerby .......... & $\mathrm{X}$ & 48 \\
\hline tomella, Duclos ............. & $\mathrm{XX}$ & 108 & delicata, Reeve.............. & XXVII. & 171 \\
\hline Australis, Gaskoin ... ... & $\mathrm{XV}$. & 78 & dermestoides (Buccimun), Kiener & XXII. & 14.4 \\
\hline austrina, (iaskoin ..... ... & XIX. & 100 & dichroa, Sowerby ........... & XXII. & 136 \\
\hline avara, Say ......... .... & XIV. & 73 & diminuta, C. B. Adams....... & XX. & 115 \\
\hline avena, Reere........ = = & $\mathrm{XXV}$ & 159 & discors (Foluta), Gmelin....... & XXXII. & 208 \\
\hline bacenta, Getslioin... .... & XXII. & 133 & dormitor, Socerby $\quad \ldots \ldots \ldots$. & XIXVII. & 236 \\
\hline bacnius, Reeve........ & XXV. & 157 & dorsata, Sowerby $\ldots \ldots \ldots \ldots$ & IV. & 15 \\
\hline bella, Recce........ . . & XXVII. & 172 & Duclosiana, Sowerby ......... & IV. & 76 \\
\hline picaualifera, Sowerby.. . . & XIII. & 64 & Dysoni, Reere............ & XVII. & 92 \\
\hline identata, Menke........ & XXXII. & 205 & elata, Reeve.............. & XXV. & 155 \\
\hline iflammata, Reeve...... . & XXXV. & 226 & clectroides, Reeve .......... & XIV. & 72 \\
\hline blanda, sowerby ...... . . & XIX. & 103 & elegans, Sonerby ........... & I. & 4 \\
\hline Boivini, Kiener . . . . . . . . & IX. & 43 & emarginata, Reeve... . ..... & $\mathrm{XXX}$ & 190 \\
\hline ridgesii, Reeve .. ... . . & IX. & 40 & encaustica, Reeve........... & XI1. & 56 \\
\hline Broderipii, Sowerby.... . .. & XXIII. & 139 & Essingtonensis, Reeve $\quad \ldots \ldots$. & XXVII. & 174 \\
\hline Brookei, Reeve. ........ & XXVII. & 169 & eximia, Rreve ............ & XXXV. & 222 \\
\hline Buccinoides, Sowerby & XVIII. & 98 & fabula, Sowerby ... ...... & XV. & 77 \\
\hline Californica, Reeve..... . . . & XXVI. & 165 & fasciata. Sowerby .......... & III. & 12 \\
\hline ancellata, Gaskoin ..... & X.XI. & 126 & fenestrata, Reeve.......... & XXVII. & 175 \\
\hline carinata, Hinds..... . & XXI. & 121 & festiva, Kiener............ . & XIII. & 60 \\
\hline castanea, sowerby ..... - & II. & 6 & flava (Buccinnm), Brnguière... & VI. & 27 \\
\hline catenata, Sozoerby ... ... & XXI. & 119 & flewidu, Lamarek.............. & VI. & 27 \\
\hline cavea, Rerve. .... ... & AXXI. & 203 & flexuosa (Buccinum), Lamarck. & VII. & 34 \\
\hline realis, Menke . ....... & XXI. & 118 & floccuta, Reere............ & XXVI. & 160 \\
\hline chlorostoma, Petit ..... . . & XXXIII. & 210 & fluctuata, Sowerby........... & IIII. & 38 \\
\hline choava, Reere ............ & XXYVII. & 239 & formosa, Gastioin . .......... & XXXIV. & $2 \mathrm{I} 6$ \\
\hline
\end{tabular}


COLL ILBELLA. INDEX.

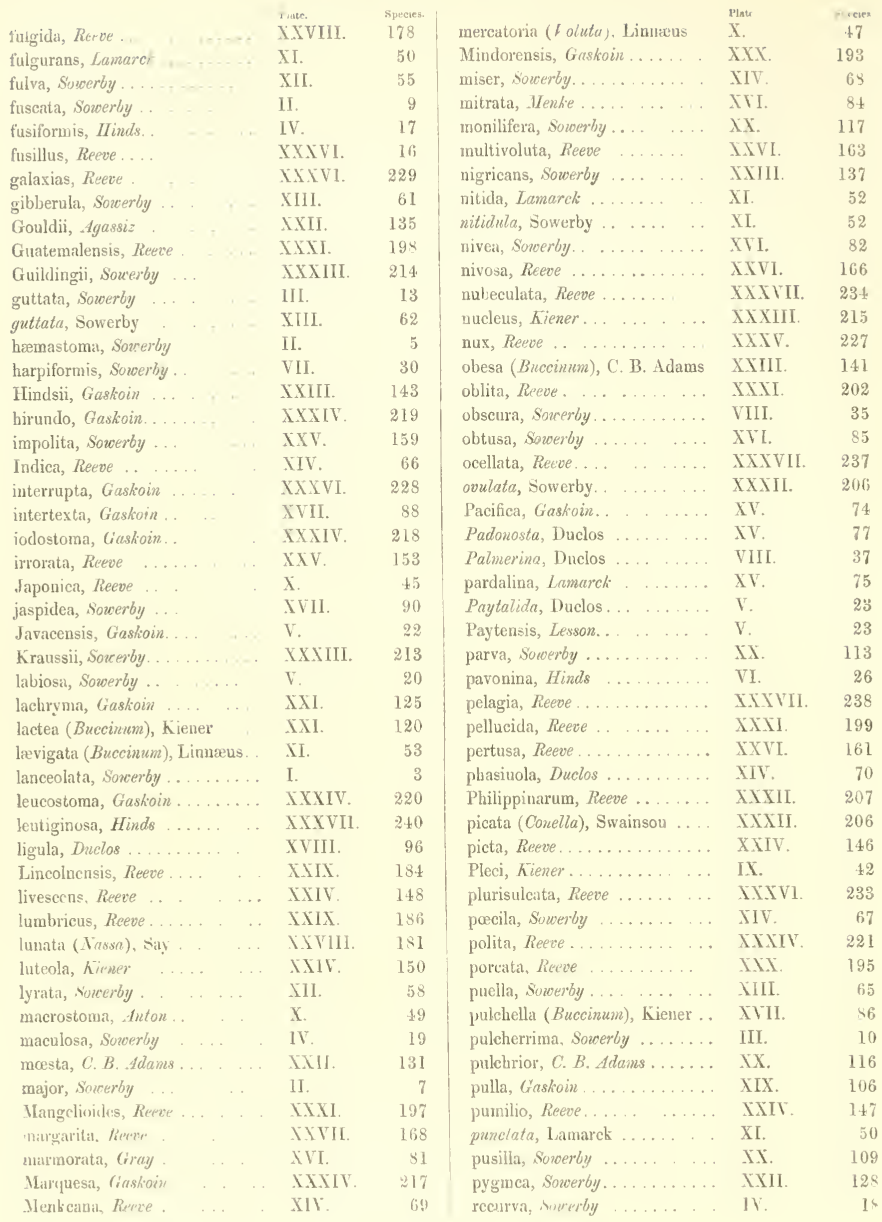


COLLMBELLA.-INDEX.

\begin{tabular}{|c|c|c|c|c|c|}
\hline reticulata, Lermenzel in & $\begin{array}{l}\text { Pinte. } \\
\text { IX. }\end{array}$ & $\begin{array}{l}\text { Species. } \\
41\end{array}$ & Tayloriana, Reeve ... ... y i : & Xxxv. & $\begin{array}{l}\text { Speres. } \\
22.5\end{array}$ \\
\hline 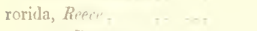 & XXYIII. & 176 & tcuebrica, Reeve . ........ & XXXI. & 204 \\
\hline rosacea, liee pr. & XXX. & 183 & teunis, Gaskoin ... & XXIT. & 224 \\
\hline rudes, Sowerby & II. & 42 & Terpsichore, Soverby .. & XII. & 59 \\
\hline rugosa, Soncerly & VIL. & 32 & tessellata, C. B. Allame = & AXII. & 134 \\
\hline rugulosa, Soxterby . . _... & $\mathrm{IIT}$ & 71 & Ticaonis, smeerly ... . . . . & XVIII. & 93 \\
\hline rustica $($ ovluta), Lituæu & дXXII. & 211 & tringa, Sozcerby ..... . it. & $\mathrm{V}$ & 24 \\
\hline fecharati, Recie...... ... & IXIX. & 187 & tuberculata, liceve & MTTII. & 173 \\
\hline agena, Reere ........ & XXTI. & 162 & tunida, Duclos ........... As & XIII. & 63 \\
\hline sagitta, Gashin ........... & IXVIII. & 150 & turturina, Lamarck. . . & XVI. & 83 \\
\hline Santa-Barbarens s, Carpen'or & III. & 122 & turrita, Sozoerby ......... I & I. & 2 \\
\hline 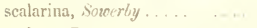 & III. & 11 & Tyicri, Gray ...... in i & TIII. & 37 \\
\hline scalpta, Reeve ......... . . & IXXVII. & 235 & uncinata, Sonoerby ... & XXIIL & 142 \\
\hline seutulata, lieere............ & SXX. & 191 & unicolur, Soverby .... . w & XIX. & 105 \\
\hline semiconvexa (Bucrimun), Lan. . & IVIII. & 95 & unifasciata, Sozoerby..... i , . & XIX. & 107 \\
\hline mipuzctato, Lamarck ....... & IXXII. & 204 & mizonalis, Gray ....... , w. & XIX. & 107 \\
\hline soliclula, Reere. ............ & X.IIV. & 149 & valida, Reeve....... & XXIV. & 151 \\
\hline spadicea, Phitippi .......... & XII. & 123 & varia, Sorerbly. . . . . ... & III. & 14 \\
\hline sparsa, Reveve........... & IXXI. & 200 & varia, Sowcrby ....... & XIXIL. & 206 \\
\hline spectrum, lieeve ...... . . & XXX. & 194 & varians, soccerby . . . . . . . & IVII. & 91 \\
\hline splendidula, Soxerby . ....... & VI. & 25 & varicosa, Gastivin ......... & VII. & $3 \mathrm{I}$ \\
\hline spongiarum, Duclos.......... & VIII. & 39 & velata, Reeve....... , ,... & NXVIIL & 182 \\
\hline spurea, Sowerby .. ....... . & V. & 23 & renusta, Reeve............. & rill. & 130 \\
\hline strigata, keete............. & XNIV. & 154 & versicolor, Sowerby .......... & XI. & $5]$ \\
\hline Strombiformis, Lamarct: . . & II. & 8 & vexillum, Recce.......... & XII. & 57 \\
\hline subulita, forrerly . . .... . & XIIIII. & $2 \mathrm{I} 2$ & vittata, Reees ............ & XXx. & 192 \\
\hline suffusa, sucerby ............ & XVII. & 89 & vuIpecula, Sorcerby ... .... . & XVI. & 80 \\
\hline sugillata, Reeve... ....... & XXIX. & 189 & xiphitella, Duclos. . . . . . . . . & IX. & 44 \\
\hline sulcosa, Sozerby .......... & XXII. & 132 & zebra, Gray.............. & IV. & 79 \\
\hline eniati, Adams and herce. & IXIII. & 140 & zelina, Duclos $\ldots \ldots \ldots \ldots \ldots$ & XXIV. & 152 \\
\hline aniata, Philippi ...... ... & XXII. & 130 & & & \\
\hline
\end{tabular}

ERRATUM.

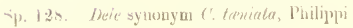





\title{
MONOGRAPH
}

\author{
OF THE GENUS
}

M E T A.

- Shrin'd in the undst, majestre Nature stands. Estends o'er earth and sea her huudred hands Tower upou tower her beany forehead erests, tod birth nnumbered nilk ler hundred breasts." 


Heta Pl. I.
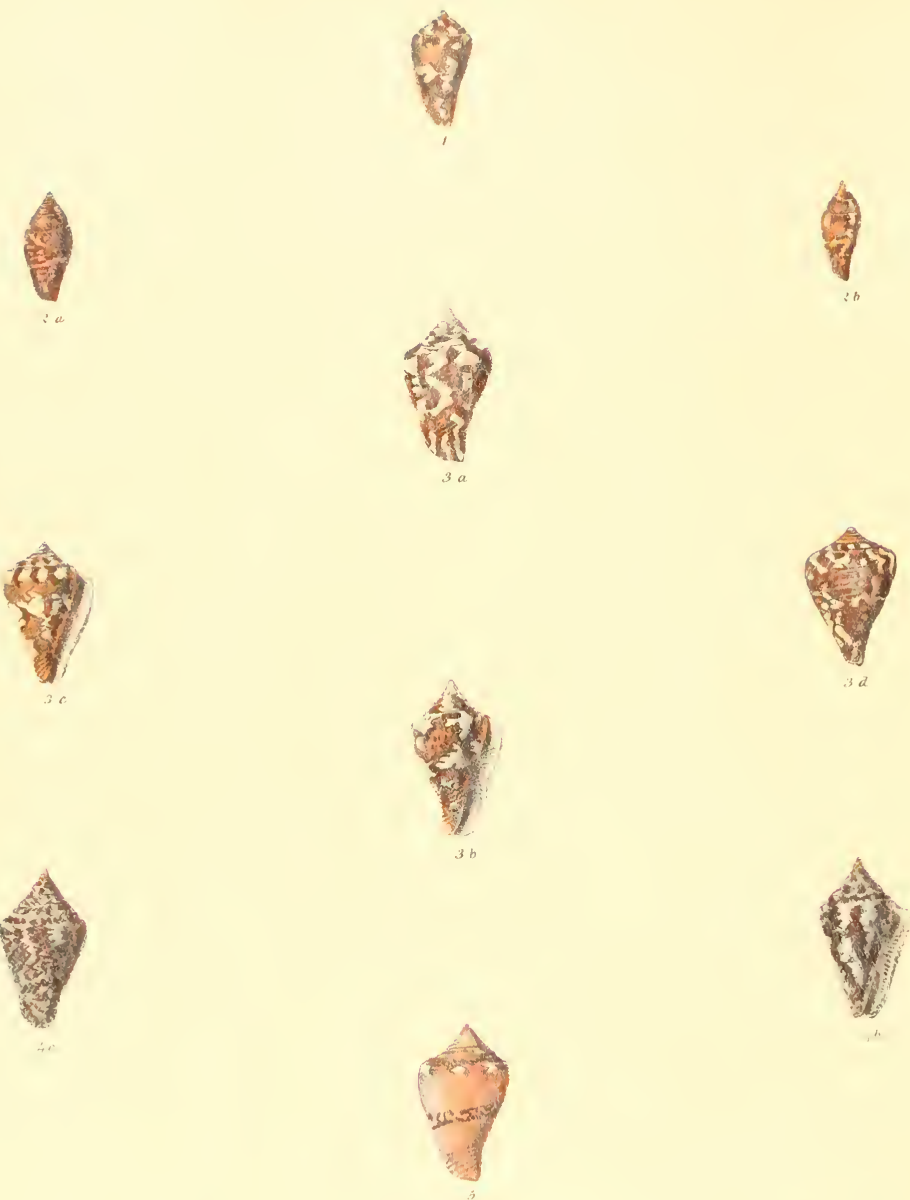


\section{E T $\mathrm{A}$.}

Plate 1.

Gieuns META, Reeve

Tesla ronoidea, versus basin regulariter attennata, spera breviusculâ, plerumque superficialiter canaliculatá. Apertura elongata, angusta, fance prope marginem radiatim lirat $\vec{a}$, liris brevibus.

Shell conoid, regularly attenuated towards the base, spire rather short, generally superficially channelled. Aperture elongated, narrow, interior radiately ridgell ucar the margin, ridges short.

The shells for which I here introduee a new genus are exactly intermediate in character between Mr. Swainson's two gencra Stromboidea and Conclla; but they constitute a group of better definition, and consequently higher rank in the system, than either. Stromboider, on the one side, represented by the Lamarckiau Strombi urceus and gibberula, and Conella on the other, of which the Columbella semipunctata and picata may be quoted as types, can only be regarcled as subgenera of the parent groups, whilst the six spccies which I associate together nuder the head of Irta are distingushed by an asseublage of characters peculiarly their own. There must necessarily be intermediate links ou the confines of all genera, and in the preseut there is a species, .1Y. ovuloites, with the lip ascending upon the penultimate whorl, which might with equal propriety be placed among the Conella. In the other specics of Ifeta this character, which is one of the typical features of Conella, is wanting.

The form of Meta is that of a solid cone, but the lip is sculptured within with short radiating ridges, such as in Columbella are developed as tcetli, and in Strombus as more extended ridges. There is also a peculiarity, so far as the species are at present known, in the style of painting.

The only information possessed relative to the habitat of the species, is that one is from south Africa.

\section{Species 1. (Mus, Cuming.)}

Met. macrostoma. Met. testâ subanyustè conicâ, spirâa cylindraceâ, apice obtusè elatâ, anfrartilus supernè spiraliter lineari-sulcatis, deinde lrevibus, cito fortius sulcatis el lirutis; aurantio-fuscâ, albo cariè nebulatâ, apice rosaceo; aperturâ elongatâ, fuuce radiation liratâ.

The LARge-Movth IExa. Shell rather narrowly coni- cal, spire eylindrical, slrusely raised at the apex, whorls spirally linearly grooved at the upper part, then smooth, soon more strongly grooved and ridged, orange-brown, variously clouded with white, apex pink; aperture clongated, radiately ridged within. Conus macrostoma, Anton?, MS. in Mus. Cuming. Hab. - ?

This species, which has I believe been described by II. Auton as a Cone, very much resembles Mr. Broderip's Conus concinnus; but it may readily be distinguished from that shell by the radiating ridges of the aperture, which constitutes its claim to a place in the present genus.

Species 2. (Fig. $2 a$, Mus. Tilylor. Fig. $2 b$, Mus. Cuming.)

Meta oveloines. Met. testẩ cyliedracea-oblongâ, spirä abtusè etat $\hat{a}$, anfractibus supernè spiraliter striutis, deinde levibus, ad basin pauciliratis; fulvo-crstaneä, albido punctatâ et variegat $\vec{a}$, apice albâ; apertarâa angustâ, fauce radiation liratâ, labro subinflexo, supernè ascendente.

The ovuloid Meta. Shell eylindrically oblong, spire obtusely raised, whorls spirally striatcd round the. npper part, then smooth, sparsely ridged at the base; fulvous-chestnut, dotted and variegated with white; aperture narrow, radiately ridged within, lip rather inflected, ascending at the upper extremity.

Conella oruloides, C. B. Adams, MS, in Mus. Cuming. IIab. —?

The lip of this species aseeuds at the upper extremity on the penultimate whorl, after the manner of columbellet semipunctata, picata, and coulata, which are types of $\mathrm{Mr}$. Swainson's Conella, and it may be therefore regarded as the intermediate link between that genus and the present, of which $M$. Dupontire is the type.

Species 3. (Fig. $3 a, b$, Mus. Cuming.)

NETA CEDO-NULli. Met. Lestä conoideâ, versus busin cu"rrctato-attenuetâ, spirấ subelatî, acut â, anfractitus supernè anyulatis, ad basin panciliratis; fulvo-aurantint, albo conspicuè eleganter maculatâ et retirulatáa; npertur $\hat{a}$ subuntgustâa, fuuce radiation liratâ.

The Matchless Meta. Shell conoid, contractelly at- 


\section{META.-Plate I,}

tenuated towards the base, spire somcwhat raised, sharp, whorls angled at the upper part, sparsely ridged at the base; fulvous-orange, conspicuously elegantly blotched and reticulated with white; aperture rather narrow, interior radiately ridged. IInl.

An elegantly formed and very charncteristic specics, painted not much unlike the Conus cedo-nulli.

Species 4. (Fig. $a, b$, Mus. Cuming.)

Meta coniformis. Met, testâ conoideâ, spirâ subamplâ, elatâ, superficialiter canalicnlatâ, anfractibus supernè subacutè angulatis, deinde lavibus, ad basin fortiter liratis; albâ, purpureo-castaneo undique inconditè reticulatâ; aperturấ subangustâ, fance violascente, parum liratâ.

The cone-shaped Meta, Sbell conoid, spire ratlier large, raised superficially channelled, whorls rather sharply angled at the upper part, then smooth, strongly ridged at the base; white, confusedly reticulated throughout with purple-chestnut; aperture rather narrow, interior pale-violct, but little ridged.

Sowerby, Thesaurus Conch. rol. i. p. 122. pl. 37. f. 77, 78 (misprinted $C$. cornifornis). IIab. —?

This species may be distinguished without difficulty by its more fusiformly conoid shape and confused pattern of painted network.

Species 5. (Mus, Cuming.)

METa Dubia. Met. testẩ ovato-conicâa, solidiusculâ, spirâa superficialiter canaliculatâ, anfractibus supernè olitusè angriatis, ad basin liratis; rosaceo-aurantiâ, fasciá fuscescente, ulbo ntarmoratâ, supernè et medio cingulatâa, apice rosaceo; aperturâ subangustâ, fauce parum liratâ,

The doubTful, Meta. Shell ovately conical, rather solid, spire superficially ehannelled, whorls obtusely angled at the upper part, ridged at the base; roseateorange, encircled above and round the middle with a white-marbled lrownisb band.

Strombus llubius, Sowerby, Thesaurus Conch. vol. i. pl. 7. f. 80 .

IIab. - ?

Distinguished by a delicate yellowish-roseate bue and central marbled band.

Species 6. (Fig. $c, d$, Mus. Cuming.)

Meta Depoxti.:. Met. testâ abbreviato-conicâa, supernè tumidiusculâ, spirấ breci, anfractibus supernè obtusè angulatis, lavibus, ad basin pauciliratis; auruntiä, olivaceo linctâ, maculis albis subamplis fasciatim reticulatâ, apice rosaceo; aperturâ oblongâ, fauce parum liratâ.

Dupont's METa. Shell shortly conical, rather swollen at the upper part, spire short, whorls obtusely angled at the upper part, smooth, sparsely ridged at the base; orange, tinged with olive, reticulated with bands of rather large white spots, apex pink; aperture oblong, interior but little ridged.

Conus Dupontic, Kiener, Icon. Coquilles vivantes.

Itab. Ichabo, South Africa.

The painting of this specics is very similar in character to that of $M$. cedo-nulli, but the form is well distinguished by its broader and more swollen aspect round the base of the spire. 


\section{MONOGRAPH}

OF THE GENUS

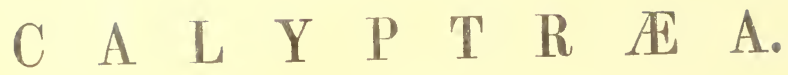

"But that $I$ am forbid

To tell the secrets of my prison-house,

I could a tale unfold."-Shakspeare. 


Caliptrara PI I
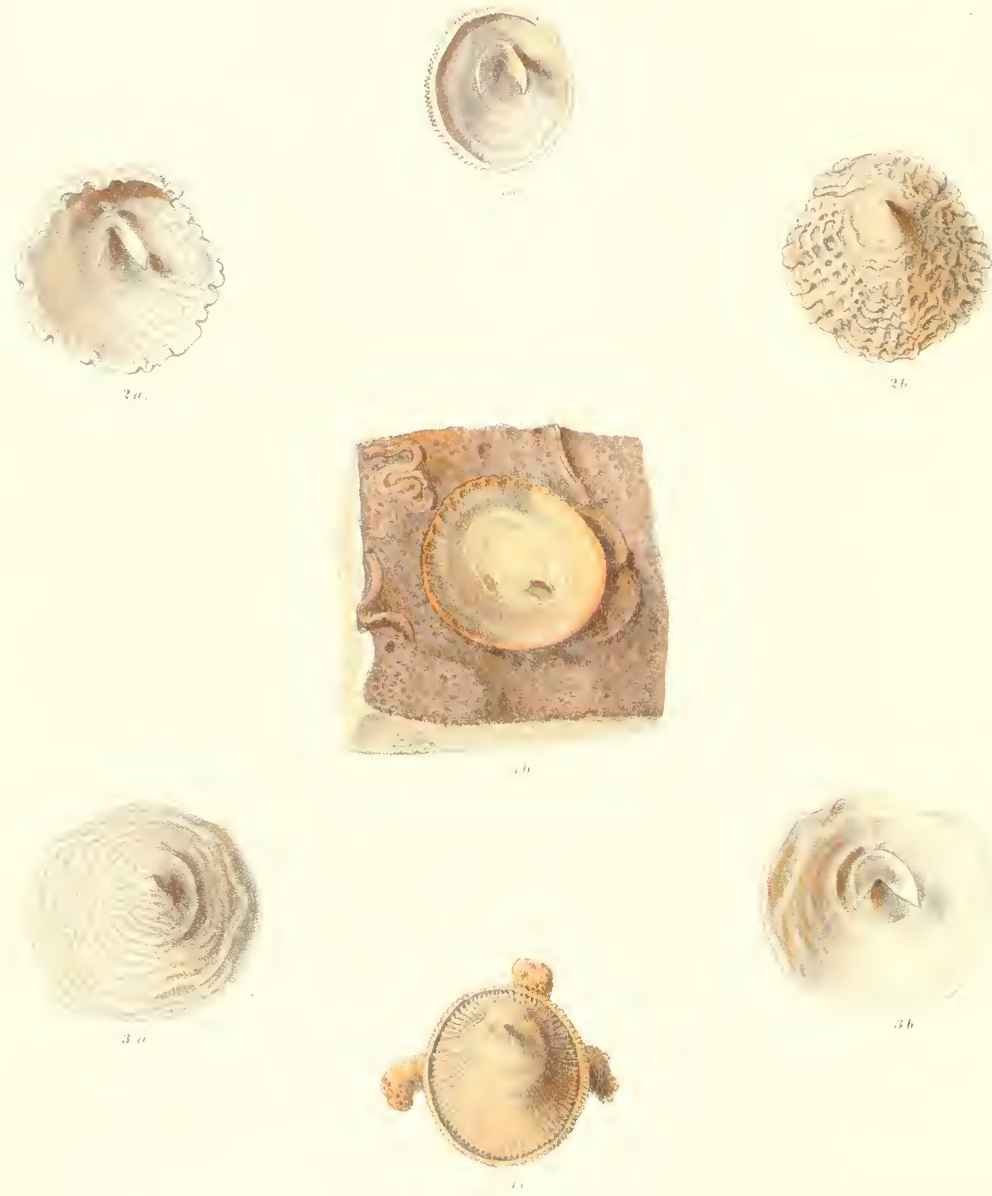


\section{A L Y P T R A A.}

Plate I.

\section{Genns CALYPTR玉A, Lamarck.}

Testa globoso-conica, tenuis, irregularis, vertice plerumque rostrata, pellucido-alba, radiatin densè minutissimè slriata, appendice internâ obtiqnä, semi-infundibuliformi; interdum valvam basalen formans.

Shell globosely conical, thin, irregular, generally beaked at the top, transparent-white, radiately densely very ninutely striated, with an internal, oblique, scmifunnel-shaped appendage; sometimes forming a basal plate.

When M. Deshayes, in his edition of the 'Animaux sans Vertèbres' of Lamarck, eame to examine the Cop-andSaucer and Slipper limpets, eornprised respeetively in the genera Calyptrca and Crepidula, he found them to be so nearly allicd to cich other as to desire that they should be united into a single genus, after the manner of Helix and Carocolla. "There exists a eertain number of particular forms," said M. Deshayes, "to serve for grouping them in seetions, but the internal appendage, wlich in some Culyptrace is funnel-shaped, passes insensibly into the trochiform appendage of others, and into the septum of Crepidula; and the two genera must therefore be united." "This conclusion," continues the learned editor, "which we have in some degree foreseen, has been rigorously drawn and acted on by incontestable evidence, in a paper recently published by Mr. Broderip in the first volume of the Transactions of the Zoological Society."

Since the forcooing was written, the discovery of the animal of Calyptraca equestris has afforded evidenee, not only that the Crepidule are distinct, but that the seetions of Calyptreca indicated by M. Deshaves should be regarded as genera of the same rank. I propose, then, to retain Crepidula in its Lamarckian form, and for the cup-appendaged, and the troehoid, Calyptrece to adopt the genera respectively instituted for them by Schumaeher, Crucibulum and Trochita. It will be seen presently that the three very charaeteristic groups litherto ineluded under the head of Calyptrea eanuot be regarded as sub-genera of a rank inferior in the seale to Crepirlula. The Calyptrace proper, represented by the Linnaan Patella equestris, are all characterized by a shell of pcculiarly fine, semitransparent thread-like tissue, and it may be fairly inferred that the animal whieh has been shown to be distinct in one species, corresponds with the shell in its distiuctness in all.

When Mr. Cuming visited the island of Zebu, one of the Philippine group, about twenty years since, he ohserved on some coral reefs a number of dead shells of $\mathrm{Ca}$ lyptrac equestris. Supposing that living specimens could not be far off, lie was induced after eonsiderable seareh to turn over a mass of coral that lay sunk about two feet in the sand, just below low-water mark. To his surprise, he found the living Calyptrea equestris attached by the foot to a separate calcareons plate. Upon further search he discovered specimens of other species similarly attached, and some also at the island of Bohol; and having captured the animal, he submitted it to Professor Owen for dissection. The phenomenon was observed about the same time at Mahé, one of the Seyehelle 1slands, by M. Dufo, a distinguished French eonehologist, but no dissection appears to have becn made by him of the animal. Professor Owen found the animal to differ from other known forms of Calyptraide " in the smaller development of its locomotive and respiratory organs, and in the greater development of the organs for the prehension and assimilation of food." "The foot," continucs the Professor, "may well offer diminished proportions when the animal has chosen a site for the deposition of its ventral plate, and has taken up a fixed abode. Muscular action being thenceforward mueh restrieted, the necessity for extensive respiration is in the same degree abolished."

The C. tectum-Sinense was the only other species of this group known to Lamarck, but attention having been drawn to them, upwards of thirty have been colleeted, chiefly from the l'bilippines, Moluceas, and Galapagos 1slands, but some from Honduras, the West Indies, Ceylon, and Australia.

\section{Species 1. (Fig, 1 $a, b, c$, Mus. Cuming.)}

Calyptrea equestris. Calyp. testâ suborbiculari, solidiusculâ, rudè convexâ, vertice minutè rostratâ, albâ, prope narginem fulvescente, radiatim tenuiliratâ, liris acutis, compressis, undulatis, subtuberculatis, interstitiis rudiatin minutè striatis; appendice internâ subamplâ; valvâ basali amplâ, concavâ, patellaformi, margine irregulariter obscurè corrugatî.

The knightoy Calyptra. Shell nearly orbicular, rather solid, rudely convex, minutely beaked at the top, white, fulvous near the margin, radiately finely ridged, ridges sharp, compressed, a little waved, somewhat tubereled, interstices radiately minutely striated; in-

December, 1858. 


\section{CALYPTRÆA.—PLATE I.}

ternal appendage rather large; basal plate large, concave, platter-shaped, irregularly obscurely puckered at the edge.

Patella equestris, pars, Linnaus, Syst. Nat. p. 257.

Calyplran equestris, pars, Lamarck.

Culyptrca Roissyi, Dufo.

Litkedaphins longirostris, Owen.

Hab. Island of Bohol, Philippines (attached to the under surface of masses of coral pressed to some depth in in the saud); Cuming

It is impossible to determine which of the two or three nearly allied forms of Calyptricea represented by this species is the original type of the Limnæan I'atella equestris. The shell which $I$ assign to it, the same of which the animal was deseribed in 1842, by Professor Oweu, under the title of Litliedapleus longirostris, corresponds the best with the Lamarckian dingnose, "striis longitudinalibus acutis, undulatis, subtuberculatis," though not with the Lamarckian figures of reference; and it corresponds also best with Dufo's C. Roissyi, which he describes as having the margin of the upper shell dentated, the extremities of the ridges giving it that appearance. The basal valve of this species takes the form of a concave platter, obscurcly puckered round the edge, without reference to the nature of its place of attachment. The two specimens here figured have precisely the same platter-like valve at the base, though attached to very different substances. The specimen fig. $1 b$, the upper valve belonging to which is represented above at fig. $1 a$, is set in the bed of a solid coral mass; while the specimen fig. $1 c$, with the upper valve in situ, is attached to a sprig of branching cornl.
Species 2. (Fig. $2 a$ and $2 b$, Mus. Cuming.)

Calyptráa tortilis. Calyp. testä suborbiculari, depresso-conicith, vertire obtusâ, candidâ, sub lente minutissimè radiatim striatâ, versus marginem peculiariter corrugatâ, rugis tumidis, valdè promiscuis; appendice internâ mediocri.

The crumpled Calyptran. Shell somewbat orbicular. depressly conic, obtuse at the top, white, beneath the lens very minutely radiately striated, peculiarly crumpled towards the margin, the crumples being swollen and very promiscuous; internal appendix middling.

Ilab. Galapagos Islaurls; Cuming.

Strongly marked by a peculiar crumpling or shrivelling of the outer surface.

Species 3. (Fig. $3 a$ and $3 b$, Mus. Cuming.)

Calyptria cjcatricosa. Calyj. testâ orbienlari, depressî, vertice parmu eleontâ, tenui, candidâ, sub tente minnlissiurè ralint in striati, concentricè peculiariter plicuto-corrugatä, rugis tumidis, irregularibus; appendice intrüi latiusculâ.

The cicatriced CaIy PTR.A. Shell orbicular, depressed, but little raised at the top, thin, white, beneath the leus very minutely radiately striated, concentrically peculiarly plicately crumpled, crumples sivollen, irregular; internal appendage ratber broad.

Hab. Catanauan, Province of Tayabas, Islaud of Luzon, Philippines; Cuning.

An interesting species, of rather flattened growth, curiously crumpled, but on a different plan to the preceding species. 


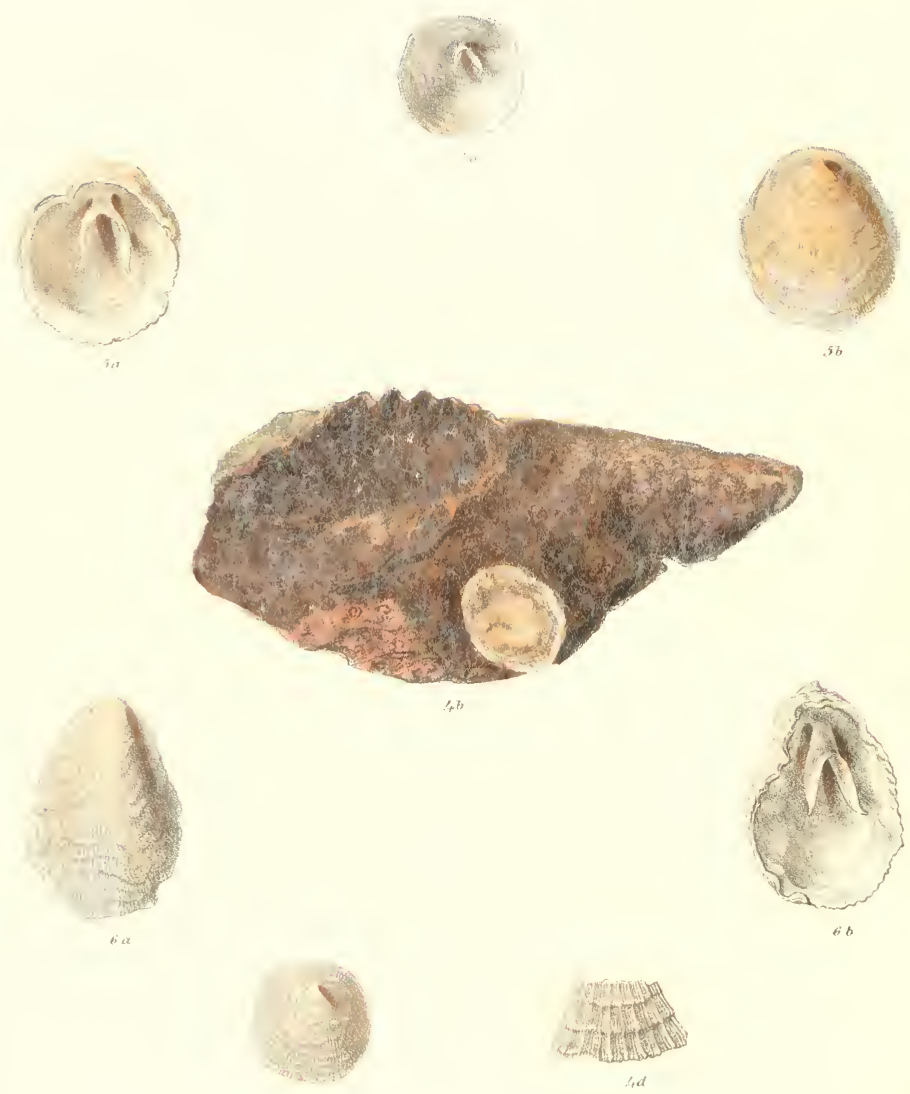


\section{A L Y P T R E A.}

Plate II.

Species 4. (Ft, $4 n, \delta, c, d$, Mus. Cuming.)

Cilyptr.ea bunla. Culyp. testä suborbiculari, tenuissinâ, prilucido-allhâ, subconoide $\hat{a}$, concentricè plicatocorrugatä, nertice eix rosirat $\vec{a}$, andique pulcherrimè radialin lirato-striatâ, strïs striatulis concentricis sub lente subbilissimè fenestrafis; appendice interna $\vec{a}$ breriusculâ, gracili; valvâ basali tenui, irregulari, opacêt.

The bтbBle Calyptr.fa. Shell nearly orbicular, very thin, transparent-white, subconoid, concentrically plicately wrinkled, scarcely bcaked at the top, cverywhere very beautifully radiately ridge-striated, stria very finely latticed beneath the lens with concentric finer strix; internal appendage rather short, slender; basal valve thin, irregular, opaque.

Hab. Island of Zebu, Philippines (attached to the under surface of the ledge of a hard sandstone-rock); Cuming.

An extremely delicate glassy shell, the elaborate latticed texture of which, represented on a highly magnified scale at Fig. $4 d$, is quite warvellous when examined with a lens before the light. It is, nevertheless, only a form of sculpture which predominates with a peculiar typical exactness under various phases in all the species. The basal valve, seen at the lower edge of the piece of rock, Fig. $4, b$, is but a slight irregular deposit of calcareous matter, void of any regular sculpture. Fig. $4 a$ and $4 c$ represent the interior and exterior of the shell removed from its place of attachment.

Species 5. (Fig. $5 a$ and $5 b$, Mus. Cumizg.)

('alyptráa dommitoria. Calyp. testâ ovalâa, rudè convexẩ, margine simuatâ, olliquâ, vertice laterali, obtusi, pellucido-albä. supernè subferrugineâ, superficialiter corrugatâ, radiatin regulariter subtiliter striutâ ; uppenelice interná valdè obliquâ.

The NigHT-Cap CalyptraA. Shell ovate, rudely convex, sinuated at the margin, oblique, vortex lateral, obtuse, transparent-white, tinged with rust towards the upper part, superficially wrinkled, radiately regularly finely striated; interual appendage very oblique.

Hab. Island of Burias, Philippines; Cuming.

An obliquely formed tumid species, rather crumpled at the margin, finely striated throughout.

Species 6. (Fig. $6 a$ and $6 b$, Mus. Cuming.)

Calyptrana papyracea. Calyp. testâ compressè ovatâ, tumido-conicấ, obliquâ, vertice postico, pellucido-albâ, radiatim subconspicuè striatâ, undique pecnliariter corrugatâ, margine sinuatấ; appendice internâ, valdè obliquá.

THE PAPER CALYPTREA. Shell compressly ovatc, swollen conic, oblique, vertex posterior, transparent-wbite, radiately rather conspicuously striated, everywherc peculiarly wrinkled, sinuated at the margin; internal appendix very oblique.

A. AdaMs, MS. Mus. Cuming.

Hab. Philippine Islands; Cuming.

A light, swollen, compressly ovate species, very obliquely grown, the vertex being quite posterior. The strix are more conspicuously developed than in the preceding species, and there is a peculiar wrinkled character about the surface which does not appear to have arisen from any irregularity of its place of attachment. The crumpling of the margin is also characteristic. 

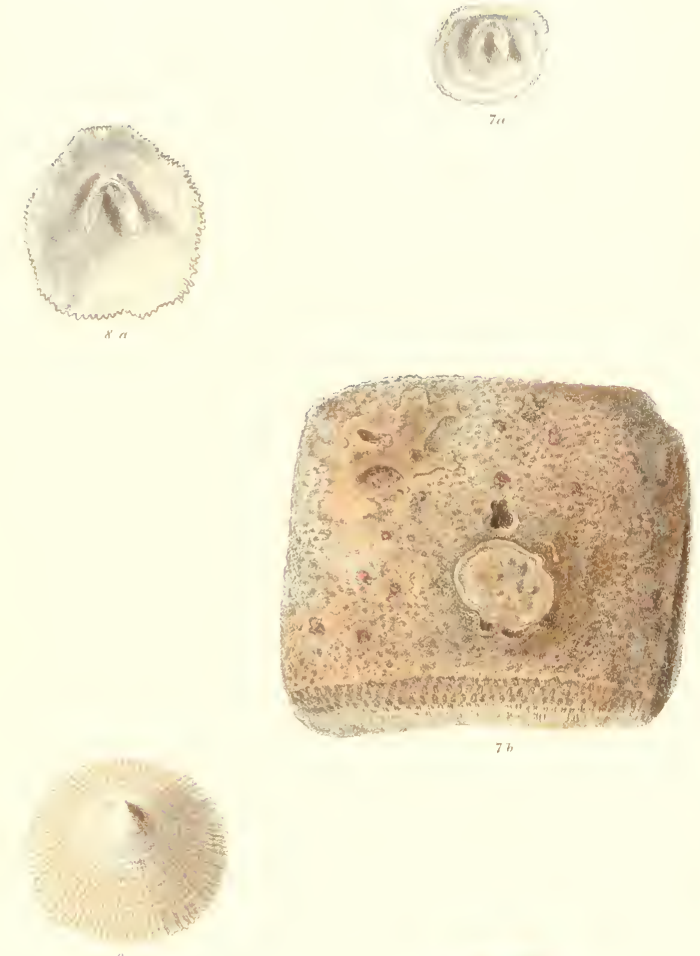

76
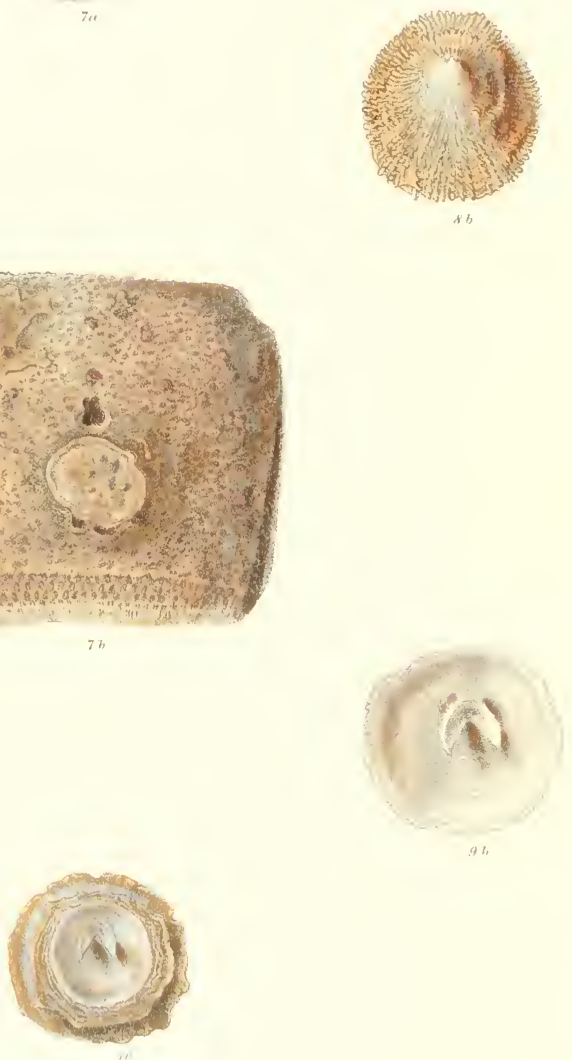


\section{A L Y P T R E A.}

\section{Plate III.}

Species (Fig. $7 a$ and 76 , Mus, Cuming.)

Calyptra Adansit. Calyp. testâ suborbiculari, solidiusculâ, depressu-conicá, concentrirè plicalo-laminatâ, vertice abtusâ, radiation densè lirato-striat $\vec{t}$, striis valdè acutis, conferlis, undulatis; appendice interná prominente; valcá basali tenui, subobsnurâ.

Aisass's Calyptrxa. Shell nearly orbicular, rather solid, depressed, conical, concentrically plicatcly laminated, obtuse at the top, radiately densely ridgestriated, strixe very sharp, close set, waved, internal appendage prominent; basal valve thin, rather obscurc.

Calyptrca depressa, Adams and Reeve (not of Lamarck), Moll. Voy. Samarang, 1. 70. pl. 11. f. $2 a, b$.

Hab. Dalegucte, Island of Zebu, Philippines (on masses of coral, buried in saud at a depth of from two to four feet); Cuming.

Detached specimens of this species, collected by Sir Edward Beleber in the Clima Sea, and described by Mr. Adams and myself in the 'Mollusea of the Voyage of the Samarang,' under a name which I find has been used by Lamarck in retereuce to a fossil species, prove identical with the specimen before me collected by Mr. Cuning on its native coral at the Philippine 1slands. Fig. if represents a piece sawn from a block of coral with the thin basal plate in the centre; and Fig. 7 a represents the sbell letached from it to show the interior.

Species 8. (Fig. $8 a$ and $8 b$, Mus. Cuming.)

Calyptrea alveolata. Catyp. testâ suborbiculari, sordidè albâ, deprisso-convexâ, vertice acutè rostratâ, vertice sublaterali, radintim lirntá et striatâ, liris fexuosis, valdè irregularibus, undique conpresso-squamatis, concentricè hic illic tenuè finbriat $\hat{a}$; appendice internâ subextensá.

THE HONExcombed CALyptr fa. Shell somewbat orbicular, dull-white, depressly convex, sharply beaked at the top, top rather lateral, radiately ridged and striated, ridges flexuous, very irregular, everywherc compressly sealed, concentrically thinly fimbriated

here and there; internal appendage rather extended. A. AdAMs, MS. Mus. Cuming.

Hab. Galapagos islands; Cuming.

The ridged sculpture in this species bas a peculiar wildly flexuous character, and is laterally compressed and raised into scales tliroughout, interrupted at intervals with fine concentric laminar frills.

Fig. $9 a$ and $9 b$. (Mus. Cuming.)

This transparent and elaborately carved shell, collected by Mr. Cuning, at Baclayan, Island of Bohol, Plilippines, appears to be a variety, of more regular and delicate growth, of the preceding species from the Galapagos Islands. The ueneral form, especially as regards the vertex, is the same, and the idea of sculpture, though differently dereloped, is similar.

\section{Species 10. (Mus. Cuming.)}

Calymtrea tectum-Sinense. Calyp. lestâ orbiculari, pellucido-albut, depressâ, lancellis tenuitus concentricis nunerosis peculiariter contabutatâ, lamellis striis densè radiatis, vertice recto; appendice internâ subprominente.

The Chinese-roof Calyptrfa. Shell orbieular, transparent-white, depressed, pcculiarly roofed with numerous concentric lamellæ, which are densely rayed with strix, vertex straight; internal appendix rather prominent.

LAMARck, Anim. sans vert. vol. vii. p. 624 .

Patella tectum-sinense, Chemnitz.

Hab. Islaud of Capul, Philippines (abundant under stones at low-water); Cuming.

The peculiar succession of raised lamellæ with which this species is roofed, giving an appearance to the shell which suggested to the old French naturalists the name of Le Toit Chinois, has been so often figured that 1 have deemed it sufficient to give the under surface and interior. 



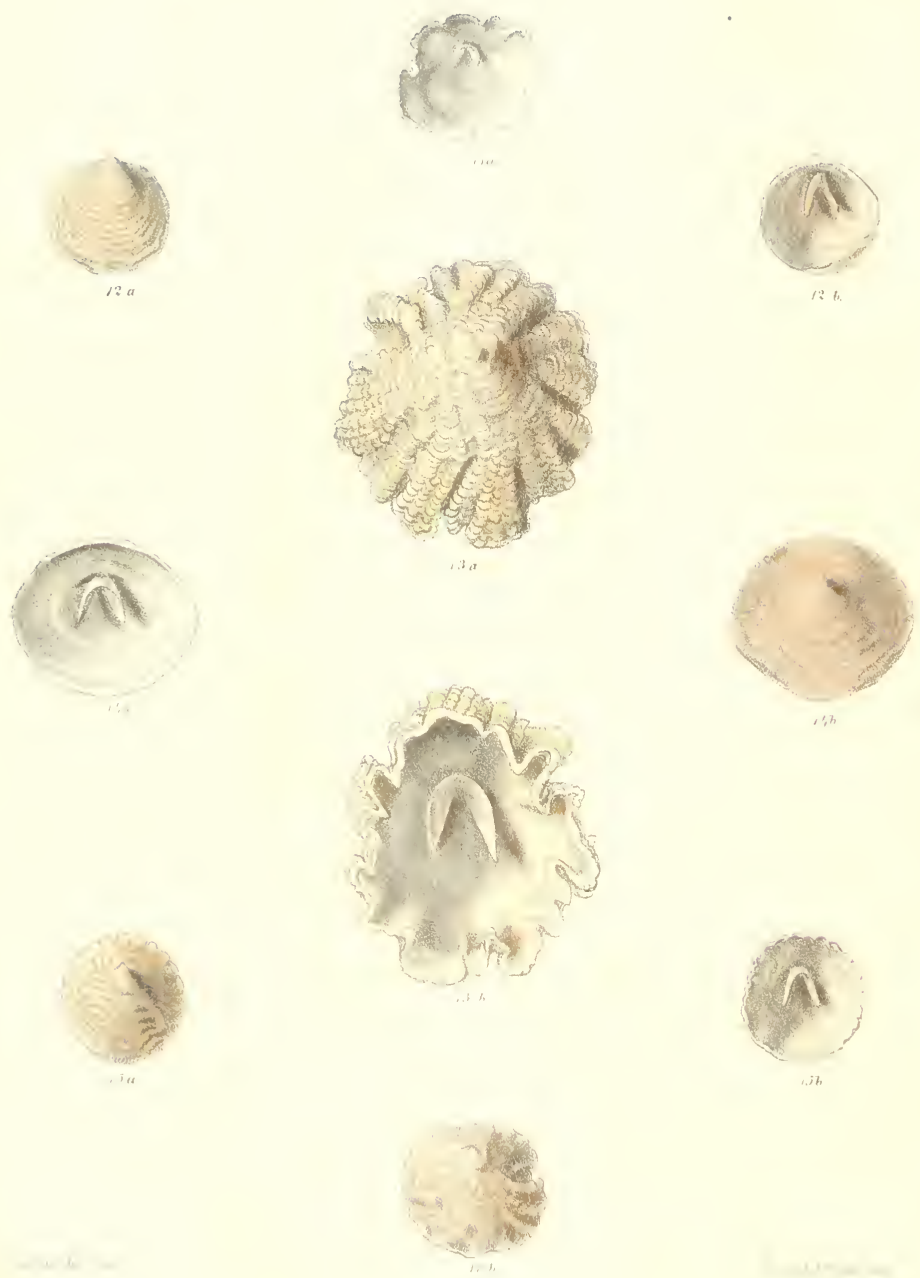


\section{A L Y P T R A .}

\section{Plate II.}

Sproio = 11, figr. $11 u$ and $11 b$, Mus. Cumiug.)

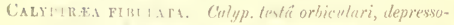

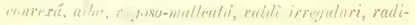

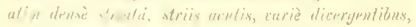

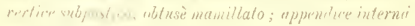
phithit, bir rissimit.

lhe bettonen Calyptrea. Shell orhicular, d pressly conver, white, wrinkle-indented, very irregular, radiately densely striated, striae sharp, fariously diverging, rertex somewhat posterior, obtuscly uamillate; interial appendage surall, very short.

Hab. Catananan, Province of Tayalus, Istand of Luzon, Philippines; Cuming.

$\mathrm{Ol}^{\prime}$ a dipressed slirivelled gronth, striated somewhat Hivaricately throughout, with the internal appendage very small.

Species 12. (Fig. $12 a$ and 12 b. Mus. Cuming.)

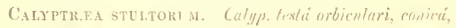

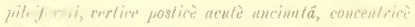

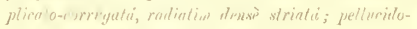

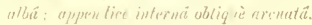

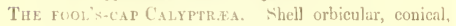
eat?-shaped, posteriorly sharply hooked at the top, concentrically plicately wrinkled, radiately densely striateil transparent-white; internal appendage obliquely arched.

IIab. Moluccas.

A delicate Pilropsis-shaped shell, of thin transparentwhite substance, very sharfly hooked at the top, encircled concentrieally, more especially towards the margin, with irregular wrinkle-like folds.

species 13. (Fig. $13 a$ and $13 b$, Mus. Cuming.)

Camptrea Mintriana. Calyp. testâ ovatá, elevaloconv-xit, jellucido-alluâ, crassiusculâ, validè undatocorrugatâ preswertim ad marginem, undiqne mugis erasperată, rertice subcentrali, obtuso; appendice interni obliquâ, prowinente.

Martini's Calyptria. Shell orate, elevately convex, transparent-white, rather thick, strongly wave-crumpled, especially at the margin, everywhere roughened with wrinkles, top nearly central, oltuse; internal appendage oblique, prominent.
Lepus alba, Martini, Conch. Cab. Yol. i f 150. pl. 15 f. 117,114 .

Hab. Batangas, Island of Luzon, Philipt'hes; Cuming.

All the shells of this genus that came into the hauts of the earlier writers were referred to the Linnaan P'cetplle equestris, and this among the number. It was onc of the first sledls published by Martini in his great work the 'Concirlicn Cabinet,' commeneed in the old academic town of Nuremberg, in 1769 . The specimen here figured, collerted by Mr. Cuming at the island of Iuzon, is an unusually finc specioucn, remarkable for its bold crumpled growth.

Sjecies 14. (Fig. $14 a$ and 14, b, Mus. Cnming.)

Calyptrea cepacea. Chlyp. teslâ suliorlímlari, parum

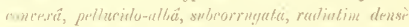
striatü, striis sulevonspicuis, certice sublposticu, parro, acufo, minutiे uncinato; appestie-internấ breri, lutiusinlat.

The OXIGN-PEel CALYPTR.eA. Shell nearly orbicular, but little convex, transparent-white, rather wrinkled, radiately densely striated, strie rather couspicuous, top somewhat posterior, small, sharp, miuntely hooked; interval appendage short, rather broal.

Broderip, Trans. Zool. Soc. vol. i. p. 197. pl. 27. f. 4 . IIab. Island of Muerte, Bay of Guayaquil ; Cuming.

A rather flat, hyaline shell, with the beautiful radiating stria which characterize nearly all the specics of this geuus under different phases, rather conspicuonsly developed.

Species 15. (Fig. 15 $a$ and $15 b$, Mus. Cuming.)

('alyptraza sacehari-meta. Calyjp. Lisfï ortieuluri,

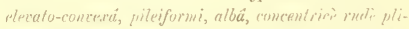

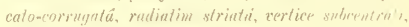

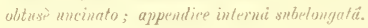

The sugati-loaf Calyptraa. Shell orbicular, elevately convex, cap-shaped, white, concentrically rudely plieately wrinkled, radiately striated, top nearly central, obtusely hooked; internal appendage rather elongated.

Hab. Island of Bohol, Philippines; Cuming.

Tery closely allied to C. stultorwm, but of more solid structurc and more elevated conical form. The vertex is not however so postcriorly hooked and cap-like. The wrinkled sculpture is coarser, but that might be due to the more roughened surface of its place of attachment.

December, 1858. 



\section{Cialyptrera PI. IV}
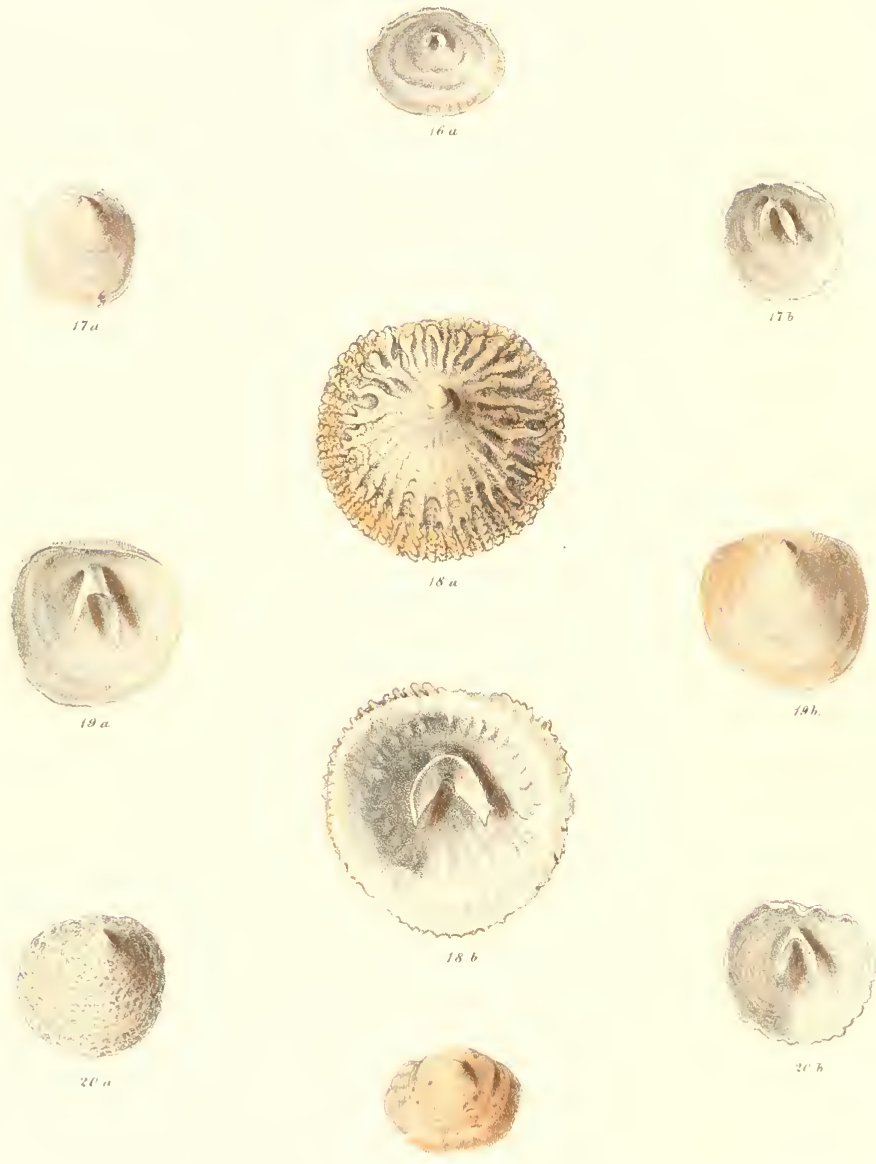

2) $h$ 


\section{A I Y T R A .}

\section{Plate $T$}

Syrres the flow Tha aw 7wo, Mus. Cuming.)

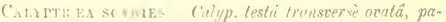

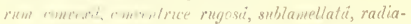
lims minutisumi vriatâ, purtice obtuso, subpostico; ap-

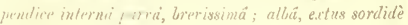
fiulerwereste.

Tin scis C.n.yprat. Shell transversely ovate, but little convex, cuncentrically rugose, sublamellar, radiately very minutely striated, top obtuse, somewhat posterior; internal appendage small, very short white, extcrior dull-fulrous.

IIal. Philippine Islands: Cuming

The internal appendage in this speries is somewhat obscurely dereloped.

Species 17. (Fig. $17 a$ and 17h, Mus. Cuming.)

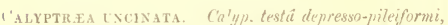

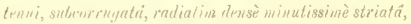
resticr postico, acutè deyressì mucinalo; pellucido-albà, humlina: appemtice interna ublingá, prominente.

THz ноокер Calyptrax. Shell depressly eap-shaped, thin, slightly wrinkled, radiately denscly very minutely striatcd, top posterior, sharply depressly hook'rd: transparent-white, hyaline; intermal appendage oblique, prominent.

Hab. Island of St. Thomas, West Indies.

I hyaline, sharply-hooked, rather depressly eap-shaped shell, from the West Indies, composed of the same minute thread-rayed tissue as the Plhilippine Island species.

Apucies 18. (Fig. $18 \mathrm{a}$ and $18 \mathrm{~h}$, Mus. Cuming.)

Calyptica conruiata. Calyp, texli suborbiculari, depressisi, wedio concided, rudiutim striatio et costato-

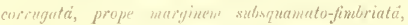
deinde reflexta, rerfice sulirerto, obscurè uncinuto: alb $\hat{a}_{2}$ rersus maryinem surdidè fuscescente; appendice intrinẩ sub implä, latâ.

The wriskled CaLiptraA. Shell nearly orbicular, depressed, conoid in the mirlde, radiately striated and rib-wrinkled, slightly scalc-fringed near the margin, then reflecied, top nearly straight, obscurely hooked; white, dull-fulvous towards the margin; intcrual appendage rather large, broad.

Brodem1p, Trans. Zool. Soc. vol. i. p. 197. pl. 27. f. 2 .

IIab. Guacomayo, Central America (under stones at a depth of fourteen fathoms); Cuming.

A fine depressly-spread conoid shell, sculptured with rib-like wrinkles radiating from the centre, and at the margin becoming slightly fimbriately scaled.

Species 19. (Fig. $19 a$ and $19 b$, Mus. Cuming.)

Calyptrea ossea. Calyp, testä arbiculari, depressá, medio conoideâ, pellucido-allâ, luyalinâ, radiation densè striat $\vec{a}$, striis subconspicuis, vertice postuco, acutè uncinato; appendice internấ obliquâ, prominente.

THE BONE CALyptr.eA. Shell orbicular, depressed, conoid in the midelle, transparent-white, hyaline, radiately densely strinted, strix rather conspicnous, top posterior, sharply booked; internal appendage oblique, prominent.

Hab. Island of Burias, Philippines; Cuming.

A very transparent depressly-spread species, in which the radiating strix have a somewhat lattice-ridged aspect.

Species 20. (Fig. $20 a$ and $20 b$, Mus. Cuming.)

CALYPTRAa porosa. Calyp. testâ orbiculari, elevatoconicâ, pileiformi, undique densè reticulato-corrugatî, porosä, albâ, vertice postico, minutè acutè uncinato; appendice interní subarcuatí.

The porous Calyptrea. Shell orbicular, elevately conic, cap-shaped, everywhere densely reticulately wrinkled, porous, white, top minutely sharply hooked, internal appendage slightly arched.

Hab. Australia ; Strange.

Like all Anstralian forms, there is something extremely characteristir about the species. The entire surface of the shell is shrivelled, so to speak, into a close network or honeycomb of wrinkles, the tissue of the shell being still composed of radiating thread-like strix, as in all the typical species of the genus. 




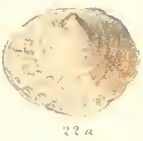

\section{is}
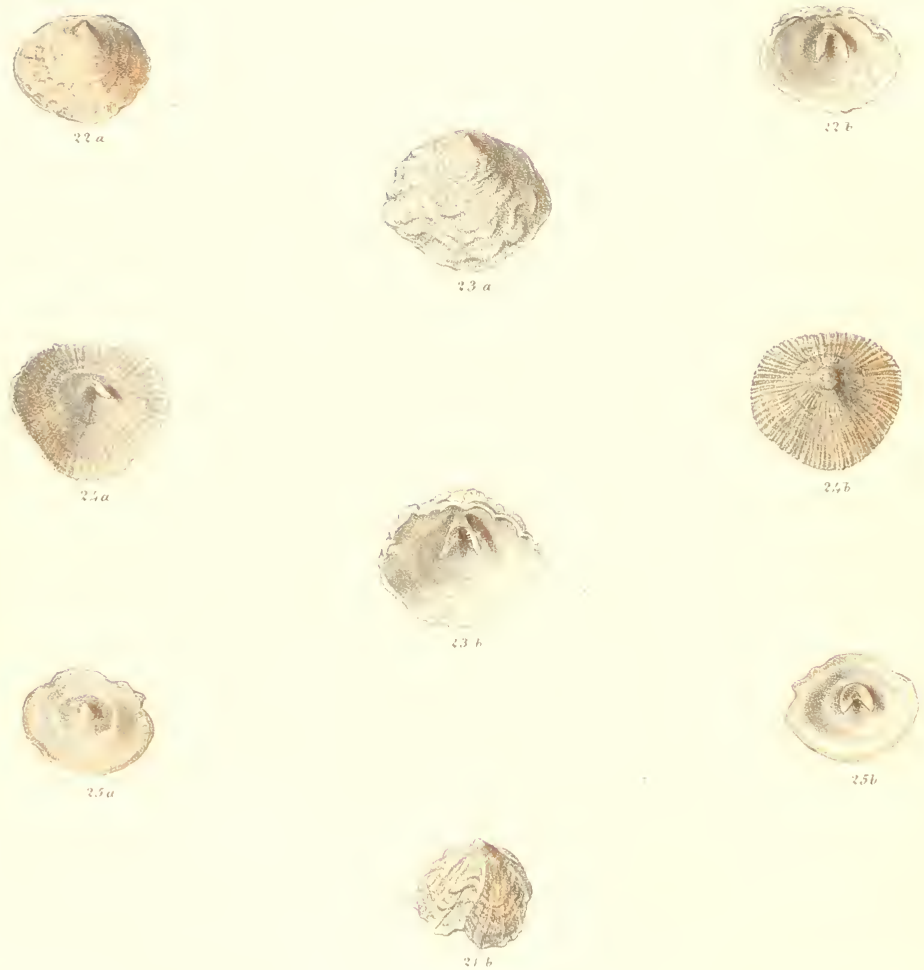


\section{A L Y P T R A A.}

Plate it.

Species 21 . (Fir. $21 a$ and $21 b$, Mus. Cuming.)

Calyptrea Balanoides Calyp. testâ obliquè conicâ, irregulari, radiatim minutè striatâ et promiscuè costato-corrugatût, albâ, vertice acito, subuncinato; appendice internẩ obliquit.

The Barnacle-like Calyptraa. Shell obliquely conic, irregular, radiately minutcly striated and promiscnonsly rib-wrinkled, white, top sharp, slightly hooked; internal appentage oblique.

IIab. Island of Bohol, Philippines; Cuming.

The wrinkled sculpture in this little Balanus-like species takes somewhat the form of straggling ribs.

Species 22. (Firg. $22 a$ and $22 b$, Mus, Cnming.)

Calyptra cornea. Calyp. testâ transwersè ovatâa, depressâ, ratliatim minutè striatâ, concentricè lìeatâ, complanalä, yarmu corrugatä, vertice postico, unciuato; appendice internâ obliquâ.

The hoRNy CALYPTk.EA. Shell transversely ovate, depressed, radiately minutely striated, concentrically lineated, smooth, but little wrinkled, top posterior, hooked; internal appendage oblique.

Broderip, Trans. Zool. Soc. vol. i. p. 197. pl. 27. f. 5.

Hab. Peru (from sandy mud at the depth of nive fathoms); Cuming.

A. plain depressed shell, finely hooked, and inclined posteriorly.

Species 23. (Fig. $23 a$ and $23 b$, Mins. Cuming.)

Calyptrea diaphana. Calyp. testá oratâ, rudè convexâ, pellucido-albâ, diaphanâ, radiatim minutè striatâ, striis subdiraricatis, concentricè corrugntâ, rugis plicato-reticulatis, vertice postico, obtusè uncinato; appendice internẩ oblinuâ.

The diapbanous CaLYPTREa. Shell ovate, rudely convex, transparent-white, diaphanous, radiately ninutely striated, striæ subdiraricate, concentrically corrugated, wrinkles plicately reticulated, top posterior, obtusely hooked; internal appendage oblique. Hab. Philippine Islands; Cuming.

Of peculiarly clear diaphanous substance, sculptured with a promiscuous open network of tumid wrinkles.

Species 24. (Fig. $24 a$ and 24b, Mus. Cuming.)

Calyptrea stella. Calyp. testá suborbiculari, planulatâ, liris subtilibus radiantibus striis concentricis decussatis, densè nitidè stellatâ, vertice subcentrali, parvo, acuto; appendice interná brevissimâ.

The star Calyptrea. Shell nearly orbieular, rather flat, closely neatly starred with finc radiating ridges crossed with concentric striæ, top nearly central, small, sharp; internal appendage very short.

Hab. Belize, Honduras; Dyson.

The sculpture of this little thin flattened species is more regular and symmetrical than in any other species. It appears to represent a different type.

Species 25. (Fig. $25 a$ and $25 b$, Mus. Cuming.)

Calyptran varia. Calyp. testâ orbiculari vel transversè ovatâ, plano-concavâ, nunc tenui, nunc crassinsculâ, radiatim creberrimè striatâ, lacoigatâ, pellucido-albâ, vertice subcentrali, parvo, subacuto; appendice interná lativsculâ.

The variable Calyptræa. Shell orbicular or transversely ovate, flatly concave, sometimes thin, sometines rather thick, radiately very closcly striated, smooth, transparent-white, top nearly central, small, rather sharp; interna] appendage rather broad.

Broderip, Truns, Zool. Soc. vol. i. p. 197. pl. 27. f. 3.

IIab. Lord Hood's Island, the Galapagos and Island of Muerte, Bay of Guayaquil (on the reefs); Cuming.

In all its rariations this specics is contracted at the margin on the side next the vertex.

December, 1858. 


Cialvereran l't. ITI.

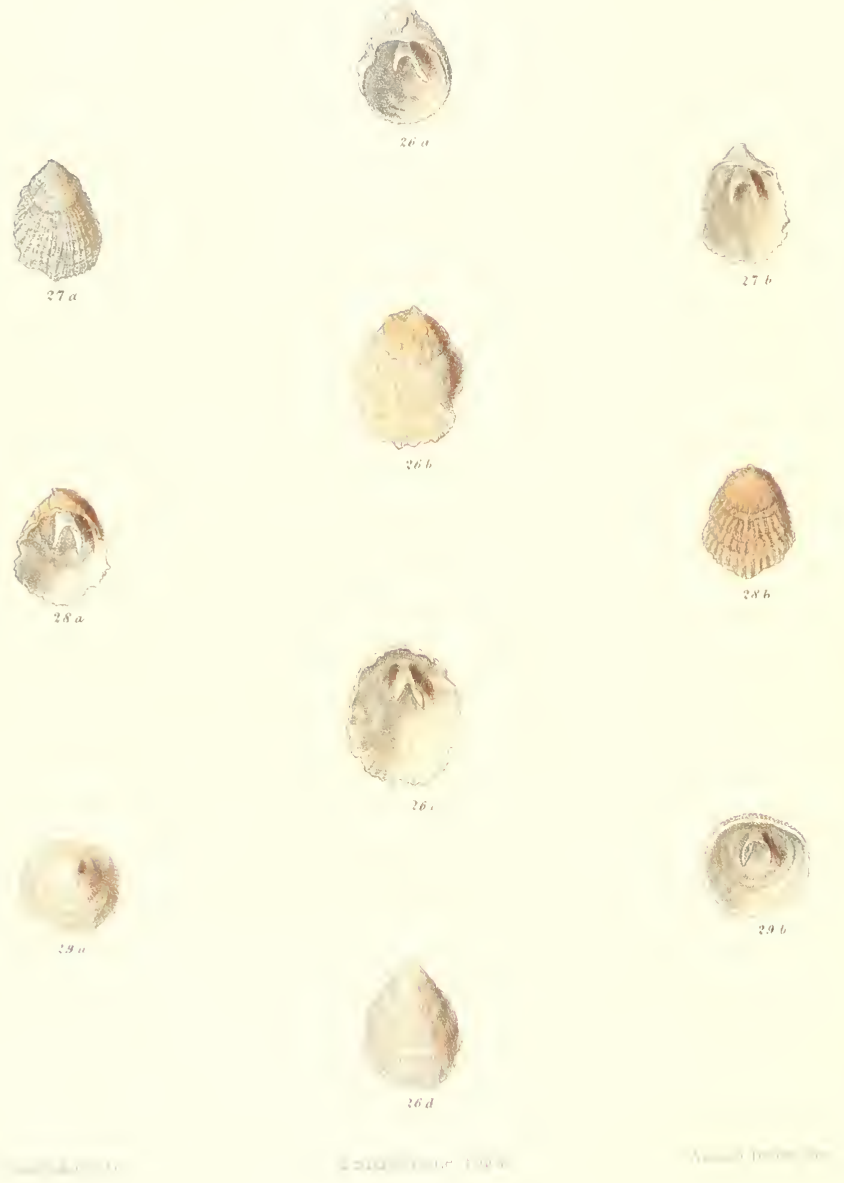




\section{A L Y P T R E 1 .}

Plate VII.

Spurbs 26. (Fig. 26 + b. $c, d$, Mus. ('uming.)

Alyptrea Hipponiciformis. Calyp. testâ plevatoconicấ, obliquâ, pe'l ucido-albâ, undique subtiliter filostriath, interdum rudè corrigatâ; vertice postico, valdè ubliquo, obtuso; appendice interuấ gracili.

line Hippoxys-shaped Calyptra.A. Shell elevately conical, oblique, transparent-white, evcrywhere finely thrcal-striated, sometimes rudely wrinkled; top posterior, very oblique, obtuse; internal appendage slender.

Has. Island of Bohol, Philippine Islands; Cuming.

In form this shell has an unusual tendency to lean over ibli quely to the posterior side. It is of an exquisite threadtriated tissue.

Species 27. (Fig. 27a, $b$, Mus. Cuming.)

' Alyptrea Caxcellata. Calyp. testi ubliquè conzicá, pellucido-albâ, rarliatim temuicostutâ, cost is medio subtilivimè sulcatis, striis concentricis cancellatis et fimbriato-squamatis, rertice mimuto, acuto, posticè valde producto; appendice intemâ subprominente.

L ae Cáceltated Calytriza. Shell obliquely conical transparent-white, radiately finely riblied, ribs very finely grooved down the middle, eancellated and fimbriately sealed with concentric strix, top minute, sharp, very much produced posteriorly; internal appendage rather prominent.

ADAMS and REEVE, Moll. Voy. Samarang, p. 70. pl. 11 f. 4 .

Hab. China Sua.

This species is characterized by a more elaborate pat- tern of cancellated scifid sulpture than any other, the ribs being mostly distinguished by a fine groove down the middle.

Species 29. (Fig. $28 a, b$, Mus. Cnming.)

Camptrifa Layardi. Calyp. testâ elevato-conicâa, subglobosit, radiatim subaculé stri to-costatá, vertice obtuso, pusticè obliquo; albia; appendice internâ rectâ, silprominumte.

LAY $\$$ LLD'S CALYPTR.EA. Shell elevately conical, rather slobose, radiately rather sharply striately ribbed, top obtuse, posteriorly oblique; white; internal appendaçe straight, rather prominent.

II $a b$. Ceylon; 1., L. Layard.

A well-marked species, more globosely elevated than tbe preceding, with a simpler form of sculpture.

Species 29. (Fig. 29a,b, Mus. Cuming.)

Calyptra cyatrella. Calyp. testâ orbiculari, semiglobusâ, pellucillo-albâa, radiatim temuistriatâ, concentricè compressè la mellatấ, alb $\hat{a}$, vertice vix obliquo, obtuso; appendice interná subrectá.

The little cup Calyptrea. Shell orbicular, semiglobose, transparent-white, radiately finely striated, concentrically compressly lamellated, white, top scarcely oblique, obtuse; internal appendage nearly straight.

Hab. Island of Bohol, Philippines; Cuming.

This little shell bas searcely any oblique growth, being a half sphere. 


C'alyplrata l'l. IIII.
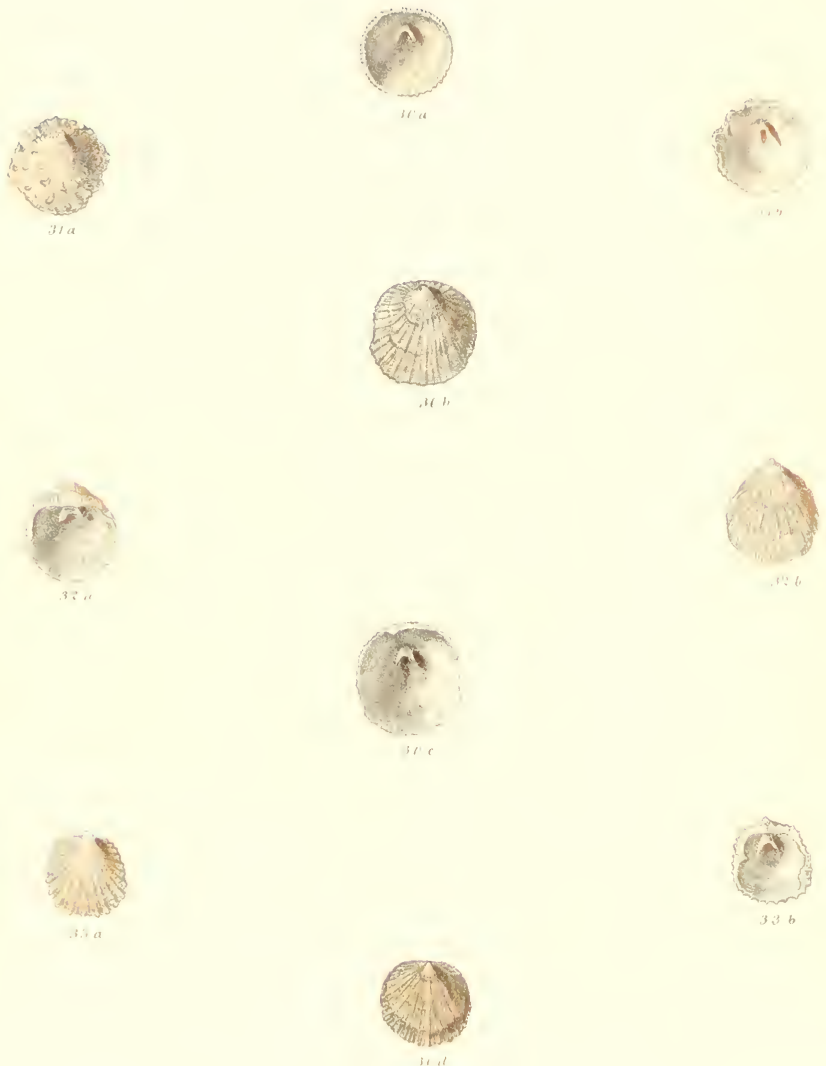


\section{A L Y P T R A A.}

\section{Plate Vili.}

Species 30. (Fig. A, 4, $c, d$, Mus. Cuming.)

alyptr.ea scutulum. Calyp. testä orbiculari, regulariter ronvexẩ, pellucilo-albâ, lyyalinâ, radintim liratâ, liris apquidistantibus, interstituis radintim striatis, verlire postica, necinalo; appendice internâ partit.

The littre shield Caliptrea. Shell orbicular, reguarly corvex, transparent-white, hyaline, radiately ridged, ridges cquidistant, interstices radiately striated, top posterior, hooked; internal appendage small.

II 2 b Philippine Islands; Cuming.

Characterized by a broad orbicular form, with the radiatiug ridges ratber conspicuous, at equal distances.

Species 31. (Fig, $a, b$, Mus. Cuming.)

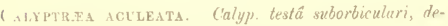
Iresa-conzira, pellucido-albâ, hyalinâ, sub lente teunissimè radiatim striatä, margine cormigatâ, aruleuto-squanut $a$, squamis promiscuis, subdistantibus, verTice postico, acutè uncinato; appendice interiấ yracili.

LHE PKICKLY CALYPTUEA. Shell nearly orbicular, depressly convex, transparent-white, hyalinc, beneath the lens very finely radiately striated, crumpled at the margin, prickly sealed, scales promiscuous, rather listant, top posterior, si arply hooked; internal appendage slender.

Ifab. Honduras; Dysoll.

This very delicate little species is distinguished from all others by the presence of s number of rather distant squamate spines.

\section{Species 32. (Fig. $a, b$, Mus. Cuming.)}

Calyptrea Vankorensis. Culyp. testä obliquè conicä, crassiusculâ, pellucido-albâ, ralliatim liratri et striatâ, vertice postico, elemato; appendice interná perobliquá.

The Tanikoro CalyptraA. Shell obliquely conical, rather thick, transparent-white, radiately ridged aud striated, top posterior, raised; internal appendagc very oblique.

Quor, Moll. Voy, de l'Astrolabc, pl. 72. f. 20-24. Hab.

Resembling C. scutulum in sculptare, but of more rude oblique growth.

Species 33. (Fig $a, b$, Mus. Cuming.)

Calyptr.ea umbo. (alyp, testâ elevato-conicâ, pileiform, pellucido-albâ, raliatim liralât et striatä, liris rudè fortibus, rugoso-interruptis, vertice subpostico, unciuato; appendice internâ yracili.

The boss Calyptrea. Shell elevately conical, capsbaped, transparent-white, radiately ridged and striated, ridges stroug, roughly interrnpted, top subposterior, booked; internal appendage slender.

Hab. Honduras; Dyson.

The ridges of this little erect, cap-shaped species are strong and peculiarly roughened. 



\section{A L Y P T R EA.}

aculcata, Reeve

Adamsii, Reeve

alvcolata, A. Adames

Balanoides, Reeve

bulla, Reeve

cancellata, Adains and Reeve

cepacea, Broderip

cicatricosa, Reeve

rornea, Broderip. .

corrugata, Broderip ....

cyathella, Reeve

diaphana, Reeve . ... . . VI

dormitoria, Revve ...... II.

equestris (l'atella), Linnæus . I

fibulata, Reeve ..... IV . IV

Hipponiciformis, Reeve ..... VII.
Layardi, Reeve

Martiniaua, Reeve

ossea, Recve.....

papyraceis, A. Adams

porosa, Rreve ...

Roissyi, Dufo

sacchari-meta, Reepe

scabies, Reeve..

scutulum, Reeve

stella, Rerve ....

stultorun, Reeve. .

tectum-Sineuse (Patella), Chem

tortilis, Reeve .............

nubo, Reeve . ............

uncinata, Reeve .... ...

Vanikorensis, Quoy ........ TII]

varia, Broderip ........ VI.
Plate $\quad$ Species

III. 28

IV $1:$

V. $\quad 19$

II.

V 20

J.

IV. 15

I 16

VIII. $\quad 30$

VI 31

IV. 12

III. 10

I.

iIII. $3: 3$

17

25 

MONOGRAPH

OF THE GENLS

C R E P I D U L A.

I hi wh thy swem grace's -Hpper.'
Shrekispeure. 



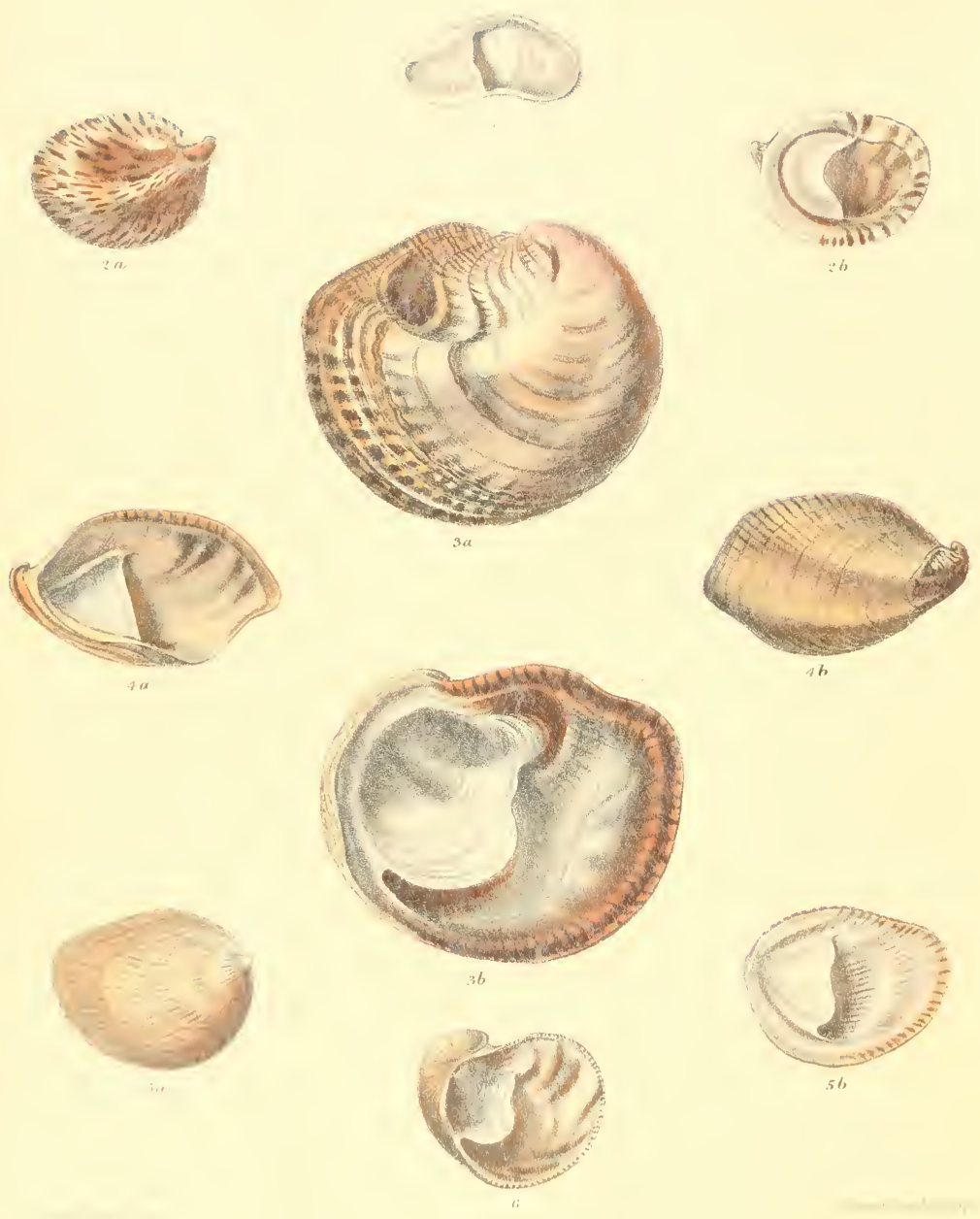


\section{REPIDULA.}

Plate 1.

Genus CREPIDULA, Lamarck.

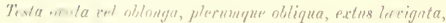
rari, costatu, upite breri, seppissime maryiuali, plus wimus rostrato, intus cova, lamná lissizontali septiformi, interdun ad latns emaryiuntá.

shell ovate or oblong, gradually oblique, smooth exteriorly, rarely ribbed, with the apes mostly marginal an more or less beaked, interiorly hollow, with a horizontal septum-like lamina, sometimes notehed at the side.

The Crepidule, or true Slipper Limpets, are charaterized by the internal appendage, which is the distinguishing feature of this family, assuming a horizontal deck-like form The species have been little added to since they merc monographed twenty-five years ago by Mr. Broderip, and several then deseribed as new have proved to be varictics of others. They are cbiefly inbabitants of the New World.

\section{Species 1. (Mus, Cuming.)}

Crepidila ungeiformis. Crop. testâa orali rel oblongâa, planii aut cancuva, sicpe contorlâ, complamata, extus conentricì slriatii, epidermide subpilasä, flacescente inLerdun cersus murginent indutri, intus nilente-albii; appendice subampliter septiformi, od latus subemarginatii.

THE NAIL-SHAPED Creprocta. Shell oval or oblong, flat or concave, often tivisted, smooth, externally eoncentrically striated, sometimes covered towards the margin with a yellowish somewhat hairy epidemis, internally shining-white; appendage rather largety septum-shaped, slightly notched at the side.

LAMARck, Inim. sans vert. rol. vii. p. 642

Patella creprilnlu, Limmeus.

Crepidula calcpotinu, 1)eshayes.

Crejuidula sinuosa. Turton.

Crepillulu camblida, Risso.

Cropilula Itulica. Defirauce.

Crepirtula plona, Say.

Hab. Meditcranean and Atlantic sers.

Extremely variable in form, aecording to its place of attachment, but milormly of a thin, white, brittle substance, shining and subdiaphanous on the imner side, while the outer is frequently eovered towards the margin with. yellowish somewhat hairy epidermis.

Specics 2. (Fig. $a, b$, Mus. Taylor.)

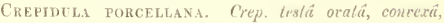

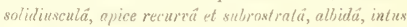
exlusique livido-rufo ef purpureo linct â et radiation ma-

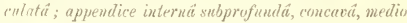
sinerati.

THE PoRcelain Crepidula. Shell ovate, convex, rather solid, recurved and slightly beaked at the apex, whitish, stained and radiately spotted within and without with livid-red and purple; internal appendage rather deep, concave, sinuated in the middle.

LAMARC K, Anim. sans vert. vol. vii. p. 642 . Patmiln porevllmu, Linnans.

Hab. West Africa.

Mr. Cuming possesses small specimens of this species from West Africa, but there is every reason to behere that it has a far wider range of habitation.

specios 3. (Fig. a, h, Mus. Cuming.)

Crepidula dilatata. Crep, terala orato-rotundata, crassinsculat, subirrequlari, obliquè curvatä, infus extusque albidit, lirito-fusco ad marjinem tincla el radiatim li-

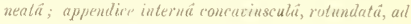
lalus prufundè thorifinatá.

THE DILATED ('KEPIDLLA. Shell ovately rounded, mather thick, somewhat irregular, curved obliquely, whitish within and without, stained and radiately lineated at the margin with livicl-brown; interual appendage rither coneave, rounded, deeply notched at the side.

LAмakck, Anim. sins vert. vol. vii. p. 6t4.

IIab. Straits of Magelhacus and Falklaud Islands. Chili: Cuming.

This fine species may be chiefly recognized by its obliquely curved concave form, and livid-brown marginal colouring. It is common of a smaller size.

Species 4. (Fig. $a$, l, Mus. Cuming.)

Crepidula excavata. Crep. lestí oblongo-oralâ, crassiusculi, subtortuosil, interaliter compressit, apice obli.

June, 1859. 


\section{CREPIDULA.-Phate I.}

पaè iurvrvấ el rostratâ, intus extusque ful rescente-albä, purgureo et rufuscente-fusco tinctá et lineatä; appendice internâ profundâ, planâ.

The excavated Crepidula. Shell oblong-ovate, riather thick, somewhat twisted, compressed at the side, obliquely incurved and beaked at the apex, fulvouswhite within and without, stained and lineated with purple and reddish-brown; internal appendage deep, flat.

Broderip, Trans. Zool. Soc. vol. i. p. 205. pl. 29. f. 7. Hab. Chili; Cuming.

The lateral compression which gives a somewhat twisted form to this species appears to be natural to it, and not the result of any peculiarity in its place or mode of attachment.

Species 5. (Eig. $a, b$, Mus. Cuming.)

Crepidula squama. Crep. testâ subobliquè ovalä, planoconcavâ, complanatâ, fulvescente-albâ, lineis fuscescente-rufis radiatim strigntâ; appendice interná elecatinseulâ, ad latus subemarginatâ.

Tue scale Crepidela. Shell somewhat obliquely ovate, flatly concave, smooth, fulvous- $-\pi$ bite, radiately streaked with brownish-red lines; internal appendage rather raised, slightly notched at the side.

Broderif, Trans. Zool, Soc. rol. i. p. 205. pl. 29. f. 10

Hab. Panama; Cuming.

A delicate and well-marked species, rayed outwardly with fine fuscous-red lines from the apex to the margin, where they are lost in a covering of yellowish epidermis.

\section{Specics 6. (Mlus. Cuming.)}

Crepidula Nautiloides. Crep. testâ obliquè ovata profundè gibbosá, tenniculâ, albidâ, carneo-fuscescent, tinctâ et strigatâ; appendice internâ subrotundatâ, convexâ, ad latus emarginatâ.

The Nautiloid Crepidula. Shell obliquely ovate, deeply gibbous, rather thin, whitish, stained aud streaked with light flesh-brown; internal appendage. somewhat round, convex, notched at the side.

Lesson, MS. Mus. Cuming.

Hab. Ncw York.

The species which Mr. Cuming has from New York with the above aame, is of the same type of the genus as C. dilatata. 


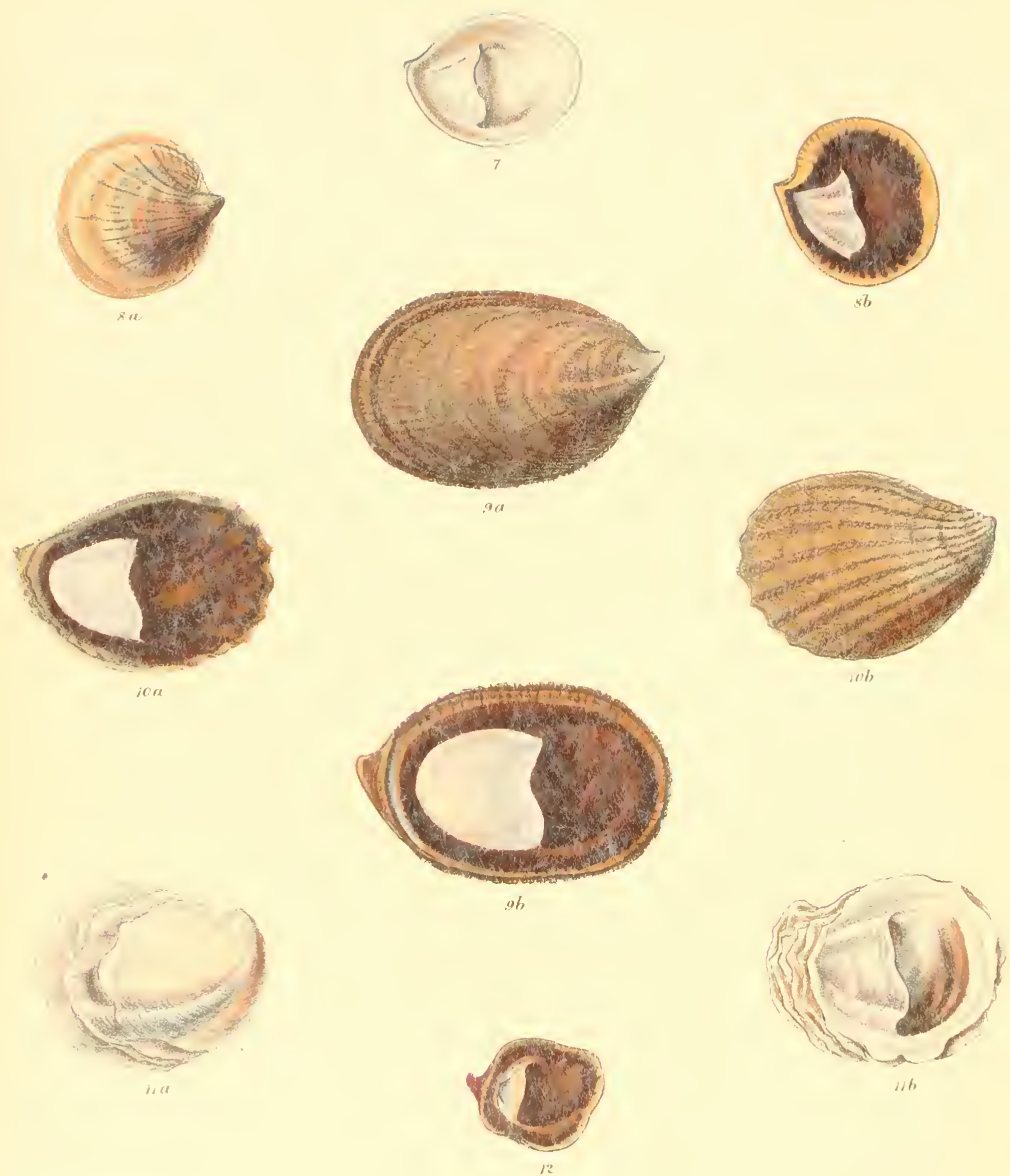


\section{R E P I D U L A.}

Plate II.

Species 7. (Mus. ( Cissung.)

Crefidola glauca. Crep. testâ obliquè ovatâ, temui, contexinsentlä, complanatä, albä vel glaucescente, maculis suturatioribus interdum aspersa ; appendice in. le'mâ parcâ, suleprofundâ.

The glaucous Crepidula. Shell obliquely ovate, thin, rather convex, smooth, white or glaueous, sometimes sprinkled with dots of a darker colour; internal appendage small, rather deep.

SAY, Journ. Aead. Nat. Sci. Philadelphia, vol. ii. p. 226. Hab. Rhode Island, United States; Gould.

The shell here figured from Mr. Cuming's collection, without any indication of colour, is not a very satisfaetory representation of the species. It is not known to me in its typical state.

Speeies 8. (Fig. $a, b$, Mus. Cuming.)

Crepinula marginalis. Crep. testâ unatâ vel orliculari, converâ, interdum planû, lacigntî rel subcorrugatá, flavido-albâ, prope apicem caruleo tiuctá et radiatim lineatit, intus intewè purpureu-castuneri, ad marginem flavidie et castaneo strignta; appendice interna diapliano-albä.

Tile marginal Crepidula. Shell ovate or orbieular, convex, sometimes flat, snooth or funtly wrinkled, yellomish-white, stained and radiately lineated near the apex with blue, interior deep purple-ehestnut, yellowish-and chestnut-streaked at the margin; internal appendage diaphanous-white.

Broderip, Trans. Zool. Soc. vol. i. p. 205. pl. 29. f. 9.

Hab. Panama; Cuming.

Well distinguished by its rieh internal eolouring, upon which the septum has a bluish diaphanous-white appearance.

Species 9. (Fig. $a, b$, Mus. C'uming.)

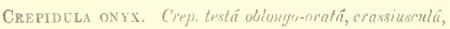
intus extusine fusri, rufi-limetat, intus suturatiore, lividâ; "pperudice subamplä, plan $\hat{a}$, albâa, margine medio emaryiusto.

The onrx Crepidela. Shell oblong-ovate, rather thick, brown within and without, rayed with red lines, in- teriorly darker, livid; appendage rather larw' flat, white, edtre notehed in the middle.

Sowerbi, Gienera of Shells, Grepirlula, f. 2 .

Crepirlulu amygdalus, Valenciemnes.

Crepitula Cerithicula, C. B. Adams.

Hab. Panama; Cuning and C. R. Adams. MazatlitiCarpenter.

This fine species may be ensily recognized by its straight oval form and liver-coloured chestnut interior. The septum is of a bright opal-white substance.

Species 10. (Fig. $a, b$, Mus. Taylor.)

Creprdula regosa. Crep. testá obliquè ovatä, versus apicem attenualâ, apice subrostratâ, extus fuscescente, rufo punctatä et obliquè lineatâ, intus intensè castaneâ : appendice opali-albâ, concaviusculâ, margine in nedio et ad latux subemaryinato.

The rovgil Crepinula. Shell obliquely ovate, attenuated towards the apex, apex slightly beaked, exterior light-orown, dotted aud obliquely liueated with res, interior deep-ehestnut; appendage opal-white, rather concave, edge slightly notched in the middle and at the side.

Nutrall, Jay's Catalogue of Shells, p. 41.

IIab. Upper Californiat.

This shell appears to be uniformly distinguished from C. onyx by its more obliquely beaked growth. The ribs in the speeimen figured are nerely occasioned by its having grown on to a ribbed shell, probably a Pecten.

Species 11. (Fig. $a, b$, Mus. Cuming.)

Crepinula fimibriata. Crip. testä obliquè orutî, planai, apuce lateralitir incurvâ, cancentricè striatä, versus marginem conspicuè laninato-fimbriatâ, extus intusque pellucido-allin, ad lutus lixido-fusco uniradialä; appendice ad lutus emurginato.

The Frilled Crepidula. Shell obliquely ovate, flat, laterally ineurved at the apex, concentrieally striated, conspicuously laminarly frilled towards the margin, transparent-white without and within, stained with a livid-brown ray on one side; appendage notebed at the side.

IIab Vancouver's Straits.

June, 1859 . 


\section{CREPIDULA.-PLATE II.}

This fine new species is of pure white substance, marked on one side with a single dark ray, which, seen through the outer coat, has a milky appearanee. Towards the margin the shell is developed in irregular fimbriaterl layers.

\section{Speeies 12. (Mus, Cuming.)}

('Repidula adenca. Crepr. testấ ovatâ, lateruliter pileiformi, apice producto, conspicuè adusco, livido-fusr $\hat{a}$, extus epidermide indula $\vec{a}$ appendice internâ, parriusrula $\vec{a}$, albấ.

THE HOOKED C'REPIDU1:A. Shell ovate, laterally eap- shaped, apex produced, conspieuously hooked, lividbrown, eovered outwardly with an epidermis : internal appendage rather small, white.

Sowerby, Tankerville Catalogue, App. p. 7.

Crepidula solida, Hinds.

Gumotia solida, Gray.

Crepitula rostriformix, Gould.

Crepidula uncala, Mrenke.

Hab. Panama.

Of a livid-brown colour, with a rather small white septum, chiefly remarkable on account of the prominent hooked development of the apex. 


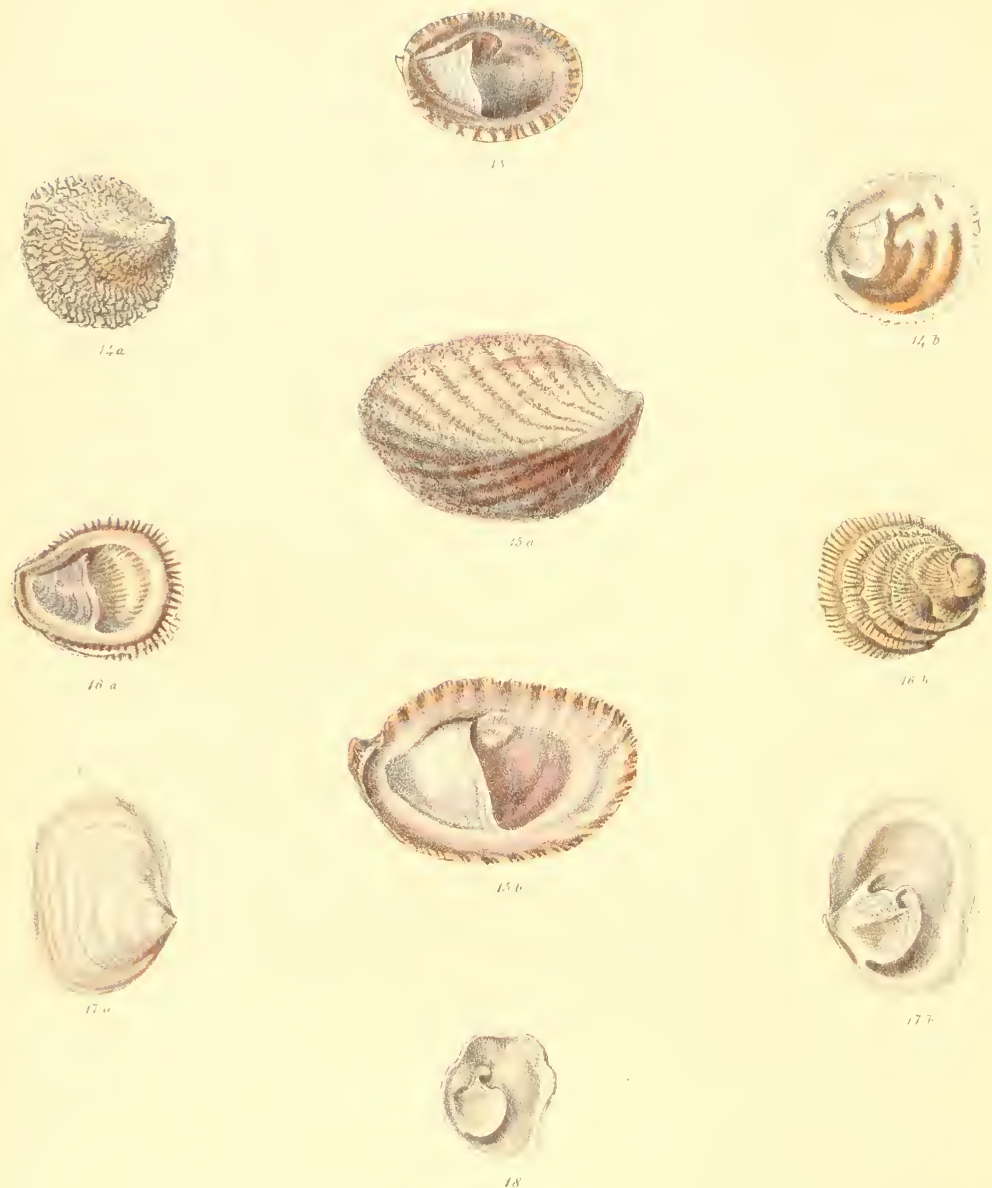


\section{REPID U L A.}

\section{Plate III.}

Species 13. (Mus, Cuming.)

Chepideli arenata. Crep. testâ suboblimuimeatá, lrevi, epidermide lenuissimâ rersus marqinem imulutâ, albidâ, fusco-rufo creberrimè punctatâ, intus carneo-alb $\vec{a}$; appendice lirernsculâ, opali-albâ.

The sindy Crepidula. Shell rather obliquely ovate, smooth, covered towards she margin with a very thin epidermis, whitish, rery closely dotted with brownred, interior flesh-white; appendage rather short, opalwhite.

Broperip, Trans. Zool. Soc. vol. 1. p. 205. pl. 29. f. 8.

IIab. St. Elena, W (st Columbia (from sandy mud, on shells, at a deptli rauging from six to eiglit fathoms); Cuming.

Characterized by a sprinkled painting of red dots, and closcly allied in this respect to C.fornicata. The loeality, - 1-land of St. Helena,' given by II. Deshayes, is a slip of the pen in copying the ('umingian habitat.

\section{Species 14. (Fig, $a, b$, Vus, Cuming.)}

Crepidula foltacea. Crep. testá suborbiculari, rudè vermicoso-folime $\hat{n}$, all $\hat{n}$, fermyineo-fneco rudiatim strigutâ; appuedice inlernä parviusculá, subconcuvâ, metio ditutatit.

line foliaceots Crepidels. Shell nearly orbicular, rudely wart-leaved, white, radiately streaked with rust-brown ; internal appendage rather small, slightly concave, dilated in the midalle.

Cnlyptrea folincen, Broderip, Trans. Zool. Soc, vol. i. p. 202. pl. 25. f. 9 .

Calyptrina strigata, Broderip.

Hab. Shores of Peru (adhering to shells and stones); Cuming.

This speries has two well-marked claracters, a coating of rudely developed leafy warts, and a faint colouring of rust-brown rays diverging from the umboes, and sometimes leaving a white ray-like hiatus. This last-named state Mr. Broderip named with some doubt $C$. strigato. thinking it might prove to be a variety of $C$. dilututu.

\section{Speries 15. (Mus. Cuming.)}

('repidela Forricata. ('mp). trsta suboblougo-ovatâ, naviformi, apice incurvi, complanutä, albila, carno- fusco divaricatim striyatä, intus carneo-a/ista : uppendice opali-albâ, subdepressâ.

The arched Crepidula. Shell somewhat oblong-oval. boat-shaped, iucurved at the apex; smooth, whitish divaricately streaked throughout with Hesh-brown, interior flesh-white; appendage opal-white, rather depressed.

Patella fornicata, Linnæus, syst. Nat. p. 1257.

Ilab. United States.

In this fine speeies the painting is sometimes in dots, especially towards the margin.

Species 16. (Fig. $a, b$, Mus. Cuming.)

Crepidola Lessonis. Crep. testâ obliquè ovatâ, subplunută, undique concentricè laminato-fimbriat $\vec{a}$, dia-

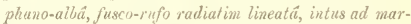
ginem fusco-rufo eiliato-strigatü; appendice medio elevatinsculit, ad latus subemaryinata

Lesson's Crepidula. Shell obliquely ovate, rather flat, concentrically laminarly frilled, diaphanous-white, radiately lineated with brown-red, hair-streaked round the margin with browu-red; appendage rather raised in the middle, slightly notched at the side.

Broperip, Trans. Zool. Soc. vol, i. p. 204. pl. 29. f. 5.

Hub. Island of Muerte, Bay of Guayauil (under stones, at low-water); Cuming.

This elegant species is constructed in layers, which form a series of concentric laminary frills. It is of a subtransparent white texture, more or lcss densely rayed with brown-red lines.

Specics 17. (Fig. $a, b$, Mus. Cuming.)

Crepidula Wisshi. Crpp. Testû̉ transversè ovatû́, planulatâ, apice obliquè lateratiter incurvấ, diaphano-albâ, appentice plaro-dilatuta, ad latus obsolete inflexá.

II.Als II's CREPtuUla. Slicll transversely ovate, rather flattened, obligucly laterally incursed at the apex, diaphanous-white; appendage flatḷ dilated, obsoletely inflected at the side.

Hemaxisox, Ms. in Mus, (uming.

Culyplicen planu, Adarus and Reeve (in Moll. Voy. Samarang). 


\section{CREPIDULA.-Plate III.}

IIab. Singapore; Cuming. Ceylon; E. H. Layard.

A subtransparent white shell, well characterized by its broadly-ovate form, and by the curious rudiment of a cup in connection with the internal appendage.

Species 18. (Mus. Cuming.)

('repidula scabies. Crep. testâ suborbiculatá, convexá, irregulari, apice non maryinali, concentricè plicatostriatâ, diaphano-albâ, interdum ferrugineo-tinctâ. appendice internâ plano-concavâ, ad latus obsoletè inflexâ.
The scab Crepidula. Shell somewhat orbicularly convex, irregular, apex not marginal, concentrically plicately striated, diaphanous-white, sometimes stained witb rust ; internal appendage flatly convex, obsoletely inflected at the side.

$\mathrm{Hab}$. China Scas.

A convex diaphanous shell, presenting a striking irregularity of growth, in which the internal appendage bas a flattened inflected fold of even more rudimentary structure than the preceding species. 


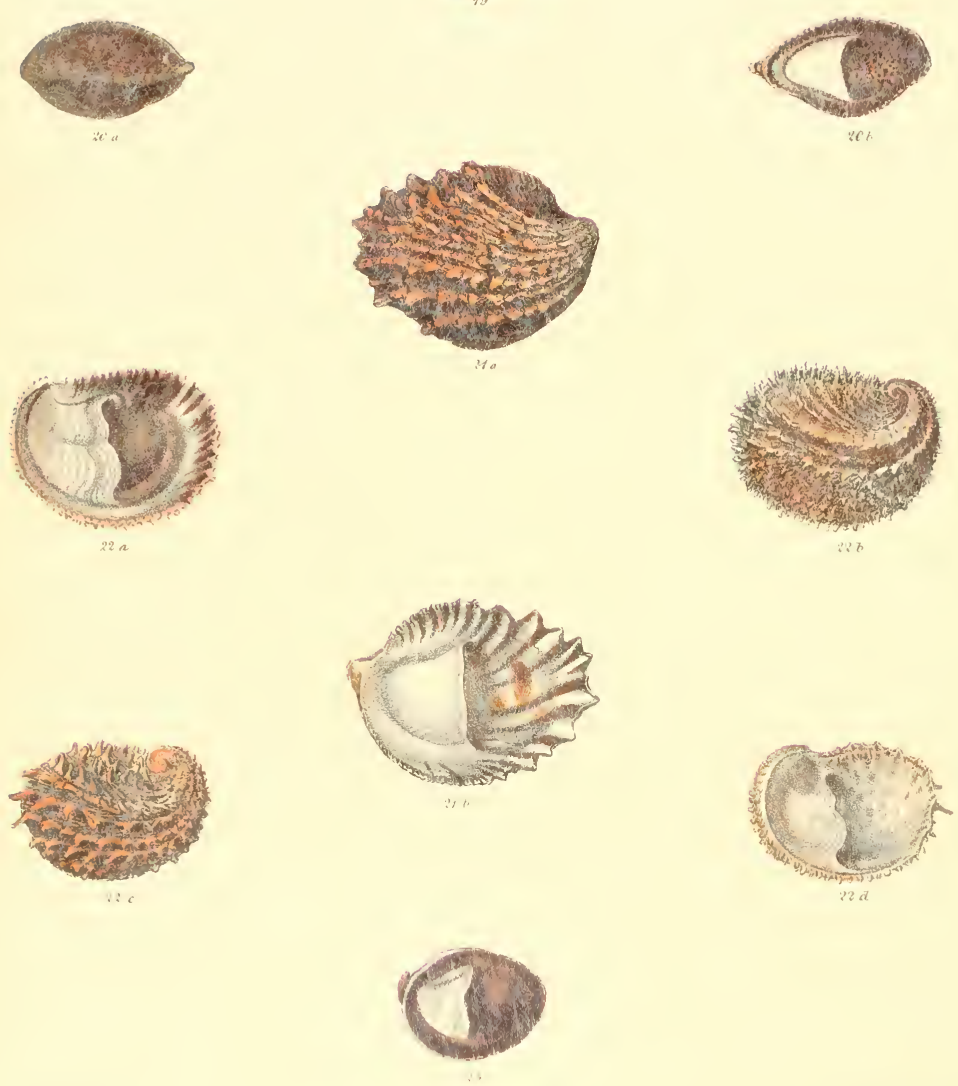


\section{Plate IV}

Sprotes 1: (Mus. Cuning.)

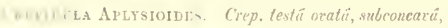

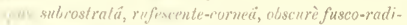
Whas, appendice intermit subprofundâ, opali-albâ.

fir: IrLxSIA-like Cliepidula. Shell ovate, rather concave, slightly beaked at the apex, reldish-horny, shiscnely brown-rayed; internal appendage ratlicr deep, opal-white.

II" Rio Janeiro; Macgillivray

reddish-homy species, looking on the outside curiwhy like an tplysia.

Species 20. (Fig. a, b, Mus. C'uming.)

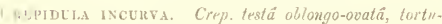
usu-rompressâ, apice culuncâ, radiatim striat $\vec{n}$, purpumol) vel nigric uste lentiginosâ; appentice internâ opalialluat.

[1.] incurven Crepidula, Shell ollong-ovate, tortuusly compressed, booked at the apex, radiately striatcd, freckled with purple or blackish ; internal ap, encage opral-white

Bätiкr, Pro. Zool. Soc. 1834, p. 40.

Hal st. Elena and Xipixapi, West Columbia (found on dead shells, dredged from sandy mud, at a depth ranging from six to ten fathoms); Cuming.

The tortuous compression of this shell is the samc in il indiriduals of the species.

Species 21. (Fig. r, b, Mus. Cuming.)

I. i. PIDUla costata. Crep. Lestâ ovatá, radiatim cosLutü, costis distuntibus, Jecreosis, muricato-tuberculatis, interstitiis striatis; fuscescente-nlbâ, versns marginem purpureo tincti it lineat $\overrightarrow{\hat{n}}$, margine flexuso; appentice internâ subamplâ, opali-allâ, cuncavấ.

TuE hibBen Crepidula. Shell ovate, radiately ribbed, ribs distant, flexuous, prickly-tubercled, interstices striated; brownish-white, stained and lineated towards the margin with purple, margin flexuous; internal appendage rather large, opal-white, concave.

1) Eshayes, Anim. sans vert. vol. vii. p. 64t

IIab. New Zealand.

I finc tubercularly ribbed species, stained and lineated towards the margin with purple, which is seen through the 1. jul-white lining of the interior.
Species :"?. (Fig. ", ", c, $l$, Mus. Cuming.

Crepidela arlleata. Crep. testâ ovatâ, Haliotidiformi, upies luteraliter incurvî, rudiatiju densè muricatosquanatâ, fusco ant purpureo et albo radiatâ; appendice internâa diajheno-albâ, concariksculâ, in medic et ad latus subemaryinatâ.

Tile prickly ('repidola. Shell ovate, Haliotis-shaped, laterally incurved at the apex, radiately densely pricklyscnled, raved with brown or purple and white; internal appendage diaphanous-white, rather concave, slightly notclicd in the middle and at the side.

Patella artileata, Gmelin, syst. Nat. p. 3693.

Crepidule aculecta, Lamarck.

Cirpidula hystrix, Broderip.

Crepidult echimus, Broderip.

Crepielula Californica, Nuttall.

Hab. Lobos Islauds, Peru; Cuming. California; Nuttall, Carpenter. Hondurns; Dyson. Samdwich Islands. Australia. Kurracbee, mouth of the Indus.

As Mr. Brodcrip truly predicted, when describing his C. lyy lrix and echinus, these are both varieties of one and the same species, the Patella acuteata of Gmelin. Having a widespread greographical range, the specimens vary according to locality. The finest are those from Peru, figurcd in the accompanying Plate, richly purple-coloured, with the seales froquently produced into erect, tubular spines. From California and the Sandwich Islands the species is smaller, and mostly of a rust-brown colour.

\section{Species 23. (Mus. Cuming.)}

Crepidela hepatica. Crep. tisti ovata $\vec{a}$, subprofundè roncexâ, laccigatâ, apice obliquè rostrato, marginali, inteusì castaneâ, aul apicem wiunutè nlbiradiata ; appendice interuî umpliter septiformi, concavâ, opuli-allâ.

The liver Creptoula. Shell ovate, rather deeply convex, smooth, with the apex obliquely beaked and marginal, dark-chesnut, miuutely white-rayed at the apex; internal appendage largely septum-shaped, concave, opal-white.

Deshayes, Enc. Mléth. Ters, vol. ii. p. 26.

Hinds, Moll. Voy. Sulphur, p. 53.

$\mathrm{Hab}$ -

This species differs from $C$. alunce in baving the apex not produced into a hook, while there is a marked difference in the septum, which is much larger, covering quitc one-lalf of the intcrior of the shell. 


\section{.}




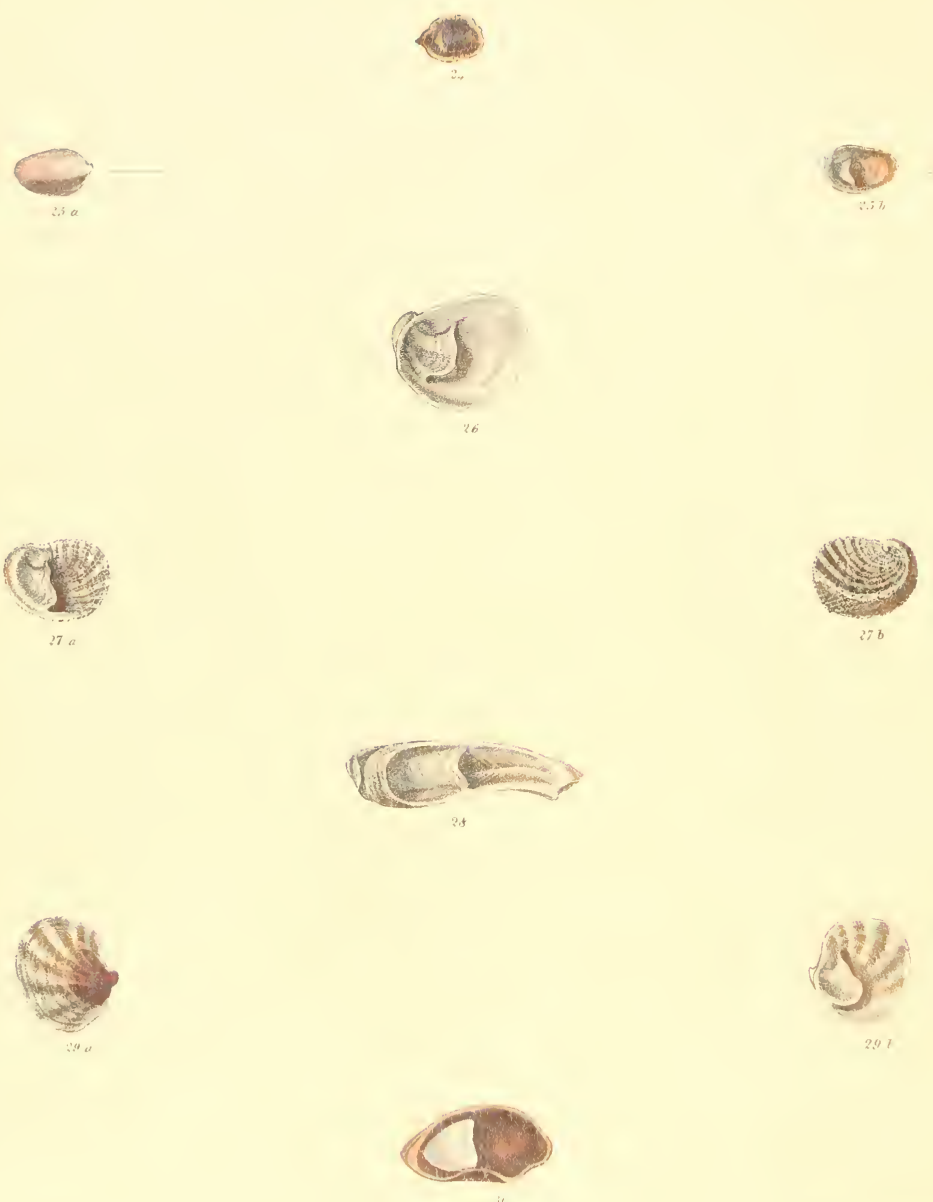




\section{R E P I D U L A.}

\section{Plate V.}

Species 2.t. (Mus. Cuming.)

Onepidnla rostrata. Crep. testí oratâ, apice producto, rostralo, juscescente, subpellucidâ, interdun nigromunctatấ; "ppendice internâ parvâ, diaphano-albâ, suthimmersâ.

Tile beaked Crepidula. Shell ovate, apex produeed, beaked, brownish, subtransparent, sometimes blaekdotted ; iuternal appendage small, diaphanous-white, rather immersed.

C. 13. A DArs, Panama Shells, p. 235.

Hab. Panama.

Though of the same typical form as C. adnuca, this appears to be a distinct speeies.

Speeies 25. (Fig. $a, b$, Mus. Cuming.)

Crepincla convexa. Crep. lestâ ozatâ, tmuiculat, comvexâ, snbcmujuressä, apice abliquè rostrato, marginali, paltiele fuscracente: appendice internâ parviuscula subinunersâ.

The convex Crepidela. Shell ovate, rather thin, convex, somewhat compressed, apex obliquely beaked, margiual, pale-brown; internal appendage rather small, a little immersed.

SAr, Journ. Aead. Nat. Sei. Philadelphia, vol. ii. p. 227. Hah. - - ?

I slightly compressed convex shell, of lighit transparent substanee.

\section{Speeics 26. (Mus. Cuming.)}

('REPIDtla PAllida. Crep. trstâ ovatâ, subdilatalâ, apice abliquè incurvâ, sordidè alba ; appendice internâ in medio praduclí.

THE fale Crepidu'A. Shell ovate, sowewhat dilated, obliquely incurved at the apex, dead-white ; internal appendage produced in the middle.

Broverip, Trans. Zool. Soc. vol, i. p. 204. pl. 29. f. 3. Hal. Falkland Islauds.

This is not a satisfactory speries, and will, doubtless, prove to be a variety of $C$. dilatata.

Fig. 27. (Mus, Cuming.)

The shell here figured is a speeimen of $C$. uculeatus, trom the mouth of the Indus, at Kurrachee
Specue 25. (Nus. (uming.)

Crepidula extriata. Crep. teslä clonguto-productá. angustấ, curratâa, sordidè albầ; appendice interná convexü, diaphano-allbâ.

The cast-skin Crepidula. Shell elongately produced. narrow, curved, dead-wlite; internal appendage convex, diaphanous-white.

Nutrall, Jay's Catalogue of Shells, p. 41.

Hab. Monterey, Upper California.

Of a singularly produced growth, narrowly drawn in at the sides, with the diaphanous septum convexly raised in the middle.

\section{Species 29. (Fig. $a, b$, Mus. Cuming.)}

Crepidela bilobata. Crep. testâa obliquè orbiculari, apice subrostratâ, tenui, subpellucido-albâ, rufescente

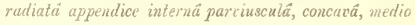
productâ.

THe two-lored Crepidula. Shell obliquely orbieular, slightly beaked at the apex, thin, subtransparentwhite, raycd with pale-red ; interual appeudage rather stnall, eoneave, produeed in the middle.

Gray, MS. Mus, Cuming.

Hab. - ? ?

A thin obliquely-grown speeies, with a septum similar to that of $C$. dilutata.

\section{Species 30. (Mus. Cuming.)}

Crepidula lirata. Crep. testá ovatâ, subcompressâ, radiutim corrigato-liratâ, apice marginali, subrostralo; livilu-castantê, versus apicen rubente; appendice interna diaylıano-albấ, subconcavâ.

THe ridged Crepidula. Sibell ovate, rather compressed, radiately wrinkle-ridged, apex narginal, slightly beaked; livid-chestnut, red towards the apex : internal appendage diaphanous-white, rather eoncave. 11ab. California.

The outer surfaee of this speeies, of which $I$ have seen several examples, is characterized by a seulpture of irregular waved radiating ridges, which do not appear to result from having grown apon a ribbed shell. The region of the apex in all the specimens is also peeuliar in being of a livid-reddish eolour. 



\section{R E P I U L A.}

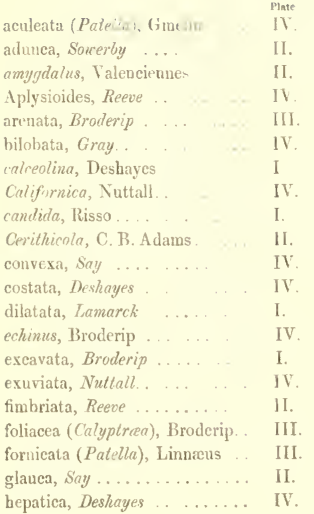

\begin{tabular}{r|} 
Species. \\
22 \\
12 \\
9 \\
19 \\
13 \\
29 \\
1 \\
22 \\
1 \\
9 \\
25 \\
21 \\
3 \\
22 \\
4 \\
28 \\
11 \\
14 \\
15 \\
7 \\
23
\end{tabular}

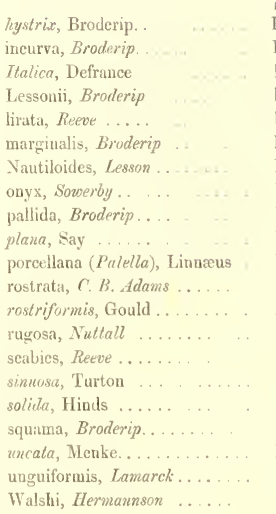

$\begin{array}{lr}\text { Plate. } & \text { specier } \\ \text { IV. } & 22 \\ \text { IV. } & 20 \\ \text { I. } & 1 \\ \text { III. } & 16 \\ \text { IV. } & 30 \\ \text { II. } & \\ \text { I. } & 6 \\ \text { II. } & 9 \\ \text { IV. } & 26 \\ \text { I. } & 1 \\ \text { I. } & 2 \\ \text { IV. } & 24 \\ \text { II. } & 12 \\ \text { II. } & 10 \\ \text { III. } & 19 \\ \text { I. } & 1 \\ \text { II. } & 12 \\ \text { I. } & 5 \\ \text { II. } & 12 \\ \text { I. } & 1 \\ \text { III. } & 17\end{array}$





\title{
MONOGRAPH
}

\author{
OF THE GENUS
}

$$
\begin{gathered}
\text { liniliar in his mouth as household words, } \\
\text { Bit in their flowing cups freshly remembered. } \\
\text { Shakspinor }
\end{gathered}
$$




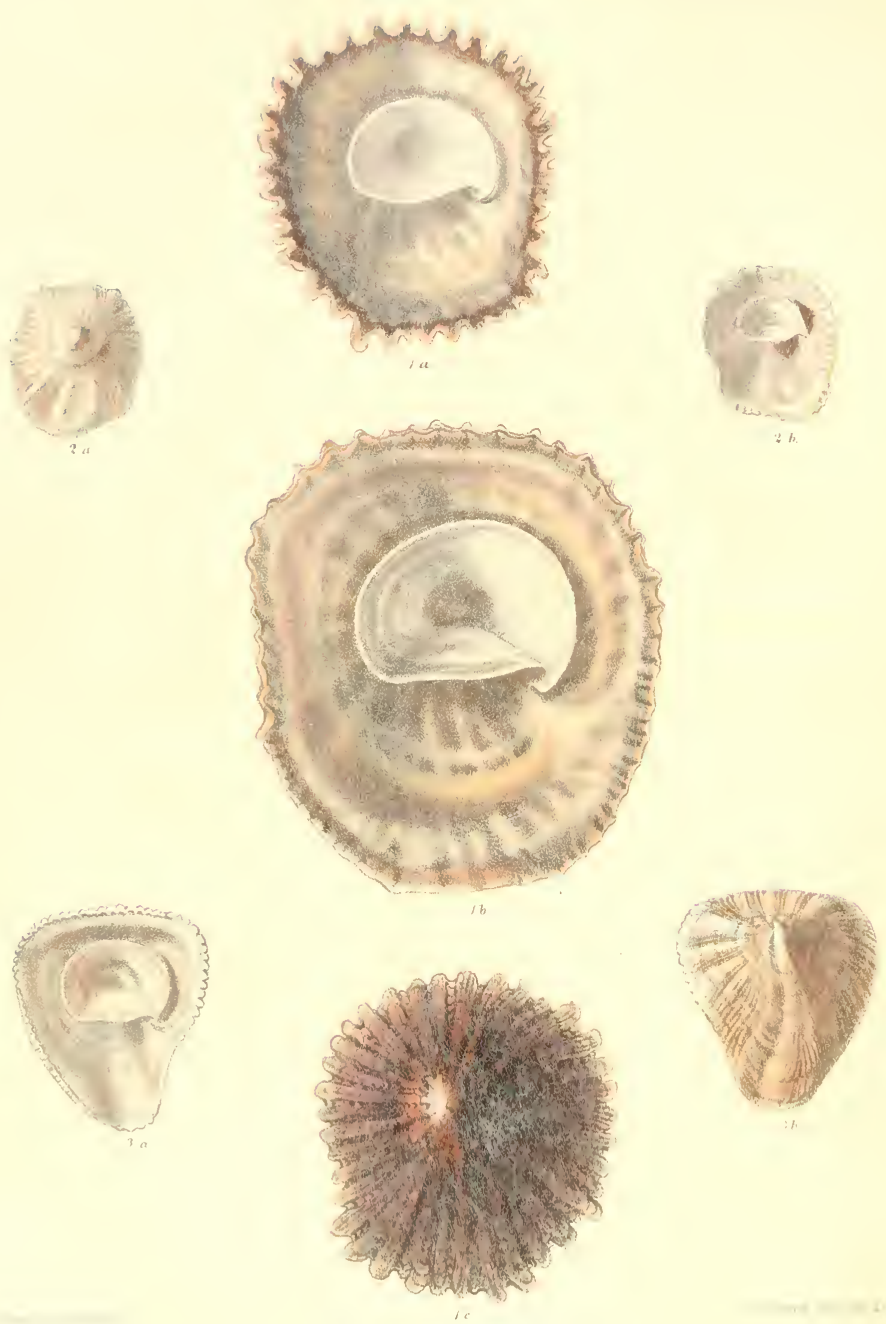


\section{R U C I B U L U II.}

Plate I.

Genus CRUCIBULUM, schunacher.

Testa ovutu vel orbicularis, nune depressa une conoidea, radiatim costata vel liruto-slriatu, intertum spinosa, rertice sapissiniè subcentrali. Aypondix interna cyathiformis, interlum lateraliter coilpressa.

Shell orate or orbieular, sometimcs depressed, sometimes couvid, radiately ribbed or ridge-striated, sometimes spined, with the top mostly near the ceutre. Internal appendage cup-shaped, sometimes laterally eompressed.

This genus, founded in 1817 by the eminent astronomer and naturalist Schumneher, is retained lor that seetion of the Lamarekian Calyptrece in whieh the internal appendage takes the form of a cup, which is sometimes free and sometimes laterally eompressed and attached. Concomitant with this there is a marked generic difference in the sluell eompared with the Calyptrea proper. In CrucibuI/Ii/ there is no traee of the trausparent thread-striated '1 isue of Catyptrea. The shell is larger and much more solidly developed, and geverally dark-coloured.

The Crucibula eminently belong to the New World. Onc or two small species have been collected in the Eastern Sras, lunt all those of mark are from California and the western shores of Sonth and Central America.

Species 1. (Fig. $a, b$, Mus. Cuming.)

Crucibulum tenue. Cruc, testât elerato-convexâ, irregulari, tenui, subcliujhanâ, creberrimè striat $\hat{a}$, althiel $\hat{a}$, interdum fusco-rubente pullitè strigutä; appentice interni cyathiformi, subampli, eburneâ.

THe thin Crucibulum. Sbell elevately convex, irregular, thin, subdiaphanous, very closely striated, whitish, sometimes faintly streaked with fuscous-red; internal appendage cup-shaped, rather large, ivorywhitc.

Calyptrea tennis, Broderip, Trans. Zool. Soc. vol. i. p. 199. p]. 27. f. 9 .

$H a b$. Peru.

A light shell, of very irregular growth, mostly painted with rather faint, promiscuously divaricating, fuscous-red streak-

Species 2. (Fig. $a, b, c$, Mus. Cuming.)

Crocibulum scutellatum. Cruc, teslâ ovalä vel orli- culari, subdepressâ, radiutim fortiter rigoso-costat $i$ custis strialis, interstitiis subobsoletè inbricato-fenustratis, livido-cinereâ vel fuscâ, variè marmoratâ, punctis linearibus rufo-fuscis interdum pictâ, vertice latewliter subcompresso, uneinato; appendice internâ cyathiformâ, peranplâ, wherneâ, interdum fusco marginatâ.

The sHLfld-Like Crucibulum. Shcll ovate or orbicular, rather depressed, radiately strongly wrinkleribbed, ribs striated, interstiees rather obsoletely imbricately latticed, livid-ash or brown, variously nottled, sometimes painted with linear red-brown dots, top laterally rather compressed, looked; internal appendage eup-shaped, very large, ivory-white, sometimes edged with brown.

Patella scutellata, Gray in Wood Ind. Test. Supp. pl. 8. f. 4. (inlyptrcea rugosa, Lesson.

Calyptrea imbricatu, Sowerby (not of Broderip).

Hab. Payta, Peru; Lesson. I'unta, St. Elena, West Columbia; Cuming.

The typical state of the ribs of this species is, to be rather spread and longitudinally striated, sprinkled with linear red-brown colouring, but these characters soon become roughened or obsolete with age.

Species 3. (Fig. $a, b$, Mus. Cuming.)

Crocibulem trigonale. Cruc. testâ triyono-ovatä, crnssit, profindè convexâ, lcevigatâ, versus marginem plicato-corrugatâ, albidâ, fusco-rubente variè striyatâ, vertice acutè uncinato; appendice inlerná cyathifurmi, peraneplä, eburneâ.

The triangular Crucibelum. Shell triangularly ovate, thick, deeply eonvex, smooth, plicately wrinkled towards the margin, white, variously streaked with fuscous-red, top sharply hooked; internal appendage cup-shaped, very large, ivory-white.

Calyptrae trigonalis, Adams and Reeve, Moll. Voy. Samaring, p. 70. pl. 9. f. $7 a, b$.

Hab. China Seas.

The principal distinguishing features of this species are its triangular coupression, which is alike in all speeimens, and not occasioned by any particular circumstances of attachment, and plicately wrinkled margin, streaked witls fuscons-red as in C. tenue.

December, 1858. 



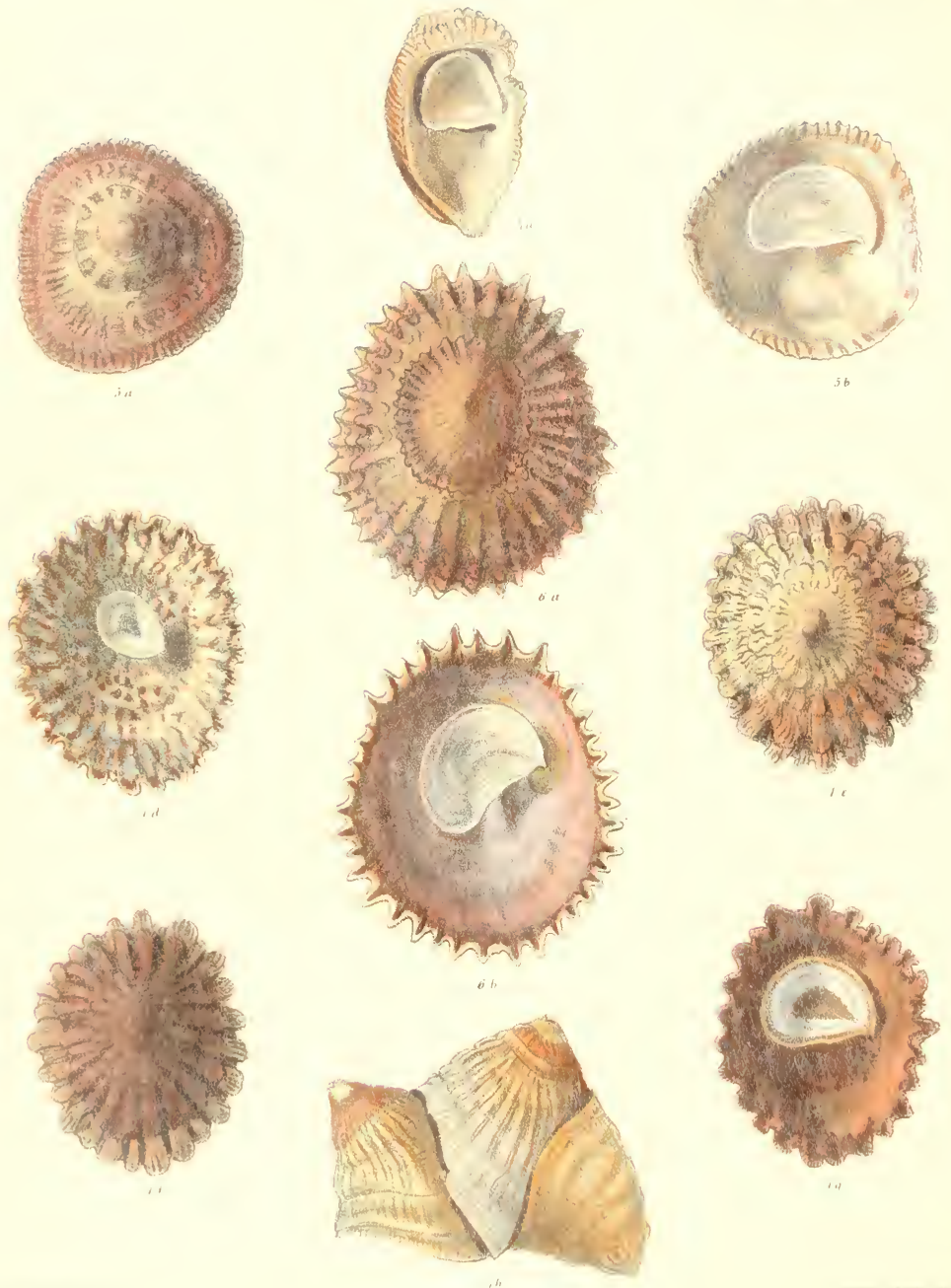


\section{R U C I B U L U M.}

\section{Plate II.}

Species 4. (Fig. $a, b$, Mus. Cuming.)

Crucibulum rugoscm. Cric. testâ elevato-conirấ, pileiformi, subregulari, rugoso-corrugatâ et striatâ, nlbidlit, fulvo-rubente striyat $\vec{a}$ et dicaricatim lineat $\vec{a}$, vertice postico, obliyuè pluto, suhobtusè uncinato; appendice interuâ ryathiforimi, peramiplá.

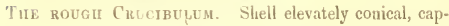
shaped, rather roughly wrinkled and striated, whitish, strraked and divarieatively lineated with fulvous-red, top posterior, obliquely raised, rather obtusely hooked; internal appendage cup-shaped, very large.

(alyptran ruyosa, Desbayes (not of Lesson); Anim. sans vert. vol, vii. p. 637 .

Calyptran iguaria, Broderip.

An var.? Calyptren gemmacea, Valcnciennes.

Hat. Island of Chiloe; Cuming.

Chiefly remarkable for its elevated cap-shape. Fig. 4t) represents the habit of this species to attreh one upon inother.

Species 5. (Fig, $a, b$, Mus, Cuming.)

('recibelum ferruginely. Cruc. testâ suborbiculati, elatâ, versus verticem attenuatâ, levoigatâ, versus warginem rugosâ, albidâ, fermyineo-rubente tinctâ et strigatâ, vertice subcentrali; appendice internä cyathifurmi, peramplat, eburneá.

The resty Crucibulum. Shell nearly orbicular, raised, attenuated towards the top, smooth, roughened towards the margin, whitish, stained and streaked with rust-red, top nearly central ; internal appendage cupshaped, very large, ivory-white.
Hab. Bay of Conception, Chili; Cuming.

The form of this speeies is that of a regular attenuated cone, and it is painted with rust-red in a manner to stain through to the interior round the margin.

\section{Species 6. (Fig. $a, b$, Mus. Cuming.)}

Crucibulum umbrella. Cruc. testâ ovatâ, irregulari, subdejressâ, radiatim costatâ, costis subacutè angulatis, ad citremitates mucronatis, purpurascente-fuscât, livida, vertice subobsoleto; appendice internâ cyathiformi, amplâ, liyalino-albá.

The cmbrella Crucibulum. Shell ovate, irregular, rather depressed, radiately ribbed, ribs rather sharply angled, pointed at the extremities, purple-brown, livid, top nearly obsolete; internal appendage cupshaped, large, hyaline, white.

Calyptraa umbrella, Deshayes, Enc. Méth. Fers, vol. ii. p. 173, n. 8 .

Calyptrea rudis, Broderip, Trans. Zool. Soe. vol. i. p. 196. pl. 27. f. 1.

Hab. Panama and lical Llejos; Cuming.

Distinguished from C. scutellatum, to which it is very nearly allied, by the sharply angular development of the ribs.

Fig. $1 d, e, f, g$. (Mus. Cuming.)

These specimens are figured to illustrate further varicties of C. scutellatum, described at Plate 1, having the ribs more spread and more grooved and red-dotted. 


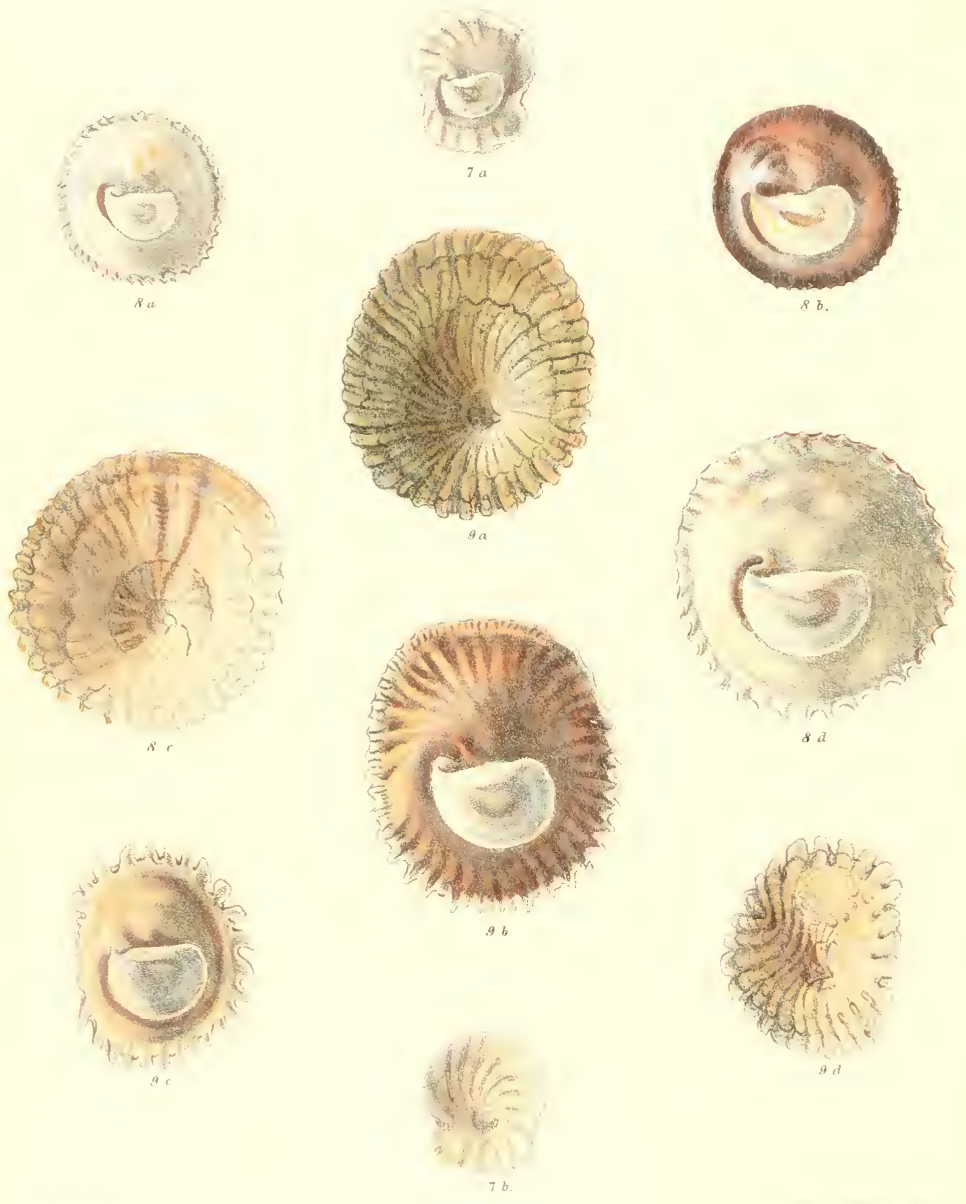


\section{R U C I B U L U M.}

\section{Plate III.}

Fig. 7 , (Mu- Cuming.)

This shell appears to be a specimen of $C$. tenue, in fiucr :ondition than the Broderipian type figured in Plate 1. The vertex beng free from any decortication is, though ceniral, twisted obliquely, and sharply hooked, and the shell is more strongly sculptured with close-set, ridge-like strix.

Species 8. (Fig. $8 a, 8 b, 9 a, 9 b$, Mus. Cuming.)

('rucibulum conrugatum. Cruc. testâ orbiculari vel ovat $\hat{a}$, elevato-conexiâ, wertice lateraliter rompresso, radiatim custatâ, costis peculiariter flexuoso-rugatis, albidâa aut livido-fiscâa; appendice internâa amplâ, eburneá.

Phe Wrinkied Crucibulum. Shell orbicnlar or ovate, elevately convex, top laterally compressed, radiately ribbed, ribs peculiarly flexuously wrinkled, whitc or livid-brown; intcraal appcudage large, ivory-white.

Carpenter, Pro. Zool. Soc. 1856, p. 204.

Hab. Califormia.

There is a strong peculiarity in the ribs of this species. They have a flexuously wrinkled shrivelled appearance, and a new rib commcuces abont halfway down in the interstices between those that spring from the top.

Species 9. (Fig. $8 c, 8 d, 9 c, 9 d$, Mus. Cuming.)

Crucibulum imbricatum. Cruc. testâ orbiculari vel ovatâ, subelevato-convexâa, obliquè radiatim costatâ, costis fortibus, subfternosis, vertice acuto, lateraliter compresso, albidâ, fusco-rubente interdun strigatâ; appendice interna cyothiformi, amplâ.

The imbricated Crucibulcm. Shell orbicular or ovate, rather elevately convex, obliquely radiately ribbed, ribs strong, rather flexuous, top sharp, laterally compressed, whitish, sometimes streaked with brown-red; internal appendage cup-shaped, large.

Calyptraca imbricata, Broderip, Trans. Zool. Soc. vol. i. p. 198. pl. 27. f. 7.

Hab. Panama (on stoncs in sandy mud at a depth of from six to ten fathoms): Cuming.

The ribs are much more strongly developed than in the preceding species, and hare an oblique inclination orer the margin. 



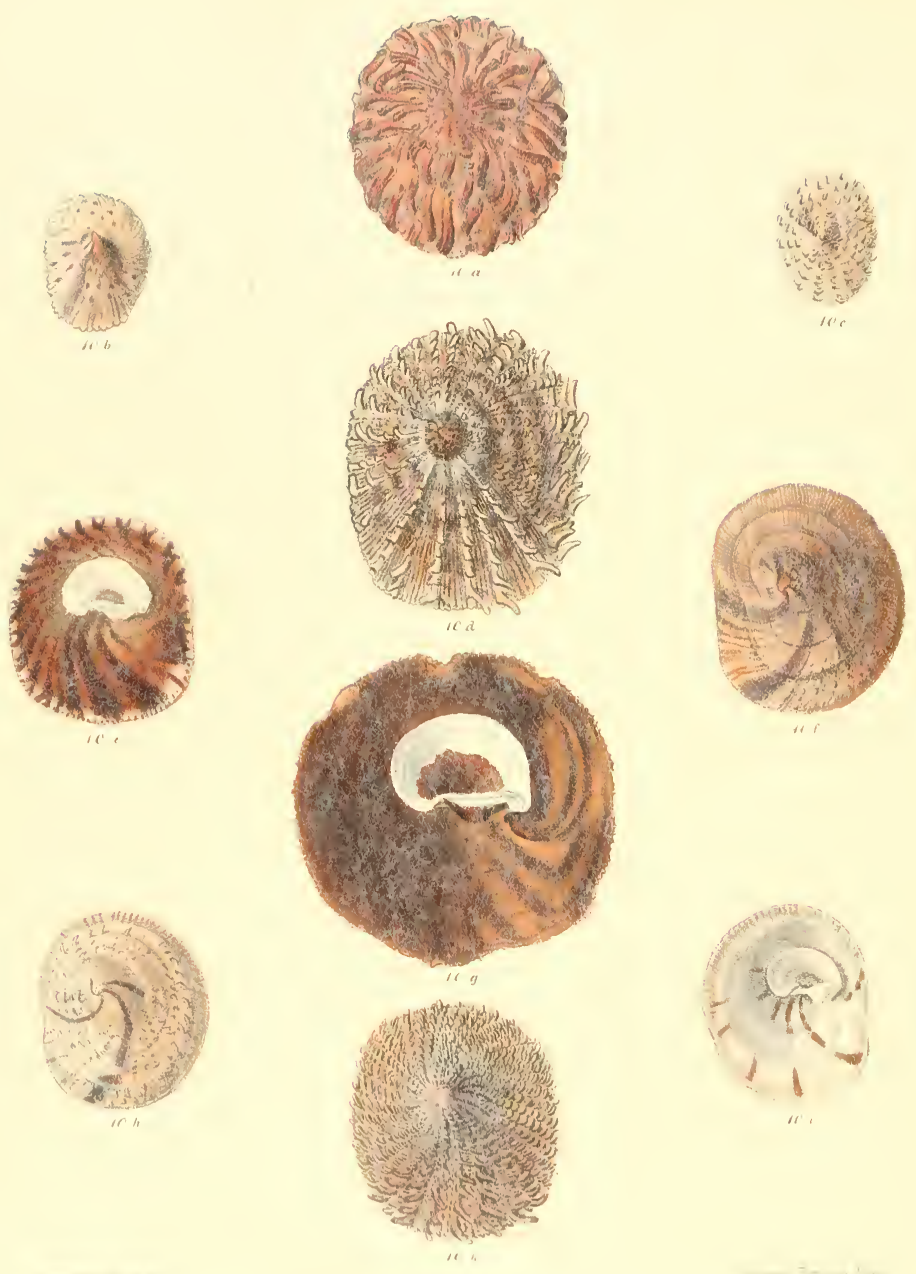


\section{R U C I B U L II.}

\section{Piate IV.}

Species 10. (Fig. $a$ to $k$, Mus. Cuming.)

Crucibulcu spinosum. Crue. testä orbiculari, interdum subquadrato-orat $\vec{a}$, nunc solidiuscula $\vec{a}$, convex $\vec{a}$, nunc depressi, trmuiculî, radiation liratâ et irregulariter corrugato-striatâ, lubuto-spinosâ, interdum autem raro inermi, vertice subcentrali, obliquè contorto; lividât aut lutescente-albi, purpureo contorto-radiatá, intus intensè cinercâ vel albî́; appendice internâ cyathiformi, amplit, tateraliter compressâ, crystallino-albâ, medio interdum cinereâ.

The spined Crectbulum. Shell orbicular, sometimes squarely ovate, rather solid and convex, or depressed and rather thin, radiately ridged and irregularly wrinkle-striated, generally tube-spined, sometimes, but rarely, withont spines, vertex nearly central, obliquely twisted; livid or yellowish-white, twistedly rayed with purple, intcrior dark-ash or white; internal appendage cup-shajped, large, latcrally compressed, crystalliue-white, sometimes ash-stained in the middle.

Calyptrae spinosa, Sowerhy, Gencra of Shells, f. 6 .

Calyptrcea Peziza, Gray.

Varieties. ('alyptrica hispida and maculata, Broderip.

Calyptraa tubifira, Lesson.

Calyptrea cinerea, milhi.

Hal. Seas of Central America.
It has been neccssary to devote an entire Plate to the illustration of this extremely variable species. To commence with the most highly spined state of it, the specimen represented at Fig. $10 a$ aftords a remarkable instance. In this depressed shell, extraeted by Mr. Cuming from a hollow in a large stone hauled up from deep water, the spines are eomparatively distant and promiscuous, standing up in the form of erect or slightly reeurved tubes. In Fig. $10 d$ the shell is more convex or limpet-like, and the spines are in direct radiating ridges. In Fig. $10 k$ the shell is equally convex with the spines, more numerous and tubnlar, surronnded with a plentiful spronting of smaller seale-like spines; while in Fig. $10 \mathrm{~g}(\mathrm{C}$. cinerea, mihi, in Conch. Syst.), the spines and scales are becoming obsolete, and the shell is rounder, and of a mort irregularly depressed growth. In the shells represented at Fig. $10 \mathrm{e}$ and $10 \mathrm{f}$ the scale-ribs disappear, and the wrinkled striæ become conspicnous, the twisted-rayed purple colouring, of which there are indications in the preceding varieties, are here more revealed to view, and there are traces of a few scattered spines, more or less obsolete. The specimen Fig. $10 h$ and $10 i$ presents a link with the Broderipian C. hispida and maculata, at Fig. $10 \mathrm{C}$ and $10 \mathrm{~b}$. The former is enaracterized by its delieate structure, in which the spines are also delicate, like finc prickles, and the latter is peculiar in having the purple rays more or less broken up into spots. 



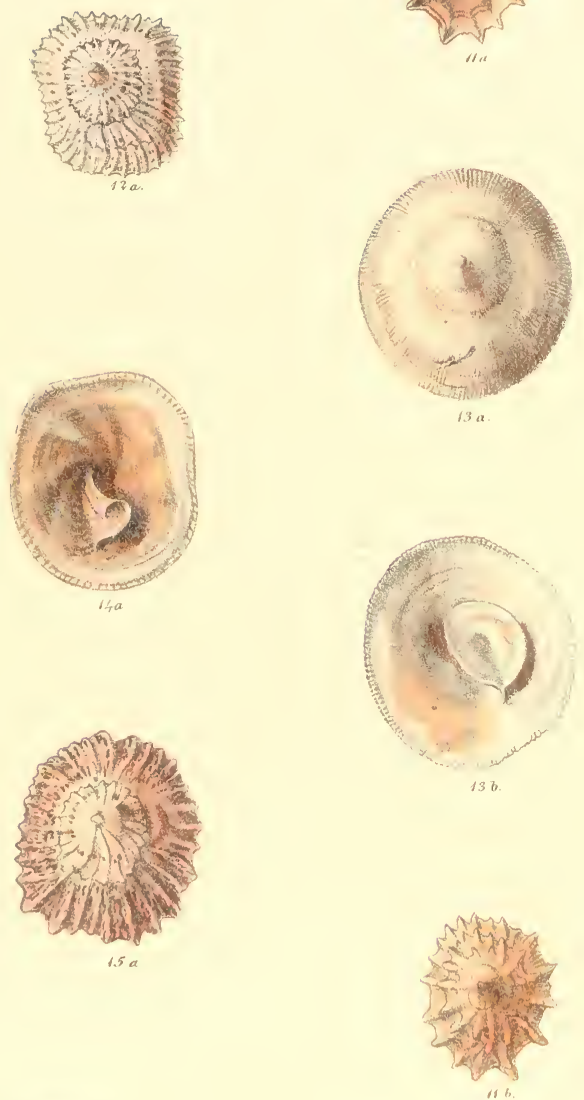
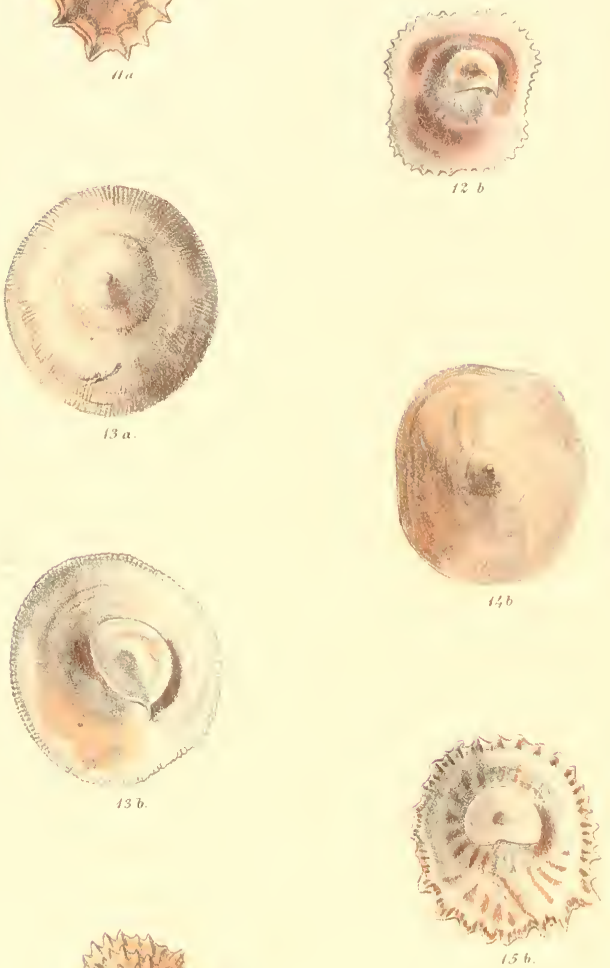

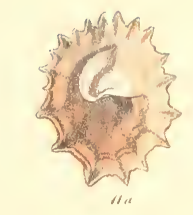




\section{R U C I B L U II.}

\section{Plate V.}

Speci s 11. (Fig. $a, b$, Mus, Cuming.)

Drucibulum pectinatum. Cruc. lestâ ovalä, subpileiformi, vertice acuto, prominente, subincurvâ, radiatim valuè costatâ, costis distantibus, concentricè acutè imbricatis, ad murginem mncronatis; spadicro-lactea ;

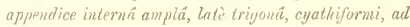
latus affixíl.

The pectinated Crucibulum. Shell ovate, somewhat cap-shaped, top sharp, prominent, slightly incurred, radiately strongly ribbed, ribs distant, concentrically sharply imbricated, pointed at the margin; fawncream-colour; internal appendage large, broadly triangular, cup-shaped, affixed to the side.

Carpenter, Pro. Zool. Soc. 1856. p. 168.

Hab. l'ert.

Chiefly distinguished by its broally imbricated ribs, the ends of which project conspicuously over the margin.

Species 12. (Fig. $12 a, b$, Mus. Cuming.)

('rucipulum violaceur. Cruc. lestá subquadrato-oratá, irrel/ulari, radiatim costuta $\vec{a}$ costis interruptis, rucle undato-carrugutis, valde irreguluritus, vertice acuto, dezrressinssulo; ulbidá, punctis rufo-fuscis plus minus lentiginosâ, intus violucea : appendice internâ albrâ, cyathiformi, latiusenlâ, subcentrati.

The violet Crucibulus. Shell somewhat squarely ovate, irregular, radiately ribbed, ribs interrupted, rndely wave-wrinkled, very irregular, top sharp, rather lepressed; whitikh, pore or less freckled with red-brown dots, interior violet; internal appendage white, cup-shaped, rather broad, nearly central.

Carpentek, 1'ro. Zool, Soc. 1856. p. 167.

Hab. Ceylon; Capt. Templeton.

The fow specimens kuown of this species in the Cumingian collection, brought from Ceylon by Captain Templeton, are all coloured in the interior by a delicate roseviolet, a character which is at present unique.

Species 13. (Nig. $a, b$, Mus. Cuming.)

Cructbulum spectrum. (ome. testï orbiculari, depressinsculâ, incrassat $u$, vertice centrali, subobtuso; opacialbä, radiatim decksatim corrngato-striatí; appendice interná amplä, latè cyathiformi.

Tue spectre Crucibulum. Shcll orbicular, rather depressed, thick, top central, rather obtuse; opake- white, radiatcly decussatciy wrinkle-striated; internal appendage large, broadly cup-shaped.

Hab. Malacca.

A round opake-white shicld of simple structure, having the surface carved, particularly towards the margin, with irregularly decussating wrinkle-like striæ.

Species 1t. (Fig. a, b, Mus. ('mming.)

Crucibulum extinetorium. Crur. testit subquadratoovatâ, tenui, subcorneú, pellucillä, depressiusculâ, vertice conico, centrali; tutescente, livido-purpurascente obscurè contorto-radiatä, lineisyu rufis obliquis pallidis tinctâ; appendice intermi compresso-crispatâ, ad latus affixia.

The extinguisier Crucibulum. Shell somewhat squarcly ovate, thin, rather horny, transparent, somewhat depressed, top conical, central; yellowish, obscurely twisted-raycd with livid-purple, and stained with oblique faint red lines; internal appendage compressly curled, affixed to the side.

Calyptran entinctoriun, Lamarck, Inim. sans rert. vol. vii. p. 622 .

Ilab. Malacea; Cuming.

A somewhat horny shell, in which there are traces of radiating purple and oblique red lines.

Species 15. (Fig. $a, b$, Wus, Cuming.)

Crucibulum auriculatem. C'ruc. testâ suborliculari, depress $\hat{a}$, radiatim costat $\vec{t}$, cost is oblusis, irregularibus, interdum dirergentibus of interruptis, vertice subacuto, depressinsento; albiela, punctis ot lineis rufo-fuscis promiscuè atspersâa; appendice interuâ cyathiforni, latiusculâ, subcentrali.

The auricutated Crecibulua. Shell somewhat orbi('ular, rather depressed, radiately ribbed, ribs obtuse, irregular, sometides divcruent or interrupted, top rather shar;) a little depressert; whitish, promiscuously sprinklal with red-brown dots and lines; internal appendage eup-shaped, rather broad, nearly central.

Patella auricutainn, Chemnitz, Concb. Cab. vol. x. p. 336. pl. 168. f. $1628,1629$.

Hah. ('umana; and Island of St. Thomas, West Indics.

The rilss in this species are not unlike those of C. viulacrum, and the freckle of red-brown dots is sumilar, but the colouring is darker, and is seen within the margin, while there is no indication of rose-violet in the interior.

February, 1859. 



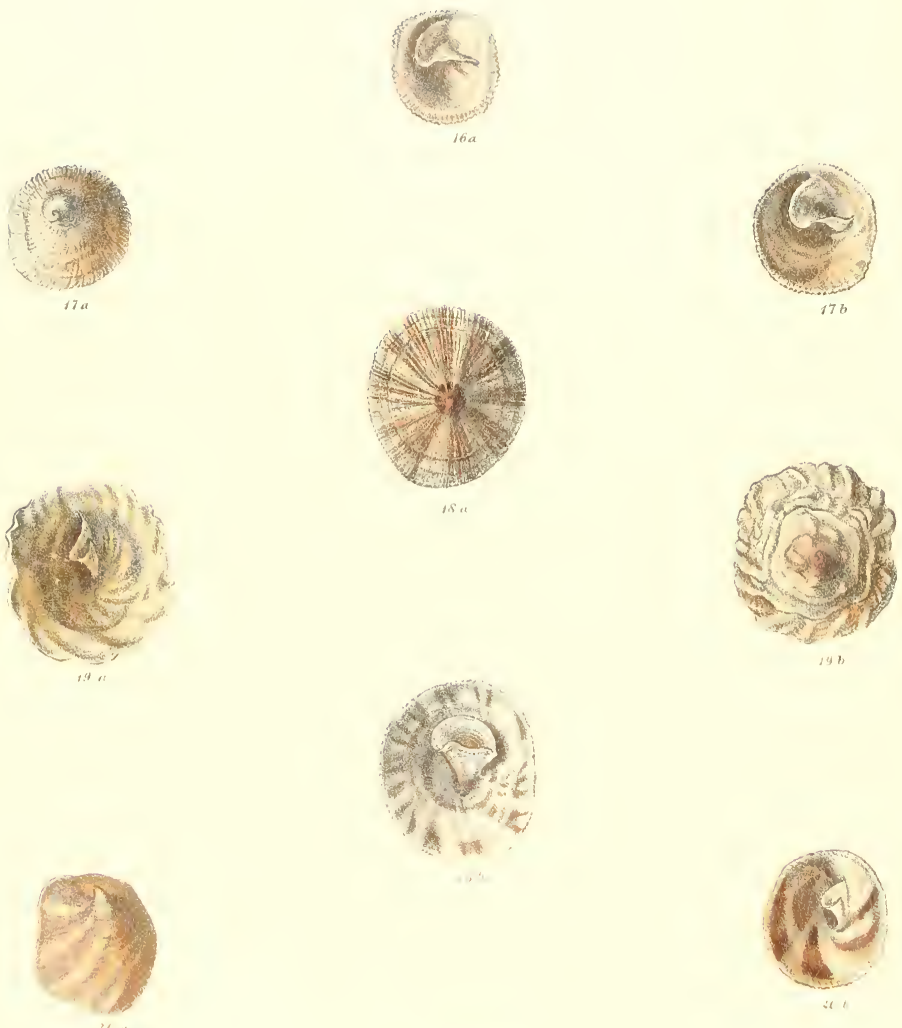

$14 b$
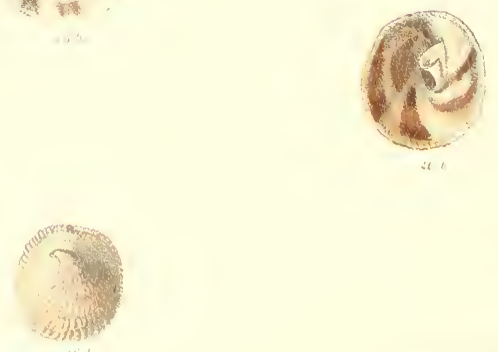


\section{R U C I B UL U II.}

\section{Plate VI.}

Species 16. (Fig. a, o, Mus. Curning.)

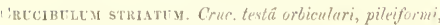
vertice conoideo rostruto; sordide fuscescente, radiatim striotá, striis subamplis, distantibus, concentricè obsuletè fimbriatis; appendice interna latè patulte, od latus uffic.câ.

The striated Crecibclis. Shell orbicular, capshaped, top conoil, beaked; dirty light-brown, radiately striated; strie ratlier large, distant, concentrically obsoletely frilled; internal appendage broadly open, attixed to the sirlc.

Civinutrea striata, Say, Journ. Aead. Nat. Sei. Phil. vol. v. p. 216.

Hab.

A conoid cap-shaped sliell in which the radiating striæ are rather large and distant, arranged almost in concentric irills.

Species 17. (Fig. a, b, Mus. Cuming.)

Crecibeley auritum. Cruc. testa orbiculari, depressiuscula $\vec{a}$, contexấ, vertice wibtuso, radiatim densè striatâ, striis corrugatis, irregularibus; sordidè fuscescente; appendice interna amplä, auriformi, patulit, submarginali, ad latiss affixia.

The eared Crtcibulum. Shell orbicnlar, rather depressed, convex, top obtuse, radiately densely striated, striæ wriukled, irregular; dirty light-brown; interual appendix large, ear-shoped, open, almost marginal, aftixed to the side.

Culyptrea striata, Broderip (not of Say), Pro. Zool. Soc. 1834, p. 35

Hab. Valparaiso (on shells dredged from sandy mud at a depth of from forty-five to sixty fathoms); Cuming.

This species is less conoid than C. striata, say, and differently striated. The internal apyendage reaches nearly to the margin.

Species 1S. (Fig. $a, b$, Mus. Cuming.)

('rucibulum radiatem. Cruc. testá conico-orbiculari, albît, fusco-rufescente radiatî, vertice acutu, castaneo tincto, punctato, radiation striatâ et creberrimè tenwiliratî; appendice internâ cyathiformi, productú, lateraliter concaro-compressâ.

THE RAYED CRTC1BULtM. Shell conically orbicular, white, rayed with fuscous-red, top sharp, stained and dotted with ehestnut, radiately striated and very closely finely ridged; internal appendix cup-shaped, produced, concavely compressed on one side.

Calyptrae raliata, Broderip, I'ro. Zool. soc. 1834. p. 36. Hab. Bay of Caraceas.

The internal cup-shaped appendage of this species is quite peculiar. "It is pressed in, as it were," as described by Mr. Broderip, "on one side, and adheres to the shell not only by its apcx, but also by a lateral seam, which scarcely reaches to the rim of the cup."

Species 19. (Fig. a, b, Mus. Cuming.)

Crucibule rerrtcostu. Crue. testâ orbiculari, medio conicâ, verlice centrali, subinamillari, lutescente-lacteä, sulopacü, levigatâ, versus maryinem peculiariter corrugato-verrucosît; appendice internâ angustè cyathiformi, compressî, ad latus affixâ.

The Warty Crucibulum. Shell orbicular, conical in the middle, top central, somewhat mamillary, yellowish crean colour, rather opake, smooth, peculiarly wrinkle-warty towards the margin; internal appendage narrowly cup-shaped, compressed, affixed to the side.

Hab.

Distinguished by a peculiar wart-like sculpture of very irregular but conspicuous development.

Fig. 20. (Fig. $a, b$, Mus. Cuming.)

This sluell is presented as an illustration of the elevated conical form of $C$. extinctorium, described in the preceding Plate, as figured by De Blainville in his 'Manuel de Malacologie,' pl. 48. f. 8 .

February, 1859. 


$$
\text { • }
$$



Crucibuhn PI. III.
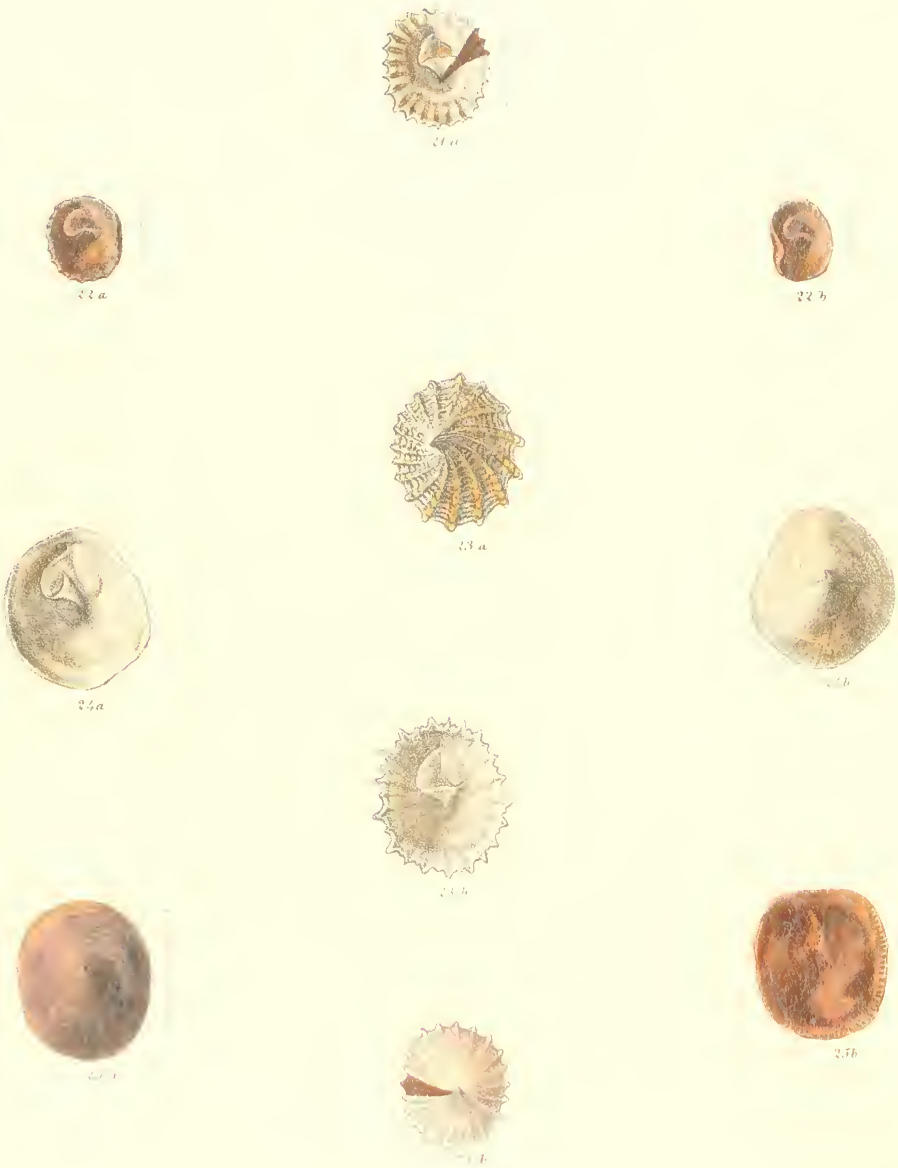


\section{R U C I B U L U V.}

Plate VII.

Species 21. (Fig. $a, b$, Mus. Cuming.)

Cruciblum serratum. Cruc. testä suborbiculari, tenui, depressá, pellucido-albâ, purpureo-castaneo interdun marulatio if uniradiatâ, radiatim costatā, costis prominentibus, interstitiis decussatim rugosis, margine serrato, vertice acuto; appendice internat vix cyathiformi, lateraliter valde compressâ.

The serrated Crucibulim. Shell somewhat orbicular, thin, depressed, transparent white, sometimes spotted and one-rayed with purple chestnut, radiately ribbed; ribs prominent, with the interstices decussately wrikkled, margin serrated, top sharp; internal appendage scarcely cup-shaped, latcrally very compressed.

Calyptrcea serrata, Broderip, Pro. Zool. Soc. 1834, p. 37.

Hab. Real Llejos and Muerte, Central Imerica (found on dead shells in a muddy bottom at a depth of from six to eleven fathoms); Cuming.

A thin semi-transparent white shcll very conspicuonsly ribbed, usually characterized by a single dark ray of purplechestnut.

Species 22. (Fig. $a, b$, Mus, Cuming.)

Crucibulum sordidir. Cruc. testâ subconicá, sordidè luteâ, intus cinereo-fuscâ, subradiatâ, vertice subturbiuato; appendice internâ subtrigono-compressâ, crystallino-alliti.

Tre sompin Crucibulum. Shell sulsconical, sordid yellow, ash-brown within, faintly rayed, top slightly turbinated ; internal appendage somcwhat triangularly coupressed, crystalline-white.

Calyptrae sordida, Broderip, Pro. Zool. Soc. 1834. p. 37 Eadem var. Culyptron unguis, Broderip.

Ilab. Valparaiso and Panama (found on stones and shells); Cuning.

A small cap-shaped species of a yellowish asb-brown colour in the interior, with a laterally compressed crystalline appendage. The shcll represented at Fig. $22 \dot{b}$ is Mr. Broderip's Calyptrcea unguis.

Species 23. (Fig. $a, b$, Mus. Cuming.)

Crucibulum concameratum. Cruc. testâ pileiformi, vertice acuto, valdè incurto, albidâ, radiatim costatä, costis prominentilu, inh rstitios undiyue profunde cunrameratis; appendice interwit subcyathiformi, amplâ. ad latus offixiti.

The vallted Crucibulix. Shell cap-shaped, fop sharp, very much incurved, whitish, ratiately ribloed, ribs prominent, with the interstices everywhere dceply vanlted; interual appendage somewhat cup-shaped. large, affixed to the side.

Hab. — ?

This remarkable shell, collected by Sir Edward Belcher in the Sumarang, but omitted in the 'Zoology' of the voyage, is curiously chambered into deep vaults. Ttic ribs are rery prominent, and the interstices between them are crossed throughout by broad septa.

Spccies 24. (Fig, $a, b$, Mus, Cuming.)

Crecibulem Morbinem. Cruc. testä orliculari, piterformi, vertice erecto, centrati, subpellucidè allä, concentricè rugoso-striatü, maculis rufis promiscuis tineisque numerosis intermptis pallide pirti; appendice internâ compressè cyuthiformi, ad latus affixât.

The diseased Cruciblacm. Shell orbieular, capshaped, top erect, central, semi-transparent white, concentrically wrinkle-striated, fantiy painted with promiscuous red spots and numerous interrupted red lines; interual appendage compressly cup-shaped, fixed to the side.

Hab. China Seas.

The faint red painting noticed in the above description, and which does not appear in the specimen figured, is very characteristic of the species.

Species 25. (Hig. $a, b$, Mus. Cuming.)

Crecraulda lividur. Cruc. testâ pileiformi, subirregulari, tenui, livido-fuscâ, lineis rufis tenuissimis decussatim pictâ; appendice internâ compressè cyathiformi, ad lutus affixâ.

The livid Crecibelis. Shell cap-shaped, rather irregular, thin, livid-brown, decussately painted with very fine red lincs; internal appendage compressly cup-shaped, fixed to the side.

Hab. China Seas.

Very like the preceding species but of more irregular growth, and of a peculiarly livid colour on the fine reclline painting strongly marked at the margin.

February, 1859. 



\section{R U C I B UL U II.}

\begin{tabular}{|c|c|c|c|c|c|}
\hline ouriculatum (Patrila), Chemutc & $\begin{array}{l}\text { Plate. } \\
\text { V. }\end{array}$ & $\begin{array}{l}\text { species. } \\
15\end{array}$ & serrntuu (Calup) Broderip & $\begin{array}{l}\text { Piste. } \\
\text { VII. }\end{array}$ & $\begin{array}{l}\text { species } \\
21\end{array}$ \\
\hline $\begin{array}{l}\text { uriculatum (Patida), Cnemut } \\
\text { uritım, Rere }\end{array}$ & V1. & 17 & scutellatum (Calyp.), Gray & I. & 1 \\
\hline oneaneratım, Reeve & VII. & 23 & sorilidum (Calyp.), Broderip. & VII. & 2.2 \\
\hline -rugatum, Carpenter & III & 8 & spectrum, Reeve ..... . ... & V. & 13 \\
\hline xtinetorium, Lamarck & r. & 14 & spinosum (Calyp.), Sowerby. . & IV. & 10 \\
\hline 'errugineum, Reeve & II & 5 & striatum (Calyp.), Say ......... & VI. & 16 \\
\hline Imbrieatum (Calyp.), Broderip & III. & 9 & tenue (Calyp.), Broderip ...... & 1. & 2 \\
\hline lıvidmu, Reeve $\quad . . .$. & VII & 25 & trigonale (Calyp.), Ad. and Reeve & l & 3 \\
\hline morbidum, Reeve... . & VII. & 24 & umbrella (Calyp.), Deshayes. & II. & 6 \\
\hline furtinatum. Carpenter. & V. & 11 & verrucosum, Reeve... . . & VI. & 19 \\
\hline radiatum (c'alyz.), Broderip. . & V1. & 18 & violaceum, Carpenter & $\mathrm{V}$ & 12 \\
\hline mos-um (Culyp.). Deshayes. & II. & 4 & & & \\
\hline
\end{tabular}

ERRATUN

Plate 1 -The deseriptions of Species 1 and 2 should be transposed 



\title{
IIONOGRAPH
}

\author{
OF THE GENLS
}

\section{$\begin{array}{llllllll}T & \mathrm{R} & \mathrm{O} & \mathrm{C} & \mathrm{H} & \mathrm{I} & \mathrm{T} & \mathrm{A} .\end{array}$}




Trechita Pl. I

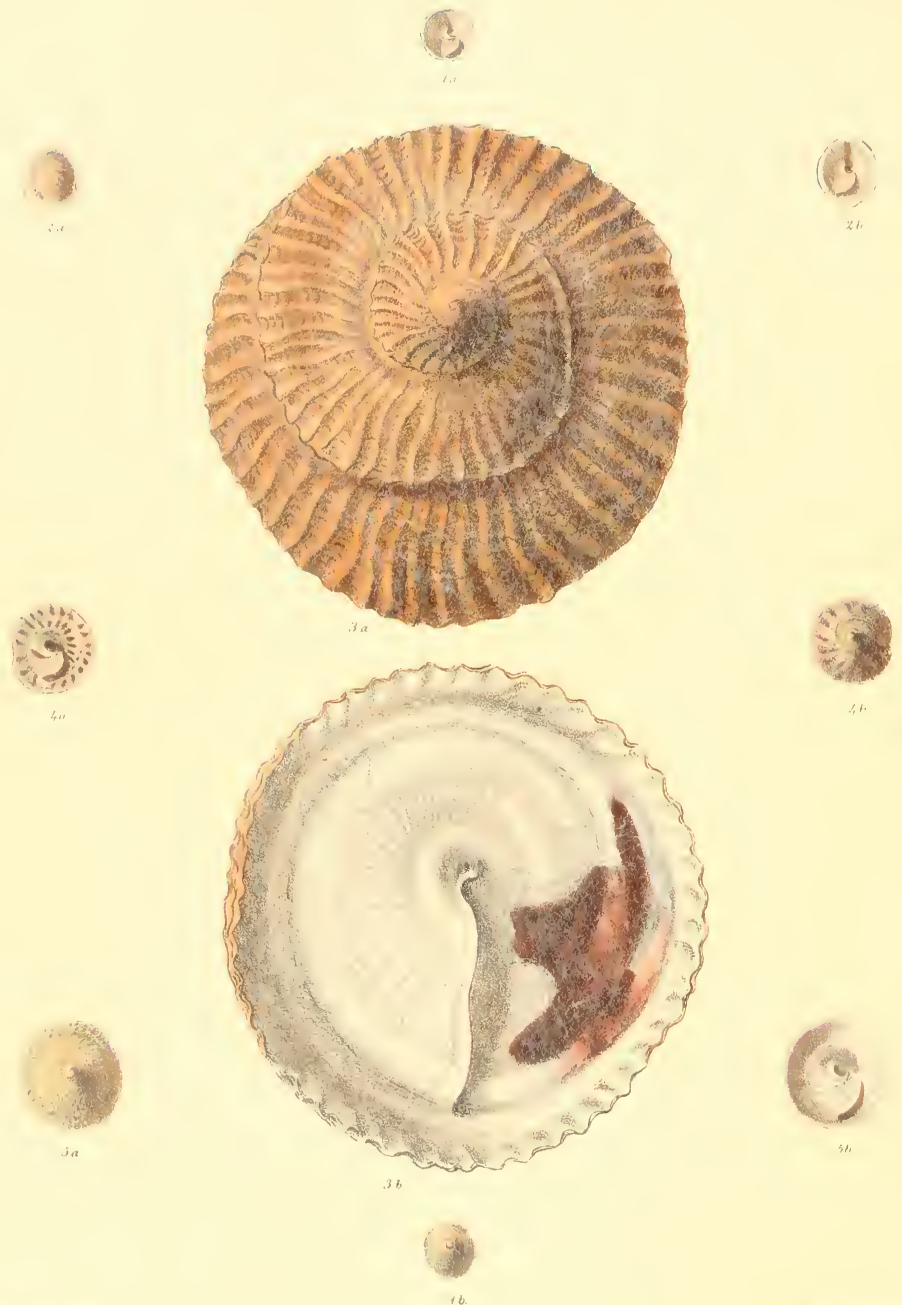




\section{T ROCH I T A.}

Plate 1 .

(..7us Tiz)CHIl'A, Sehmacher.

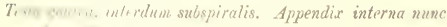
tutera is, effusa, nunc trochoidea, ad marginem producto.

Shell conical, sometimes subspiral. Internal appendage somewhat lateral and effused, sometimes trochoid, reaching to the margin.

After assigning to the genera Calyptran, Crucibulum, and Crepidula the members of this family respectively characterized by the presence of a basal plate, by a ccntral cup, and by a transverse septum, there remain about filicen species, in which the internal appendage assumes in spiral septum or trochoid form. For these Professor Schumacher founded the genus Trockita. In some, as in $T$ radians, spirata, and clypeolum, the internal appendage reaches to the margin; in others, as in $T$. conicn, subreffexa, and simmsis, the appendage is comparatively small, latrial, and effused. These last constitute 1)r. Gray's genus Graterns.

The western cuasts of South and Central America and New Holland are the prineijual habitats of the geuus. ()ne species is found in Britain, but only on the southern shores.

Species 1. (Fig. $a, b$, Mus. Cuming.)

Trochita poculum. Troel. testâ orbiculuri, pileiformi, vertice elato; alba ; appindice interna spiratiter septiformi.

ThE LitTLE-cup Trochita. Shell orbicular, cup-shaped, vertes raiscd; white internal appendage spirally scptum-slinped.

Hab. Valparaiso; Cuming.

A sinall, rounded, cap-shaped species, distinet in form from any of those described by Mr. Broclerip. The outer surface is corered with a parasitic coralliue.

\section{Species 2. (Mus. Cuming.)}

Trocinta peluecina. Troch. testä orbiculari, depressizescula $\vec{a}$, subtiliter concentriè striatá, vertice centrali: albä, pellncidai; appendice internâ subdepresso-septiformi.

The transparent Trochita. Shell orbicular, rather depressed, finely concentrically striated, vertex central; livid-white, triusparent; interual appendage rather depressly septum-shaped.
Hab. Philippine Islands. Cuming.

A small, livid, transparent species, rather depressect

Species 3. (Fig. $a, b$, Mus. Cuming.)

Trocmita Radians. Troch, testâ orbiculari, subdepressá. costis subnodulosis undique radiatâ; albidâ, intus interdum castaneo-nigro tinctâ, extns epidermide lutescente fibrosa $\vec{a}$ induta $\vec{a}$; subtus concavâ, appendice interná peramplit, Trochifarmi.

The radiating Trochita. Shell orbicular, rather depressed, rayed throughout with slightly nodulous ribs; whitish, sometimes stained within with chestnnt-black, covered without with a yellowish fibrous epidermis; concave beneath, internal appendage very large, Trochus-shaped.

Crepidula radians, Auim. sans vert. vol. vii. p. 626 .

Troclews radians, Lamarck.

Infundibulum radians, Sowerby.

Calyptrca Peruviana, Deshayes.

Testa juvenis, Troclitu rentricosa, Carpenter.

Ilab. Valparaiso; Cumiug.

This species, deseribed originally by Martini, among others of the group, without any spccific name, under the general head of Lepas, was placed by Lamarck in his genus Troclus. M. Deshayes was the first to perceive its true affiuitics.

Species 4. (Fig. $a, t$, Mus. Cuming.)

Trochita aspersa. Troch. testâ orbiculari, tenuiculâ, cancentricè tenuistriatä, vertice subspirali; pellucidoalbâ, intus rufo maculatâ; appendice internâ laterali, appressè effusä.

The sprinkled Trochita. Shell orbicular, rather thin, concentrically finely striated, vertex somewhat spiral; trausparent-white, spotted within with red; internal appendage lateral, appressly effused.

C. B. ADAMs, Ann. Lyceum Nat. Hist. vol, v. p. 443 .

IIab. Panama (under stoues, at low water-mark); C. B. Adams.

Of semitransparent substance, eonspicuously painted in the interior with red spots; but of a somewhat fainter and less clouded character than those in $T$. conica. 


\section{TROCHITA.-PLATE 1.}

Species 5. (Fig. a, b, Mus. Cuming.)

Trochita Sinensis. Troch. testâ orbiculari, depressoconicâ, extus tenuisquanosî, squamis sape obsoletis, mtus lavigatâ, nitente; pellucido-albâ ; appendice interná laterali, appressè effusâ.

Thz Cunnese Trochita. Shell orbicular, depressly conical, finely scaled externally, scales often obsolete. smooth and shining internally; transparent-whitc; internal appendage lateral, appressly effused.

Patella Chinensis, Linnæus, Syst. Nat. p. 1275.

Patella Sinensis, Gmelin.

Trochita Chinensis, Schumacher.
Patella alba, Donovau.

Calyptraa Chinensis, Fleming.

Calyptrcea lavigata, Lamarck.

Catyptran Sinensis, Deshayes.

Patella muricala, Da Costa.

Patella oulgaris, Philippi.

Hab. Southern shores of Britain, the Channel lslands, and the Meditcrranean.

Excepting Pileopsis Hungaricus, this is the only British species of the family Calyptraida. It is pcculiar in being finely scaled, but the scales become more or less tisolete with age. 


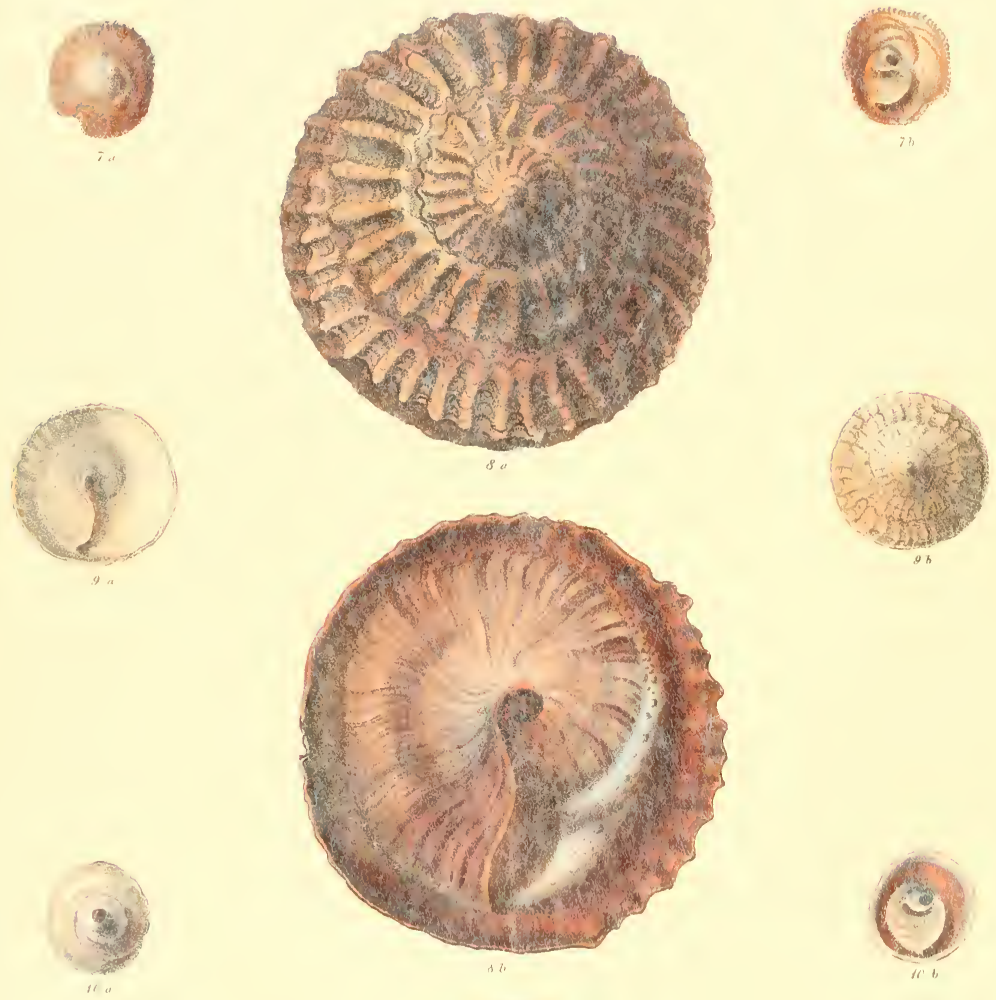

th 


\section{T R O C H I T A.}

Plate 11.

Spectes 6. (Fig. $a, b$, Mus. Cuming.)

Trochita lichen. Troch, testâ depressä, concentricè rudi plicatâ, lavigatấ; albâ, subdiaphanâ, obscurè fusco-rufo punctatî́ et lineatâ; appendice inlerná laterali, appressè effusâ.

The lichen Trochita. Shell depressed, concentrically rudely plicated, smooth; white, subdiaphanous, obscurely dotted and lineated with brown-red; internal appendage lateral, appressly eftused.

Calypticen lichen, Broderip, Pro. Zool. Soc. 1834, p. 37.

Hal, Island of Muerte (found on dead shells, in sandy mud, at a depth of eleven fathoms); Cuming.

This little species would seem to be the representative of our European T. Simensis. It is of the same typical character, and very elosely allied to it in species.

Species 7. (Fig. $a, b$, Mus. Cuming.)

Trochita subreflexa. Troch, testâ obtusè concexâ, mumutricè irregulniter plicatâ, uadique promiscuè minutè spinoso-squanutâ, apice spiraliler maniltari; inellucidu-albat, fermugineo-rufo tinctâ; appendice inlentâ laterali, "ppressè effusâ.

Thн. subreflecten Trochita. Shell obtusely convex, concentrically irregularly plicated, everywbere promiscuonsly minutely spine-sealed, apex spirally mamillary; transparent-white, stained with rust-red; internal appendage lateral, appressly effuscd.

( ARPexter, Mis. in Mus. Cuming.

H/rb. Gulf of California.

of an irregular globosely convex form, finely spinescaled throughout, stained towards the margin with a characteristic transparent rust-red.

Species 8. (Fig. a, b, Mus. Cuming.)

Truchita spirata. Tivelh. testât subgloboso-conicâ, costis valudis tonyiturlinalibus, subnodosis, distantibus undique plicntâ, subtus concarấ; purpureo-cinereo et rastaneo cinetât; npprulice interna peramplat, trockiformi.
ThE spiral Trocinta. Shell somewhat globosely conic, plicated throughout with slightly noduled distant strong longitudinal ribs, concave beneath; stained with purple-ash and chestnut; internal appendage very large, trochiform.

Calyptrea spirata, Forbes, Pro. Zool. Soc. 1850, p. 27\%. pl. 11. f. $1 a, b$.

Patella trochifurmis? Chemnitz.

Hab. Gulf of Calitornia.

This fine species may be chiefly recognized from its congener $T$. radians by its dark purple-ash and chestnut colouring. It is also, in its typical state, more globosely conical.

Species 9. (Fig. $a, b$, Mus. Cuming.)

Trochita corrugata. Troch. testâ orbiculari-conicâ, pileiformi, exlus radiatim corrngato-liratâ, intus concacâ, appendice spiraliter septiformi; albidâ, ferrugineo vix ti. cti.

TRE WRINKLED TROCnIT. Shell orbicularly conical, cap-shaped, externally radiately wrinkle-ridged, concave within, the appendage being spirally septumshaped; whitish, slightly tinged with rust

IIob. Callao, Peru; Cuming.

The internal appendage of this species is of the same spiral septum-shaped structure as in $T$. radians, but the shell is more deeply concave.

\section{Species 10. (Fig. $a, b$, Mus. Cuming.)}

Trocmita solida. Trock. testá conicâ, crassizssculâ, concentricè rudè striatá; calcareo-albit, apice purpureâ, intus fusco-purpureâ; appendice laterali, diaphanâ, appressè efficsâ.

TIE soLID TrochitA. Shell conic, rather thick, concentrically rudely striated; chalk-white, purple at the apex, brown-purple within; appendage lateral, diaphanous, appressly effused.

Hab. Conchagua, Central America.

A solid, conical, chalk-white species, with a purple apex, brown-pmrple in the interior. with a bright, diaphanous-white, lateral appeudage.

May, 1859. 


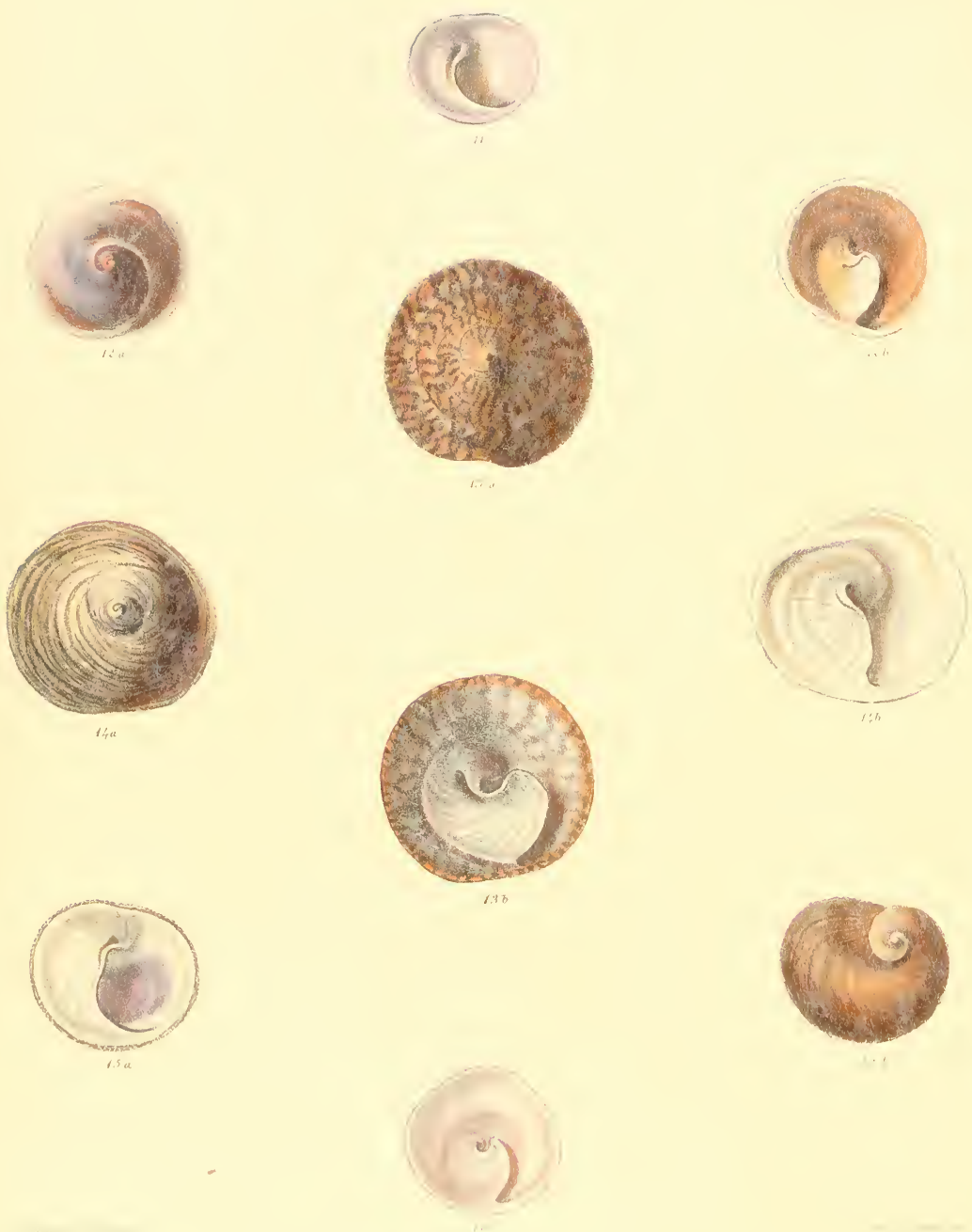


\section{T R O C H I T .}

\section{Plate III.}

Species 11. (Mus, Brit.)

Trocuta Calyptr.eformis. Troch. testâ orbiculatoconvexâ, subspirali, apice mamillala $\vec{a}$ allât vel lutescente. epidermide tomentosá indutê, intus albâ, purpurasente-carneo interdum tincta, appendice septiformi, latiasculâ.

The Calyptra-shapen Trocnita. Shell orbicularly convex, rather spiral. manillory at the apex; whitc or vellowish, covered with a hairy epidermis, interior white, sometimes tinged with purple-tlesh, appendage septum-sbaped, rather broad.

Trochus Calyptraformis, Lamarek, Inim. sans vert. rol. vii. p. 627

Calyptra Lirmarchii, Deshases.

Crepidule tomentosa, Qnoy aud Gaimard.

Hab. Tasmania.

Rather more spirally convoluted than in its uearest allied species, $T$. maculata, and of smaller size.

\section{Species 12. (Fig. $a, b$, Mus. Cutning.)}

Trochita Manenllaris. Troch. Itsti conici, pileiformi, larigatâ, nqice mamillari; corneu-ulbâ, tivido-purpurascente linct $\vec{a}$, intus ferragincu-purpureâ, appendice sublaterali, ad marginem centralen reflexât.

Tre mamulary Trochita. Shell conical, cap-shaped, smooth, mamillary at the apex; horny-white, stained with lwid-purple, interior rust-purple, appendage rather lateral, reflected at the central margin.

Calyptrae mamillaris, Broderip, Trans. Zool. Soe. vol. i. P. 201. pl. 28. f. 5 .

nlab. Island of Muerte, Central Ameriea; Cuming.

This speeies is ehietly characterized by its livid-purple horny substance, and simple cap-like conical form.

Species 13. (Fig. $a, b$, Mus. Cumiug.)

Trochita consca Trocle. Testá conicâ, subpilefiformi, te-

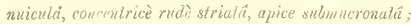
corneo-albirlu, rufo undique nebutatî el irregulariter maculatû, appendice internâ diupleano-albâ, loterali, efficsâ.

Tue conical Trucnita. Sliell conical, somewliat capshaped, rather thin, concentrically rudely striated, rather pointed at the apex; flesh-white, clouded and irregularly spotted throughout with red, interual appendage diaphanous-white, lateral, effused.
Calyptraa conica, Brodern, Trans. Zool. Soc. vol. I, I 202. pl. 28. f. 7

Hab. Xipixapi and Salango, West Columbia (attached to stoues, in deep water); Cuming.

This fine spceies may be recognized by its densely redspotted culouring, and smaller diaphanous-white internal appendage.

Species 14. (Fig. $a, b$, Mus. Cuming.)

Tnochita cLypeOLom. Trocle, testâ orbiculari-depressa, apice subuamillari, concentricè rudè strialá; sortidè albâ, epidermide densâ fibrosâ indutâa, inlus eburne $\hat{a}$ appendice amplâ, septiformi, parmm reflexâ.

The ittTle-shielu Trochita. Shell orbicularly depressed, rather mamillary at the apex, concentrically rudely striatcd; dirty-white, covered with a thick fibrous epidermis, interior ivory-white, appendage large, septum-shaped, but little reflected.

IIab. Straits of Magalbaens.

A fine species, of rather depressed growth, covered with a dense fibrous cpidermis, with the internal septum-shaped appendage rcaching to the onter margin in a regular, trochoid growtl.

Species 15. (Fig. $a, b$, Mus. Cuming.)

Trocmita haculata. Troch. lestâ orliculari, convexâ, subspirali, concentricè striatîे; allutit, epidermide densât fibrosî induti, intus concarâ, albâ, violaceo mimurulalâ, appendice umplä, septiformi, vix reflexî.

The blotched Trochita. Shell orbicular, convex. somcwhat spiral, concentrieally striated; whitc, coFered with a thick fibrous epidermis, interior concave. white, stained with a single blotch of violet, appendage large, septum-shaped, scarcely reflected.

Quor and Gaimard, Voyage de l'Astrolabe, vol. iis. p. 422. pl. 72. f. 6, 9 .

Hab. New Zealand.

The interior of this species is characterized by the presence of a large violet stain.

Fig. 16. (Mus. Brit.)

The shell bere figured appears to be a large subtropical state of $T$. Sinensis. 



\title{
MONOGRAPH
}

\author{
OF THE GENCS
}

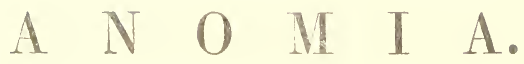

Why, love forswore me an my mothe * s sub And, for 1 should not deal in her suft laws She did corrupt frail nature with some bribe To shrink mine arm up like a withered shrub To make an cnvious mountain on my back Where sits deformity to mock my body.

To disproportion me in every part.

I,ike to a chaos

But to command, to eheck, to o'erbear such

$A$ - are of better person than myself,

1 can ard colours to the chameleon,

("hange shapes with Pinteus." 




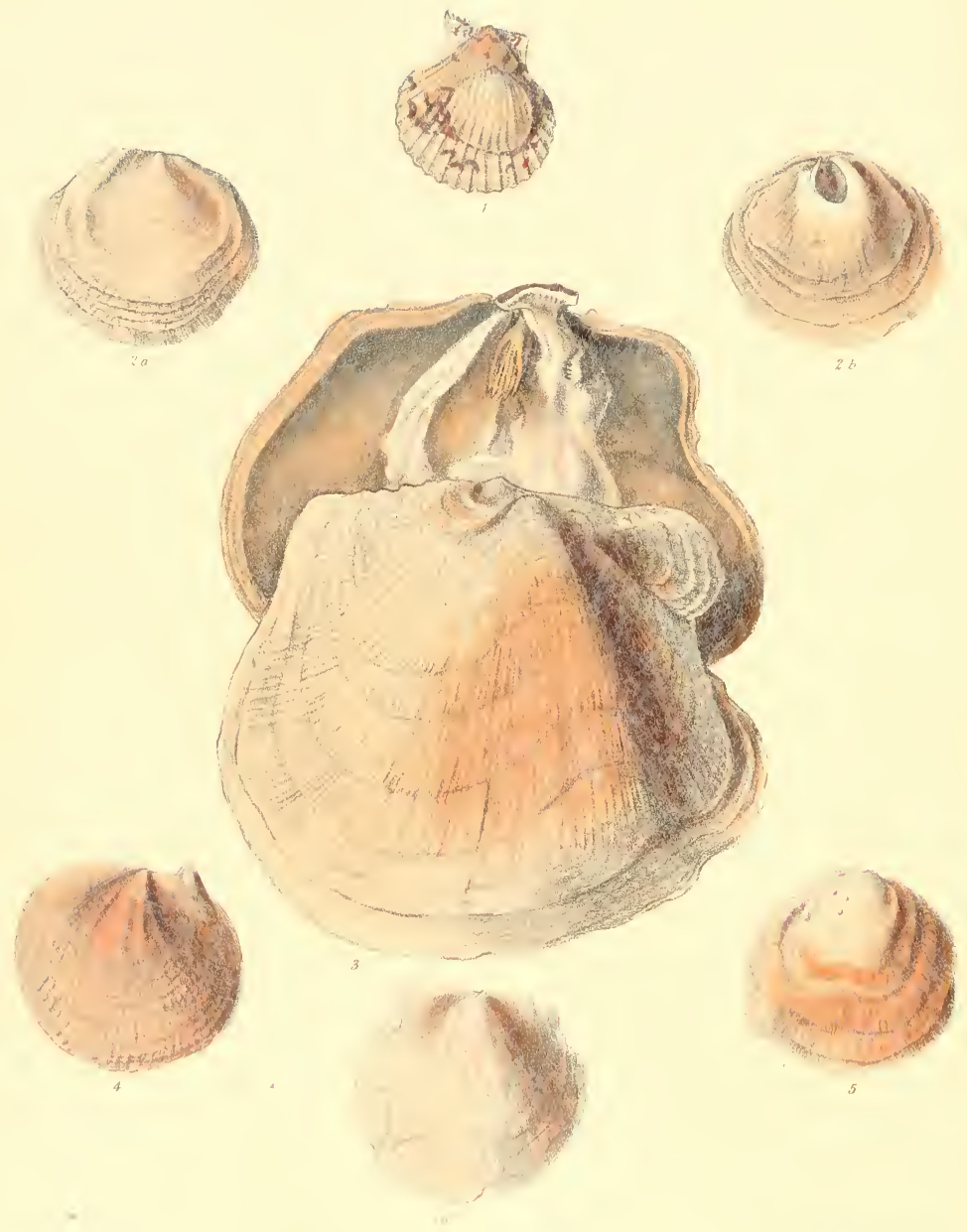




\section{A NOMIA.}

\section{Plate 1.}

\section{Genus INOMIA, Linnceus}

Testo ple runque orliculuris, inaquivalvis, irreqularis, afti.rn, interiom solidiusculu, seppissine trmaixsima, hyatina. Valere inferior plana. prope cardinem orbiculatim perforata et emaryinati, perforatione cuneolo adlucesionis subralcarmo librè̀ impletât. Falva superior comrerr. squamato-7aminata, striata aut rostata, impressiunibus muscularibus tribus, subcentralibus. Cardo edentutus, Figamento brri; ad callusitatem affixo.

Sheti generally orbieular, inequivalse, irregnlar, affixed, sometimes rather solid, mostly very thin, hyaline. Lower valve flat, orbicularly perforated and notched near the hinge, perforation treely filled with a subcalcaresus plug of adhesion. I.pper valve convex, squamately laminated, striated or ribbed, with three subecntral museular impressions. Hinge toothless, with the ligament short, attached to a callosity.

Anomice are of all shells the most dificult to determine the speeies. Living attaehed to foreign bodies, and being mostly of fragile texture, the shell becomes more or less shaped to the irregularities of its surface of attachment. If growing upon a ribbed surface, the sheil assumes a ribbed structure; but the rilss formed under these circumstances are not marked hy the definition and character which belong to a species that has a typical ribbing or striation of its owu. There is perhaps greater diffienlty in diseriminating between the different states of a species incident to aget and hatritat. The well-known A. rphippium of the European seas has been described twcnty times over. Fiven of the nine recent Anomire deseribed by Lamarck, eight are supposed to be referable to this one species.

Sevoral important spceies of Anouria had bcen long known in Mr. Cuning's eabinet, when Dr. Gray, in 1519 , undertook to deseribe them. To these a few are now added, including one of large size and striking eharacter, d. nobilis, from the sandwich Islands, and the list is extended to thirty-thres.

There is little to generatize upon in connection with their places of babitation. Australia contributes the finest species in A. elyros, and the rest so far as the habitats are known, would appear to be almost limited to the shores which bave been dredgert by Mr. Cuming, some in the New World and some in the Old.
Other sources of unt mation as to the locaities inhabited by this geuus are much needed.

\section{Species 1. (Mus. ('uming.)}

This sheli represents Anowia polymorpha of Pluhipj: who has given definitions of seren distinct virietirs. If is of a thin, erystalline texture, with a well detined unbo, and is found abundantly both in the interior and ( 1 the cxterior of sliells and other marine bodies, varyug m appearance and structure according to the irregularties, its place of attaehment. It bas been eonsidered hy 1)r Gray and by Messrs. Forbes and IIanley to be only st many states of $A$. ephippium, and 1 ineline to concur in that opinion.

\section{Specics 2. (Fig, $a, b$, Mus. Cuming.)}

Axomia pleniluniun. Anom. teslât orbiculari, smbopacre allet, flavicante, versus marginem pellucido-luminat $\hat{a}$ valvâ inf-riore lineis flexuoso-radiatâ.

TIIE FULb-Moon ANomiA. Shell orbicular, somewhit opacue-white; yellowish, transparently lamimated towards the margin; lower valve flexuously rayed witi. lines.

Hab. Borneo.

The under valve of this species is tumidly raised abont the orifice, with flexuous limes diverging around.

\section{Speries 3. (Mus. Cuming.)}

Anomia elymos. Anom. testâ subquadratá, ampla, ciassiusculâ, radiation densè rayoso-striată, striis irreyulturibus; opaco-albâ, valvâ superiore ferrufjineo tinciâ, inferiore virescente.

The Port Essington Anomia. Shell somewhat square; large, rather thick, radiately densely roughly striated, strix irregular, opaque-white, upper valve tinged witb rust, lower valve greenish.

Ginay, Pro. Zool. Soc. 1849, p. 118. pl. 4. f. 1.

IIab. Port Essington, Australia; Earl of Derby.

This fine speeies, of which another exanple in a younger state is represented at J'ate II. Fir. 9, is remarkable tor the manner in which the callous deposit of the interior is

August, 1859 . 


\section{AYOMIA.-Plate I.}

produced around the upper part of the orifice. The shell is moreover distinguished by a square, subauriculated form, very conspicuously radiately striated.

\section{Species 4. (Mus. Cuming.)}

ANoмia sol. Anom. testâ valvá superiore convexá, tenui, hyalinâ, flexuoso-radiatá, radìis interruplè rugosis; umbone subprominente, acuto; pellucido-albâ, aurcorufescente-tiuctâ.

THE sun ANomid. Upper valve of the shell convex, thin, hyaline, flexuously rayed, rays interruptedly rugose ; umbo rather prominent, sharp ; transparentwhite, tinged with golden-red.

$H a b$. Kurachee, mouth of the Indus.

Mr. Cuming possesses only a single upper valve of this species. It is extremely thin and hyaline, flexuously rayed, and of a bright transparent golden-red colour.

Species 5. (Mus. Cuming.)

Axoma celata. Anom. testä suborbiculari, irregulariter concentricè laminatâ, radiatim liratâ, liris linearibus, conferlis ; valvâ superior hyalino-albâ, aureo- rufescenle tinclâ, inferiore virescente-albâ, concentricè striatä.

The CARVED ANomia. Shell somewhat orbicular, irregularly concentrically laminated, radiating ridged, ridges linear, close-set; upper valve hyaline-white, tinged with golden-red, lower valve greenish-white, concentrically striatcd.

Hab.

The upper valre of this species has a close-set, radiating, ridge-like sculpture of its own, quite distinct in character from that of the preceding species. In colour it is of a bright golden hue, greenish-white beneath.

\section{Species 6. (Mus, Cuming.)}

Anomia placentella. Anom. testä subquadrato-ovatá, tenuissimá, convexiusculâ, laevi, submalleatâ, albá.

The Placenta-like Anomin. Shell somewhat squarely ovate, very thin, rather convex, smooth, slightly malleated, white.

Hab. — ?

Aa extremely thin convex shell, of rather a Placentalike, form having the upper surface faintly malleated. 


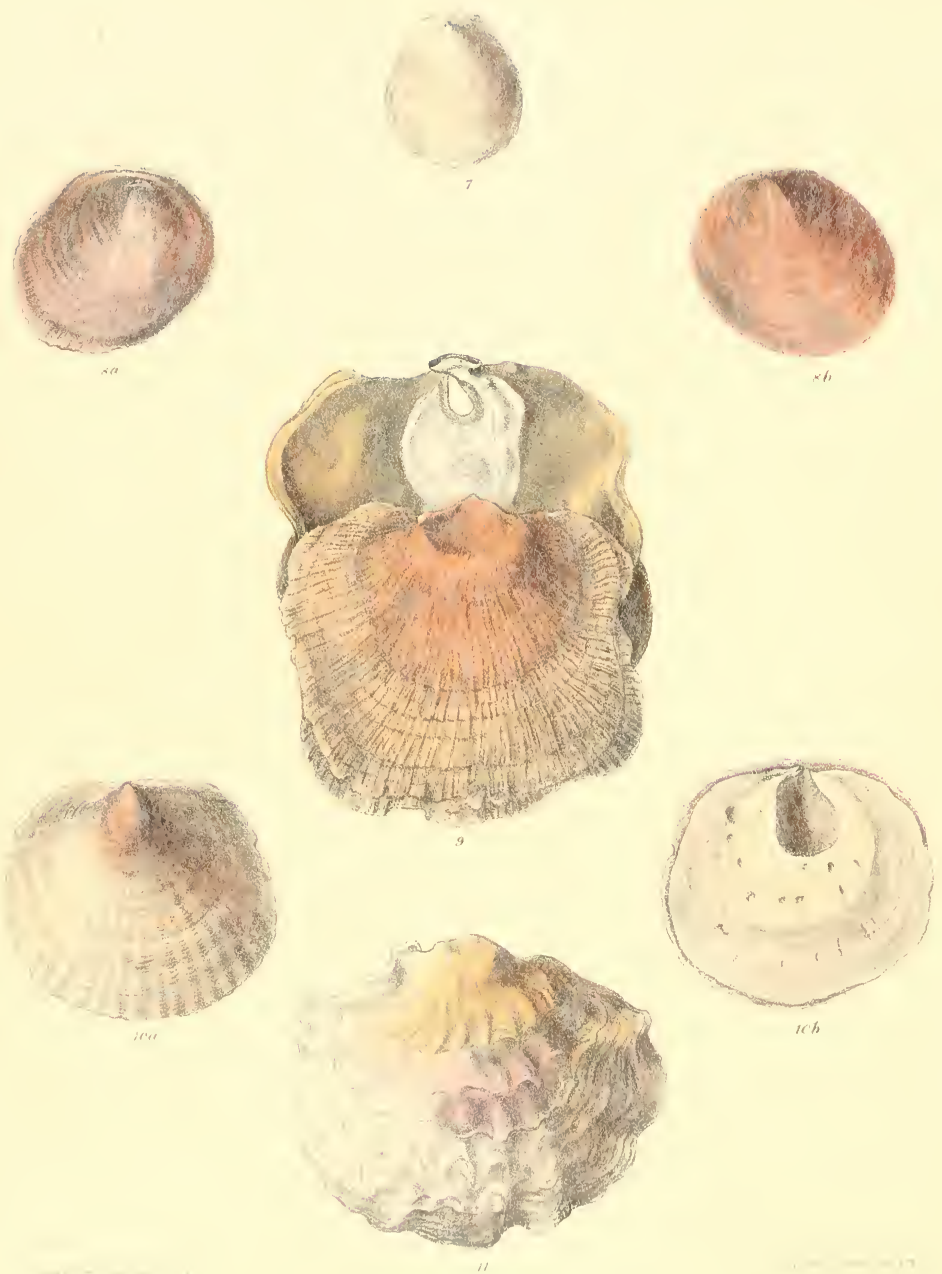


\section{A NO II A.}

Plate II.

Species 7. (Mus. Cuming.)

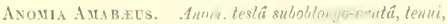
lnviyatit, argenteo-albä. plunulatit, mmione subacuto.

The silvenY INouia. Shcll somewhat oblong-ovate, thin, swooth, silvery-white, rather flat, unbo sharp.

Grar, Pro. Zool. Soc. 18 \$, p. 115.

Mab. Island of Burias, Philippines (on stones, in sand, at a depth of ten fathoms); Uuming.

A small, silvery-white, transparent shell, of a rather spoon-shaped, oblong-ovate form, laving a sharp, well-defined umbo somewhat removed from the margin.

$$
\text { Aplecies 5. (Fig. a. is, Mus. (uming.) }
$$

Axomia 11 mprereysiana. Arom. testa abliquè notata, solidiusculä, rencentricè striatâ, sulppellucidâ, cupreorufescenti, umbone acuto.

IItuphreys' Axomia. Shell obliquely orate, rather solid, coucentrieally striated, somewhat transparent ; eoppery-red, umbo shirp.

$\mathrm{Hal}$.

An odd valve, from the eollection of George Humplireys, the old dealer, and predecessor of the elder Sowerby. Though of comparatively solid texturc, it is transparent, and of a coppery-red colour. The oblique, enppery-red shell represented in the next Platc at Fig. $14 a, \dot{b}$, and whieb is known to be from the same old collection, appears to be another example of the species, ribbed from the surfaee of its place of attachment.

\section{Fig. 9. (Mus, (uming.)}

This shell, ticketed in Mr. Cuning's collection A. stria$t u s$, Gray, does not appear to have been descrilsed under that name, and proves to be a younger state of A. elyros. figured in the preccling Plate.

Speeies 10. (Figr. $a, 7$. Mus, Cuming.)

A момиа сүт.есм. Anem. testê subarlinulari, radiutim corrugulo-costatá, costis subotsoletis, pellucido-albi. circa umionem aurantio-cnealâ, umbone actoto : vatrâ inferiore virescente.

TuE suield Anomia. Shell somewhat orbicular, radiately eorrugately ribbed, ribs rather obsolete, transparent-white, orange-bronzed around the umbo, umbo sharp; lower valve greenish.

Girar. Pro. Zool. Soe. 1849, p. 115.

Hab. Mouth of the Zangtze Keang River, Chinal: Forttune

This speeies is eharaeterized by a faint wrinkle-ribbed seulpture in the npper valse, which is not derived from the surface of any foreign body, as the under valve is perfectly smooth.

\section{Species 11. (Mus. Cuming.)}

Anomia ephippirm. Anom. testâ subabliquè orbiculari, plus minus irregulari, r'udè striata ato-squamata; Iutescente-alliâ.

The SADDle ANomia. Shell somewlat obliquely orbicular, more or less irregular, rudely striated, sometimes fimbriately scaled; yellowish-white.

Linnaus, Syst. Nat. p. 1150.

Anomia electrica, cepa, and squamula, Linneus Anomia punctato, Chemnitz.

Anomic flerkosa, ruyosa, and cylindrirn, Gmelin. Anomia margaritacen, sulcaln, and pectiniformis, Poli Anomia cyinbiformis, Maton and Raeket.

Anomia violacea and striatula, Brnguière. Anomia pyriformis and formicata, Lamarek. Anomia polymorpha and scabrella, Philippi. Anomia tubularis, Turton. Anomia coronata, Beau.

Hah. European Seas.

The long list of synonyms of this speeies above quoted show how largely eonehologists have been deeeived by its Protean eharacter. On whatever foreign body the Anomia ephippirm attaches itself, the shell grows with some eorresponding impression of the surrounding irregularities; and along with this it differs in texture, etc., at different periods of its growth, and aceording to the depth and circumstanees of its habitation. 



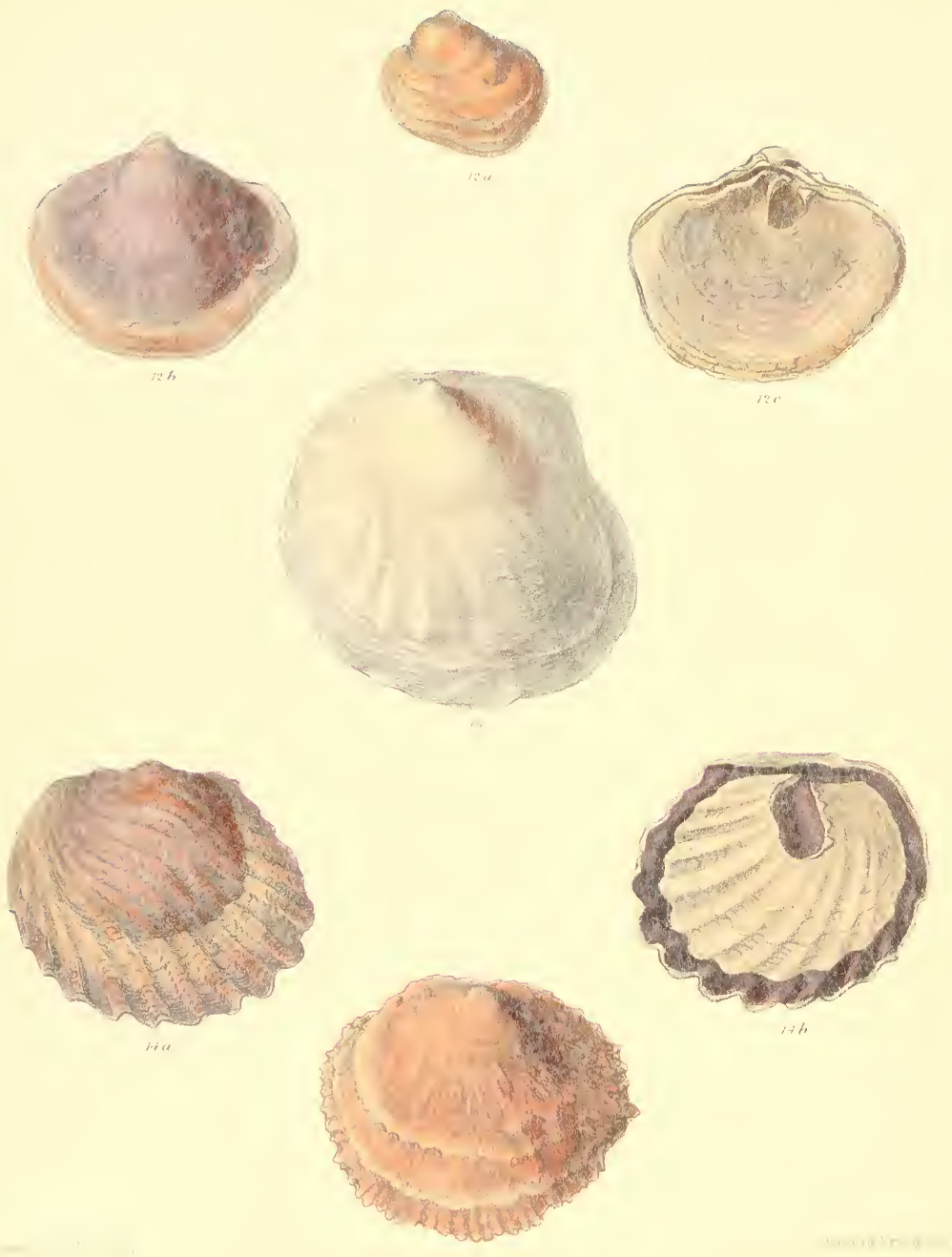


\section{A NOMIA.}

\section{Plate III.}

Species 12 Tig. $a, b, c$, Mus. Cuming.)

Anоми Acheus. Anom. testä latè ovatâ, lievigatâ, purpureâ vel aureo-lutescente, valvẩ inferiore concentricè subsquamato-striatâ, superiore convesâ, versus umbonem tumido-unciuntâ.

Tне Асн.z's ANoma. Shell broadly ovate, smonth, purple or golden-yellow, lower valve concentrically somew hat scaly-striated, upper valve convex, tumidly hooked towards the umbo.

Gray, Pro. Zool. Soc. 18.9, p. 116.

Hab. Kurachce, mouth of the Iudus; Major Baker.

The swollen looked growth of this shell is obviously a character of the species, and not a distortion arisiug from its place of attachment.

\section{Species 13. (Mus. Cuming.)}

ANoma larbas. Anom. testâ subquadrato-ovatâ, tenni, argenteo-albâ, lavigatâ, rudiatim fiexuoso-costatâ, costis ferè obsoletis; valuä inferiore oruginoso-caruleâ.

ThE WAVED ANomia. Shell somewhat squarely ovate, thin, silvery-white, smooth, radiately flesuously ribbel, ribs almost obsolete, lower valve bright verdigris-blue.

Grax, Pro. Zool. Soc. 1849, p. 117

1lab. Payta, Peru; Cuming.

A fine faintly-waved shell, of a delicate silvery-white, verdigris-blue beneath.
Fig. $14 a$, . . (Mus. Caruiug.)

This specimen, conspicuonsly ribbed in both valves from having grown upon a ribbed shell, is from the collection of the old dealer George Humplreys, and is doubtless another example of .1. Humplereysiana, described at Pl. II. S1. 8. Though differing so much in general appearance, it is of the same oblique form, solid transparent texture, and coppery-purplish colour.

\section{Species 15. (Mus. Cuming.)}

INomia ADAMas. Anom, testâ ovatô, versus marginem Inminutû, rudè costatâ, costis angustis, vatde irregularibus, versus marginem conspicuè mucronatis; vividè rufescente-aurantiä.

The adamant Anomia. Shell ovate, laminated towards the margin, rudely ribbed, ribs narrow, very irregular, conspicuously pointed towards the margin; bright reddish-orange.

Gray, Pro. Zool. Soc. 1849, p. 115.

Hab. Lord Hood's Island, Galapagos (attached to Avicula margaritifera at the depth of nine fathoms); Cuming.

The upper valve of this species is distinguished by a very bright reddish-orange colour, as well as by a peculiar kind of irregular sharp ribbing, developed on appressed laminæ. 


Ancminir Pl. II.
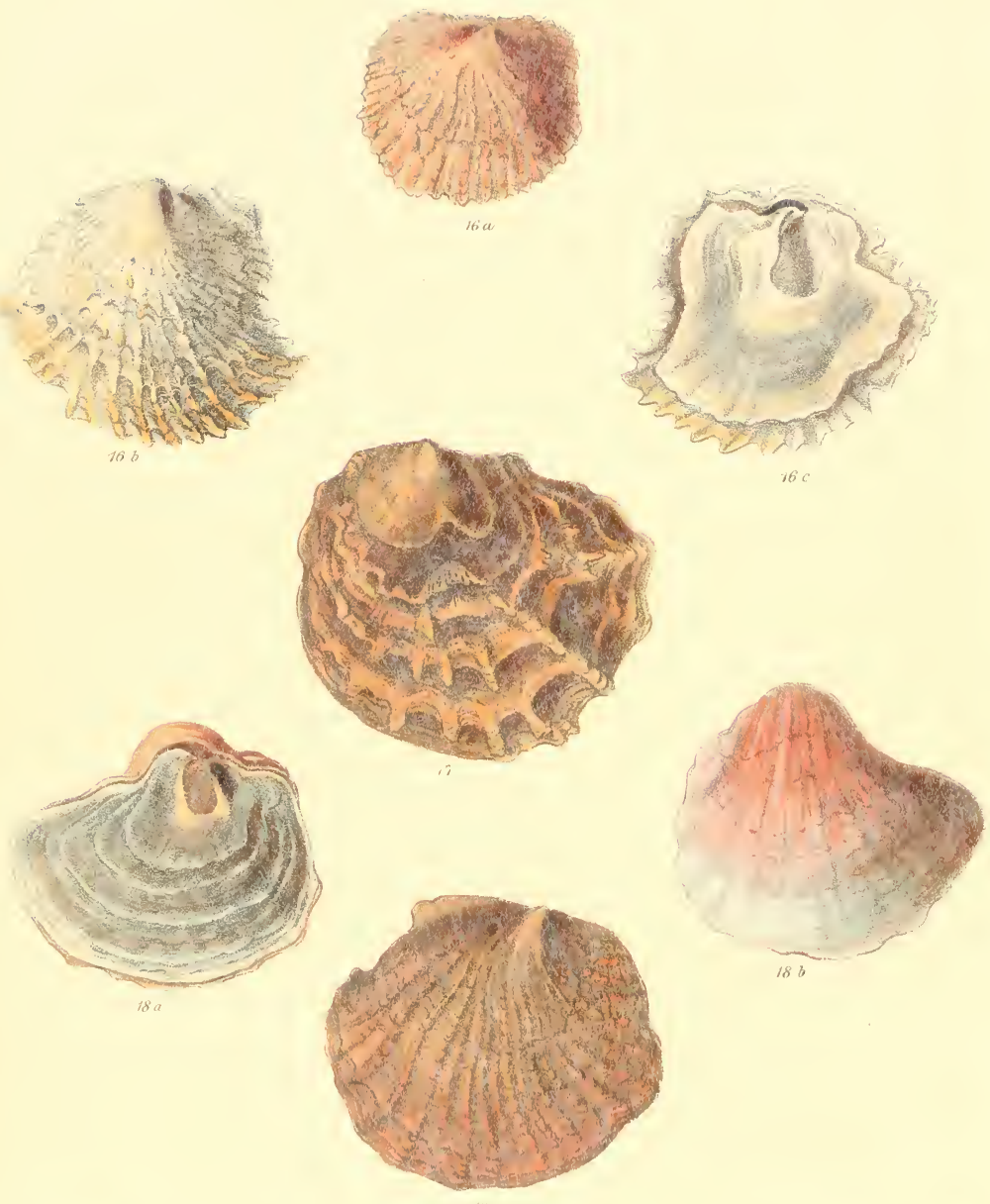


\section{A NOMIA.}

\section{Plate IV.}

Spccies 16. (Fig. $a, b$, Mus. Ciming.)

ANomia lampe. Anom. testâ subobliquè quadratâ, rudi, radiatim costatä, costis interruptis, irregutaribus, flexussis, versus marginem nuricuto-squamatis; tenui, kyalino-albâ, valvä superiure virescente-luleo vel aurantio-rufo, inferiore aruginoso-caruleo tinctâ.

The scum Avomis. Shell somewhat obliquely square, rude, radiately ribbed, ribs interrupted, irregular, flexuous, prickly-scaled towards the margin; thin, hyaline-white, upper valve stained with greenish-yellow or orange-red, lower ralve with verdigris-blue.

(iray, Pro, Zool. Soc. 1849 , p. 115.

Hab. California; Lady Wigran.

The ribs of the upjer valve of this hyaline bright-coloured specics are irregularly wrinkled, and sometimes prickly-sealetl.

\section{Species 17. (Mus, Cuming.)}

ANoMia strigilis. Anom, testấ vbliquè ovatâ, rulè fimbriato-laminatâ et peculinriter pectinato-costatâ; luteocomeâ, medio purpurascente.

The currycomb ANomia. Shell obliquely ovate, rudely fimbriately laminated and pectinately ribbed; yellowish-horny, purplish in the middle.

Hub. - - ?

Of this shell, formerly in the colleetion of George Humphreys, nothing is known as to its haljitat. The peculiar pectinate festooned ribs, protrudiug from the laminte, appressed into the byaline texture of the upper valve, leave little doubt as to its spccific distinctness. Such a regularity of sculpture could not be accidental, nor could it be derived from any pattern connceted with its place of attachment.
Species 15. (Fig. $t, b$, Mus. Cuming.)

Anomia lanueata. Anom. testâ subobliquè oratâ, valvấ superiore tunido-incurvâ, radiatim costatâ, costis angustis, regularibus, subllistantibus, versus marginem obsoletis; hyalino-albâ, plus mineus aurantio-aneatr, valeá inferiore planulat $\vec{a}$, concentricè lminate-striatâ. aruyinoso-ceruletî.

THE FLUTED ANomia. Shell somewhat obliquely ovate, upper valve tumidly incurved, radiately ribbed, ribs rather narrow, regular, somewhat distant, obsolete towards the margin; hyaline-white, more or less orange-brouzed, lower valve flat, concentrically laminately striated, verdigris-blue.

Jlab

The distinguishing specific character of this shell consists in the regularly radiating fluted sculpture of narrow listant ribs, and delicate orange-bronze colouring in the upper valve, wbich is almost as tumidly incurved as in $A$ Ailucens.

Species 19. (Mus. Cuming.)

INomia pacilus. duom. testä suborbiculari, canvexoplanâ, radiatim flexuoro-costat $\vec{a}$, cost is subdistuntiloses, plus minus obsoletè nodulatis; firsco-ceneatá.

The sivartiry Anomia. Shell somewhat orbicular, eonvexly flattened, radiately flexuously ribbed, ribs ratlicr distant, more or less obsoletely noduled; tuscousbrouze.

Gray, Pro. Zool. Soc. 1849, p. 117.

Hab. Tumbez, Peru; Cuming.

A rery characteristic fuscous-bronze slell, rather flat, with faintly noduled ribs radiating in a flexuous manner at unequal distances from a rather sharply defined umbo. 


-



Anemia Pl. IT

\section{)}
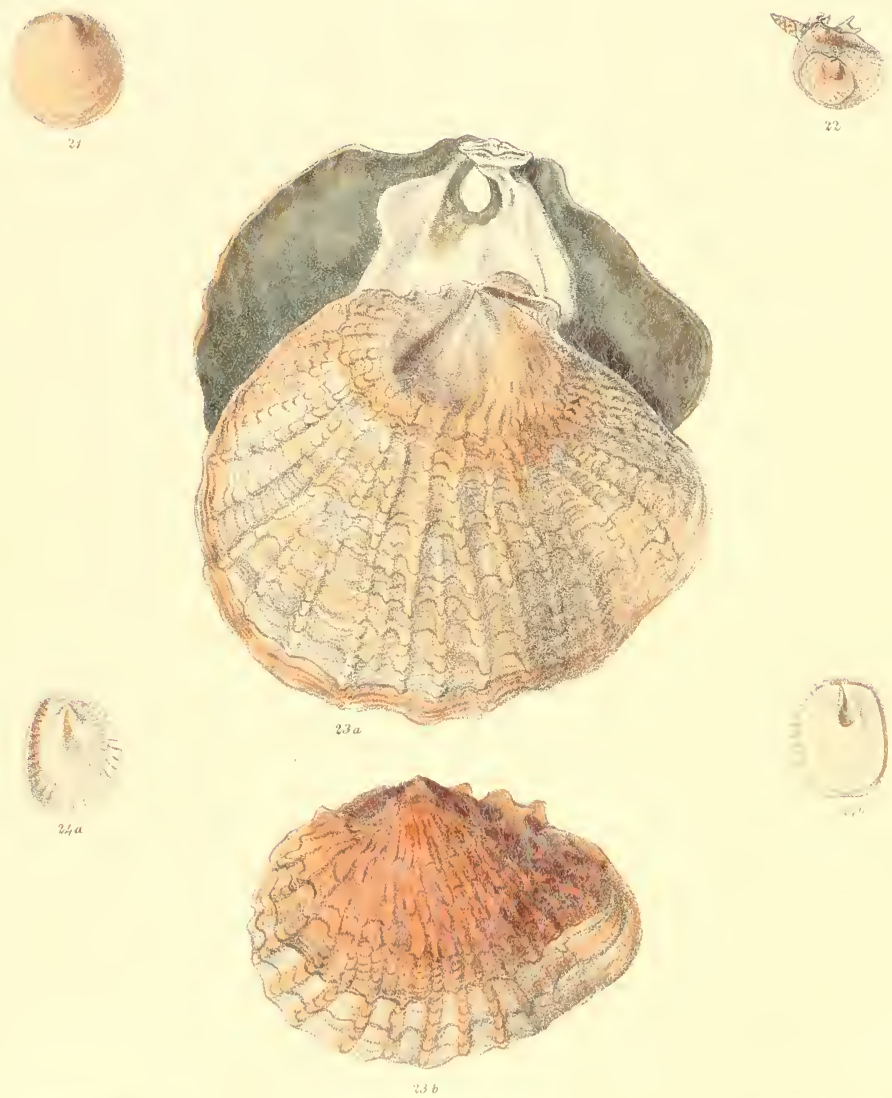


\section{A N O II I A.}

\section{Plate T.}

Specus 20. (Mus. Cuming.)

Axima nétita. Anom. lestâ oblongo-ovatâ, temui,

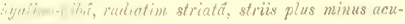
leat an, zamea $\vec{\alpha}$.

Tal: PRICKLY Axomis. Shell oblong-ovate, thin, hyaline-wlite radiately striated, striæ more or less prickly-scaled.

Muler, Zool. Danica, Prodrom. p. 249.

Anesaia striolale, Turton.

Hab. Tritain and North Atlantic generally.

A small hyaline species, morc or less rayed with minute, vi uheu, prickly scales.

Species 21. (Fig. $a, b$, Nus. Cuming.)

Axuma Acoxtes. Anom. textâ suborbiculari, tenui, plamulatî, laeri, Lutescente-allá.

[He Acostrs Anoma. Shell wearly orbicular, thin, fiattened, smooth, yellowish-whitc.

Grar, Pro. Zool. Soc. 1849, p. 116.

Hab. Jamaica; Giosse.

Of very simple form, without any trace of sculpture.

Specics 22. (Mus, Cuming.)

Anomia spinosa. Anom. testä oblique ovatä, tenui, albidâ, versus umbones radiatim spinosa-squamatâ.

The spixed Axomia. Stuell obliquely orate, thin, whitisl, radiately spine-scaled towards the umbo.

Hab. Norway.

This shell, having a regular oblique growth, appears to difter from $d$. aculeata in a manner that should be regarded of importance in determining species. ipecies 23, (Fig. a, b, Mus. Cuming.)

Axomia nobrus, Anom. testi latè oxatâ, planâ, solidiusculâ, subirregulari, radiatim costatâ, costis subdistantibus, ottusè squanatis, ralvá superiore virescentealbâ, luteo vet rufiscente-aurantio tinctâ, valia inferiore pallidè arnginoso-carniescente.

THE NOBLE ANomi. Shell broadly ovate, flat, rather solid, somewhat irregular, radiately ribbed, ribs rather distant, obtuscly scaled, upper valve greenish-white, tinged with yellow or reddish-orange, lower valve pale verdigris-bluc.

Hab. Saudwich Islands.

A fine new species from the Sandwich lslands, sculptured with characteristic flexuously rayed scaly ribs, varying in colour from yellow to reddish-orange.

Species 24. (Fig. $a, b$, Mus. Cuming.)

Anomia Dryas. Anom. testä suborbiculari, tenui, planiusculâ, hyalino-albât, valvẩ superiore intus extrusque radiutim lineata, lineis subdistuntibus; umbone subproducto.

The Dryas Anoma. Shell nearly orbicular, thin, rather flat, hyaline-white, upper valve radiately lined within and without, lines rather distant; umbo slightly produced.

Gray, Pro. Zool. Soc. 1849, p. 115.

Hab. Singapore (on dead shells, in coarse sand and gravel. at a depth of about ten fathoms); Cuming.

The upper valve of this species is curiously distinguished by a radiation of rather distant lines, which are seen both within and without. 



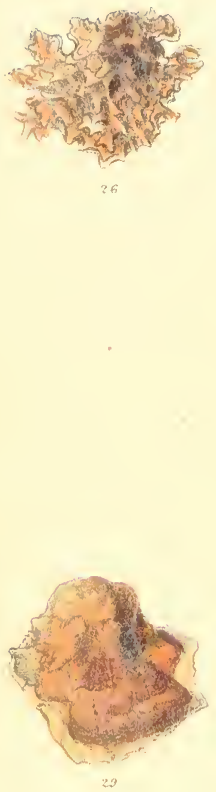
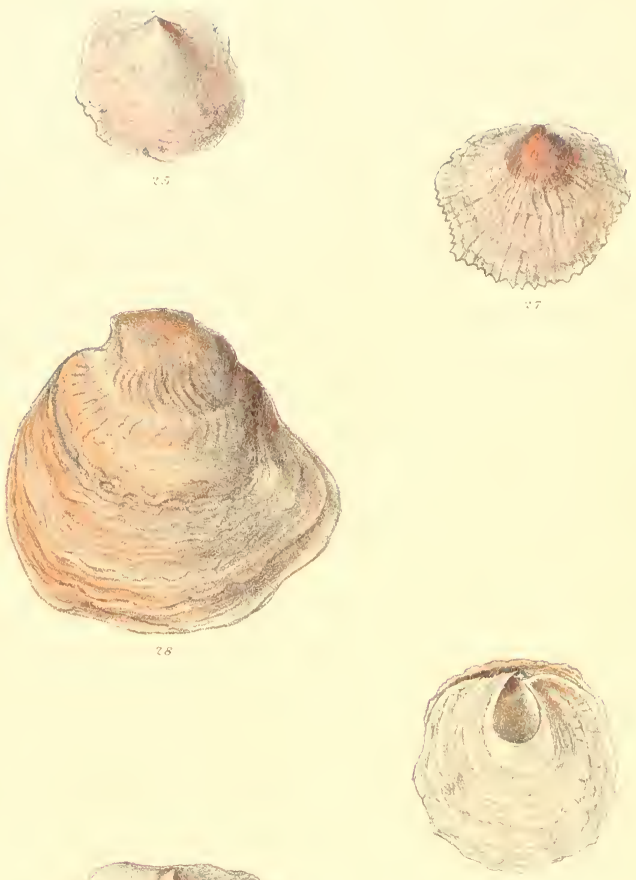

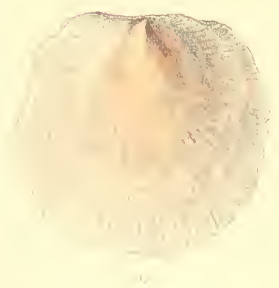




\section{A N O II I.}

\section{Plate VI.}

Species 25. (Mus. Cuming.)

Anomia malleata. Anom. testâ suborbiculari, tomissimâ, hyalino-alb $\hat{a}$, rugoso-mulleat $\hat{u}$, umbone subprominente, acuto.

The malleated Axomia. Shell nearly orbicular, very thin, hyaline-white, roughly malleated, umbo rather prominent, sharp.

Hab.

Of a delicate trausparent texture, with a rude malleated urface and sharply defined umbo.

\section{Species 26. (Mus. Cumiug.)}

Asomia ramosa. Anom. testâ suborbiculari, tenui, lutrseente, copiosè ramiso-squamatâ.

THE BRaNched ANomia. Shell ncarly orbicular, thin, yellowish, copiously branch-scaled.

Hab. Tunis: Fraser.

Distinguisted by a copious growth of branching scales.

$$
\text { Species 2\%. (Mus. Cuming.) }
$$

Asoma scabra. Anom. testâ suborliculari, hyalino-albâ, circa nubbmem pallidì rufiscente-sneâ, radiatim liratâ, liris rudibus, irregularibus, ad marginem acutis.

THE Rotgh ANoura. Shell nearly orbicular, byalinewhite, pale reddish-bronze about the umbo, radiately nidged, ridgres rude, irregular, sharp at the margin.

liub. Bombay.

Iu colour this species approaclies $\mathcal{A}$. cytcun, from China, but the shell has a sculpture natural to it, which is quite distiuct.

\section{Species 28. (Mus. (umiug.)}

ANomia Alectus. Anom. testât subtrigono-orbiculari, irregulari, solitiusculu, rersus umboutem acutè flexuoso-costat $\vec{a}$, deinde concratrice laminatâ; raluta superiore rufescente-fiongineat a it purpurascente, inferiwre virescente.
The Alectes Axoma, shell somewhat triangularly orlicular, irregular, rather solid, sharply flexuously ribbed towards the umbo, then concentrically laminated; upper valve reddish-rust or purplish, lower valve greenish.

GraY, Pro. Zool. Soc. 1949, p. 115.

Hab. Bay of Guayaquil; Ilinds.

The chief peculiarity of this species consists in the sharply flexuous ribs, which become obsolete towards the margin amoug the conceutric laminæ.

Fig. 29. (Mus. Cuming.)

This shell represents the state of $A$. ephippium named A. cepa.

$$
\text { species 30. (Mus. Cuming.) }
$$

ANomia fIDENAs. Anom. testâ ovatâ, temui, planutatu, levâ, albidala ; valvâ inferiore concentricè laminato-striutâ.

The smoотн Axомг, Shell ovate, thin, flat, smooth, whitish; lower valve concentrically laminately striated.

Grax, Pro. Zool. Soc. 1849 , p. 116.

Itab. West coast of Panama; Cumiug.

Of very simple character, found by Mr. Cuning at the above-ramed locality, attached to a Fima.

\section{Species 31. (Mus. Cuming.)}

Aуоміа ARgritis. Anom. testá subquadrato-orbiculuri. tenuissimâ, diaplianâ, aryenteo-albâa, circa umbonem subrolorat $\hat{a}$, undique raluetim striatâ.

TIIE sILVER-Fosm ANomia. Shell somewhat squarely orbicular, very thin, diaphanous, silvery-white, faiutly coloured about thic umbo, everywhere radiately striated.

Hab. - ?

A delicate, radiately striated, silvery species, faintly tinged with colour about the unbo. 

Alu'rmua III III.
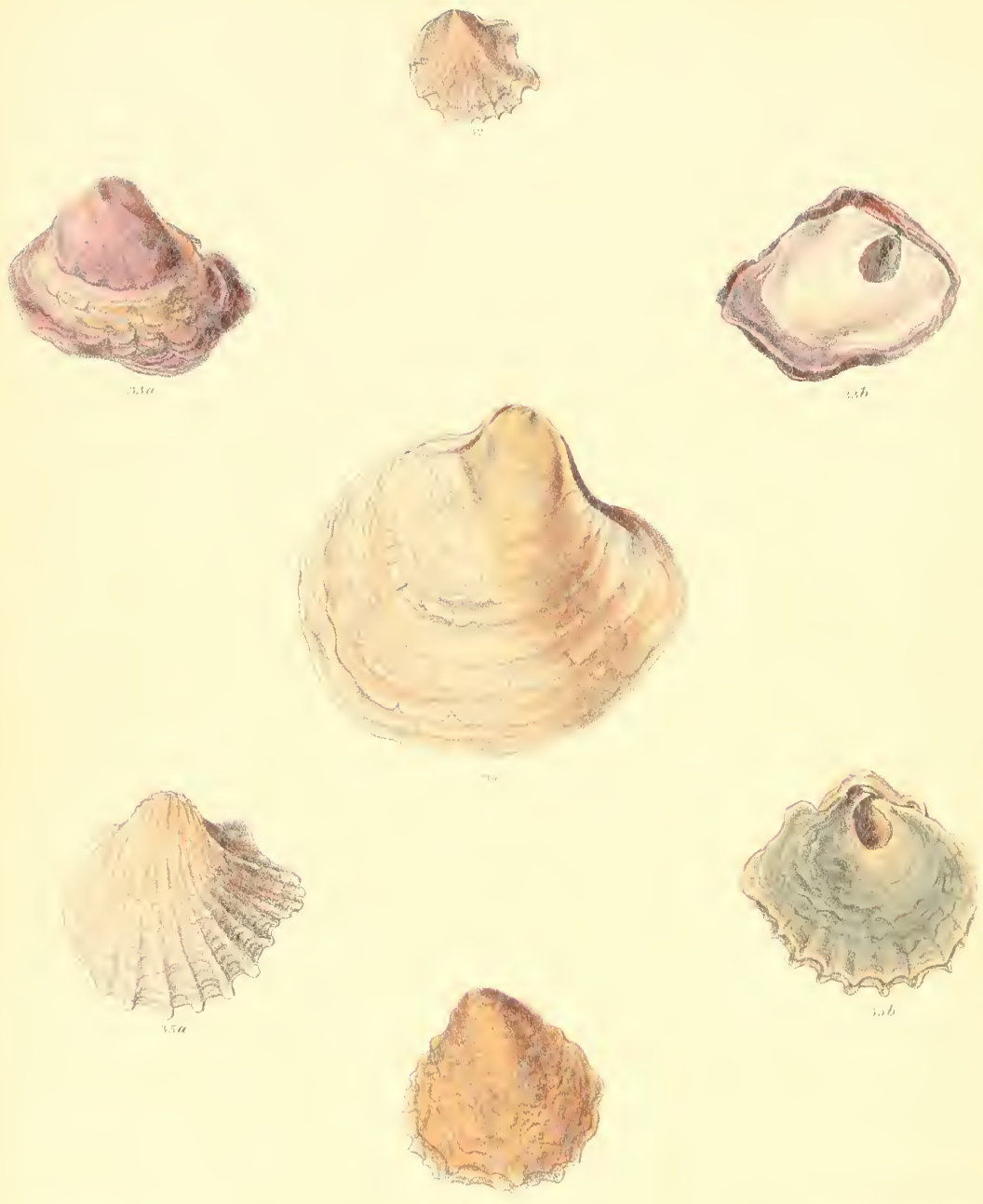


\section{A NOMIA.}

\section{Plate 1II.}

Species $3 z$. (Mus. Cuming.)

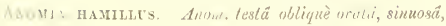
tenui, pellucidi, rufoxcente, irregularitr rugoso-mallirutä.

Tite sincocs Anomis. Shell obliquely ovate, sinuous, thin, transparent, irrcgularIy roushly mallentcd.

Finay. Pro. Zool. Suc. 1849, p. 117

IVu' Bay of Canes, West Columbia; Cuming.

(1) a thin sinuous growth and redilish colour.

Spercs 33. (Fig. $a, b$, Nus, Cuming.)

IN⿴囗十 TrRia Anom. trotä subtrigmo-oratia, tumidi, - whlyo lanigat $\hat{a}$, intensè aneo-purpureâ.

IH. J'rian Avomia. Shell somewhat trangularly 1..te, tumid, everywliere smooth, deep bronze-purple.

the sandwich Islands.

richly purple-stained species from the Sandwich fiand- with a smonth apparently worn aspect.

Species 34. (Nris. Cuming.)

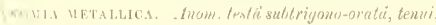
mpresiusculat, comrentricè obsoletè laminato-striata, wiventeonalli, luteo linct $\vec{a}$.

IHe METALLI ANома. Shell somewhat triangularly orate, thin, rather compressed, concentrically obsoletely laminatcly striated, silvery-white, tinged with yellow.

Hut
Of a delicatc, vetallic, yellow-inged, silvery texture, differing specifically in this respect as well as in form from any varieties that 1 have secn of $A$. "plippium.

Species 35. (Fig. ar, l, Mus. Cumiug.)

INoMLA costata. Anom. trstä subtrigone-prthiculuri, versus umbernere lumito-ineurvâ, semipelluerilo-albi, rer-

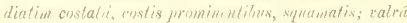

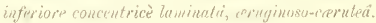

THE RIBBED ANOMIA. Shell somerwhit triangularly orbicular, tumidly incurved towards the umbo, semitransparent-white, ruliately ribbed, ribs prominent. scaled; lower valve concentrically laminated, verdigris-blue.

$\mathrm{Hah}$. - ?

This charactcristic species appears to be ribbed independently of its place of attachment, aud the ribs ar largcly sealed.

Specics 36. (Mus. Cuming.)

Anomia lucerna. Anom. lestâ trigono-yjobosí, tenu valdè inflatri, rudi, irregulari, rersus umbonem tumido incurvä, wbsoletè squamato-laminatü.

The lamp Anomia. Shell triangularly glohose, thin. very inflated, rude, irregular, tumidly incurved towards the umbo, obsoletely squamately laminated.

$\mathrm{Hab}$. - ?

A thiu, inflated, Trebratula-shaped species, of very irre gular growth, obscurely seale-lamiuated. 





\title{
A NO MI A.
}

\author{
PLATE VIII
}

-peries 37. (Fig. 37, 38, M9, and 40 a to d, Mus. Cuming.) Aкомia exiguitici. Anom. trastï oblongo-oontü, tenui, valkâ superiore plus minus obliquit, nune levei, nue radialim lirati, liris distuntitus, revinoss vel fere ubsoletis, intensè "upreo-purpurể valrâ inferiorr argentro-alluá aut lutescente.

THF m zzlixg Axoma. Shall oblong-ovate thu, upper valve oblique, sometimes snoos he, sometınes radiately ridged, ridges distant, warty or al most obsolete. deep coppery-purple, lower valve silvery-white or yellowisli

TMllina enigmatica, Chemnitz, Courch Cab. sol xi. pl. 194 f. $19+9$ and 1950 .

fuomia roven, Gray.

fumia raciformis, Jonas.

Uab. Philippine Islands (in Nango-1ress and Vipa Ptiurs, on the seashore): Cuming.

It will be seen by the numbers of th aecompanyug figures that the shells sclccted for illustration werc intencks to represent four species. On further examination, however. I camnot resist coming to the conclnsion that they are all varietics of one and the same-the Tellina emuwatica of Chemnitz. When attached to narrow stens or stieks the shell assnmes an elongated boat form, as in the variety A. naviformis, Jonas, at Fig. 37. The variets, Fig. 38, from Borneo, is smooth, broad, and rather solid; that at Fig. 39 has a more obliyue growth, and is rayed with nore or less obsolete warty ridges. It is fonnd on piles of wood forming the wharves at Singapore. The shells represented at Fig. $40 a, b, c, d$, which may be regarded as the typical form of the species, are of a more regular growth, sometimes smooth, sometimes presenting indications of the warty ridges. They were found by Mr. Cuning attached to the Mango-trees and Vipa Palms, growing between tides on the shores of the Ptilippune Isiands, some adbering to the leaves, as at Fig. 40 . 



\section{$1 \times 0.11$.}

Achrus, Gray

Acoutes, (iray

aculeata, Mäller

adamas, Gray .

anigmatica (Trlline), Clsemnity

Alectus, Gray .......... .

amabaus, Gray .......... II

argyritis, Reene .... .... . VI.

cælata, Reere ............ I.

cepa, Linnæus. . ......... 11.

coremata, Bein .......... II.

costata, Reere........... VII.

ylindrica, Gnelin ......... II.

rymbiformis, Maton and Racket. II.

cyt:cum, Gray............ II.

Iryas, Gray ........... V V

electrica, Limæus .......... Il.

elyros, Gray ........... I.

cphippium, Linnens ... ..... II.

fidenas, Gray .......... YI.

Mexnosa, fimelin .... .... II.

fornicata, Lawarek

hamillus, firuy ..... V1I.

Ilumplurcysiana, Reree . . II.

lampe, Gray ... ...... IV.

laqucata, Reere $\quad . . \quad \ldots$. IV.

larbas, Gray

lncerna, Reror
III.

.

III.

VIII.

I.

.

I.

.

iI.

.

I.

.

.

1.

I.

I.

II.

I.

IV.

III.

III. malleata, Reene

margarilacen, P'oli

mctallica, Reeve

naviformis, Johas.

nobilis, Reve .... ....

pacilus, Gray .... ... II

pertiniformis, Poli ..... 11.

placentella, Reeve .. . . . $\quad$ I.

plenilunium, Reeve.... ... . 1 .

polymoryha, I'hilippi .. , II.

punctata, Chemnit\%.... . II

pyriformis, Lamarck ........ II

ramosn, Rece............ VI.

rosea, Gray ..............

rugosa, Gimelin ...........

scabra, Reeve ............

scabrella, Philippi ........ II

sol, Reeve .............. I

spinosa, Reeve ........ .. V. V.

squamula, Limnicus .... . ... II.

striate. Gray ........ ... II.

striatula, Bruguire ... ... II.

strigilis, Reeve .......... IV.

striolala, Turton........... V V

sulcata, Poli. . ... ..... II.

Anbularis, Turton .... II.

Tyria, Reeve.... . .. . VII

riolueer. Brugnute
VI. 25

11

II. 34

111. $\quad 37$

23

19

11

6

2

11

11

26

VIII. $\quad 37$

II. 11

I. 27

11

4

22

11

9

I]

17

20

1 I

H 



\title{
MONOGRAPH
}

\author{
OF THE GENUS
}

\section{P L A C U N A N O M I A.}

"Each creature holds an insular point in space : let what man stirs a finger, breathes a sound, But all the multitudioons beings round Io all the countless worlds, with time and place For their conditions, dowu to the central hase, Thrill, haply, in vibration and rehound, Life answeriog life across the vast profound, In fall antiphony, by a commoo grace!" Elizabeth Barrett Browning 

Placunancmia Pl. I.

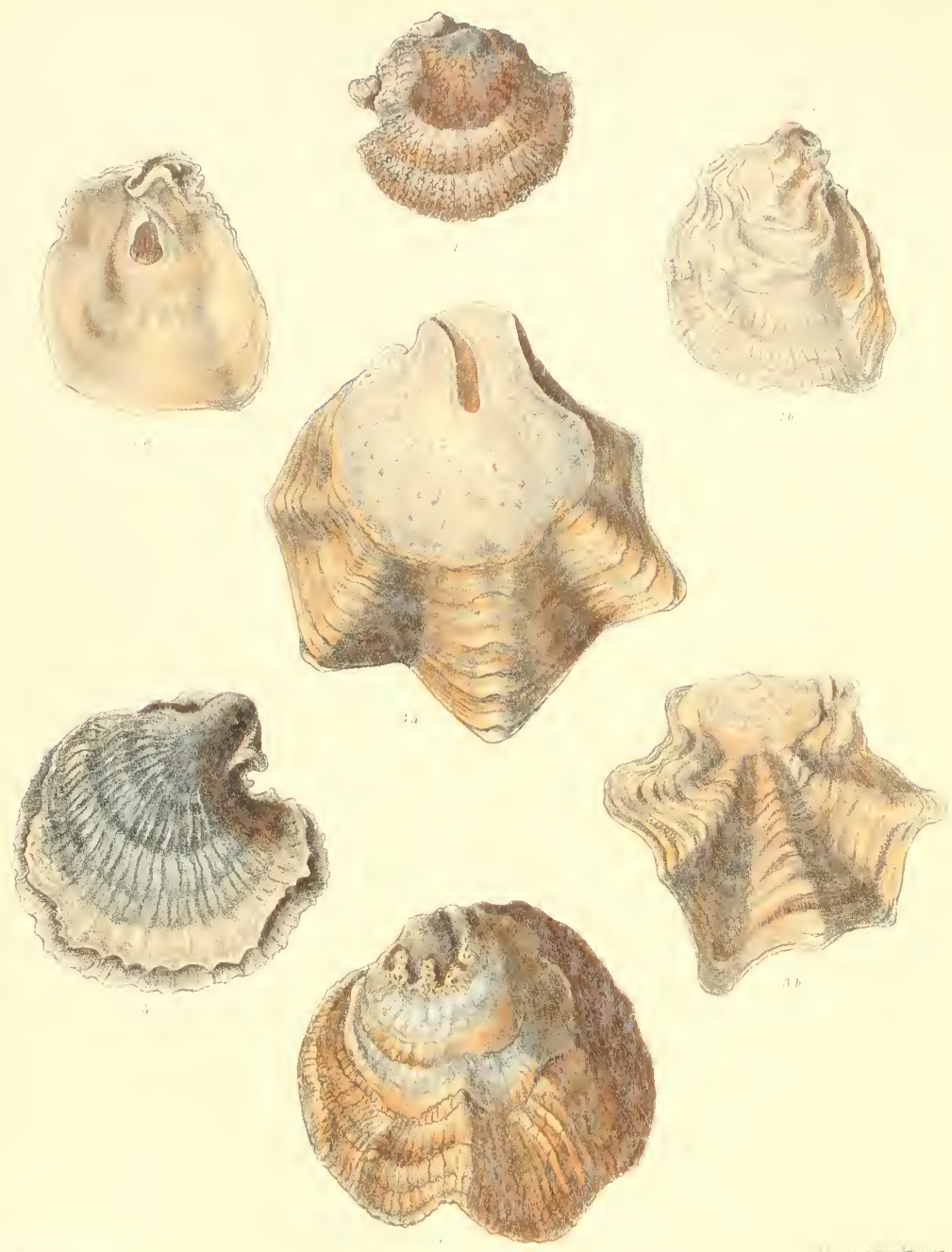




\section{PLACUNANOMIA.}

\section{Plate I.}

Genus PLACTNANOMIA, Broderip.

Testa subcequivalvis, irregularis, tenuis, interdum solitiusculu, plerwinque complanata, carline interno dentibus duobus divaricatis convergentibus in valnä inferiore, sulcis dnobus ligumentifreris in superiore. Talva inferior prope carlinem fissurata vel trigono-perforata, perforatione cardim. descendente, tendinem adlhcesionis subosseam interdum inter testa. laminas insertam, admittente. Imprexsio muscularis in valvâ inferiore unica, in superiore duplicatn, subcentralis.

Sheil ncarly equivalve, irregular, thin, sometimes rather solid, generally smooth; hinge internal, composed in the lower valve of two divaricate, converging teeth, in the upper of two ligamentary grooves. Lower valve fissured or triangularly perforated near the hiuge: perforation descending from the linge, admitting a partially bony tendon of adhesion, which bccomes sometimes inserted between the lamine of the shell. Muscular impression in the lower valve single, in the upper valve double, nearly central.

This remarkable genus was founded in 1532 by .Ir. Broderip, on a single species collceted by Mr. Cuming in the Gulf of Dulce, Central America, presenting a liuge approaching very nearly to that of Placuna, in connection with the appearances and distinguishing organization of Anomia. As many as a dozen other specics have been found to partake of these typical characteristics, but in none are they so conspicuously dercloped as in the original Placunanomia Chningii. Their generic peculiarity consists in this: the orifice in the lower valve, through which the ossificd tendon of adhesion, or plug, passes, is not open at the top as in Anomia, but is soldered (so to speak) by the intervention of a dirarieatc, Placuna-like hinge, or by some morc or less rude modification of it. Owing to the soldering of the orifice, the tendon of adhesion is so far restricted in its growth as to insinuate itself in some species in the form of a plate between the lamine of the surrounding shell; this is not, however, as Mr. Broderip had reason to suppose from the $P$. Cumingii, a chnracter of the genus. In most of the species the orifice is large enough to admit the utmost growth of the tendon.

The species, it will be seen, are from widely-spread localities, one of which inhabits our own shores.
Species 1. (Mus. Cuming.)

Placunanomia echinata. Plac. testä subtumidá, calvâa superiore radiatim echinato-squamatâ,; albida, medio fusco tinctâ.

Tae prickly Placunanomia. Shell somewhat swollen, upper valve radiately prickly-scaled; whitish, stained in the middle with brown.

Broderip, Pro. Zool. Soc, 1R3t, p. 2.

Hab. Island of Nevis, West Indies (dredged up attached to shells from sandy mud, at a depth of six fathoms): Mr. Powers.

Dr. Gray regards this species as an imperfect specment of $P$. foliata, and states in his monograph of the genus, Pro. Zool. Soc. 1849, p. 121, that " Mr. Broderip doubted if this might not be the case when he described it." It may be so, but I cannot find that Mrr. Broderip has made any such statement. The $P$. fuluta has a much larger orifice for the tendon of adhesion.

\section{Species 2. (Mius. Curaing.)}

P'Lacunanomi rtdis. Plac, testâ sordidè albâ, crassrit, concentricè irregulariter corrugatâ, intus politâ, perforatione parvá.

The rude Placenanoma. Shell dead-white, thick, concentrically irregularly wrinkled, polished within, orifice small.

Broderip, Pro. Zool. Soc. 183t, p. 2. Pododesinus decipiens, Philippl.

Ilab. West Indies; Broderip. Havana; Philippi.

Of rude growth and solid substance, with the orifice suall.

\section{Species 3. (Fig. $a, b$, Mlus, Cuming.)}

Placenanoma Cumisir. Plac. textâ subrotundutâ, obscurè argenteo-albielâ, virescente-tinctâ, complanatâ, margine plicatä, plicis naximè angularibus.

Cuming's Placenanomia. Stell somewhat rounded, obscurely silvery-white, tinged with green, smooth, plaited at the margin, plaits largely angular.

Broderip, Pro. Zool. Soc. 1832, p. 29.

IIab. Gulf of Dulce, province of Costa Rica, Central America (dredged from a unddy bottom at a depth of eleven fathoms, attached to dead bivalve sheils and dead coral); Cuming. 


\section{PLACUNANOMIA.--PLATE I.}

In this species, the original one described by Mr. BroCerip as the type of the genus, the orifice of the lower valve is restricted to an oblong fissure, and the tendon of adhesiou presses itself into a space between the laminæ of the surrounding shell.

\section{Species 4. (Mus, Cuming.)}

Placunanomia Zealandica. Plac. testâ suborbiculari, albidâ, complanatâ, ralvâ superiore radiatim liratâ, liris subdistantibus; intus coruleo-virente.

The Zealand Placunajoma. Shell nearly orbicular, whitish, smooth, upper valve radiately ridged, ridges rather distant; interior blue-grcen.

Anomia Zealandica, in Dieffenbach's New Zealand, vol. ii. p. 261 .

Hab. New Zealand.

A semitransparent blue-green shell, radiated with tine rudges, which are obsoletely scaled, and rather irregular.
Species 5. (Mus. Curning.)

Placunanomis foliata. Plac. testâ subdiaphanâ, subcirculari, rudi, subfoliatä; sordidè albä, intus splendente, valva superioris medio purpureo-fusco; perforatione maximâ.

The foliated Placunanomia. Shell subdiaphanous, nearly circular, rude, rather foliate; dead-white, shining withiu, middle of the upper valve purple-browu; orifice very large.

Broderip, Pro. Zool. Soc. 1834, p. 2.

Hab. Isle of Muerte, Bay of Guayaquil, West Columbia (dredged up, attached to a dead Pinna, from a bottom of sandy mud, at the depth of eleven fathoms).

It is not impossible that this species may prove to he a more advauced state of $P$. echinata, in which the prickly scales have becotoe obsolete. It is howerer distinguished from that species, so far as the limited number of specimens enubled us to judge, by a very much larger crifiee. 

Placunarumia PI. II.
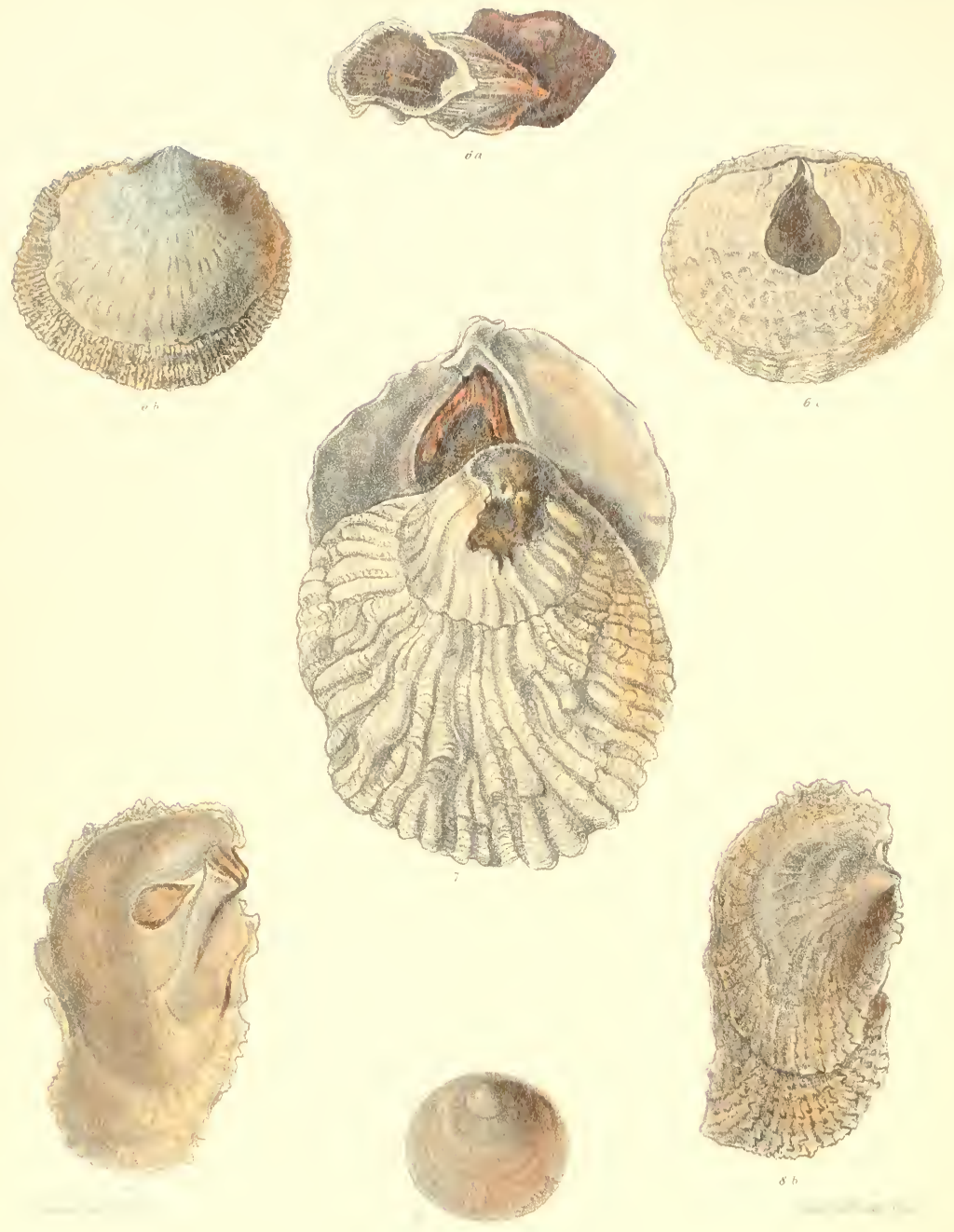


\section{PLA C U N A N O II A.}

Plate II.

Species li. (Fig, a, b, c, Mus, Cuming.)

Pracuxinowa Ione. Ptac. testâ suborbiculari, allitila, laminuri, laminarum margine spiculis parvis elomyut is instructo, perforatione maxima; intus virente.

line volet Placenaxomia. Shell nearly orbicular, whitish, laminar, edge of the lamina furnished with small elongated procisses, perforation very lare; interior grecn.

Gkay, Pro. Zool. Noc. 1849 , p. 123.

Ilat. Sydney, Australia (on rocks); Strange.

The smooth portion of the upper surlact: of this shell, thescribed by Dr. Gray as being laminar, appears to be an .thrision of the radiating spicular processes occasioned by the attachment of some other shell.

Fig. $a$ represents the plug or tendon of adhesion, Fig $b$ the upper valve, and Fig, $c$ the lower value.

Species 7. (Mus. Cuming.)

Plactinanomia macrochisma. Plac. testa ovatá, solidiusculii, radiatim rudè plicato-costatä, costis valdè urregularibus, lic illic tumidis et bifurcutis ; lutescentealbï; perforatione maximâ.

The lartiely perforated Placunanomia. Shell ovate, mather solid, radiately rudely plicatcly ribbed, ribs very irregular, here and there swollen and bifurcated; yellowish-white; perforation very large.

Anowiu macruthisua, Deshayes, Revuc Soc. Cuvierienne, 1539, Mlig. de Zool. 1841, jl. 34 .

IIał. Oualaska; Cuming. Kamtschatka; Deshayes.

This fine specics is distinguished by a broadly-ribbed growth, the rilss bcing very irregular, swollen here and and there, and bifurcated, and by a very large orifice.
Species 8. (Fig. $1 t, b$, Mus. Cuning.)

Placunanomia Harfond. Ptac. lestâ oratâ vel obliquè transererá, concentricè eximiè finbriato-squamatâ, squamis muricatis; pellucido-atba ; perforatione parrinsulut.

Harford's Placunanoma. Shell ovate or obliquely trunsverse, concentrically delicately fimbriately scaled, scales priekly ; transparent-white; orifice rather small. Hab. Jaland of Martinique, West Indies.

The surface of this species is delicately sculptured with concentrie lamini, surmounted with sharply ercet scales. Mr. Frederic lfarford, an acnte conchologist and most assiduons collector, after whom I have the honour to name it, also possesses specimens.

Species 9. (Mus. Cuming.)

Placunanomia pateluforms. Plac. teslá suborbiculari, convexâ vel planntâ, raliatiin lirat $\hat{a}$ el striata intus virescente; apice non marginali.

The disif-shafed Placenanomia. Shell nearly orbicular, convex or flattened, radiately ridged and striated; interior greenisi ; apex removed from the margiu.

Anomia patelliformis, Linnæus, Nyst. Nat. p. 1152.

Anomia sifuama, Gmelin.

Anomia nululuta, Gmelin.

Ostrea striuta, Pulteney.

Anomia striata, Loven.

Hab. Northern shores of Europe (at a depth of from five to filty fathoms); Forbes and Hanley.

This small fragile species, the only one known on out owu shores, is but very slightly striated; whilst the apex is peculiar in being somewhat removed from the margin.

June, 1859 . 




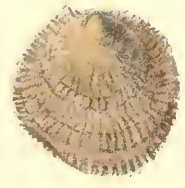

I/ $a$
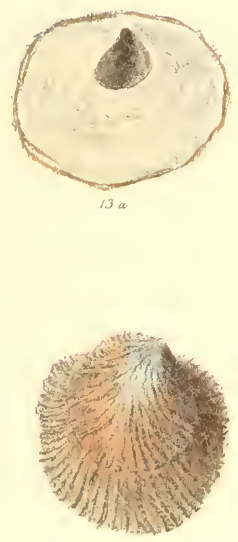

$14 a$
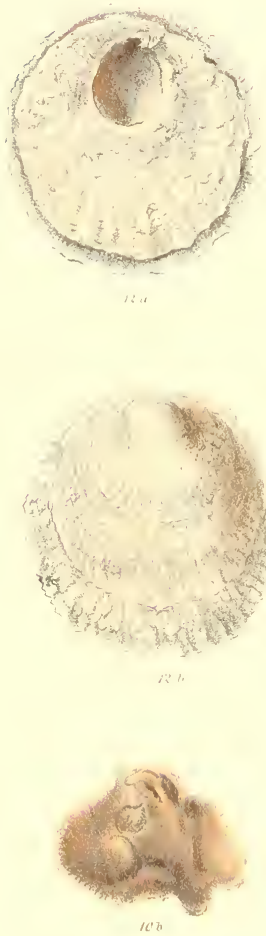
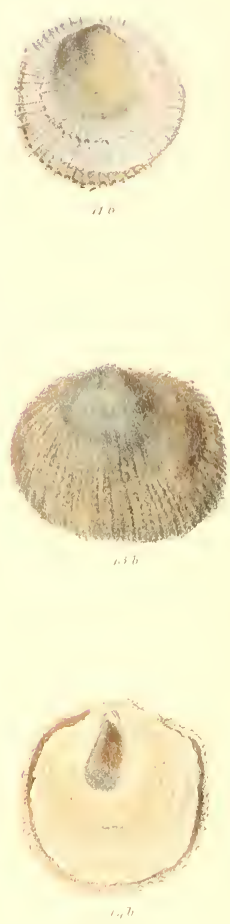


\section{PLACUNA NOMIA.}

\section{Plate III.}

Sprecr: 10. (Fig. " $b$, Vlus. Cuming.)

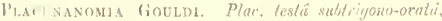
1 whlintim minutè squamalo-strialä, strïs murucalo-squuwarfis: sordide alb $\vec{a}$, inlus lnesceute-fuscri.

(iur 1.1)'s PLACLNavoma. Shell somewhat triangularly wate, radiatcily winutely scale-striated, strie pricklyscaled; dead-whice, interior yellowish-lorown. H, - ?

A small species, not referable to any hitherto described, for which Mr. Cuming is indebted to Dr. Gould, of Boston Inited stintes.

species 11. (Fig. a, 4, Mus. Cuming.)

Placenanomia alope. P'lac. leslä orbiculari, apiéte vie maryinali, valvâ superiori plonâ, radiatiu corregatorostatâ, cast is subundatis; virescenle-albât.

The rox Placunanoma. Shell orbicular, apex scarcely marginal, upper valve flat, radiately wrinkle-ribberl, ribs waved; greenish-white.

Grax, Pro. Zool, soe. 1849, p. 122.

IIab. California.

In this speeies the ribs have an irregular character, dis. posed in waved radiating wrinkles.

species 12. (Fig. $a, b$. Mus. Cumiug.)

Peatrixomid cep1o. Plac. lestât orbiculari, radiatim minuti: slriat $\vec{a}$, undique ruguso-malleatit; pethuridoalbî; perforatione subamplat.

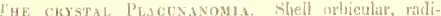

ately minutely striated, everywhere wrinkl-milu:all trussparent-white; orifice rather large.

Gruy, Pro. Zool. Soc. 18t9, p. 121.

Hab. California.

A very delieate transparent species, eurionsly wrinklu. and malleated thronghout.

Spccies 13. (Fig. $a, b$, Mus. Cuming.)

Placunanomia Alstralica. Plac. testä transersè och lá, radiatim temailiral $\vec{a}$, liris minutè muricalo-squmutis; pellucidu-alhat, inlus cerruleo-virente.

Tile Australian Placunanomia. Shell transuerscly ovate, radiately finely ridged, ridges minutely proklyscaled; transparent-white, interior blue-grcen.

II $u$ b. Australia.

Finely sculptured throughout with minutely sealed ridges.

Sprecies 14. (Tig. a, b, Mus. Cuming.)

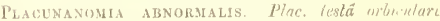
radiatin dicaricato-lirata, liris promiscue undulis. minutè squmalis; sorlide albâ, inlus virescenle

The abnormal P'lacunanomra. Shell orbieular, radiately divaricately ridged, ridges promiscuously witrol minutely scaled; dead-white, interior greenish.

Gray, Pro. Zool. Soe. 1849 , p. $12 \mathrm{I}$

Hab. West Indies.

The radiating ridges of this species have a jeculitu promiscuously wrinkled character. 



\section{PLACUNA NOMIA.}

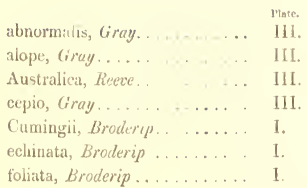

\begin{tabular}{|c|c|}
\hline Snecies. & \\
\hline 14 & Gouldi, Reeve.... ... ... \\
\hline 11 & Hartordi, Reeve $\ldots \ldots \ldots . . .$. \\
\hline 13 & ionc, Gruy ....... , , ... \\
\hline 12 & macrochisma (tnomia), 1heshayes \\
\hline 3 & patclliformis (Anomin), Linnæus. \\
\hline 1 & rudis, Broderip .......... \\
\hline 5 & Zealandica, liray. ... ....... \\
\hline
\end{tabular}


I 130,13 

$$
\text { . }
$$ 
